


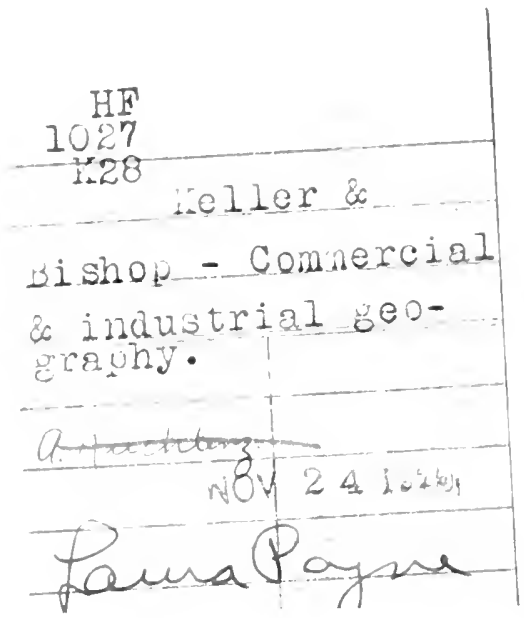

Southern Branch of the University of California Los Angeles

$$
\begin{aligned}
& \text { Form LI } \\
& \text { HF } \\
& 1027 \\
& K 28
\end{aligned}
$$




\section{This book is DUE on the last date stamped below}

\section{$\sin -x+2$ \\ NOV 24 TS}

is

WAY İ 1928
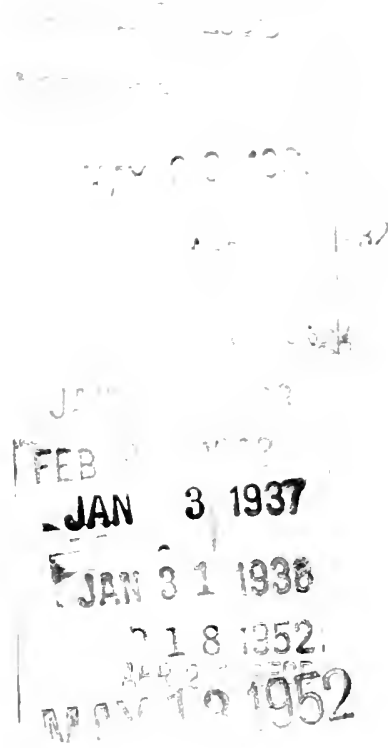

$-5 m-5,24$ 



$$
\text { . }
$$




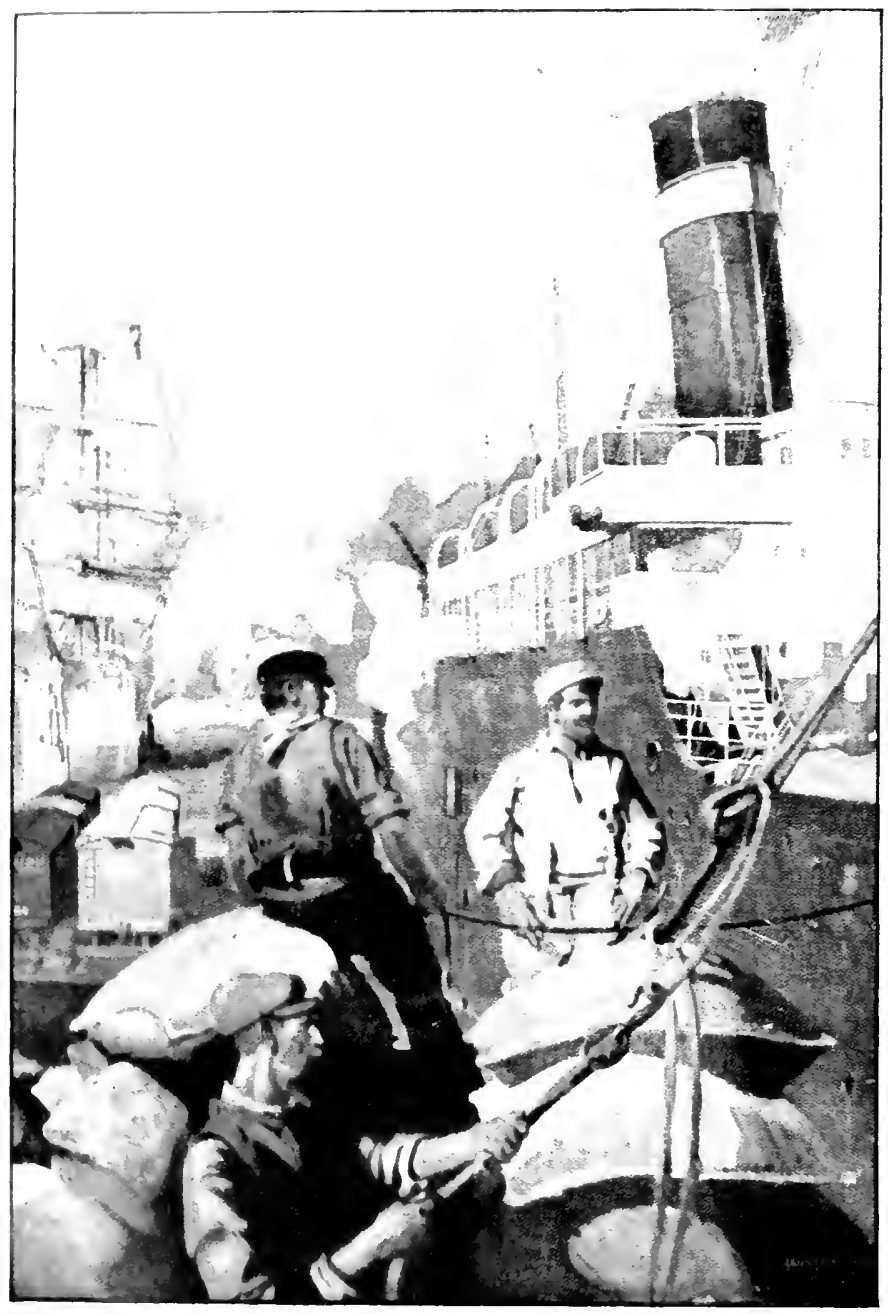

"Where the world-end steaners wait"

Kiphivi, "The seven reas." 


\title{
COMIERCTAL AND
}

\section{INDUSTRIAL GEOGRAPHY}

Bi)

\author{
ALBERT (ADLLATA KELLER
}

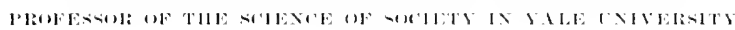

( NI)

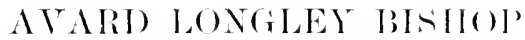

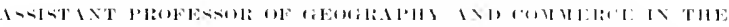

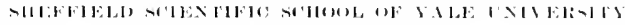

23690

GINN AND COMPANT

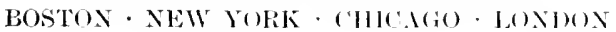




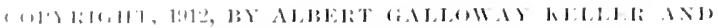

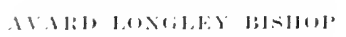

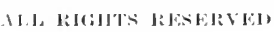

912.4

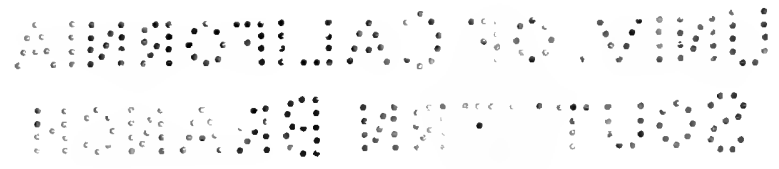

$2+1$

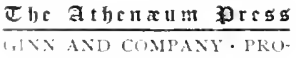




\subsection{8 \\ PREFACE}

In this volume the authors have tried to present a simple, practical study of the representative facts of commerce and industry, as interpreted in the light of scientific principles.

The leading aspects of commerce and industry are treated under three natural divisions, corresponding to the three great needs of man : Food, Clothing, and Shelter. The facts of the commercial and industrial organization are constantly referred to the physical, human, and social factors which give them meaning. The conditions of human life are brought into relation with those of nature, thus affording to the boy or girl some principles about which to group and hold together a knowledge of facts.

Because of the reasoning required, this study is redeemed from becoming, as it too often has been, a mere series of unrelated acts of memory. It is also intencled that the child shall constantly utilize knowledge which has been gained in the studies of preceding grades. What has been previously learned in geography, physiology, and science and nature studies in general is here converged upon a simple survey and explanation of the economic and social life of the present day. Thus the student is shown the use of what he has been studying.

The authors wish to acknowledge courtesies extended from several sources in the preparation of the manuscript and in securing the maps and illustrations. Mr. George II. Martin, of I ynn, Massachusetts, has made many valuable suggestions as to content and treatment. Thanks are due also to Professor Albert P. Brigham for permission to use several maps in his "Commercial Geography"; and to the Bureau of American Ethnology, from whose unrivaled collections of photographs many of our illustrations have been derived.

YALE UNIVERSTTY THE AUTHORS

New Haven, Connecticut 


$$
\text { . }
$$




\section{CONTENTS}

PART I. THE INIUSTRHES (F TIE WORLI)

(1131TR

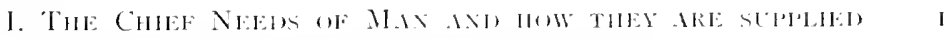

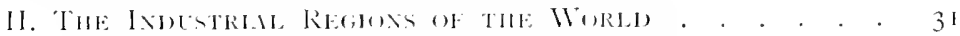

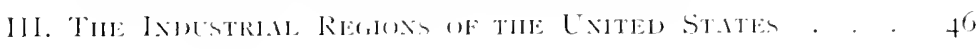

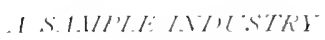

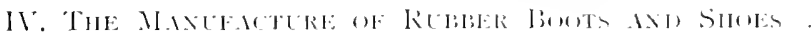

IART II. F()I) ANI) F(x) MATERISAS

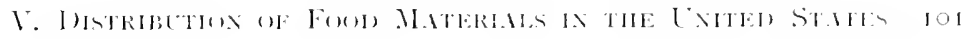

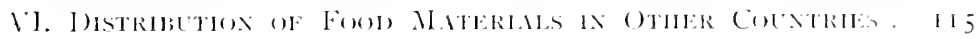

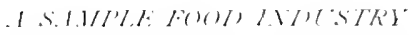

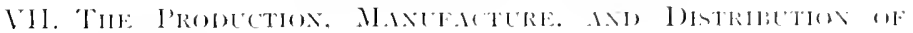

Whest. . . . . . . . . . . . $13^{6}$

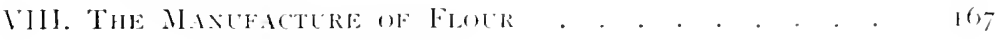

PART III. CLOTHING，.XI) CLOTHIN； MATERIALS

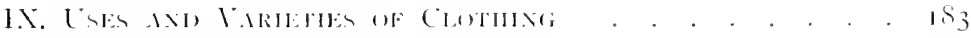

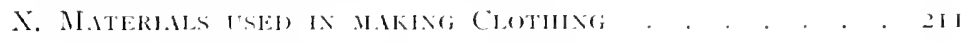

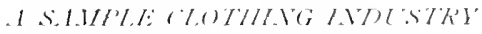

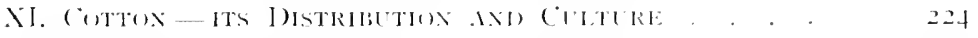

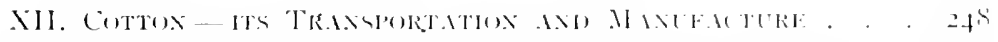

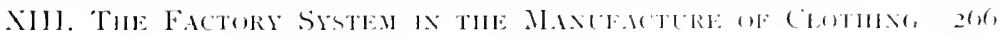

IART IV. SHELTER

XIV. Hotses axi Hotse Materials. . . . . . . . . 291

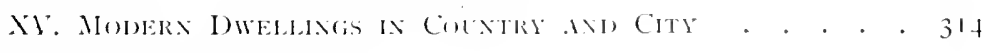

QLESTIONS FOR REVIEW . . . . . . . . . . . . . 341

INDEX . • . . . . . . . . . . . • . 353 


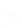

. 


\section{COMMERCIAL AND \\ INDUSTRIAL GEOGRAPHY}

\section{PART I. THE INDUSTRIES ()F \\ THE IVURLD}

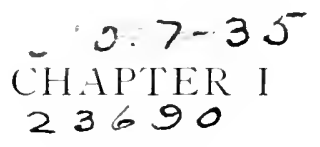

\section{THE CHIEF NEEDS OF MAN AND HOW THEY ARE SUPPLIED}

Food. If a person were shipwrecked on an uninhabited island, without any of the necessaries of life, he would want to know first of all where to get food. In his anxiety about that he would not eren think of his lack of a watch or a purse - articles which he had once regarded as necessary to his comfort. I Ie would not even care for a chest of gold pieces if he should find one on the shore, but would trade it in a moment for a small quantity of food. (Ine is never so hard pressed as when he does not know where his next meal is coming from.

The first question about food which we might ask is, "Why do we need it?" The answer is, "Because we are hungry"; but that is really no answer if we want to know the real causes of things. What does it mean when we say we are hungry? To understand the cause of hunger we must realize that it is produced by some need of the body. It is a sign that the body is not satisfied. In the same way extreme cold and heat cause a discomfort which is also a sign that the body is not satisfied.

To understand this, we must know something about how our bodies are made and how they act. This belongs to physiology, 
amb the kmowkelge we set from that subject we must use here. The borly is composed of millions of tiny cells, which unite to form its various parts, such as the bones, muscles, nerves, and brain. Erery time we move a muscle or exercise our brains, some of these cells are used up and are then carried away by the blood or otherwise

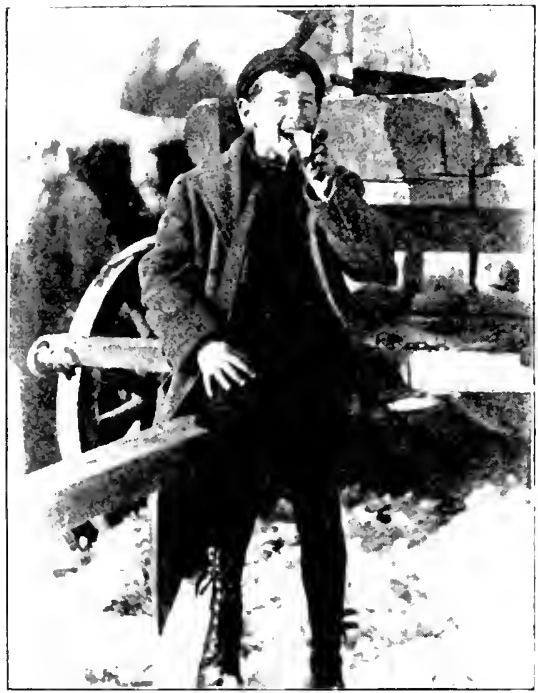

E.ITIN: IS A TLEASIRE AS WELL AS A

Necessity removed. But we eannot prevent this even by lying perfectly still and not thinking, for there are organs, such as the heart, which act all the time without our being able to have any control orer them, and the cells of these are constantly wasting away and disappearing. This occurs eren during sleep. If these cells are not in some way replaced, the organ must gradually dwindle in size and in strength.

The way in which these cells are restored is by the formation of new ones to take their places, and this is possible only when the oran is properly nourished by the blood. The blood flows as a licpuid through erery part of the body, bringing nourishment and distributing it to the various organs. This nourishment is poured into the blood from the lymphatic system, which takes it from the intestines. In the intestines the nourishment is taken out of the fluid called chyle; and the chyle, as we learn in physiology, is really the food after it has been ehewed and swallowed, and finally. digested; that is, acted upon chemically by the various fluids of the mouth, stomach, and intestines. Thus the course of the food is from the mouth to the stomach, to the intestines, into the lymphatic system, inte the blood, and finally to the various organs. Here 
the cells are fed and kept healthy and ready to produce new cells to take the place of worn-out ones.

Hence the replacement of the cells in any organ is dependent upon the eating of food, so that food is the most important need of the body. We ean see what lack of food does in the case of a person starving to death. The weight of the body decreases. First the fat cells disappear, leaving the body, as we say, nothing but skin and bone. Then the muscles and the various organs suffer. The starving person becomes very weak and presently dies. This shows that the need of food is, for the human being, greater than any other need.

If there were no such thing as hunger, and if food did not taste good, perhaps a person might

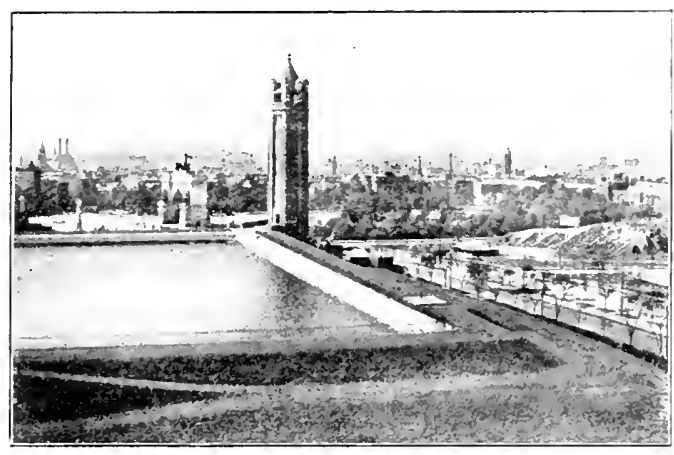

(C) Detroit Publikhing Co.

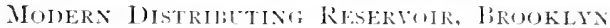
not eat until he was near death. Nature causes each one of us, if we go too long without food, to feel this painful sensation of hunger, which forces us to eat. If a person becomes extremely hungry, he gets to be ravenous; that is, he forgets his manners and everything else in his eagerness to secure food. Shipwrecked sailors have been led to eat all manner of disagreeable foods in the effort to preserve life. It is plain, then, that hunger is only a danger signal which shows that the body is not properly nourished.

Drink. In speaking of food we should not forget that water is also a prime necessity of the body - is really a food. Over one half of the body is water, and bodily well-being demands that this proportion shall be kept up. If we exereise violently and perspire a great deal, the moisture which we lose must be restored; and there is a sensation, thirst, which drives us to restore it. The distress caused by thirst is even greater than that due to hunger ; it 
becomes so vinlent that men may be crazed by thirst long before they are reatly to perish of hunger. Any one who has secn the immonse and costly waterworks built by large cities will realize how impertant a plentiful supply of water is considered to be. And when we see how carefully water is protected and saved by peoples who direll in very dry regions, as in the North African countries, we get a still clearer idea of its value to man.

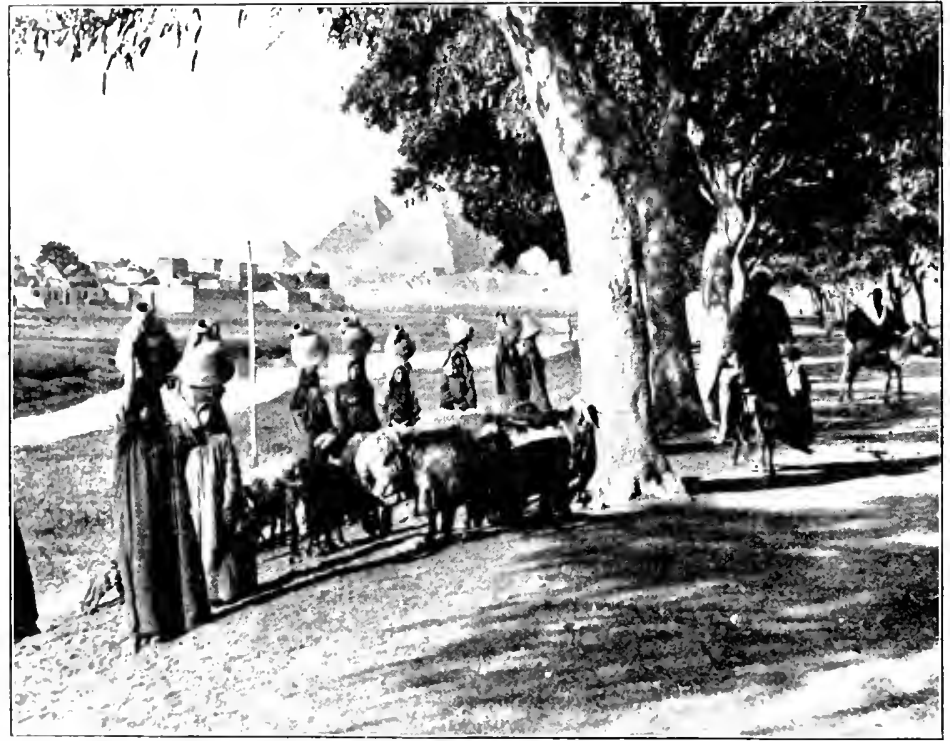

(C) Inderwood \& Inderword

1. Gisirg Whtek is Not Plentiful, and the Womex carky it in Jars

Clothing and shelter. When the hunger and thirst of our shipwrecked person have been satisfiéd, he will still be conscious of other needs. He will want clothing and shelter, for these protect him animst cold, heat, and storms. Shelter is really like clothing exerpt that it does not fit the body so closely. He will also need a fire and fuel in order to cook his food and to keep himself wam and dry.

Cothing. ("lothing, as has been said, is a protection against txuth anlit and heat. This is true also of shelter. The tent and the 
turban of the Arab shield him from the blazing sun of his native land. Even in very warm countries there may be sudden changes in tempcrature against which the body must be protected. In some deserts the change from heat to cold is so rapid at sundown that rocks have been known to fly to pieces like a hot lamp chimney sprinkled with cold water. The feeling of cxtreme heat or cold is an indication that the body is under a strain which, if prolonged, may result in the rapid destruction of cells and even in death.

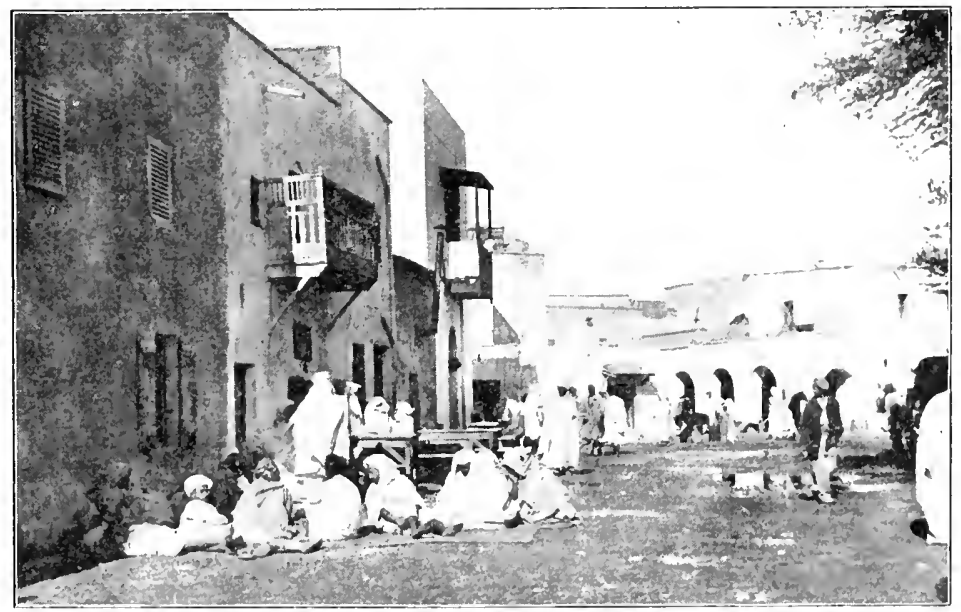

DRESSED FUR A WARM Climate

Plootograph by Brown Bros.

Thus, in a way, the discomfort of extreme cold and heat is, like hunger, a danger signal.

In fact, clothing, by protecting the body against waste, may even be regarded as a substitute for food. The food does for the body what coal does for the furnace. Not only will hot food and drink warm the body, but any food will enable the body to keep up its heat. For this reason more food is required in winter than in summer. Now, as a well-clothed body does not lose its heat very fast, it naturally does not need so much food as an ill-clothed one. (On the other hand, a fat man really has his overeorat on under his skin, and does not need the same amount of clothing that a thin man might. 


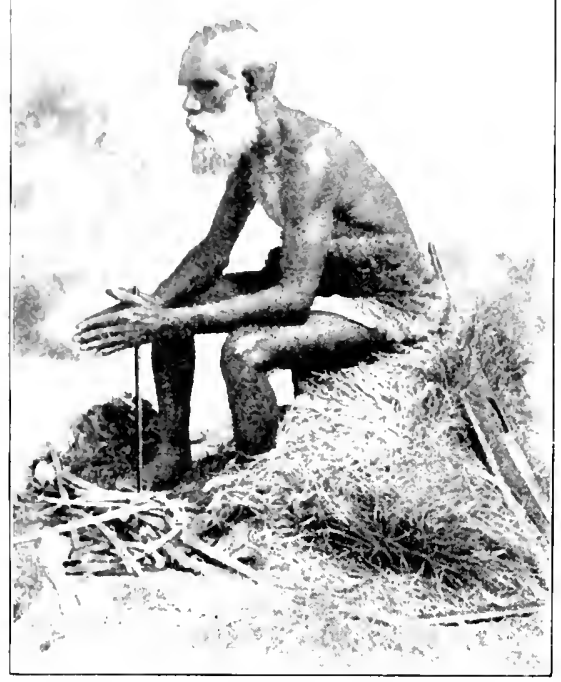

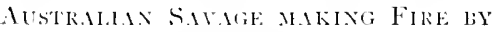
FलाTाएत

Clothing, in the form of shoes and gloves, protects the feet and hands from various hardships.

shaltor. Shelter is like clothing in the protection it gives against heat and cold, rain, and other conditions which produce bodily discomfort. In the tropical lands the savages, and even the animals, retire into shelter during the hot hours. The siesta, or midday nap, is a regular custom in hot countries. Business is suspended and few people are scen on the streets. When we come to think of the cold regions, we see all the more clearly the importance of shelter. Probably none of us, no mitter how well fed and warmly clothed, could go through a winter without shelter ; and in the fromen north it is necessary to dife thit the inhibitints shall hate weatherlisht houses.

Fire. ()ne furtherprotectionwhich human beings have is lite. The uses of tire are se many lhitt it moule! be birel to nime them all: probubly the

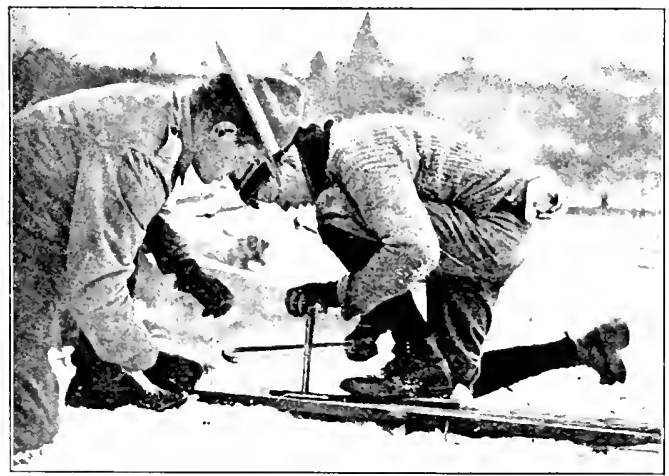

(C) Tnderwool \& I"nderwond SMatisg Fine withot Matehes 
discovery of fire was the greatest ever made by man. Fire enables us to protect our bodies by keeping them warm. It has been found that the ordinary winter temperature of the American housc is about

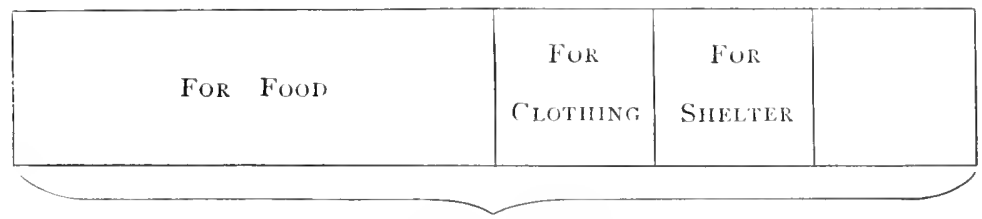

TOTAL, INCOME

How a WORKMAX SPADS IIS IXOOME

that of an Arizona desert in summer. This means that we live during the winter within a small volume of climate very different from that outside our houses. In order to keep fire going we must have fuel; and fuel, as we shall sce, is one of the important articles of commerce.

Universal character of these needs. We must not think that the need of food, clothing, and shelter stops with the shipwrecked man or the savage. Such needs continue through all stages of civilization, and are present among us at all times. This we can see by noticing how much is spent in order to secure them. It has been found that out of a workman's wages, one half or more is spent for food, about one sixth for clothing, and about one sixth for shelter, in the form of

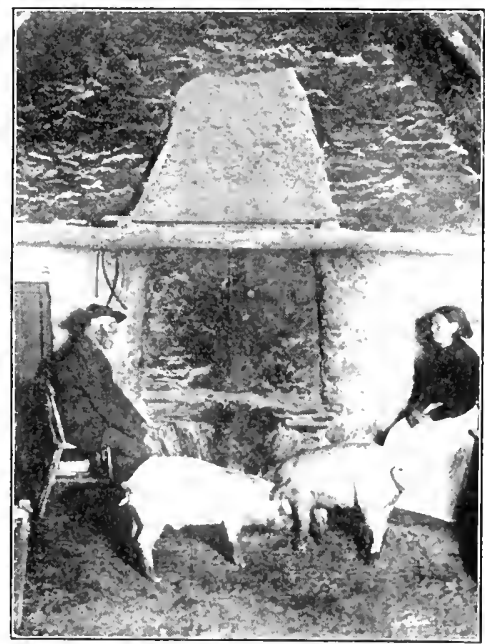

(C) I'nlerwood \& I'nderworl INTERUR (H A RUIU I'LASANT IITT rent and fuel. If a man has to spend so large a portion of his income upon these three things, it is clear that they are real necessities.

What we spend for food, clothing, and shelter is not spent so much with the idea of preserving life as of living more comfortably ; 
that is, we hate a higher standard of living, and we are always trims to secure better food, clothing, and shelter. Upon our tables there appear kinds of forel which we call luxuries. And we wish ren the simpler sorts of food to be of good quality and well pepared.

The sime is true of clothings: we are not content with clothing which simply protects us, but we wish to have it look well. For this reison we may use silk when we could live comfortably if our

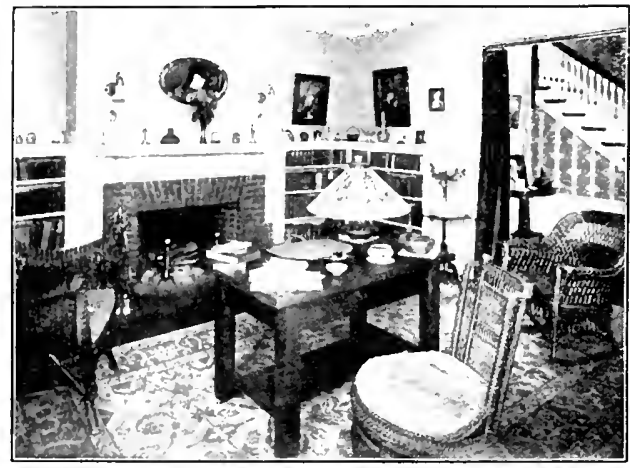

IN A MOIERX IIUME clothes were made of cotton. Ire are equally cxacting as to our houses. it hut of mud might do to keep out the cold and afford protection, but we insist upon having what we call "conveniences" in our homes. $1 \mathrm{Te}$ spend a great deal of money, too, on furniture, wall paper, and pictures, for the sake of the extra satisfaction and pleasure which these give. And not only for our comfort but for our health do we insist upon having ruming water and good scwers.

Su we see that man in all ages has needed for his well-being and happiness some of the various articles which are included in our studies of food, clothing, and shelter.

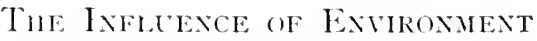

Kinds of materials. The materials from which man supplies his needs are not the same in all parts of the earth. They may be divided into two classes: (I) mineral substances; (2) those derived from plints and animals. Examples of the first would be iron, coal, clin: petrolettm; of the second, vegetable and meat foods, fruits, spicis, his, hides, wool, plant and animal fibers like cotton and wool. 
Mineral substances. Nineral substances useful to man have been located in different parts of the earth, once and for all, by nature. Salt, for instance, is to be found wherever salt can be evaporated. or where deposits of rock salt exist. Coal occurs in underground deposits, where, ages ago, trees and other regetable matter were reduced to beds of carbon. Of course, coal could never be mined on a coral island. The metals and coal are seldom found except in mountainous regions, for here the layers in which they occur have been squeezed and tilted up nearer the surface (see figure on page 36 ).

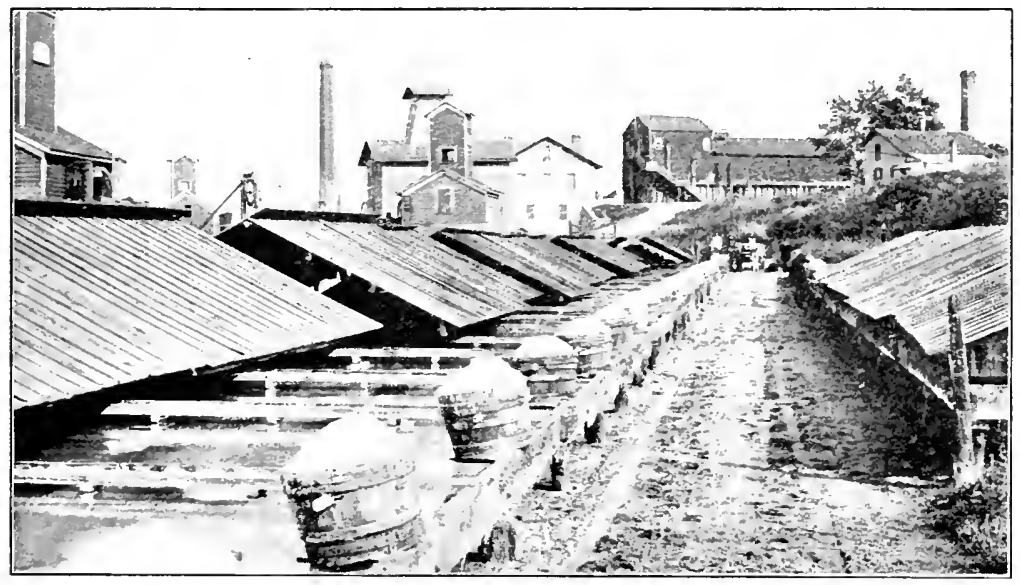

DR.ININ, SIIT, SYR.WSE, NFW YURE

These forces which have determined the distribution of minerals are entirely beyond our control - in fact, their activity took place many ages before man appeared on earth. Man, therefore, has no power to move these deposits or to locate them over again. So a comntry either has these materials or is without them, and if they are not in the ground already, there is no way in which they can be made to exist. It has been of great importance to several countries that they have had within their boundaries mines of gold, or coal, or iron. This we shall see later; but for the present it is enough to say that supplies of minerals are where nature placed them, and are a source of wealth to the country possessing them. 
Organic substances. The other set of materials useful to man are thuse derived from plint or animal life. Such life is called

"weinic." The same sort of organic life cloes not exist in all resins. In one comntry there are limitless forests, in another sonceh ans trees at all. ( )ne region will be like a great menagerie, whike in inculace a triveler can journey for days and see scarcely it living creature. I'lants and animals, like minerals, have been distributed by natural foreces orer which we have no control. Oranges will not wow in Greenland, nor groves of pine trees on a tropical shore. The polar bear would die at the equator, and a monkey would sox) perist] of exposure if suddenly transported to Spitzbergen.

The effects of environment. We know little about the natural furces which caused the distribution of minerals; but concerning phants and animals we know more. Both plant life and animal life are determined by natural or geographical conditions, such as ciimate, altitude, and the presence of water. There can be no fish in the desert, and "e have seen that the polar bear cannot live in the tropics. I'tati we find is that the plant or animal fits the natural conditions in which it lives. All these natural conditions, - atmosphere, rocks, rivers, trees, and the rest, — taken together, are called the "enviromment" ; and so we say that all living beings must be fitted or adapted to their environment.

The polar bear. Nature is full of examples of this. The polar hear is a geod illustration. In the first place, his fur is thick and long, which enables him to live comfortably in a eold land, though it is a source of great discomfort if he happens to be brought into a warm country. This we can see when polar bears are carried about in eitptivity; on a hot day they are evidently very uncomfortable in their cages. Unless they are taken good care of, they will soon lice. The fur of the polar bear is white, and this is a great advant.1.2. whim in a land of snow and iee. Not only does he escape purvit himself because he is not easily to be distinguished from his shom! mironment, but he can creep upon his prey without

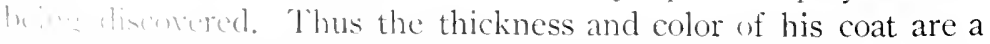

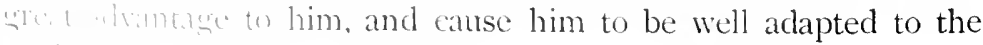
in which he lives. 
The camel. The camel is an example of actaptation to an entirely different kind of enviromment. This animal lives in the desert and leads a life very different from that of the pollo bear. The feet of the camel are broad and spongy, and cnable him to walk over the shifting sand without sinking in, as a horse would. They serve the same purpose as snowshoes, and sare him a great cleal of effort. Again, he is able to close his nostrils, and so can live through the sand storms with ease. He can go without water for a long time,

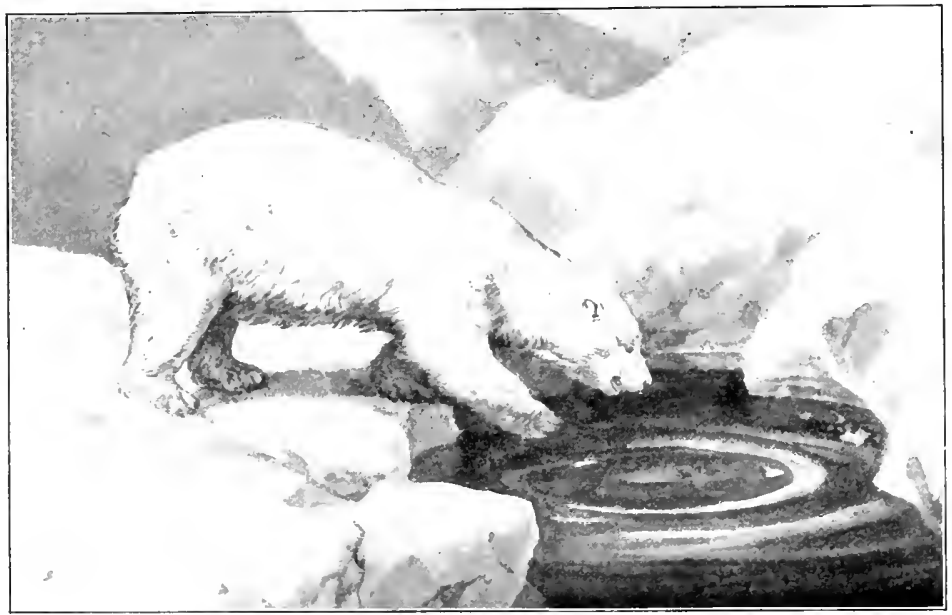

POLAR Bear (ietTiNg his FoOD

and when he gets a chance to crink, he is alble to store up water in his body for future use. Furthermore, he can travel a long distance without food, for the hump on his back is only a mass of fat and is grachally taken into the blood as food becomes scaree.

Plants. Not only animals are adapted to the regions in which they live; plants show the same adjustment. The plant which grows in the descrt is able to exist on a small quantity of moisture; its stalk and leaves are glazed and shing, which means that they are so constructed as to lose by evaporation very little of the moisture which they contain. On the other hand, there are plants, such as mushrooms and swamp plants, which can only grow where there 
is a great deal of water in the soil. Some grow in the water, like pond lilies. Mlost of them need at great deal of sunshine, but

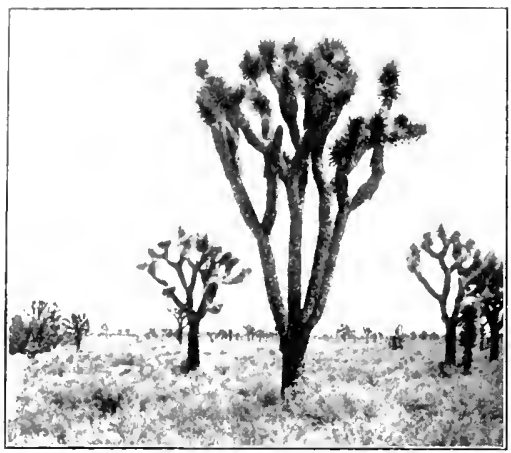

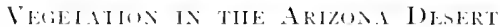
there are a number of kinds which grow best in the shade of heary forests.

\section{Variations in the necessaries} of life. We see from these few examples, to which might be added thousands and thousands of others, that organic life differs in different environments ; and as there are not many places on earth which are precisely alike in climate, rainfall, and other conditions, we must not expect to find many regions which have, by nature, exactly the same lind of plant and animal life. For this reason the food, clothing, and shelter of human beings in different regions, when ob. tilined from the plant or animal life of the region, we not likely to be the same.

The Eskimos. This maly be shown most clearly if we compare tro perples who live in rery different environments. The liskimos inhabit the polar regions. and their forod, clothing, and sheltar are derived

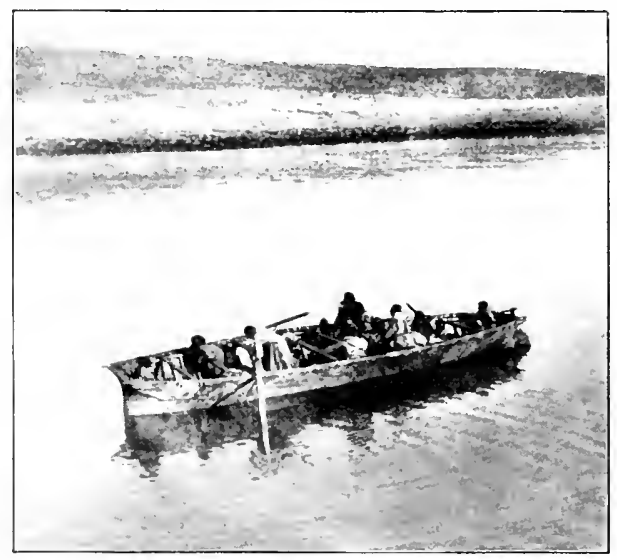

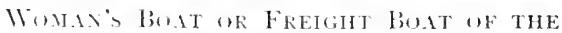
ESKIMO

almust cutirely from the animals and plants of the arctic zone. There anc but fer plants in this region, and it is only in the short smmer that these are to be found: consequently the 
Eskimos are obliged to get along almost entirely with materials taken from the animal world. Let us see how this affects their

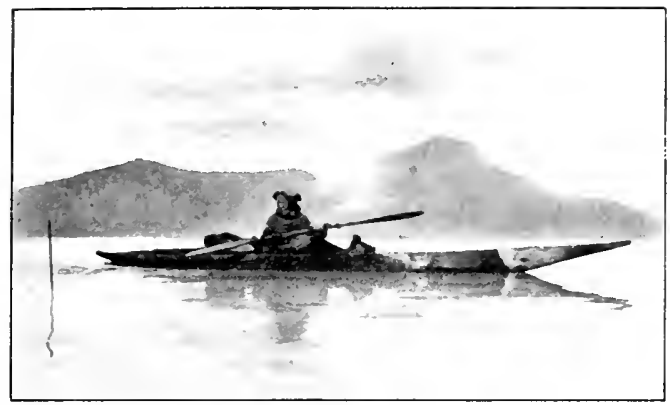

MAN'S IMAT OR IILYTIXg lWAT OF THE ESKIIO method of living.

The food of the Eskimos is largely. the flesh of animals and fish. They kill the walrus, seal, bear, and other animals, and are able to get only a little vegetable food from the mosses and berries collected in the sum-

mer. Their meat food contains a great deal of fat, or blubber, for the animals of the far north are protected from the cold by having beneath the skin thick masses of fat. The Eskimos, like the animals, need this same sort of protection, and they grow fat upon the fat food they eat. It would be very difficult to find a lean Eskimo; they are fat and oily-skinned, and they like the blubber as well as we like our lean meat and vegetables. Anything that is greasy or oily seems to please them, for this is the kind of food which the body, in that environment, calls for.

The clothing of the Eskimos is made from the only materials they know; that is, from the

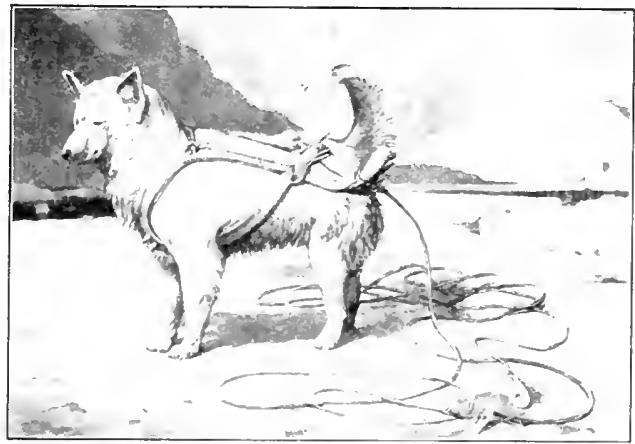

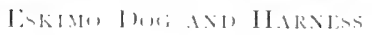
skins and other parts of animals and bircls. The underwarment is sometimes of a softer skin, but the outer chething is of fur. As it is necessary that their cluthing shall be water-tight, the trousers 
amd bonts maly be of one piece, with the seams carefully packed with serease ; the coat, hood, and gloves may also be made in one piece. Babies are carried in a warm pouch, or hood, lined with dimn and soft fur, on the batels of the mother's coat.

It would be interesting to notice how the other possessions of the Eskimos show their dependence upon their environment. For instance, sinee there is often no wood, except oecasionally driftwood, the Eskimo boats are made of hide stretched over frameworks

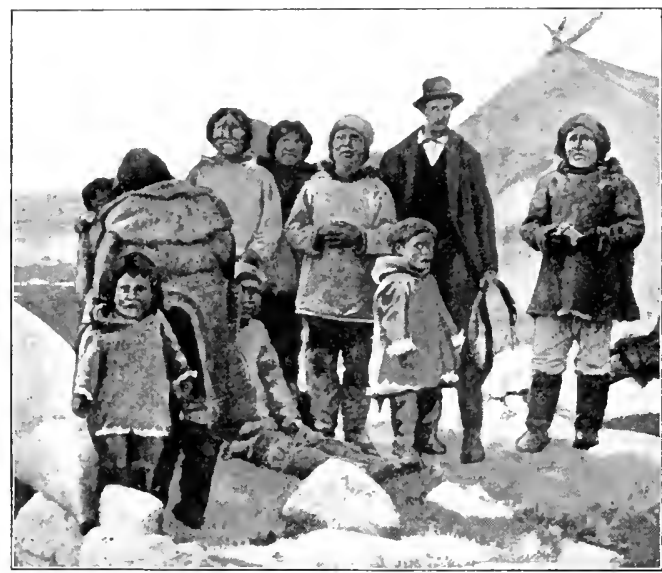

ESKIIO CHLLELA ARE ROENL ANE FAT of bone; the Eskimo sledge is made without nails or metal, is tied together with rawhide, and is sometimes shod by freezing small fish in a row along the runners. Practically everything used by the Eskimos in hunting is made of bone, horn, skin, glue, or other substances derived from animals.

When it comes to shelter, we find the Eskimo building his winter house of the only material at hand which will keep out the intense cold. The house is made of blocks of hard-packed snow, cut out with a knife and built inte the form of a dome. The entrance to the house is a lw passage just high enough for a man to crawl through on his hands and knees, and the door is a block of snow. Inside this house the temperature can be raised to a very high degree by the use of an cil tamp.

The furniture of the house is mostly of snow. The becls are snow benches cosered with furs, and if there is a table, it is a squane bloxk of snow. Light is let in through blocks of ice, which tatie the place of glass. The stove and the lamp are one and the 
same thing - a shallow bowl of soapstone filled with oil pounded out of frozen blubber, and with a wick made of moss.

As these houses fall to pieces under a warm sun, the Eskimos change their lodgings in the summer and live in tents made of skin, which are pitched on the shore.

The Pueblo Indians. When we contrast this sort of fond, clothing, and shelter with what is required in other parts of the world, we

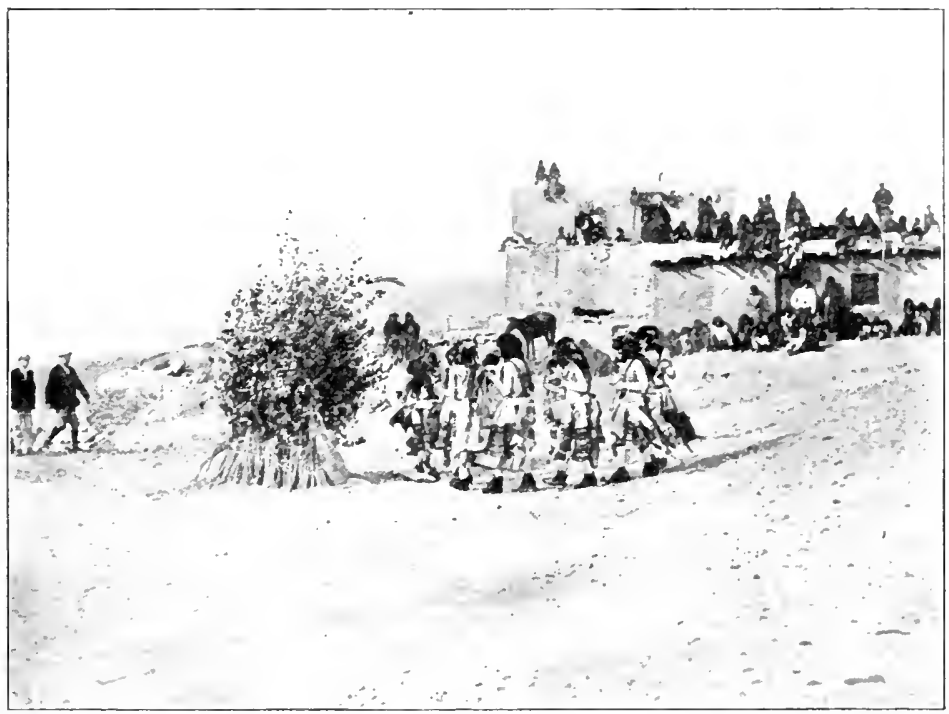

Courtery ol binrean at Anerican Ethoulegy

SXAKE D.NCE WF TIE PLEHLO INIIANS

get a clear idea of how the life of man varies in different localities. In the far llest of our own country there are a number of Indian tribes inhabiting the arid districts of Arizona and New Mexico. Of these, the \%min, Hopi, and some others alle often called the "Pueblo" Indians, because they live in a commmnity, which is what the Spanish word proble means.

It is of these that we intend chiefly to speak, for they show rery clearly how man's life must be directed in a nearly rainless reasion. The whole existence of these tribes seems to eenter on the question 
of waler: and their priests, or medicine men, exert all their magic in oreler to get showers at the time when the crops are growing. They have a coremeng called a "smake dance," which they think is necessary in order to secure rain. The priests dance about, holding live rattlesnakes by the necks in their teeth; then these snakes are let bose to tell the gods that there is need of rain.

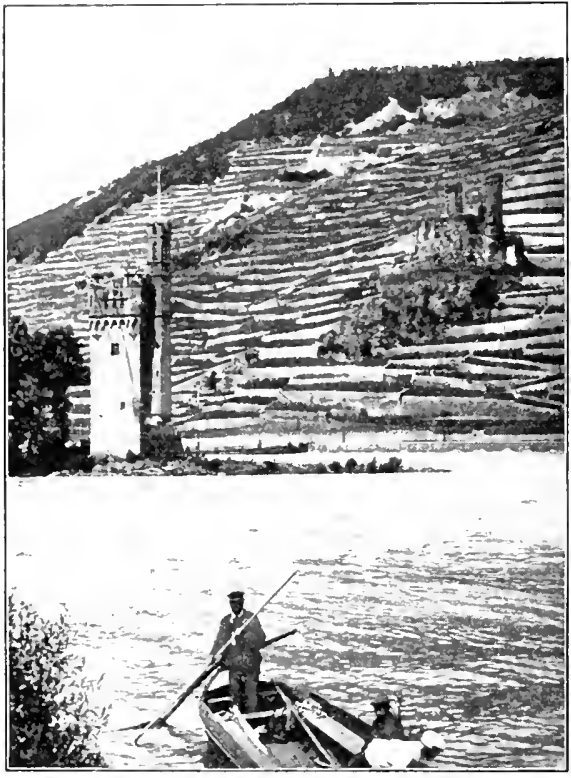

(C) Inderwori \& Inderwoul

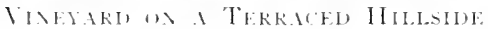
(iI.KMNY)

The food of these tribes consists mainly of a few regetables, and corn, which they can grow if they exercise the utmost care. Before the white men brought domestic animals to them, they had no flocks, but of late they have taken to raising sheep in considerable numbers.

The great need of these people has always been water, and the great fear that of drought. Water is often carried to the crops in jars, and the utmost efforts have been made to prevent its waste. Irrigation has been practiced for centuries, and the land where there is some moisture has been cultivated most painstakingly. Terraces have been built on land sloping down to the streams, in order to use every bit of the moist soil.

Mbout it third of the crop of maize is saved every year in case uf future crop falure through drought. Any accident to the harvest is bikely to reduce these Indians at once to the verge of starlation. It such times they have to fall back on the plants of the desert for forul. The animals which they have need water, too, 
and when times are hard these desert tribes become discouraged, break up their settlements, and try to find a better place. In thus wandering about they come into contact with other tribes, or with white men, and there is likely to be trouble. In order to provent this, the government has recently sent out to the l'ueblos geolugists, who are trying to get water for them by boring artesian wells.

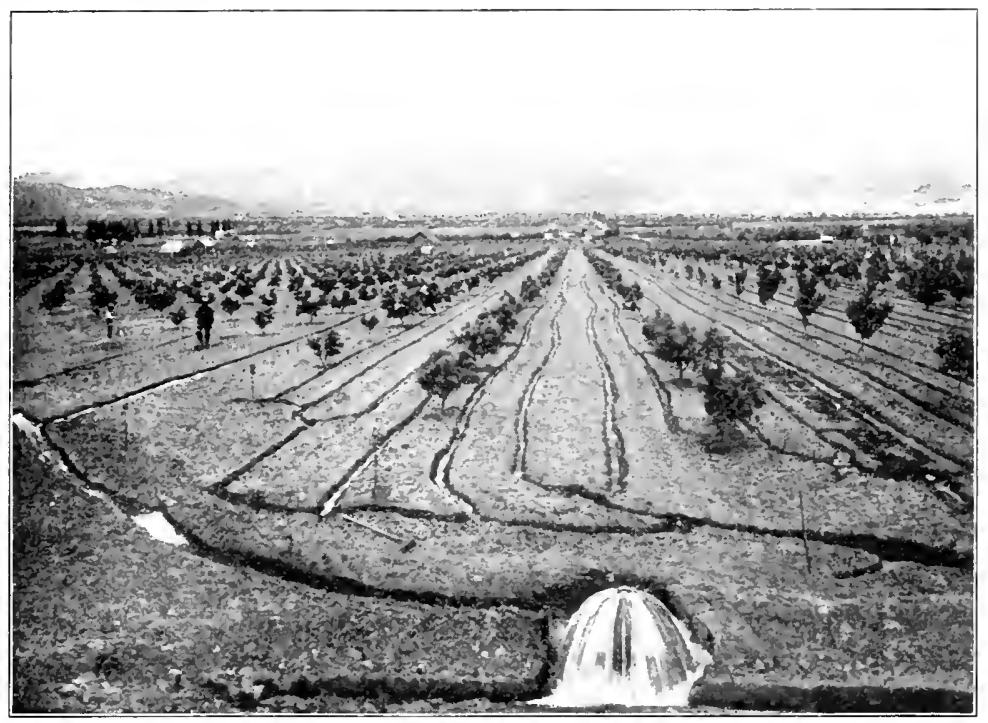

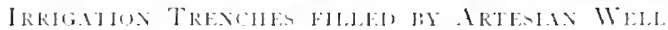

The clothing of these tribes is composed of cotton, which they have long raised, and wool from their sheep. They hase become skillful in spinning wool and in wearing the yarn into cloth. They make blankets, and dye them with substances obtained from the plants of the region. These blankets are often rery beautiful. Before the sheep were introduced the leubles hat only outton, rabbit skins, and wher products of their coviromment to chothe themselres with.

The natural cavities in the cliffs alle often the only homes of these Indians of the desert: ther are then called "cliff chellers." Elsewhere sandstone and lata blocks have been used, and among 
the southem l'uchles clay, or adolse (a-do'bé), was the chief building matcrial. This clay is not burned hard in a fire, as our bricks are burned in a kiln, but is simply sun-dried; it therefore remains comparatively soft, and if continuous rain occurred, these houses would som melt awaly. The base of the wall is generally of stone, to withstand what moisture there is on the ground. It is only the absence of rain in these regions which makes it possible for houses built of the adobe, or sun-dried clay, to last on for generations.

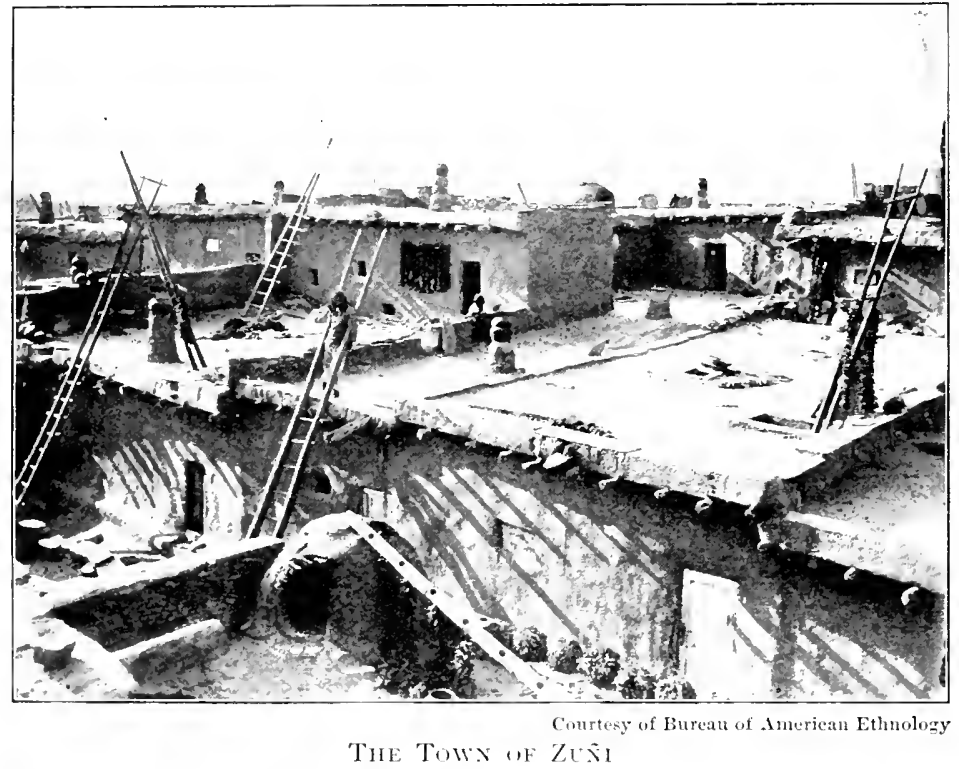

The shape of a house built of such materials must be different from that of the Eskimo hut. The adobe house is narrow, with sfune corners, instead of being round and dome-shaped. The Pueblos have never leamed to build a dome, and probably the Eskimos would not have learned if they had had any wood for beams.

These houses were built in numbers close to each other, until they formed a sort of town, or fuchlo, looking like a pile of boses. () n hillsides they were built terrace fashion, the upper tiers of houses being set beak if those next below, so that the roofs of the lower 
stories formed a sort of front yard for those next above. As a rule, these dwellings were entered from the roof by moxable ladders, which were sometimes only notched tree trunks; there were few openings in the side walls. Chimneys were often made of pots whose bottoms had fallen out, set one upon the other.

The sort of life which the I'ueblo leads is thus different from that of the Eskimo, largely because the environment is different.

\section{THE INTSION (IF LABOR}

Natural limitations. Thus far we have shown how man's life is determined by the natural conditions amidst which he lives. We see that he is imited on all sides, and that his life is made what it is by forces which he cannot control. In the course of time, however, he learns about these forees and gradually gets to a point where he can make some changes to suit his desires and needs. Man is never content when he is limited and prerented from living more comfortably and easily. He is always trying to satisfy his needs better and to gain greater adrantages.

Often he blunders almost by accident into ways of doing things which make life easier. It may be that he happens to think of some new derice or

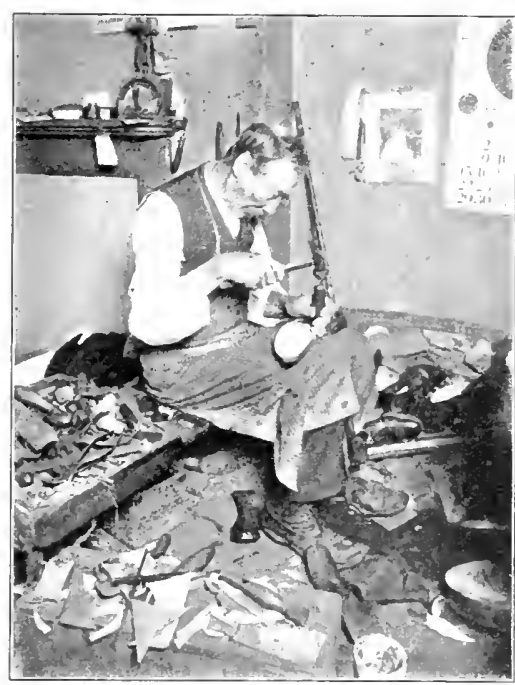

The Cumber Mabe THE ExTlke SHoE invention, and, seeing the value of it, never lets it go atgain. Chief among these valuable discoveries was one made by man in very early times; it is what we call the division of labor.

Reasons for division of labor. If every person provicted for all his own wants, there would be a sreat waste of time and labor, 
with rery porer results. Suppose three men, A, B, and C, prepared ach his own food, clothing, and shelter. Suppose each man spent five hours in retting food, five in making clothing, and five in building shelter for himself; then the three men would spend forty-five hours in providing themselves with these necessities. But

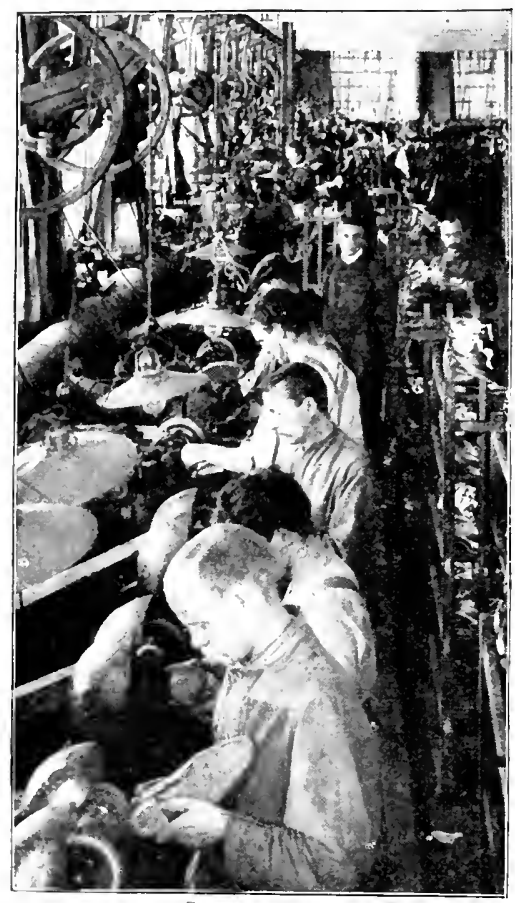

Courtesy of buot am shoe Recorler.

A MGIREX SHoE SHor suppose A were to get all the food for the three men, while I) made all the clothing for the three, and $\mathrm{C}$ built all the shelter for them; and suppose that they made this division of labor a regular custom. Then each of these men would get practice in doing one particular thing, and, as we know, " practice makes perfect." That is, by putting all his attention on it and doing nothing else, A would soon be able to get food faster than he could before; $B$ could make clothing faster ; and $C$ could build shelter faster. There would be a great deal of time and energy saved, because each would get into the habit of doing one particular thing, and could do it not only faster, but also with less effort and waste.

Practical results. If we put this into figures, we may say that A. with practice, might be able to get in four hours the food which he userl to get in five: and $\mathrm{B}$ to make clothing, and $\mathrm{C}$ to build shelter, each with the same saring of time. Then each man would work twelve hours instead of fifteen, or, all together, they would work thirty-six hours instead of forty-five. This may be clearly secm if put in a table. 
Thus: A formerly spent

$$
\begin{aligned}
& 5 \text { hours in getting his own food } \\
& 5 \text { hours in making his own clothing } \\
& \text { Total } \frac{5}{5} \text { hours in building his own shelter }
\end{aligned}
$$

A now spends

$$
\begin{aligned}
& + \text { hours in getting food for } \mathrm{A} \\
& + \text { hours in getting food for } 13 \\
& + \text { hours in getting food for } \mathrm{C} \\
& \text { Total } \mathrm{I} 2 \text { hours }
\end{aligned}
$$

A has saved three hours by the extra skill which he bas gained in doing but one thing; and the same would be true of $B$ and $C$. All of them would save effort as well as time, for none of them, in doing all the time one kind of work which he liked and was used to, would work as hard as when he was trying to do three kinds.

Advantages of the division of labor. This system, whereby one man does one thing alone, and other men other things, is called division of labor. Where there is division of labor one is likely to do that which he can do, or likes to do, best. Suppose that in an Indian tribe there is an old man who is not strong enough to hunt, but who can make fine bows and arrows, and a young man who can hunt and wants to, but who is not skillful in making bows and arrows, and who would rather not do it even if he could. Then the old man can make all the bows and arrows, and the young man can do all the hunting. Then the old man can gire the young man a new bow and arrow for a portion of the game, and both will be better off.

Improsement in product. It is also true that division of labor results in a better product. We have a saying that "a Jack of all trades is master of none" ; that is, he can do a great many things fairly well, but nothing extremely well. We could not trust him in a matter of great importance. When we are seriously ill we wish to be treated by a man who has studied that particular jllness rather than by an ordinary doctor, because the specialist ought to know more about it, and usually does. Supposing every man had to make all of his clothing. I'e can easily imagine what 
(fuere-lowking people would be walking about the streets. Robinson (moste made his own clothing, and while it is interesting to see the result in pietures of him, any one who should go about the streets to-diay, looking as he did, might be arrested for creating at public disturbance. He would look even stranger than the man in New lork, who wore a straw hat one New Year's Day and was arrested because he was surrounded by a jeering crowd which obstructed the streets. But supposing one man made nothing but hats, another nothing but shoes, another nothing but coats, then

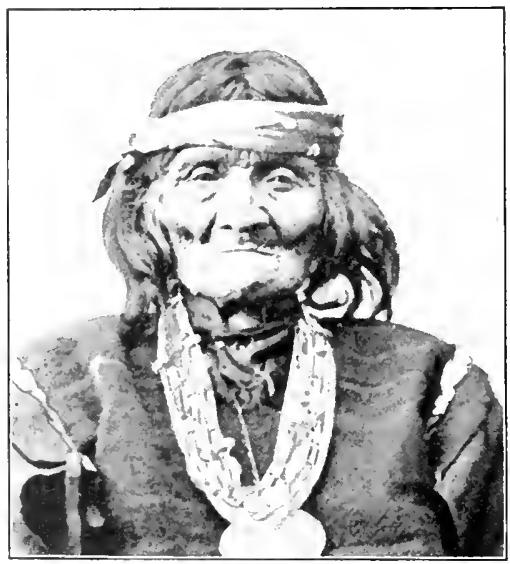

C'untesy of Burean of Amencan Ethology

Ti川 (1.1) FOK IIUNTING, HE CAN MAKE THE louNg MaN's ARRows each person would constantly improve, and what he made would fit better and look better than the work of untrained hands. That is, when we have division of labor the product is usually better than one person alone could achieve.

Procution of a'aste. Moreover there is less waste. If one of us undertook to cut a suit out of a bolt of cloth, he would make mistakes and cut in such a way as to waste a great deal of material. But a tailor, who makes a specialty of such things, wastes scarcely anything in cutting out a suit. And so it is in all trades. The carpenter wastes less wood than one of us would do, the plumber less lead and solder. The greatest skill of men has been exercised in the effort to save material and labor which might otherwise go to miste. Most of our machines are "labor-saving devices." Of course, this economy of labor lowers the price of what is made.

Division of labor between groups of men. Division of labor may take plice not only among individuals, but also among groups of men. Fir instance, there are tribes which spend most of their time in mining, while there are others which do not mine at all, 
but raise cattle. The tribes which do the mining become experts and are able to get flint or copper in less time and with less effort than another tribe would expend for the same result. On the other hand, they know nothing about cattle raising, while the cattleraising tribe becomes expert along that line. In modern times one nation becomes skillful at manufacturing, while another does little manufacturing, but becomes successful in agriculture. Some states of our country are what we call manufacturing states, while others specialize chiefly in agriculture or in mining.

Whether division of labor occurs among individuals or among groups of men, the result is the same. Skill is acquired, time and labor are saved, the result is better, and there is less waste.

Influence of natural products. Just as in division of labor among individuals each man does what he can do most easily, because it falls in with his talents and abilities, so it is with groups of

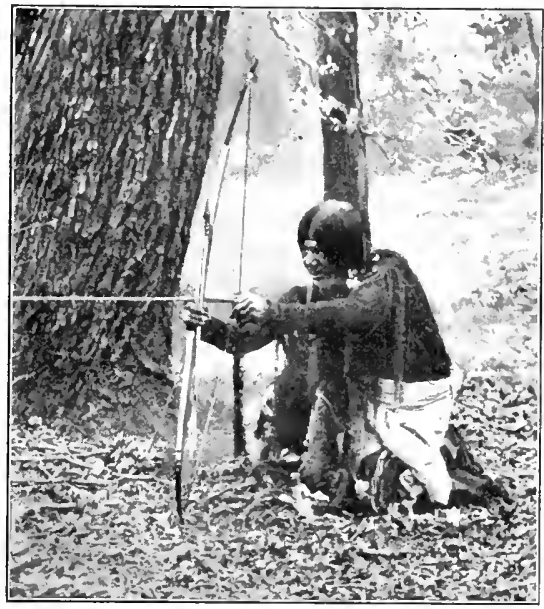

ruUng INDIAN IIUNTER

men. A group can produce most easily from that raw material which can be obtained in greatest quantity and with the least effort. If a group does that which is easiest for it, it will make a specialty of producing such food and clothing as correspond to the plant and animal life of the region. This shows how the industries of a region are largely dependent upon its natural products.

There are cases where the whole life of a people seems to center about one plant or animal. Take the bamboo; its tender shoots are used as food, while from the stalks are made posts, poles, rafters, flooring, masts, fire-making apparatus, weapons, buckets, baskets, furniture, and even a kind of paper. 


\section{COMNERCE}

The benefits of exchange. Another way which men have adopted to provide themselves with necessities is the result in large part of this division of labor. (Of course division of labor would be of no use to $A, B$, and $C$ if they could not trade or exchange with one another; for if A proviched three times as much food as he needed, and then were unable to exchange with $B$ and $C$, he would have a great mass of food, to be sure, but he would have no clothing and no shelter. If the old Indian could not trade with the young one, he would have many bows and arrows, but no venison; and he could not eat the bows and arrows, however hungry he was. In the same way, if one tribe had mined enough copper for the use of two tribes, but could not exchange it, it would have all this copper, but no fond; and if the agricultural states of the IVest were unable to exchange their corn for something else, they might find themselves with so much grain that they could not possibly use it all, but entirely without many other things which would contribute to their comfort. It is only by exchange that the valuable results of division of labor can be won.

The extent of exchange. Exchange is what we generally call trade or commerce. Among savages there is very little of it, but trade, like division of labor, becomes more highly developed as civilization increases. In fact, it is largely through the perfection of division of labor and of tracte that the civilization which we enjoy has grown up. It is difficult now for us to realize that there was a time when commerce scarcely existed, for we have come to talie these things as a matter of course.

Hatcrials for food. If an Indian boy were asked, while eating his dinner, where his food had come from, he would have no trouble in answering the question. IIe would have seen the dead deer from which the meat before him had been cut; he would have seen the corn growing, from which later the mush had been made: perhaps he would have seen the older people getting the salt, with which his food was flavored, by evaporating sea water. Ilis clothing and shelter too would have been made before his 
eyes from the skins of deer or bison, and his toys from materials with which le was familiar.

But if the American boy is asked to explain where his food, clothing, and playthings come from, and from what they are made, he can answer only in part. L pon looking the matter up, he finds that what he eats and wears often comes from a great distance, and that many grown people have never seen the plants or animals which furnish some of the food and clothing materials for civilized peoples. For instance, one may see on the dinner table bread,

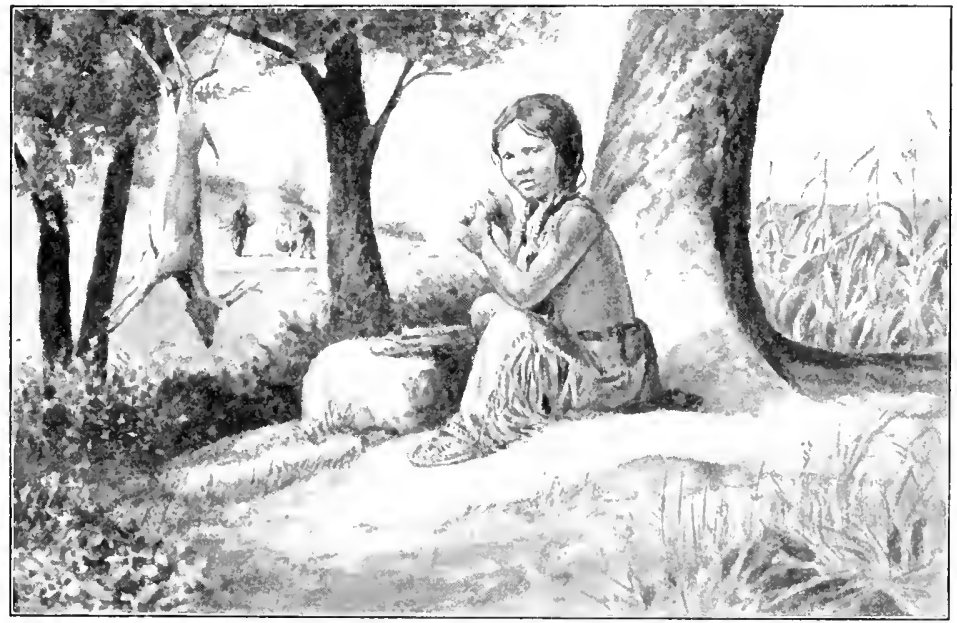

INH.AN ('HHLD EATING HIS IONATR

macaroni, salt, pepper, sugar, olives, beefsteak, cheese, bananas, and coffec. But these foods come from very different localities. For instance, the bread may have been made from Kansis wheat, the macaroni from another kind of wheat in Italy, the salt mily have come from San Francisco bay, the pepper from the last Indies, the sugar from I Iawaii, the olives from Italy, the beefsteak from cattle raised in the Middle West, the cheese from Switzerland, the bananas from Jamaica, and the coffec from Brazil. If there were some such article as minec pic on the table, the materials from which it was made might have been as follows: wheat flour from 
Minmeapmis, apples from l'ennsylyania, lard and meat from Chi(a) corrants from (incece, rasins from California, lemons from Sicily, oranges from librida, brandy from France, sugar from lonisiana, spieces from the bast Indies, and cider from Connecticut.

l'antically all the countries of the earth would contribute to supply the table if the bill of fare were somewhat more extensive. It might easily include tapioca from Venczuela, sago from the Vist Indies, cocoa from Ecuador, coconuts from Samoa, cinmamon from Ceyton, cloves from the Molucca Islands, pepper from Cayeme (Guiana), dates from l'ersia, tea from India or Japan, onions from Bermuda, salmon from Labrador or Oregon, and corl from the Newfoundland Banks.

Thaterials for clothing. Similarly we call upon the wide world for our chuthing: the cotton from which much of it is made is a product of some southern state in our own country, or of Egypt, and the furs are taken from animals which could not live where we do. Some other artickes of clothing derived from far-away lands are silk from lapan, alpaca from the Andes, linen made from flax grown in Kussia, woof from Australia, keather from Argentina, and rubber from the Kongo or Amazon region. Buttons of bone, horn, and pearl, together with whalebone, dyes, and other articles useful in making clothing, also come from a great variety of regions.

Materials for shelter. The materials for building and furnishing houses are derived from widely scattered sources. The various woods might be tilken as an example: mahogany from Honduras, teak from the last Indies, pine from Canada, cypress from the South, bambor from the Philippines, and oak, cedar, ash, and chestnut from different parts of our own country. Of the more common metals, iron misht have been mined in Pennsylvania or Missouri, copper near lake Superior, silver in Arizona, jead in Colorado, and tin in England or the East Indies. Glass, cement, tiles, and brick seldom come from the immediate locality where the building is going on. And if we were to go further into houschold furnishings, we might find it wreill number of articles, such as rugs made of jute grown in Bengal, hambon chairs, Swiss clocks, English "china," German cutlery, lipanese rases, Russian brassware, and French tapestry, 


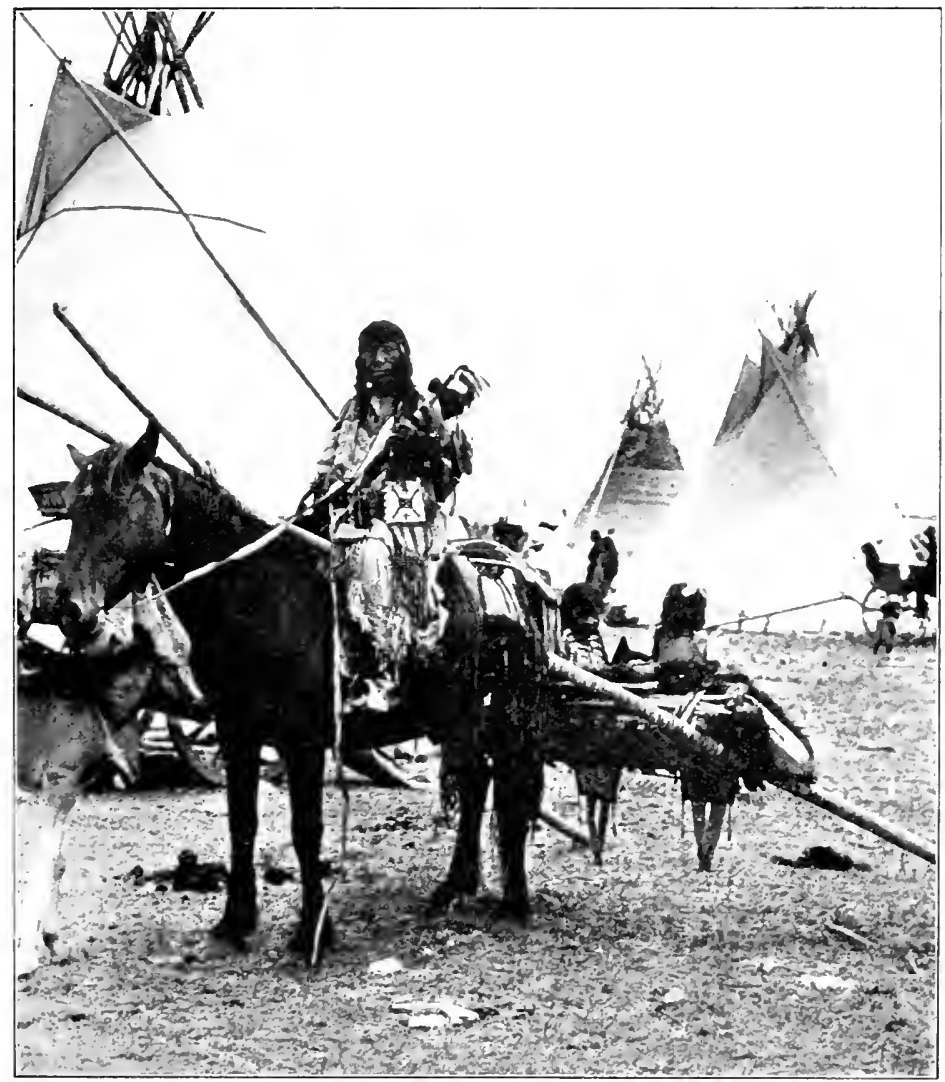

Photoeraph by N. A. Forsoth

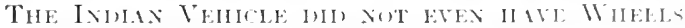

which would further show how dependent we are upon the productions of distant parts of the world for the articles of our daily life.

Supply and demand. In view of all these facts, a child living in a civilized country might be puzzled to answer questions as to where his dinner, his clothes, and his shelter come from. In some cases he would only be able to saly that they come from the store or shop. But if these needs for fond, clothing and shelter are so important that we call upon the world to supply them for us, it 
is right that we should learn as much as possible about the ways which perple have adopted to provide lor their wants, either directly or through cichange.

The value of exchange. ITe are able to draw our food and other necessities and luxuries from so wide a field because we have what the Indians did not have - a wide commerce with other lands and peoples. These other lands and peoples exchange with us the things which we want for things which we raise or make, and

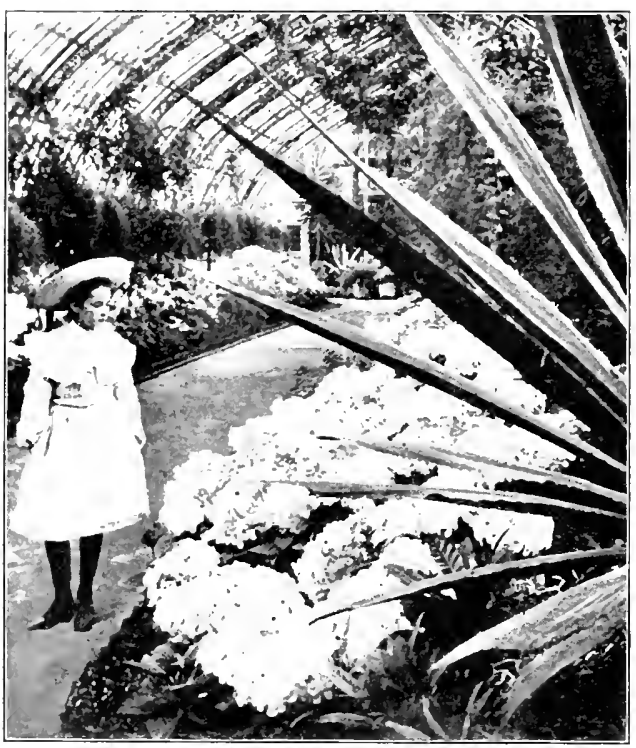

INIERLR OF A HOTHUL'SE which they want. In orcler that this may be easily done, there must be some means of carrying such articles to and fro; that is, there must be means of transportation. Trade and transportation go with the adrance of civilization; and among uncivilized peoples, like the Indians, only the beginnings of these important activities are to be found.

The study of trade. The study of trade and transportation is very interesting and necessary, for every one would like to know and ought to know where our articles of food, clothing, and ornament come from, and how the means of bringing them to us have been gradually built up. And we also want to know what we ourselves are making and sending to other peoples. We can see that certain food plints have to be raised in certain climates, and that certain animals camnot live unless the climate is suitable: bananas cannot be grom in (amirla (except in hothouses), and the elephant cannot 
be raised in cold countries. Some regions faror agriculture, some cattle raising, some mining, and others manufactures.

Commercial products are so widely scattered about the grlobe that if one wants a particular kind of product, one has to go, or get some one else to go, where it grows or is made. This study is not only a study of trade, but it is also a study of scography, for we must know about the climate, location, plants, and animals, as well as the men of the regions between which trade is carried on. And so our study is not only " industrial geography, "or the geography of industries, but it is also "commercial geography," or the geography of trade. Our most important purpose is to find out why certain articles of trade are produced in certain countries rather than in others: and then to learn how they are carried about the earth until they reach the people who want them.

\section{Artificial environ-} ments. It is not impossible for a region to secure for itself a

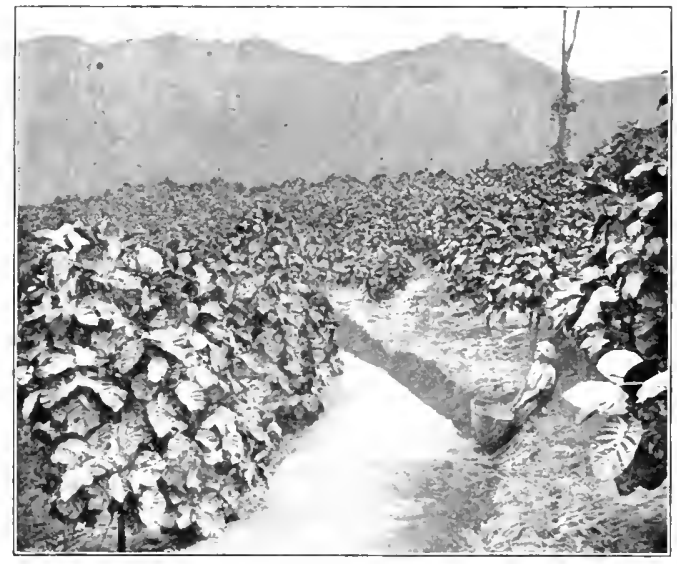

THE CHCHONA PLANT FRUM WHACH QUININE IS MAIE

natural adrantage which it did not oricrinally have. It cannot have deposits of mincrals unless they are there already, as we have seen ; but it may introduce a plant or an animal which is native to another country, if conditions of climate and soil will permit, and then go on producing it. For instance, Indian corn and potatoes, though they were native to Ameriea only, are now grown very widely in other countries. The plant from which quinine is deried is a native of the eastern slope of the Indes, but it is now raised in Ceylon and elsewhere. Wheat, barley, and most of the other valuable grains and fruits have been introduced into America from 
the ()kl Morkl. There was no important domestic animal in this hemisphere before 1492 , but now we are able to raise all the impertant animals which were originally natives of the Old World.

Conditions of success. However, we must not forget that none of these plants and animals will thrive unless the new conditions closely resemble the ones under which they formerly lived. The acricultural department of the federal government has been very strcessful in bringing in a number of valuable plants. But this was done by first carefully studying the plant in its own home and then placing it in a spot which was as nearly like its native region as possible.

An unfortunate experiment. I ess careful efforts, on the other hand, were once made to introduce the camel into the arid regions of the IV'est. Here the environment was not farorable. The camels are reported to have become sick from drinking alkali water; their feet were filled with spines from the cactus: they were continually falling over the edges of the ravines, to which they were not used; and it is said that the comboys of the IVest kept them in a constant fright by lassoing the alluring humps on their backs. Plainly the camels were not fitted to live in such a region and among such men. The attempt to introduce them was naturally a failure.

Thus it is evident that the plants and animals of a region, whether they are natives or have been brought in from outside, must be surrounded by conditions farorable to their growth. 


\section{CHAPTER II}

\section{THE INDUSTRIAL REGIONS OF THE WORLD}

\section{Climte iNi MaN}

Not only are plants and animals different in different regions, but man himself is affected by environment, so that men differ in different parts of the world. We could not well understand the industries and trade of the world if we did not know something of the differences between peoples. One of the first differences to be noticed is that there are parts of the world where men are industrious and civilized, and others where ther are not.

There is no great industry or trade - there is no high civilization - except in the temperate zone; and there never has been. And even in the temperate zone there are a number of countries which are not of much account as regards the industry and trade of the world.

The tropics. The influence of climate is such that the peoples of the tropics are shiftless and live a happy-go-lucky life.

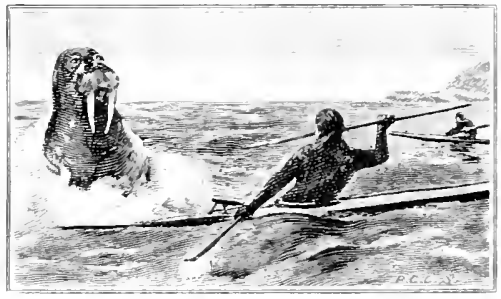

E.KJMO HLNTIX: WILRIS They seem to be made sluggish by the steady heat. In those regions life is often very easy, and there is nothing to force men to be active and enterprising. They are content if they have enough to eat for the day, and they need but little clothing and shelter. They will work only if they have to. Their wants are simple and easily satisfied, and they are not ambitious to go further.

The frigid zone. Again, in the frigid zone there is little industry or commerce, but here it is because of the porerty of the natives and the difficulty they have in living. There are not many people 
in the aretic regiom, for there is not enough food for many. Clothins and shelter, howerer simple, cannot be easily provided. With all their efforts and cleverness these people cannot get ahead very far. They are like a man who has fallen into the water, and who, by the utmost exertion, can do no more than keep his head out. Since their life is so hard and their neighbors are so few, they cannot practice division of labor very much, nor can they have any tracle to speak of.

The temperate zone. But in the temperate zone it is different. I Iere a man cannot live without effort, but if he is willing to work, he can succeed and get ahead. Life is neither so hard that he has no chance, nor yet so easy that he has no spur to industry. The climate does not, like that of the tropics, weaken him and make him lazy, nor does it, like the arctic climate, put such a strain upon him that he has no time and strength left after securing his bare living. This is the region of the earth where people are energetic, industrious, and eager to live in better ways. Here they try to use everything in the environment which may add to their comfort. They look forward to the future and plan for it, do with all their might what they can do best, and so work up separate industries and a large trade.

Some one has said, speaking of the effort and the return for it in different zones, "In the arctics you get nothing for something, in the tropics something for nothing. while in the temperate regions you get something for something." This is putting it too strongly, but there is some truth in it. If one works hard and gets little or nothing out of it, one cannot get on very fast, and soon becomes discouraged. If a man gets something for nothing, he is like a gambler, and is always trusting to luck; he becomes unwilling or unable to put forth wholesome effort. But if he gets a solid reward for his toil, as in the temperate zone, he is encouraged and goes on to the next effort with conficlence.

Rewards of effort. Consider what a reward the farmer gets when he raises corn; it will not grow for him without any effort on his part. but if he puts forth effort, the return is generous. It is all ligured ont in Jules Verne's "Mysterious Island." Suppose 
a man has one grain of corn. He plants it and tends it, and presently a stalk grows up. (On this stalk there will be several cars, say three. And it would be a poor ear indeed that did not have a humdred grains. If the three ears had only that number apiece, the return would be 300 to $\mathrm{I}$, or 30,000 per cent. Duubtless in the majority of cases it would be several times that figure.

The white race. Of all the races of the temperate zone, the white race seems to have done the most tomard developing civilization. Although the Chinese were ahead of all the whites many centuries ago, they are not so to-day. The trade of the world is now, for the most part, in the hands or under the control of European nations, or of countries in the temperate zone that began commercial life as colonies of European nations, lilie the L'nited States and Canada.

Disadvantages of some environments. There are, of course, peoples in the temperate zone who have done very little in industry, but these have had clisadvantages of one kind or another in their enviromment. They have been separated from other peoples by mountains, or they have had a comtry with little rainfall and so with few plants and animals, or perhaps they have had neither seacoast nor great rivers upon which to cary on trade. All these disadvantages have made them backward, like the people of a remote country tows.

If a boy were shut off from all other people and lived alone, he could not learn much, or make much of himself. IVe learn by watching other people and listening to what they have to tell us. If they know and can do things which we do not know or cannot do, we try hard to equal them by learning and doing more. And so it is with a nation: it cannot do much by itself. In order to become highly civilized, it is necessary to have much communication with other nations, to exchange products and ideas with them, and so to keep up with the best that is linown.

Control of world industries. Nie see, then, that coriromment has a great deal to do with making human beings what they are, just as it had in making plants and animals what they are. Men too are fitted to their enviromments. When, therefore, we come to 
look over the workl and sec where the great inclustries are carried on, we shall not be surprised to find so large a part of them in the hands of one race, and located in one zone. Indeed, we shall notice that, even outside this zone, wherever there is much industry, it is arencrally carried on by white men. And the men belong to a few nations only; they are chiefly British, Irench, Germans, Dutch, and Americans.

An examination of the accompanying map will show that the important routes of trade lie chiefly between countries in the temperate zone's; and that one end at least of a trade route practically always touches a country in those zones. But the ways of trade must lic between centers of production; thus a map of trade routes illustrates graphically the distribution of world industries.

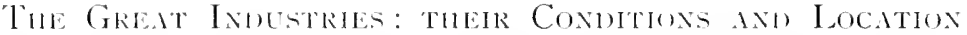

Industrial divisions. In the division of labor among groups, each group naturally devotes its time and effort to those things that count most. If a certain region is full of ore, its people naturally take up mining; if it has a great deal of water power, they make a specialty of manufacturing. And so the whole earth has come to be divided into broad regions of industry.

This division of labor among groups of mon depends upon the degree of civilization and amount of commerce which they have. There is not much among savage peoples; but when there is a lively trade, so that products can be readily exchanged, great industrial regions, each depending upon one or more natural advantages, are formed.

Mining. The regions which take the lead in mining are Alaska, California, Australia, and South Africa for gold ; the United States for coal ; England, I Imngary, and some of the islands of the Malay Archipelago for tin; and so on. Since there seems to have been no rute for the deposit of mineral substances, we have to memorize the fitets about them without much explanation. But we do know that mining accurs chiefly in mountainous regions, and there is a reason for this. 


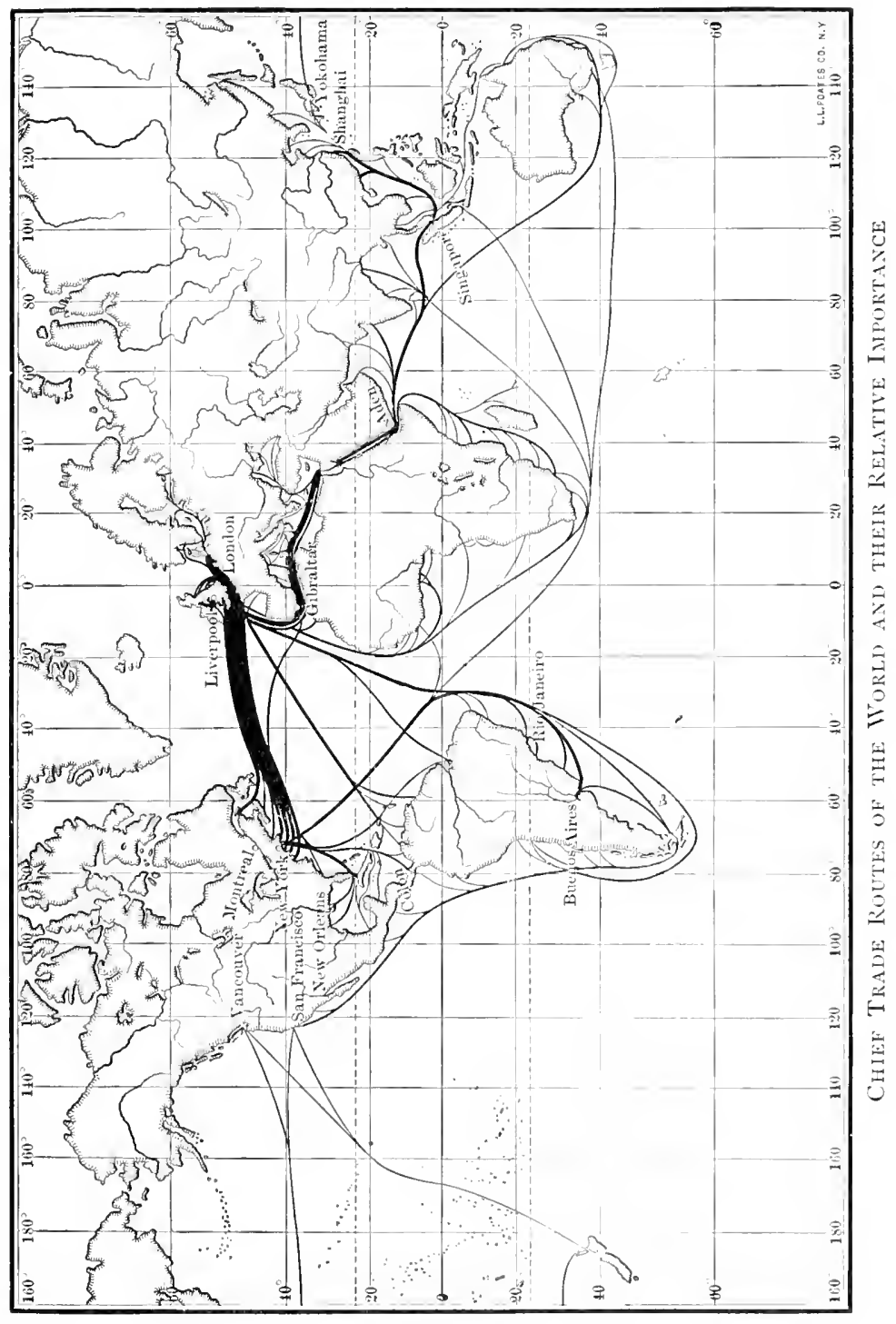


Mountains are formed by the crumpling up of the layers or strata of the earth's crust, which are sometimes so tilted that those

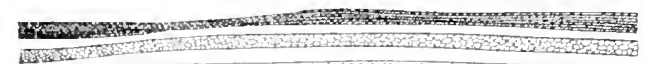

Mr.

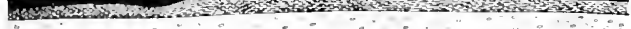
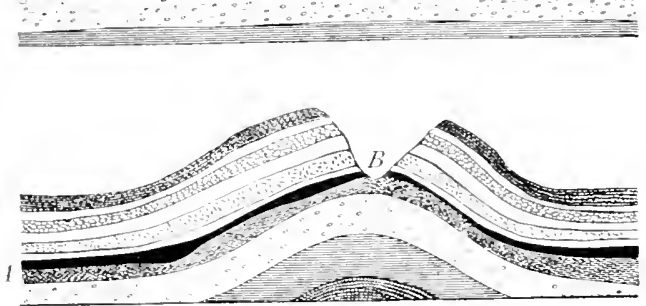

THE CUAL IS FURT IX LAYERS IN THE CRTST UF THE E.IRTH

layers which were buriced deep in the earth are brought to the surface.

In the first illustration on this page, suppose $A$ is a layer of coal, lying far down in the earth. Then suppose there comes great pressure from the side and the layers are crumpled and broken, and forced up into hills and mountains. Iayer A may then appear as in the lower half of the illustration. If, now, a man is passing at the point $P$, he may see a coal rein exposed to his riew. Then, as he digs the coral out, he will follow the rein deep into the earth, and so will, after a while, have a mine.

Sometimes in a coal mine the lavers are not tilted very much, but are like waves. Then a person passing through the mine is always going up and down little hills. And as the branches of the mineral veins are dus out, there may be in a mine a network of passages, or galleries. Is the branches of the rein act smaller, the

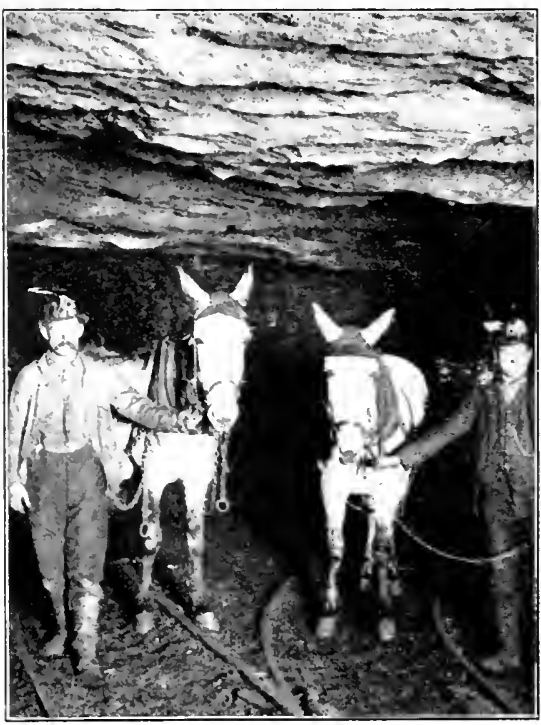

IN a Pexistirisia Coll Mise, Three MILES UNDERGROUND 
galleries become lower and narrower until they disappear altogether. One of the reasons why we find slate and other stone in the coal we use for fuel is because the blasting of these thin veins brings out a good deal of stone with a little coal, and the stone is not always carefully picked out.

Fishing. When we come to study plant and animal products we can more easily explain the location of the industries. Thus fishing can occur only where the conditions are favorable to the fish: whales are found only in the cooler waters, and the sperm whale only in those south of the equator. The seal does not thrive in warm climates, the cod clings pretty closely to the region of the Newfoundland Banks, the herring to the North Sea, and so on. But fishing for sponges and pearls is confined to warmer waters.

Lumbering. Lumbering depends upon the presence of forests. It cannot be carried on, then, in a desert or arid climate. Furthermore, since certain woods are more in demand than others, it depends upon the location of certain sorts of trees. Tropical forests yield mahogany, teak, and other hard and ornamental woods, while those commonly used in house building, such as pine, oak, and spruce, grow in the north temperate zone. Central America, India, the East Indies, and other hot countries furnish the former woods, while the United States, Canada, and northern Europe supply the latter.

Grazing. Grazing, or cattle raising, is an industry demanding broad and grassy plains, which may be more or less dry. Favorable locations occur generally within the temperate zone, in regions where the rainfall may not be sufficient for agriculture on a large scale. Thus, in the north temperate zone, grazing is the chief oceupation in the plateau states of this country, and in fexas and the Mexican highlands, while in the ()ld World a lectt of cattleraising peoples extends from China to Russia. In the south temperate zone, Australia, South Africa, and Argentina are important grazing regions. P'erhaps the desert tribes of Arabial and those of the Salhara and Sudan should be mentioned here, though their camels and horses, which are their chief animal products, are not very important in modern trade. 


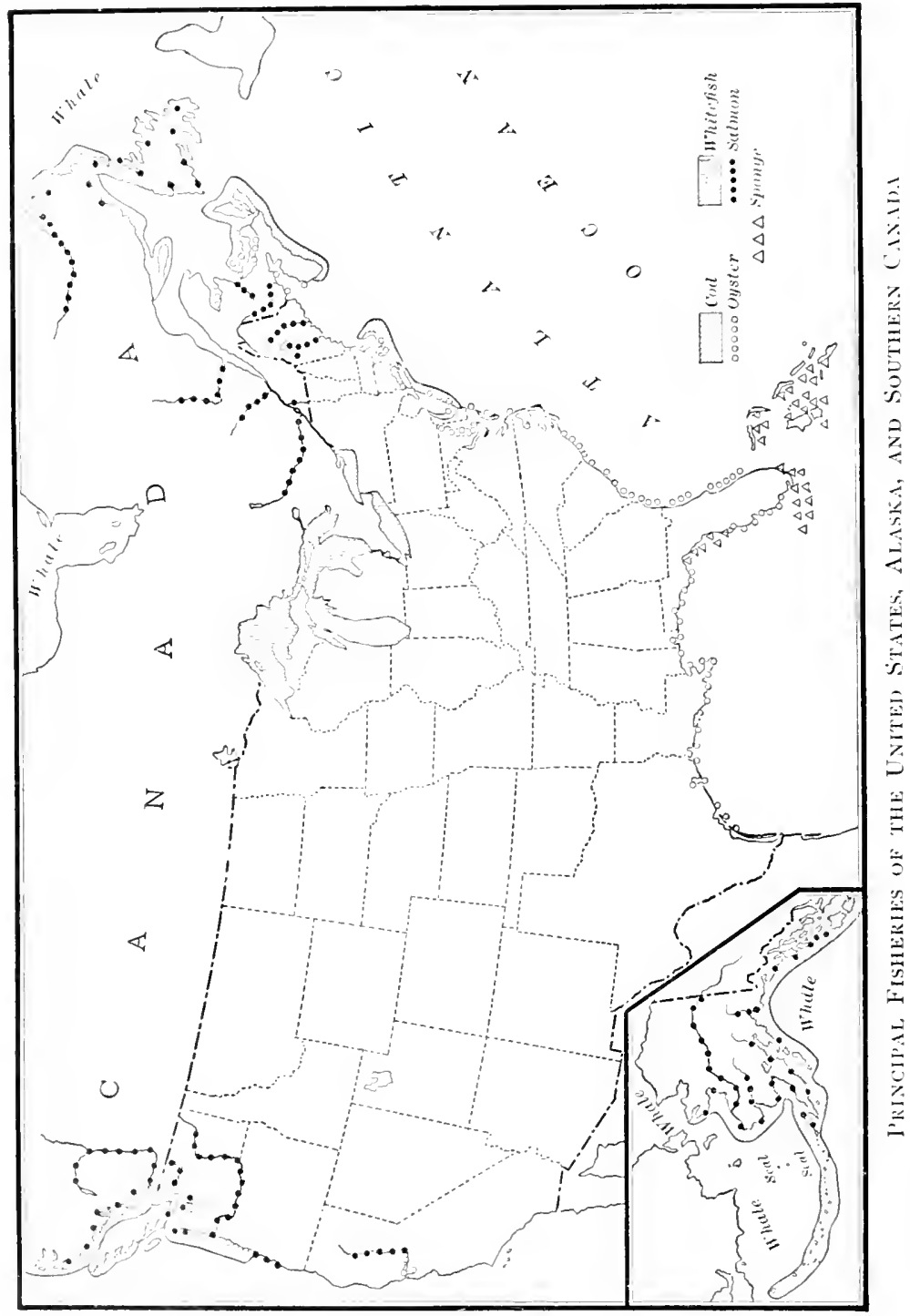


Agriculture. Agriculture demands sumlight and moisture and certain kincls of soil. North of the equator, crops will prosper upon the south sides of hills, when they fail to do well on the less sunny north sides. There can be no agriculture in desert or arid regions without irrigation. The favorite place for agriculture is on flat or rolling ground near rivers, and especially in the deltas of rivers. Here there is plenty of moisture, and the alluvium brought down by the streams and deposited at their mouths makes the most fertile of all soils. It is also to be said that while the mountainous country abounds in stones, large and small, the soil of the river bottoms is likely to be comparatively free from them.

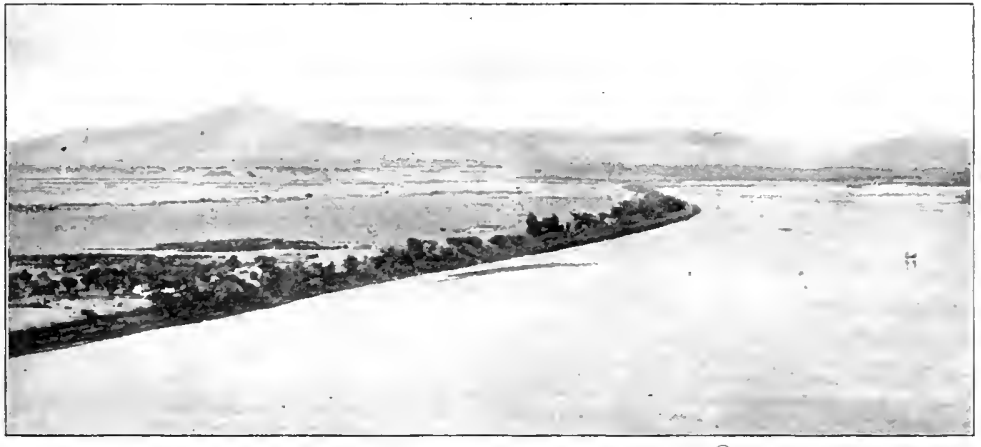

A RIVE borton along the Nile

Favorable regions for agriculture. If, now, we try to pick out the regions of the earth where favorable conditions exist, we meet with them chiefly in the north temperate and the torrid zones. In temperate Asia we find that southern Siberia, the valley's of the Chinese rivers, and the southwestern part of the continent are agricultural. In Europe every region is largely agricultural except the most northerly, the very mountamous, and the dry ones, such as Spain. In the New World all of the temperate-zone lands are agricultural except the mountainous regions, the far northern ones, and the dry plateaus bordering on the Rocky Mountains. In the south temperate zone South Africa, southern Brazil, and Argentina are successful in agriculture. 
IVithin the tropies, the laast Indies, India, T'arther India, Fgypt, cintral Ifriea, Brazil, Venezucla, the Antilles, and large parts of many of the islands of the Pacific are very fertile. What prevents the high derelepment of agriculture in the tropics is, as we have secon, the inability of human beings to make the most of natural ad lantages. The white man cannot stand the climate, especially if he worlis harel; the other races will not work unless enslaved,

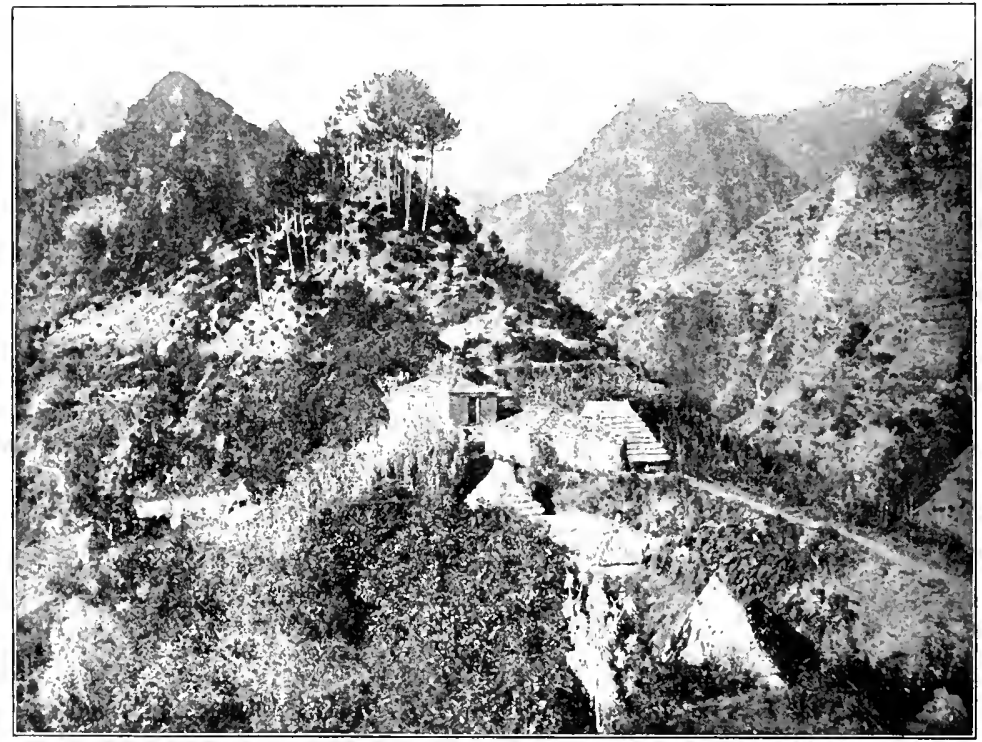

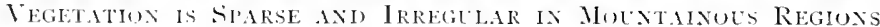

and, after bloody conflicts, it has been decided that one man shall not make a slive of another.

If ever the difficulties of climate are overcome, or the character of the natives is changed, perhaps the tropics will become productive along agricultural lines. The great productive agriculturall regions are now and have alwass been chiefly in the north temperate zone.

Manufacturing. Manufacturing is another occupation which, through division of labor, is taken up by certain groups of men 
and not by others. Some manufacturing is done by every people, howerer uncivilized; eren the sarage makes his own spears and traps and boats. Sut manufacturing on a large scale is in the hands of civilized nations, for they are the ones who have invented the machinery and processes by which it is now carried on. Practically all the manufacturing of importance is done in a very few parts of the earth. Because civilized peoples live for the most

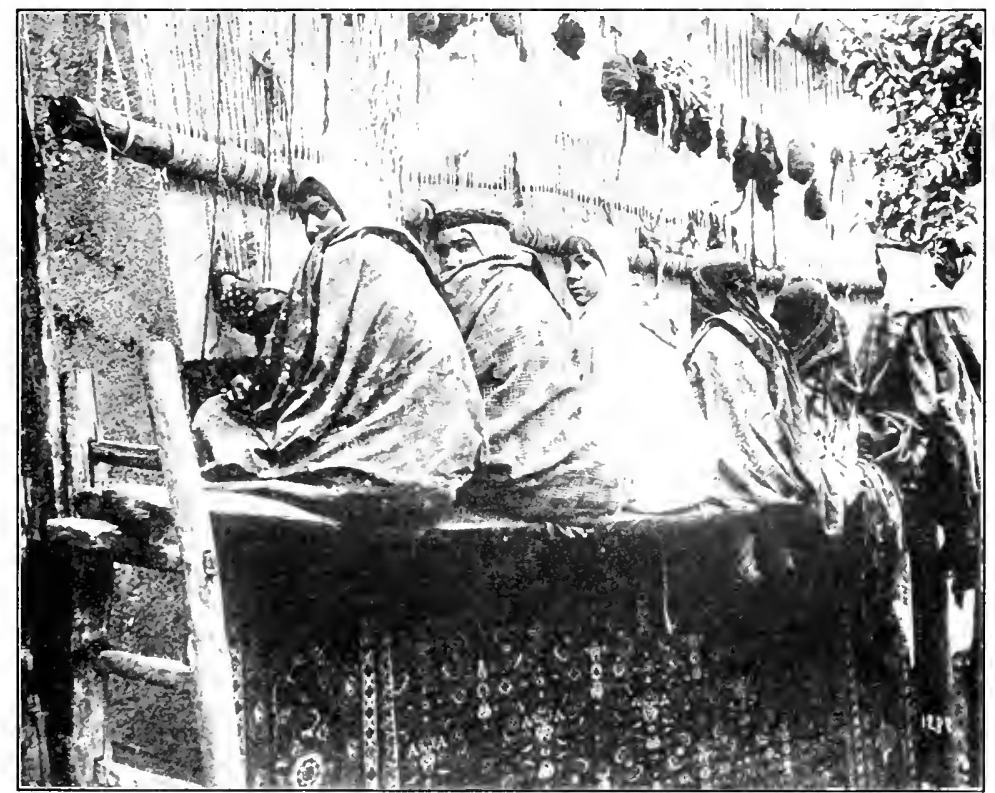

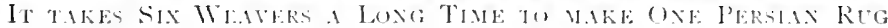

part in the temperate zone, it is here that manufacturing is found in its strength; and because as ret the civilized peoples in the south temperate zone have not been there longe enough to work up their manufactures, most manufacturing is done in the north temperate zome'.

Also because the white race is so far ahead of the other races in ideas and inventions, most of the manufacturing is in the hands of whites; that is, it is done in Europe and North Imerica. The 
Chinese and Japanese are artistic and male many beautiful things; the l'ersians malie russ that are better than any that can be made by machines; but on the whole their output is very small compared with that of limopeans and Americans.

Not all the comntries of Europe are equal in manufacturing ability: Russia, Scandinavia, ltaly, - in fact, all except England, Germany, France, Belgium, and Holland, - are inferior in this respect. In North America, Canada does much less manufacturing than the United States, and Mexico scarcely any. Certain parts of our country do much less than others, as we shall presently see ;

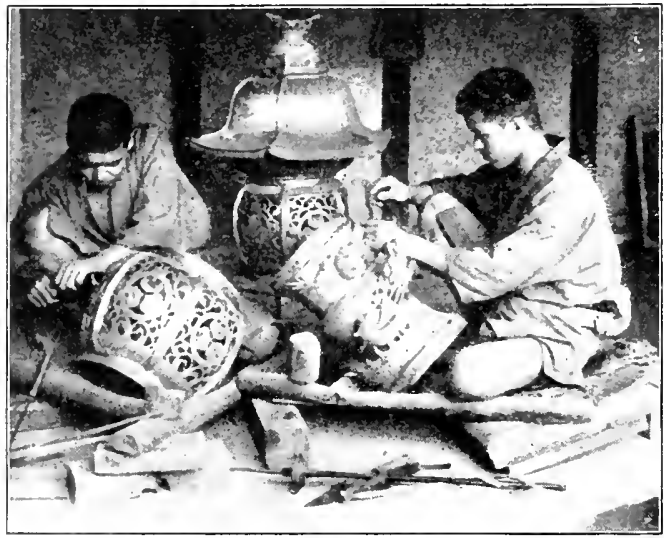

(C) II."C. White Co.

JAIANESE WORKMEN MAKING BRONZE LANTERNS but the United States as a whole belongs with England, France, and Germany, in the first rank of manufacturing nations.

Aids to manufacture. We have seen that a favorable climate and a high degree of civilization lead to the spread of manufacturing. There are other influences which help people in this direction. Plenty of water power is one, and before coal was used, an abundance of wood to burn in furnaces was another. But since so much of manufacturing now depends upon coal and iron, the countries which have these, like England and the United States, are especially favored. It is important, too, that the iron and coal shall be found close together. Here England had once an adrantage over us, but now our rapid and cheap transportation makes distances less important, and the two countries are more nearly equal.

The necessity of trade. In this book we deal chiefly with the production of materials which satisfy the needs of man, but we 
must not forget that transportation and trade are necessary in order that there shall be any division of labor at all. Food, clothing, and building materials are produced in one place, but they are used or consumed in another; and a large part of the business

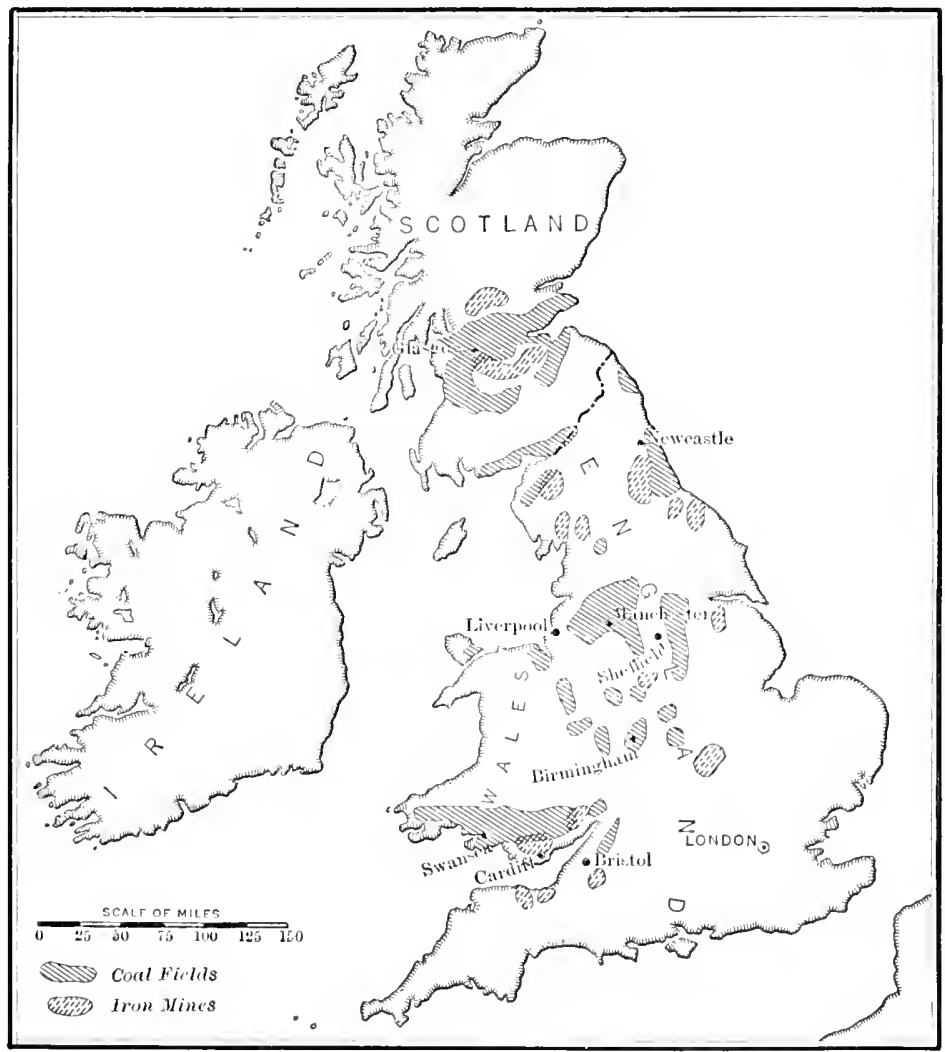

IN GREAT BRITAIN THE CUAL ANI IRUN DEIUSITS ARE NEAR EACH UTHER

of the world consists in taking them to places where they are wanted. Many thousands of business men earn their living by trade; when we talk of "business" we generally mean trade.

Importance of means of transportation. Transportation is so important that if for any reason a people cannot send its goods to 
other markets and buy from them in return, that people becomes shut off from the rest of the world and falls behind. There are mam batriers to casy transportation, such as mountains and deserts; and there ate conditions fivorable to trade, like level plains, mountain passes, rivers, lakes, seas, and the ocean. A people which possesses these advantages is usually able to dispose of its products casily, and so can specialize and become skillful in one or more forms of inclustry. Thus the English, because of their many fine

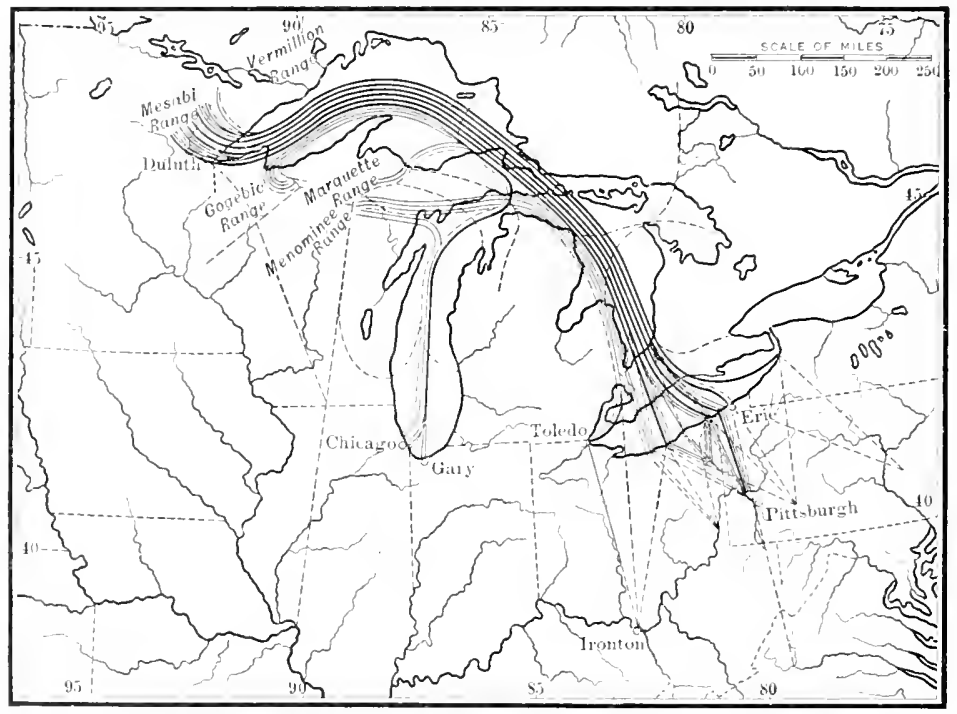

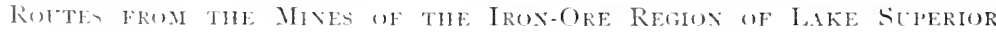
TU FERIRE

harbors and their superior merchant flect, were enabled several centuries ago to specialize in manufacturing, and to become rich and prosperous by trading with the rest of the world. Ocean transportation is so important to England that if it were cut off, many of her people would die, for Engriand has made such a specialty of manufacturing and commerce that her famers could not raise (nemen to feed the population. Suppose that all means of transportition were entirely destroyed, what would happen to the population of Xew Vork City? 


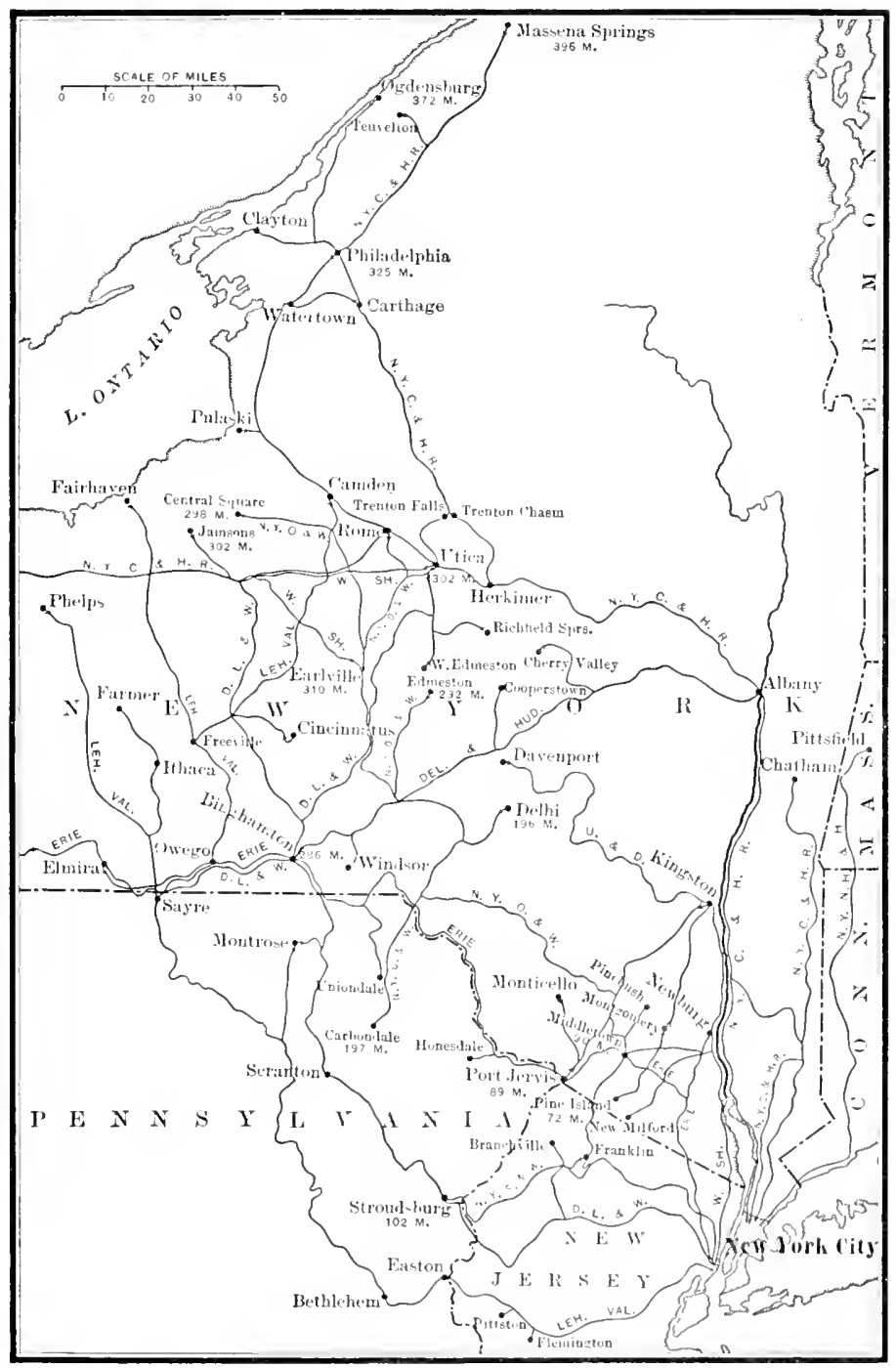

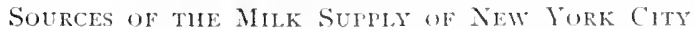




\title{
CHAPTER III
}

\section{THE INDUSTRIAL REGIONS OF THE UNITED STATES}

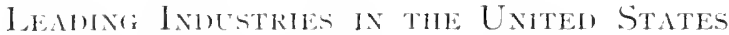

Narrower divisions. Ne have now seen that owing to division of labor the world is divided into broad industrial regions, which produce different things to satisfy men's needs, and which then trade with one another. But within these broad regions all the separate parts are not doing exactly the same thing. Just as the world is divided into great industrial regions, so these are further divided into smaller industrial regions. As a large industrial region, Germany is both an agricultural and a manufacturing nation, yet ayriculture and manufacture are not carried on in the same parts of fiemany. In one section of the Empire almost every one is engaged in raising beets for sugar, while in another part few beets are raised, but the people are busy manufacturing — in one place, steel for guns; in another, the guns themselves; and in another, mechanical toys.

The best eximple for us of this narrower division of labor is that furnished by our own country. There is no one of the six methods, described in the preceding chapter, of producing materials which we need for food, clothing, shelter, and other purposes, which is not practiced by the people of the Lnited States.

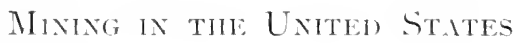

Iron. Irom and coal are the most important mining products of our modem civilization, coal being of importance chiefly because it cnables us to manufacture iron and steel, and to run machines made out of them. ( )ur age has sometimes been called the "iron age," and it is said that our present civilization rests upon this 
metal. The United States is in the lead in iron production, for it furnishes nearly one half of the world's yearly output of pig irom, and also about one half of the world's steel. Of all our minerals coal alone surpasses iron in value of output.

Iron ore is found in nearly every one of our states, but there are several sections of the country which surpass the others in mining iron. The Lake Superior district, including Michigan, Minnesota, and Wisconsin, produces about four times as much as all the rest put together. But iron is also mined in considerable quantities in the southern district, mainly in Alabama and the neighboring states. The chief iron state in the east-central part of the country is Pennsylvania. Here there is a particular advantage in mining iron because there are so many coal mines near at hand; this saves the cost of carrying the iron to the coal or the coal to the iron.

Coal. We first hear of coal from Marco I'ols an Italian who traveled across Asia to China more than six hundred years ago. He said that the Chinese burned black stones; that these stones grew red, and stayed hot for a long period.

Coal is of two kinds, _- "soft," or bituminous, and "hard," or anthracite. The former lights easily and burns with a bright flame; it is the chief fuel for producing steam, and the rilinads use great quantities of it. Anthracite contains more carbon, and burns with little flame but with great heat. It is used for heating houses and for cooking, especially in the eastern part of the United States.

Soft coal. Soft coal is mined chiefly in Pennsylvania, though West Virginia and Ohio produce a great deal. The largest field is called the Appalachian, and extends nine hundied miles, from New York to Alabama, with a width varying from thirty to one hundred and eighty miles. Another field runs through Virginia and North Carolina, and a third through Indiana, Illinois, and western Kentucky. Coal, by being heated in orens, loses nearly all the substances, cxecpt carbon, of which it is composed. It is then coke, which is the fuel chiefly used in smelting iron in this country; about nine tenths of our pig iron is so smelted. 
Hered corl. Hart coal is mined chiefly in P'ennsylvania, the anthracite area consisting of nearly five hundred square miles. This state profluces nearly half of the coal, of both kinds, which is mined in the L'nited States.

coal recurs in layers or seams at a considerable depth beneath the surface of the earth. When the layers have been crumpled up

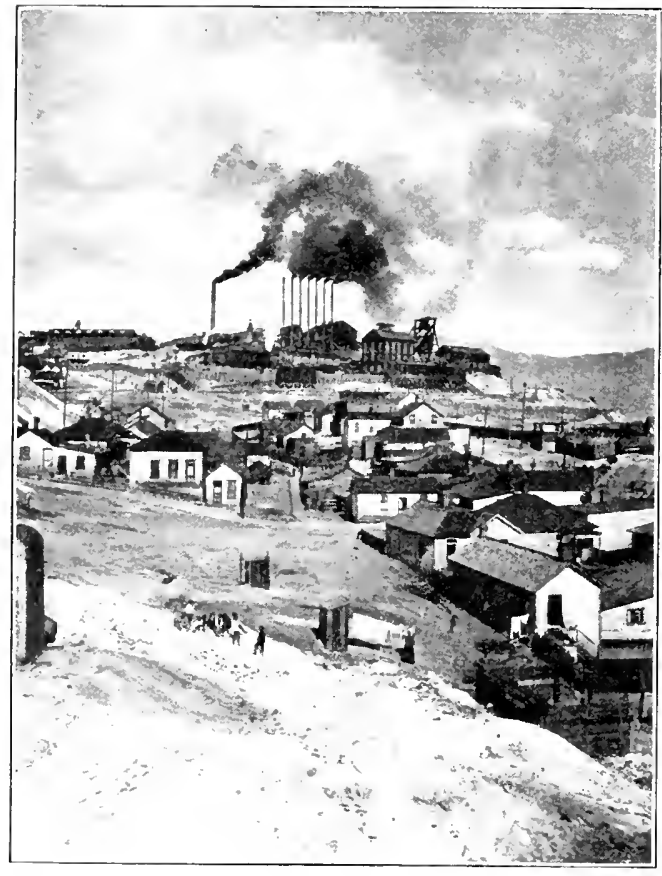

Photegraph hy N. 1. Forsyth

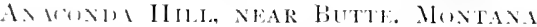

by pressure, as we have seen, they are sometimes so tilted that they are exposed on the surface. This is how they came to be discovered. Then the veins are followed down beneath the surface. The largest hard-coal rein in the Pennsylvania mines, "the Mammoth," was forty feet thick, but, as it has been worked out, the miners have come to thinnerveins. This makes much more difficult the work of blasting, and of piching out the slate and other stone. When the coal is dug out, the ground above, which forms the roof of the mine, has to be propped up strongly to prevent its caving in. Many of the people of l'emnsybania live orer the mines, and oceasionally the ground does care in. causing as great destruction as an earthquake might.

Copper. (opper is found in most of the countries of the world. It recurs often in a pure state, unmixed with other substances. firm this reatson, and also because it was easily worked, copper 
was one of the first metals to be used by man. The Indians who lived near I ake Superior used to hammer out vessels of various sorts from solid lumps of pure copper found there; but there are only a few regions where it occurs in large enough quantities to make mining profitable. Its great use in recent times has been in connection with electricity, for in this field no substitutes for it have met with much success. When it is mixed or "alloyed" with zine it forms brass; when alloyed with tin it forms bronze.

The United States mines over half of the world's yearly output of copper. Michigan, Montana, and Arizona are the chief states in which it occurs. On the Keweenaw peninsula in Michigan there is a copper district seventy miles long and from three to six miles wide. The Indians have taken copper from this region for many ages, and their mines, sometimes with great lumps of copper in them, which the lndians had been mable

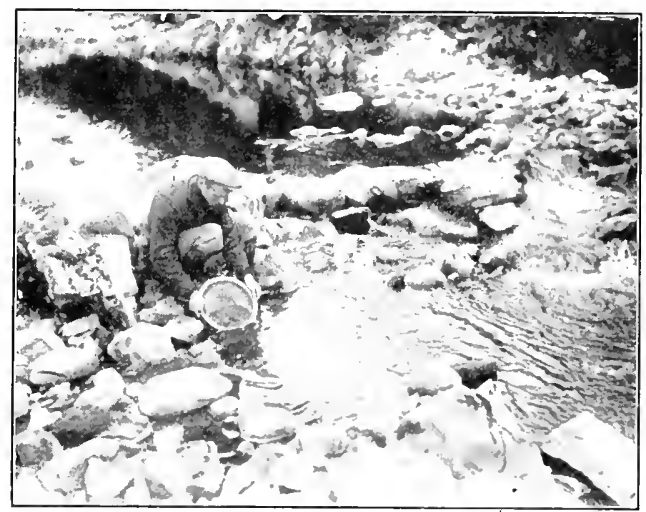

PINNING IOR (BRANS OF GOLI)

to lift out, were discovered by the whites when they came. In Montana there is a district called Butte, which is the greatest copper camp in the world. The copper mined in Arizona dees not come from one particular place, but from many different localities within the state.

Gold. Gold occurs all over the world, but chicfly in voleanic districts. It may be found embedeled in rock, sometimes in nuggets, and again in small particles. As the rock wears away, the gold is washed into some neighboring stream, where it soon becomes mixed with sind and grasel. By shaking the sand about in pans it is possible to separate the particles of gold, for, being heavier than the rest, they sink to the bottom and may then be 
separated out. This is called "placer mining." Sometimes another metar, like mercury, which has a great attraction for gold, is mixed

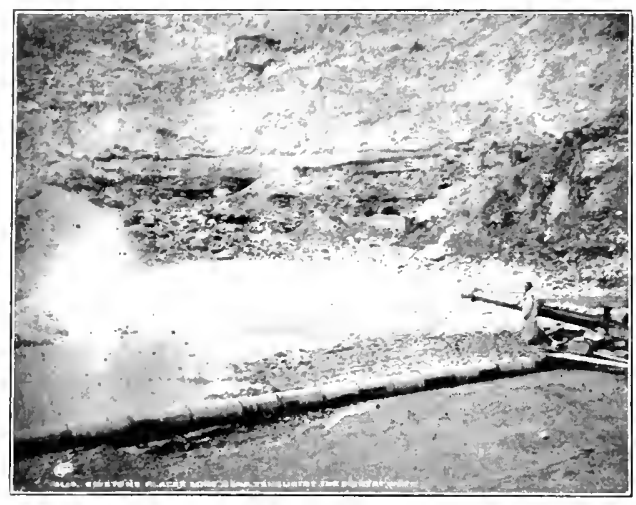

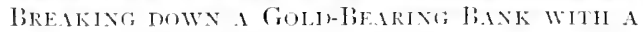
P'WEREL JET OF WITER

with the sand: the two motals unite to form an amalgam, from which the gold can readily be extracted.

Gotd has always been a precious metal, and, because it does not tarnish and is pleasing to the eye, has in all ages been used for ornaments of every sort. It is also the basis of our money, all other forms of currency resting in the end on the value of a certain weight of gold. Pure gold is very soft, and the links of a watch chain made of it would soon wear away, become thin, and break apart: so all the gold which we ordimarily see is mixed with some other metal, such as silver or copper, to give it halrdness.

The L nited States is second in the production of gold. South Africa lead-

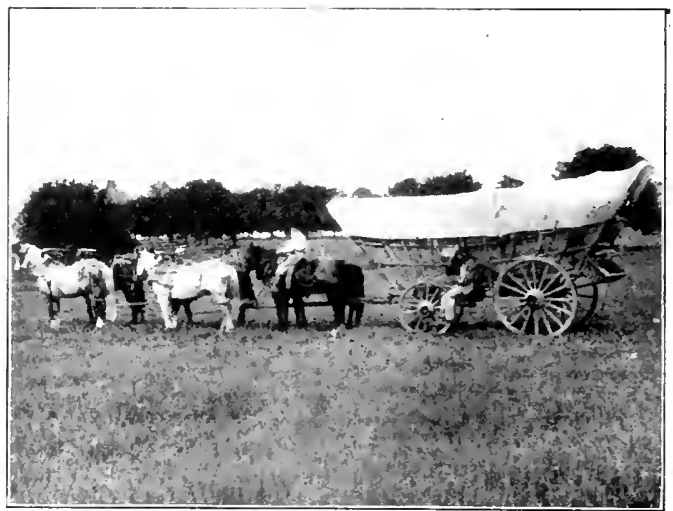

A PRIIRIF SAIOUNER ing. In our comntry the chief gold-producing localities are California, Colorado, and Alaska. Gold was discovered in California just before 1850 , and there was at once a great rush to the 
Pacific coast of fortune hunters, who were called the "fortyniners." They journeyed across the country in "prairie schooners," sailed around Cape Horn, or went by way of the Isthmus of Panama. The settlement of California was really begun by them. In Colorado most of the gold production is from mining the metal out of quartz, whereas in California placer mining has been common. The discovery of gold in Alaska came only a few years ago, and immediately there occurred, as in the case of California, a great rush of people who wanted to get rich quiclily. This has led to a rapid growth of the Alaskan population. In Alaska much gold has been found along the bars or banks of rivers, notably the I'ukon.

Silver. As silver is generally found combined with other substances and with metals, like copper, lead, and zinc, it is more difficult to mine than gold or copper. In ancient times silver was regarded as even more valuable than gold because it was harder to get. Almost all of our states contain some silver, but Colorado, Montana, and Nevada, with other states of that region, lead in production. In I 859 a great deposit of silver, known as the "Comstock Lode." was discorered in Nevada, and at once the United States came to the front as a silver producer.

A large amount of silver is made into coin, but it always has to be made harder for this purpose by mising about one part of copper with nine of silver. Great quantities of silverware are manufactured yearly. Some of the compounds of silver are noteworthy for the effect which light has upon them, and so they are largely used in photographic processes.

\section{Fismeries ()F the Limel) STtTes}

Whale fishing. It is interesting to remember that some of the first Europeans who came to this country came for fish. later some became settlers, but still continued their fishing alomg the coast. The capture of whales was one of the chicf industries, and there are a number of old towns along the New Fingland coast or on islands, like Nantucket, whose inhabitants formerly gave much 
attention to whaling. Since the whales have become less numerous, this industry has lost its former importance.

Codfishing. These first settlers came over mainly to fish for cod. The chief region for this sort of fish has always been the New-

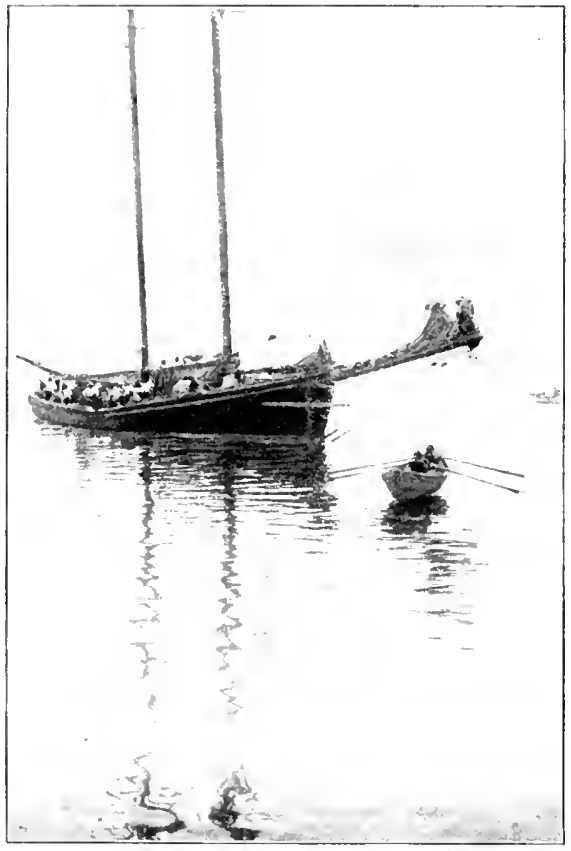

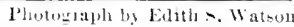

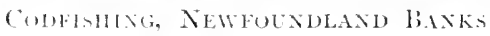
foundland Banks - real submarine banks where the water is much shallower than the surrounding ocean, and generally rough or covered with fog. The cod swarm over these banks in quest of food, such as oysters and crabs, which they find more abundantly in the shallower water: and they are generally taken by fishermen who use rather small saiboats and who get their bait from the people of Newfoundland. There has always been a great deal of dispute between Canada and the United States about these fisheries.

Codfishing is a dangerous business, partly because the fishing grounds lie in the path of the huge ocean steamships, which plow through the fogs at high speed, and not infrequently crish into a fishing ressel, cutting it in two and destroying life. Mr. Kipling has written a story called "Captains Courageous," which describes life on the Banks.

The cod is a very important fish from the standpoint of trade. It is called the "beef of the sea." Besides its flesh, which is generally salted ats soon as the fish is caught, the cod yiclds an oil (codliver (iil) which is good as a medicine, though not pleasant to take. 
Oyster fishing. On the eastern coast of our country there is another industry generally called fishing, though it is not carried on with hooks and lines, or with nets. This is oyster fishing. The

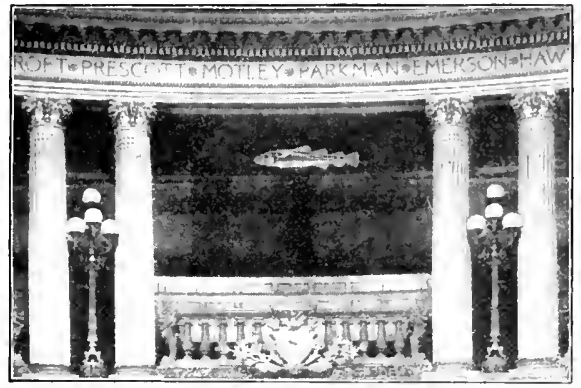

TIHE FAMOUS CUI IN THE MASSACHUSETTS

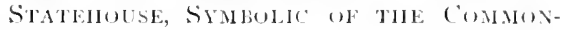
WEALTH's GREAT INUUSTRI IN EARLY TIMLS chief regions for oyster raising - for orsters are "planted" in beds and taken care of somewhat like vegetibles - are in I ong Island Sound and in Chesapeake Bay. l'erhaps greater care is griven to orster raising in the former locality. Any one going along in a steamer through the Sound will see the oyster fieldsstaked out with poles and buoys, and a number of busy tugboats working orer them.

It is no easy matter to attend to oyster beds. After the young oysters are placed in the beds it is necessary to protect them, chictly from sand and starfish. If there is a storm and the sand drifts orer the oysters, it must be removed. And the starfish are even more dangerous, for they feed on the oysters. They manage to do this by forcing an entrance between the slightly opened shells, so that ther are able to absorb the help-

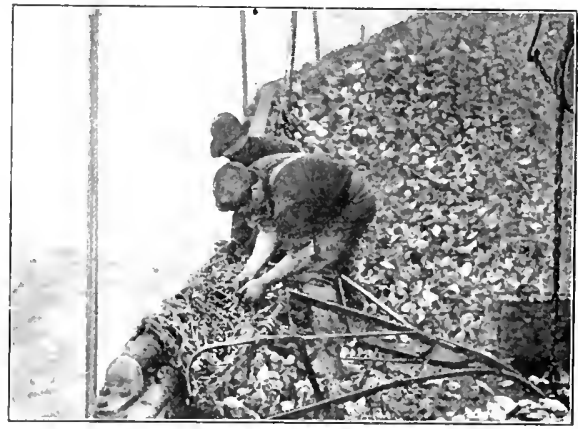

FISHINA FUK (OYTLKS less creatures within. The damage done by stiufish to the oyster beds of Long Island Sound amounts avery year to many theusands of dollars.

Oysters are supposed to be good when taken during any of the months of the year except Mity, June, July, and August; the 
saying is that they may be caten whenever there is an $r$ in the month. Circall care has to be excreised, however, to guard the berls andinst the pollution of sewage, and in some localitices native ossters are unfit to cat at any season. When in good condition they are so valuable an addition to the table that they are canned and sent abroad in great quantitics.

Salmon fishing. On the northwestern coast of our country there are extensive salmon fisheries. In some of the rivers of Oregon

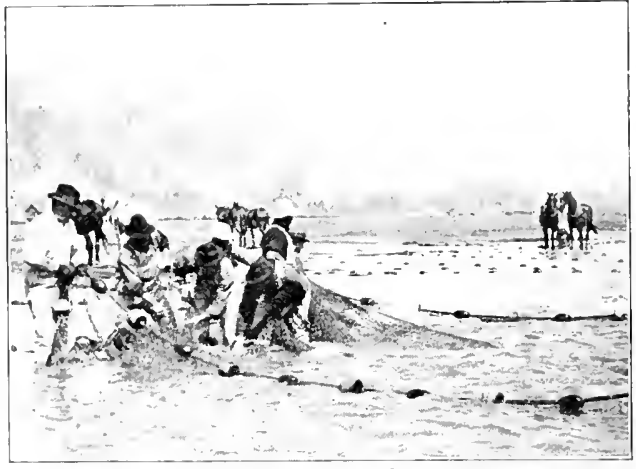

(C) Inderwoul \& Inderwoul

SEINING FOR SALMUN IN THE COLUMIIA

KIVER, OREGUN and Vashington, at certain times in the year, these fish go upstream to spawn, or lay their eggs, in such numbers that the water is alive with them. It is said that one could not thrust a stick into the water without striking a number of fish. A few salmon are caught also by the fishermen of eastern Maine. Salmon are camned in enormous quantities for home use and for shipment to distant ports. Ve are familiar with canned salmon in the form of a reddish-colored block of flesh, with all the bones softened by some special process. In some parts of the country fresh salmon is rarely seen.

Seal fishing. One other kind of fishery comes in part under the comtrol of the United States, and that is the seal fishery. Taling seals is really not fishing, for one does not use a hook and line, or a net, or a spear, but a club. And of course the seals, like the whales, are not fishes. The industries, however, are usually spoken of as fisheries.

In Maskit and on the Aleutian Islands seals are taken, but the f'ribilof lskands in liering Sea remain the breeding ground of the largest fur-seal herd in the wortd. 
The seals go up on the land to sun themselves, and there, since they move only rery clumsily on shore, they are easily wertatien and knocked on the head. In the past the seals hare been killed with great cruelty and recklessness, so that if this had not been stopped, probably there would have been rery few seals to-day.

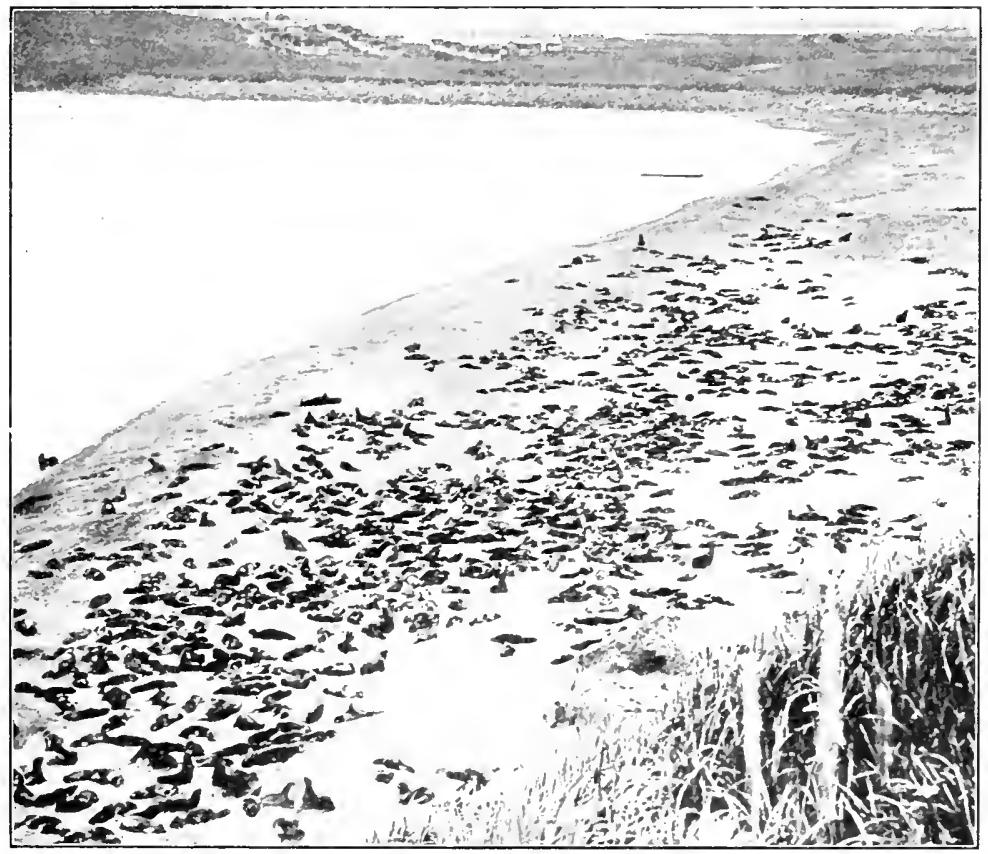

A IIFKL OF SIIILS

But the civilized nations chiefly interested - Russia, Jalpin, Canada, and the United States - have tried to check this foolish slaughter; not more than fifteen thousind skins maly be taken in the Pribilof Islands each year ; and now; under a recent treaty, the shooting of seals in the open sea (pelagic sealing is to be punished.

The chicef value of the seal to civilized peoples lies in its fur, out of which sealskin garments are made. The fur is yellowish in color and is dyed the rich brown familiar to us. 


\section{LCMBERLA; IN THE, UNATED STATES}

Value of forests. ( )ne of the great advantages of any country is wood. When the Indians were asked why they supposed the white man had left Europe and come to this country, they answered that probably his wood had given out at home. But wood is useful for many other purposes than for fuel, and the country which has

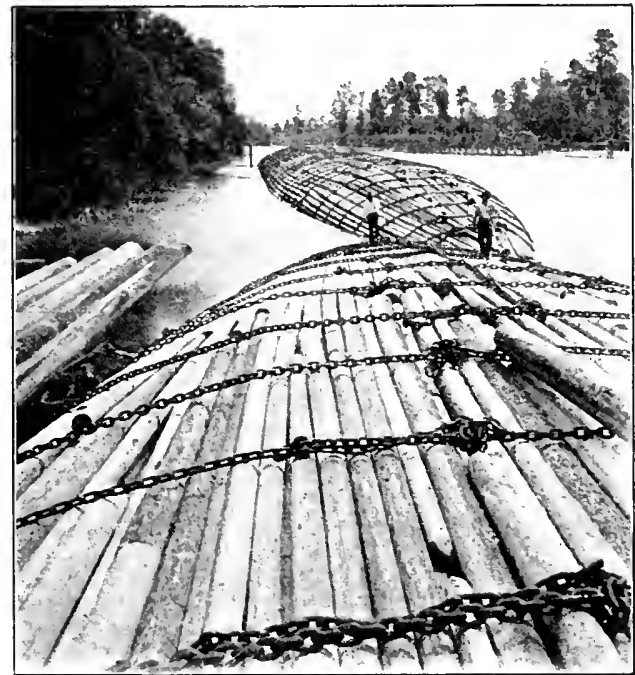

Photograph by Brown Brow.

There are Mhllions of Feet of Lumber in THESE RAFTS forests is fortunate.

Logging and sawing. There are three separate industries uncler wood production, namely logging, sawing, and the manufacture of wood into furniture and other articles. So the lumber camp and the sawmill are at the bottom of all wood manufacture. The tree trunks need but little attention in order to convert them into telegrapin poles, railway ties, and fence posts. But when it comes to laths, veneers, sashes, blinds, and interior finish for houses, the wood must go through a number of processes.

Lumbering is not a stationary business, like iron and steel manufacture. The logging camps and mills have to shift with the cutting down of the forests, for lumber is often costly to transport, and it takes a gond many years to grow new forests. Once the sawmills were on the streams and used water power, but when the trees near by had been sawed, the mills had to shift to where there were more, and perhaps use steam instead of water power for the sawing. 


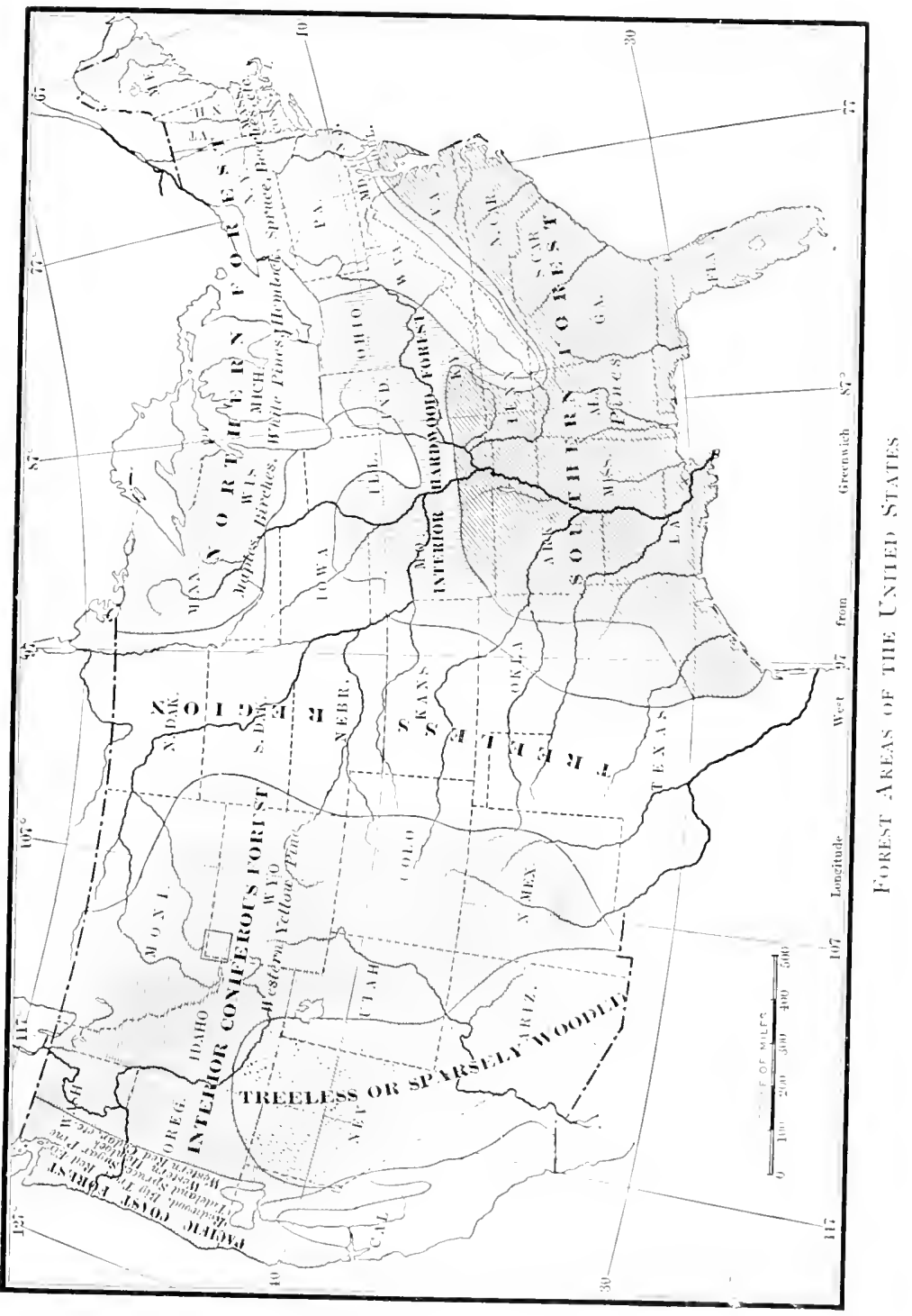


Niturally the large trees are most desirable, because only from large trunkis can wide, stratight beards be cut. When the lange trees are used up, the inferion ones are male into match sticks, or into wool pulp for paper manufacture.

Ihasteful methods: conscriertion. We are to-day the first woodproducing country in the world. It is doubtful whether we can hold that place if we continue using our supplies as wastefully and

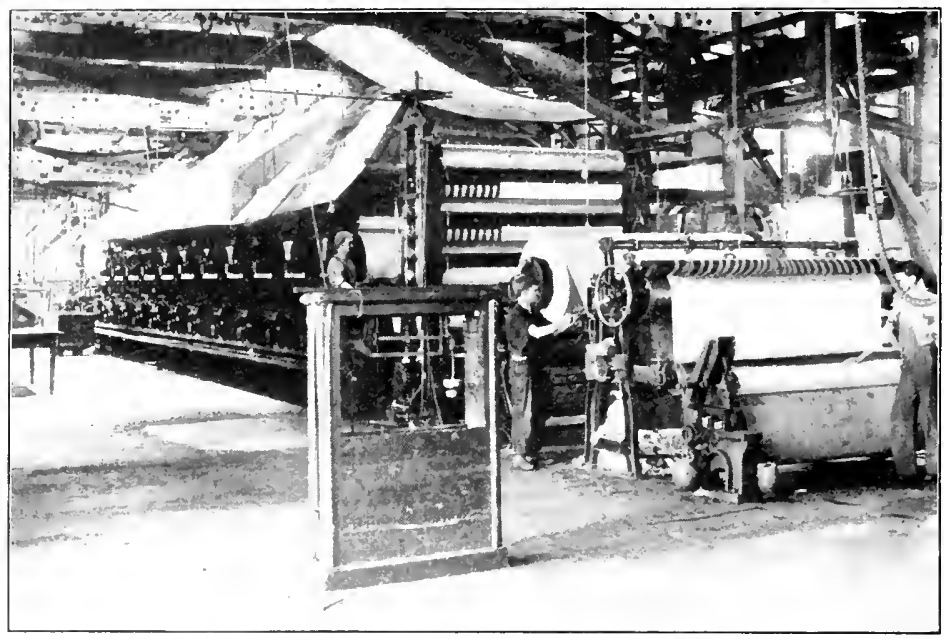

C) Interwood \& Lnderwood

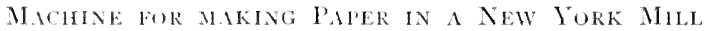

carelessly as we have done in the past. There is a great effort being made at present to preserve the forests which remain to us, and to plant new trees when old ones are cut down. This belongs to what is known as the "conservation movement."

Pine lumber. One of the most valuable woods of this country is pine. Until recent times pine and similar woods have been the chicf sources of building materials, not only for houses and barns, but also for ships. In many large cities, however, people are no longere allower a put up wooden house's near other buildings becanse of the danger of fire: and, as we know, ships are more and more frepuently being made of iron. Yet both houses and ships 
are finished in such woods as pine, and it is the increasing cost of pine, in particular, which has led people to realize how our forests have been destroyed.

In commerce there are two kinds of pine, the white and the yellow. The chief source for white pine was at first the northeastern states; then from 1870 to $18 S 0$ it was derived in large quantities from the region of the Great Iakes, and of late years

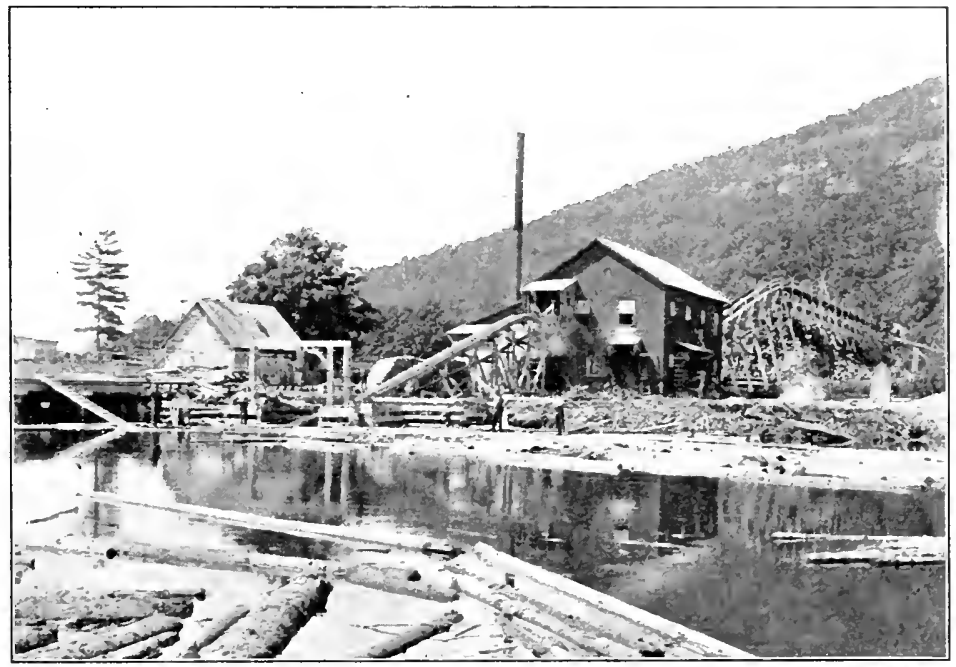

A S.IWMHI. IN NEW YUKK SIITE

the Northwest has been called upon to furnish this wood. The greatest producers of the yellow pine (also called Georgia pinc) are to-day the Southern states, but, as things are now going, soon the only soft woods left will be those of the Rocky Mountain section.

With these changes in the source of pine there has occurred al shift in the location of the lumbering business, which illustrates how an industry is determined by the enviromment. The states which now lead in the production of lumber are Vashington, Louisiana, Misconsin, and Michigan.

Hard woods. There are other kinds of wood called " hitrd woods," such as hickory, oak, and maple, which grow upon the lower slopes 
of the Appalachians and throughout the adjacent plateau. These are less valuable than pine for the frames of houses, but are more useful for fleors and other interior woodwork.

Redwood. 'There is a peculiar kind of wood in California, known as "rechourl." It does not shrink so much as many other woods,

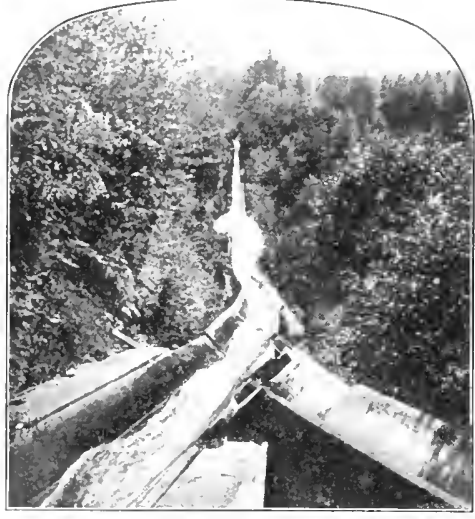

A Lumber Fleme in ORegua and it decays very slowly. For both these reasons it is especially useful for floors and for those parts of buildings that are exposed to the weather. Redwood has a fine grain and makes a handsome finish for the interior of buildings. The trees from which it comes are enormous in size and of very great age. Some of them are about four hundred feet high, and fifty feet around near the base. By counting the rings of growth on their trunks it has been estimated that some of them were young trees a thousand years before the birth of Christ. Of course one of these trees would make an immense amount of lumber.

\section{Grazing in the Uniten States}

Importation of cattle. According to history the Spaniards introduced horned eattle into Mexico about I 525 . They brought them from the IVest Indies where they had been taken by Columbus. Later, the English, I)utch, and other colonists brought over their own breeds, from which have come most of the cattle found in the Lnited States.

Cattle raising. Cattle raising in this country has gradually extended westward, being crowded out in the East by agriculture. The best environment for cattle is to be found in the states on the Great l'kains, for here are the best grazing lands in the United States. (attle raising cannot be driven out from this region by ordinary agrieulture, for the rainfall is insufficient for crops. Yet 
there are large areas here which could be used for agriculture if they were irrigated; and if, in spite of the expense of irrigation, farming becomes more profitable than grazing, then grazing as a great industry will disappear. It is on the wide ranches and ranges of the West that most of the cattle in this country are raised; the leading states in cattle raising, in 1900 , were Texas, Iowa, and Kansas, while in 850 they were New York, Ohio, and Pennsylvania.

Sheep raising. W'hat has been said of horned cattle is true in about the same degree of sheep. In fact, not one of our domestic quadrupeds was native to this hemisphere. Sheep were first kept in the Atlantic coast states, but later the industry moved west. Montana, Wyoming, and Idaho are the chief wool-producing states.

It must not be thought that eattle are raised for meat alone, nor sheep solely for wool. Catthe are sometimes raised chiefly. for their hides, as in Argentina: and, since I900, the tendency with us has been to raise sheep for the sake of mutton. How-

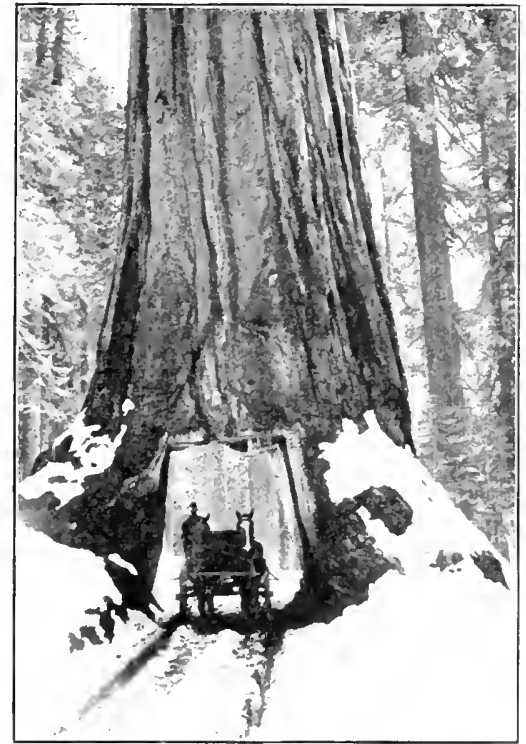

GINT C.ILFURNA TREE ever, it pays better, in this country, to raise cattle mainly for their meat, and to get elsewhere what hides are needed.

Nor must it be thought that because cattle and sheep are chiefly raised in the West, that the industry has been entirely given up in the East. Small herels, especially of cattle, are very common in the East; this is largely because of the need of milk and milk produets. Raising sheep for mutton is also prevalent cast of the Mississippi, where a growing population demands the food, but where the enviromment is not farorable to the growth of the best wool. 
For growing wool of a very fine quality there is need of a climate and other conditions such as may be found in Montana.

Hog raising. Another animal widely raised for food is the hog. I logs are raised all over the country, but the great region for swine, not only of the United States but of the world, includes Iowa, Illinois, Nebraska, Missouri, Indiana, Texas, Kansas, and Ohio. Except for Texas this group of states is the same group in which two thirds of the corn crop is raised. The hog is another illustration of an animal fitted to its environment. Corn is the chief food for

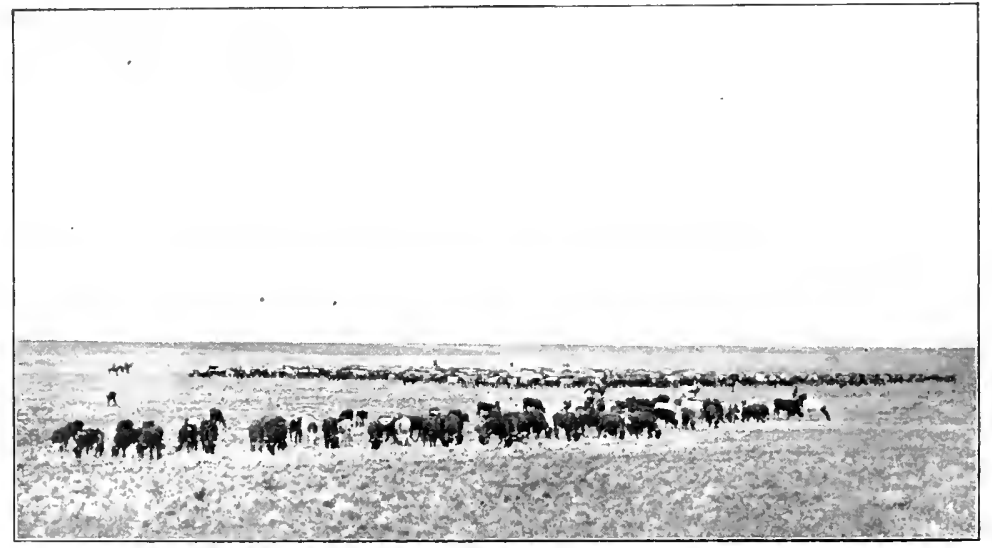

CATTLE GRAZING ON A WESTERN PLAN

swine, and so it is only natural that the "corn belt" and the swine region should be the same. "Hog and hominy" go together. Nearly one half of the corn crop does not go to market as corn; it is fed to the hogs and goes to market chiefly as ham and bacon.

\section{Arikiculture in the United States}

Spread of agriculture. Agriculture is one of the chicf occupations of our country. Two hunched years ago it was almost the only one, because manufacturing had not yet been developed. Starting from the Atlantic seaboard, the American people gradually moved westward, taking up the land first for cattle raising and 
later for farming, until now grazing is confined, as we have seen, to regions that are somewhat too dry for agriculture. Faming has become very important, and we shall find that the United States leads all the nations of the world in many agricultural products.

Wheat. One of the chief grains cultivated in the United States is wheat. The "wheat belt," which produces almost two thirds of the wheat grown in the country, includes nine states, - Minnesota, Kansas, North Dakota, Nebraska, Illinois, Indiana, Missouri, South Dakota. and Ohio. It will be noticed that all these states are well

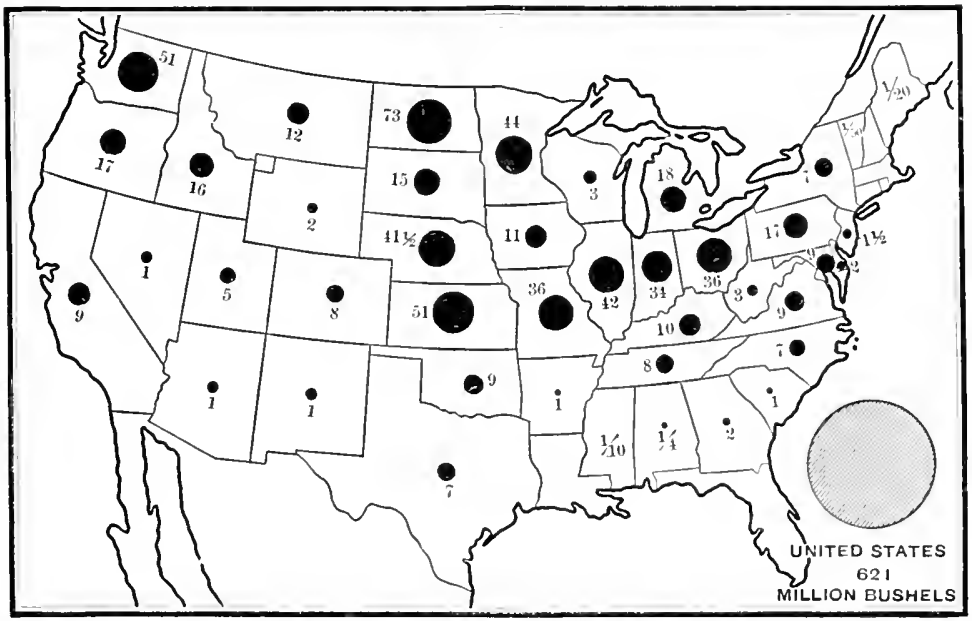

Wheat Production by States (I9I)

After map in (rof Reforter, January, 1012

watered by rivers, large and small. Wheat requires a good and fertile soil, and consequently has flourished in the river bottoms. But it cannot stand too much heat, and so has been cultivated in the north-central rather than in the more southerly parts of our country. There is a wheat belt also on the Pacific coast, extending through California, Oregon, and Washington, but this is of less importance. Later we shall take up more carcfully the study of this grain, and so we need spend little time on it now.

Corn. Indian corn, or maize, is a product of the New Irorld, and was carried from this continent to the eastern hemisphere. 
As yet no (ountry has approached our own in corn production, for the Enited States yields four fifths of the world's crop.

The " com helt," which grows nearly two thirds of all the corn raised in this country, includes Kansas, Nebraska, Illinois, Iowa, ()hio, Indiana, and Missouri. Corn demands the same kind of wellwatered regions as wheat. But it will be noticed that this belt reaches farther south and not so far north as the wheat belt; this is because maize is not so hardy as wheat. If the temperature becomes too cold, as it sometimes does on the northern edge of the

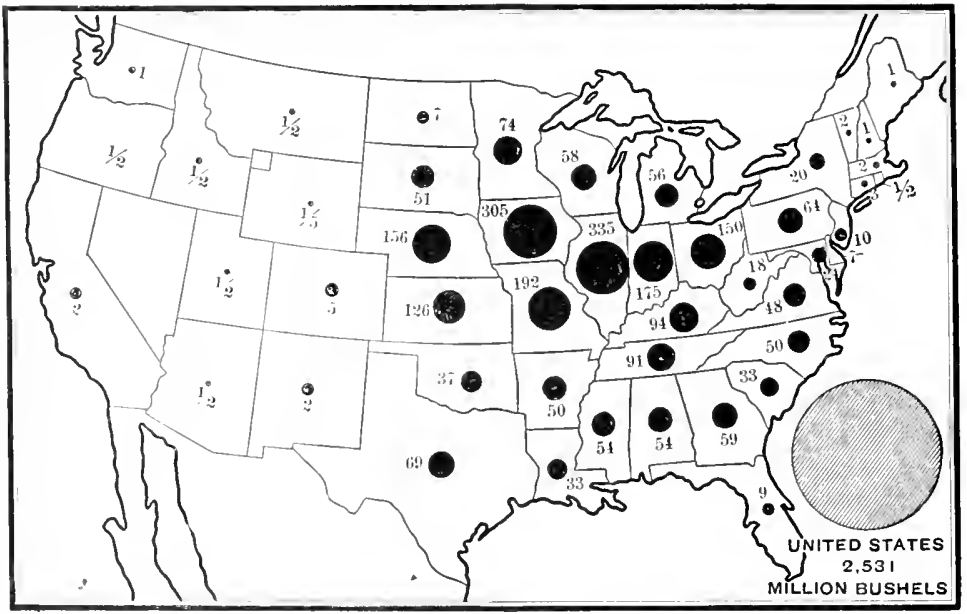

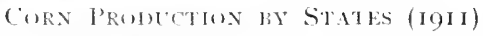

After map in Crof Ricforter, January, I9I2

com belt, the plants will not mature. Corn needs heavy rains with much sunshing weather between. The best soil for it is one which drains casily and does not bulid in rly weather.

Corn is our most valuable crop; it takes up more ground and is proluced in greater quantity than any other. Its annual value is but - little less than the combined crop value of the cotton, wheat, and oats. But it is interesting to notice that very little of it is exported. The reason for this is that while it serves as food for both man and beast, the sreater part of it is used for stock feed. Then the stock is experted. Thus our exports of corn are largely in the form of meat 
products. In this country ears of umripened corn of the sweet raricties, after being boiled, are eaten in the form of "corn on the crob." This sort of food rarely appears elsewhere in the world.

If it had not been for corn, it is probable that this comntry could not have been settled rapidly. When the arly settlers first came they were obliged to live very largely on corn. They learned about it and its cultivation from the Indians, who had become skillful in raising it. Indeed, the Indians, all the way from our country to Peru, knew of this grain and raised it wherever the climate would permit. Corn, unlike most of the other cereals, will grom without

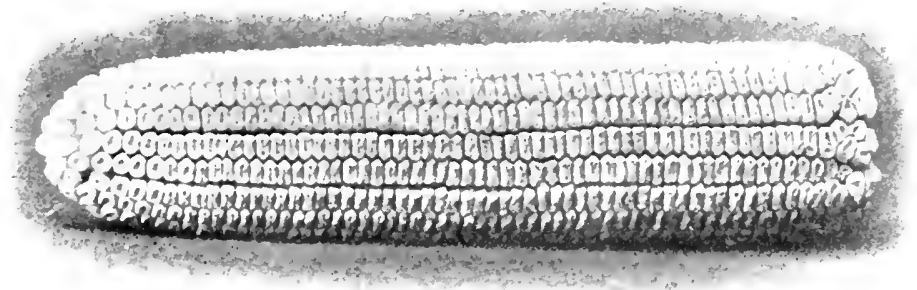

A PRIZE EAR UF CUKX

very much preparation of the soil, so the Indians, even with their poor tools and processes, had little difficulty in raising it.

Cotton. Another very important product of this country is cotton. The seeds of the cotton plant grow in a pod which bursts open when ripe, showing a mass of soft white fibers. I'robably the sort of cotton now chiefly cultivated in this country came originally from southern Egypt, but there was a native cotton grown by the Indians before the time of Columbus.

Cotton requires a rarm climate. The Inclians cultivated it in the region between Mexico and southern Brazil, north and south, and from the West Indies to I'eru, east and west. I'ractically the whole crop of our "upland" cottom, a variety described later in this book, grows south of the 37 th parallel and east of the looth meridian. The "cotton belt" is about fourteen hundred and fifty" miles long from east to west, and about five hunclred miles wide, 
north and south, and includes all the southeastern states from the North Carolina coast through Texas.

Rice. Rice is a plant which demands a great deal of moisture, and the best soil for it is clayey loam. It is a tropical or semitropical plant. In this country the production of rice has moved westward. In colonial times rice was as important a crop in South Carolina as tobacco was in Virginia, but now Louisiana and Texas

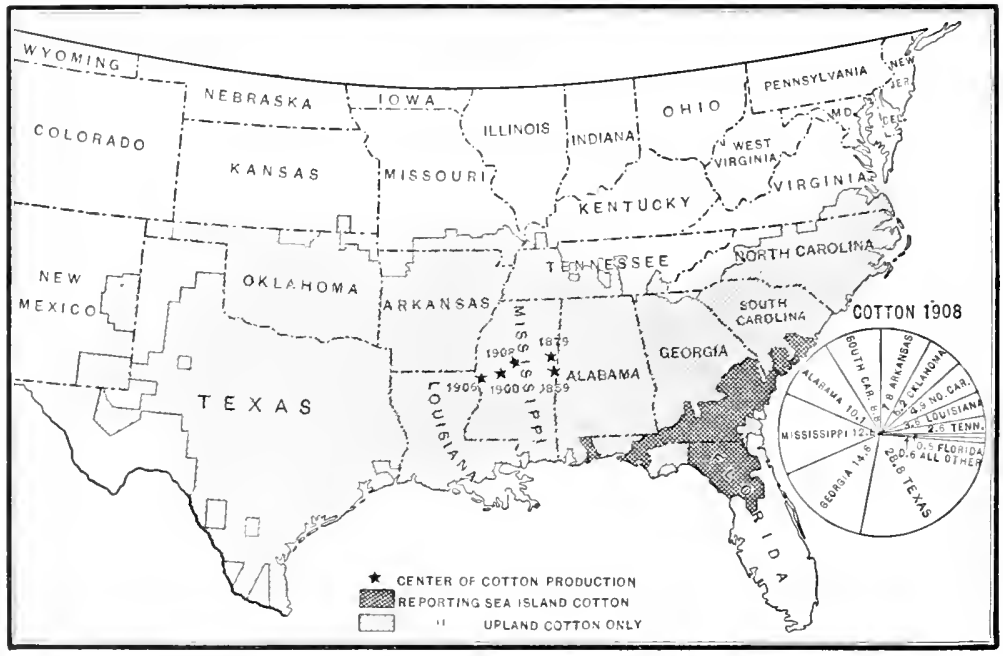

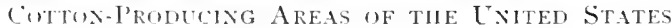

After Map in Bulktm No. 100, Lnited States Bureau of the Census

raise practically all our rice. Irrigation has helped increase the crop, and machine methods have been adopted, so that now in the United States one man with his machinery can produce as much rice as sixtr-four laborers in India.

Fruit growing. For the growing of fruit there must be favored localities, and these occur in many states of the Lnion. North of the equator fruits are often grown where there is a southern exposure, while they will not grow on the northern slopes of hills. They must also be protected from frost, and must have enough moisture from the rainfall. 
New Jork. In the Last, New Jork is a state which has many such farored localities. This state is also famous for its fruit nurseries at Rochester and elsewhere, from which are sold millions of fruit trees, to be planted in eastern Canada and in different parts of the United States.

The South. In the South many varieties of fruit are raised, some of them being tropical. Peaches and other tender fruits, when they

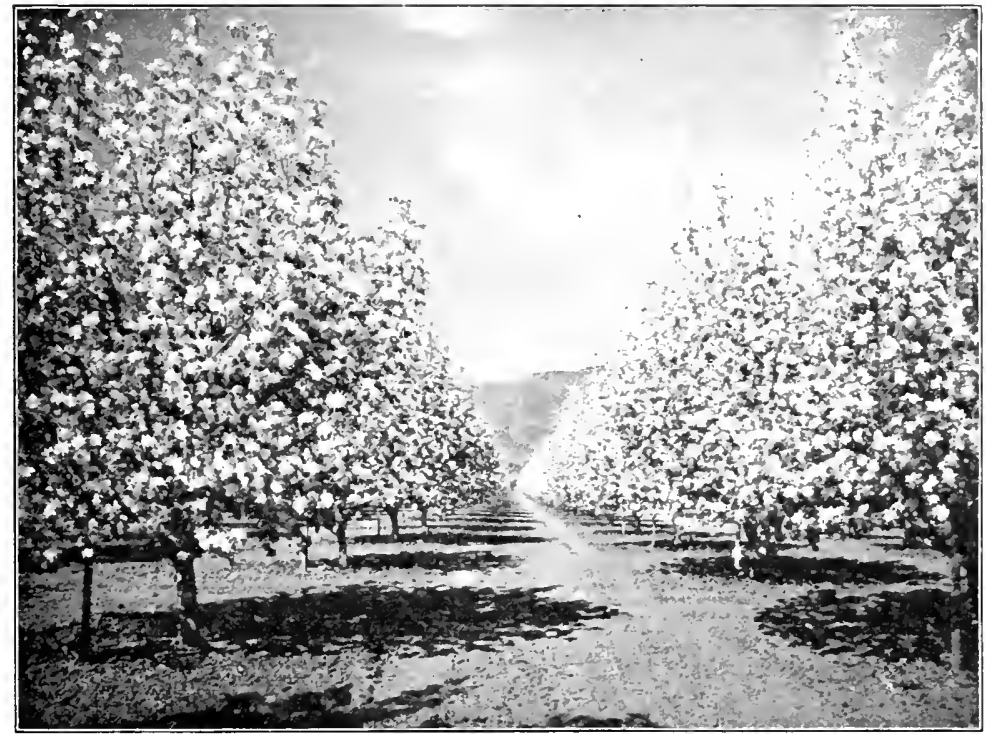

(c) Kainer Jhutu Co.

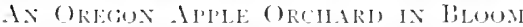

grow in the South, as in Georgia, thrive best at moderate elevations. Apples, being more hardy, will grow on higher elevations there, and in cooler regions such as New England. In Florida, oranges and grapefruit are raised in large quantities; other fruits demanding warmth are produced along the Gulf shore.

Califomir. The principal fruit-growing state is California. Many varieties are found here, - apples, apricots, cherries, peaches, plums, and grapes, - and also fruits that were formerly raised chiefly in southem Europe, such as oranges, lemons, olives, and figs. 
California alforcls a fine example of the benefit of good transportation. Before railloarls were built there was little use in specializing

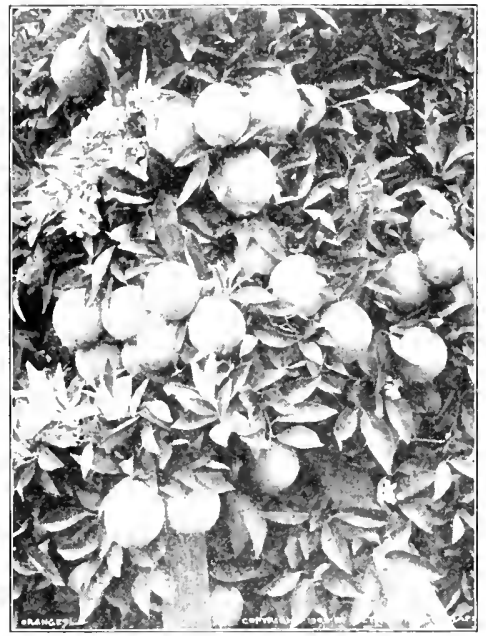

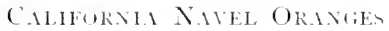

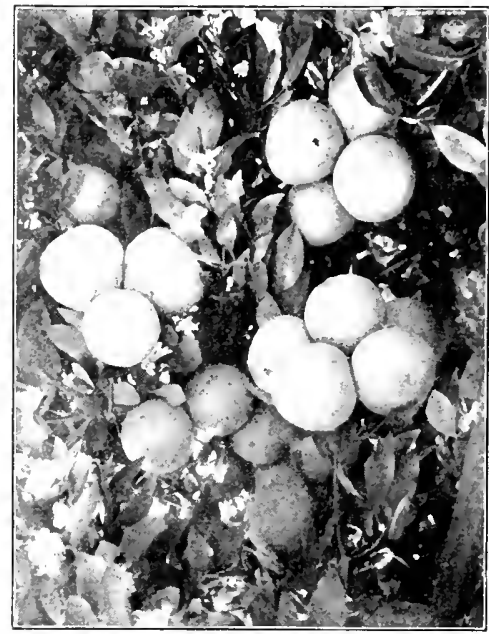

(c) Detroit Publishing Co.

CALFURNA GRAPEFRU1T

in fruit raising, becaluse the fruits had to be carried by ship around Cape IJorn in order to rach Europe or the Eastern states of our

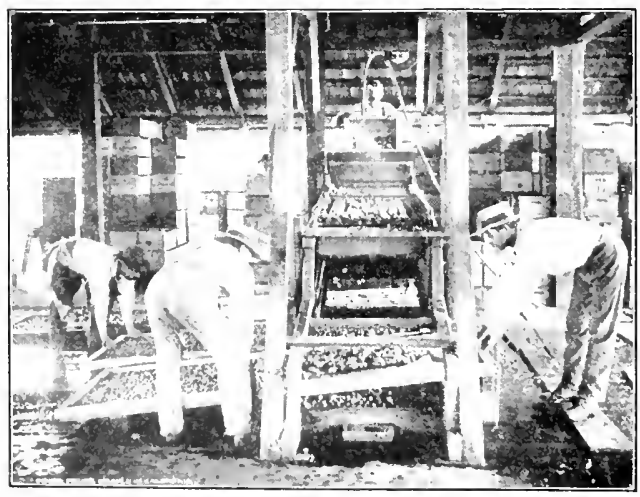

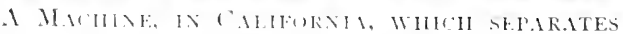

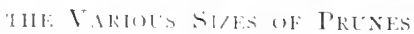

country. But when they could be carried across the country on swift and smoothly running trains, and could be delivered on the Atlantic coast within a few days, fruit raising could be made to pay. Then the refrigerator carswere invented, and it became still easier to get fruits to market without loss. 
INDESTRIAL REGIONS OE THE IXITEI STITES 69

Of course, the secret of California's success in fruit raising is the milel and even climate, especially that of the suuthwestern coast.

Market gardens. Along the eastern cuast of the L'nited States, and in the neighborhood of large cities, there is usually a great

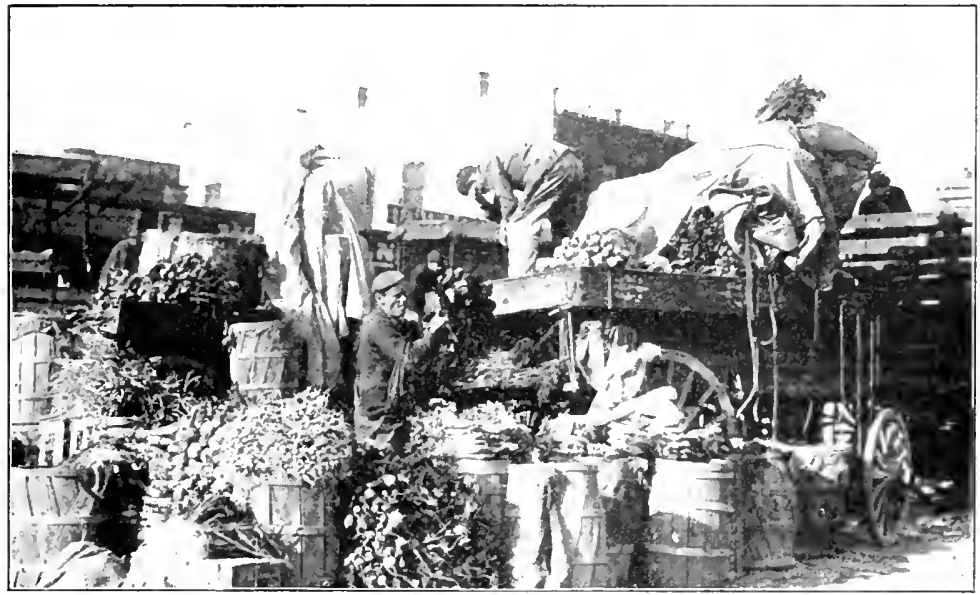

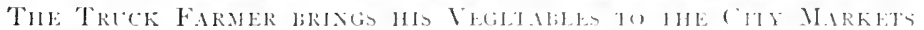

deal of market gardening. V'egetables and fruits spoil easily and must be disposed of quickly, so the farmers bring them in to the cities near by and either peddle them from house to house, or sell them in the open marlict, or to the groeers who are to retail them.

Some years ago market gardening was unprofitable unless it was carriced on very near a city. Great quantities of excellent apples even now go to waste within a few miles of a good market because it does not pay to pick them and send them in. Marliet

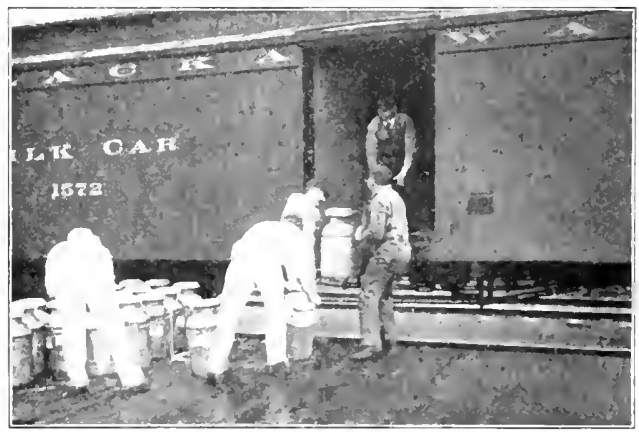

KI.JIGIKIIUR \& IR 
sardeners depend upon the fact that people in cities are willing to pay high prices for fresh vegetables and fruits. Prompt delivery is an essential to success.

Here, again, growth of transportation has allowed of division of labor. The running of fast trains, with refrigerator cars, has made it possible for numerous regions on the southern Atlantic coast to specialize in supplying Northern cities, like New York, Philadelphia, and Boston, with fresh fruits and vegetables. And because there are people who will pay so much for vegetables and fruits at a time when these camnot be grown at all near the Northern cities, the market garcleners of the South are able to make a good profit by raising these products and selling them in the North out of season. Thus they ship lettuce in January and strawberries in March.

\section{Manufactuking in tile Uniten States}

Conditions of success. In the census report of I900 a writer gives this list of causes why a manufacturing industry is located in one place rather than in another.

I. Teamess to materials and ncamess to fucl. If the manufactory is near the raw materials, they do not have to be carried to it, and the cost of freight is saved. And since all our manufactories need a great deal of fuel, it is an advantage not to have to pay freight on that.

2. Tiancss to maricts. This means that the cost of carrying the products to the places where they are sold will be small.

3. Irater fower. As every one knows, water power is cheap, and so the manufactory which has it spends much less than one which has to use coal.

4. Firionble climate. If the climate is too hot, the workmen cannot do their best work; and if it is too cold, much money has to be spent in heating buildings. Also, if the weather is often foggy and there is not much sunlight, as in London, there is extra expense for illumination.

5. Supfly of labor. Exery large manufactory needs many laborers. Such an industry cannot exist in a thinly settled country. One 
reason why manufacturing is found chiefly in the eastern part of this country is that there the population is more dense.

6. Capital arailable for incestmont. It takes a great deal of money to build factories and to buy machinery. For this reason a very poor country cannot have many manufactures. Where people are well off and have money to lend, it is possible to borrow enough to start manufactories, because the people who lend the money are usually glad to have investments near home.

7. The momcutum of an carly start. If an industry is already started, it has a better chance than other similar ones which may follow it. Its first difficulties and expenses are over, and because it is now free to study methods and opportunities, it is more likely to suceed than are its struggling rivals.

It is necessary to bear in mind all these advantages in order to understand why some industries are more successful than others in the same place.

Growth of manufactures. The United States is one of the chief manufacturing nations of the earth, as we have seen. But it is plain that it could not have been so from the first. At the beginning the settlers had to get their living out of the country around them, and so they could not do much manufacturing. But gradually there came about a division of labor, so that now certain parts of the country do most of the manufacturing, while other parts raise food and trade it for the manufactured products.

The northeastern states. Our chicf manufacturing region is in the northeastern states where the population is most numerous. The state whose manufactures have the greatest value is New York; they amount to about two and one-half billions of collars a year. Then come Pennsylvania, Illinois, and Massachusetts, in order.

Transportation. Rapid transportation has been of the greatest importance in developing manufacturing. Nanufacturing is sometimes done, contrary to the ordinary rule, at a graat distance from the place where the raw material is produced. In such cases the reason has been that cheap power for driving the machines, like water power, is to be had, or that there are numbers of laborers, or that the cost of marketing the manufactured goods is small. 
'The rapiclity and the cheapness of transportation frequently make it more profitible to bring the raw materials to the factories than to have the factories built near the raw materials. For example, much of the iron now manufactured in Pennsylvania is made from irom ore that is brought from the Lake Superior region. Cheap fuel near the factories, cheap transportation of the ore, and a market close at hand for the finished product explain this fact. Sugar cane is raised in Iouisiana and the sugar beet in the Mississippi region, yet the sugar refineries are generally near the coast. So are many other manufacturing plants.

The "fall line." It is interesting, as showing how industries fit their enviromments, to see that many manufactories are located along what is called the "fall line." This is the line where the highlands approach the coast, and so where the rivers, as they flow to the sea, have a decided fall. Here are the places where water power can be most easily obtained. Fall River, Massachusetts, although not on the fall line, is, as its name shows, a city with good water power and hence a manufacturing center.

Nearness to materials. Where there is no great adrantage in a distant location, the manufacturing is done near the materials. Much flour is ground in Minnesota, not far from the wheat fields. Here $t(x)$ are the famous Falls of St. Anthony, so that water power is close at hand. The manufacture of furniture in Michigan, for instance at cirand Rapids, near the place where the wood is cut, is another illustration of the same principle.

An early start. Still more interesting is it to notice that some manufactures are now located almost exclusively in one spot. In Tro. Xew York, there is a great collar manufactory, and the city manufactures wer four fifths of the collars made in the United States. In a number of cities, laundries are called "Troy" laundries. This is due to the fact that the collar business had an early. start in that city, and made its reputation there. Now, with rapid transportation, it makes so little difference where collars are manufactured that the falctories have staved where they were.

We now sec why manufactures are located chicfly in the northeastem states, and why some of them are found elsewhere. 


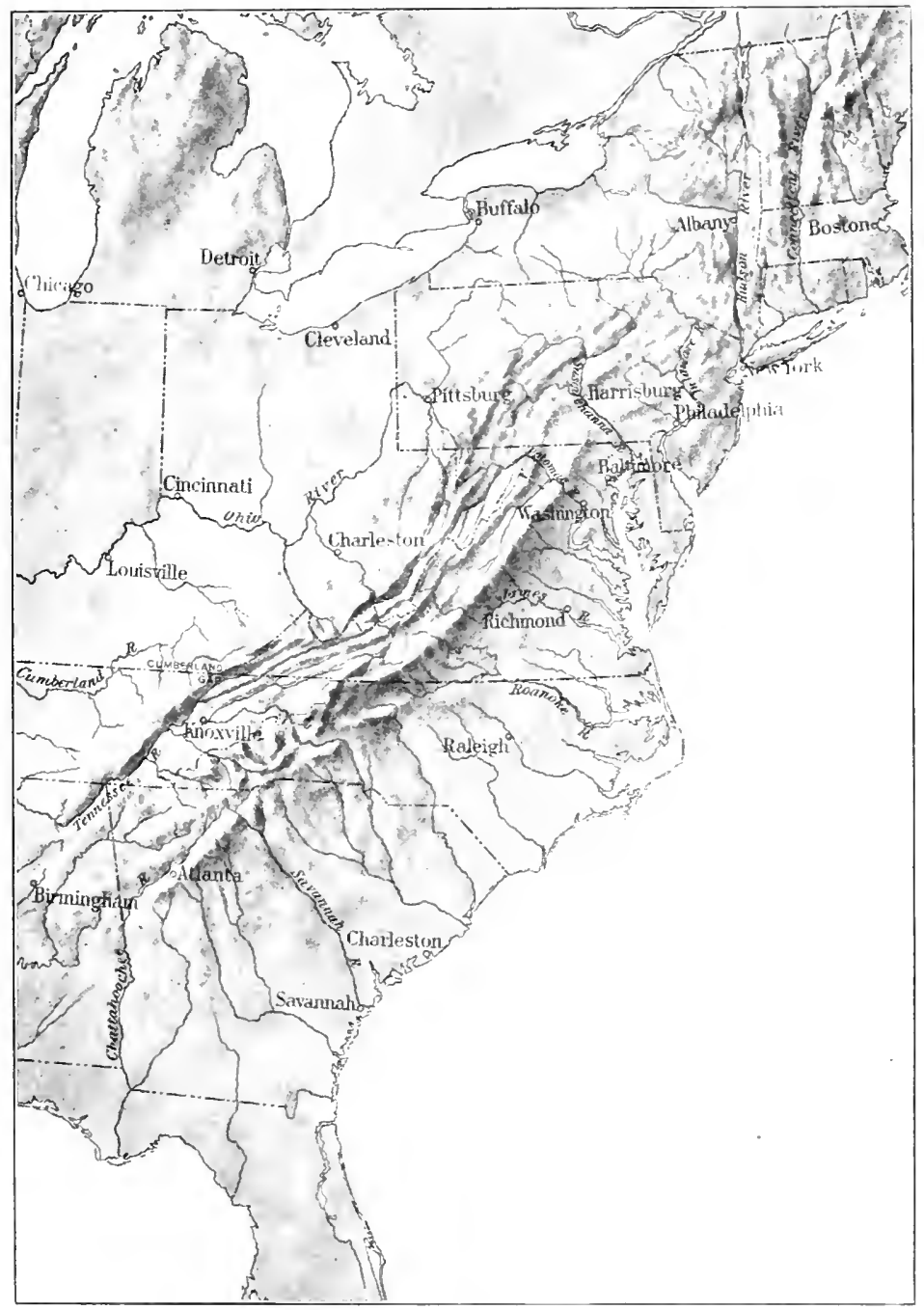

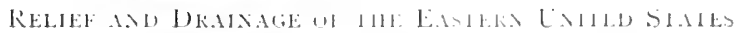


Variety of manufactures. In I005 the manufacture of lumber and timber products sare work to the largest average number of our laberers. There are nearly three hundred and fifty different kinds of manufactures in the United States. Some of these have a great number of what are known as "by-products." lior instance, in petroleum refining there are by-products such as vaseline, paraffin, and many other substances useful in manufacture and as medicines. In this book we shall study a few of the most important industries by which men supply themselves with food, clothing, and shelter - their three great needs.

\section{The Fon-Pronderag Regions of the Uniten States}

We must remember that as food is the most important of our needs, no industry interests the people of a country more than the manufacture of the things which they cat. We could get along without silk clothes and without relvet carpets, but we must have food to eat, and much of it has to be manufactured by working over the raw materials.

Slaughtering and meat packing. One of our chief foods is meat. The manufactures connected with this are chiefly slaughtering and meat packing. These industries are carried on in almost every state in the Union, but especially in Illinois. Kansas, New York, Nebraska, and Missouri are also important centers.

Chicaso as a conter of this industry. In Illinois the chief center of these industries is Chicago. Enormous numbers of cattle, swine, and sheep are brought into the Chicago stockyards, to be slaughtered, packed, and then shipped all over the world. The industry is handled in Chicago on a very large scale and with great celerity. A pig will enter the slaughterhouse on his own legs, and within trelve minutes will arrive in the refrigerating room, all cleaned and cressed, hooked up by his feet, and sliding along on an overhead track.

The bodies of these animals are turned into a number of meat products, various parts being worked up into different forms. The tongues are canned, and the hearts, livers, kidneys, etc. are 
INULSTRIAL REGIONS OF THE LNITED STATES 75 separated from the rest of the body and shipped as special products. Odds and ends of pork are made into sausage, and the fat of the swine is put up as lard.

The reasons why Chicago is such a great center of meat packing are numerous. It should be noticed that this city is on the edge of the com belt and is therefore near the raw materials. Chicago

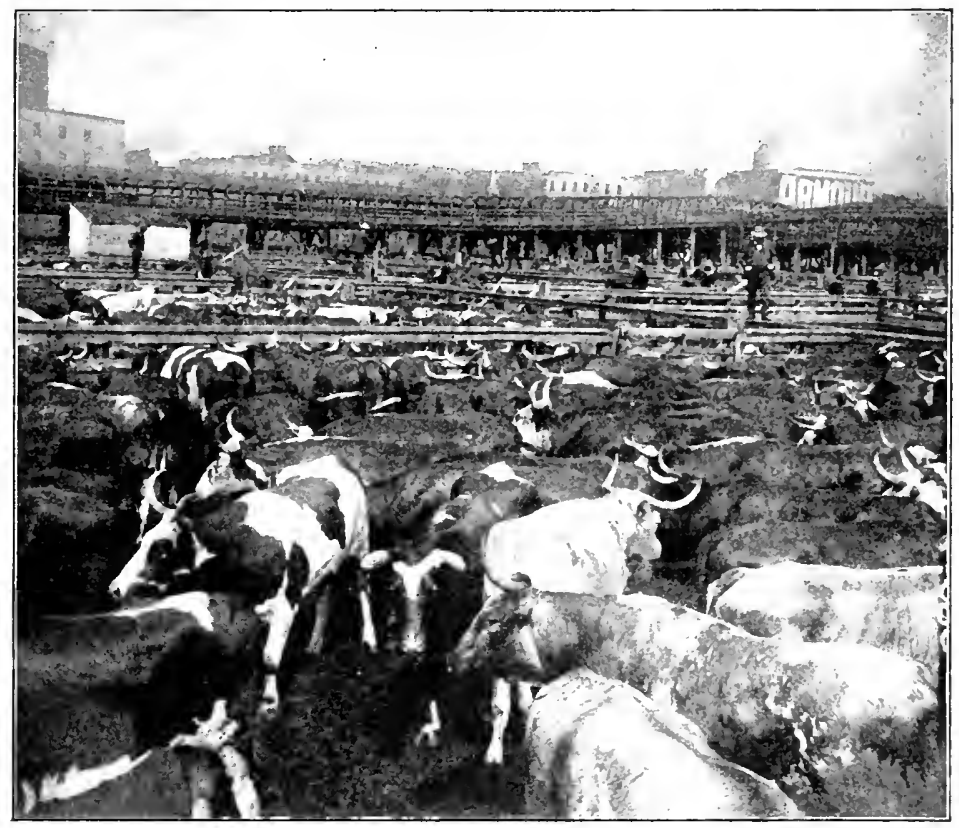

UNION STOCKMARDS, (HHCAGO

C II. C. Whute Cio.

has a wonderful advantage, too, in that so many railroads come together at that point; this means rapid and cheap transportation.

Refigeration. The perfecting of apparatus for artificial cooling has made it possible to carry on the business at all seasons of the year, and to transport fresh meat to all parts of the country and across the ocean. It is carried on the railroads in refrigcrator cars, and on the steamships in chillrooms, and it is kept in cold-storage warehouses until ready for consumption. 
By-products. The principal market products from swine are bacon, hams, salted pork, lard, and sausages. The chief market product from cattle is fresh beef, though the annual value of canned and salted beef and of tallow reaches several millions of dollars. Other valuable products, which cannot be eaten, such as hides, wool, hair, bristles, and bones, are derived from the bodies of these animals, and out of them knife-handles, buttons, glue, candles, brushes, and soap are made. As any industry grows there is more and more saving of what was formerly regarded as useless. The Indian used the meat, hides, and other parts of the animals which he killed, and he even made glue of their hoofs; but he would be amazed to see how much value there was in the parts which he threw away. He used to kill many bison and cut out the tongues only as special titbits; but all this is changed, for when animals are killed for profit, nothing of value is wasted.

Milling. A great deal of grain is fed to horses and cattle in the raw state, but the grains of all plants are better fitted for man when they are ground up into powder or flour. When little grain was raised, our milling industries were unimportant. Now, with the enormous growth of agriculture, especially since i 850 , milling has come to be a great industry. Since the corn and wheat belts are located, as we have seen, in the northern part of the Mississippi Valley, naturally the milling industries are located near by. Minneapolis has become the largest milling center in the world. Among the states, New York is second to Minnesota in milling. Once it stood first. Forty or fifty years ago "Genesee" flour held the same high place in the Eastern markets that Minnesota flour now holds.

\section{The Textile Regions of the United States}

Textiles. Textiles are manufactured from regetable and animal fibers. The chief of these, and the only ones which we shall study at present, are cotton, wool, and silk. These fibers are very fine strands, which, before they can be made into cloth, must be first spun and then woren. Spinning consists in twisting a number of these fine strands together to form a thread. Weaving 
is the interlacing of the threads so as to form a cloth or fabric. The spider is said to "spin" its thread, and the Germans call the spider "Spinne," but the spider's or silkworm's thread is no more than a single strand emitted from the body. The silkworm does not weaye its cocoon, but winds it. When we come to the study of clothing we shall learn more about spinning and weaving.

Cotton. In this country, cotton is manufactured chiefly in Massachusetts, Rhode Island, the Carolinas, and Georgia. It will be noticed that the two New England states are very far from where the raw material is grown, whereas the other states are near. The reason why the faraway states do so much of the manufacturing is because they have other advantages which we learned

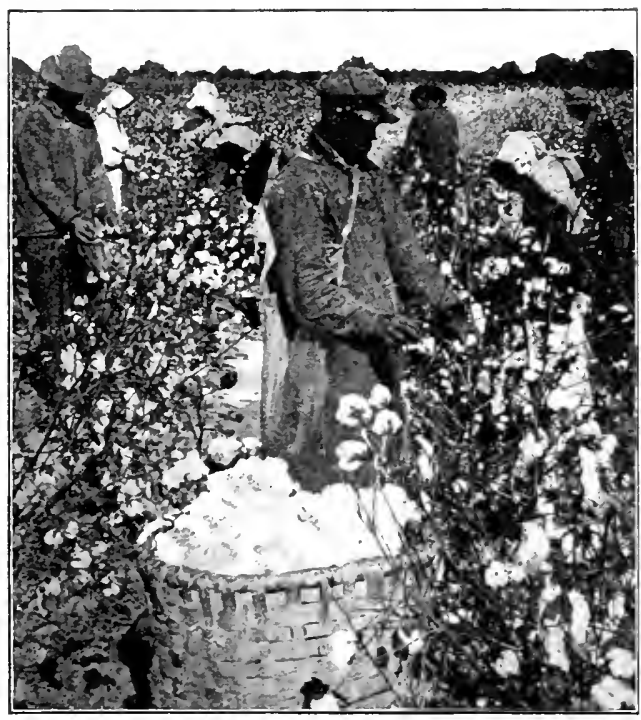

(C) II. C. White Co. about on pages 70 and 7I. These advantages make it possible for them to pay for transportation and yet do as well as the Southern states.

Of all the cotton-manufacturing states in this country Massachusetts is and always has been at the head. Recently South Carolina has taken second place, forcing Rhode Island into the third. Most of the Massachusetts mills are in the eastern part of the state. Cotton manufactures are likely to be near harbors, for the raw cotton is so bulky in proportion to its value that the cost of transportation is an important item. In general, the South has sold New England its raw cotton, and has taken in return various kinds of 
manufactured goods. Because labor is cheap and unskilled, South Carolina and Creorgia make the coarser kinds of cotton cloth. Massachusetts, having a higher grade of labor, is turning to the manufacture of finer goods, and so is able to maintain her superiority. In this case nearness to the regions of production counts for less than the quality of labor.

Wool. Sixty years ago most of the wool grown in the Lnited States was produced in the North Atlantic and the North Central

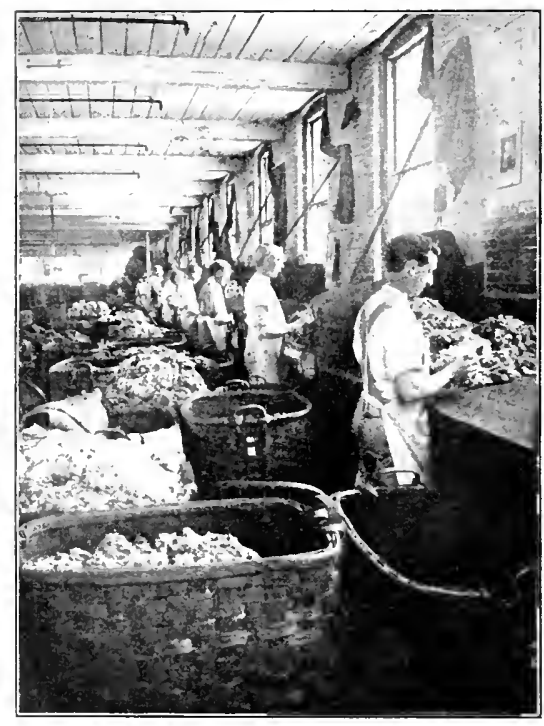

SORTIXG IHE W(mL States. But since that time it has been found that the best place for raising sheep is in the Vest, where there is plenty of cheap land, and where it is often too dry for agriculture. Now the Viestern and the North Central States are the great wool producers.

But again, the manufacture of woolen goods is carried on in the East. Massachusetts ranks first in producing worsteds and woolens, with Rhode Island, Pennsylrania, and New Jersey next in order. Pennsylrania is the first state in carpet manufacture, with New England next. Knit goods of wool, such as stockings and underwear, are manufactured chiefly in Pennsylvania and New York.

The reasons why wool is manufactured in the East, far from the regions of supply, are somewhat like those which led to the building of cotton mills near the sea. The wool-raising regions of this country are, in the first place, unfavorable for manufactures; and, secondly, they are unable to furnish us with all the wool we need. Some wool must be sent to us from abroad, and woolen mills are 
built near the seaports so that the owners shall not have the expense of further transportation.

Other animal fibers are manufactured into fabrics in this country; for instance, the hair of cows, and the hair or fur of other animals, is used in large quantities in manufacturing carpets, felt, and coarse articles like horse blankets.

Silk. Silk is a fiber which silkworms spin to make their cocoons. The silkworms live on mulberry trees, and the climate of the Lnited States is favorable for the growth of these trees and the rearing of the worms. But a great deal of hand labor is necessary in getting the silk from the cocoons, and the high cost of labor in this country prevents us from producing raw silli as profitablyas it can be done in such countries as Japan. Consequently the raw

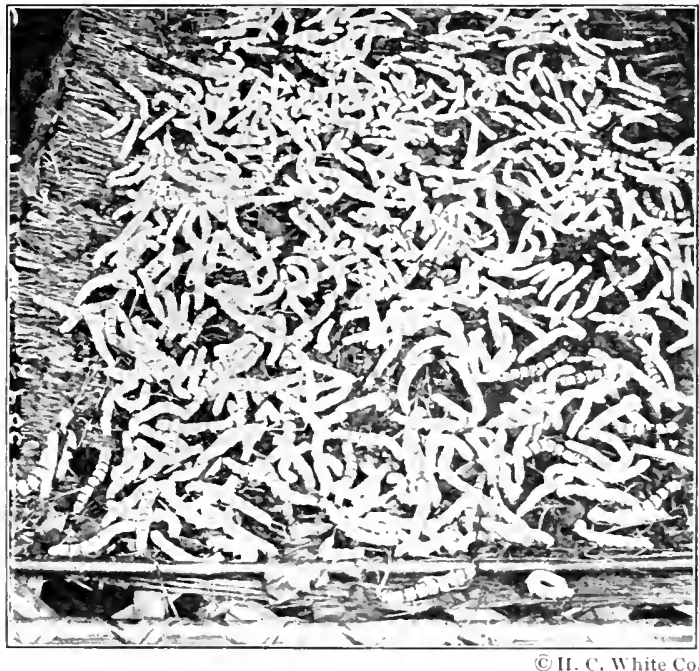

SILKWURWS FEEHAG ON MLLIERRY I.EATFS

material is often produced thousands of miles away from our mills.

Set the Lnited States is one of the leading countries in the world in the manufacture of silk goods. In the regions where silk is produced, the people have generally been unable to manufacture it with anything like the success shown by Americans. Formerly we made only the coarser varieties of silk, but since isgo we have succeeded in using machinery to better and better adrantage.

About nine tenths of all the silk manufacturing in this country is done in four states. Until recently New Jersey was the chief of these, Paterson being called the "I yons of America," after Lyons 
in France, a city famous for its silli manufactures. But Pennsylvania is now in the lead, and the order of importance is Pennsylvania, New Jersey, Connecticut, and New York.

Textile industries as a whole. Textile industries, taken as a whole, are confined to a rather limited area in the United States. In 1905 , of 4430 textile factories (excluding flax, hemp, and jute manufactories) in this country, 3041 were located in fourteen

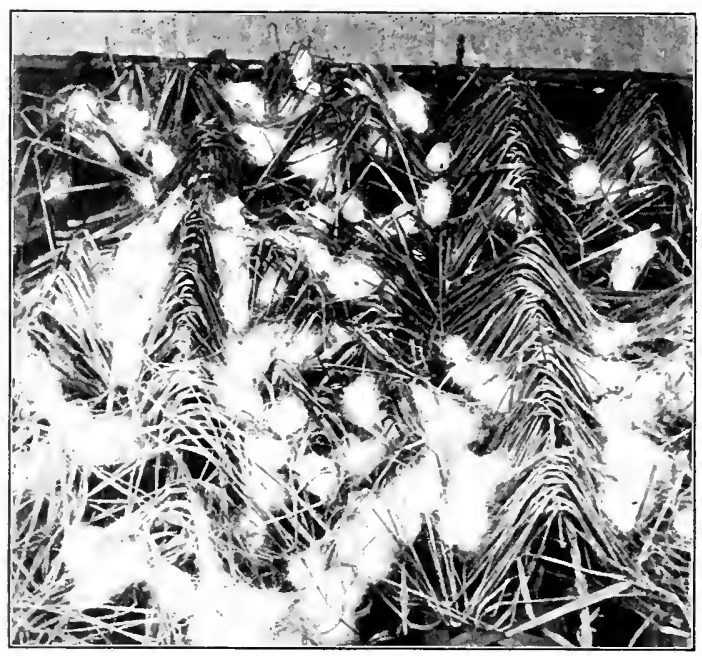

(c) II. C. White Co.

AfTer the Woras have spUn their Cocouns states, bordering the Atlantic coast from Maine to Georgia. Ne may say that cotton manufacturing is concentrated in southern New England, Pennsylvania, the Carolinas, and Georgia; that the woolen industry and knit goods are found chiefly in southern New England, New York, and Pennsylvania; and that silk manufacturing is confined to the four neighboring states of Pennsylvania, New Jersey, Connecticut, and New York.

There is a considerable tendency for manufactures, particularly cotton manufactures, to develop in the South, but, in spite of this, in 1905 the three southern states of New England, together with New Jork, New Jersey, and Pennsylvania, contained 301 r textile establishments; that is, about seven tenths of those of the whole country. 


\section{The Manufacture of Clothing}

Clothing. Ready-made clothing is cheaper than that which is made in a tailor's shop, for the same reason that machine-made products are almost always cheaper than those made by hand. A suit of clothes bought at a clothing store will often cost less than half of what one would pay for a tailor-made suit.

The sweating system. In order that ready-made clothing may be turned out so cheaply there must be a wide market and plenty of cheap labor. Therefore such clothing is made chiefly in the principal cities, especially those where large numbers of immigrants are to be found. Many immigrants are very poor, and are obliged to do whatever they can to earn a bare subsistence. They have come from countries where they have suffered great hardships, and they are ignorant not only of sanitary laws but of all better ways of living. They know little about the wages that are paid to good workers in this country, and are willing to take what will keep them from starvation. Consequently, they are often imposed upon by those who manufacture ready-made clothing. A great number of these poor people are crowded into small, dark rooms, under very unwholesome conditions, and here the whole family works at sewing. This is called the "sweating" system, and earnest efforts are being made to stop it.

New York a clothing center. New York City is the place where most of the immigrants land, and as they are often too poor and ignorant to go where they might earn better wages, they settle down into the life we have described. Ready-made clothing is manufactured in greater quantities in New York than anywhere else in the United States. The industry is an enormous one now, although clothing has been made in factories for only about seventy-five years.

In 1905 the state of New York held the first place in the manufacture of clothing, and the rest of the states were far behind. Nearly half of all the clothing made in this country for men, and nearly three quarters of that made for women, is manufactured in New York. 


\section{The Iron and Steel Regions}

Iron and steel manufacture. There are thirty-seven different inclustries having to do with iron and steel products, of which the manufacture of iron and steel is the basis. These industries produce structural iron and steel, rails, machinery, tools, hardware, tin plate (which is thin sheet iron covered with a wash of tin),

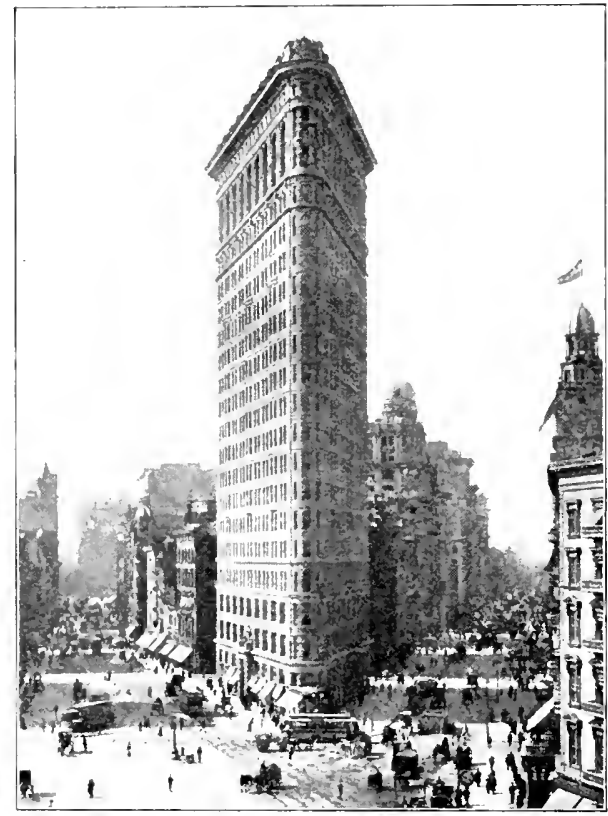

The Flatikox bullong, New York cutlery, wire, and many other more delicate manufactures, such as watch springs, steel pens, and needles.

The iron and steel industries in this country rank second in the value of their products, and first in the amount of money invested in them and in the amount of wages paid each year. The chief region for this industry is western Pennsylrania, which, in an average year, produces more than half of the country's output. Although jron and steel are made in twenty-seren of the states, Pennsylrania, Ohio, Illinois, and Alabama so far surpass the rest that they produce over four fifths of the total output.

One of the chief uses of steel in modern times is in the framework of buildings, particularly of the huge skyscrapers which make the peculiar "sky line" shown by the city of New York. This steel is called "structural steel," and three fifths of it comes from Pennsylvania. The enormous railroad systems of this and other 
countries call for millions of tons of steel rails, and of those made in the United States. Pennsylvania tums out about three eighths.

Pennsylvania an iron center. The reason why Pennsylrania is so successful is because of its mines of soft coal. In the early history of the iron industry eharcoal was the fuel used in the smelting furnaces. At that time Scandinavia was prominent in iron manufacture, and in this country New Jersey and other Eastern

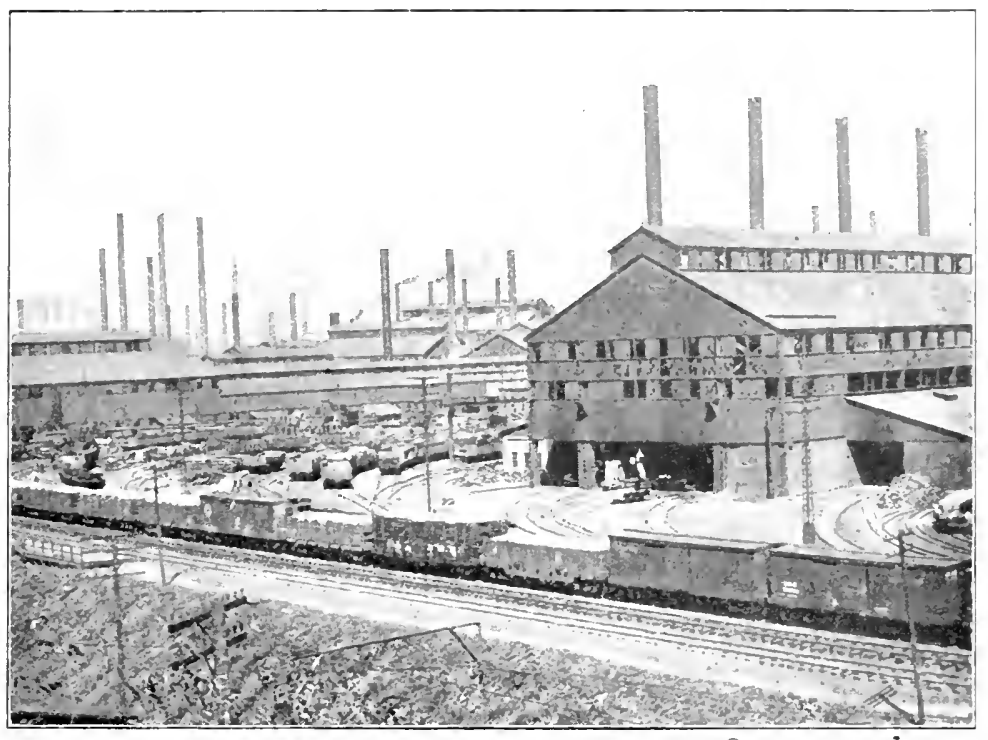

(C) Inderwend \& IPinderwood

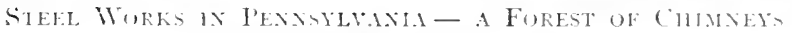

states were ahead of the rest. Now, since erolic, which is made from soft coal, is the principal fuel, the industry is located mainly west of the Appalachian Mountains. The iron ore, as we have seen, eomes chiefly from the rich Lake Superior rexion; but as it is cheaper to bring ore to the fuel than to take fuel to the ore, the industry is in Pennsyrania rather than near I alie Superior.

Some of the greatest fortunes of our times have been made in connection with the iron and steel industry, and "irommaster" is another name for a wealthy man. 


\section{BoOTS AND SHOES}

Hand labor. Until about 1850 boots and shoes in the United States were made by hand. In some parts of the country the cobbler traveled about from house to house in the winter time, making boots and shoes for the whole family for the coming year (see figure on page 19). He made these articles from the hides of farm animals which had been killed for food, and whose skins had been tanned by a local tanner. To-day most of the boots and shoes worn in this country are made in factories, and chiefly by machinery.

Machine labor. As soon as machines took the place of hand labor in making footwear, the industry began to increase greatly. The first machine in this business was the leather-rolling machine, which came into use about I 845 . Before that time sole leather had been pounded flat with a hammer upon a stone called a "lapstone." By the use of the rolling machine it was said that a man could do in a ninute what would require half an hour of hard work with a lapstone and hammer.

In a modern shoe factory there are sometimes over one hundred operations, each requiring a different treatment, in the manufacture of a single shoe.

Massachusetts a boot-and-shoe center. New England has long been the chief center of the boot-and-shoe business, and Massachusetts sets the standard for the world in shoes. This state had the great advantage of an early start, and was soon so far ahead that it was only in the latter part of the nineteenth century that much effort was made to establish the industry elsewhere. Shoemaking began at Lymn in 1636 . The shoes of the Revolutionary army were made in Massachusetts, and were thought to be as good as English shoes.

Massachusetts has no particular natural advantage in this industry, and the westward movement of cattle raising, tanning, and leather dressing is likely to draw the shoe industry after it. In New York City, and in other cities of New York state, especially in Rochester, the shoe business has made great progress. Newark, New Jersey, and Philadelphia also have an important business, and Cincinnati, Chicago, and St. Louis are not far behind. 


\section{CHAPTER II}

\section{THE MANUFACTURE OF RUBBER BOOTS AND SHOES}

\section{The RAW MAteriaL}

Sources of supply. The principal raw material required in the manufacture of rubber boots and shoes is India rubber, or, to use the native name, caoutchouc (kơo'chook). Crude or raw rubber is obtained from different trees, shrubs, or rines, native to the tropics. The chief regions where these plants grow are Brazil, especially in the valley of the Amazon, and Central Africa, especially in the neighborhood of the Kongo River.

How raw rubber is obtained. Formerly all the rubber of commerce came from trees or plants in their wild state, but at the present time man has domesticated them, and so he now cultivates the rubber plant. Rubber plantations have been established in several parts of the world, within the tropics, where the soil and climate are farorable. In Mexico alone there are said to be over a hundred rubber plantations; and others have been started in Ceylon, the Malay Peninsula, and various districts of tropical Asia.

In Brazil the chief source from which the rubber is obtained is a tree known as the Pará rubber tree, which often

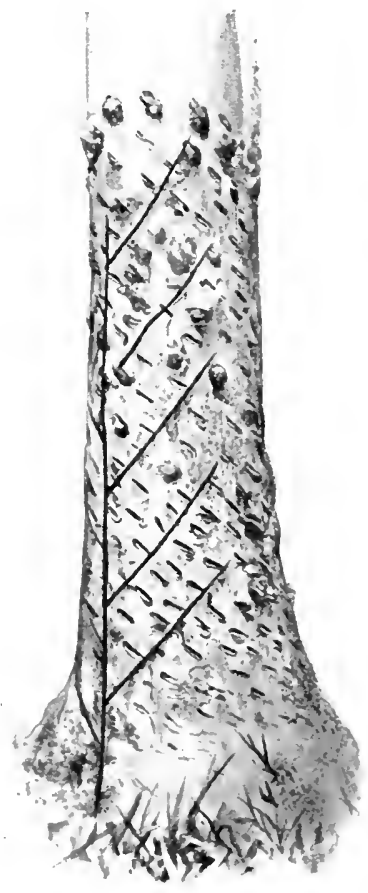

Methoi (F TAPPixg A RÜHILLR TREE 
grows to be sixty or seventy fect high and eight or ten feet in circumference.

Raw rubber is a milky juice from the bark of the tree. When fresh it is white, like cow's milk, but it turns dark brown in drying. It was formerly obtained by cutting down the tree or plant, and in

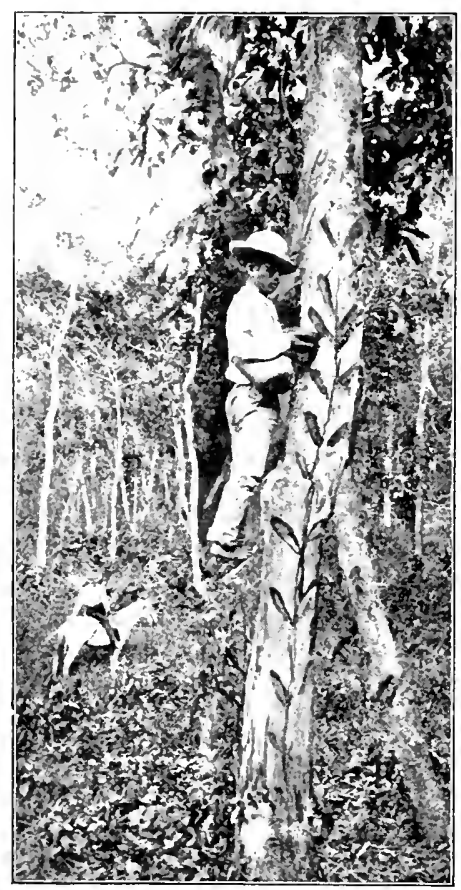

(C) Enderwoml \& Lnderwood

ANUTHER MYTHOD OF TAY'YNG

many cases this destructive method is still followed. But the supply of crude rubber is in clanger of exhaustion, and other less wasteful ways of getting the juice have been adopted.

Tapping. The rubber tree is now tapped as maple trees are tapped in the sugar camps of this country. Under the most favorable conditions Pará rubber trees are not ready for tapping until they are about five or six years old. One of the earliest methods was to make a $V$-shaped cut at a place where the bark had been carefully cleaned. The dripping sap was then caught in coconut shells placed on the ground, and was allowed to stiffen or coagulate. The dried juice that had collected on the trunk of the tree was peeled off and rolled into balls of "scrap rubber."

Spiral tapping. An improved method of tapping is the so-called "spiral" method. A number of cuts are made about halfway around the tree within a few feet of the ground; these seem to heal very readily without damaging the tree. In Ceylon some trees, tapped in this fashion, produce as much as twenty-five pounds of rublere each in a season, without injury to the tree; but the average yield of a tree five to ten years of age is from one to three pounds of dry rubber each season. 


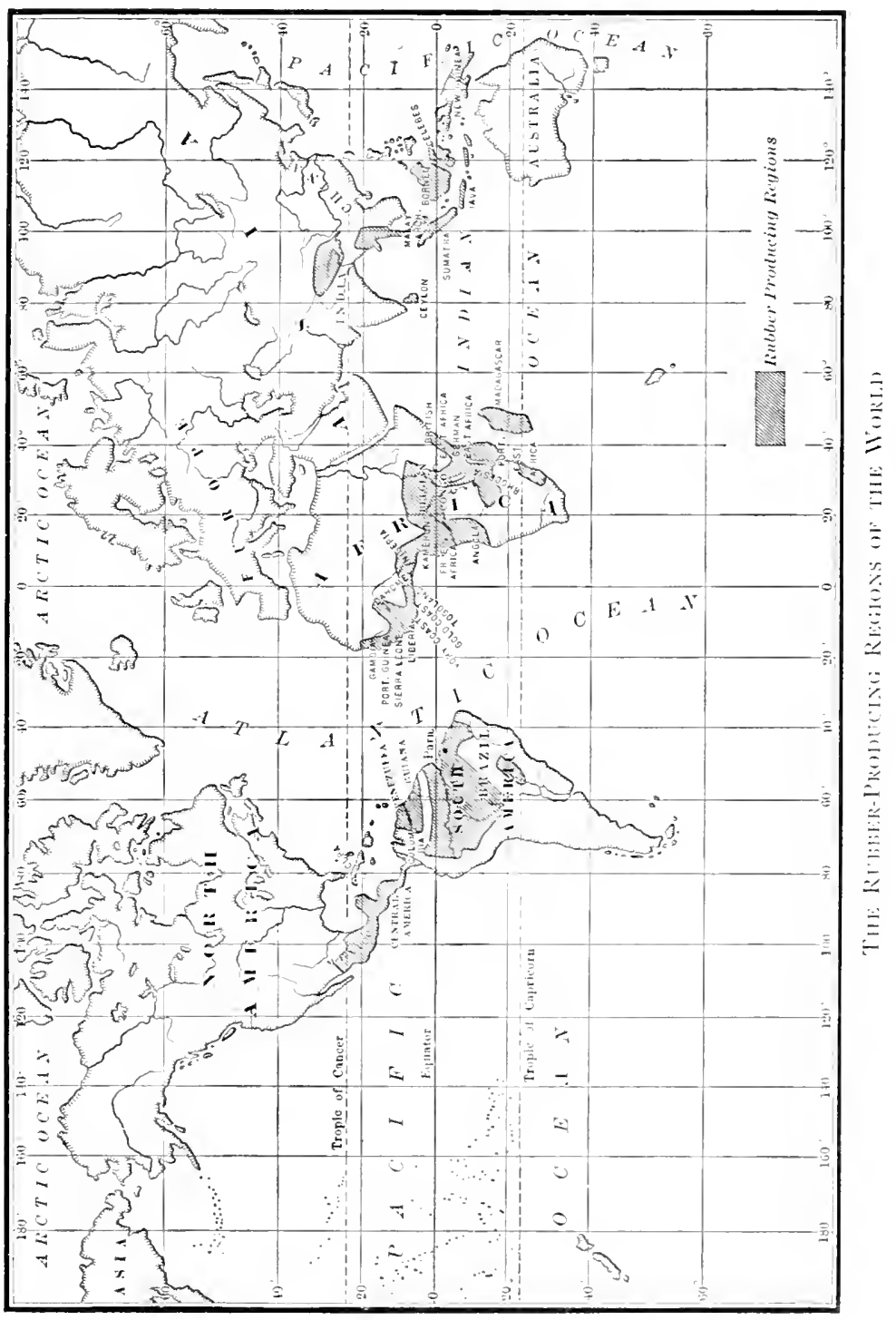


Some botanists think that all plants having a milky juice, such as the milkweed, really contain rubber; they believe that the juice of the milkweed plant contains about 4 per cent. But the price of rubber, though high, does not yet make it profitable to try to gather it from such plants.

Preparation for market. When rubber is collected without the care which is given to the process by the best gatherers, the juice is allowed to stiffen, or coagulate, at once. But this method has been improved. Sereral trees are tapped at the same time; then

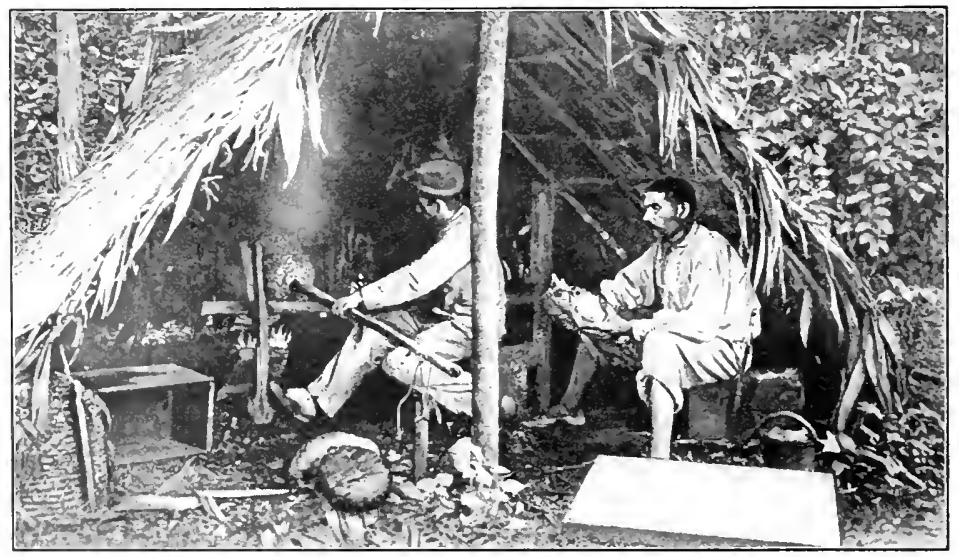

SMUKING RUBBER

when the juice, after ruming for a few hours, ceases to flow, it is all poured into a larger vessel. To convert it into a good quality of solid rubber, it is then smoked or cured. A fire is kindled, and orer it is placed a clar funnel from which issues a thick smoke. The rubber gatherer dips a paddle-shaped stick into his gourd of rubber juice and holds the adhering mass in this smoke until the rubber is stiffened. This operation is repeated, layer after layer being added, until the mass on the end of the paddle is thick enough. Then it is slit up and taken off, and after drying in the open air is ready for market. By this process a good workman can cure five or six pounds of rubber in an hour, 
Another method of preparation is as follows: A thin layer of juice is poured on large leares. When these have an even coating about one quarter of an inch thick, they are piled one on top of another and placed under great pressure. The leaves are then slipped out, and the thin sheets of rubber are made into slabs. These slabs are packed in bales of about one hundred and fifty pounds each, covered with a matting made by the natives, and sewed up in sacks; they are then ready for shipping.

A destructive method. In speaking of rubber gathering it is natural for us to think of Brazil, because it is the leading American source of supply. The Pará rubber of this region comes from the vast area drained by the Amazon and its tributaries - an area about two thirds the size of Europe. Hitherto the Brazilian rubber has been gathered in the back country by Indians. These halfwild people are, of course, eager to secure the largest pos-

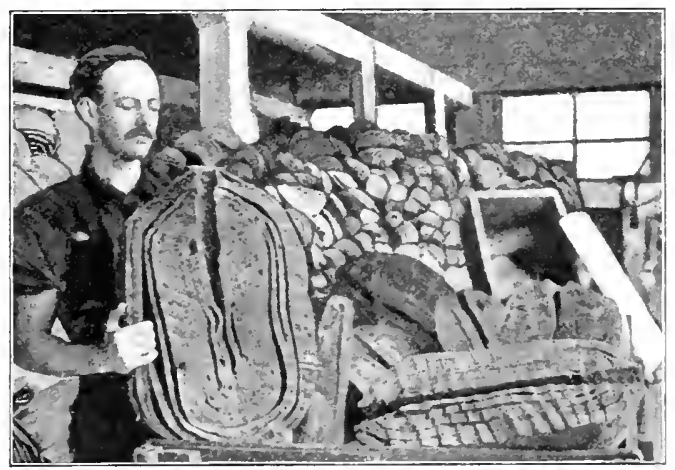

A Ruliber "Biscuit"

sible amount of rubber, and they have had so little thought of future harvests that they have already cut down an immense number of the trees in their efforts to get the juice in the easiest way. This destructive method has forced the natives every year to penetrate farther and farther into the forests. A large part of the labor of the rubber collector consists in long journey's through the swampy woods.

Method of transportation. After the rubber has been gathered it is brought down the river to various collecting stations, of which Pará, at the mouth of the Amazon, is the most important. It is carried for the most part in the canoes and other small craft of the natives. The transportation from the forests, in other 
rubber-producing countries, such as the Belgian Kongo, was formerly accomplished in the same crude fashion.

Sea routes. From the seaports it is then shipped, chicfly to Europe and the United States. In the year 1900 about 50,000,000 pounds of crude rubber were imported into this country; about three fifths of this came from South America. Of this latter amount Brazil furnished fourteen fifteenths, and the shipments

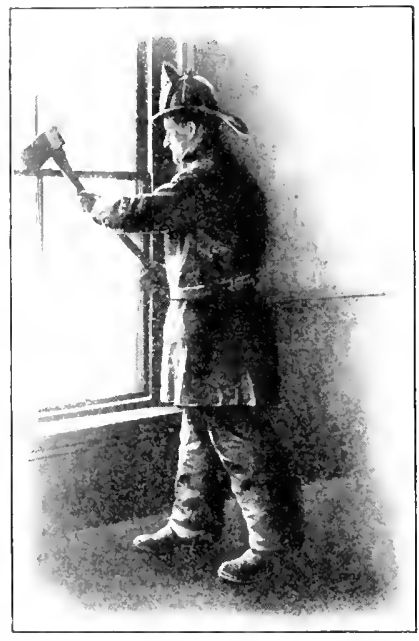

('LOIHED IN KUHBER FROM IIEAH Tw $\mathrm{F}(u) \mathrm{T}$

were made direct from Brazilian to American scaports.

Some of the rubberwas imported by way of Europe ( I 7, ooo, ooo pounds), though of course it must have been gathered in the tropics. About 2,000,ooo pounds came from other parts of North America, and less than 650,000 from Asia. Nine tenths of the crude rubber imported from countries other than South America came from the United Kingdom, Belgium, Portugal, Germany, and France, in the order named. Of course the rubber which Belgium sends us comes chiefly from Belgian Kongo, formerly the Kongo Free State; the other European countries just mentioned have tropical possessions likewise, which naturally send their rubber first to the countries which own them.

Another reason why rubber does not come directly to the United States, except from Brazil, is because the commercial countries of western Europe have closer trade relations with the tropical regions than we have. In the year 1900 no crude rubber whatever came directly from Africa to the United States, and yet in that year we used 5.000,000 pounds of African rubber in the manufacture of rubber boots and shoes.

Use of rubber. In that same year nearly I $8,000,000$ pounds - over a third of the total quantity imported - were used in 
manufacturing rubber boots and shoes. This shows that while rubber is used more and more for other purposes, particularly in the making of tires for the rapidly increasing automobile business, yet its use in the special trade which we are studying is still very extensive.

Importation. All the rubber which we use in this country must be imported; it is not a home product. We have seen that it demands a tropical climate and so could not be raised here unless we made such a climate for it. This we cannot do, since we cannot control the sun. It is true that we can make a small amount of tropical climate, in hothouses, and sometimes in our own homes, where tropical plants will grow; but any rubber that we should raise in this country would be so costly that a rubber-producing industry would be out of the question.

Customs duty. The governments of many countries charge an importer a certain sum on the goods which he imports. This is called a "customs duty." These duties are charged for two purposes: (1) to get revenue to pay the expenses of the government; and (2) to encourage home manufacture.

I. Duty for revemue. A duty charged for government expenses only is called a "revenue duty," and generally falls upon articles of Juxury, such as costly wines, jewelry, and the like. No such duty is charged on rubber, because it is not a luxury, but is an article of great service to all classes of people.

2. Protective duty. When imposed for the second purpose, such a duty is called a "protective duty," because by placing a tax on foreign goods it allows our own producers to charge a higher price for the same things, and "protects" them from foreign competition. This is supposed to encourage our people to produce things for which we should otherwise have to send abroad. No protective duty is charged on crude rubber, for under no conditions could it be produced in this country, and there is therefore no use in trying to protect or help along a rubber-producing industry. For this reason crude rubber is imported free of duty. 


\section{Manufacturing}

Early uses of rubber. Rubber is manufactured into a great number of useful articles. It was known for many years before people began to realize its great value and its many uses. It is said that the Indians, before the time of Columbus, used to play ball with globes made from the gum of the rubber tree; but it was not until about 1770 that civilized people began to use rubber for any practical purpose. For two hundred years or more the people of Europe looked upon the elastic balls used by the Indians for games as mere curiosities. But it is said that the Spaniards found

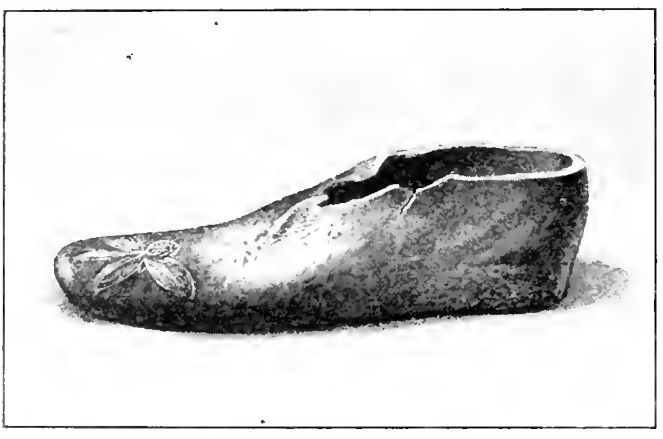

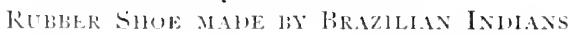
out from the Aztec Indians of Mexico that overcoats could be made to keep out the dampness by smearing them with rubber.

\section{Why called "rub-} ber." One of the first practical uses of rubber was as an eraser of pencil marks. IV'e still call an eraser a "rubber," that is, a thing we rub with. It was this use of the tropical gum which gave it its common name, and since some of the first specimens of gum came from the East, it has often been called "India rubber." When we study the processes of rubber manufacture we shall learn more about its various uses.

Early processes and their failure. In 1823 a Boston sea captain, returning from a tropical voyage, brought with him a clumsy pair of rubber shoes made, it is said, by natives of the Amazon region. The shoes attracted much attention because they were water-tight. A few years afterwards some enterprising merchant imported five hundred pairs, which sold for from three to five dollars a pair. It was not long before this crude manufacture 
was taken out of the hands of the South American natives. In those early days raw rubber was very cheap, but even these poorly manufactured products could be sold at a high price. Accordingly certain persons began to experiment with the rubber, and in ${ }_{1} 8_{3} \mathrm{I}$ a manufacturer of leather goods in Roxbury, Massachusetts, found out that by dissolving crude rubber in turpentine and then adding some lampblack he could produce a varnish which would make leather or cloth water-tight. A company was organized in 1833 . called the Roxbury India Rubber Company, to place this new discovery upon the market. Other companies followed, and soon several millions of dollars had been put into the new industry.

But soon after the products came on the market it was found that they were almost useless, because the rubber melted and became sticky in hot weather, and cracked in cold weather. The goods could not be sold, and the business was temporarily abandoned.

Later processes. Even before this, in England, waterproof cloth had been manufactured as early as I 797, but it would not stand heat. In I 823 Charles Mackintosh, a Scotchman, was able to dissolve rubber in naphtha and thus make a varnish that rendered cloth waterproof. IIackintosh gave his name to a kind of raincoat with which we are familiar. Other experiments followed, both in this country and in Europe; but it was finally an American, Charles Goodyear, who invented a process by which rubber could be made useful for commercial purposes. Daniel Webster thought that Goodyear was one of our greatest inventors, and ranked him with Fulton, Whitney, and Morse.

Goodyear's invention. What Goodyear discovered was the process known as "vulcanization." After ten years of patient study and experimenting he accidentally spilled a combination of rubber and sulphur on a hot stove, and quickly discovered that the heat made the rubber dry like leather, and that thereafter it was neither melted by the heat nor cracked by the cold. Many other processes have been developed around the Goodyear process, which consists in mixing rubber and sulphur at a moderate heat, and then raising it to a temperature ranging from about 250 to 300 degrees Fahrenheit. 
The story of Goodyear's efforts to perfect a process which would make rubber less sensitive to heat and cold is a striking example of the great results that come from unfaltering perseverance under difficulties. For years he lived a miserable life, spending all he had in the world, without success, in trying to do what he felt sure could be done. His family and friends sometimes condemned him, and sometimes laughed at him, but he went on undiscouraged. To-day vulcanized rubber, the material which he finally succeeded in making, is the basis of more than two thousand useful branches of manufacture. But for the self-sacrificing life of Goodyear, probably civilization would have gone without this seemingly indispensable material for many years longer.

\section{THE MAKIXg of FoOTWE.IR}

History of the industry. The manufacture of rubber boots and shoes in this country commenced about i 850 , but it was of very small importance up to I 880 . Since that time it has steadily increased, and between $\mathrm{I} 890$ and 1900 the number of factories rose from eleven to twentr-two. Of these, Massachusetts and Rhode Island each had six, Comnecticut five. New Jersey and Pennsykania each two, and Missouri one. Thus we see that the industry is confined almost solely to the northeastern states on the Atlantic seacoast.

Massachusetts leads in making rubber boots and shoes, just as she does in manufacturing leather footwear. In I905 the rubber boots and shoes manufactured in this state were worth more than all those manufactured elsewhere in the country, and since that date the business has been growing rapidly. In $\mathbf{I} 900$ the manufacture of rubber footwear stood eleventh in importance among the industries of Massachusetts, and in 1905 it stood sixth. This was not due to the establishment of new factories, but to the increased efficiency of the older ones: between 1900 and 1905 only one new factory was founded, but the value of the product had increased more than I 36 per cent. Among the manufacturing industries of Comnecticut in 1905 , the rubber boot-and-shoe manufacture stood seventh. 
Cleansing the rubber. When the crude rubber comes to this country it has first to be cleansed of its various impurities. Picces of bark, bits of dirt, and eren stones are frequently found in it. After being softened by lying in hot water for a number of hours, it is put into a machine and crusheck between gronved rollers. As it comes from the rollers a stream of water flows oxer it, washing away all dirt and bark. When it has been rolled and washed sereral times it is hung in a warm room and thoroughly dried. It is then

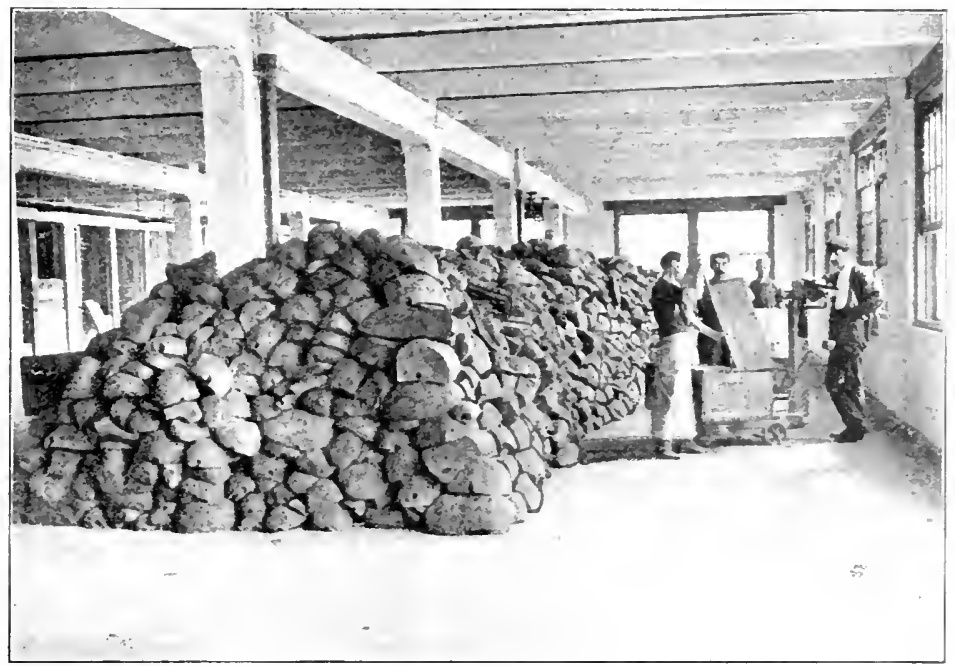

A l'ile uf Colde Rlabek

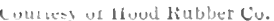

stored in a dark, dry place. Before it can be made into boots and shoes it must be mixed with sulphur and other substinces.

Modern shoes. The first overshoes imported into this country were made of a single piece of rubber; to-day a rubber shoe has seren or eight different parts, and a rubber boot orer twenty. The preparation of these parts requires various machines. For instance. the rubber which is to make the sole is passed through a mathine which gives it the "crisscross" pattern familiar to all of us. The other parts also have to be made ready for their special uses. 
Besides the ordinary rubber boots and overshoes, our factories make temnis shoes, aretics, and heary shoes for lumbermen.

Use of cloth. Rubber boots and shoes, as well as many other articles that are usually spoken of as being made of rubber, contain, in adclition to the rubber, something else which gives additiomal strength. This is a stout canvas or cloth, which makes the foundation of what are usually sold under the name of rubber

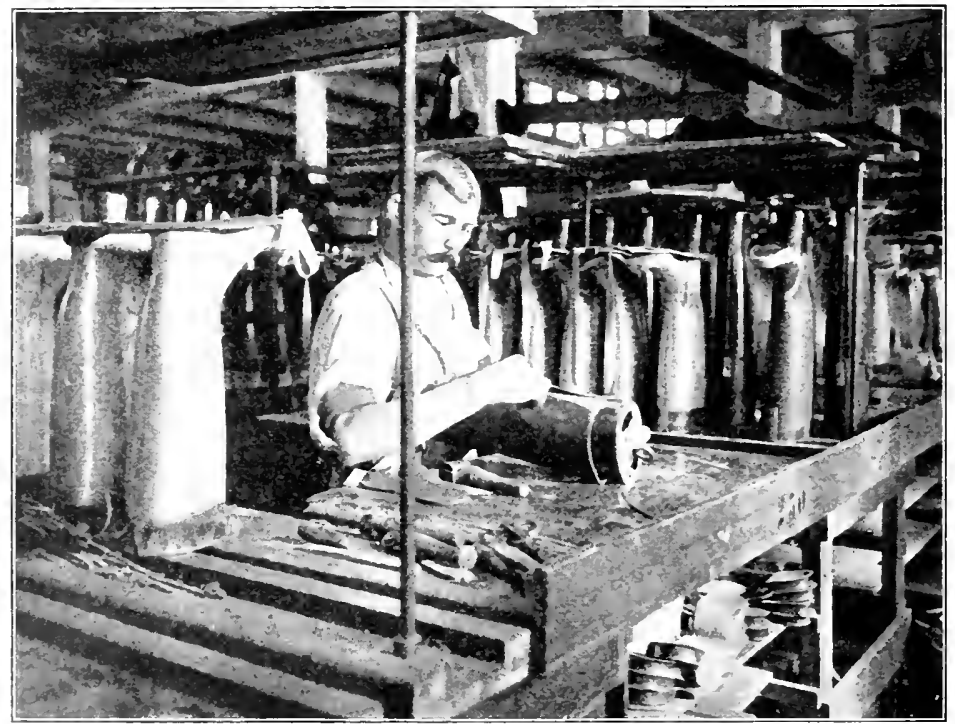

Courtesy of Houd hubber Co.

LASING THE LANING FOR RUBBER BUUTS

groods; as in the case of garden hose, it gives both strength and form to the article.

In making the boots and shoes a sheet of rubber together with a sheet of fabric are passed through a machine and subjected to operations which make the two amost inseparable. When this operation is not done very well, the rubber part is likely to separate from the fabric. This sometimes occurs in bicycle and automobile tires, especially where roads are oiled, for the oil loosens the rubber from the cloth. 
The cloth part varies in thickness in the different parts of rubber footwear; for example, the part above the knee of a pair of rubber hip boots is lighter than the rest of the boot, for the fabric is thinner in that part. The different parts of the boot or shoe, such as the soles, heels, and tops, are all of different thicknesses. They are cut out with dies, generally by hand, and then are brought together over a smooth "last" and cemented firmly. Next they are varnished with an asphalt lacquer, and are rerulcanized for seven or eight hours, at a temperature of 260 degrees Fahrenheit. They are then ready for the market.

\section{Use of waste rub-} ber. Another important feature of the industry is the use of waste rubber. This waste, consisting of old rubber boots, shoes, hose, belting. and other rubber articles, is first run

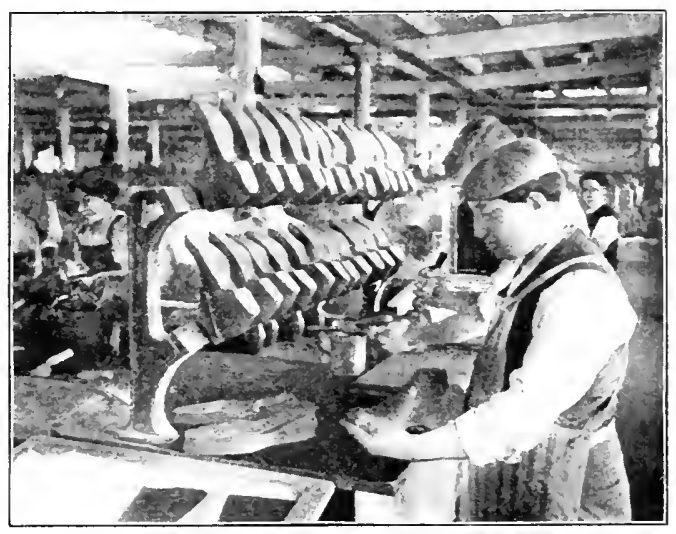

Courtesy of llood liubber $\mathrm{Co}$.

P'LACING OUTSULES ON RUBBERS through machines which reduce it to powder. It is next passed over magnetic plates, which draw out any particles of iron or steel, after which another machine sifts out the dirt. The mass is then boiled in a vat, in a solution of acid which destroys any fibrous matter. Then, after being washed in large tubs, it is thoroughly dried and sent to the mills for refining.

Improvements. Since the granting of Goodycar's patent in I $\$ 4 t$ the industry, as we have seen, has steadily grown. There are now produced more than a thousand varieties of rubber boots and shoes. Great improvements have been made as regards both appearance and comfort.

Tendency to lower quality. Rubber boots and shoes are no longer worn by the wealthy only, but are sold at a price within the reach 


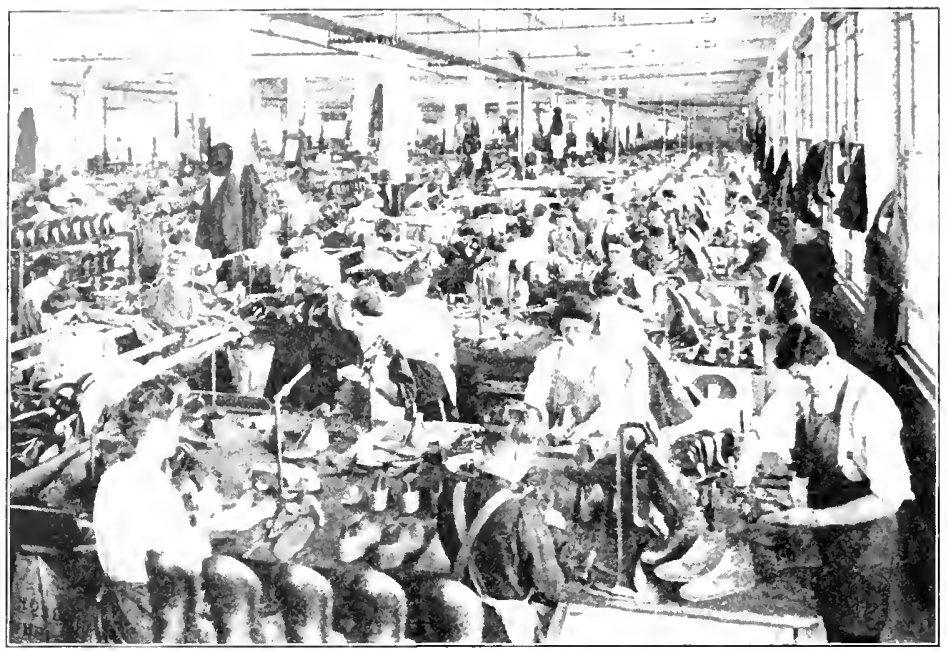

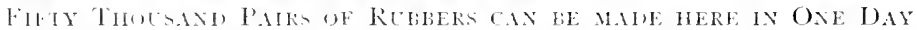

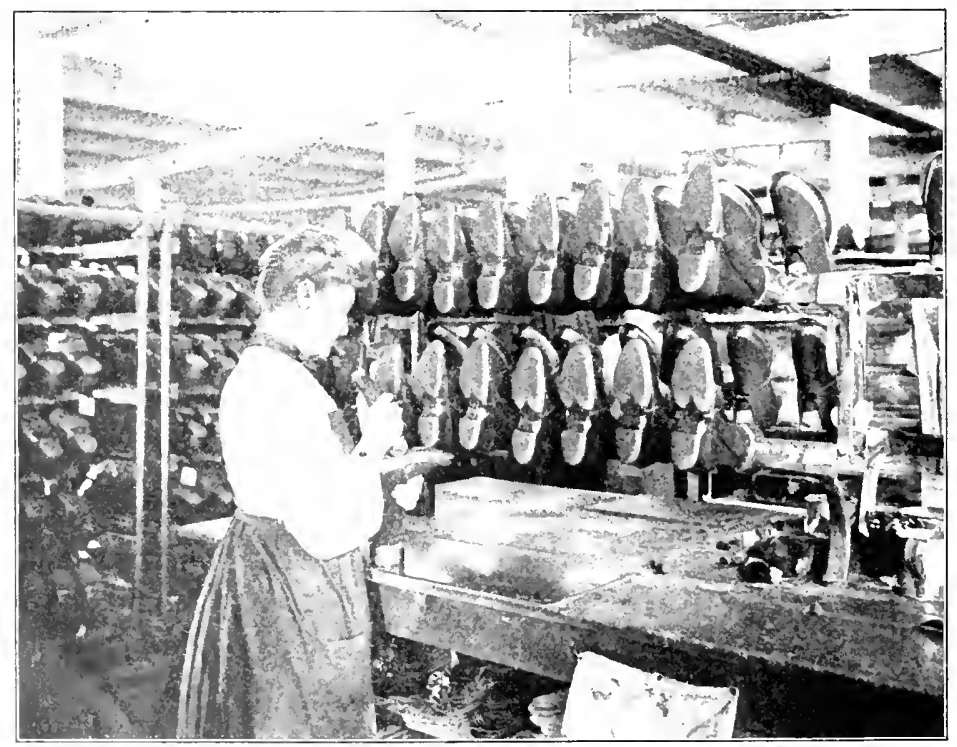


of everybody. However, this cheapening has had its ill effects, for the rubber has been adulterated, and in some cases orershoes are not worth the small price asked for them. Crude rubber costs much more than it once did, and the tendency is to use some substitute which is less expensive. Adulteration occurs in many other industries also, owing to the efforts of manufacturers to lower the price of their goods in order to sell more of them, or to make a greater profit at the same price by using cheaper materials.

\section{LOCATION OF MNOETRE}

Near raw materials. All the sources of raw material are outside the country. Consequently, if the manufactories are to be as near as possible to the raw material, they must be near the seaports; and since the rubber comes, as we have seen, almost wholly by way of the Atlantic Ocean, the best places are near the great Atlantic ports, such as New York and Boston. If we look back upon the list of states with important rubber manufactories, we shall see that all but one of them are close to these two ports.

Near available power. Before steam became the principal available power in manufacture, the chief plants in all industries were located where there was water power. Along the fall line this was easily arailable. And often, after the use of steam came in, there were a number of reasons why manufacturing prospered chiefly in the eastern and northeastern sections of this country (see pp. 70 and $7 \mathrm{I}$ ).

Near abundance of labor. Labor is more plentiful where population is more dense, and therefore in the East rather than in the West, and in the cities rather than in the country. This is another reason why we find the rubber factories in the cities of the last.

Near market. There is probably no other country in the world where rubber boots and shoes are regarded as so indispensable in rainy weather as they are in the Lnited States. In former days leather boots and shoes were made water-tight by greasing them thickly with tallow; no further protection against dampness was attempted. Now most grown people and children have rubber 
boots or overshoes, and many have long rubber coats. This makes a market for these articles in all sections of the United States except very dry ones, and in these the population is too small to be of commercial importance. In the year I 900 we produced nearly 50,000,000 pairs of rubber boots and shoes of all kinds. In the same year we exported only 767,000 pairs. This shows the extent of the home market.

Near transportation facilities. The railways of our country furnish such excellent means of transportation at low rates that rubber footwear can be sent almost anywhere within the United States at the cost of only a few cents a pair.

Consolidation. In I 892 the United States Rubber Company bought up the rubber-footwear concerns. This brought about a considerable reduction in the operating expenses of the various plants, and made a strong business power of the company.

Duty on rubber goods. Ne have seen that raw rubber pays no duty, and we know the reasons why this is so. But rubber manufactures are protected by a large duty. Manufactured rubber articles must pay a duty of 35 per cent ad valorem $\left(\frac{35}{100}\right.$ of their value) on entering this country. That is, if an English manufacturer sends to the United States a pair of rubber boots which he would sell in England for \$I.OO, in this country the price would have to be $\$ 1.35$ plus the cost of transportation; otherwise he would lose money by sending his goods here. This means that the American manufacturer may charge $\$ I .35$ for his rubber boots without fear that his customers will be tempted to buy the foreign product at a lower price. 


\title{
PART II. FOOD AND FOOD MATERIALS
}

\section{CHAPTER V}

\section{DISTRIBUTION OF FOOD MATERIALS IN THE UNITED STATES}

\author{
Grains and Vegetables
}

We have already learned something about the distribution of the various raw materials of industry in our country. Now we come to review a part of this, and to add something about other food materials which we have not yet taken up. First, let us consider the distribution of plant foods - the grains and vegetables.

Wheat. The chief wheat belt extends through the valleys of the Missouri, the Ohio, and the upper Mississippi ; of all the states in this region Minnesota raises the most

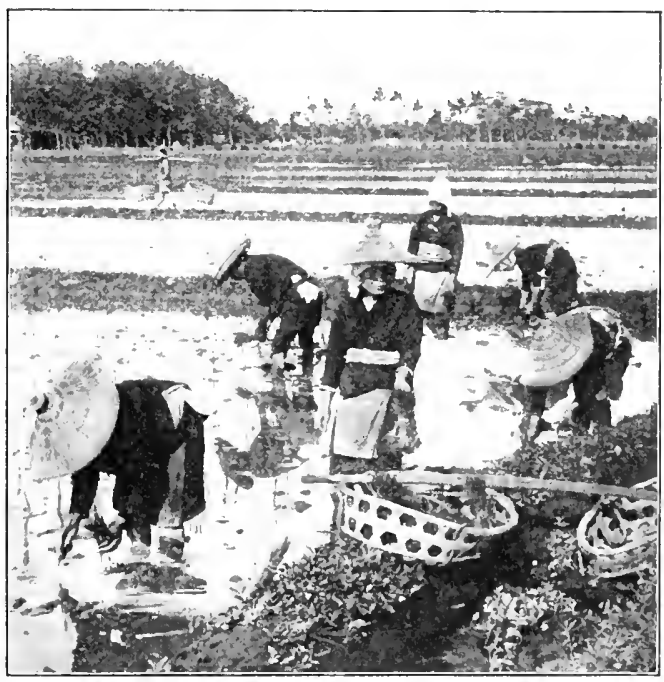

(c) H. C. White Co.

Transplanting Rice (Jaran)

wheat. There is another wheat belt along the Pacific coast. If, now, we make a list of the wheat-producing states in the order of 
their importance, they are Minnesota, Kansas, North I)akota, Nebraska, Illinois, Washington, Indiana, South Dakota, Ohio, l'('mnsylvania, Missouri, California, and Oregon. The present center of wheat production is about one hundred miles west of Des Moines, Iowa; since I 850 it has moved westward nearly seven hundred miles, and northward about one hundred miles.

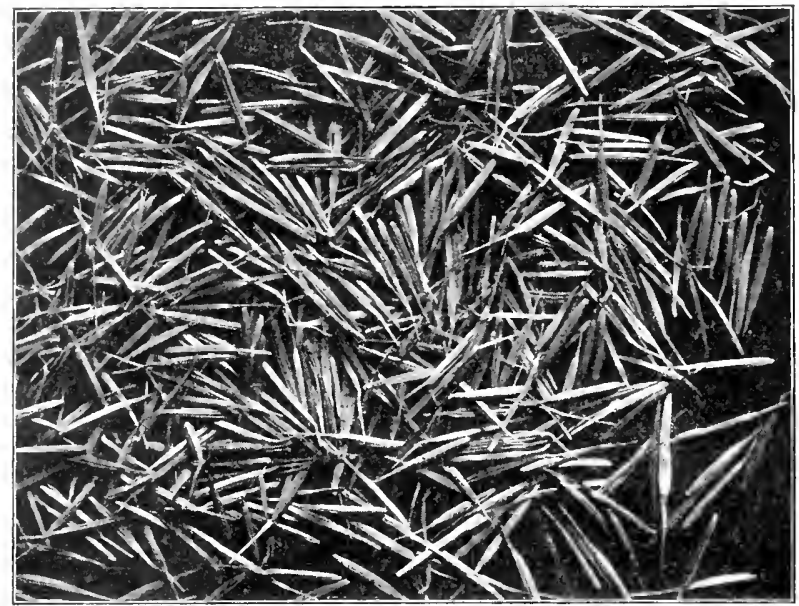

Courtesy of Bureall of Amertuan Lthmulues

WIID RIRE (B.AIIEREI, JY THF INIHANS

Corn. This is our principal crop, both in the area covered and in the quantity produced. IVe saw that the corn belt is a little farther to the south than the wheat belt, all the most prominent of the corn-producing states being located in the valley of the Mississippi and its tributaries. These states are, in order, Kansas, Nebraska, lllinois, Inwa, Ohio, Indiana, and Missouri.

Rice. We have seen that this grain, since it is a tropical or semitropical one, is located only in the warmer parts of this country. Originally brought from Asia, its culture in this country began at Charleston in I694. Since that time rice cultivation has shifted westward, but, of course, it has always clung to the warm, moist regions. A new variety of rice, called Kiusiu, has been recently introduced from Japan, and to-day about one half of the total crop is of this variety. Louisiana and Texas are now the chief locations for rice raising, although other Southern states carry it (on to some extent. 
There is a kind of rice, native to this country, called "wild rice." This is not a tropical plant, but once extended over large areas from Texas to Canada, being more common in the north-central section than elsewhere. It was long used by the Indians as food, and at the present day is sometimes eaten with game.

Potatoes. The common white potato is an American plant, and was first seen by Europeans during Pizarro's conquest of P'eru. The potato was not appreciated as a vegetable when first taken to Europe, but was fed to cattle and hogs; afterwards it was used as food for the poor in times of famine. Its cultivation in Ireland became extensive, and for this reason it is often called the "Irish potato." In I $S_{45}$ the Irish potato crop was ruined by the "potato rot," and there followed a terrible famine, with much suffering and death. Deep sympathy was felt in this country for the sufferers, and

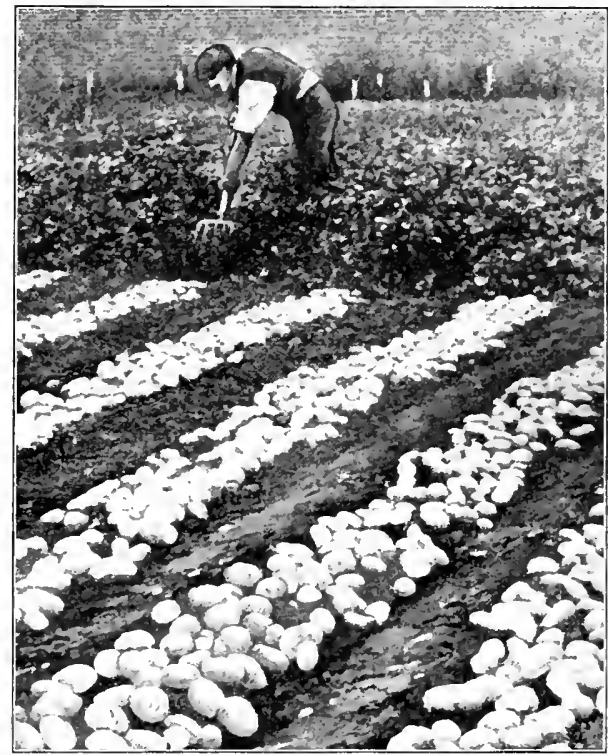

Big Yiele of potatoes an New York state

whole shiploads of potatoes were hurried to Ireland. But even then the conditions were so bad that thousands of the Irish left their homes, most of them emigrating to the L'nited States.

Potatoes are raised in many parts of the United States, for they will grow almost anywhere, provided the ground is not so damp as to cause rot. In this country there are few farmers without their potato patches. The chief potato states are New York, Wisconsin, Michigan, and Pennsylrania, but some of the best potatoes are produced upon different parts of the Rocky Mountain plateau. 
lrish potatoes, in addition to forming a very important food for man, are used, among other things, for making starch, glucose, and alcohol, and are fed to cattle and hogs.

Sweet potatoes. The "sweet potato," as it is now generally called, is raised by more than a million farmers in this country. It demands a warm climate, and prospers in sandy soil, and so it is cultivated chiefly in the Southern states, though more northerly ones, like New Jersey, Illinois, and Missouri, raise sweet potatoes to some extent. It belongs to a different family from that of our common white regetable, but it was nevertheless the original "potato," and has the best of rights to its name.

Fruit. Fruits of various kinds are raised in many sections of this country. They are not all alike in their requirements as to soil and climate, and so it is impossible to map out the fruit-raising regions as definitely as we can the wheat or corn belts. Certain fruits, like apples, will grow in Connecticut, but for oranges we must have warmth such as that of Florida. In general, the fruits will grow in the farming regions, but we should not expect to find them where the climate is very dry or where the ground is stony and infertile. The principal fruit-growing region is in southern California. California's product is greater than that of any other state, and is about twice as valuable as that of New York, which ranks second.

In the United States more kinds of fruit are raised than in any other country, and we lead the world not only in the value of our product, but also in our methods of preserving and marketing it.

Market gardens. Narket gardens, as their name shows us, are places from which markets are supplied. Most of the market gardening is in the East, first, because many of the large cities are there: and secondly, because in the West the broad stretches of level land tempt farmers to raise great quantities of a single product like corn, whereas in such a state as Connecticut each farmer has a smaller farm and cannot produce one thing so extensively. He is likely to keep a few cows, some pigs, and a number of chickiens, and to raise regetables and fruit. By giving close attention to these smaller crops, and by frequently fertilizing the 
ground, he is able to raise in abundance a variety of products. For these he can get sufficiently high prices in the neighboring cities to pay him for the extra care and expense.

The market gardeners raise several crops on the same land in the same season, by careful, intensive cultivation. They also practice hothouse growing, and thus supply cucumbers, lettuce, spinach, etc. for the table in the winter. By specialization some of them grow only one of these hothouse products, as, for instance, cucumbers. They have even used electricity to stimulate the growth of their regetables.

\section{Axinal Prontcts}

Meat. Animal products are very important in this country, and we have read something about the places in which they are prepared for market. There are three regions in the world that surpass all others as sources of supply for meat food - the

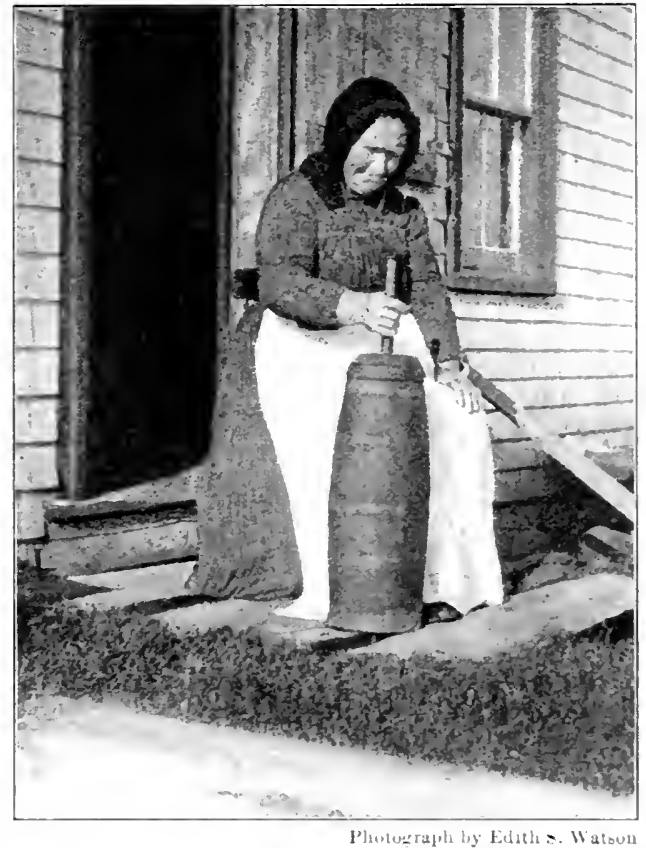

() LD-FASHONEI) HANH (HeRN

United States, Argentina, and Australia. Our products are chiefly cured pork, lard, and fresh beef. Mutton is less important; in this country, sheep are not so much valued for their meat as are cattle and swine.

Cattle. It has been shown that the cattle industry has steadily mored west, and is now located in the drier regions beyond the Mississippi. In $\mathrm{I} 8 \mathrm{j} O$ the states which led in number of cattle 
were, with the exception of Ohio, all on the Atlantic seaboard. In 1900 the first six states were Texas, Iowa, Kansas, Nebraska, Illinois, and Montana; New York held the serenth place and ()hio the ninth. Thus the greatest development of grazing has been in regions which were formerly waste lands.

A certain number of cattle must, hoverer, be kept in the East. The dense population demands a great deal of milk, and since milk is perishable, herds of cows must be kept near enough to

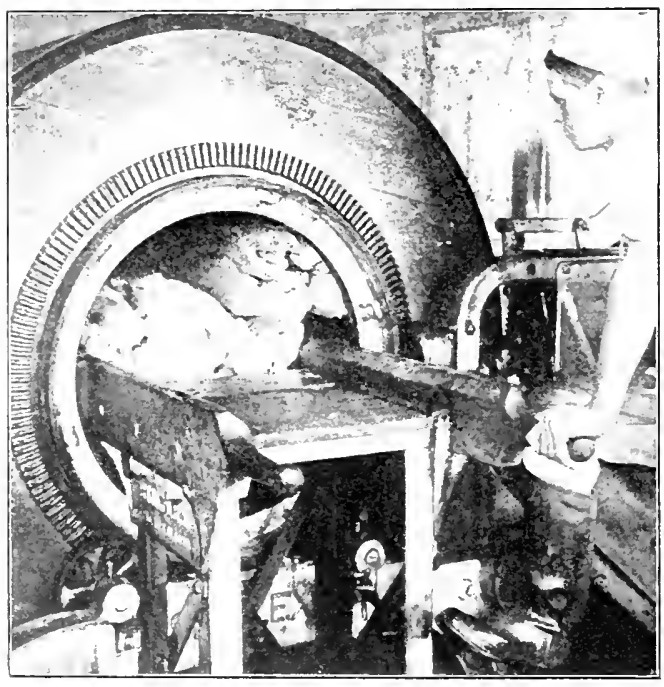

(C) Inderwood \& Inderwoud

MUNERX PUWER CHLRN the market so that wagons or fast trains can distribute a supply daily. The great dairy state is New York, and in the North Atlantic States dairying is the chief source of income for a large number of the farms. In the central V'est, on the contrary, other branches of farming are the mainstay of the owners. Health commissions now insist that to avoid epidemics of typhoid fever, dairies must be run with greater attention to sanitary conditions. This costs the dairyman a great deal, but the rise in the price of milk allows him to spend more on his cows, to replace old-fashioned churns with the most modem type, and yet to make money.

Swine. The pig goes with corn, since the corn is chiefly fed to the pig. As we have seen, the "swine belt" and the corn belt cover about the same regions. Excepting Texas, all the chief swineproducing stittes are in the corn belt; the states, in order, are Iowa, Illinois, Nebraska, Missouri, Indiana, Texas, Kansas, and Ohio. 
Sheep. The sheep industry has moved from the Fast and the South to the Far West for the same reason that cattle raising dicl. Here the sheep are raised mainly for their wool, though their flesh is eaten to some extent. Montana, Nyoming, Idaho, and Oregon are the chief wool-producing states. There is some raising of sheep for mutton, which demands far less care, in the East, but even here mutton is not so generally eaten as in England.

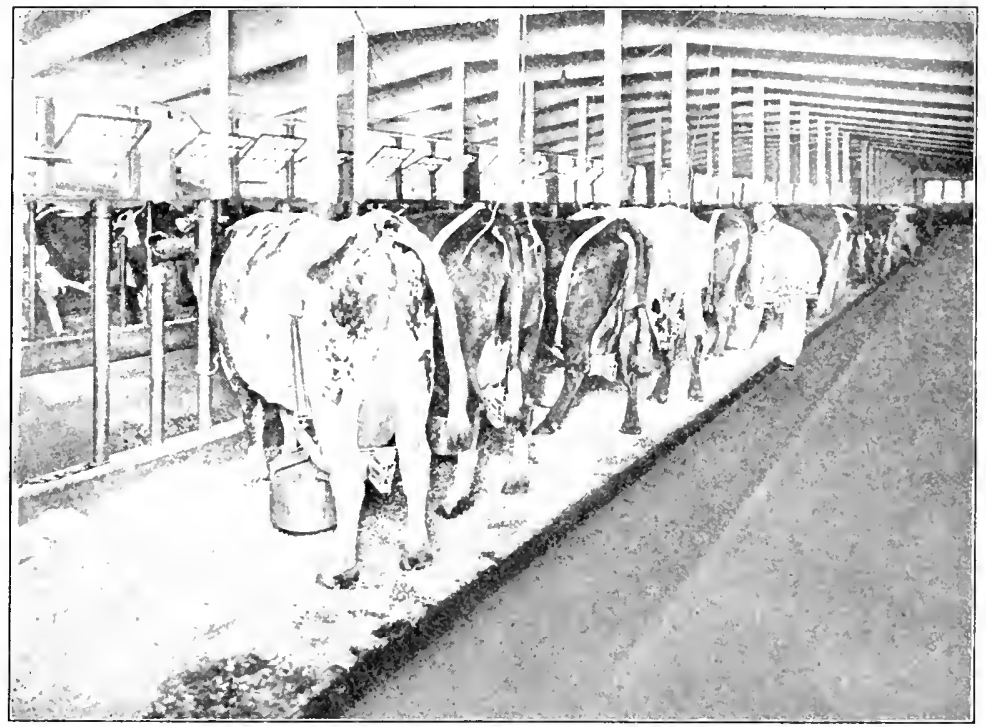

A Model Dairy

Fish. Codfish. The cod are caught chicfly in Atlantic waters, as far south as Cape Hatteras and as far north as the Arctic ( cean. In the Pacific they are found along the shores of Oregon and Washington, but most of our catch is from the Newfoundland Banks and off the shore of New England. The cod are prepered by salting and drying, and our yearly product would proviche a pound of cod for every person in the country.

IThitefish. Whitefish are found in both fresh and salt water. The fresh-water whitefish are excellent food, while those taken in salt water are used chiefly as fertilizing material. The fresh-watter 
whitefish are found in the lakes of the United States and Canada, chicfly in the Great Iakes. Because of overfishing, the catch in the Creat Lakes is declining. Whitefish form one of the most importint varieties of fresh-water fish used as food.

Salmon. Salmon are caught all along the Pacific coast from California to the arctic regions; not nearly so many are taken in the waters of the Atlantic. We may say that the cod is an Atlantic fish, and that the salmon belongs to the Pacific. As we have seen, salmon are caught very largely in the rivers with traps and nets. Great quantities are taken in Puget Sound and in Alaska. They are canned as near the place where they are taken as possible, and the canning industry is an enormous one.

Oysters. Oysters are taken all along the coast from Massachusetts to Florida, in the Gulf of Mexico, the Gulf of California, San Francisco Bay, and in the waters of Oregon and Washington. They have been planted in a number of places where they did not grow naturally.

The chief oyster-packing centers are near the oyster beds of Chesapeake Bay - where years ago the industry got its first good start - and along the shores of Long Island Sound.

\section{POLLTRI}

Hens and hens' eggs. Our domestic hen and chickens came first from India, and were brought to this country by the earliest colonists. There is no place in the country where poultry will not thrive. Lntil recently, however, the industry was not a separate one, but went along with general farming; now, however, it has become a special business.

Poultry raising, like swine raising, is carried on chiefly in the corn belt. Corn is used for fattening chickens, and so another form under which it goes to market is in the shape of poultry and eggs. Half of the poultry produced in the United States is raised in the North Central States, and over half of the eggs come from the same region. But, like darying and market gardening, poultry raising is being taken up more or less on the smaller farms 
in the more thickly settled parts of the country. From the nature of the industry the raising of poultry will always be carried on all over the country; but the development of transportation allows

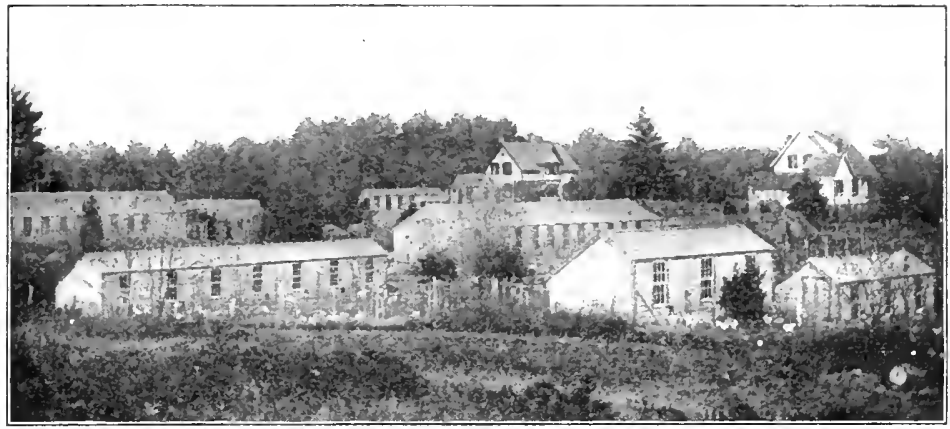

I'UXLTRY F IRM

it to be concentrated in the best place, - near the food supply of the central West, - and yet remain in reach of the big markets.

Turkeys. The turkey is the only domestic creature of any importance native to America. Wild turkeys can still be shot in the

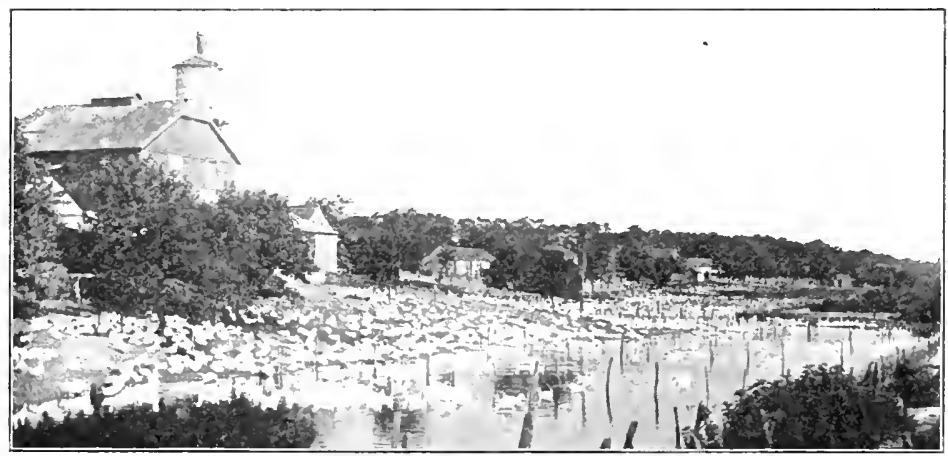

THOLSAXIS OF JUCKS AKE RAISH HHRE

less populated parts of the South. They were not domesticated by the Indians, but were taken to Europe and there domesticated. later to be brought back. Turkey raising is difficult because the young ones are so delicate. The turkey is the Thanksgiving hird 
throughout the list. They are raised largely in Vermont and Rhode Island. An immense turkey is sent every year from Rhode Islind to the White House for the l'resident's Thanksgiving.

Ducks. I lucks and geese are to be found in a wild state in both hemispheres, but our domestic varicties come from the Old World. The raising of ducks for the city market has been carried on with great success on Long Island. One would think that ducks must be raised in regioms where there is water, but this is not necessarily so. It is more important to have good food with which to fatten them, and so we find them raised in great numbers in the same com belt where pigs and poultry flourish best.

\section{Sweets ANh Beverares}

Sweets. Besicles the foods which supply the actual needs of the body, there are others which appeal strongly to the taste. A

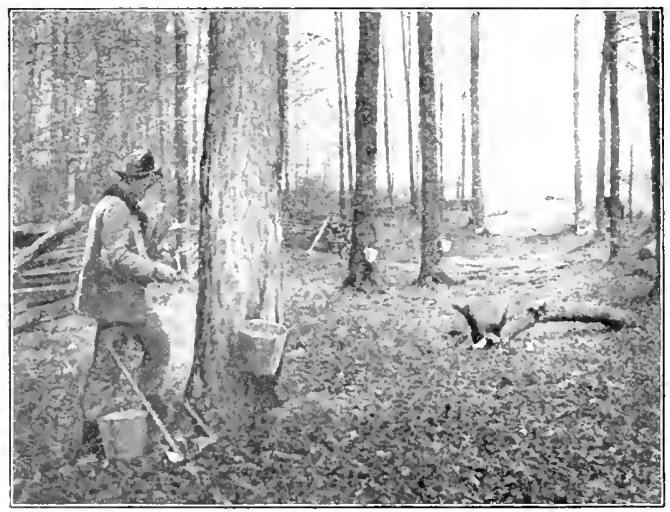

TAIPAG TRLLS FU MAlL SAP number of animals are fond of sweet foods, just as they are of salt, and human beings consume an enormous quantity of sweets, chiefly in the form of sugar. Sugar was once considered to be a great luxuiy, and a child was as pleased with a lump of sugar as he would be now with a box of candy. When first used in Europe, it was thought to have value as a medicine, to cure diseases of the throat and lungs. Lectures in Europe often depend upon a glass of sugared water to keep the throat and vocal cords in good condition.

Maple susar. This form of sweet is made from the sap of the sucir maple. Nost of us are familiar with the tapping of the trees and the gathering of the sap. The sap is boiled down, becoming 
thicker and thicker until it turns into sugar. The chief region for the sugar maple is in the northeastern and north-central parts of the country. More maple sugar is produced in Vermont, New York, and Pennsylvania than anywhere else.

Cane sugar. This is obtained from a reed or cane grown chiefly in the tropics. It is supposed to have come from southern Asial, but was introduced into this hemisphere about I 520 . It grows best where the temperature is about $80^{\circ}$ Fahrenheit and the rainfall sixty inches or more a year. There is only one place in the Lnited States where it can be raised to any advantage, and that is in Louisiana, though a little is grown in Texas.

In the Hawaiian Islands, which now belong to the United States, the cultivation of sugar cane is the chief industry. Sugar from these islands is shipped chiefly to San Francisco and New York, where it is refined.

Bect sugar: Sugar is not confined to the sugar

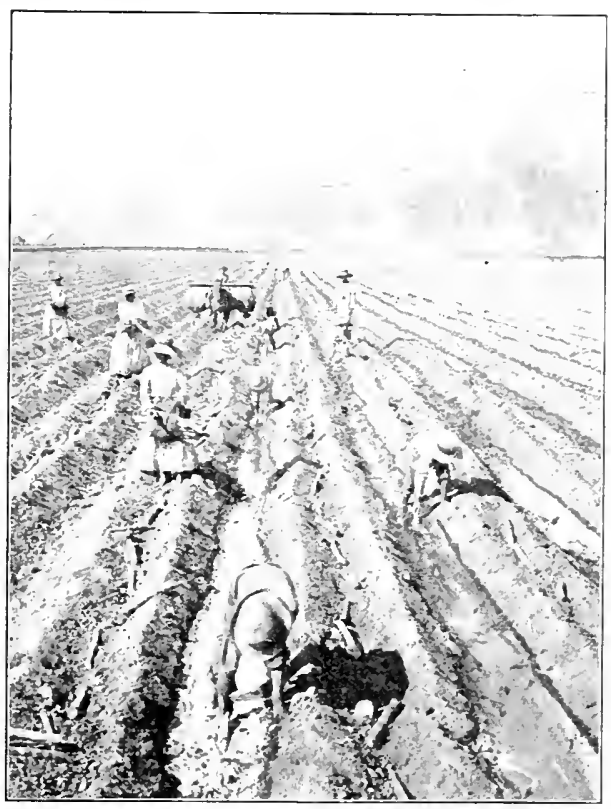

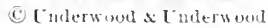

PLANIING SUGAR CANE

cane or to the maple tree, but is found widely throughout the regetable kingdom. Some time ago it was discovered that a certain variety of beet contained a great deal of sugar. The climate best suited to the production of this beet is found in the north temperate zone. More beets per acre can be raised where the climate is warm, but they are likely to be less rich in sugrar, and the sugar is less easily removed, than where the climate is somewhat cooler. Any kind of soil suited to ordinary farm crops is right for sugar 

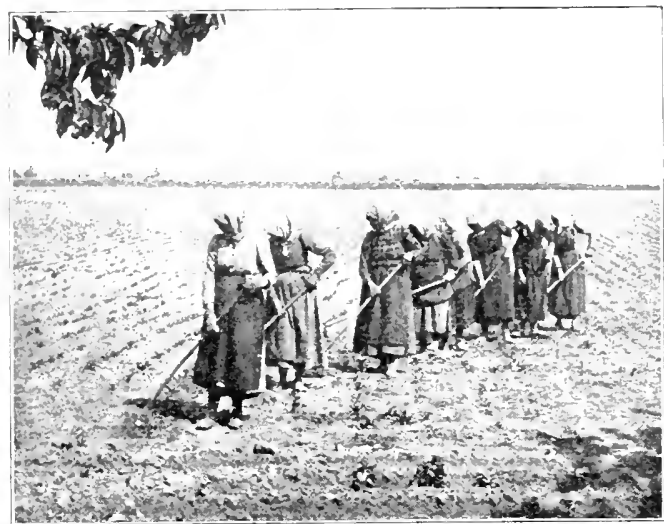

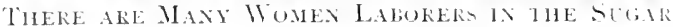

bekT FIELAS OF SAXUNX beets, provided there is grood drainage. Europe is the chief source of beet sugar, but the beet is raised in this country in Colorado, California, Michigan, Utah, and Iclaho.

Sugar, as has been said, was once a great luxury, but now a family which cannot afford to use it must be poor indeed.

It is the chicf import into this country, and so large is the revenue rained from duties upon it, that when, in I 890 , these duties were remored, a deficit in the national treasury speedily resulted.

Honly. () f all sweet substances honey, made from the nectar of flowers, has always been spolien of as the symbol of sweetness. In Bible times a land " Howing with milk and honey " was a most desirable home. Cntil the middle of the sixteenth century honey was the only sweet in general use. Bee-keeping as an industry has developed rapidly of late years, and is a farorite pursuit of

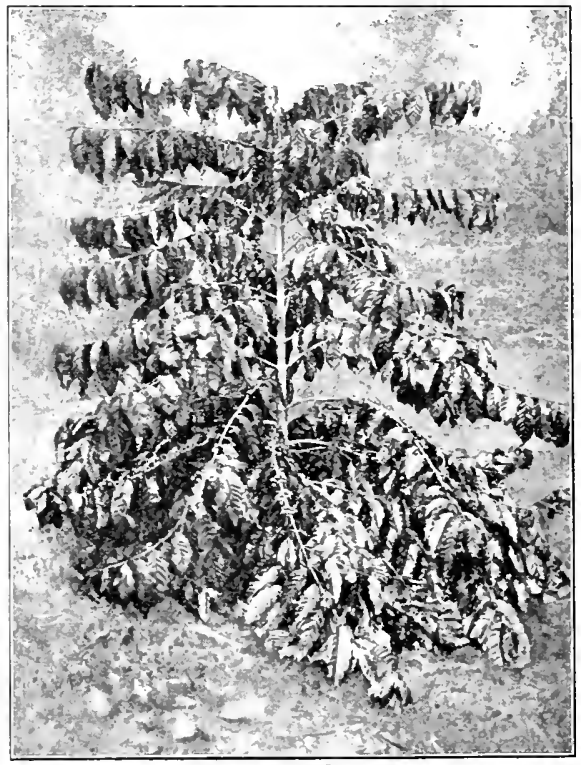

C. Cnderwoul \& Lnderwood CUFFeE Plant 


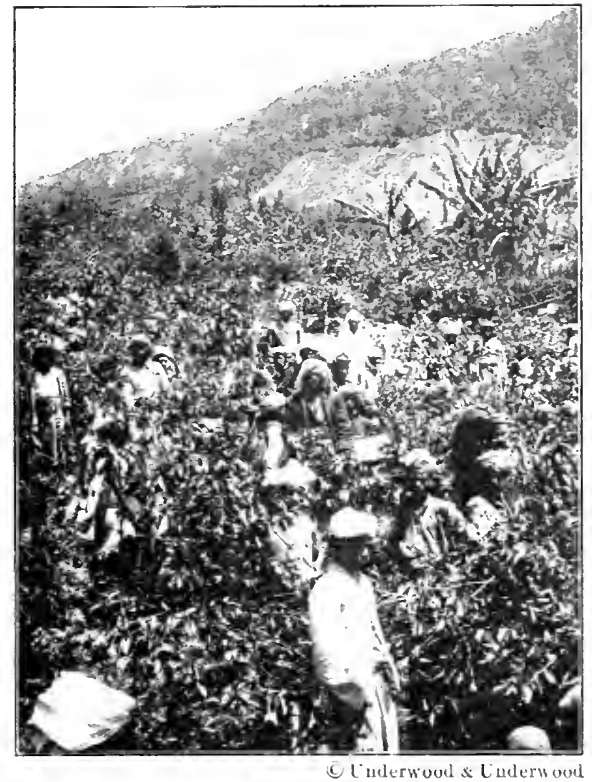

Picking Coffee

many farmers throughout our country. The hives are said to furnish an annual supply of about fifty pounds of surplus honey apiece. Bee-liecping is pursued on the large scale in California and Texas : here are to be seen what are probably the largest bee-keeping plants, or apiaries, in the world. The hives are cleverly constructed so that the combs may be easily remored, and there are glass doors through which the bees can be observed at their work.

Beverages. There are also certain drinks which do not have much food value, but of which people have become very fond. Some of these are alcoholic and are dangerous to man, while others, such as tea and coffee, are considered harmless if used in moderation.

Coffec. Coffee is a berry or bean which grows in the tropics. It cannot therefore be raised in this country, though it is grown somewhat in our foreign possessions - Porto Rico and the Philippines. When roasted and ground it is made into a pleasant and stimulating drink.

Ter. Tea came originally from China or India, and although it is cultivated in a number of

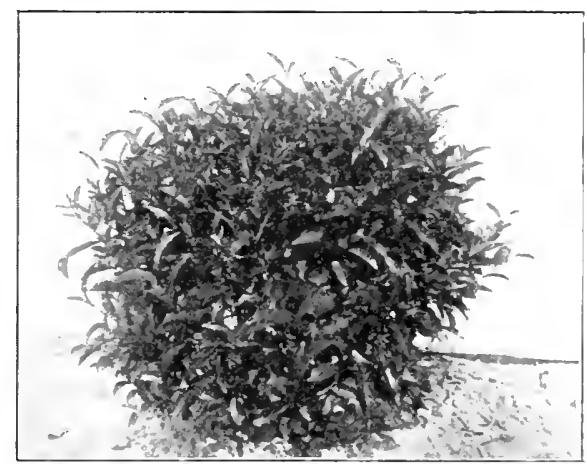

TEa I'laNt 


\section{II ('MMERCIAL ANI) INIOSTRRAL GEOGRAPHY}

countries, it still comes chiefly from these two regions. Conseguently, like coffee, it appears in this country only as an import. Tea is made by steeping the dried leaves in hot water.

l)ming the Civil War, when the Southern ports were blockarled, the people in the South found it hard to get on without tea or coffee, and tried to find substitutes for them. They used chicory

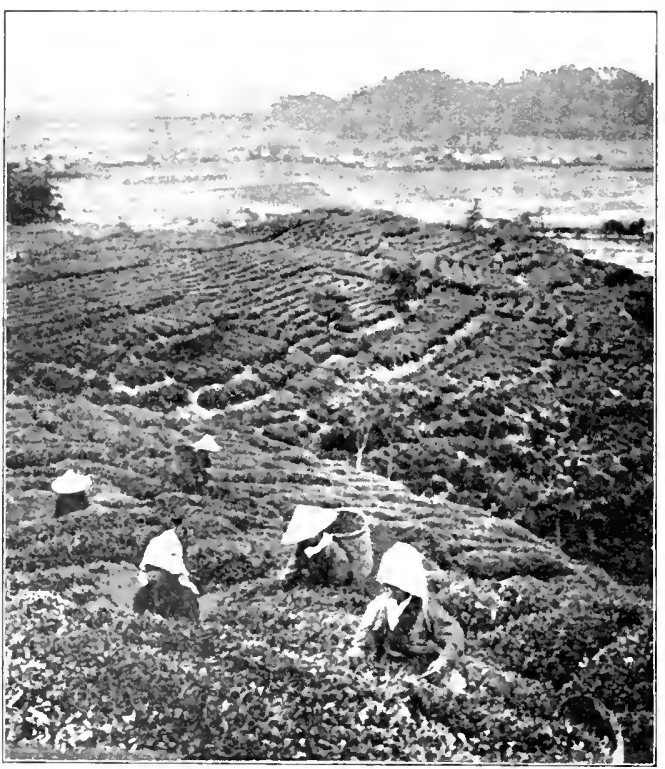

(C) H. C. White Co.

JAEANESE TEA P'LANTATIUN REALY FUR THE II AREST instead of coffee, and the leaves of a variety of plants instead of tea. Chicory is often used nowadays to adulterate coffee.

These two beverages are mentioned in this place, not because they are really products of this country, but because they are so commonly used here. They give us an example of the importance of division of labor between countries, and of the exchange which results; and they show how we are obliged to depend upon our fellow men in other parts of the world. lineral auters. In various parts of the country there are mineral springs, some of which are medicinal in quality, while others are merely pleasant to the taste. Saratoga has always been famous for its mineral waters. Some spring water is so pure and wholesome that the bottling and distributing of it has become a profitable industry. In cities, especially, people are often unwilling to drink the water supplied to their houses, and prefer to pay for bottled water instead. 


\section{CHAPTER VI}

\section{DISTRIBUTION OF FOOD MATERIALS IN OTHER COUNTRIES}

In order to get an idea of the place our own country holds in the production of food materials, we shall now study for a time the distribution of food products in other countries. IV cannot study every country; that would take too long and would be confusing, because of the great number of facts which we should have to learn. But we shall take up the British Isles; and then Canada, Australasia, India, and South Africa, which are the chief British colonies. After that we shall follow the various zones around the globe and see what are the leading products of other important countries, and how they happen to be what they are.

The British Isles. Food plants in the British Isles are cultivated much more carefully than they are in this country; hence the yield per acre greatly exceeds that of American farms. The cereal crops of the United Kingdom are oats, wheat, barley, and rye. The most important, for the whole kingdom, is the crop of oats, but taking England abone, wheat, which will not grow so far north as oats, takes the lead. Exen in England wheat is cultivated chicfly in the southeast. Potatoes and turnips are important crops, the former being the chicf product in the west of Ireland. Market gardening, as in the United States, is profitable upon the outskirts of the larger cities.

Meat products are mostly importech into Great Britain, for the conditions which favor grazing no longer exist. One of the reasons for this is that the country is more fully settled. Several hundred years ago the raising of animals was more important, but as in this country, when population has increased, agriculture has driven cattle raising to the west, so in England farming has driven grazing nearly out of existence.

In fact, the increase of population and the great growth of manufacturing in Great Britain have resulted in a division of labor, 
through which the British do a large part of the manufacturing for the world, and in return are supplied with food and raw materials from other countries.

The sea fisheries of the British Isles are of great value. They are carried on in the shallow regions of the North Sea and among the northern islands. Mackerel are caught off the southwest coast of Ireland, and herring about the Isle of Man and the Shetland Islands.

The Dominion of Canada. Canada is practically an extension of our own country toward the north, so that conditions in southern Canada are about like those in the northern part of the United

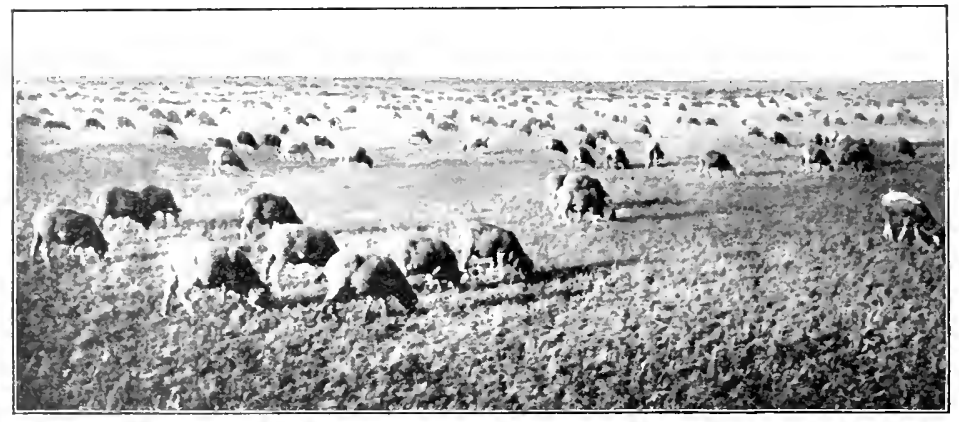

Simeep Grazing, Alberta, Canada

States. The same westward movement has taken place as the country has become settled, only it has been considerably later than that in our own land.

Cereals are being raised in great quantities in the Canadian IVest. The production of wheat is increasing very rapidly, and the ricld of oats is about double that of wheat. In Igos the crops of greatest value were hay and clover.

Southem Ontario is a famous fruit region. It is in the same latitude as northern Italy; and produces the choicest apples, pears, peaches, grapes, and other small fruits.

Canada is also noted for dairy products, but there is no such great development of grazing as in the United States. 
The Canadian fisheries are very important; Nova Scotia takes high rank here, contributing about one third of their total product. As in the United States, cod represent the Atlantic fisheries, while salmon are caught off the coast of British Columbia.

Australasia. This includes Australia and Tasmania; and the two islands of New Zealand are usually considered along with them.

Australia. Australia is especially fitted for sheep raising. The climate is mild enough to permit the flocks to live in the open the year round. Moreover, pasturage can be carried on profitably where it is too dry for agriculture, and since most of the interior of Australia gets but little rainfall, sheep raising has become the great Australian industry. In 1907 there were about eight million sheep and ten million cattle. The sheep are raised chiefly for their wool, though much frozen meat is exported, and the dairy products are valuable.

Agriculture is confined

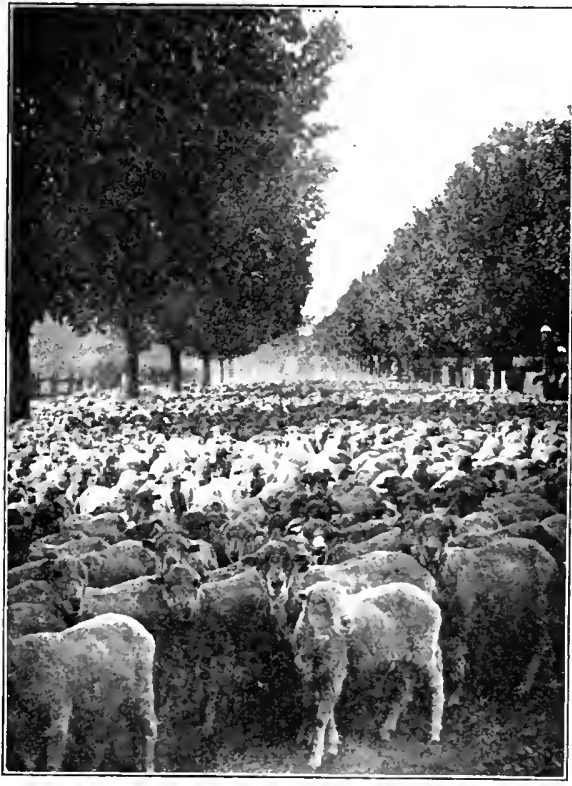

(C) Imlerwoud \& I me terwood

Four Thousand Sheel changing Pastuke DURING A DRY SEASON IX AUSTR.IIIA almost entirely to strips of land along the coast, where there is sufficient rainfall and where there are rivers. The interior is arid, but the northern peninsulas, being within the tropics, raise sugar cane and tropical fruits, such as bananas. The farm lands of the cooler south yield the various crops of the temperate zone; cereals, especially wheat, the sugar beet, and grapes, are the chief products. The wheat crop is often damaged by drought, floods, pests, or scarcity of labor. 
Tou Kerlemel. New Zealand has an advantage orer Australia because there is never any danger of a drought. It is said that the conditions of New Zealand are so like those of Great Britain that in no other British colony does an Englishman feel so much at home. The two islands are as yet thinly populated, and so sheep raising is still carried on where farming would be possible. Wool and frozen mutton form about one half of the value of the exports.

Large cereal farms are found in the South Island and in the southern part of the North Island, and, as elsewhere in the

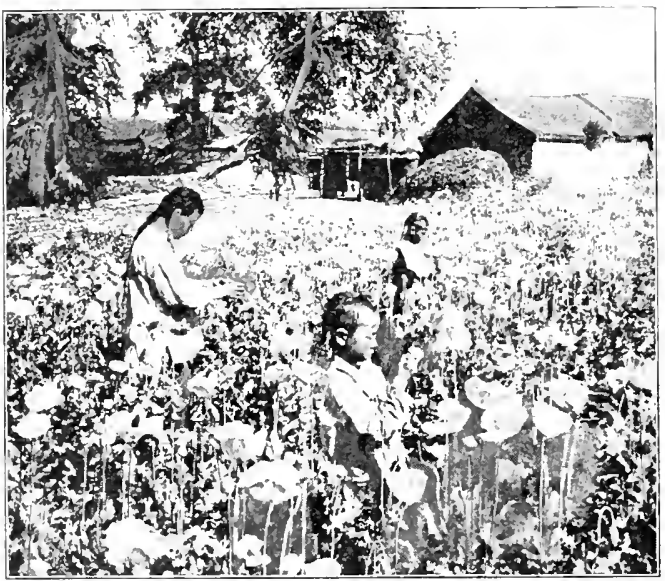

A l'UP'Y FIELD

temperate zone, agriculture is gradually prevailing over grazing; only here its progress is from south to north instead of from east to west, as in the United States and Canada.

India. Agriculture is by far the most important occupation of India, but one of the chief obstactes to its progress is the unwillingness of the lindu to adopt modern methods. He uses the same sort of stick for turning over the soil that was used three thousand years ago, and he still reaps with the sickle or scythe. India has so many different climatic regions that a large number of the crops of both the temperate and tropical zones can be raised there.

Rice is grown widely in the hot parts of the country, where there is great moisture, as in Lower Bengal, Madras, and Lower Burma. Nillet is the chief food of the poorer classes, while the richer folk eat wheat and barley. Millet thrives in regions which are ton dry for rice; it grows in the Dekkan, the Punjab (pŭn jäb'), and elsewhere. Wheat is cultivated in the cooler northern regions; 
India is third or fourth among the wheat-producing countries of the world. Other crops of importance are sugar cane, tea, and coffee. Opium is a dangerous drug, obtained from poppies, but its use for illegal purposes is on the decline.

Some people think that there are even more cattle in British India than in the United States, but in India cattle are raised less for their meat than for their skins and as clraft animals. The Hindus have a great horror of killing a cow, and so there is always a large number of old, useless animals to be provided for. But in spite of these difficulties, since there are large areas of India where agriculture cannot thrive on account of the dryness, cattle raising has developed to a considerable extent. Immense numbers of goats are found in most of the provinces.

South Africa. The climate of these colonies fits them for grazing farbetter than for agriculture. Nithout spending large sums for irrigation, agricul-

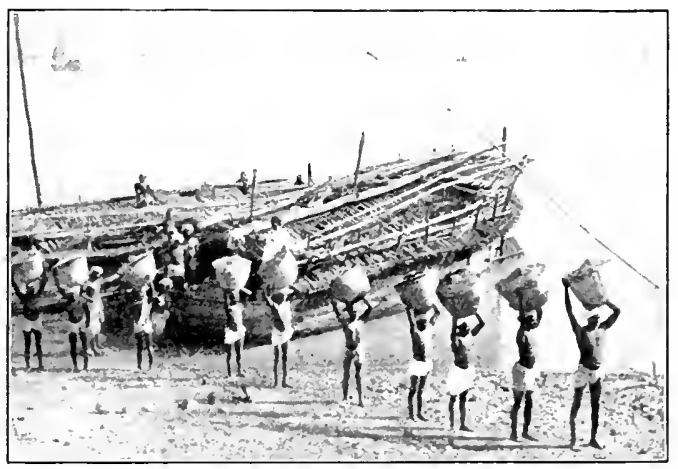

UNLOADING OPILA ture can never be widely developed; in fact, even grazing is uncertain in many sections of the country. Grazing here is chiefly for the purpose of wool growing, and does not count for much in any other way in the trade of the world.

There is better rainfall in the extreme southern and southwestern districts, near the coast, and in these sections wheat, maize, and most of the other crops of the temperate zone may be raised. Great quantities of grapevines thrive on the sunny northern slopes of the hills near Cape Town. It should be liept in mind, however, that cattle raising and not agriculture is the chief food-producing industry of South Africa. 


\section{Other Countries}

We have up to this point studied the food materials of the most important food-producing countries, and we have seen that among these our own country stands first. But now we wish to complete the picture by learning about the important products of a few other parts of the earth. We shall not take these up by countries, but in order to see how the food materials are suited to different kinds of environments, we shall take them up by climatic zones.

Climatic zones. In general, there are three of these zones, which we call the frigid, torrid, and temperate; their boundaries on the map are the arctic and antarctic circles, the tropics of Cancer and Capricom, and the equator. According to this division the zones of climate are laid out by parallels of latitude, but we must not forget that there is another important factor which determines climate: this is the altitude. A mountain at the equator may be snow-capped, and have a frigid climate at its summit. As a rule, the temperature becomes one degree colder for every three hundred feet of altitude.

Therefore there may be regions within the boundaries of the tropics which are temperate in their climate, and these should not be called tropical simply because they are in the tropic zone. If there is a lofty country within the tropics, we must consider it as belonging to the temperate belt.

In studying the products of these three zones it is evident that those of the frigid zone are not sufficiently important to spend time upon. We have already learned, in what we have studied about the Eskimos, the chief facts as to the kind of food upon which the inhabitants of cold countries must live. So we will omit that zone and commence with the equatorial regions.

If we take a map of the world and begin with the western hemisphere, the tropical countries of importance are Central America, the IVest Indies, the republics of the north coast of South America, and Brazil. The chief food products of all these countries are tropical fruits, cacao, manioc, and coffee.

South America. The north coast. The manioc is raised chiefly in the countries on the north coast of South America. It is a 


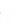




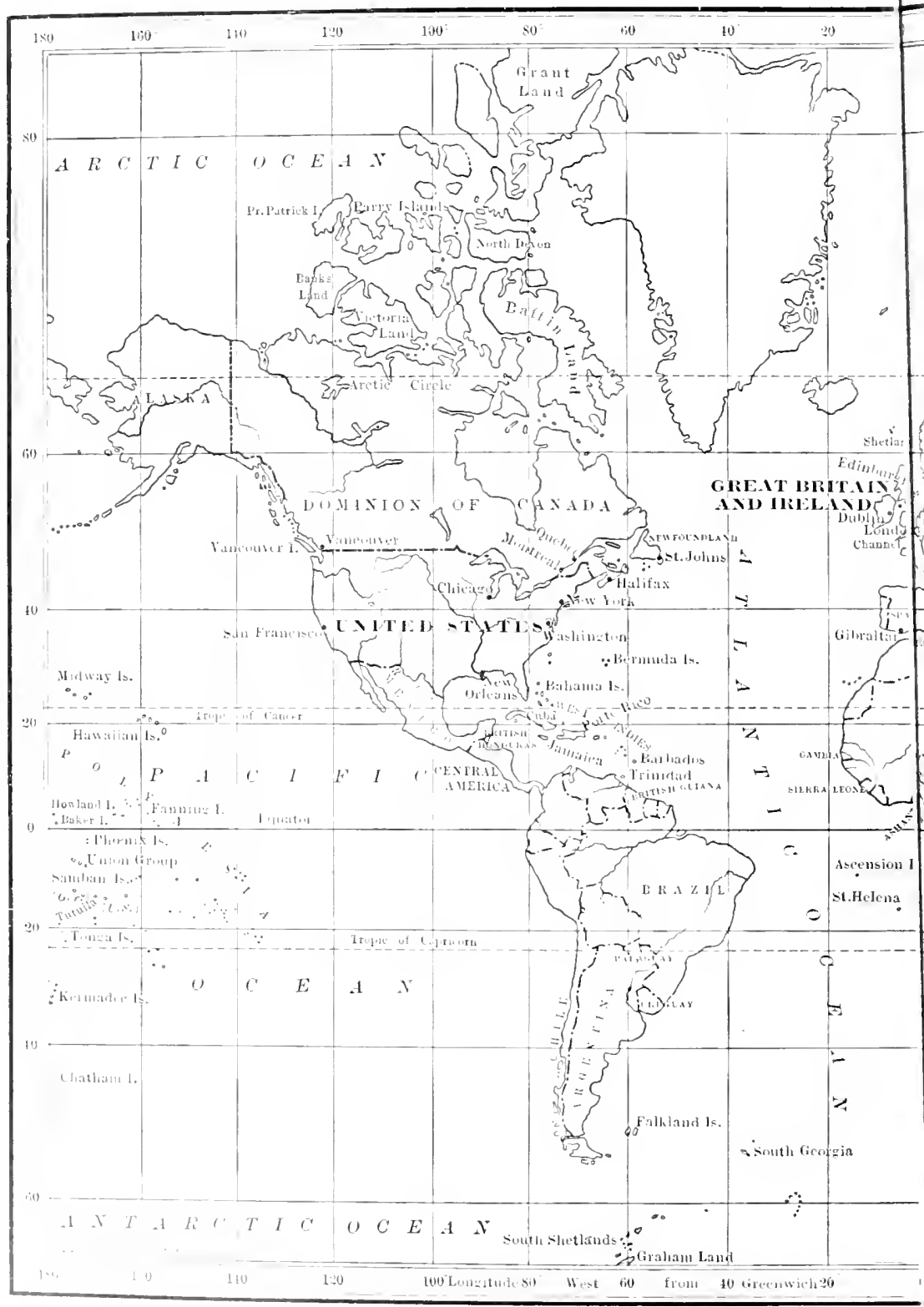




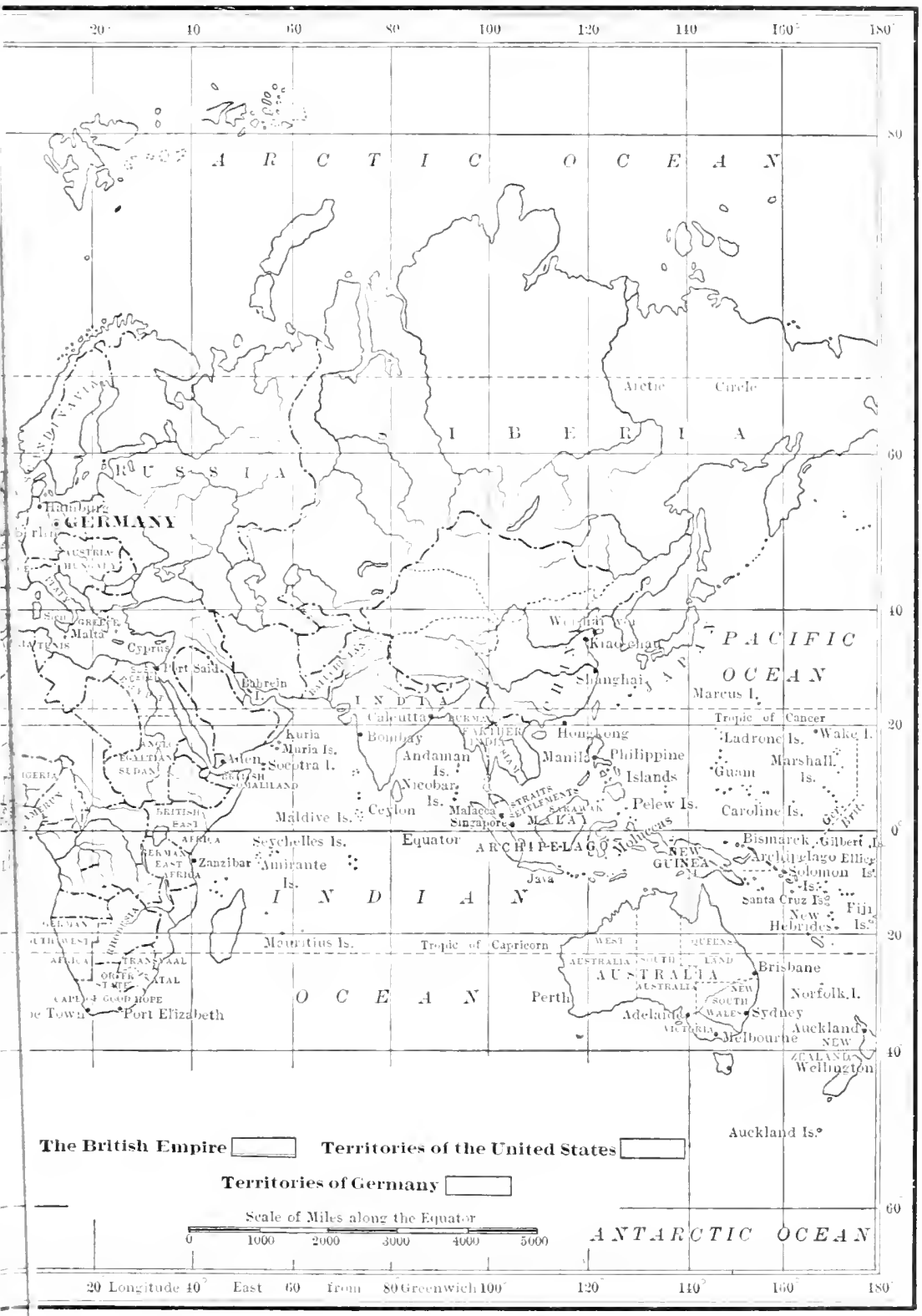


live on, like sagro and yams, do not enter very largely into the trade of the world.

Java. Passing on toward the east on our map, we next come to India, about which we have already studied. But beyond India there is a region including Farther India and the Malay Archipelago, which is rery rich in tropical food products. The most important country in these regions is Java, an island which is said to

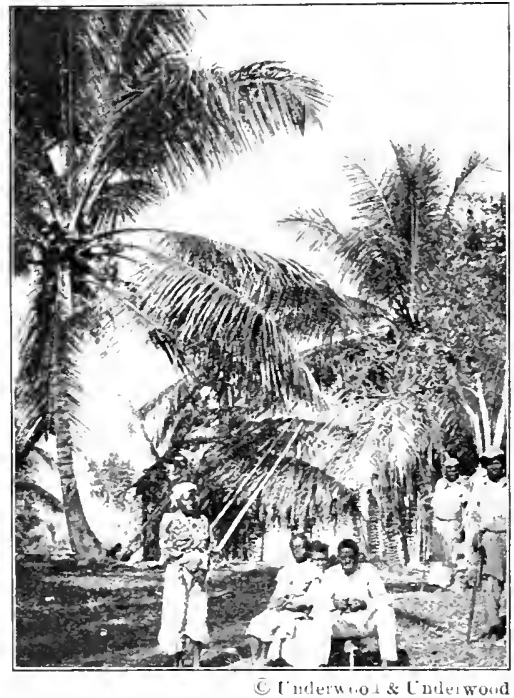

A TAMMra FARMer's HoMe axi Coco. XLT TREES WHACH PRACTICALLY SUPPORT HIS FAMILY be the only rival of Cuba in fertility. The most important crop of Java is rice, but sugar and a high grade of coffee are also produced. Many years ago the Dutch conquered Java, and the Dutch government, in order to make as much money as possible out of it, obliged the people to cultivate coffee, sugar, and indigo. This was very hard on the natives, and their lives were made miserable. In these Eastern islands and in the Philippines a great deal of tobacco is raised, though none of it, not even the socalled "Manila" or "Sumatra" tobacco, compares in value with the "Havana" tobacco raised in Cuba.

The Spice Islands. One of the most interesting parts of the history of commerce is connected with the spice industry of the East Indies. Cimamon comes very largely from Ceylon; but nearly all the very valuable spices, such as pepper, ginger, cloves, and nutmegs, come from the Malay Archipelago.

The people of Europe in the Middle Ages were fond of spices, particularly pepper. It is supposed that the reason they liked them so well was because there was such a sameness and lack of flavor 
in their food. It tasted better when " spiced up." They received, many centuries ago, sugar and spices, chiefly pepper, in small quantities, which were brought orerland from the East. I ater they were brought up the Red Sea and across the Isthmus of Suez. The trade was mainly in the hands of the V'enetians and made them very wealthy. Then Portugal and Spain became so eager to share in this wealth that they sent out ships to find an easier route to

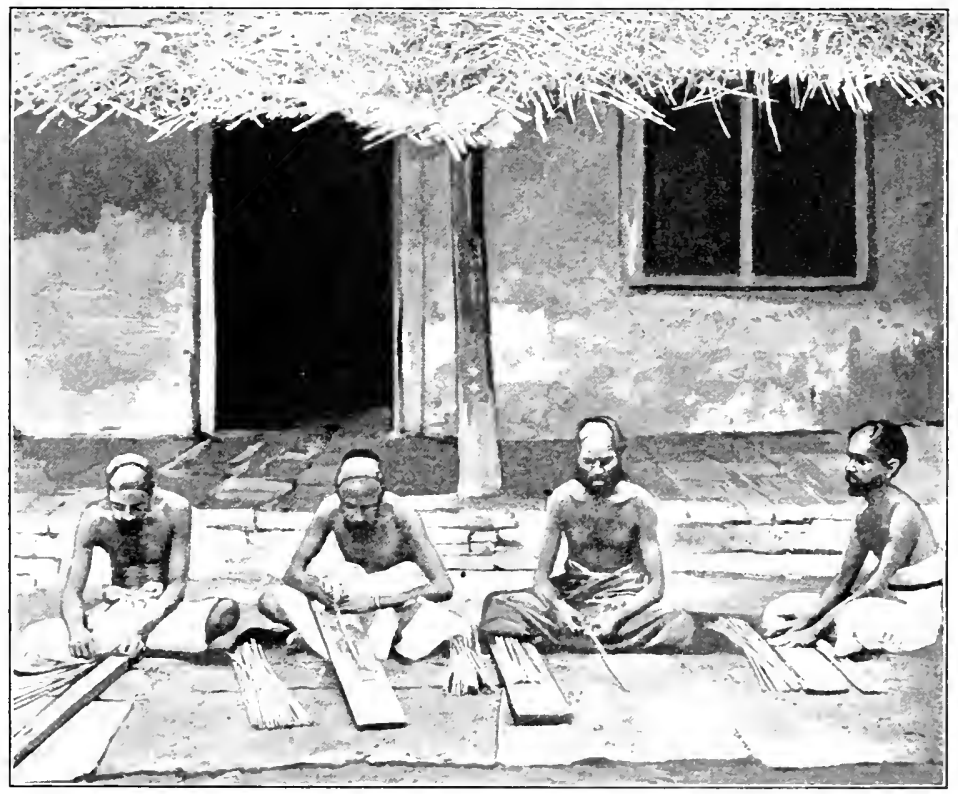

P'REPARING (INNAMUN

the Indies. Finally, just before 1500 , Vaseo da Grama circumnavigated Africa and reached the East, while Columbus, in order to get to the same region, had been saling westward.

After the Portuguese reached the Indies, spices came in greater quantities to Europe, but the prices were still high. Then the Dutch tried to capture some of this profitable trate, and finally managed to seize and hold most of the East Indies. And just as 
they made the Javanese raise things which they themselves wanted, so in the Spice Islands they were very unreasonable and cruel.

Dutch methods. There was a group of little islands, called the Moluccas, which produced the kind of spice regarded then as most valuable, namely cloves. The Dutch made the people of these islands stop raising food products for their own use and spend all their time in producing what was needed for the Dutch to make

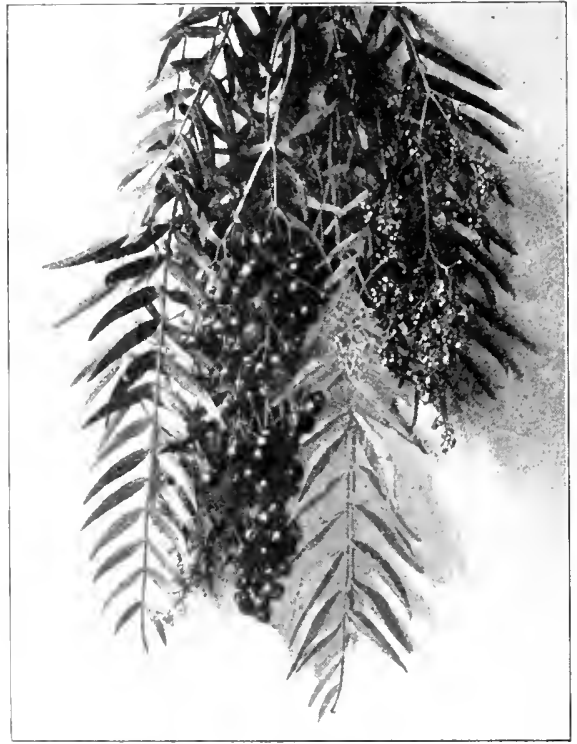

CALIFURNIA I'EPPER money; the result was that the natives became poor, had frequent famines, and were reduced to a wretched condition.

The Dutch were also very wasteful, for in order to prevent prices from becoming low, they used to take only certain amounts of these Eastern products to Europe. If they had gathered more than they needed, they used to destroy great quantities of very valuable spices. When prices seemed likely to go down, they would make expeditions around the East Indies and cut down many of the coffee trees and spice-producing plants which they had obliged the natives to cultivate.

All this was done in order that people in Europe should pay hearily for something to eat which was not, after all, a necessity. The spices were great luxuries in those days, and people bought them just as they buy costly dainties now. These spices could not be raised rutside the regions to which they were fitted by nature, and so the natives of these regions had to suffer for it. The whole story of the spice trade is interesting, but it is also a sad example 
of the misery which men will cause one another in order to satisfy the desire for money or for the luxuries which money will buy.

Polynesia. If, now, we move still farther eastward on our map, we come to the numerous islands of the Pacific known as Micronesia and Polynesia. The Polynesians are dependent chiefly upon the palm tree and the breadfruit tree, though they raise a number of tropical vegetables and fruits, and also have pigs. The most productive region of Polynesia is that of the Hawaiian or Sandwich Islands, now belonging to the United States. Here, as we have seen, great quantities of cane sugar are produced. The only difficulty in the way of this industry is the absence of a good labor supply.

\section{Temperate regions in Amer-} ica. When we leave the tropics and return to the temperate zones, we find that we have already covered most of their products, chiefly because our own country and the British Empire raise so many of them. But let us take the map, and, commencing with America as we did before, go around the

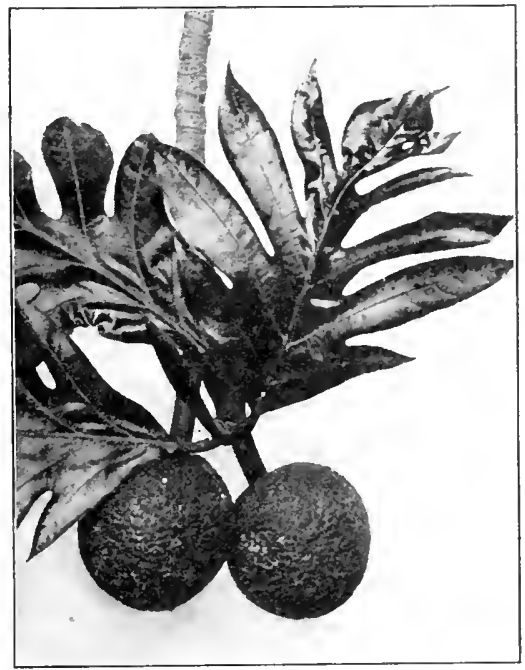

BREAUFRUIT world from west to east, noticing such other products as we have not yet studied. In America the temperate regions which remain for us to examine are Mexico, the states along the Andes, Argentina, Chile, and southern Brazil.

Mexico. The regions of Mexico which are not high have a tropical climate, but the interior plateau, where the city of Mexico is located, is temperate because of its altitude. The chief industry of this part of Mexico is grazing, for the conditions are similar to those just across the Rio Grande River in our own country. But agriculture is forcing an entrance, and already Mexico has made 


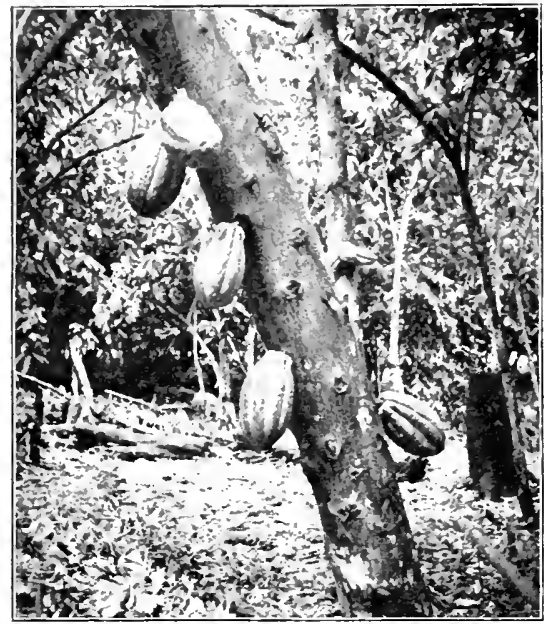

THE CACAO TREe ANI Frtit

some advance in the raising of maize. If irrigation can be introduced on a larger scale, there is no reason why the production of this cereal should net increase. As yet no other food industries of this region are of much importance.

Ecuador, Peru, and Bolivia. In South America let us consider first the states of Ecuador, Peru, and Bolivia. Here we find one of the important products of the world which is native to this hemisphere, namely cacao. The cacao is a sort of bean, out of which, after it is properly treated, cocoa and chocolate are made. There is a great cleal of food value in these products, so that as nourishing drinks they entirely surpass coffec and tea. There is also in them a chemical substance called therbromine, which has something of the same pleasing effect as the caffeine of coffece or the theine of tea. The cacao plinnt was highly testeemed by those who discosered it, for its name "therbrima means "food of the

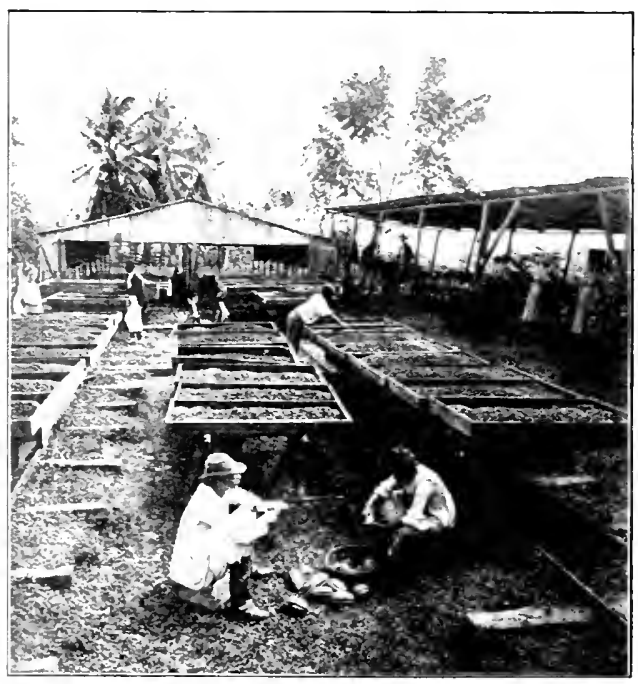

(c) I'nferwool \& Cnlerwood UIENIXG CACAU PUU AND DRJIXG THE BEANS 
gods." I arge quantities of cocoa and chocolate are exported, and since Spain once owned all these regions, it is interesting to notice that the Spaniards are the people who drink the most cocoa.

A certain amount of grazing is clone in this region, but the domestic animal raised here is not found anywhere else in the world. This animal, a sort of camel, is called the llama (lyah'mah) and is a beast of burden. The alpaca, another animal belonging to this same species, is raised mostly for its long woolly hair.

Argentina. The great productive country of temperate South America is Argentina. and we might include with it Uruguay and Paraguay. Argentina contains rast, dry plains called the pampas, which are well fitted for cattle raising. Enormous herds of cattle graze over these plains : but no such progress has been made in improving the breeds as we see in this country, and the cattle are raised chiefly for their hides. However, as in our own country, agriculture is gradually driving out the grazing industry. Is irrigation is introduced, more farming becomes possible. It

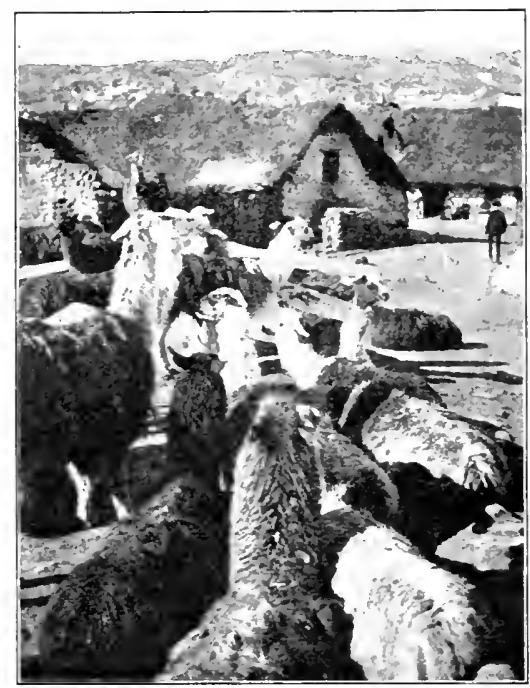

o Puderwond a lmiterwood

LIAMAS IX I'LKL is thought by some writers that the day will come when Argentina will surpass the Lnited States in the production of maize.

Southern Brazil. One of the most important regions of South America is southern Brazil. Here the climate is so cool that the ordinary occupations of the temperate zone can be pursued. There was, at one time, a great impetus giren to this region by the discovery and mining of diamonds; later a considerable number of people, many of them Germans, immigrated into this section, and are now raising the most valuable food products of temperate regions. 
Temperate Europe. When we take up the temperate regions of Europe, we find, first of all, that the northern countries raise great quantities of grains which are more hardy, though less valuable, than wheat. These are chiefly rye, oats, and barley.

Ryc. Rye is used extensively as food in Scandinavia, northern Germany, and parts of Russia, where the "black bread " made from it is the principal article of diet. Over nine tenths of the world's

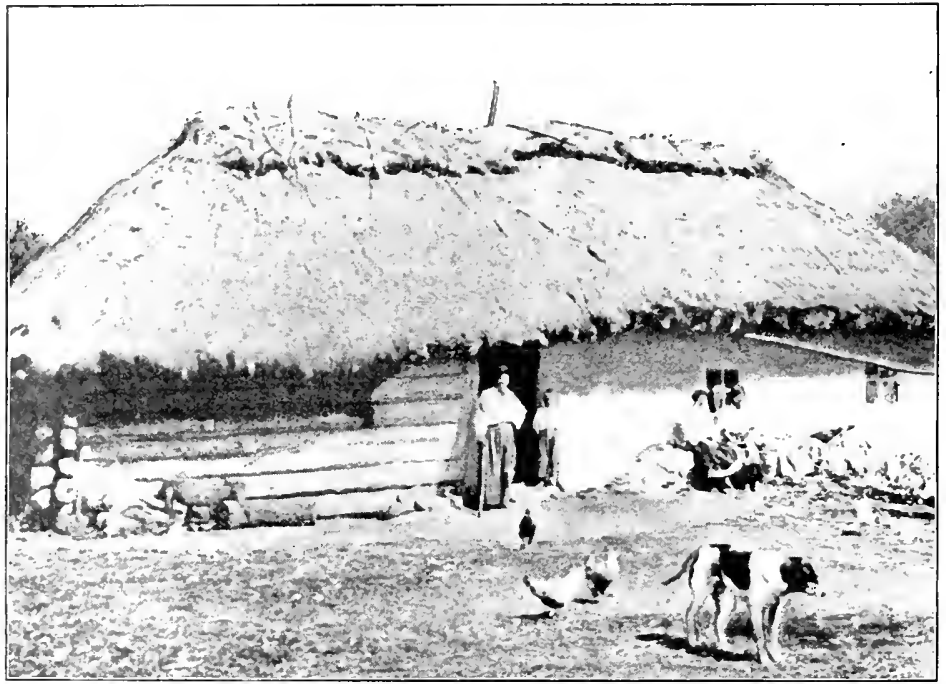

A Russian Peasant's Home

rye grows in Europe, Russia and Germany leading all the other countries.

()orts. Oats will grow in a cooler climate than wheat or maize can bear, and are a common crop in northwestern Canada and in Norway. Europe produces two thirds of the world's crop of oats more than any other continent - because here the climatic and other conditions are most favorable. Among the nations the United States talies the lead in the production of oats, though the industry is not so important here as it is in Europe. Our wheat crop, though much smaller in quantity than the yield of oats, has a greater 
commercial value. Oats are raised chiefly in the northern states, Illinois and Iowa being the largest producers. European Russia holds the second place, and Germany the third in the list of nations.

Oats are used chiefly as food for stock, but the eating of oatmeal, which was known in the eighteenth century as a Scottish custom, is now becoming general.

Barley. Barley was one of the earliest of cultivated plants, and until recent times was used extensively for human food. Now,

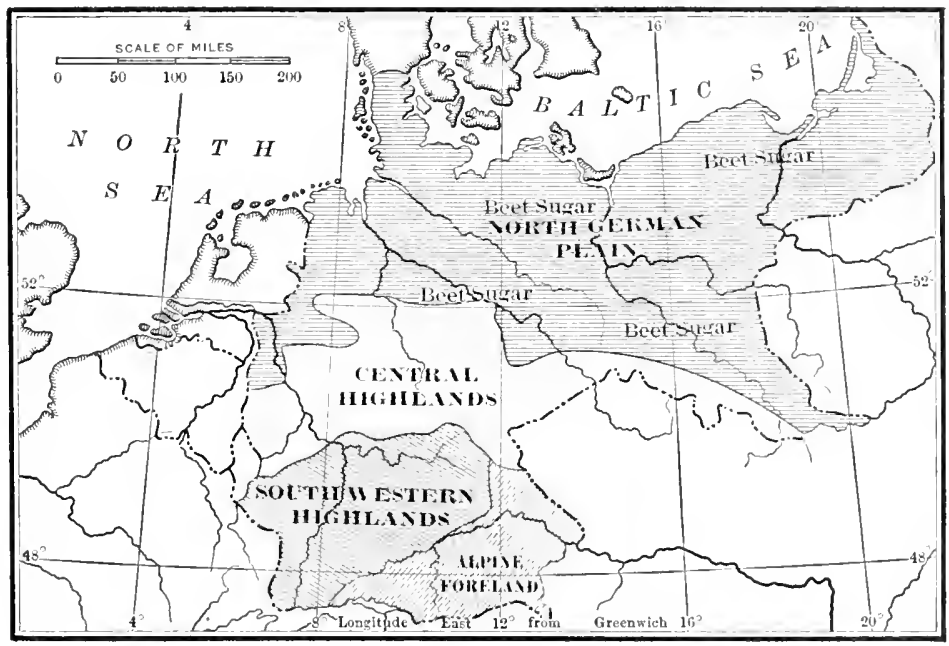

Sugar-Beet Region uf Germany

however, wheat has largely supplanted it. Barley is the hardiest of the cereals and has been grown with good results north of the arctic circle. Of the European crop about seven tenths is produced by Russia, Germany, and Austria-Hungary. Barley raising is increasing rapidly in this country, the chief producing states being Minnesota, Wisconsin, Iowa, and the Dakotas.

The sugar bect. The first country in the world in the production of the beet from which sugar is made is Germany. The only other country which produces much beet sugar is the United States. There are several reasons why its production is more successful in 
Cicmany. First of all, the cultivation of the bects requires a great deal of hand labor, and Americans prefer machine labor to hand latur. Then asain, the crushed beets are of very little use in this country, whereas the beet raiser in Germany can sell this socalled "bect cake" as cattle food. Most of the cattle in Germany are stall-fed rather than pastured, for most of the useful land is under cultivation. The picture shows how little land is left for pastur-

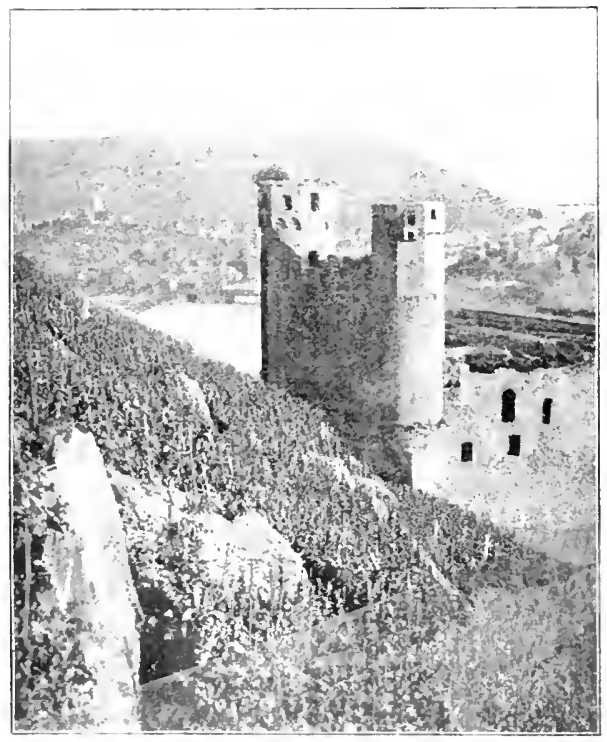

$11,1,11,1\rangle 1,1 \times 1, n+11$ agge in parts of Germany.

The first of these adrantages may not remain to Germany long, for while tearing the beets out of the ground by machinery bruises them and causes them to rot very quickly, transportation in this country is so rapid that they can be thus torn up and yet get to the sugar mills before they are spoiled. This makes the industry less dependent upon hand labor, and so does artay with one of our disadrantages in producing beet sugar. Thus an adrance in one line of md a mate pusible by progress in another, though the second at first sight entirely unrelated to the first.

Southern Europe. The southern countries of Europe - and with these may be considered the countries of northern Africa and thuse of Asia Minor - are largely interested in fruit raising. Southern France is corered with vineyards, and the French have recently been raising the grape with success in Algeria and Tunis. Spain. Italy, and Greece have been for many centuries the chief countrice to raise olives, although now California produces great 
quantities of them. But the European olive oil is as yet better than that obtained from California olives. Oranges of the best

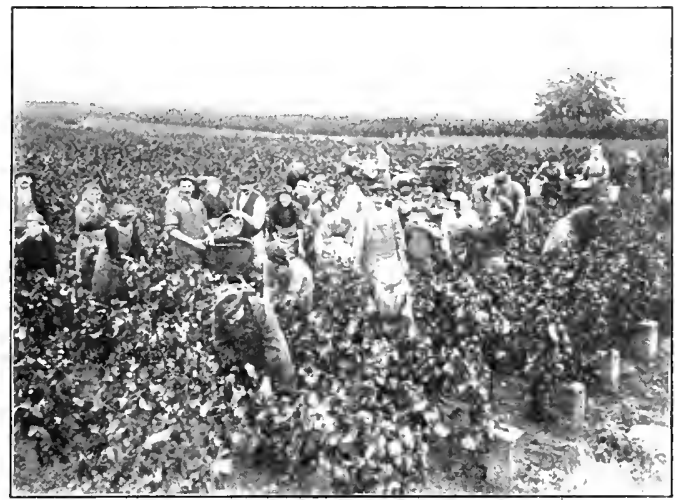

(C) Paul Thompsen

Gathering Grapes in a kilne Vinetard quality are raised in Sicily, and Greece is famous for currants.

Central Asia. l'assing over to Asia, we find that the great industry of Central Asia is grazing. Here the climate is dry, and the immense plains are corered with the flocks and herds of the natives. Where these plains are cooler, as in Siberia, the people live on their herds of reindeer. However, not very many articles from this region get into the trade of the world, because the people are backward and methods of transportation are poor. Grazing in Asia does not lead to an export of food products. From southwestern Asia come valuable rugsand carpets, but wool is about the only product which is of much commercial value. In the warmer parts of temperate Asia many

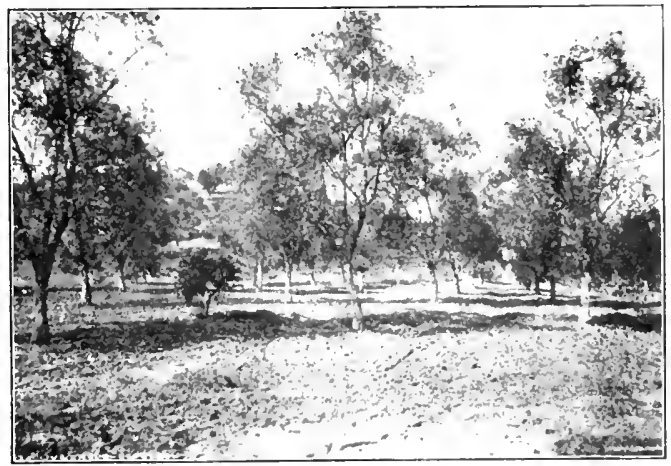

Grote or OLIVE TREES IA C ALIFURNIA fruits are raised, of which the most important are dates and figs. Coffec is exported, as we have seen, from Arabia. 
China and Japan. The most important countries of temperate Asia are China and Japan. China was a highly civilized country when our ancestors were half-naked savages. Japan has borrowed a great deal from China, and, as a result of contact with European and American civilization, has made wonderful progress since $\mathbf{1} 850$.

Rice. The chief food product of China is rice, and the same may be said of Japan; rice is to these nations what rye is to

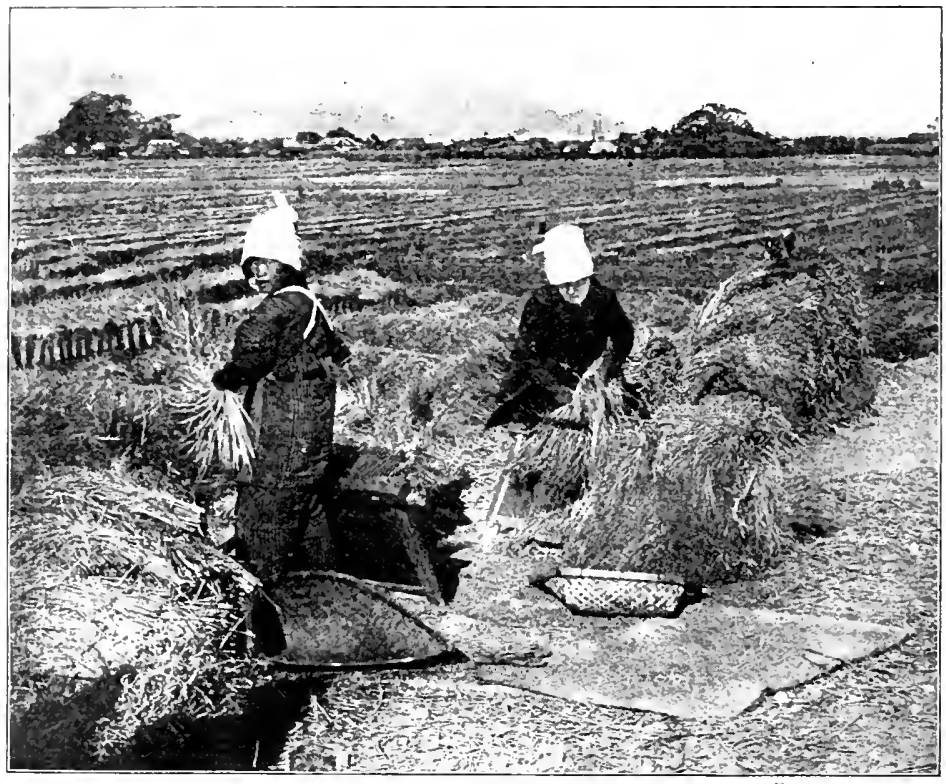

Among the Fanous Rice fieldos of Jay an

(c) I. C. White Co.

northern Europe, and what wheat is to Great Britain and the United States. Rice is also the leading crop in the Philippines and in Siam, and is raised very extensively throughout the tropical and subtropical regions of Asia. It needs a great deal of heat and moisture; in fact, it is often planted and cultirated under water.

Tie have already said something about rice when speaking of the inclustries of our own country. It is interesting to notice that it is, wn the whole, the chief food of the world; for the enormous 
populations of India, the East Indies, and China live very largely upon it, and it is used considerably by the civilized peoples of Europe and America. Millet alone rivals rice as a local food of the teeming East, but it does not figure much in foreign trade.

It is umnecessary for us to take up the south temperate zone of the Old World, which includes, after all, little land and much ocean. There are only two regions there to be considered, namely South Africa and Australasia, and these we have already studied.

What has been learned by the study of foods. We have now examined pretty carefully the distribution of food materials in our country and in other countries inhabited by Englishspeaking folk; and we have gone over the rest of the world, showing the chief foods upon which the people of different zones are dependent.

By this study we

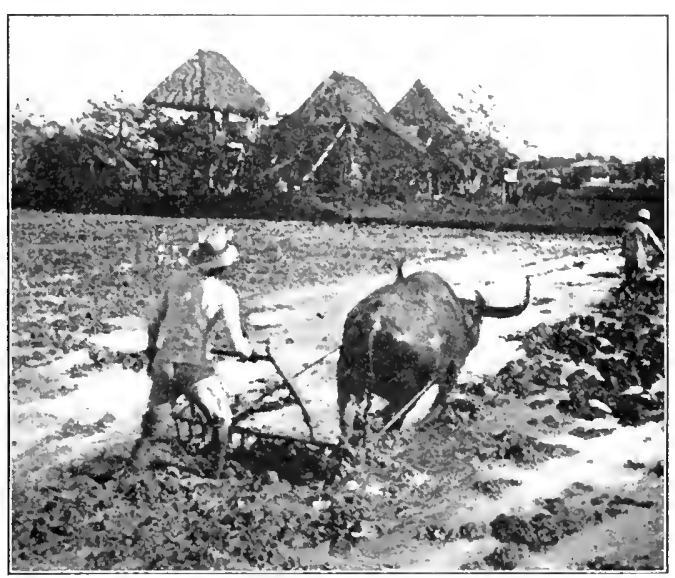

(C) 11 . C. White C'o.

Pluwing Rice fieles with Buffalues in the PHILIPINES

should have learned how the peoples of the world are fed, and why they eat what they do, for we have seen that the kind of food men cat is determined not by chance but by great natural laws.

There is first the enviromment, which is the combination of all the natural conditions, such as climate and rainfall; then there are plants and animals and human races, which fit the environment. The human beings have need of food, which they get from the plant and animal world. Since only certain plants and animals can grow in certain environments, only certain kinds of food can be eaten there unless they are brought from outside. By realizing all these things it is possible to remember nore easily the facts about certain regions. 
Among the food products of the world we shall now select one for sipecial sturly. We shall take as our example wheat, because of its wralt importance to the world. We shall study this grain carcfully, taking up the places where it is raised, the best conditions for raising and harvesting it, and the way it is manufactured, transported, and finally sold to the consumer. Any other one of

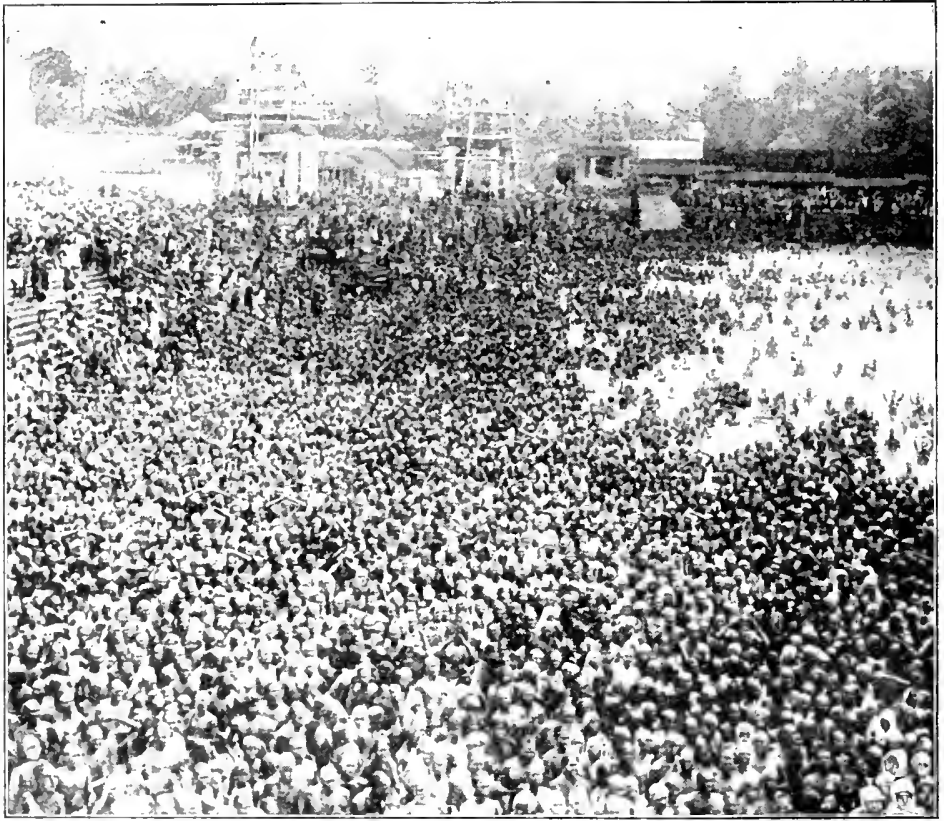

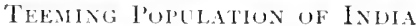

the many food products of the world could be studied in this special way, but to study them all would be an endless task. Howex're, if we study this one important food product thoroughly, we shall at the same time find out many of the conditions and processes which affect every food product; that is, our study of wheat is a solt of sample study, and from this sample we shall lean many things not only about wheat, but about the food of the worler in seneral. 


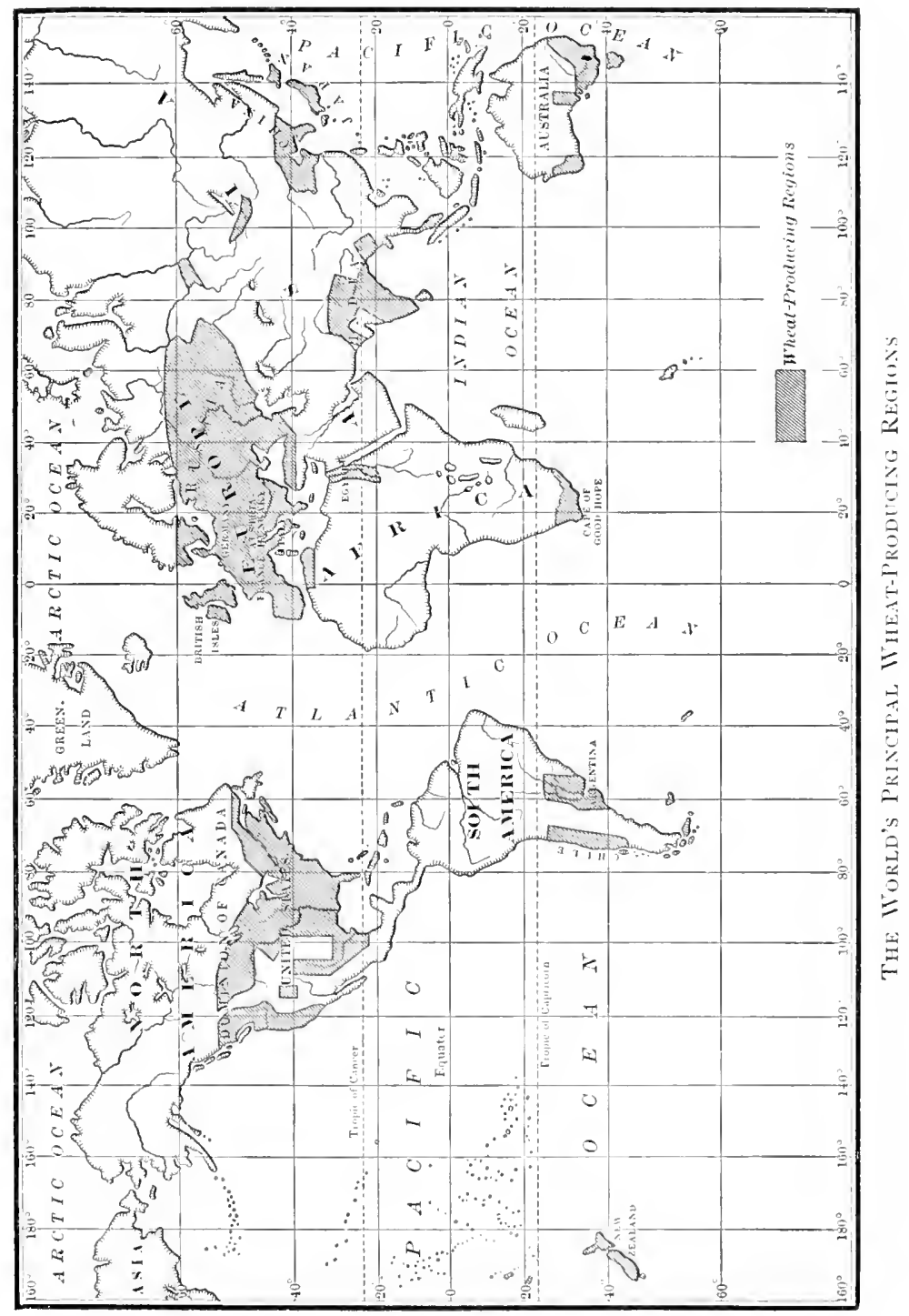




\title{
CHAPTER VII
}

\section{THE PRODUCTION, MANUFACTURE, AND DISTRIBUTION OF WHEAT}

\author{
The Nineat Fields of The World
}

The United States. The greatest wheat fields of the world are located in our own country; we have seen, in general, where they

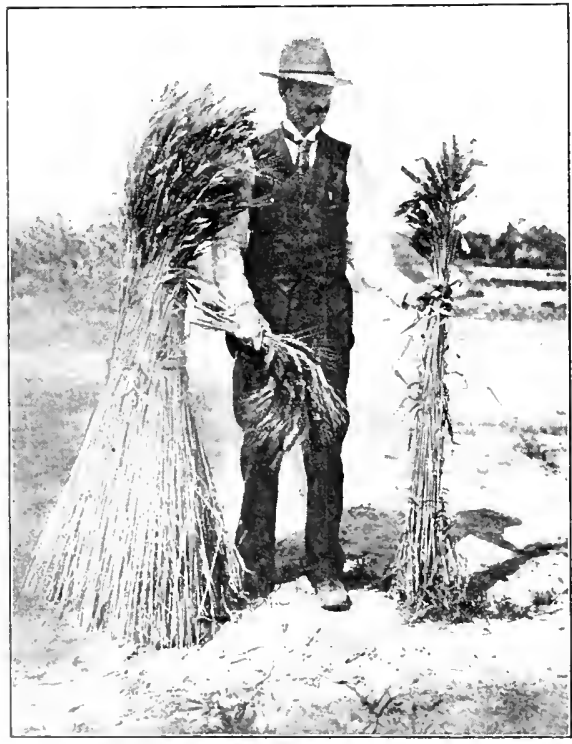

WHEAT AS TALL AS A MAN are, and now we shall go into the matter a little more deeply.

Torth-contral section. The wheat fields of this section are called the "interior wheat belt." About three fifths of the wheat grown in the United States comes from this region. The states included in it are Minnesota, Kansas, North Dakota, Nebraska, Illinois, Missouri, Indiana, South Dakota, and Ohio; and the present center of production, we remember, is near Des Moines, Iowa.

IV cstem section. This is called the "western wheat belt," and lies along the Pacific coast; it includes the wheat lands of California, Oregon, Washington, and northern Idaho.

Eastem scction. It was in this section that all our wheat was grown in the early part of the nineteenth century. As the settlers 
moved westward, wheat production moved westward with them. Although but little wheat is now grown east of the Allegheny Mountains, compared with what is grown west of them, it must be remembered that wheat growing has not been entirely abandoned in New England and in the North Atlantic States. The industry here is more like garden culture than is the case on the prairies of the Vest; that is, more care is given to the lands, and consequently the yield per acre is often very high. In Maine, for

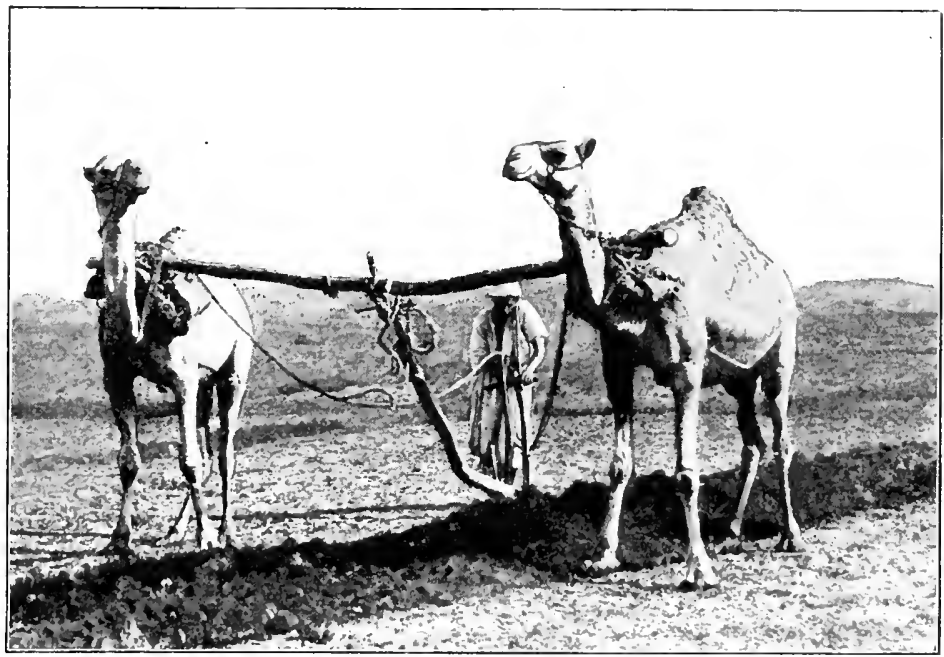

A Imano l'Low

example, the yield per acre for I9IO was nearly 30 bushels as compared with 14 in Kansas and 16 in Minnesota. For the same reason, namely that more attention is given to each acre, the yield in the Pacific coist region is also high. The principal wheatproducing states in the East are New York, Pennsylvania, Maryland, Virginia, New Jersey, and Delaware.

Sonthern scotion. Considerable wheat is now being raised in the Southern states, chiefly in Texas, Oklahoma, and Tennessee, but the yield per acre is somewhat beneath that of the interior wheat belt, and very small as compared with that of Maine, Vermont, or IV ashington. 
Russia. Russia has wide areas of fine wheat lands. In European Russia almost all the wheat is grown in what is known as the "blacksoil belt." This region is extremely fertile, being enriched by decayed grasses and leaves blown southward from the great Russian forests. It stretches all the way across the empire to the Ural Mountains and even reappears in Siberia. There is probably no larger fertile section of land anywhere in the world. The soil is really black or very dark in color, is remarkably uniform, and in some cases is four feet deep.

A few years ago less than one fiftieth of the wheat area in European Russia was outside the black-soil belt. Wheat culture is

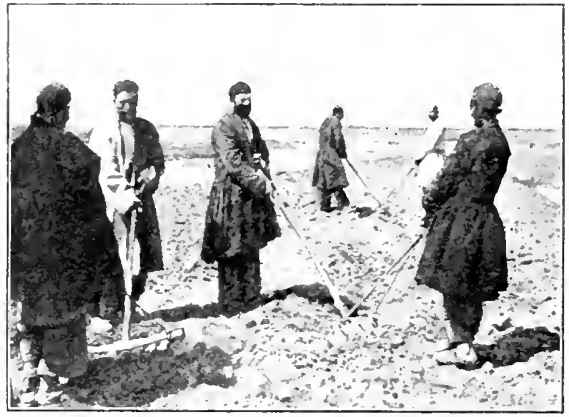

I. l'Ersia the Farmers furxish their OWN POWER increasing very rapidly, and the total crop in European and Asiatic Russia now exceeds that of any other country in the world, including the United States. The total crop in 1909 was $78_{3,000,000}$ bushels.

India. In I9 Io British India produced over 350 , ooo, ooo bushels of wheat, which gave this country third place among wheatgrowing districts, though France has often held that position.

Wheat is grown in the cooler regions of northern India; nearly two thirds of the agricultural land there is planted with it. But it is not raised for the people of India to eat, because they are too poor to consume such an expensive grain; only the foreign residents can afford to eat it, and the great mass of the native population live on millet. A large part of the wheat crop is therefore exported.

The Hindus are backward and have no wish to change their ways of doing things. They will not use the modern plow or the threshing machine, but cling to the old-fashioned agricultural tools and processes of their forefathers. 
France. In most vears france ranks slightly aheal of british India, with an annual crop of about 350,000,000 bushe?s. The soil and climate of france are good for angiculture, and about half of her area is cultivated. Of the cultivated part one hall is given to cereals, and of the cereal areal abut one half to wheat. Thus one eighth of the total area is taken up by this crop.

France has an area of only about 20\%,000 square miles, but she raises half as much wheat as the whole L nited states. The yield per acre must be, then, several times that of the Lnited States.

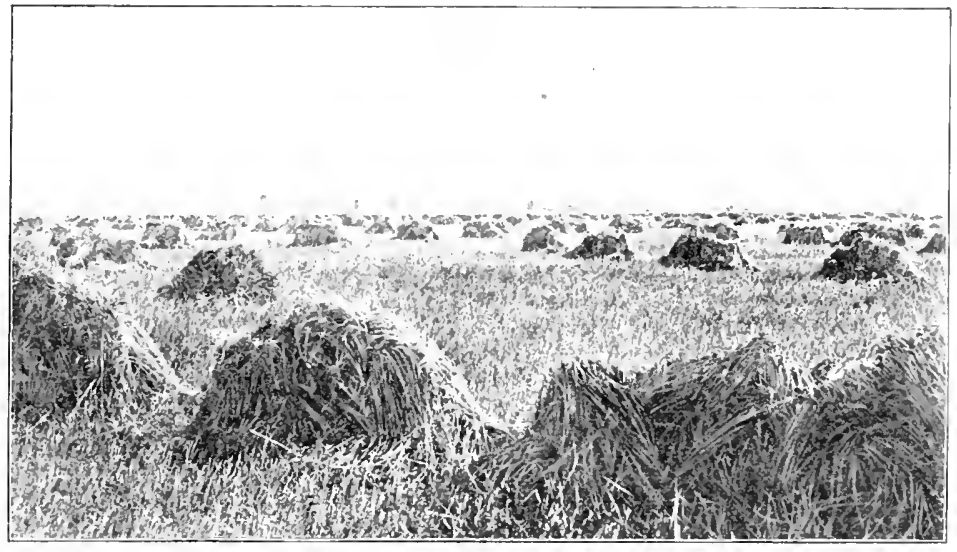

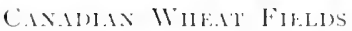

(C) I inderwom! \& [ indirwoul

This is due to extremely careful culture; the farms are small, and the cultivation is almost like that of a garden.

France eneourages wheat cultivation by an import duty of 37 cents a bushel on wheat, and of $\$ 2.75$ a barrel on flour. Years ago the people of lirance were too poor to eat wheat breacl. but now they can afford it. In most vears the whole wheat crop is consumed at home, and a large amount has also to be imperted.

Austria-Hungary. This double kingolom is one of the chicf wheat-producing countries, standing fifth in order. The plains of I Iungary are smooth and fertile, like the Mississippi Valley, and form a fine agricultural regiom, of which wheat is one of the principal crops. A large prepertion of the people of llungary are 
farmers, cultivating wheat and com: but the people live largely on rese, selling much of their wheat to other countries. The Iungarians are rery skillful at flour making; Hungarian flour is known all ower the world and brings a high price.

Canada. Cimada is rapidly becoming one of the leading wheatproducing countries: the amnual yeld has passed the two-hundredmillion-bushel mark. The grain is grown in all the provinces from Nora Scotia to British Columbia.

As late is 1870 all the Canadian wheat was grown east of Lake Superior, but with the settlement of the great Canadian IVest wheat culture also has mored westward, as was the case in the

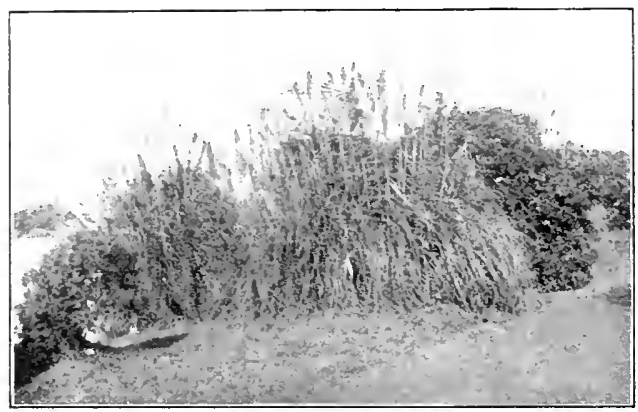

Pampas Grass

United States. The present center of production is within the three prairie provinces, Manitoba, Saskatcheman, and Alberta.

These three provinces are almost five times the size of the United Kingdom, and a large section of their area is excellently adapted to wheat culture. Both soil and climate favor it, for the soil is of the same sort as that of the northwestern states of our country, and the climate is not severely cold. The wheat belt of these provinces stretehes to the northwest from the valley of the Red River of the North, and is two hundred miles or more in width. l'robably not one tenth of this area has ever been sown to wheat, which shows that it holds much promise for the future.

Argentina. Argentina also shows great progress in wheat culture. At present the crop nearly equals that of Canada. Only a small part of the land suited to wheat has ever been cultirated.

It is estimated that in the provinces of Santa Fe, Corrientes, Corchba, and Buenos Aires alone there are over one hundred and fifty million acres of lanci capable of yielding excellent crops of 
wheat without irrigation. This area is much larger than that of all the wheat fields of the Lnited States. The present wheat-growing area in Argentina lies east of Cordoba, and, roughly; between the 3oth and $35^{\text {th }}$ parallels of latitude.

\section{Connthosi uf Cultivaton}

Soils. The best soil for raising wheat is one which is somewhat clayey, but not too stiff and heary; in other words, light clayey soils or good loams are considered suitable. It is true that wheat is not very exacting about the kind of soil on which it is grown. If other conditions are favorable, it is possible to raise a fair crop from a heary or eren from a sandy soil ; but to produce the best results a welldrained, loamy soil is essential.

Climate in general. Wheat is a plant which seems to be able to adapt itself to a variety of

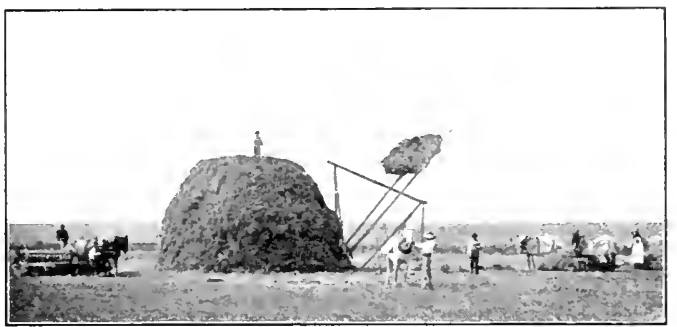

(C) Detruit Publishing Co. ONLY A MARINE CAX PITCH HaY TO THE TOP UF THIS STACK climates. It is also possible to breed wheat so that it can endure much more severe and arid conditions than exist in its normal climate. But we may say that wheat does not thrive well where the temperature is below $55^{\circ}$ Fahrenheit for three months of the growing period.

In general, countries which have cold winters, such as Canada, the United States, and Russia, are the principal producers of wheat : but there are exceptions like California and India. As We all know, climate is not the same every year in the same region; this variation causes considerable change in the wheat from year to year. If there are great extremes of temperature and moisture, the wheat grains are likely to be small and hard. Again, if the season is short, there is less starch in the wheat. If, again, the 
altitude is low and the moisture abundant, the grain of the wheat is likely to be soft.

Varieties of wheat. There are several varieties of wheat, such as hard and soft, light and yellow, spring and winter wheat.

spring wheat is that which is planted in the spring and cut in the fall, while winter wheat is sown in the fall and is cut early the following smmmer. In a country like Egypt, where there is no sharp distinction between summer and winter temperatures, we do not find the spring and winter varieties; but in districts like the central wheat belt of the United States, where there is a decided difference between summer and winter, these two varieties appear.

In some of our states spring wheat grows better, in others winter wheat. For example, in Kansas and other states of the same latitude the farmers can plant their wheat in the fall, and the crop, which does not come to maturity until early the next summer, is not killed during the winter. Where the cold is not too intense the shoots are really protected by the snow and so have a good start when spring comes on. But in the latitude of I akota it is so cold during the winter that the grain, if planted in the fall, would be "winter-killed."

so we see that the grain is planted either in the spring or in the fall, according to the climate. In general, spring wheats are considered the best, especially for bread making. The important spring-wheat states are the more northerly ones of the wheat belt - Minnesota, the Dakotas, Nebraska, Wisconsin, and Iowa. The important winter-wheat states are Kansas, Missouri, Indiana, Illinois, ()hio, and Oklahoma. IVinter wheat is excellent for pastry, and it also makes good bread.

In this study of the effect of climate upon wheat culture we have in illustration of the importance of enviromment in determining the nature of a plant, even when that plant is not growing wild.

Temperature. Something has been said of this in the preceding pages. Ne saw that when the temperature is below $55^{\circ}$ Fahrenheit during the principal part of the growing period, the grain does not thrive well. This growing period, which means the time it takes for 
a crop of wheat to ripen, varies according to climate. In (imnelal, for example, a shorter period is required for a crop to mature than in Texas; this is because the summer days are rery long in northern latitudes, which gives the crops more sunlight each day than they can get farther south. Near Minnipeg the groming season is about one week longer than it is five hundred miles farther north.

Rainfall. The rain received by any region determines for its plant life, in large measure, the chances of survival and growth.

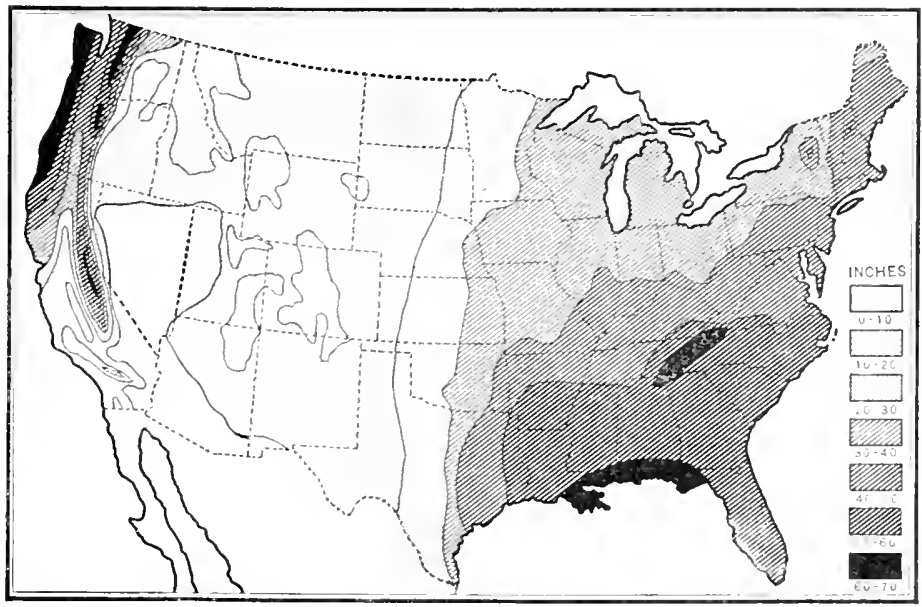

R.MYFIL NII GF TIL UXITEI, SIATS

Moisture is absolutely necessary for plants, though some of them can adjust themselves after a while to a rery small amount of rainfall. In general, in the temperate zone, about twonty inches of rainfall each year is required for successful argiculture. If inisir tion is practiced, of course less rainfall is required.

But it must be remembered that twenty inches would not be enough inless the rains were properly distributed throughout the

$\because \ldots$ morel be to prinent. s in a year might be enough if it all came during In other words, more depends upon the timesan upon its actual amount. 
The Lnited States has only a moderate amount of rainfall, but it is so distributed as to be effective in the growing season. The months upon which everything depends in the United States are April, May, June, and July; and during these months the great central valley in which the cereal crops are grown, receives from one third to one half of its annual rainfall. This insures the growth of crops. When, as sometimes occurs, the rains fail at the important times, the wheat erop becomes a partial failure.

\section{Methons of Cultivaton}

Plowing and sowing. In the case of spring wheat, fall plowing is said to increase the rield, and it also tends to destroy weeds and insects. In general, fall plowing is preferable for economical farm management. In the case of winter wheat, it is best to plow the ground soon after the harresting, the object being to destroy the weeds before they ripen. The depth of plowing depends largely upon the nature of the soil and the subsoil. It is best to sow spring wheat as soon as the ground can be suitably prepared. If winter wheat is sown too late, it is likely to be injured by the cold because it has not had time to get a start; while if it is sown too early, there is likely to be a rank, juicy growth easily injured by the frost.

The seed. NTheat should generally be covered with not more than one inch of moist soil. If the soil is dry or sandy, it seems best to som the seed deeper than where it is wet and clayey. The amount which should be sown per acre depends upon the condition of the seed; if it is poor and shriveled, more seed will be required per acre. Where a great cleal of care can be expended, as when the wheat is sown in drills or rows instead of broadcast, less seed is required.

It may be said that the rield per acre is not in proportion to the quantity of seed sown, for even a small amount to the acre will, if cultivated very carefully, respond to this treatment and cover the whole field. If, on the other hand, the seed is sown broar inct as is the case where there is plenty of land, the wheat wi more spindling: that is, the plant adjusts itself to its environ 
This also shows why the yield per acre is so much greater where much care is expended.

About a bushel and a quarter is the usual amount of seed sown per acre in the United States. It is likely to be less in the winterwheat regions, but it may be considerably above or below this figure in different places. No exact rule can be giren.

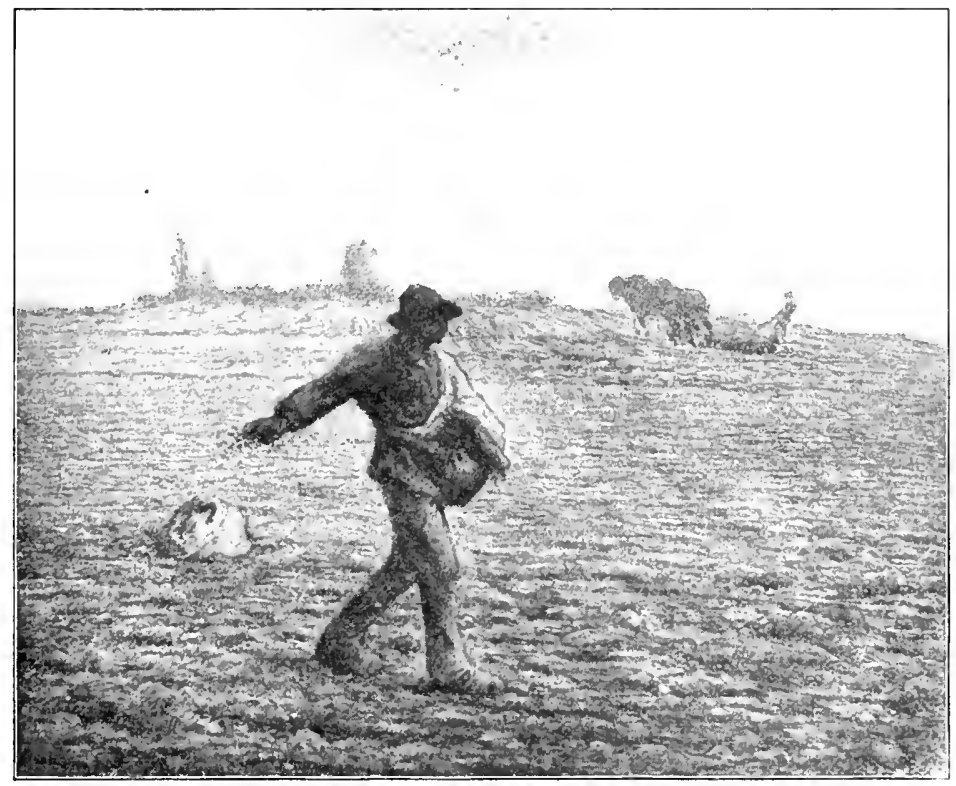

SHING WIEAT BROAIXANT

From Millet's 'The Sower

In parts of California only about half a bushel to the acre is sown. This is probably due to the fact that nature secels the gromed; that is, considerable wheat seed falls before the harvest, and if this is cultivated by harrowing, there is grown what is known as a "rolunteer" crop. As much as twenty-five to thirty bushels per acre may be obtained in this falshion. Sometimes the farmer will scatter more wheat orer the field, if he thinkis enough has not been dropped to produce a good crops. 
In the United States. The method of cultivation practiced in a country depends chicfly upon the degree of civilization, the wealth of the population, and the cost of land. In the United States agriculture hats always been the preeminent producer of national wealth. This is dere to farorable natural conditions rather than to our thrift and ability, for, in this country, system and good business management are not so common in agriculture as in other occupations.

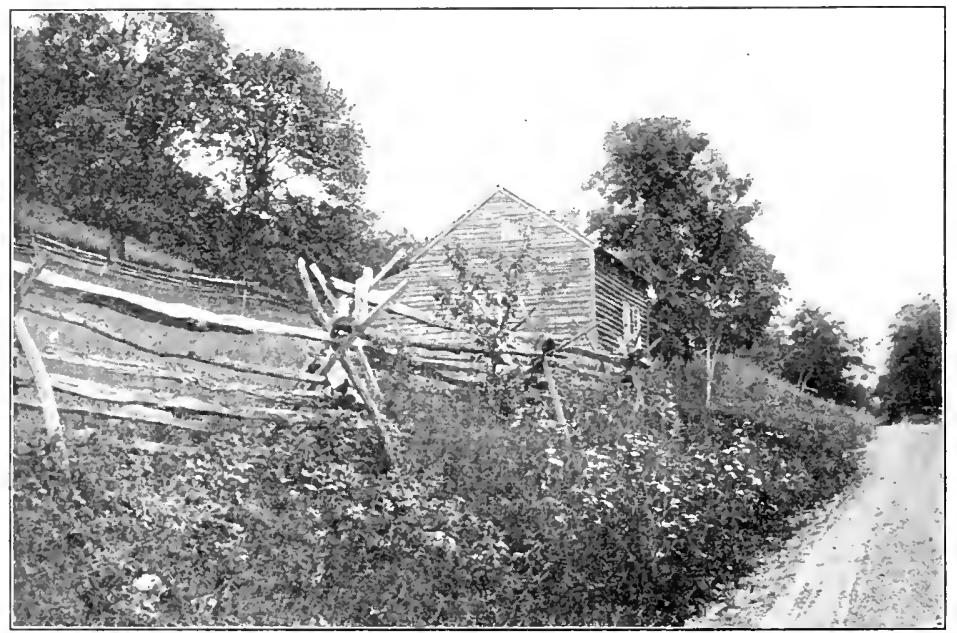

AX APANIONED FARM

In the Lnited States, which is the leading agricultural country in the world, sererel causes have combined to encourage this industry. () these factors, the more important are the fertility of the soil, the variety of climate and other conditions of environment, the energy of the people, the encouragement lent by the government to scientific agriculture, and the unrivaled transportation system for marketing the crops. Again, land has been very cheap in this country, and wages have been very high in other industries. It has therefore been difficult to get farm hands, and this has led to the incention of maloinery by which one man can do the work 
of many. There is no country in the world where machinery is used so extensively in agriculture as in the L'nited States.

The abundance of land has made farms cheap, so that they are, especially in the West, very large. In cultivating these wide fields no such care can be used as where the farms are small and are cultivated almost as painstakingly as gardens are. When large areas of land are cultivated without special attention to the needs of the soil, it is called "extensive cultiration" ; when great care is used, and every square inch of soil is cultivated to the limit of production, it is called "intensive cultivation." Most of our farming is done extensively, and when one goes to Europe and sees the intensive cultivation there, he gets some idea of the lavish and wasteful methods of Americans. In this country not a few farms have been abandoned because the owners were unwilling to cultivate intensively, in the Old World style. European immigrants frequently: take up these "abandoned " farms and are able to make a good living out of them.

In India. In India, land is so valuable that the farms in the wheat district are very small. Hence it would take several of them to make a farm of even a small size in this country. But while land is dear, labor is cheap, and a grown man will work all day for less money than a child in this country would want for doing an errand that would take him only a short time. This fact greatly lowers the eost of eultivation and makes it possible to raise wheat which ean compete in price with that of the United States.

In Russia. In Russia the yield of wheat per acre is small. The area upon which wheat is raised in Europe outside of Russia is only about one third larger than the Russian whent lands, but it produces over two and one half times as much wheat. If the yield of European Russia per acre were as great as that of fermany, Russia would produce nearly fifteen hundred million bushels instead of about one third of that amount.

This is a strange eondition of affairs, because, as we have seen, the Russian wheat is grown on the wonderfully fertile soril of the biack-arth region. Agriculture on private cestates in Russia is generatly of high quality, and on such land the yield of wheat is 


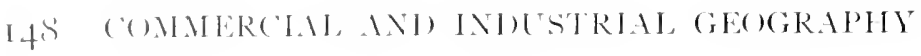

high. What brings down the yield per acre is the fact that most of it is raised on peasant lands. The Russian peasints are too poor to buy machinery, eren if they should wish to do so; and they

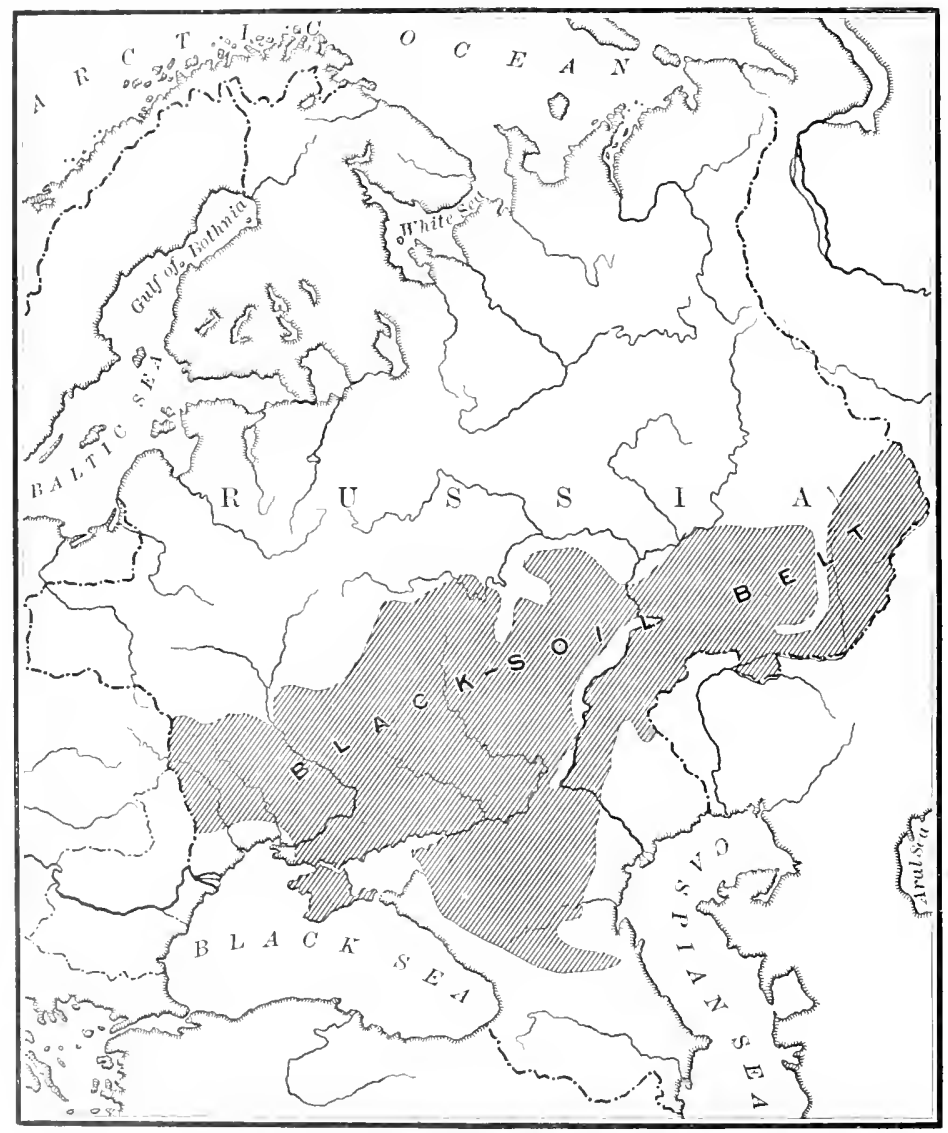

The Rlack sull Regrox of Russia

know so little of better methods of agriculture that they have never he:ircl of the machines and processes which all our wheat raisers use ats a matter of course.

Pror as these peasants are, they have to pay heary taxes, and this wives them little chance to send their children to school or to 
improve their own condition. They are too ignorant to learn from books and newspapers how things are done elsewhere in the world, and so they have never found out that there is anything better to strive for. In the last few years there have been signs that they are beginning to understand how miserable their lives are. Many are leaving the country, and others are only too ready for violent and lawless acts at home.

One of the commonest methods in successful wheat raising is to rotate the crops; that is, the same thing is not planted year after

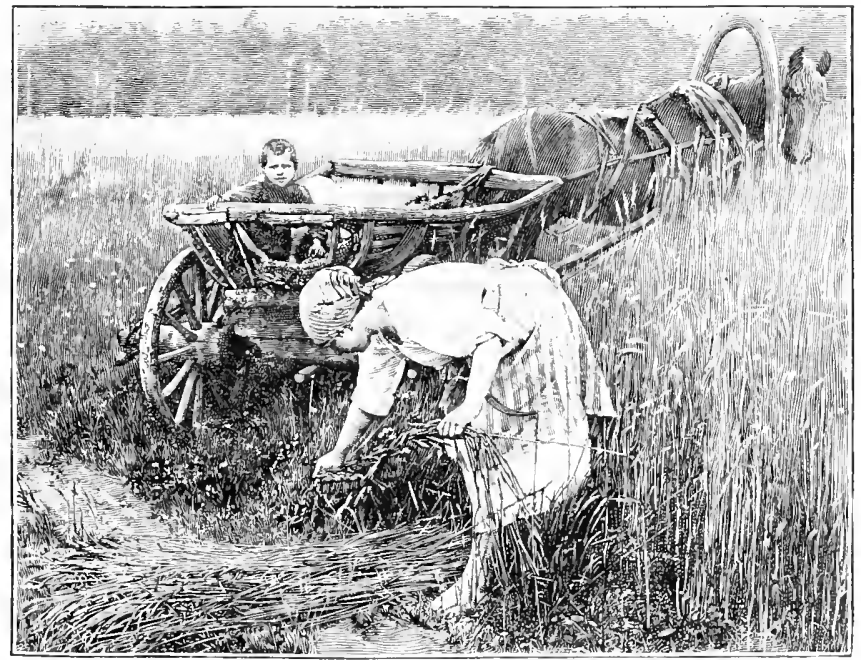

Gathering What hy Ihand

year in the same field, but one plant follows another. Every crop takes certain chemical materials from the soil, and these may be restored in various ways. The old way was to let a field "lie fallow" for a year or two, during which time it would be restored or fertilized by the rotting grass and other vegetation. I ater it was discovered that all crops do not take the same substances from the soil, so that it is possible to plant one crop one year and another the next, and to get good results each year without hurting the land. While one crop is taking its food from the soil, another 
kind of plant foned is being stoned up for the next crop; and in two of thece years the farmer gets around to his first crop again and begins the series anew. Since "rotation of crops" is not practiced in Russia, the land there, good as it is, is being continually imporerished. In both the middle and lower Volga regions, where the soil is rich and black, the average yield for nine years on peasints' lands was only about six and one half bushels per acre.

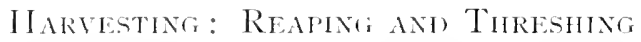

In order to prevent the dropping or "shelling" of the grain, it is best to begin to cut the wheat before it is fully ripe. There has

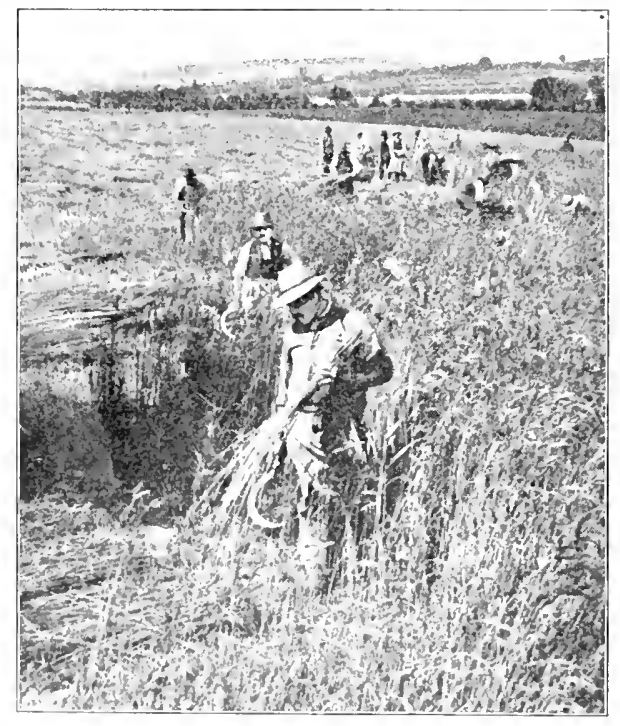

RFUIM: WIIH THE SHCKLE IN GFRMAN

been a wonderful development in the machinery for harvesting wheat, but the progress in recent years has been greater than that made in several thousand years before. It is difficult to find any kind of agricultural implements in which the development of machinery has been more rapid than in those used for harvesting.

Early methods. Probably the earliest method of harresting wheat was simply to pull the plants up by the roots. The harrester would then strip the heads of grain from the stalks with his fingers, or with a crude instrument something like a comb. But lom before history begin to be written there was invented a sort of loukert knife or reaping hook, mate of bronze or iron, which made reaping less crude and difficult. 
The sickle. The sickle form was gradually developed; and from very carly times oriental peoples like the Chinese have harvested their grain with such an instrument. The Russian peasants still cut their wheat with a sickle, In former times the blade of the sickle was often notched. When wheat was first raised in the Canadian Red River valley, which belongs to the great interior wheat belt of North America, the grain was cut with sickles and

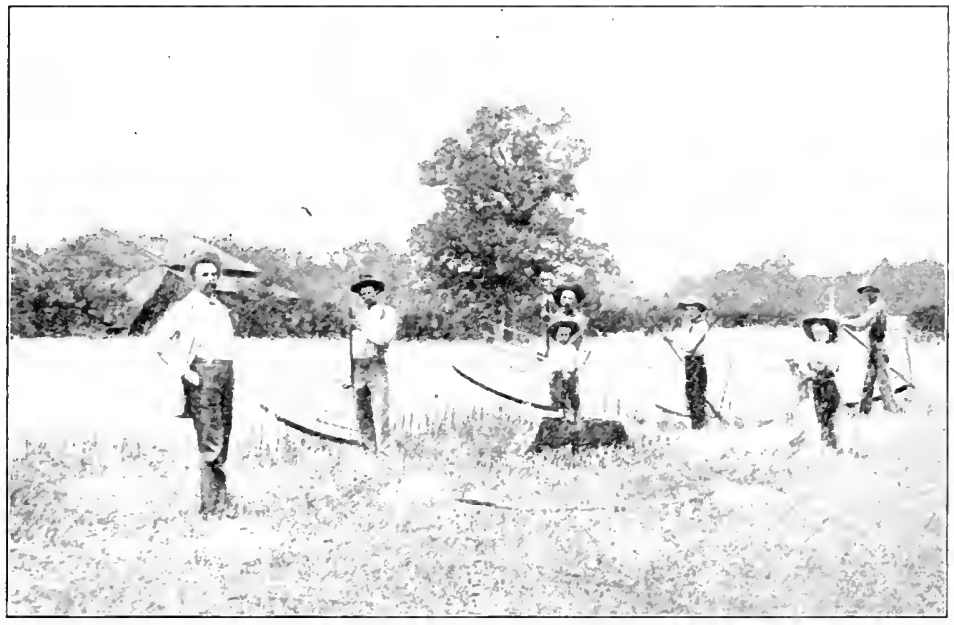

CRALLING A FIELI UF WIIEAT

bound up with willow withes. Harvesting in this style is cxtremely slow, for a man can use but one hand in cutting the grain, and can harvest only about an acre a day.

The scythe. The next advance beyond the sickle was the seythe. In some places it is still used for cutting wheat, but its chice value is in cutting long grass rather than in the grainfield.

The cradle. The cradle was probably developed from the seythe. The former is heavier and more awhward to handle than the latter. The cradle was probably so called beciuse the man who uses it can cut the grain best by giving the implement a swinging or rocking motion. It seems to have been perfected in the United States, but its use soon spread into other countries. 
Before i $\$ 50$ the principal instruments the world over for cutting grain were the sickle, the scythe, and the cradle. In Europe, especially in Russia, the latter two are still much used; and in not a few places in the Lnited States the cradle may yet be seen where it is not found practicable to use a more modern invention. Farmers within fifty or sixty miles of New York City, who raise wheat on a small seale and who cannot afford the costly modern machines, still use this implement.

Both the scythe and the cradle are improvements over the sickle, and enable the work to progress more rapidly. From two to four acres of wheat can be cradled in a day by a good workman.

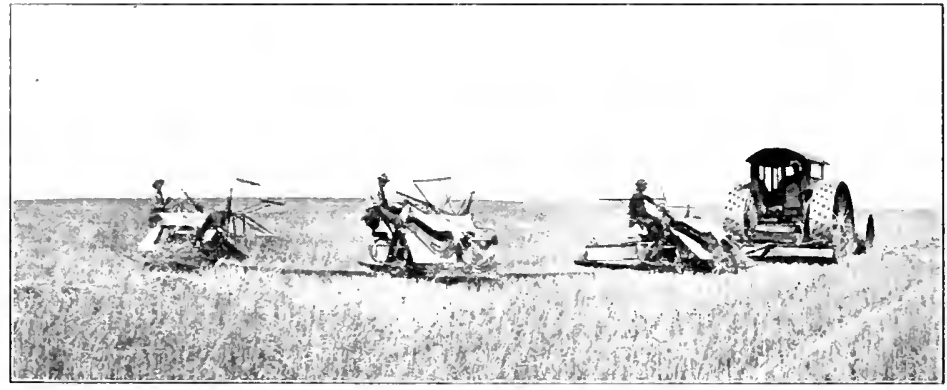

REAPERS DRAWX HY STEAM EXgINE

The reaper. The reaper is a machine which cuts the grain and also gathers it in bunches. It took many inventions, one added to another, to give us a good reaping machine; most of these inventions scem to have been made in England. Some of the machines were to be pushed instead of drawn.

A man by the name of Dobbs, a mechanical genius who was also connected with a theater, is said to have invented a reaper in Is $f$; and in order to get it before the public, he made up a play in which it could be used. The stage of the theater was represented as a wheat field, with real growing wheat, and during the course of the platy this wheat was neatly harvested by means of his machine.

It was left for Americans to perfect the reaper after its essential features had been invented in England. The picture shows one 
of these modern machines. Before i 865 the reaper had been made very efficient, but we soon found an even better method for harvesting our great wheat fields. This will be described in the next paragraph. In Europe the reaper is still in use, especially in Russia and France; and we continue to manufacture a grood many of these machines in this country for the foreign trade.

The reaper and binder. A machine which both cuts the grain and binds it into separate bundles or sheares is usually called a "self-binding harvester." The reaper merely cut and collected the grain, which was then bound up by hand; but the idea of having the machine do all the work came next. It was in the United States that the principle of the automatic binder was first worked out. This was due not only to the fact that the people of this country seem to have a genius for invention, but also to the scarcity of labor here, which forces men to work out all sorts of labor-saving derices.

A modern type of binder combines three or four processes in one machine. It cuts and binds the grain as the reaper does, and it also has a sheaf carrier which collects the sheaves into piles. When a bundle of sheaves becomes large enough, the weight of it "trips" the binder, which then proceeds to bind up the grain automatically.

This machine is used in the United States wherever wheat is grown on a large scale, and in most of the other wheat-producing countries. It cuts a swath six feet wide, which is much wider than that which can be cut with the simpler instruments. From ten to. twenty acres can be harvested in a day by one man and three horses.

The header. The header is a machine which gathers the heads of the wheat, leaving the stalks or straw standing in the field. There are two kinds, the cutting header and the stripping header.

This derice is an old one, and seems to have been used, in a rude form, by the farmers of (jaul two thousand years ago. With them an ox pushed a cart through the grain, and on the front of this cart were fastened knives which stripped the wheat from the stalks so that it would fall inte a boxlike receptacle beneath the blades. Of course, great improvements were made in this device 
before a machine such as the modern header was completed. This mathine usually cuts off the stalks a few inches below the heads of the grain. Inder these conditions it is not necessary to bind the wheat at all, or to pile it in shocks.

The header cuts a swath from twelse to twenty feet wide, so that one of them can harvest from fifteen to twenty acres in a day. It is laregely used in South America. Many of these machines are made in the L'nited States, about one fifth of them being sold abroad. In many cases, howerer, in this country, the combined harvester, which we are now to describe, has taken the place of the header.

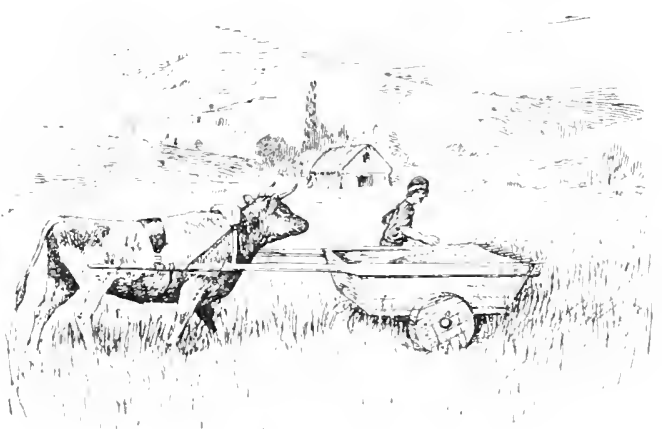

A I'RIUIIIE IIEALEK

The combined harvester. The climax of all discoveries and inventions for harresting grain is the combined harvester. A single machine will cut the wheat, gather it, thresh it, clean it. and even sack it; and during the process the hand of man does not need to touch the grain. Before the harvester goes by; there is a fietd of grain; after its passage, a row of sacks of wheat. lisery operation excepting one - sewing up the sacks - is done by horse power or steam power. The picture on the opposite page shows one of these machines in operation.

The combined harvester can be used to adrantage only where the climate is dry; that is, where it is not likely to rain during the harvest season, where the dews are slight, and where there is little moist air coming in from the ocean. In the L'nited States the machine can be used to best advantage, therefore, on the Pacific coast.

Some of these harvesters are worked by animal power, some by steam. A standard machine drawn by horses will cut a swath from siveare to twenty feat in width; it requires from twenty-four to forty horses to draw it, four men to operate it, and it will cut from 
twenty-five to forty-five acres a disy. There is a division of libor between the workmen: one is the driver, another regulates the cutting bar and operates all the machinery, a third attends to the steering of the machine, and a fourth takes care of the sacks and ties them up.

The steam harvester requires a rather complicated outfit, costing about seventy-five hundred dollars, so it is used only on the larosest

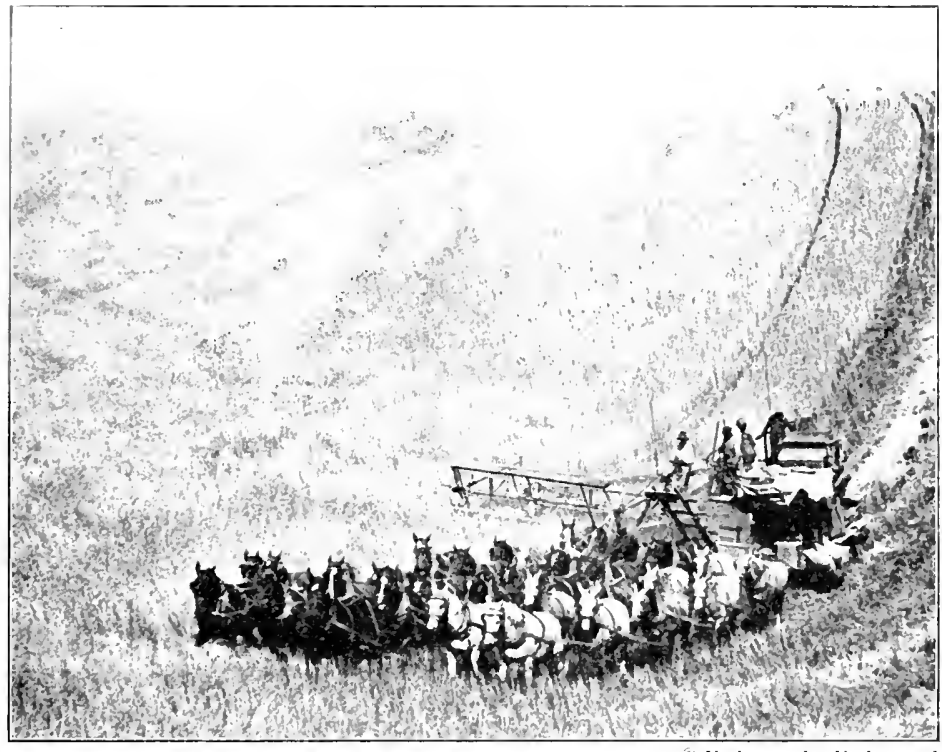

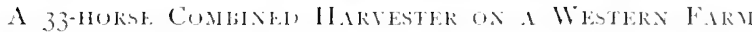

farms. Two thirds of the wheat of California is harrested in this way. "It is a novel, interesting, and picturesque valley secenc to sece this ponderous harvester sweeping through mikes upon mikes of ripened wheat, devouring swaths from sixteen to forty-two feet in width, raising its cloud of yellow dust, and learing behind a long train of sacked grain, ready to be havled to the warehouse, railureal. or mill. It is estimated that three thousand combined harresters were operated on the l'acific coast in $1903 . " 1$

1 l londlinger, "The liosk of 11 heat," Pp. $93-94$. 
Threshing with animals. By threshing is meant the separation of the grains from the stalks or straw. Very likely man at first separated them by hind. A very early method of threshing was by having animals walk back and forth over the grain on a floor. In Arabia the sheaves were laid in orderly fashion upon some level spot in the fields, and two oxen, dragsing after them a heary stone, were ked back and forth, or in a circle, over this "threshing floor." Similar methods were in use among the Syrians and Romans. In Egypt a clumsy skedge with rollers was driven over the sheaves,

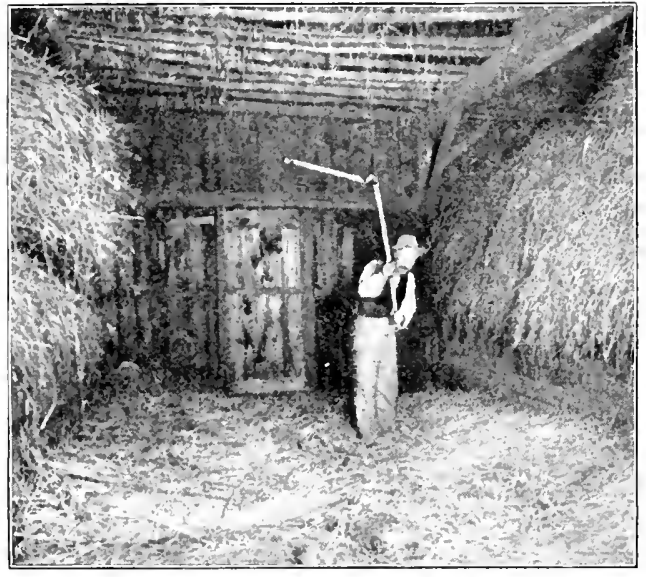

Thesingi With the Flail which were piled in a ring about two feet high and from sis to eight feet wide.

In this country, for many years, horses were used to trample out the grain; this method lasted until about 1840 . A man and boy and three horses could sometimes thresh thirty bushels a day. In such countries as Spain, Syria, and Argentina threshing is still done by driving oxen and horses over the grain. It is said that not over ten or twelve years ago grain was cut in New Mexico with a sickle, and theshed by goats trampling over it.

Threshing has also been done by beating the grain, after it is cut, with a stick. An improvement upon a mere stick or club is the Hail.

The flail. This instrument consists of two clubs tied together (nd to end with a flexible joint. It was used in ancient times, and was then about the same tool that we find used in some countries nom. The picture shows the sort of flail used in some remote districts in the United States and Canida. 
When the flail was used, threshing was done on the farms in the winter. The wheat stalks, with the heads of grain still on them. were laid on a barn floor, and two men, standing opposite each other, beat out the grain. First one would strike a blow, and then the other; in this way they would " speed each other up, " and neither of them woukl feel so tired as if he were working alone. This method of threshing is still to be found in the Lnited States and Canada, but is chiefly used to separate beans and peas from their stalks.

More modern methods of threshing have replaced this one in most countries, but the peasants of Russia are so poor that they still use the flail. One man can thresh from eight to twelve bushels of wheat in a day.

The threshing machine. The modern threshing machine wats invented in the eighteenth century by three Scotchmen. The first machines were very crude, but they showed the same principles as the modern kind. Another Scotchman, by the name of Andrew Neikle, made a machine in I Soo which was the first to thresh, clean, and drop the grains by themselves into a receiver at one and the same time.

At first these machines were driven by water or worked by horses. but later steam power was applied. Crreat Britain was the first country to make general use of the threshing machine. Some farmers have their own machines, but generally a man who owns one will move from one farm to another and thresh the grain for a fixed price per bushel.

A modern threshing machine does not have to be fed by a man standing at the beater, but feeds itself. It performs all its processes automatically, even to stacking the straw and weighing the grain: the only human power required is in pitching the grain upon the self-feeder. The straw may be burned in the engine if this is desirable.

In 1903 a thresher in Kansas threshed thirty-five hundred bushels of wheat in less than ten hours. It took only four men to operate the machine, but eighteen men and ten double-horse wagons were required to haul the wheat to the thresher as fast as it was needed. 


\section{TRANSPRTATION}

The business of clistributing the cereals of the United States is an cnormous one. Each year we have about seven hundred million bushels of wheat alone to be disposed of. Roughty speaking, the harvest of each year can be divided into three parts: a third of his wheat crop will be kept by the farmer to feed himself and his stock, and for use as seed; another third will be distributed in the

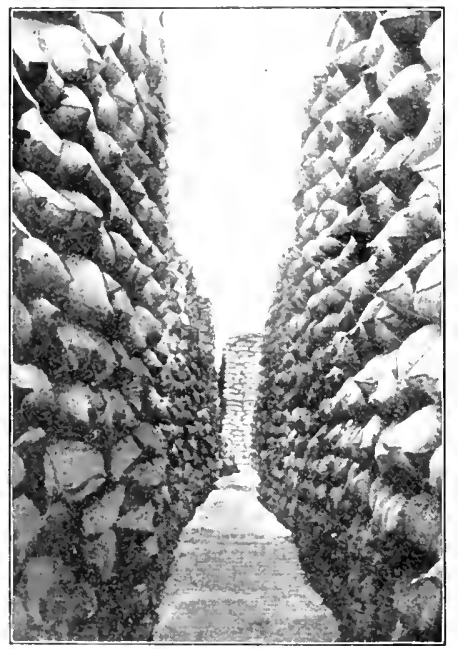

CANUOS OF SACKEL WHE.T United States; and the remaining third will be sent to other countries which do not produce as much wheat as they need.

This means that two thirds of the wheat produced in this country has to be moved from the farms to some other place, more or less distant. It is hard for us to understand what a large industry the transportation of wheat is; it is the biggest task in our agricultural life.

From farm to railroad. In most countries excepting the United States, wheat, in its journey from the farms to the railroads, is handled in saclis. In the United States it is handled in this fashion only on the Pacific coast. In that region it is usually dry at harvest time, so that the wheat can stay on the ground in the sacks without any danger of spoiling, and the farmer can wait until he is quite ready to haul it away.

Elsewhere in the U'nited States farmers talie advantage of the fict that wheat is almost like a fluid and can be handled in a loose conclition. So it is never sacked at all, but is poured directly from the thresher into a wagon or tank.

Vlmost werwhere in the wold wheat is carried from the farm (1) the nearest railroad center by means of animal power. In the 


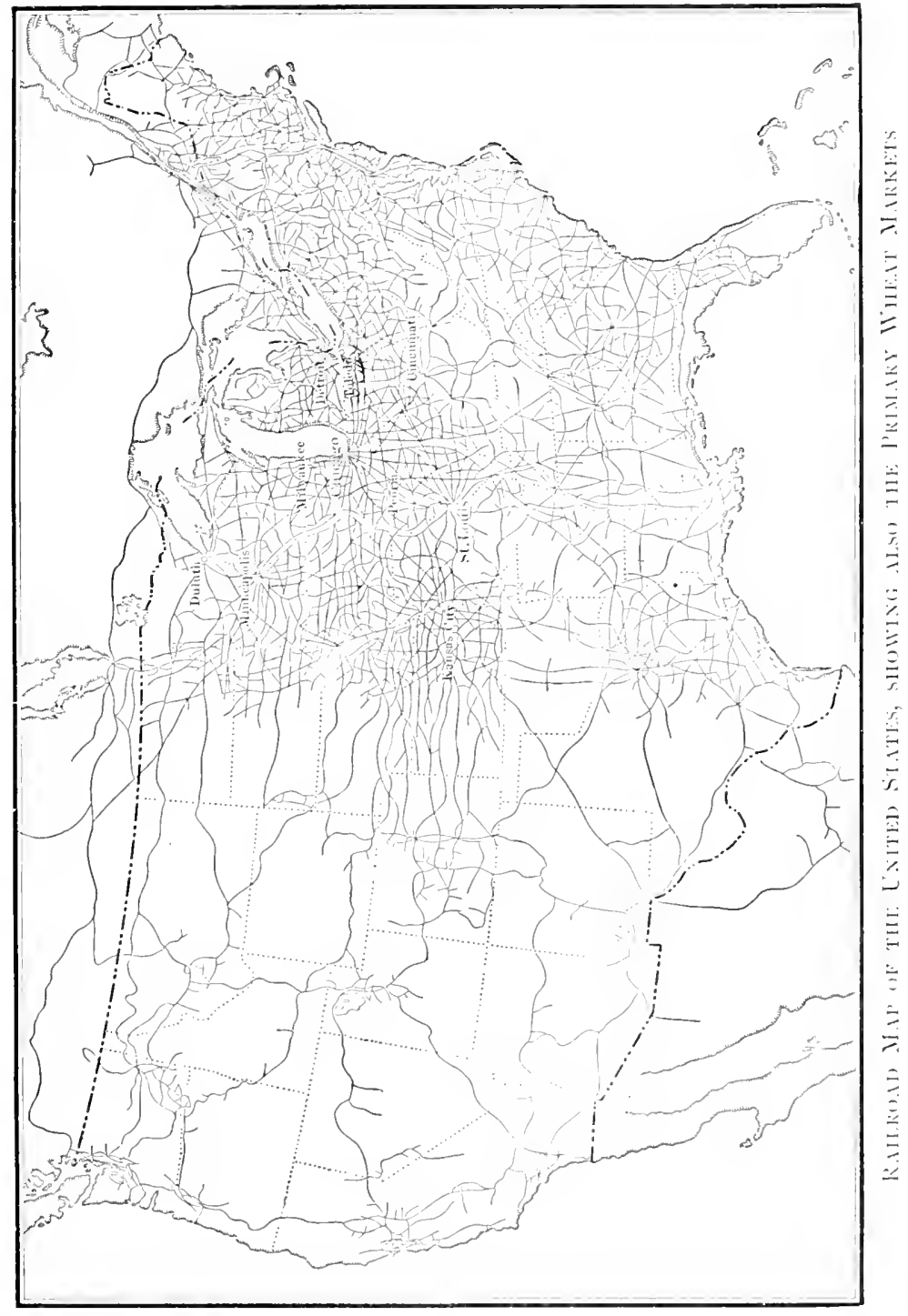


Inited States we have the two-horse grain wagon of ()his, the fourhorse grain tank of North I aliota, and the six-horse rehicle eommon on the l'acific coast. In other countries, such as liggpt or India, transportation is accomplished in a slower and more clumsy manner by the use of oxen or camels.

Grain elevators. The picture shows what a grain elevator looks like. It is really one or more tanks, rery larese and high, in which the wrain can be stored until it is ready to be shipped. The wheat would spoil if left out of doors, and the elevator has come to be necessary. Modern machinery at the elevator will take up from the wagons about a thousind bushels of wheat an hour.

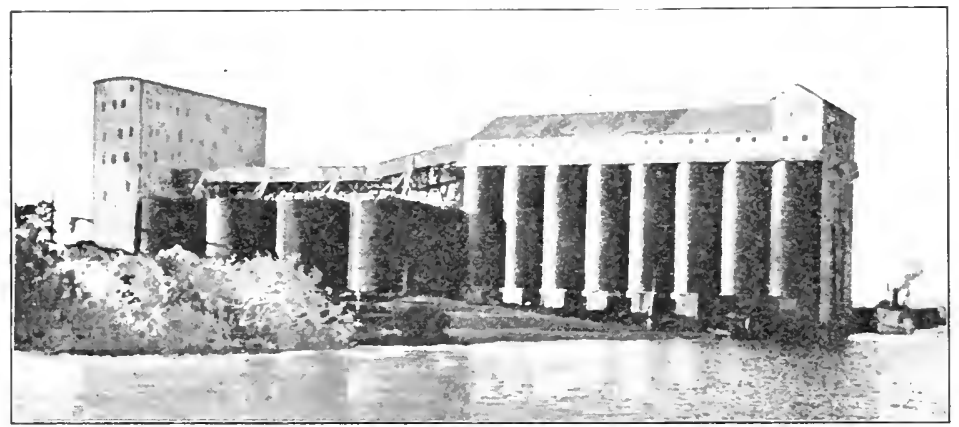

A GRAIN ELEVATUR

The elevators, which are made of wood or steel, hold from 50,000 bushels of wheat up to 3,000,000 bushels or more. Chicago, the first city to have grain elevitors, built some of them between I 850 and 1860 . Some cities in the central wheat bett, which collect for foreign shipment, can store between 25,000,000 and 50,000,000 bushels of wheat. The wheat business is so large and so difficult to conduct that a country like the L'nited States could not set along without these chevitors.

By rail to primary markets. The places to which the grain is hauled in wasons from the farms are called "local "wheat markets. but there must be further concentration in the collection of grain, and the plitces where it is collected from the local markets are called "primary" marliets. An example of such a place would be Chicago. 
We have seen that wheat can be handled almost as if it were a fluid, and perhaps we can better understand the flow of grain if we compare it to that of water. The separate wheat fields of a farm are like the springs where the water rises. The united flow from the springs makes a sort of brook, which carries the product of the farm to the local market, and here the streams of grain all unite to form what we might regard as a little river. Then the streams from various local wheat markets come together at the central

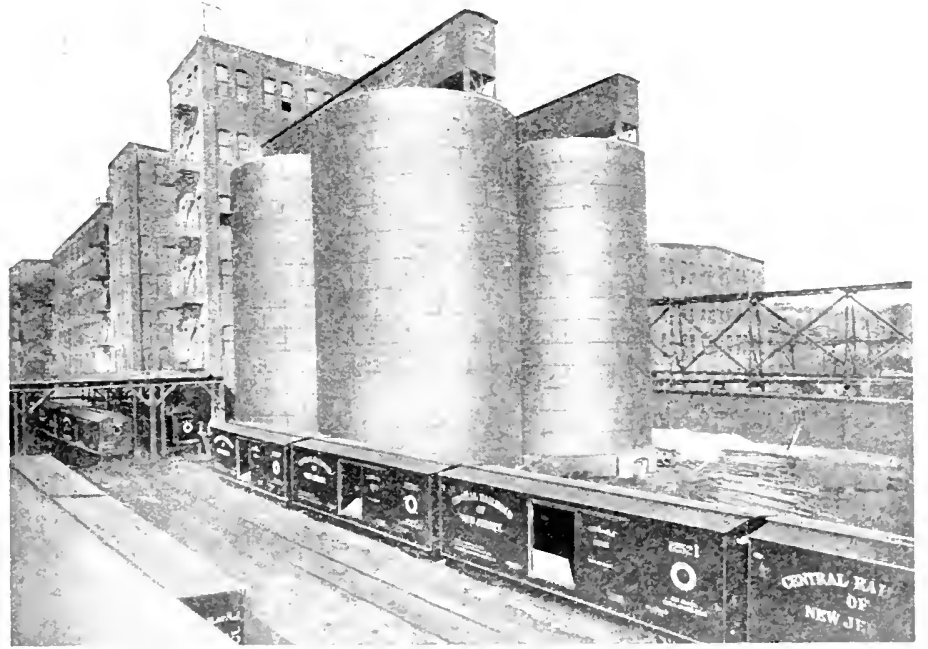

STEEI, TANKS FUR STURING CURN

From ( Isen's "Pure Foods"

market, forming what might be called a large river, or, perhaps. a reservoir or lake. From this large reservoir the wheat is drained by the railroads, part of it finally reaching the sea.

In almost all cases wheat is moved from the local markirts near the farms to the large primary markets entirely by rail; there is very little water transportation. In Isog there were received at the primary market of St. Lonis about 50,000,00o bushels, and of this about 49,000,000 were brought in by the railroads, leaving only I,ooo,ooo for water and wagon transportation. 
Loading and unloading. I ittle human power is used in handling the grain either in the local and primary markets or elsewhere.

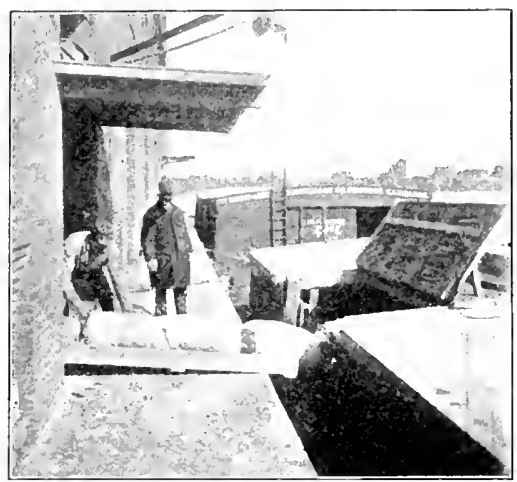

D.ARGES ARE LU.MHE WITI FLUUK KIGHT AT HHE MILL Steam or electrical power runs the machinery of the elevators and does as much work as an army of men could do. To show how human labor has disappeared in all the operaltions connected with wheat, we may say: "All agricultural implements are guided by levers, and the thresher men are only assistants to a machine which delivers the grain into a sack or grain tank. Those who unload the wheat into the magons simply loose a bolt and the grain is dumped. Those who heare wheat into bins merely press buttons, and those who load it into cars or ships need but to pull a kever."

\section{Primary markets.} It is interesting to know about the location of our primary markets ; that is, of the cities where the concentration of the graim takes platee on the larrest scale.

There are ten of these primary markets (hicager, Minneapulis, Inluth, St.

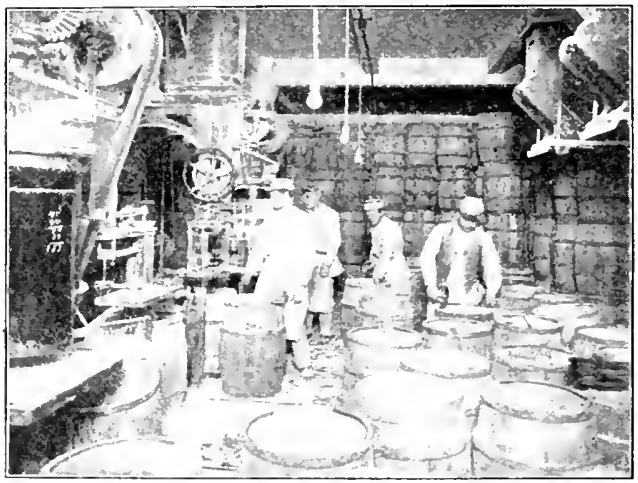

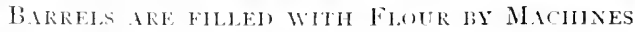
WHICH STOP AUTOMATICALLY JUST AT THE Right MWMENT

Ionis, Vilwalules, Toledo, Kansas City, Peoria, Cincinnati, and I) cotroit. Eath of these cities receives annually from ten million to a hundred million bushels of grain for further distribution. They are 
located in places which give them great advantages for transportiltion, all but Peoria being situated either on the Great Lakes or on important interior waterways. Also, as a railroad map of the United States (p. I 59) shows, from each of these cities there stretches out in every direction a network of raikwys, - in some cases as many as twenty grain-carrying lines, - all striving to secure the wheat shipments.

Minneapolis is the great grain-milling center, and for that reason is a most important collecting center for wheat. The reasons why the milling is centered at Minneapolis we have found out earlier in this book.

Chicago is the largest grain market in the wortd, chiefly because of its position on the Great Lakes, and because it is a great railroad center. Duluth is in the list because it is in Minnesota, one of the first grain states, and also because it is at the head of water transportation on Iake Superior.

Kansas City and St. Louis are large cities in the vicinity of the wheat belt; their nearness to it makes them important collecting centers.

Buffalo, while not on the seacoast, is a very important center for the collection of the grain which is to be sent abroad through the Atlantic seaports. This is because of its location at the point of transshipment of the grain which is brought down the Great Lakes, and which is to be sent to the seacoast either by rail or through the Erie Canal.

New York is a prominent wheat-shipping center, ( $\mathrm{I}$ ) because it is the chief seaport of the United States; (2) because at this point the railroad lines from the West meet; and (3) because all the wheat which comes through the Erie Canal is finally brought here.

On the I'acific coast San Francisco is the first point of shipment for the wheat from the Pacific belt, and exports about half of the grain sent abroad from this entire region. It is an important port of call for steamships, and has good rail connections with the interior. For the same reasons Portland, (Oregon, is an important point of shipment. Both of these ports, as well as Tacoma and 


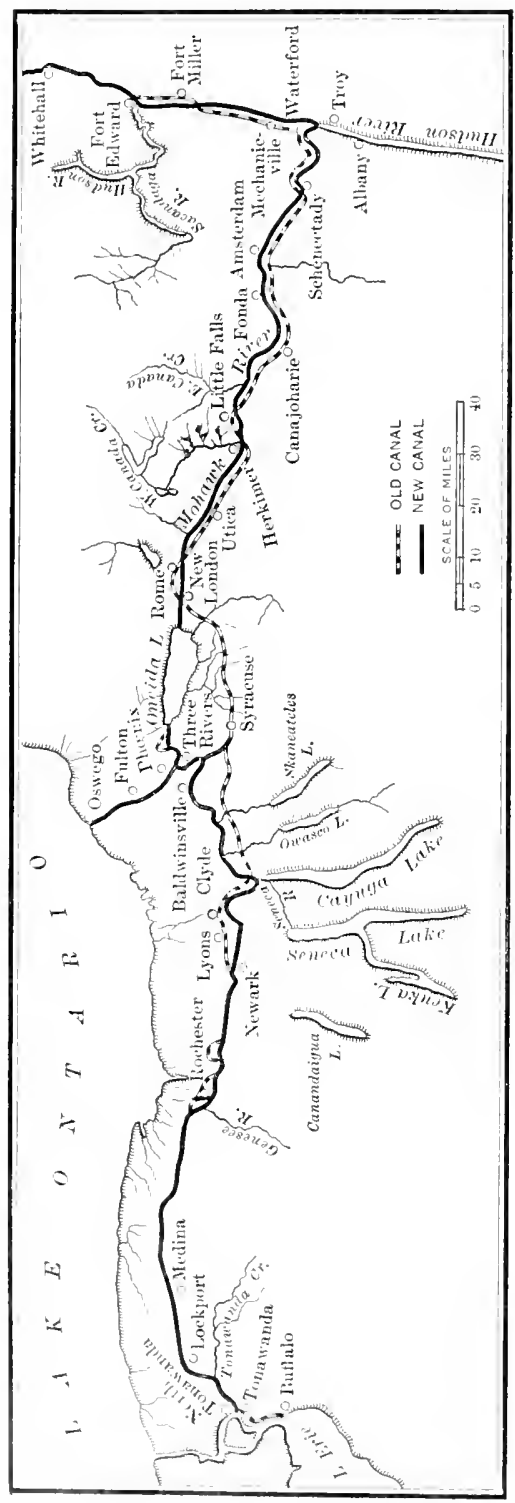

Seattle, are helped by the fact that efforts are being made to work up a commerce with the Far East.

() $)$ the Atlantic seacoast several cities have a share of the grain shipment. Montreal, Boston, Philadelphia, and Baltimore struggle with one another and with New York for this business. New lork has a great adrantage in that the - New York Central Railroad is better situated than any of its rivals. It runs through the Mohawk Gap in the $\approx$ Appalachian range, and does not have to twist and turn through the mountains, $E$ as some of the other railroads do. New Orleans, Galveston, and other Gulf ports are coming into prominence with the southern movement of the grain, of which we shall now speak.

Shipments to the sea and abroad. Here we must consider the movement of wheat from the primary markets to the seaboard, and from the seaboard to the world's market. No other country in the world has so excellent a srstem 
of internal transportation as has the Enited States. Wheat is sent both by water and by rail to the chief seaports.

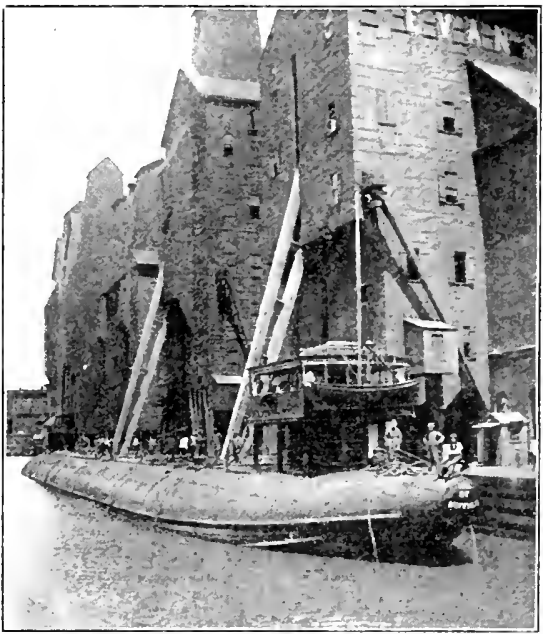

(c) Inderworl a inderwood

A Burfalo (N.广.) Whaleback bend: LOADED AT A GRAIX ELESTUR

liy areter. Before we had railroads the surplus grain at first was brought by way of the Mississippi River to New ( )rleans, but when the Erie Canal was opened, in I 825 , the movement of grain turned eastward through the canal, a fact which helped make New York the great commercial citr of the continent. For a long time all the grain went eastward by this water route, but shipments by rail began in $1 \$ 56$. and it was not long before the railroads had robbed the canal of a large part of the wheat traffic. Within recent years the movement has turned again toward the south, and a good deal of the grain has been moved to the seaboard by the railroads which stretch from the internal wheat belt to the Gulf of Mexico. Partly to meet the competition of the railroads, the Erie Canal is being enlarged and otherwise improved. Ilaclibacks. ()n the Great Lakes a curious type of ressel, called the "whale-

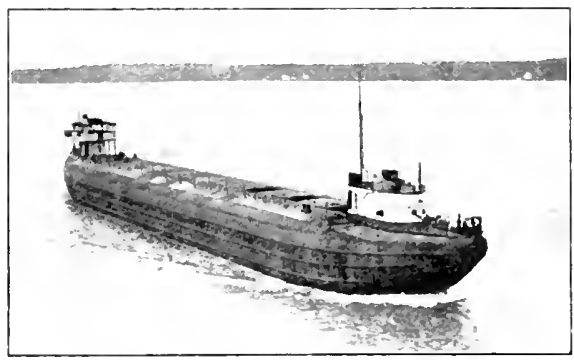

WhALHARK W IIL GREAT LAKES back," is used for transporting the grain eastward. These boats became common about 1900, and cariy from 250,000 to 500,000 bushels of wheat in a single load. 
Rerilmeds. Most of the wheat to-day moves eastward by rail. ( )n the New lork Central Railroad, for example, eighty large cars of wheat, each ear containing something like two thousand bushels, are hauled over the line by a single engine. Twenty-five years ago five hundred bushels was a large carload and a thousandbushel car had never been heard of. Very often there is a shortage of grain cars during the shipping season, so that shippers lose considerable money by not getting their grain to market at the best time. The railroads do their best to supply all the cars that are needed, for they make a great deal of money shipping wheat; but in spite of their efforts shipments are very often delayed.

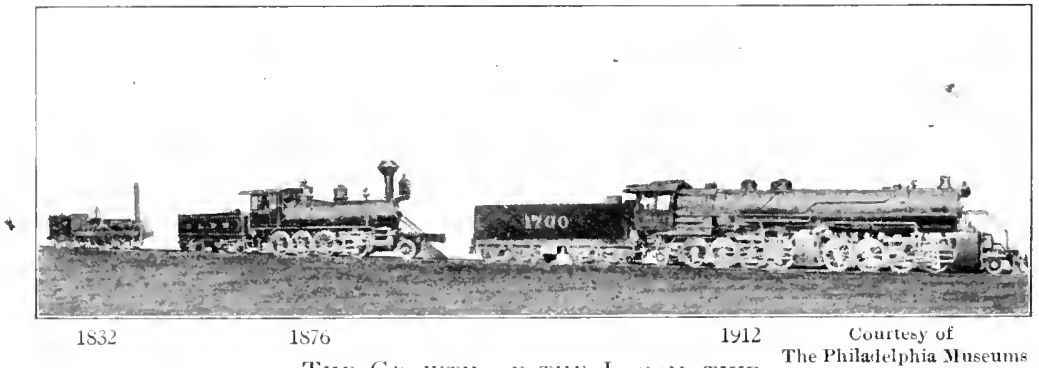

THE GKowTH of THE Loconotive

Stermers. The principal wheat market of the world is I iverpool, in England, and our grain is shipped there in large steamers. In some eases the wheat thus shipped abroad goes in sacks, but, with the exception of the Pacific coast wheat, it is more commonly dumped or sluiced into the holds of the vessels and shipped in bulk.

Cost of transporting wheat. In 1905 and 1906 the value of the wheat on the farms in the United States, before hauling, was 69.4 cents a bushel. The average distance over which it was hauled from the farms to the loeal shipping points was 9.4 miles, and the cost of hauling was 5.4 cents a bushel; the railroad freight charges to the seaboard added I I.6 cents; the ocean freight charges to the L'nited Kingdom were 9.6 cents more: the minor costs of sale and shipment, I.5 cents. If we add all these costs together, the value of the wheat per bushel at a port in the United Kingdom would be 97.5 cents. 


\section{CHAPTER VIII}

\section{THE MANUFACTURE OF FLOUR}

Purifying the grain. Before the wheat is ground it is necessary, in order to turn out a high grade of flour, to put the grain through several processes. It must be purified before it is ground, or dust, dirt, and chaff will be found in the flour. Unless impurities are removed, a grood grade of wheat will make a very poor grade of flour. Ages ago wheat was purified by throwing it against the wind, which blew away the lighter chaff, leaving the grain. The Bible speaks of separating the wheat from the chaff. This was called "winnowing." Of course, if the impurities were as heary as the grain, this winnowing would not remove them.

At the present time other means are used, such as brushing and various forms of friction; blasts of air are also blown upon the grain, so that it is now possible to remove practically all impurities. These processes might be called dry cleaning — such cleaning as is given to our clothes by the tailor, and to carpets by a racuum cleaner. Another method of cleansing is by washing the wheat with water and drying it perfectly; some millers prefer to wash all their wheat.

Tempering the grain. A further process, which precedes grinding, is known as "tempering." The object of this is to make the hull tough, so that it will come out from the grinding in one piece; tempering also so treats the inner part of the grain that it will yield the largest amount of flour. This process is done in a great number of ways, but one step is to heat the wheat to a certain temperature and then to apply moisture in the form of water or steam, or both.

Grinding. Next comes the grinding or crushing of the grain between two hard substances. "The first miller," it is saicl, "plucked the berry from the stalk, and, using his teeth as millstones, ground 
grist for al customer who would not be denied, - his stomach." Of course, the first grinders that the human race ere used were the teeth ; we call them "grinders" sometimes, and the word " molar" is from the loitin, moning "mill."

Kinds of hand mills. But soon men learned that it was wiser to crush the wain between two stones than between the teeth. There

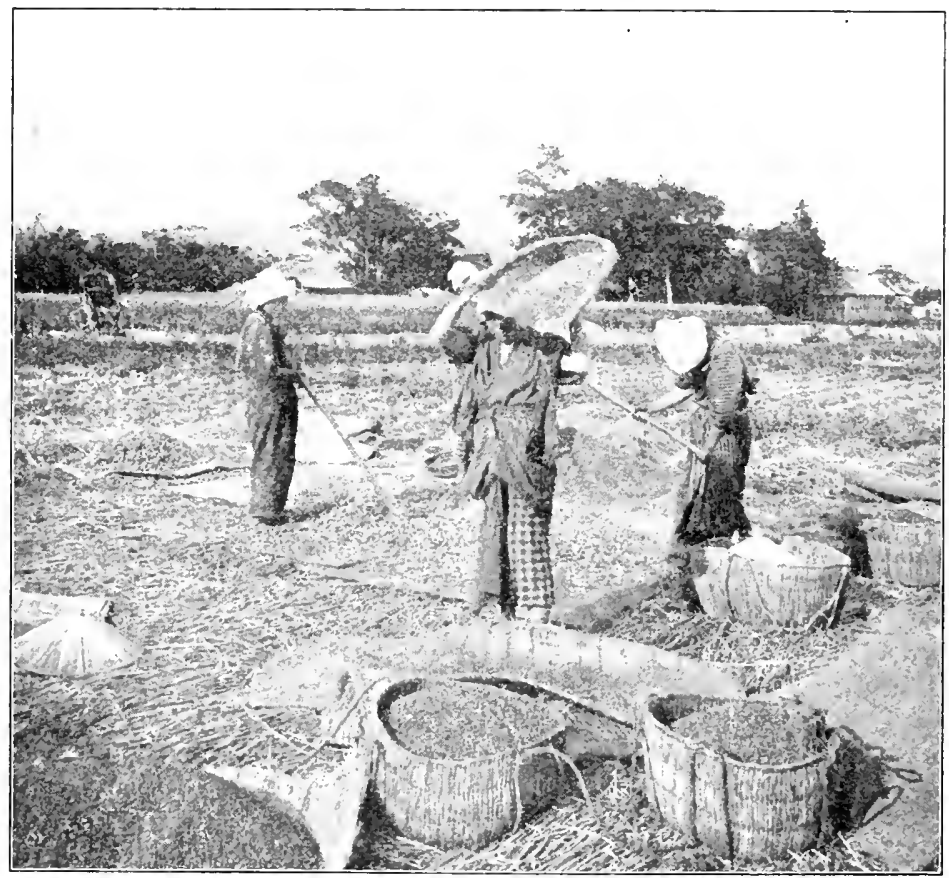

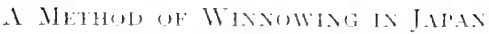

are three sorts of mills: first, the mortar-and-pestle type, where the grain is crushed in a stone bowl by rubbing it about with a stone pestle; second, where the grain is crushed by passing one rough surface wer another; and third, where the grain goes between rollers, as wet clothes pass through a wringer.

Hortar and pestle. This was the original method of breaking up the grain by hand. As the grain was pounded on a flat stone, this 
stone was gradually hollowed, and so a bowl was made. Probably a slightly hollowed stone was picked out in the first platee, so that the

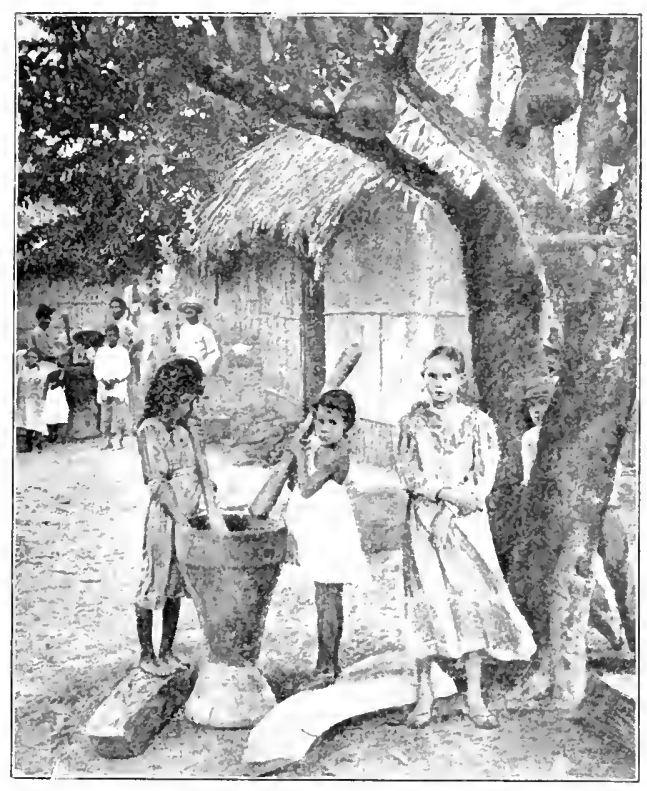

THE CHHDRF ARE PUCNUAG RJE broken grains shoult not be seattered upen the swound. Nlany of these cup-shaped mills are found among salage peoples now living, or in the cares where carly man dwelt many centuries ago. In one Indian settlement in Texas twenty-six hollows were foumd in the solid rock, within a few feet of each other. We see the drugeist still using a mortar and pestle to make powders and pills; sometimes the sign which he places in front of his store is a great gilded mortar and pestle, just as the bontmaker may have a large wooden boot. Even now, in the country, the mortar and pestle may be required to pulverize salt, when people buy a cheap grade which is coarse and lumpl:

Homing block. 'The carly' settlers in New England used the mortar and pestle for a great many years. In P'ennsylvania they had what was called a "hominy block," a big bowl burned or dug out of a block of wood. In some cases it was

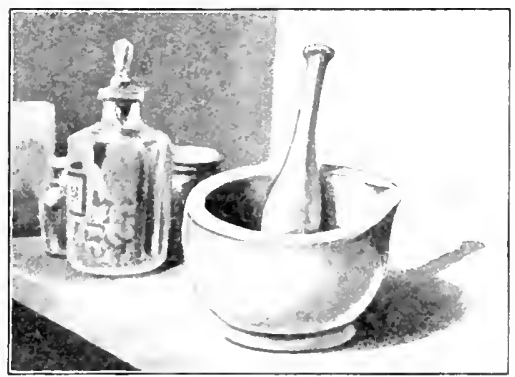

Murtar ani) Pestle used by Druggists 
merely a stump hollowed out, and sometimes it served as an article of furniture when not in use. Wherever a large bowl and heavy pestle

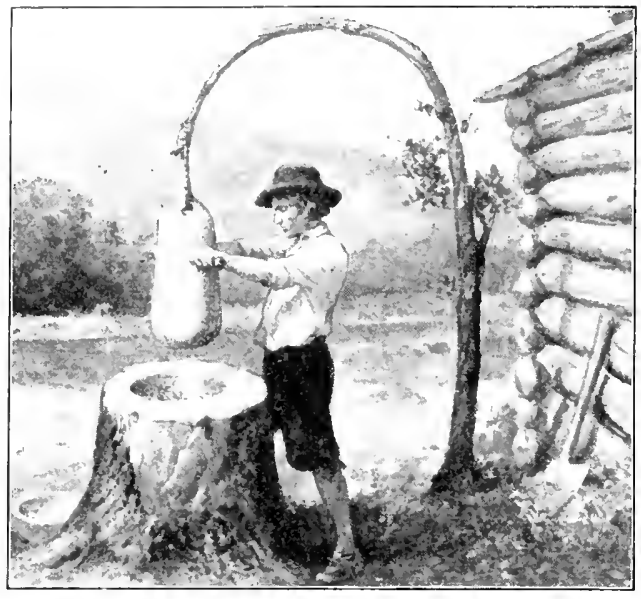

AN E.ARLY SetTler USING a HoMNY BLoCk

were used there was a clever device for easing the labor. The pestle would be tied to the top of a thin, springy tree, which would lift it again after it had been brought down upon the grain in the mortar.

Soddle stonc. The first real grinding was done when the upper stone was not merely struck down upon the lower, but was rubbed upon it. This is the way the molar teeth act upon each other. The first grinding mill was in the form of what is called a "saddle stone." The lower stone was concave and the upper one convex; the upper one was then rubbed back and forth across the lower. Great numbers of saddle stones have been found in ancient countries.

Cuem. A better type of mill was that calleda "quern." This is said to have been invented in Italyover

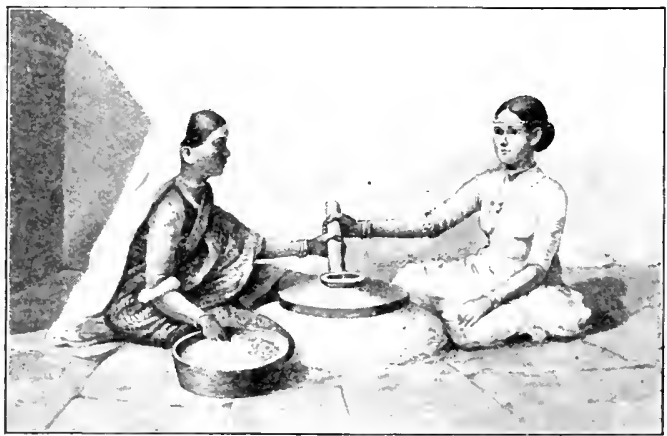

Two Women using a QuerN

two thousand years ago. One stone was placed upon another, the upper one being shaped like the lower; but the interesting thing to 
notice is that the two were fastened together, and were not merely loose stones. Also, there was a hole or hopper in the eenter of the upper stone, from which the grain descended between the stones. A hole was drilled in the side of the upper stone and in this a handle was inserted, so that the upper stone could be twirled on the lower one with greater ease. Two persons usually worked this mill, as shown in the picture. Machines of this kind were in use in England, and are still seen in some places in Europe and Asia, being not uncommon in China and Japan. In Norway, as late as 1897 , a quern was found in use in a country cottage.

Gristmills. I ater, when water power replaced human power, the grain was ground after the same fashion as in the quern, except that the stomes, placed one on the other, were much larger and heavier. In some parts of the country, even now, these old-fashioned

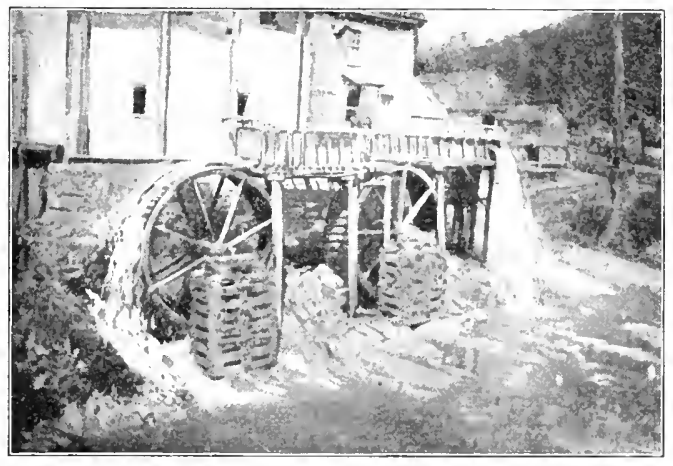

An Oli Grist Mill

gristmills can be found. The farmers used to carry their grain to the miller, who took a certain amount of it for his services. This was called "toll." In some cases the owner of a threshing machine to-day takes his pay in toll.

Where flat, circular millstones were used, they were six feet or more in diameter, and were arranged horizontally on a wooden frame. In the center of the lower one there was a hole through which went a steel bar, making a pirot on which the upper millstone turned freely. Usually in a mill there were several pairs of these stones, some of which were closely fitted to each other, and some more loosely. The grain was first ground between those which were not so close together, and the grist was coarse. It was then passed in order through the other sets, each of which 
fitted more closely than the preceding, and so it was gradually reducerl to a fincr and finer state.

Roller mills. The Indians of the Far West and Mexico made mills, called " metates," consisting of a flat stone over which a roller was passed, very much as the cook milies pie crust on a rollingboard. In improrement upon the millstone followed this suggestion. Rollers were made of porcelain or chilled iron, in earlier times eren of marble, and between these the grain was passed.

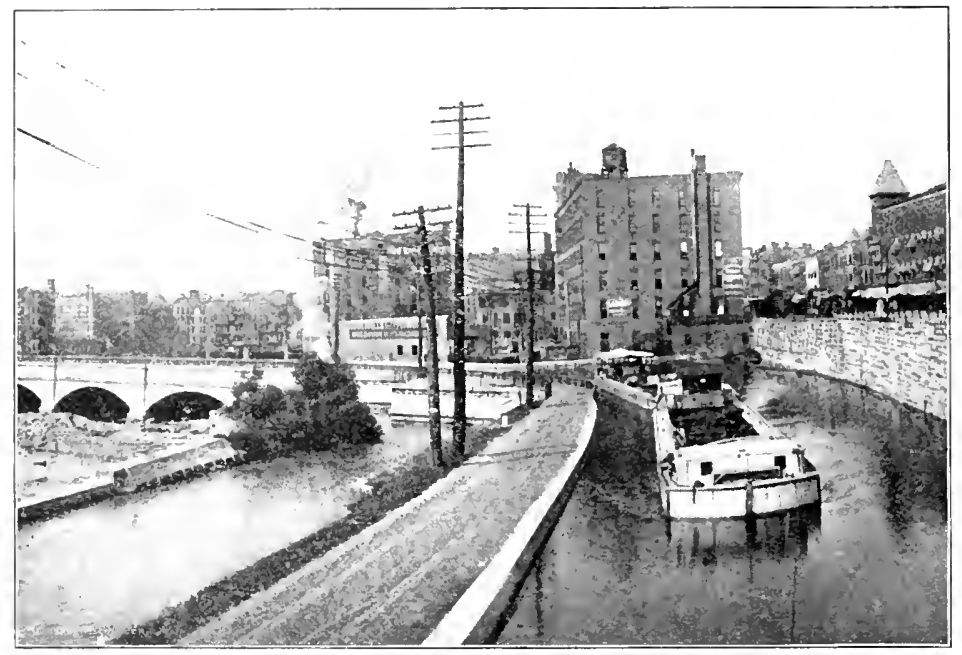

Romiester Mills and a birge in ERIE CaNal

The first complete roller mill in the Lnited States was a little one set up at Minneapolis in 1878 . In a few years all the plants in Minneapolis were roller mills. Between 1880 and $\mathrm{I} 890$ such mills tork the place of the old-style ones almost everywhere in the L nited States and Canada, and became the standard the world over.

This substitution of rollers for millstones was a very great advance. The wheat grains were completely mashed and reduced to powder, without the risk of adding stone dust to them. The earliest mills were made of rather soft stone, and the grit in the flour was so abundant that it was bad for the teeth. The roller process did 
away with all this. The grain could be passed through different sets of rollers, either smooth or corrugated, set nearer and nearer to each other, and thus made as fine as was desired.

Bolting. When the grain has been passed through the various sets of rollers, each kernel is broken up into three parts. These are known as bran, middlings, and flour. bolting is the process of sifting the crushed grain.

The bran is the outer covering or hull of the wheat; it is very tough and is not broken during the milling process, but is flattened out. The germ of the wheat - that is to say, the part of the grain

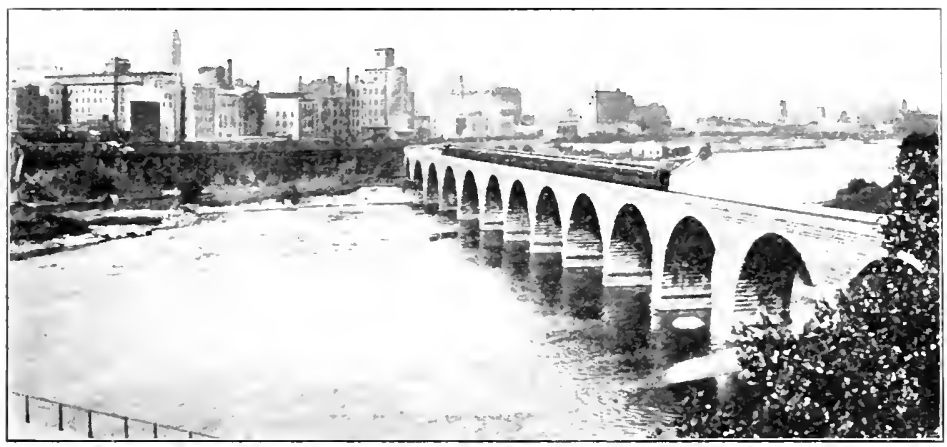

Mills AT MINEAPULIS

which grows when the seed is planted - also flattens out and looks a good deal like bran.

It is the inner part of the wheat kernel from which fine white flour is made. Between this and the coarse bran is a substance known as " middlings," which was formerly used only in the cheapest flour or as feed for stock. By the new processes, however. middlings can be used in making even the highest grade of flour. For Graham flour the whole kernel is used, and for entire-wheat flour all but the coarser bran.

The whole method of milling was onee such that the miller tricel to make the greatest amount of flour at the first grinding; but this is not his object now. The modern miller reaches his results gradually. 
I cet us see what happens at the first grinding. The wheat, perfectly cleansed and purified, is passed between rollers which are just close enough to each other to break the kernel. Generally one roller revelies about three times at fast as the other, which causes both grinding and crushing. The product of this first operation is then passed through sieves which separate it into coarse bran, middlings, and a very small amount of flour.

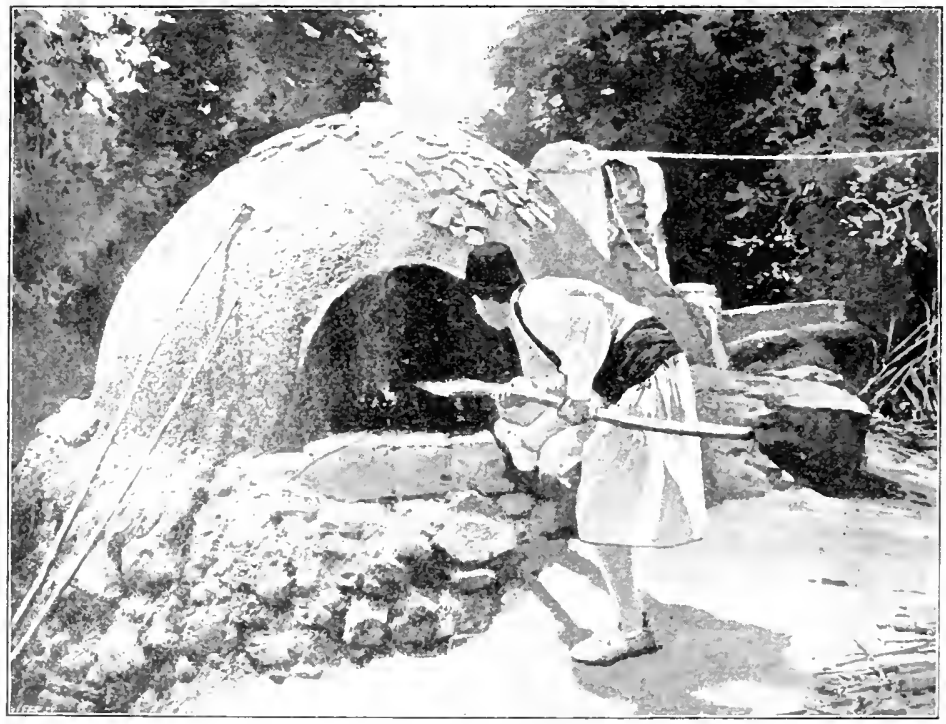

A PRIMUNE liAERY

The same process is followed until the wheat has passed through sercral sets of rollers, each set crushing it finer than did the previons one. Finally, the floury part of the grain will be free from all the bran. The middlings too are passed on through one set of rollers after another until the four is separated from them The whole process. from the time the wheat goes between the first rollers until the flour is packed in barrels, is entirely automatic.

There are a number of grades of flour made, and in most modern mills there are at least four. In orcter of value these are (1) patent, 
(2) first class, (3) second class, and (4) red dog. The red-dog flour is of a very low grade, dark in color, and is often sold as focteler for domestic animals. Below these types of flour there are various feeds, such as shorts and bran.

Bagging. In the process of milling, all the grades of flour and the stock feeds, like bran and shorts, are carried automatically, each to its special packing bin. The flour is largely sold in barrels and in large paper bags. Stock feeds are usually sold in bags. No matter what type of package the flour and the feed are put into, they are packed by automatic packers. Thus very little hand labor, and in many cases none at all, is required in the process.

From gristmill to roller mill. before the use of rollers replaced that of millstones rum by water power.

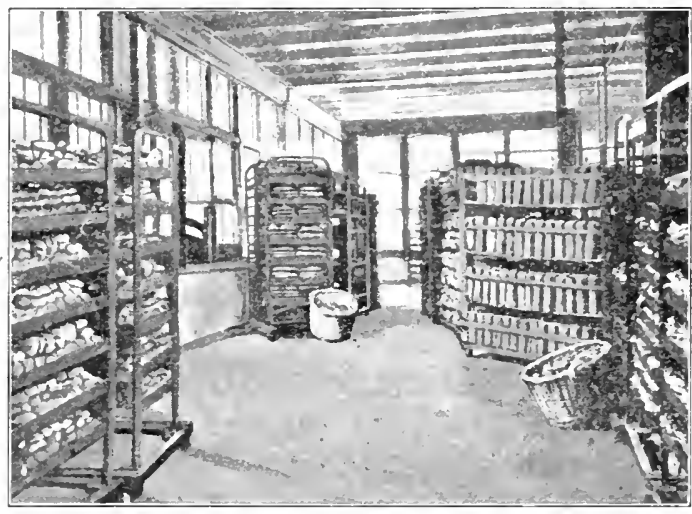

IN I MUIERX B.IKERY small water mills

could be found scattered over the country. Ther were called "custom mills," or, more popularly, "gristmills." Besides wheat they ground corn, rye, and other cereals for the farmers of the surrounding district.

But when roller mills were built they did most of the milling. and many of the custom mills were closed. With this change came the new occupation of "merchant miller," which was as different from that of "grist miller" as the latter was from that of the quern miller. The merehant mills are liage manufateturing establishments which turn out thousands of barrels of flour a day, not only supplying the home market but providing a great deal of flour for export. 
One of the largest mills in the world is in Minneapolis. It can turn out I 5,000 barrels of flour a day, and its owners expect to increase its capacity to 17,000 barrels. It is interesting to compare this type of mill with one of those common in ancient Greece, which could produce not more than five or ten bushels of meal a day.

We thus see that the village mill, or custom mill, has been superseded; if it is ruming at all to-day, it has generally given up grinding wheat, and grinds corn and feed for the local community. At the present time a small number of mills in the United States grind a large part of all the wheat that is milled.

\section{Leaning Manefacturing STates}

New York. The milling industry in the United States has generally been located near the leading wheat fields, or at points of concentration and export. About i\$25 New York state took the lead in wheat growing, and consequently in the flour-milling industry. The Genesee valley was the principal center of both. Rochester was then famous for its flour mills, and it held its reputation for a long time. In fact, until about thirty years ago Rochester was known as the "Flour City." I ater it gave way to others farther west, and began to specialize in the nursery business, so that Rochester was no longer the Flour City, but came to be called by some the "Flower City."

With the wheat-growing industry the milling industry moved westward, and located within or near the borders of the wheat belt. Thus the states of Minnesota, Ohio, Illinois, Indiana, and Kimsas came to the front in the milling business. Over half of the capital invested in mills is to be found within the north-central states, and the value of the product in this region is nearly three fifths of the whole.

New lork state, however, still ranks high in milling. In I90; milling was, in importance, the ninth industry of the state, and of the total amount of grain milled, orer half was wheat. New lork (ity came second to Minneapolis in value of output, and liuffilte camte third. 
There are several reasons why New Jork state retains so high a rank. In the first place, it had the great advantage of an early start. Again, considerable wheat is still raised in the state. and it is only natural that it should be milled near by. Buffalo is, as has been seen, an important point for concentration, and mills in that place were convenient. Finally, New York City is one of the principal points of export for wheat, and some of the grain which comes to the coast would be likely to be milled there.

Minnesota. It is easy to see that the leading state in the manufacture of flour could not well be any other than Ninnesota. And in Minnesota there is one city which has the greatest natural advantages, both because of its nearness to the source of supply, and because of its abundant water power. This is Minneapolis.

A feed or flour mill was erected in Minneapolis in 1850 , and atl through its history this city has shown wonderful progress in the improvement of milling processes. In I 890 it became the leading milling city of the world, taking first place away from Buclapest. the capital of Hungary.

A few years ago there were twelve mills in operation in Minneapolis, which turned out an annual product worth over $\$ 62.000,000$; this was over five and one half times the value turned out by the mills of New York City, which stood second. And if we leave out New York City, the value of the output of the Minneapolis mills was greater than that of the combined output of the cleren next largest milling cities.

Ohio. Ohio also has flour mills of importance; in rgoo it stood third among the states in the value of its flour and gristmill products. Nills are to be found all over the state, but the principal center of the industry is Toledo, which is one of our leading flour markets. This city, it will be remembered, is one of the primary grain markets of the United States, and so has great adrantages for flow milling.

In its westward movement the center of wheat raising was once in Ohio, and while it has moved farther westrard to points of still greater advantage, this state is still within the wheat belt and retains much of its former importance. 
Indiana. As we might expect, the manufacture of flour has now beeome an important occupation in Indiana. In 1905 the output of the flour and grist mills of the state exceded in value that of any other industry. This industry is not found in any one or two centers, but is widely scattered over the state. In fact, by far the greater majority of the mills are found in rural districts, and about two thirds of the total value of their product originates there. About four fifths (in value) of the grain that is milled is wheat, and most of the rest is corn.

Illinois. In Illinois is the city of Chicago, which is the greatest primary grain center of the world. It is no wonder, then, that Illinois stands high in the milling industry. Chicago has an almost ideal position as an industrial center. It is at the southern end of Lake Michigan, its water front is wide, its harbor deep, and it has water connection not only with all parts of the Great Lakes, but, since the navigation of the St. Iawrence River has been improved, with all the rest of the world. In the matter of railroad advantages no wher city surpasses Chicago. For these reasons the flour which is made there is easily marlieted.

Kansas. Kansas is profiting much from the westward movement of wheat raising and manufacturing. Between 1900 and 1905 its milling industry almost doubled, and in the latter year ranked second among the industries of the state in the value of its product. The mills are not concentrated in any one city or in any one part of the state, but there are a number of important centers, such as Atchison, Leavenworth, Topeka, and Wichita.

Missouri. Missouri is also becoming an important flour-milling state, having come up from sixth place in 1900 to third place in I905. Here, too, flour milling is the second industry in importance, coming next to slaughtering and meat packing. St. Louis, its chief city, has long been recognized as a center of trade because of its position on the Mississippi. and to-day its railway facilities are eren greater than the advantages offered by that great waterway. Missouri's suceess illustrates the fact that it is cheaper to manufacture wheat in or near the wheat belt, and to send the flour, rather than the raw product, to market. 


\section{MIRKETINA}

The business of marketing the products manufactured from wheat, such as flour and stock feed, the former being the more important, has come to be a large one, and is greatly helped by our rapid and cheap transportation system.

There was a time when each state produced nearly enough wheat to feed its own population; but through division of labor and specialization, various industries have come to be centered in the places best suited to them.

Benefits of exchânge. For cxample, in New lingland enough wheat was once raised to support the small population, but when the population increased, and the people began to specialize in various lines of manufacture, the IV'est was called upon for a large part of the flour used in the East. In return the East sends its manufactured products to the West.

In the same way the South has specialized in raising cotton and other products adapted to warmer regions; and they use this cotton, either in its-raw state or manufactured, to buy from the North the wheat that they need.

Each person in the United States requires about five or six bushels of wheat a year. This means that it takes between 400.OOO,000 and 500,000,000 bushels to supply the people of our country. Our annual crop is usually not far from 700,000,000 bushels, so that we need more than half of our wheat crop for our own use.

The "stream" of wheat. A while ago we saw that there wals a sort of "stream" of wheat which gathered in the faims, flowed to the local centers, next to the primary centers, then, if it was to go abroad, to such a port as New York, and finally across the ocean. But when the wheat products which are to be uscd in this country reach the primary centers, they are there turned back again into streams which grow smaller and smiller until they reach the thousands of persons who eat the food made from them. When the flour leaves the mill, that which is to be used in this country is carried by railways and steamers for distribution to wholesale dealers 
in large cities. These wholesale dealers sell it in small quantities to retailers: these pass it on to their customers, some of whom may be bakers who run large establishments consuming many barrels of flow a day. Then the baker sends his team to the various stores, leaving at each dozens of loaves of bread. These soon find their way to the consumer's table, and so the wheat finally gets upon the plate of the person who is going to eat it. What a long and complex jounney it has had!

The Indian boy. IVe saw that the Indian boy had no difficulty in knowing all about where his food came from, and how it got into the shape in which he ate it. He saw his mother plant and hoe the corn; then he watched the cornstalk grow and saw the ears ripen ; later, perhaps, he helped to pull the ears from the stalk and to husk them. He saw the grains placed in the mortar and ground up with a pestle, and then saw this coarse flour made into cakes and baked over his mother's fire. There was not one step in the whole process which he could not readily follow.

The American child. But an American child would have to take a long journey if he wished to trace the wheat which he eats in his bread. Perhaps he would have to go to Dakota to see it planted, and if he watched the whole process of reaping and harvesting, he might have to ride many miles from the farmhouse where be was staying. Then it would be necessary to follow it to the local market, and next, perhaps, to Chicago and into the elevator. After that he might go with the wheat on a train to New York City, follow it to the mill, then to the wholesale establishment, then to the retail store, then to the bakery, and then to the small grocery where his family bought their bread. Finally, he would ride to his home on the delivery wagon, and so would arrive along with the wheat which he saw planted hundreds of miles away.

This grives us some idea of the way in which civilized people are all dependent upon one another, because of the division of labor which they practice, and the system of exchange through which different regions are supplied with food and other products.

Home consumption. At present the United States can produce more than enough wheat for its population: but if this population 
continues to grow, the time may come when we shall need to import the grain or the flour. It is plain, howerer, that every time there is an improvement in the methods of agriculture it helps people to get more food out of the same amount of ground. There is room for such improvement because, as we have seen, American methods of culture are extensive rather than intensive. By using the same care which the peoples of older countries give to their land, much more wheat can be raised than is now grom in this country. And so, unless it becomes more profitable for us to specialize in something else, it is likely that for some time to come we shall grow a large proportion of all the wheat we need.

Consumption of wheat in Great Britain. A large amount of American wheat and flour is exported. This goes mainly to Great Britain, though each year we are sending more and more to the far East and to other countries. Creat Britain has imported much wheat and flour since about 1850 . Until then the British thought that they must raise their own food products, but they came to see that the most profitable thing to do was to specialize in manufacturing, and to get their food from newer and less thickly settled countries.

Great Britain buys wheat from various comtries besickes the United States; but if the United States should need all her own wheat, Great Britain would have to look for still other sources of supply. There need be no fear, howerer, about this supply, for Canada, Argentina, British India, and other regions have increasing amounts of wheat to sell.

\section{REVIEW}

Human needs. We have seen, in the study of this book, that man needs for his comfort and happiness food, clothing, and shelter, but these vary so widely in different enviromments that if it were not for trade, the various peoples would shom differences in their method of living as striking as those between the Eskimos and the Indians of the Far West. Owing to specialization of labor and the development of commerce, no group need depend upon at limited environment, but may have the products of other sroups in exchange for its own. 
Specialization of labor. This specialization of labor has brought about, all over the earth, the growth of great industrial regions agricultural, manufacturing, and the like. Within each of these larger industrial regrions there is a further specialization of industry, as shown by the different agricultural, manufacturing, and other sections in our own country. But division of labor goes still further, and within a given industry there are separate trades, such as that of making rubber boots and shoes. We took this example and studied it carefully; numerous other examples might have been taken from different parts of the inclustrial world.

Study of foods. After we had seen how division of labor and trade worked out in these various ways, we next took up the study of food in particular. First, we looked at the distribution of food materials in the United States and studied maps which brought it out more clearly. Then we learned about the distribution of food materials in other important countries. And, finally, in order to understand more about the details of these matters, we took up one of the many food products, wheat, and followed it carefully through the many industries connected with its raising, manufacture, and transportation.

We shall now go on to study the other two great needs of man - clothing and shelter. It will be necessary for the student to remember all that he has learned about division of labor and trade : for these do not occur in one inclustry alone, but everywhere throughout the world, in all industries and in all periods of civilization. 


\section{PART III. CLOTHING ANI) CLOTHING MATERIALS}

\section{CHAPTER IX}

USES AND VARIETIES OF CLOTHING

Clothing for protection. At the beginning of our study we saw that human beings need food in order to replace the used-up cells of the body and keep it in vigorous condition. Food also acts as a fuel to keep the body warm, and cating is often compared to stoking a furnace. l'art of the food goes into the production of fat cells, which scrve to protect the inner and more vital parts of the body from cold. Ve must remember how, in the arctic regions, one of the ways in which animals are fitted to their enviromment is by having

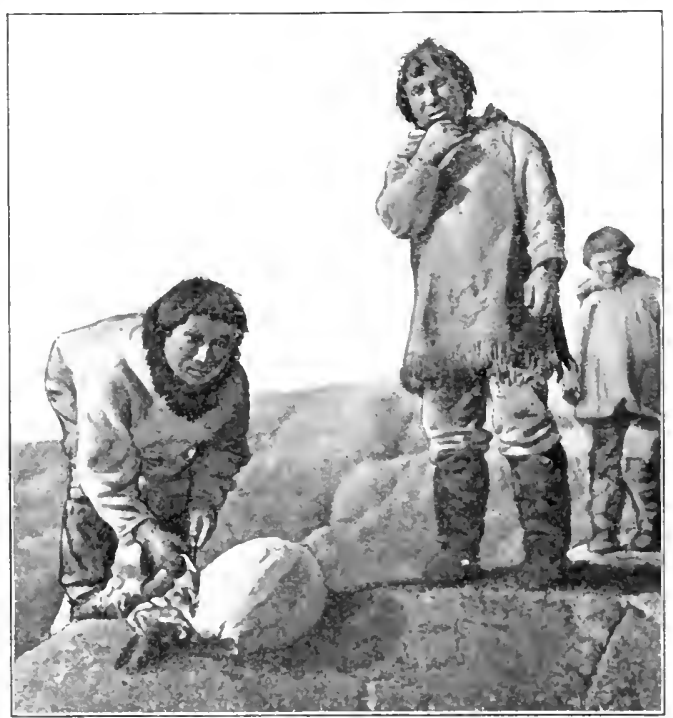

Eskmos skixixg a tikn, thick layers of fat or blubber, and often densely growing fur, as a protection against the intense cold of the air and of the water. 
Animals are thus protected by nature, and man is like! to share this protection to some extent. We have seen what a round, fat race the Eskimos are. But fat alone would not be enough for human beings, and man has learned to make for his body coverings which keep out the cold winds and at the same time keep in the natural heat of the body. Clothes are a kind of shelter and keep in the heat of the body, just as the walls and roof of a house

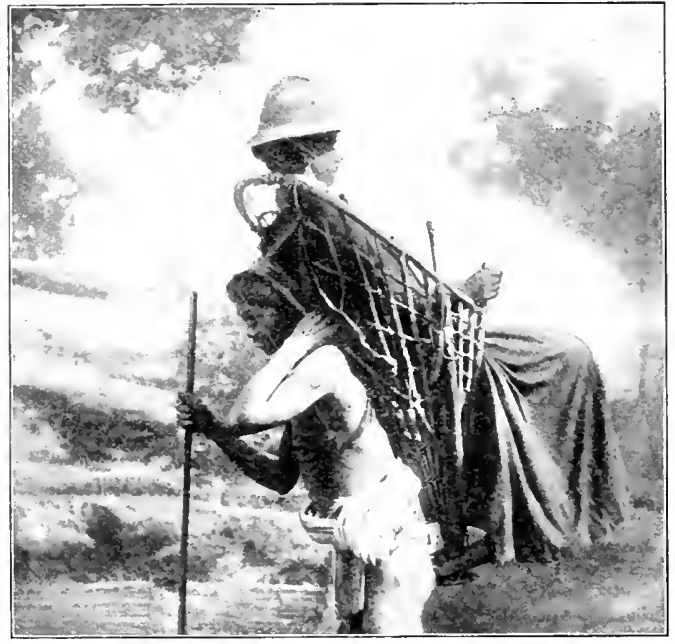

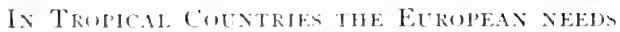
Earechal protection fur the head keep in the heat of the furnace.

But clothes are not worn merely for the sake of protection against cold, for we find them in some form in most countries, even in the hottest. The white man, living in the tropics, is protected from the heat by the duck suit and the pith helmet which he wears. If his body were exposed to the sun, it would be blistered with the heat, and he would be in constant danger of sunstroke. Therefore he incases himself in the sort of clothing which keeps out the sun's heat and yet allows the heat of the body to escape.

Furthermore, clothing protects the body from injury in other ways. Sandals or shoes save the feet from bruises, and gloves protect the hands. When we look at the picture of an Arab of the descrt, we are surprised to see that he wears a turban whose folds almost corer his face. But this turban shelters his head from the sun's riys, and the folds, when they are drawn together orer the face, protect it from the scorching sand driven by the wind of the desert. 


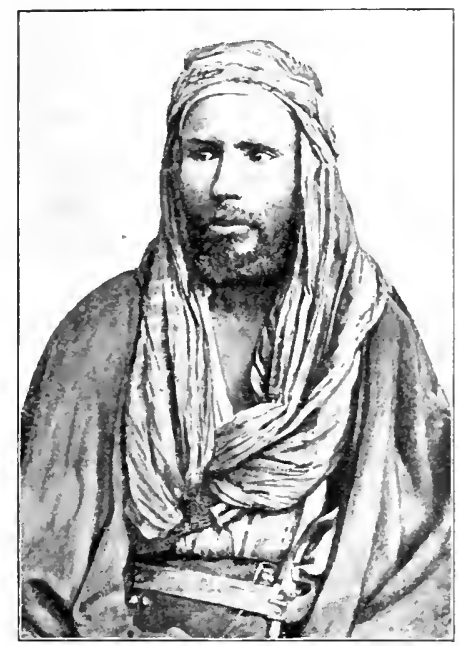

A BIIULTA ARAB

Clothing of uncivilized peoples. These are the practical uses of ckething. It is clear that there are few parts of the earth where we should not find it necessary. But we know that a number of tribes in the worlel wear almost nome, and yet seem to be quite comfortable. This is probably because they have never been used to clothing, and so their bodies are able to get alongr without it. These peoples are all uncivilized, and we generally call them sarages. When civilized man began to travel about the earth and see these savage tribes, one of the first things that struck him was that they wore no clothes. And so, when he described them, he usially called them "naked savages." Thus the adjective "naked" has come to be rery closely. connected with the word "salage." Ordinarily we expect the savage to be more or less unclothed, while, on the other hand, we connect clothing with civilization.

Even when people are accustomed to wear ckothing, the materials they use, the amount they wear, and the style of their gaments differ

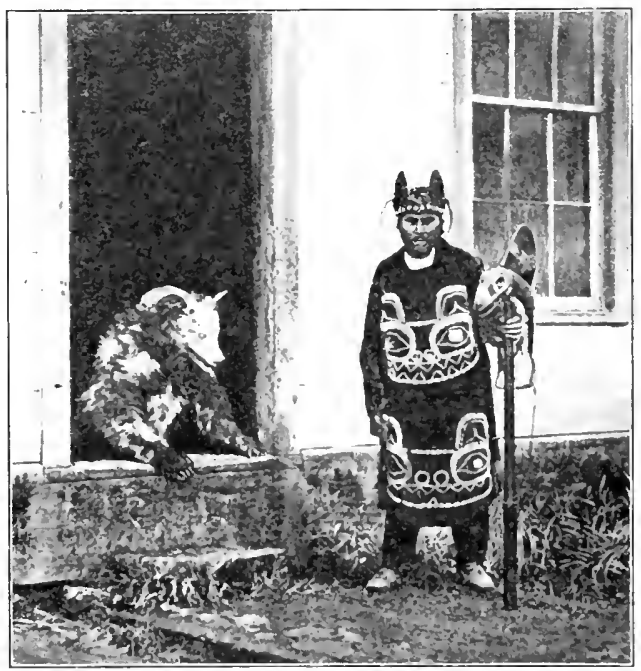

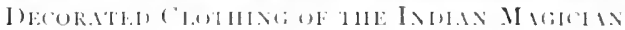


widely among different races. Some tribes use bark to make their gaments, others use grass, and many use the skins of animals. Some races, like the Arabs, corer the whole body except the face and hands: others, again, leare the feet and legs bare; while among others the clothing is a mere apron.

As for the nature of the garment, some tribes have close-fitting clothes with sleeves and trouser legs, while other tribes wrap them-

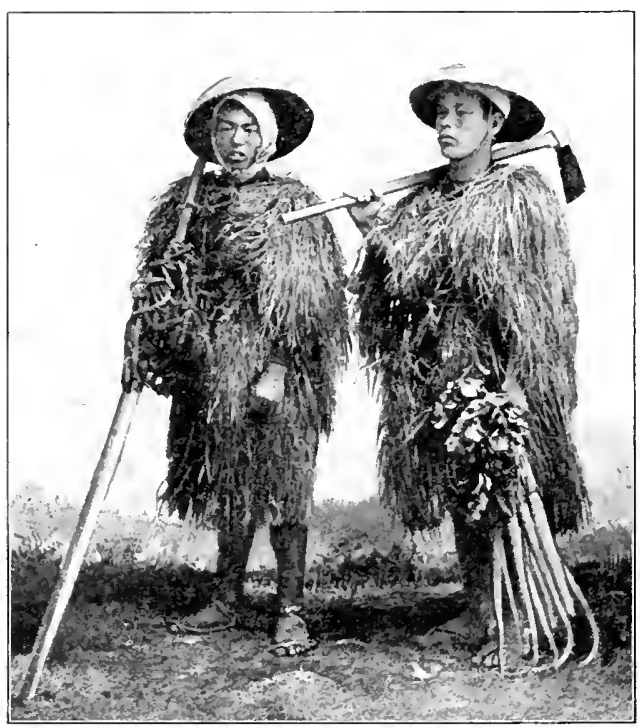

JAYANESE FARMERS WTH GRASS COATS selves in large cloths which could be used equally well for bed coverings, and which are loose and flowing.

Among uncivilized races, in regions where the climate and other conclitions are similar, the garments are few in number, are made very simply, and are generally of about the same pattern. They are few in number because of the difficulty of making them, and also because a savage does not need many changes of garments. They are simply fashioned because uncivilized tribes do not know enough to make them otherwise. And they are practically of the same pattern because the bocly is so constructed that covering can be more conveniently attached at certain parts than at others. For instance, the neck and the waist are the only places on the trunk of the body which provide a hold for belts or straps to sustain clotling.

Sources of clothing materials. Another very important fact about clothing, as about food, is that among peoples who have 
little or no tracke, the body covering is generally made from materials furnished by the enviromment. For instance, the clothing of the tropics could not be made of fur, even if it were desirable, for the fur-bearing animals live in cooler regions. ()n the other hand, the clothing of the Eskimo could not possibly be made of cotton, because the cotton plant grows where it is warmer, and he has no means of importing it. Thus each race is obliged to confine itself to such clothing materials as can be obtained in its own region, unless it is able to trade its products for those of another region. And since division of labor and trade are so poorly developed among savages, they are generally found to be clothed in materials obtainable in the immediate enviromment.

Clothing materiats are derived from the plant and animal world. But we have seen that both plants and animals become fitted to their environment and

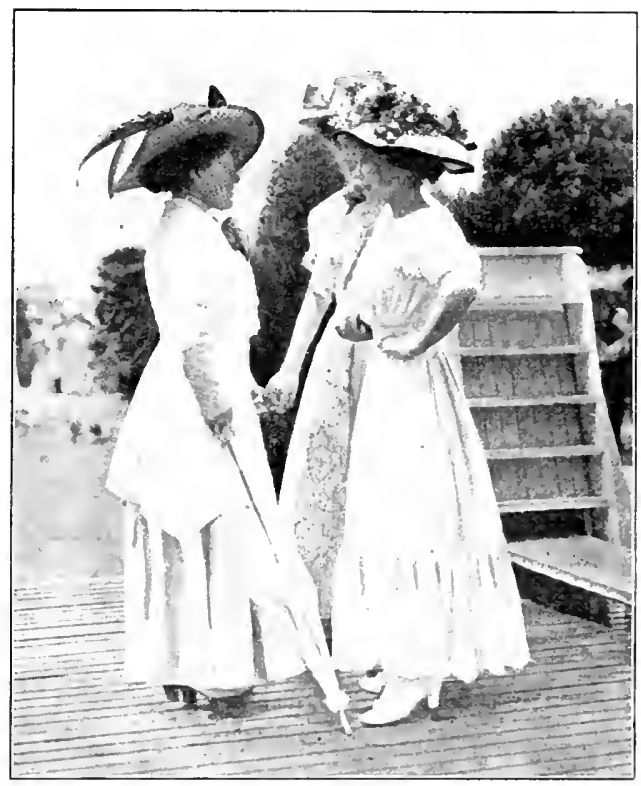

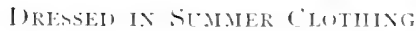

consequently are different in different enviromments. This being so, if any one were to tell us what the plants and animals of a certain region were, we could casily infer what the elothing materials would be. Then if we knew something about the mature of these materials, as, for instance, whether they could be spun or woren, we could readily guess the character of the garments mate from them. This harmony between the life of man and the environment in which he lives is one of the most interesting studies in 
the world. As we went through the chapters on food we learned many facts connected with this subject, and now as we go on to clothing and shelter we shall continually find new eximples.

\section{Chimate ani) Chothing}

Among all the conditions of environment climate is the most important. Climate has a great effect upon the nature of the food

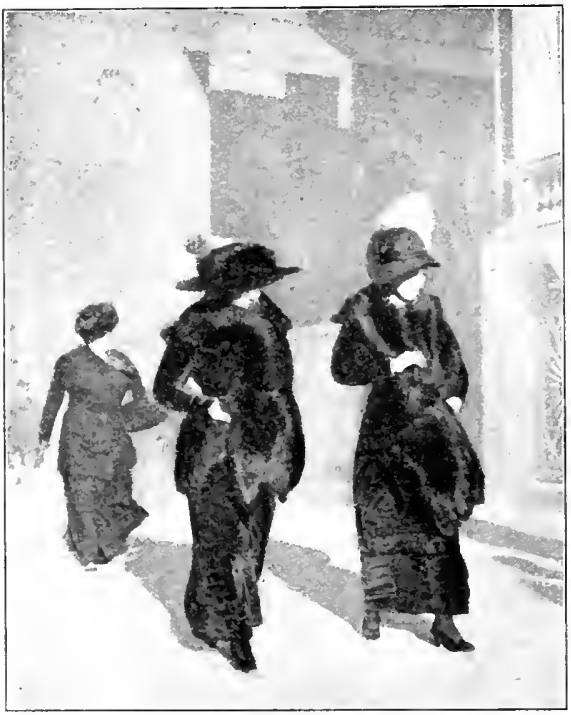

I. WINILR FIKS ARE WORX supply, and we should expect that it would have quite as much influence in the matter of clothing. IVe can see, in our own case, the changes brought about in our clothing as the seasons pass one into another. Our winter clothing is different from that of the summer, not only in the amount worn but also in the materials used. The clothing stores have a regular summer stock of clothing, which they try to sell out by fall, so that they may lay in a new and different stock for the cold months.

but if we wish to observe, in its most striking form, the effect of climate on clothing. we shall need to compare the clothing of races living in a warm zone with that of people living where it is colder. (1), what is the same thing, the clothing of those who live at the sea level with that of those who dwell high up in the mountains, for we must remember that for every three hundred feet of altitule the temperature is one degree colder.

Clothing in cold countries. In the colder countries it is necessary that clothing should retain the heat of the body. In order to 
do this it must fit the body closely and have openings that are few and small. Furthermore, the materials out of which it is made must be thick and compact. If it is full of little holes or pores, it allows the escape of the bodily heat. The clothing which would retain bodily heat most effectively would be made of a material like rubber; if a person living at the equator wore a gament of this kind for a very considerable length of time, the heat of the body woukd rise to a degree which would be dangerous to life".

Skins and furs. Rubber would be an unwholesome material io wear constantly in any climate, so perhaps it is fortunate that the natives of very cold countries have none to use. They have been able to keep warm by wearing the skins taken from the animals of the region. After the hide is taken from an animal it is generally tanned, and is often rendered soft by being thoroughly rubbed with grease. It isalso necessary, especially where clothing must be water-

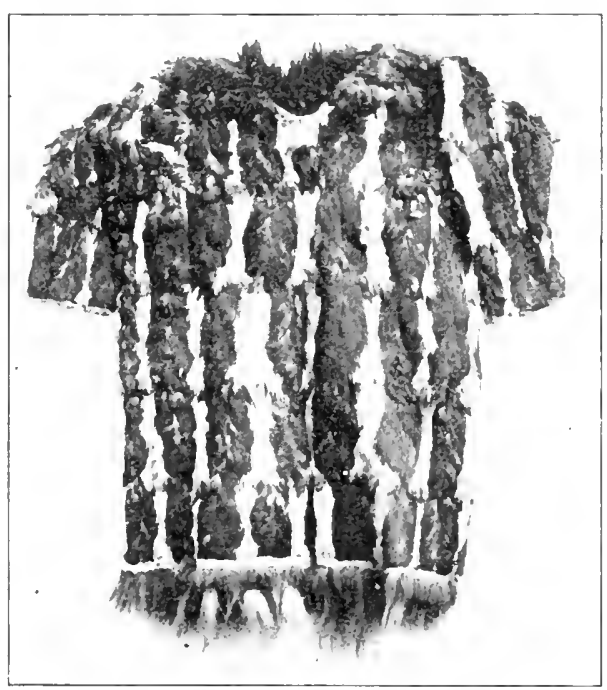

Courtesy of Bureau of . Imencan Eilunogy

ESKMU BIRUSKIN FRUK proof, that there shall be as few seams as possible, and that these shall be closed tight. Consequently, the northern peoples learn to make their garments out of the ferrest possible pieces, and all the holes made in sewing are filled with some form of tallowlike grease.

In order to render the clothing doubly warm, the natural evat of fur, which enabled the animal to live comfortably, is left on the skin when it is made into a garment.

The inhabitants of cold regions are also accustomed to malie the clothing fit closely to the body. Thus their coats lave 


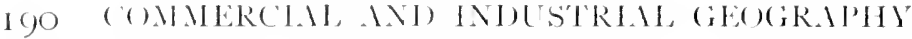

sleeves, which, in the case of the Eskimo, may be prolonged into mittens: and the undergarment, for both sexes, has legs which maly be prolonged into boots. In other words, each garment becomes it specialized one for a certim part of the body, and will not fit other parts: nor can it be used very well for any other purpose than the one for which it is made.

Nature has provided the animals of these regions with better protection against the cold than man can show. But to him was

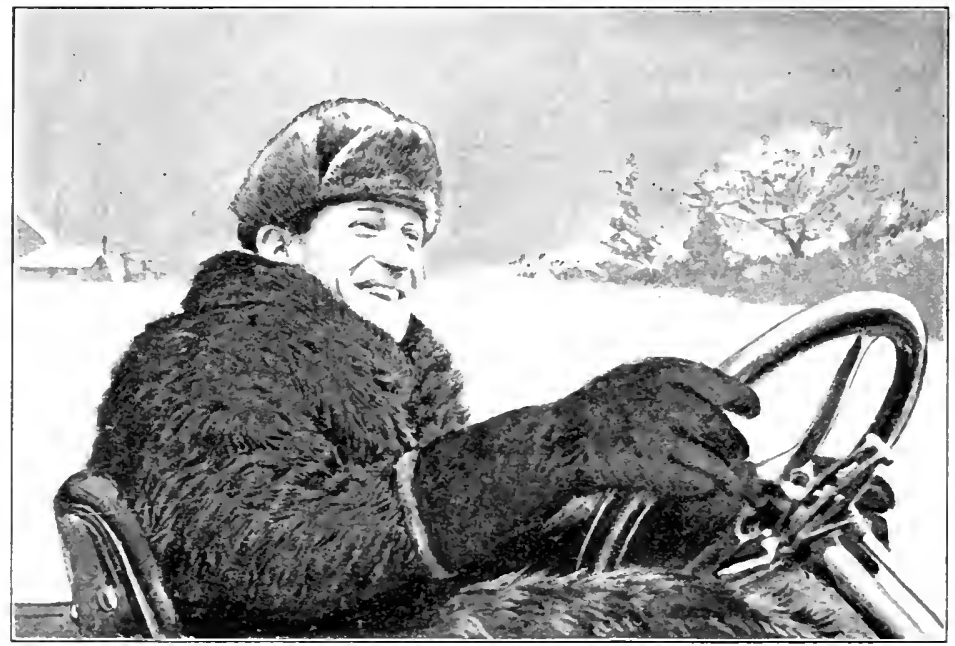

WeLL l'RUTECTEI) FROM THE ('ULD

siven the ability to take from the four-footed creatures their warm coats and to fit them in some degree to his own shivering body.

Clothing is made of skins and of furs in parts of the world which are not absolutely frigid. We all wear leather shoes and groves, and in winter some people wear furs, which come from a much colder zone. The Indians of our country used deershin for their clothing. just as the Russian peasants formerly used the hides of sheep with the wool left on.

Animal fiber. Man does not always use the whole skin of an animal, but takes only what he needs. Part of the protective covering 
is coarse wool or hair, and frequently we shear off this outer coat for our own use, From the "animal fiber" so obtained are made many of our winter garments. Noolen fabrics of all kinds, and felt, which is made from hair or wool, are extremely important as clothing materials in the cooler zones.

Clothing in warm countries. Now let us compare with this clothing of cool countries that which is worn where it is warmer. The natives of tropical regions are largely savages, and many of them go without much clothing. But there have been races living in warm climates who have worn clothes, like the peoples of Greece and Rome, or those of Bible times.

When the Greelis came to know about the tribes living to the north of them, in such regions as southern Russia, they despised them for their lack of civilization. Because the Seythians spolie a different language the Grecks called them "barbaroi" or "jab-

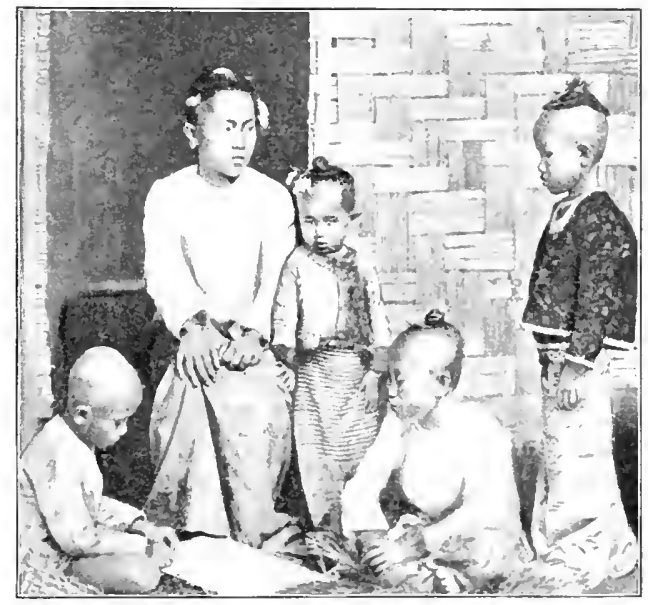

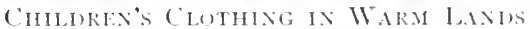
berers," and said that their speech sounded wild and senseless. And when it was discovered that these northern tribes used butter instead of olive oil, and drank beer instead of wine, the Greeks could not hide their contempt. It seemed to them to indicate a very poor and "barbarous" way of living, and this fecling of disclain for strange customs is a good illustration of how people become adapted to different enviromments. No olive trees srew in Seythia, and so the people of that country had no olive oil. They had flocks and herds, and it was matural that butter should take the place with them which olive sil held with the Greels. 
Again, no grapes grew in the northern regions, but there was considerable barley; and so, while they could not have wine, they did

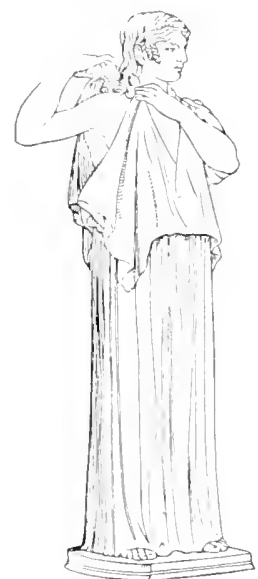

Greer I Iress have beer. Probably the Scythians thought that the Greeks were queer because they used neither beer nor butter.

In regard to clothing the case was similar. The Greeks looked down on the Scythians because they wore trousers instead of flowing robes, and regarded their costume as another mark of barbarism. But again it was the environment which caused the difference. The Scythians made themselves trousers because, in their colder climate, they needed clothing which fitted the body closely; and the Greeks did not do so because, in their climate, it was better for the body that the clothing should fit loosely. These examples of differences in food and clothing bring out very well the fact that such differences are largely due to climate.

The clothing of the Greeks was very slight. The head and neck, often the arms, and in many cases the legs and feet, were bare; and when the young men exercised, they usually wore no crothing at all. Their exercises were generally in a symusimm; this is a creek noun and comes from an adjective which means "naked."

The (irecks wore thin undergarments that were more or less fitted to the upper part of the body, but which were without sleeves. The main garment, however,

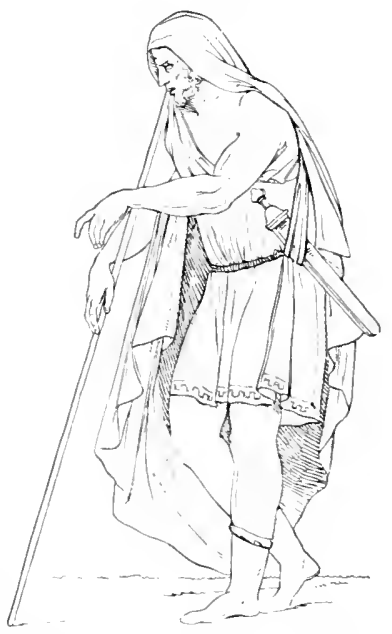
Costune (rF a Greek Max was a sort of cloak. This cloak, which was all in one piece, was wrapped loosely about the body and allowed to hang freely as a man walked. The statues of famous Greek orators and statesmen 
show them wrapped in flowing draperics of this sort. The Roman toga was somewhat similar in design.

IVe have seen that the garments of the north are made for one special use and for no other. A coat will not serve als a blanket or as a pair of trousers, nor are there many uses for a hat except as headgear. But the Greek garments were not specialized in this way. They could be used for other purposes just as easily ; in fact, they were cloths rather than clothes. When a Greek got up in the morning he could take the corering which he had used during the night, wrap it round his body, put on his sandals, and go forth fully dressed. A similar illustration may be found in the turban, which is a common article of clothing in oriental countries. It is really nothing more than a long cloth which is coiled about the head and tucked in so that it will stay. This cloth could be easily used for a number of other purposes.

Contrasts in environment. One of the ways in which we can appreciate the difference between the clothing of hot

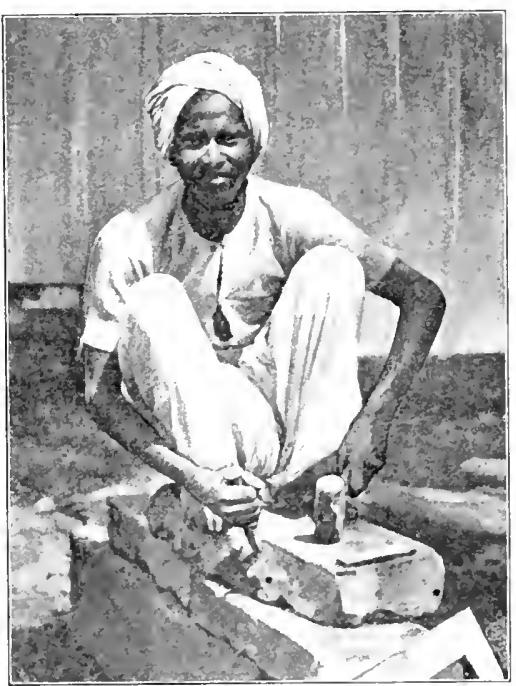

HIND WURKMAX WITI TURBAN and cold countries is to imagine a person going from one to the other. If an African savage were taken up to I abrador, he would probably perish, even in the summer, unless he wore more chothing than he did in Africa. He would be like some tropical animals, such as apes, which are well fitted to their environment, but which very quickly die of consumption or other lung trouble when they are brought to the temperate regions.

On the other hand, if one of us should aro to the tropies, he would find himself very uncomfortable in the clothing to which he had been used. He would have to wear less of it, and have it 
made of different materials. Some of the northern nations which have confuered tropical comtries have continued for a time to dress their soldiers who were sent to these countries in the uniforms common at home. But it was quickly seen that these men suffered from sunstrolic and from heat prostration, and presently the dark, heary uniforms and caps were given up in favor of duck or khaki clothing and wide straw hats or pith helmets.

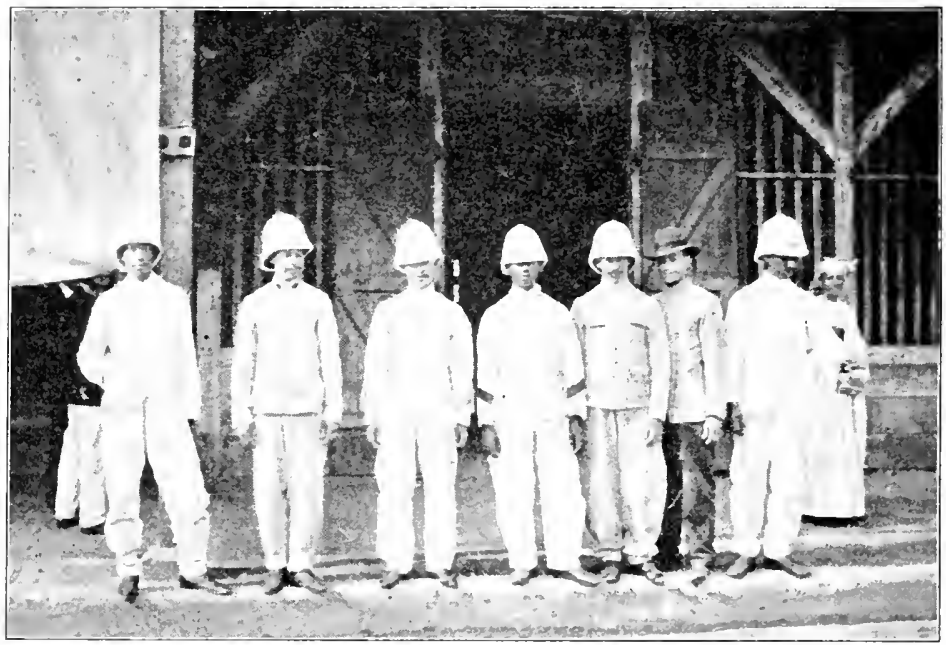

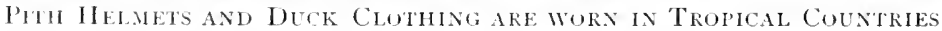

Effect of altitude. Nountain climbing furnishes another illustration of this same principle. Let us suppose that a man plans to climb Mt. Popocatepetl in Mexico. When he lands at Vera Cruz he is in a tropical climate and must wear the clothing of the tropics. He starts directly away from the coast and gradually climbs until at length he reaches the plateau of Mexico, where he is in a temperate climate and must therefore wear a corresponding body cosering.

He now comes to the foot of the mountain and begins the ascent. IIe passes through various belts of regetation as he rises, until he reaches that which belongs to the colder parts of the 
temperate zone. He would now be extremely uncomfortable if all that he had to wear by daly or night was such clothing as had been entirely satisfactory on the coast. As he goes still higher he comes to the region where regetation ceases, and approaches the snow line. Here, especially at night, he needs clothing which is characteristic of the polar zone; and during the day he will be glad also to adopt smoked glasses, or the snow goggles which are used in the far north. Thus in his journey upwards he passes from the tropical climate

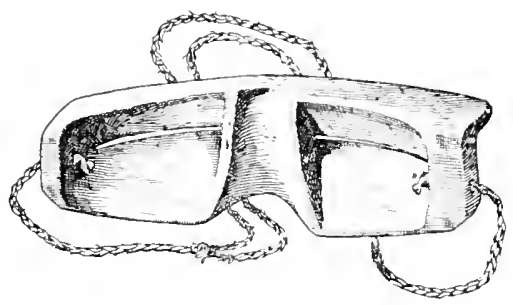

ESKIMU SNOW SIDTACLES into the arctic, and is obliged to add to his clothing with each advance that he makes.

The people who live along the route which he follows would show, then, the chief types of clothing which one would find in passing from the equator to the most northerly spot inhabited by man.

\section{Clothini for (ORNAMENT}

Ornament among savage peoples. Thus far we have seen mainly the practical uses of clothing. But its value to man dees not stop when, through it, he has secured bodily comfort. If we go to the warmest regions of the earth, where the natives wear little or no clothing. we find that what they do wear is not for the sake of protection at all. In many cases the entire clothing of a savage consists of a highly decorated apron and a few strings of beads. Sometimes the body is covered with oil or paint of some sort, which has not the slightest value as a protection. There are regions of the earth where colored clay or paint is plastered thickly on the body in order to shield it from the bites of insects, but eren this does not explain why different colors are used, and why these are laid on in patterns or pictures.

If we try to find out why the body is decolated in this way. We discover that it is because of vanity. Vanity is one of the stronesest 


\section{96 (OMMERCIAL NND INI)USTRIAI, GEOGRAPHY}

feclings that can be found among savage peoples. It is not confined to them, but perhaps they show it most simply and directly. It is probable that the first men on this earth dwelt in a warm region where clothing was not needed for protection, and that the clothing which the gradually learned to wear began in the form of ornament. It is quite likely that the very begrimning of clothing consisted in the painting of the body. There seems to be among savage people no fecling that it is indecent or improper to have the body unclothed.

The ranity of sarages is sometimes laughable. A negro chief will wear a tall hat, which he has bought from a trader for a large

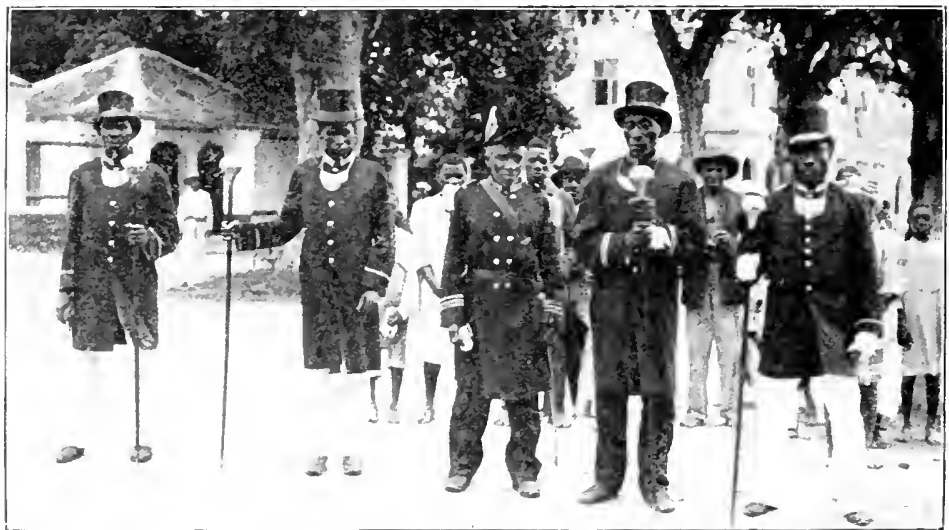

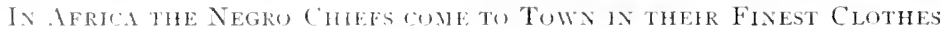

sum, no matter how uncomfortable it makes him, because he knows that all the rest of his tribe envy him and wish that they had one. It makes him a man of importance in his tribe. He may even come to be named after his fine ornament and be called " man with a hat," or have some other title, depending upon his peculiar decoration, which gives him a feeling of distinction.

All this gratifies his vanity. He will go through the greatest discomfort for the sake of being thus pointed out. Among some of the tribes living in the hottest countries a rich man will try to show how wealthy he is by wrapping around his body all the cotum cloth that he owns. Sumetimes, when receiving European 
travelers, a negro chief has been almost smothered in his riches: strips of cloth have been wrapped about him until there was no

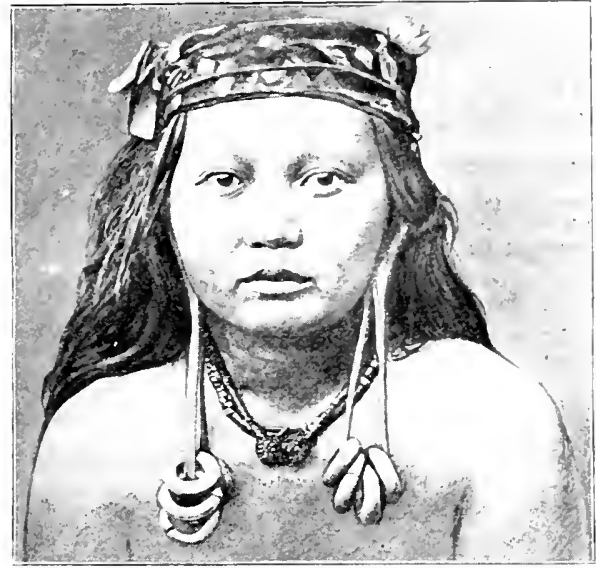

HEAYY EARRINGS

room for his arms to hangs down, and they have stuck out almost straight from his body:

() f course not all this ornamentation can be called clothing. In one district in Africa a woman is considered very distinguished if she wears upon her ankles a number of copper rings. Sometimes they come up above the knee, and are so heary that she can barely shufile along. These metal rings become so hot in the rays of the tropical sun that water has to be dashed over them occasionally in order to cool them off.

Again, in other parts of the world, women wear as earrings heavy copper ornaments. which so stretch the lobe of the ear that it rests upon the shoulder. Many other instances could be given of the vanity shown by savages: but we must remind ourselves that while rings running through the nose are not popular with us, it is not at all uncommon to see rings attached by piercing holes through the lobes of the ear.

It must be admitted that the original purpose of clothing

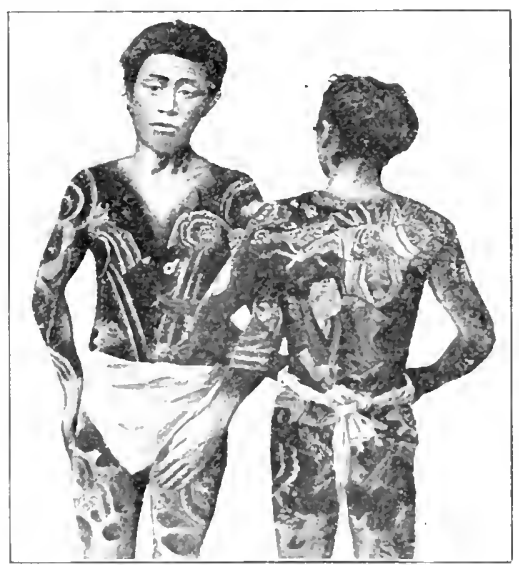

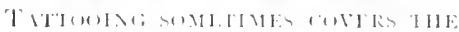
ENTIRE HU⿴囗十 
wats ornamentation quite as much as protection. And even when protection came to be the main reason for covering the body, the ideat of decoration was always present. The patterns which were formerly painted or tattooed on the skin were painted or woven upon the clothes, as shown in the figure on page I $\$ 5$. To-day much of our apparel is designed to make a beautiful or fashionable appearance rather than simply to afford protection to the body.

The development of clothing. 'The way in which clothing developed from ormament may perhaps be better understood by realizing

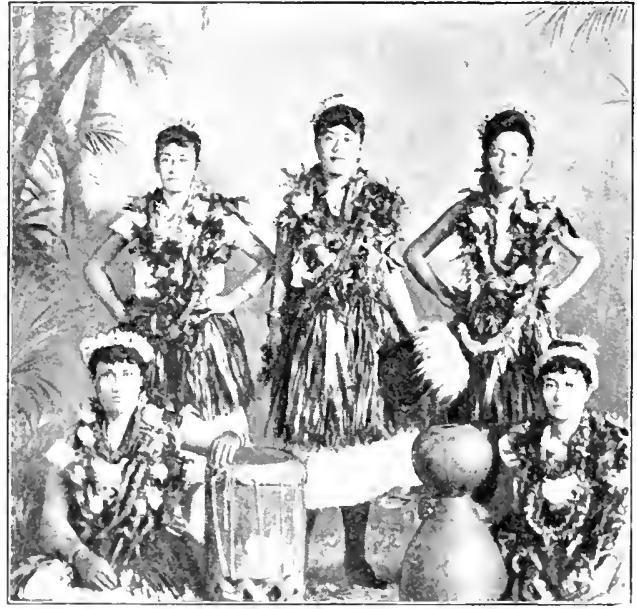

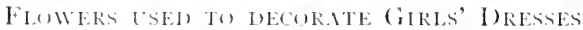
that the first ornaments were probably hung upon the body from a string or belt which went around the neck or the waist. Upon this would be hung all the small articles of adornment which a person possessed. These would form a sort of covering for certain parts of the body, and it would become the mark of propriety to have such covering. Anyone who did not have it would be ashamed, just as we are ashamed nowadays not to be clothed in the proper way - that is, as those around us are.

Gradually people would grow used to having the body covered, and it would become a disgrace not to wear clothing. Just as those tribes which have learned to cook food despise those who eat their food rim, so the tribes which had come to cover the body would despise and look down upon other tribes who did not do so.

The effect of custom. All these things were determined by custom; they are so determined now, and they probably always will 
be. If we are in a company where everybody else is wearing sorses, we are ashamed of the bareness of om hands, because we are afraid that other people will think either that we are not able to buy gloves, or that we do not know enough to wear them. At other times we are not in the least ashamed to be without them. This respect for public opinion has always had its effect upon clothing; the amount and the style which should be worn have becn prescribed by custom in all ages and at all times, and so, where customs differ, rules about clothing differ also.

This helps us to understand that there are other motives besides the protection of the body which lead people to wish for certain kinds of clothing. It makes no difference whether they actually need the clothing, or merely think that they do; in either case they try to make or to get it, which is the point that we need to consider when we talk about industry and trade.

\section{Ornament among civilized peoples.} It is not alone among savage peoples and in ancient times that clothing has been worn for the sake of orna-

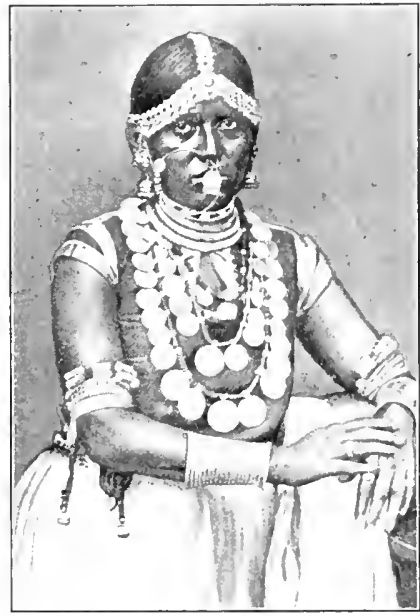

THE GIRLS IN CHYAN WEAR ALL TIEIR JEWELRY AT UNCL mentation. The civilized races are even more anxious to gratify their vanity by ornamenting themselves than are the lower races. ()nly, with more civilized people this vanity is not always so childish and crude. As civilization advances there arises a love of beaty and a taste in dressing which are much more refined.

It cannot rightly be said that civilized people buy beatiful things and wear them on the body, or attach them to the clothing, merely from vanity. There is a great difference between a person who wears gaudy garments and is weighted down with conspicusus jewelry, for the sake of making a show, and a refined woman who 
wears clothing and jewelry which may be very costly, but are yet quict and inconspicuous. However, it is impossible to deny that all this refined ornamentation goes back originally to the ruder and clumsier attempts at display shown by uncivilized races.

It would take a large book to deseribe the kinds of clothing which are worn wholly, or almost wholly, for the sake of ormamenting the body. There are a number of clothing materials which

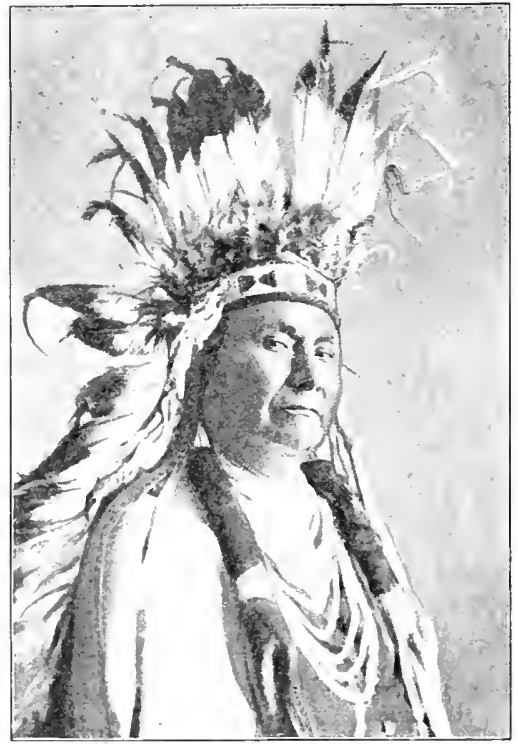

Cisurteng of Bureat of American Ethology

IXIMIX (IRNAMENTATIUN are usect scarcely at all for protection, but are almost entirely ornamental; it is doubtful, for example, whether silk would have been used to any such extent as it is for the purpose of protection alone. The same is true of laces, velvets, fringes, and many other products of this sort.

The colors selected for clothing are chosen almost entirely for ornamental reasons. Except for the white duck worn in the tropics, khaki, and certain other colored fabries, it can be said that the color of clothing is not chosen because of its utility. This is the case also with the different weaves. For the purpose of protection a few standard varieties would be entirely sufficient. However, for the sake of ornamentation there are many kinds of weaves; and patterns of all sorts, with various combinations of color, are worked out.

Modern dress. In fact, fashion has brought it about that in making the more costly suits of clothing the deliberate intention is that no two shall be alike. If a man gets a suit at the shop of a high-priced tailor, he expects his suit to be the only one of that pattern. If he should meet another man on the street with a suit made 
from the same pattern of cloth as his, he would think that he hacl cause for complaint against his tailor.

This is even more striking in the case of women's clothing, for the clothing of men is simple and uniform compared with that of women. Take, as an example, evening clothes. For men this style of clothing is always black, and is made, in general, in the same style for every one. When a man buys a dress suit it is good for any number of occasions of the same sort. Not infrequently a man wears a dress suit until it is somewhat threadbare. But a woman would be ashamed to appear many times in the same evening dress. It is necessary either that she shall have many such dresses, if she has many occasions to wear them; or, if she has fewer costumes, that they shall be remodeled from time to time.

Furthermore, the styles change very greatly, and what was all right in one year is all wrong in the next. Thus clothing as ornament admits of a great

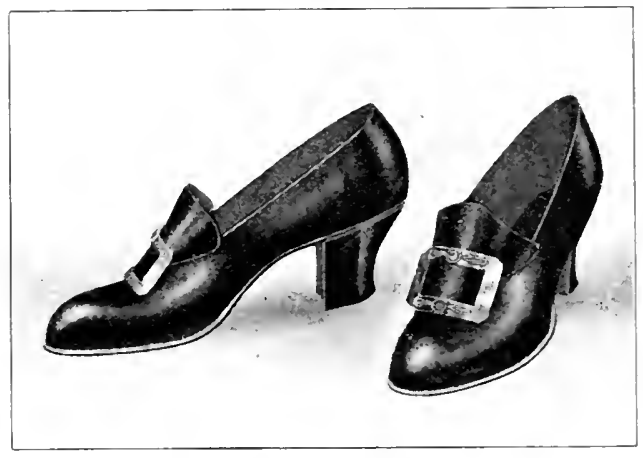

IIGH-IIEELED SHHES varicty of materials, colors, and weares; whereas, if clothing were for purposes of protection only, as in the case of workmen's oreralls, the pattern and color would not vary much in different times and places.

It often happens that the comfort of the body is entirely sacrificed for the sake of ornament. A man puts on patent-leather shoes which are very uncomfortable, when he would much prefer an old pair of slippers: and while women in this country do not squeeze their feet as the Chinese women do, many of them will enclure very tight clothing, heavy hats, high-heeled shoes that strain the ankle, and other similar tortures, in order to fall in with whatever happens to be the fatshion in ornament. 
Jewelry of any sort can be of little protection to the body. The tiara of diamonds worn by a queen is in no sense a substitute for a hat. Finger rings may subject the wearer to a good deal of discomfort, and earrings have been the occasion of actual pain. Metals and stomes worn on the body are almost wholly for show. There

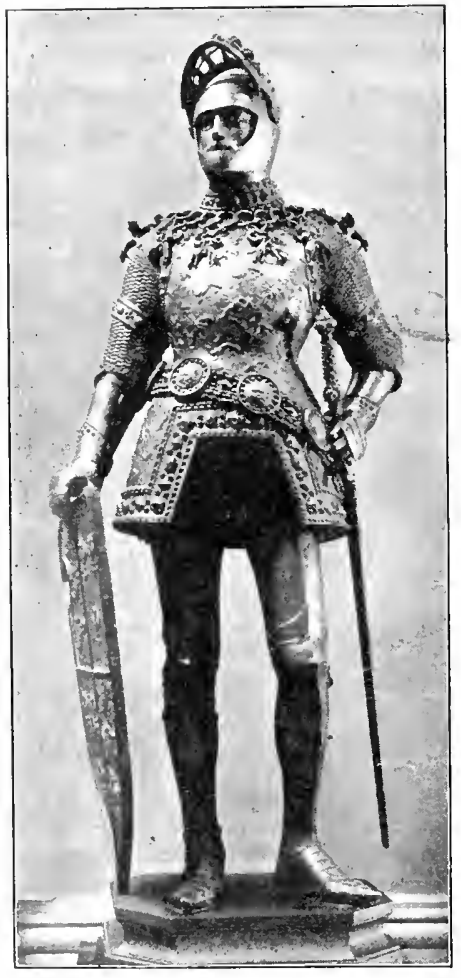

IRON AKMOR is really no article of clothing, made simply for protection from heat or cold, which comes from the mineral world. The knights of old used to wear iron armor, but, as Mark Twain shows in "A Yankee at the Court of King Arthur," it must have been an extremely uncomfortable garment.

The desire for ormamentation leads to the attempt to make things decorative which were in the beginning merely useful. There is no doubt that it is useful to have something attached to a watch to prevent it from falling to the pavement if it slips from the pocket, but for this purpose a piece of stout cord or a leather strap would be entirely sufficient. However, instead of this, a highly ornamented watch chain is worn. Thus, too, a stick pin is of use in order to prevent a necktie from loosening, but in the place of an ordinary pin a costly gold pin, with perhaps a pearl for its head, is selected. It is clear, therefore, that the iclea of ormament lies behind the color and frequently modifies the form of articles attached to the body. In fact, we often limit the usefulness of our clothing by the attempt to make it decorative, as may be seen in the popularity of white growes and shoes. 


\section{Fashion and Clothing}

We have now seen that clothing is used for purposes of protection, and also for the ornamentation of the body. But there are still other influences which determine the amount, material, color, or cut of clothing. For instance, clothing differs according as it is to be worn by men, women, or children. Moreover, clothing is different in different communities, and in different classes in the same community. The character of one's clothing is determined very largely by the fashion prevailing among the people about him. All these influences might be gathered together under the name of "social influences."

Origin of fashions. Social influences are generally known as custom or fashion. It is sometimes possible to find the origin of a fashion, but more often this cannot be discovered, and all that we can say is that it came about because it served to distinguish the people who adopted it. It marked them

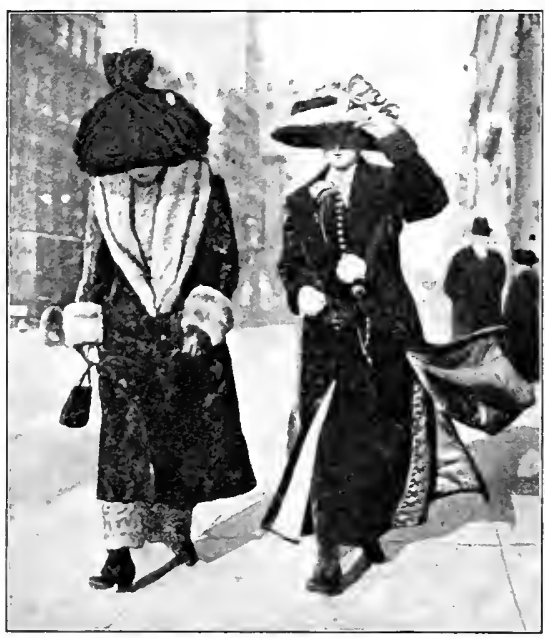

When LARge HATS are in FASHION out from ordinary folk, and so appealed to their vanity. Curiously enough, fashion, which is slavishly followed by those who wish to be like everybody else, usually has its beginning in a desire to be different from other people and thus to be made prominent.

The fashion in men's coats can be partly explained as the preservation of an older form of dressing, which is no longer of any direct use. For instance, the lapels of the coat have a peculiar notch cut in them, and often just below the notch, on the left side, is a buttonhole. If we look for a button on the other side, corresponding to this hole, we do not find it. Ilowerer, if we examine 
former styles, we find that once upon a time such coats were expected to button tightly around the neck, as an overcoat sometimes does. In those times the notches fitted together, and the buttonhole, which is now useless, except perhaps to hold a flower, had a button to correspond to it. Also, on the outside of each sleeve, and sometimes on the back of a coat, there are buttons which are not only of no use, but which are often in the way. These buttons were once useful, because cuffs were turned over and buttoned, if one wished to keep them from being soiled, and coat-tails were once buttoned up by riders, to be out of the way. Here, then, is a fashion, the beginning of which one can trace, even if it is hard to understand why it should still persist.

But it is impossible to explain in any way such a fashion as the wearing of enormous hats by women. It would appear that the milliners of Paris wished to make some kind of conspicuous, striking product in order to attract trade, and that they hit upon this sort of hat. Apparently they have been successful in stirring up a demand for such articles. And presently they will make something else quite as absurd, and that will be adopted. All through the industrial world merchants are attempting to make something new and get it into fashion. No one knows where their ideas come from, and no one can tell what will come next. Many articles of clothing seem to be the product of mere whim. The inventors of such products spend large sums of money in advertising them, in the hope that they may appeal to the popular fancy.

Power of fashion. The power of fashion is very great. It is useless for traders to try to sell clothes of certain colors to certain tribes; for some reason the fashion among these peoples is against these colors, while it favors certain others very strongly. It seems that human communities and races, civilized and uncivilized, have their own peculiar rules of fashion, to some of which they cling with great persistence. In civilized society, especially among the rich, there is frequent change, and a style becomes "old-fashioned " in a fer months. To "keep up with the fashion" requires considerable effort, but there are thousands who show unflagging zeal in the pursuit. 
In a former paragraph we have seen that the various races of the earth wear different amounts of clothing, varying from little or none up to an amount which covers the body almost entirely. It is interesting to notice how the amount of clothing depends upon fashion, that is, upon social influences, rather than upon the degree of cold. In this country the amount of clothing worn depends upon a number of things: no woman would wear in church the dress which she would wear in a ballroom, although both places might have the same temperature; and a man would feel foolish if, having had his hat blown off, he had to walk or ride through the streets bareheaded, while if he were some official, occupying the chief place in a procession and holding his hat in his hand, he would not be at all uncomfortable. A boy would be miserable if he had to go to a party in his bare feet, but he

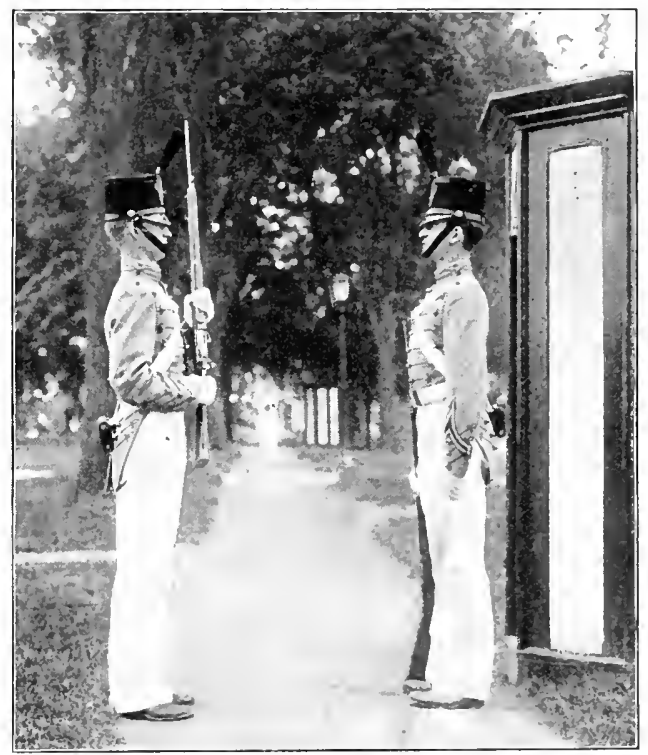

West PoInT Callets

would regard it as a great hardship if, in summer at the seashore, he were obliged to wear shoes and stockings all the time.

All these examples show that we feel comfortable when we are dressed as other people of our kind are, and uncomfortable if we are dressed unlike them, unless we think that what we have on is in some way superior and marks us as distinguished. This helps us to estimate the enormous power of fashion.

Occupation and fashion. There are certain occupations which demand a particular style of clothing. The sailor, for instance, is 
supposed to wear a certain kind of dress consisting in part of a blouse open at the neck, and trousers very wide at the ankle. This costume has now come to be so characteristic that if an artist wishes to show that the picture he is making is that of a sailor, he has only to give him this costume. It is interesting to notice that the width of the trouser legs is no longer of any particular use, although once they were so made, it is said, in order that their wearer could roll them above his knees when washing the deck.

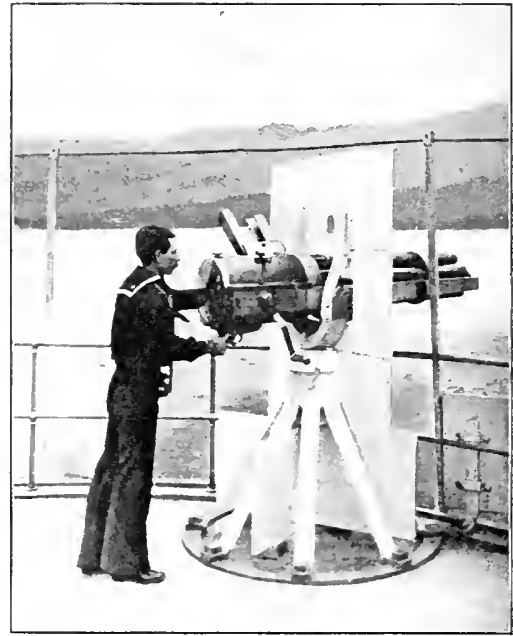

The SAILoR's Costume

If an artist wishes to indicate that his picture is that of a college man, he may do so by painting a person in cap and gown. Or if, in England, he wishes to show that a man is a judge, he gives him an enormous wig and a certain kind of robe. On the other hand, if he wants to draw a tramp, he pictures a man unkempt and with ragged clothes.

There is a saying that " clothes make the man," which means that a man is estimated by his clothes. If a merchant is going to hire a clerk, and the young man who presents himself for the place has trousers and sleeves that are too short, and if his clothes are clumsily made and unpressed, he will be taken to be a rustic. If he is dressed in the height of fashion, with cheap jewelry and flashy clothes, the merchant will distinguish him at once as a boy who is not likely to be fond of hard work. He may say, "I have that young man's number," which means that he knows where to place him and what sort of fellow he is. This he tells in no small degree from the way in which the applicant dresses.

Superstition and fashion. Superstition has had some influence upon the sort of garnent worn by man; for instance, there are 
savage peoples who think that it is unlucky to wear good clothes after a death has occurred in the family, for they fancy that the spirit of the dead person will be offended if he sees his friends wearing bright-colored clothing, and that he may do them some harm. With most races the clothes of mourning have usually been of dull colors, and ornamentation has been absent. In the civilized world to-day the wearing of "mourning," which is generally recognized as a proper mark of respect to the memory of a near relative.

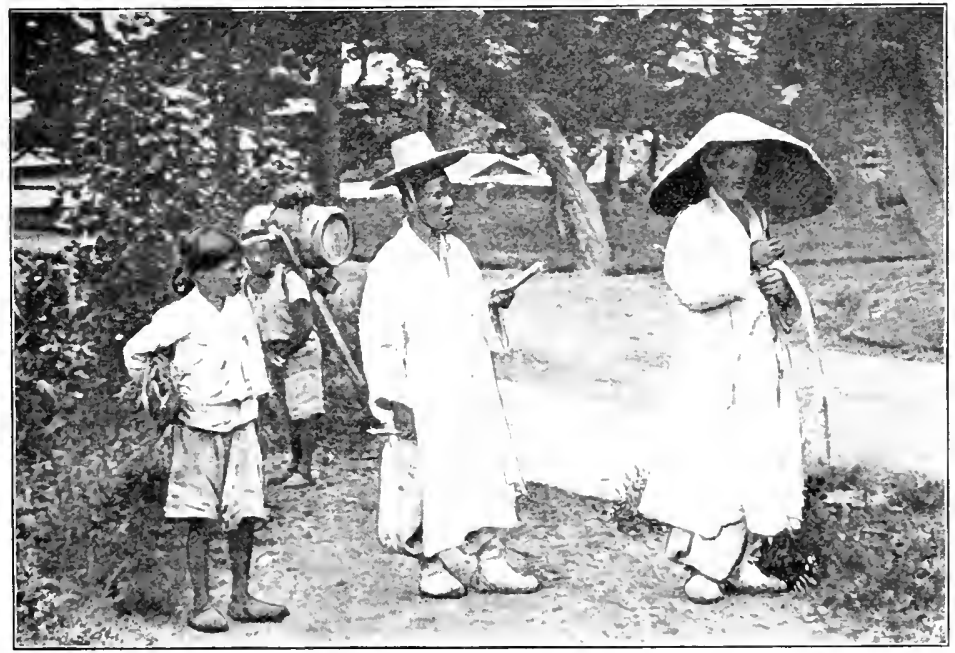

MUURNIAg IIAT of Korea

illustrates the force and permanence of social customs. Its continued use is often due to the fact that it serves as a protection against innocent but inappropriate jests and questions on the part of those who may not know of the bereavement.

Religion and fashion. Religion too has had something to do with the fashion of clothing. 'The clothing worn by a clergyman is often different from that of other people; and what he wears during the service or on Sunday may be quite unlike his ordinary or week-day clothes. There are certain communities, like the Shakers, which have a style of clothing of their own; and we can 
find other illustrations in the uniform of the Salvation Army, and in the familiar dress of the clergy of several religious denominations. In former days, especially, the Ouaker costume was markedly different from the prevailing styles.

Fashion and trade. W'e have talked about fashion a great deal, but not more than is necessary in order to understand the clothing business ; for there is probably no other trade in which dealers have to think of fashion so constantly as in that of selling coverings for

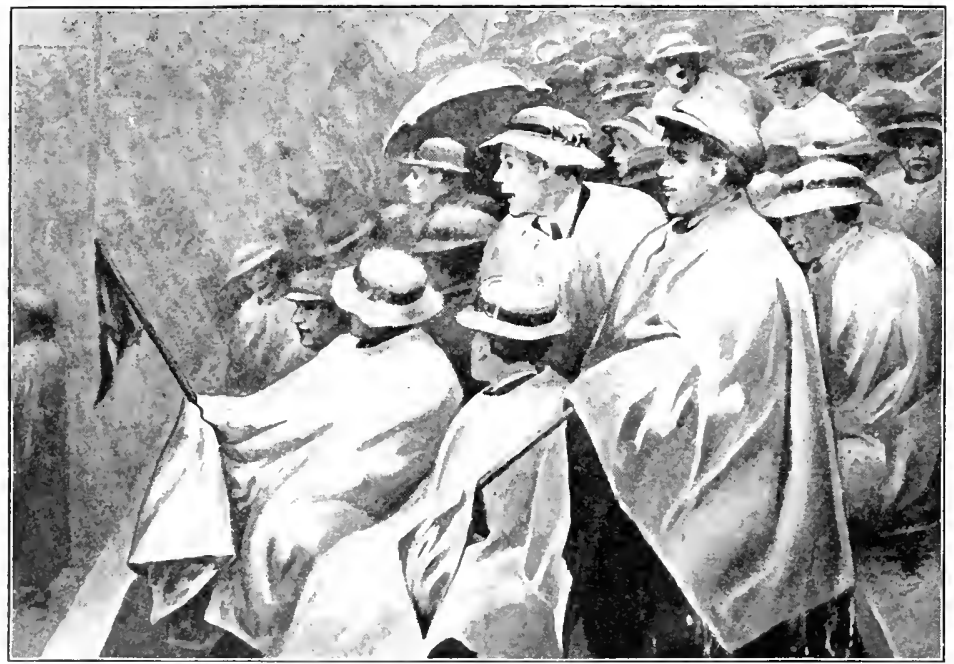

'THE OHLCLOTH RANCOATS

the body. A dealer in clothing who pays no attention to fashion is sure to lose money and fail.

Fashion is so important that man's need for clothing is not simply the need of protection for his body. But protection is the most important need, because without it, in many cases, death would result. If a man is cold enough, he will be so glad to get warm clothing that he will not care what it looks like. If the need for protection is very great, it drives out the desire for ornamentation and the wish to be "in style." 
There was once played a great game of football on a day when the sleet and rain came down in sheets. The morning had been fair, and so few people had provided themselves with protection from the weather. When nearly all the ulsters and raincoats in the town had been bought up, there still were hundreds of people who were eager to get any sort of protection, no matter how it looked. Some of them bought large sheets of oilcloth, cut a hole in the center, and thrust the head through, thus making themselves raincoats which were quite as effective as any that were in style. The football stands were a bright mass of color, for the oilcloth was of brilliant hues. These people, in their great desire to keep dry, did not think much about ornament or style, but we can be very sure that none of them wore the oilcloth coats afterwards, on ordinary occasions. At another time they would have been ashamed to wear that which had protected them so well. It may even be questioned whether a single person, apart from the students, among those who wore the gay coats, would not have preferred a thorough drenching to being the only spectator in such array.

Summary. IVe have seen, then, that all civilized people clothe themselves, and that the amount of material and the nature of the clothing are very different in clifferent places; and that where there is no trade, garments are simple, few in number, very much alike in construction and pattern, and are made from the materials furnished by the environment.

But a change of environment makes a change in chothing. Climate is one of the great factors of environment, and in different climates clothing must differ greatly. The clothing of the tropics is very different from that of the colder regions, and the clothing of summer from that of winter.

But clothing is also used as ornament. The lower races ornament the body in various crude ways, while more civilized peoples spend much time and moncy in manufacturing and using a great variety of materials, colors, and weaves of clothing, as well as ornaments of all kinds which have no protective value. This ornamentation is clue first of all to vanity, but later it is cletermined by good taste and a love of the beautiful. 
Finally, we saw that there were many social influences brought to bear upon clothing, and that fashion decides very largely what clothing shall be, in amount, material, color, and cut.

The subject of clothing, then, is not so simple as one might think at first sight. The study of clothing materials and manufacture is also less simple than it appears. We shall now learn about the materials used in the making of clothing, about their preparation and manufacture, and then about their transportation and sale. 


\section{CHAPTER X}

\section{MATERIALS USED IN MAKING CLOTHING}

\section{Materials of Plant Origin}

Fiber-yielding materials. We must look to the plant and animal world for clothing materials, since there are scarcely any mineral

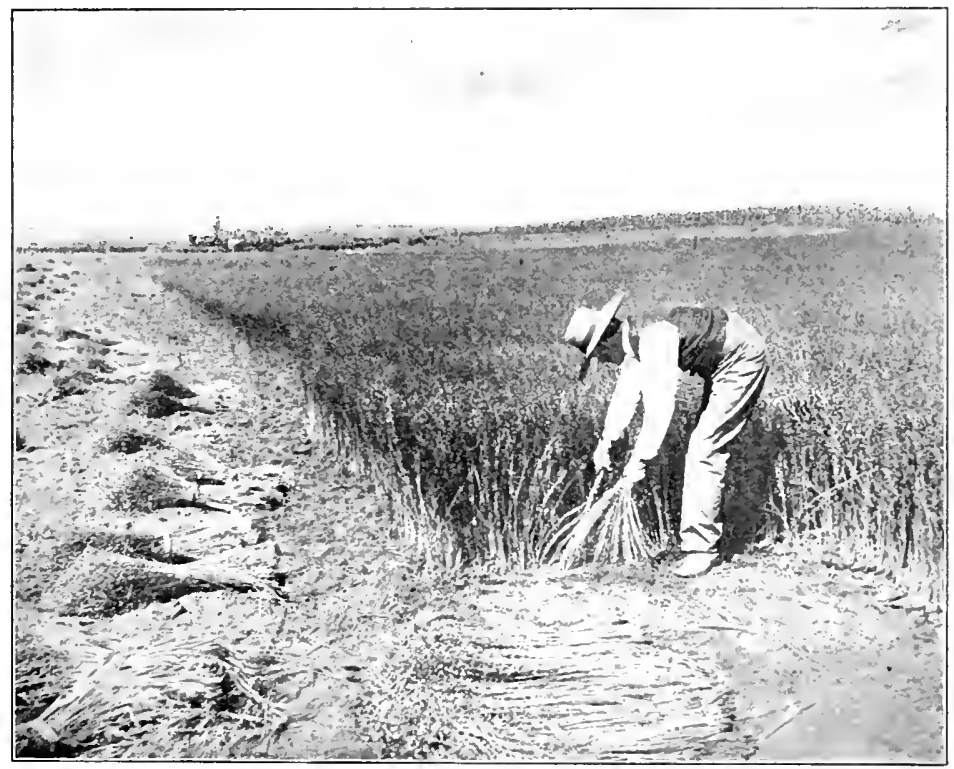

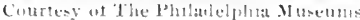

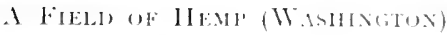

substances which could be so used. Among the fiber-yciding plants cotton is by far the most important. This we shall study more carefully later. 
Flax. Another important fiber is that of flax, from which linen is made. Like all other plants, flax was first cultivated for food material, this being found in the seed. The seed is still used for the making of oil and for other purposes; but the most valuable part of the plant is now the stalk, for within it are to be found a number of fibers which are separated from the useless part by a process known as "retting," are then cleaned, and are finally spun

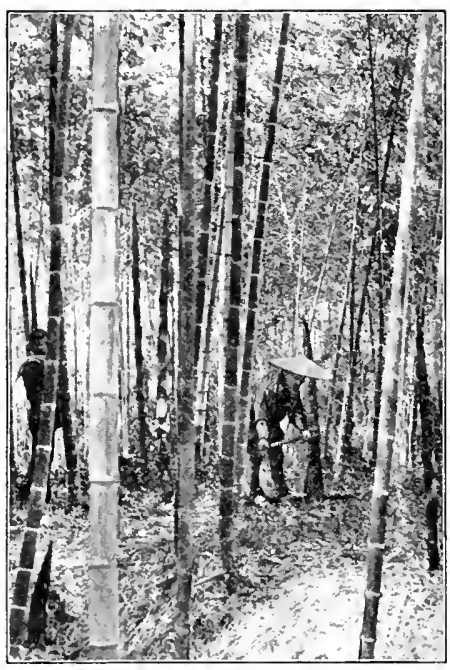

Courteny of The Philaclelphia Insetums

BAMIUU GROYE IN JAPAN and woven to make a fabric.

In order to get good fiber a great deal of hand labor is required, and so flax is not largely cultivated for fiber in this country. Americans will not take the time and pains necessary for this, when there are other occupations which can be carried on by the use of machinery, and which pay as well or better. It is not practicable to harvest from a single crop both seeds of high quality and stems containing a good fiber ; and so, the world over, flax is raised either for one purpose or the other, but seldom for both. European Russia far surpasses all other countries in quantity of fiber produced, raising about seven tenths of the world's annual output.

Hemp. Hemp is another vegetable product originally valuable for its seed, but now grown for fiber. It is much rougher and coarser than flax, and is used in making such things as bags, burlaps, and ropes. It is raised chiefly in Russia. The hemp which is grown in the United States is raised for its fiber, for, being coarser and rougher in its nature than flax, it can be treated by machine methods without so much loss.

Ramie. There are a number of grasses which are of great use to man ; in fact, it might be said that wheat, oats, rice, and bamboo are really overgrown grasses, and the same is true of flax and hemp. 
China grass, or "ramie," is prockuced chiefly in eastern Asia, though India and the Mediterranean countries have taken up its culture. It is suitable for making fine, silky underclothing, and

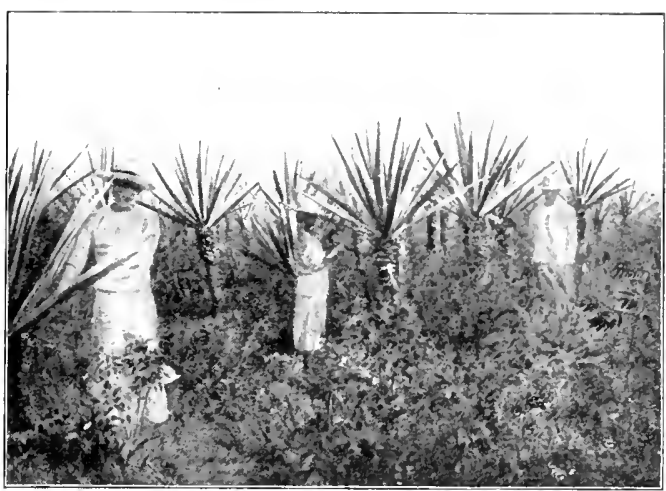

CUITING SISAL, OR IIENEUUEN, IN YUCATAN

mixes well with wool and cotton ; it is useful in a coarser state for cordage and nets.

Jute. The fiber in the lower part of the stalk of this plant is very coarse, and is used to make cheap paper, twine, and bagging; the rest of the fiber, which is finer, more glossy, and more easily spun, can be used to make finer products, such as better twines, grain sacks, cotton-bale coverings, and rugs. Fabrics made of jute soon lose their usefulness when exposed to moisture, which dissolves the materials holding the cells of the fiber together.

Sisal. Sisal (sc̀-säl'), or henequen, is raised chiefly in Yucatan, and, to a less degree, in the West Indies and in Ifawaii. It is a harsher and stiffer

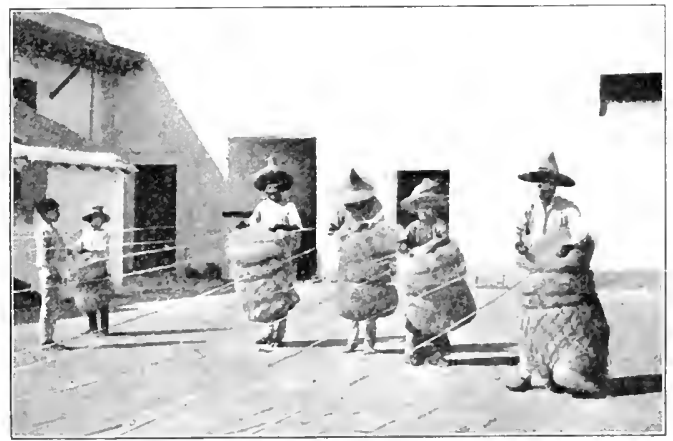

SPINTING ISTLE HY HAND fiber than hemp, and is not so strong. Salt water is destructive to cordage made from sisal, and so it is used more commonly in making twine, sacking, and brushes; with the exception of cotton, sisal is probably the plant fiber most widely used in the L'nited States. 
Plant fibers of less importance, such as "istle," are sometimes used as material for clothing and house furnishing.

An exception. As a rule, clothing material of vegetable origin is made from fiber of some sort, but there is a notable exception. One of the most useful of all plant materials is caoutchouc, or India rubber. But while it is possible to use rubber alone, as a matter of fact the gum is usually combined with fiber of some sort in the making of clothing materials. We have already studied about this product, in speaking of the manufacture of rubber boots and shoes.

\section{Materials of Animal Origin}

Leather. Perhaps the first material from the animal world to be used as clothing was the skin of a slain beast. For a time skins were used whole, with the hair or wool on them, much as they came from the animals, but now they are treated in a great number of ways. The chief product of the actual skins is leather, which is the tanned hide of the animal. Cattle, sheep, goats, horses, and swine yield the greater part of the leather of commerce, but we have, in addition to the skins of these, the hides of dogs, deer, chamois, alligators, and other beasts.

From cattlc. Leather for footwear comes chiefly from the hides of cattle. In this country, cattle are raised more for meat than for hides, but in Argentina, where the better breeds have not yet been introduced, hides form an important article for export. From the long-legged, rougher, and tougher variety of cattle which range over the pampas, the sort of hide which is most durable is obtained. Calfskin is much used in the making of footwear, being more delicate and pliable than the skins of the older animals.

From shecp. The skin of sheep is much more delicate than that of eattle, and was once used as writing material. Even now documents like diplomas are frequently printed or written on parchment made from sheepslin, and often a diploma is referred to as a "sheepskin." Such skin is also used for the manufacture of gloves and other delicate articles. Many old books are bound in sheepskin, and to-day it is sometimes used to imitate moroceo binding. 
From goats. Goatskins have long been used in the East for holding liquids, and they are still used for carrying water in Palestine, and for churning milk among the Bedouin Arabs. But generally now they are prepared for uses similar to those of sheepskin. Morocco leather was originally made from goatskins, and has always been greatly prized for its fine, soft quality.

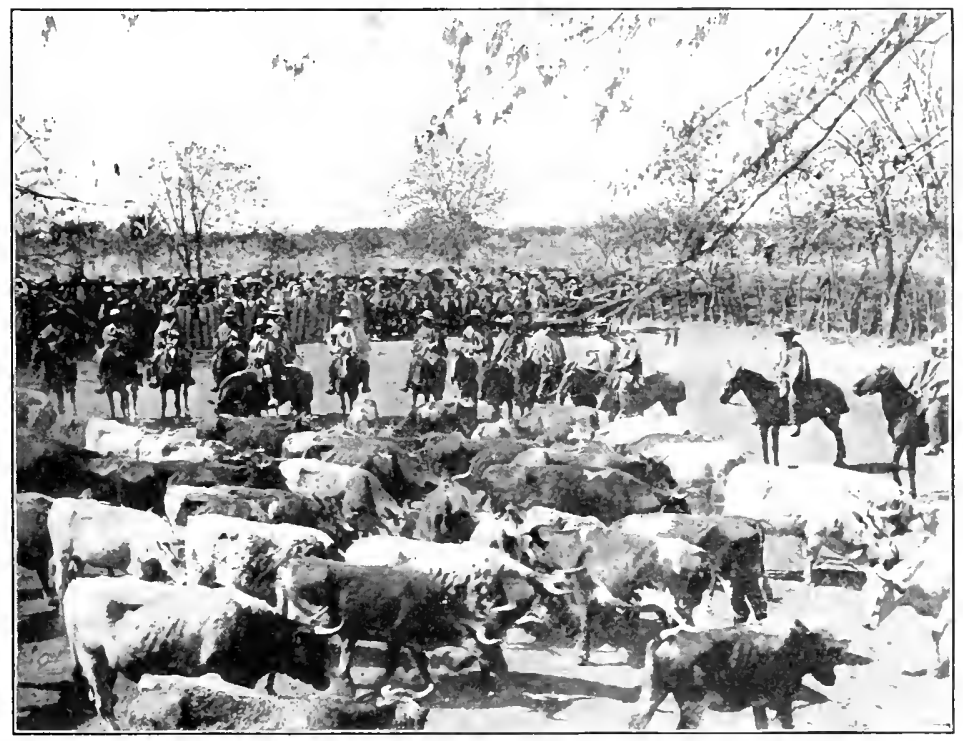

Hide CatTle (ARGeNTINA)

From other animals. Leather is made from horsehide also and from the skins of swine. Pigskin is tough as well as pliable; it is used for footwear to some extent, and also for covering such articles as footballs. Pigskins too are used for holding liquids.

Fur. At first, when the skin of an animal was used for clothing, the hair was allowed to remain. Fur-bearing animals live in the colder regions of the world, and so the man who stripped the animals of their skins needed the protection of the wool or hair on the hide as much as they themselves did. In many parts of the world furs belong to ornamental dress. 


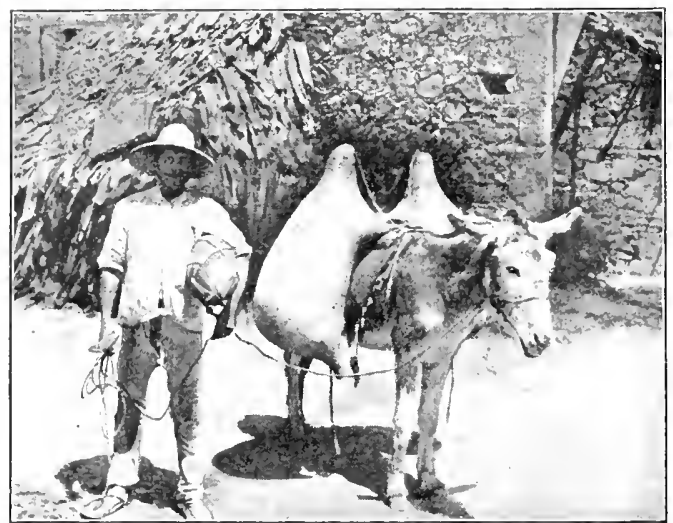

Courtesy of The I'hiladelphia Mlusems

l'IGSKINS USED FOR CARRYANG WATER

Furs are of many varicties, ranging all the way from the very costly down to those which are very cheap. A number of the aretic animals, such as the arctic fox, mink, sable, sea otter, ermine, and seal, provide furs of great beauty. These furs are also costly, because the animals have been hunted until they are now scarce. At one time, in this country, beaver skins were collected in large numbers and were in such common demand that they were used as money; to-day beaver is an expensive fur. $11 \mathrm{e}$ have already seen with what care several of the governmonts of the world are preserving the seal herds of the Pribilof Islands.

In addition to these more costly furs, there are others which either are, or have recently been, rather inexpensive. Buffalo robes were very common twenty-

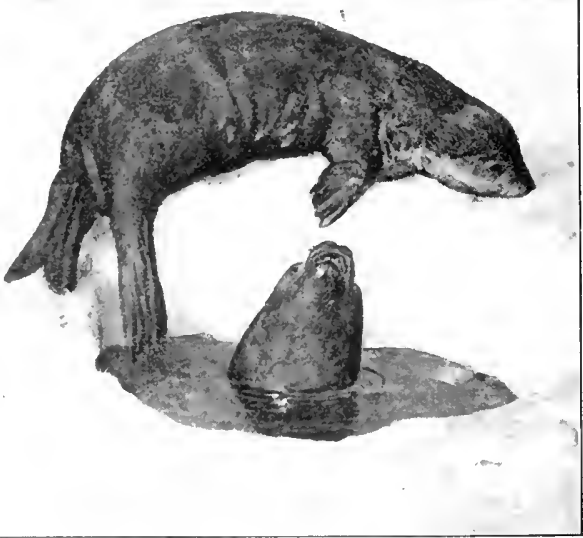

FUR SEALS

five years ago, and were still more common in earlier times, before the herds of buffalo had been reduced to such small numbers. 
In this country to-day furs are obtained from animals which were at one time regarded as of small importance, such as the muskrat and the skunk.

Persian lambskin, the wool of which curls tightly in little knots, is a favorite fur of the present time. Also, in recent years, the skins of very young horses and ponies have been used. The skins of gray squirrels are used frequently, and even those of cats. In fact.

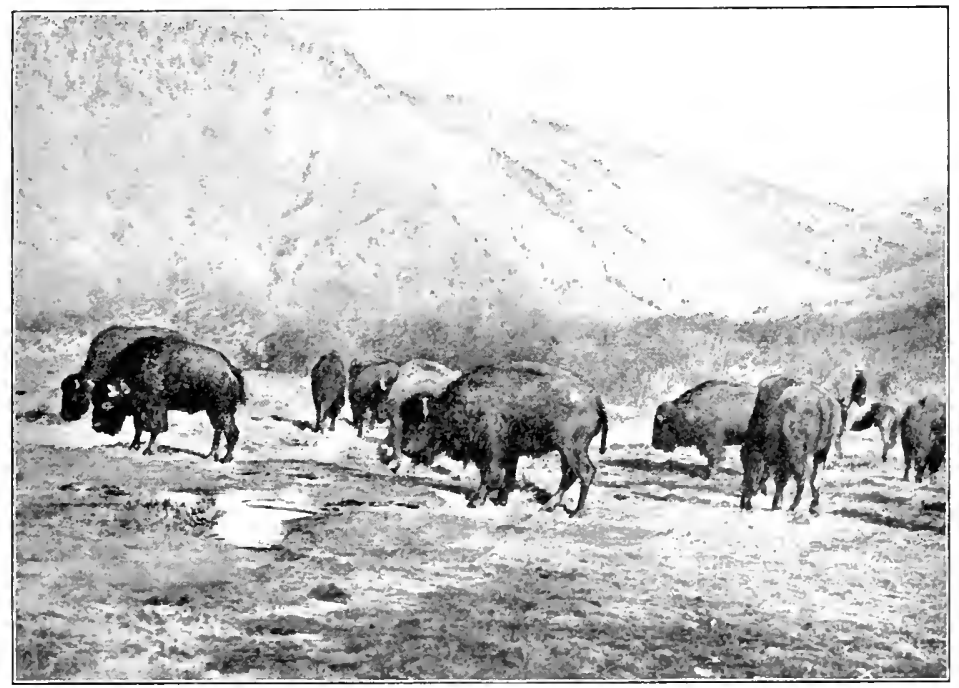

. IIERD UF BUFFALO

there is scarcely an animal that bears fur of any use or beauty which has not been stripped of its skin in order to gratify the need for protection or the desire for ornament of men and women. The fur of the ermine has long been connected with royalty; out of it the coronation robes of kings have so frequently been made that sometimes we speak of "putting on the ermine" when we mean becoming a king.

These furs are very likely to be damaged by moths, and therefore have to be preserved with great care. Any garment made of animal fiber or skin attracts moths and other destroyers, and a 


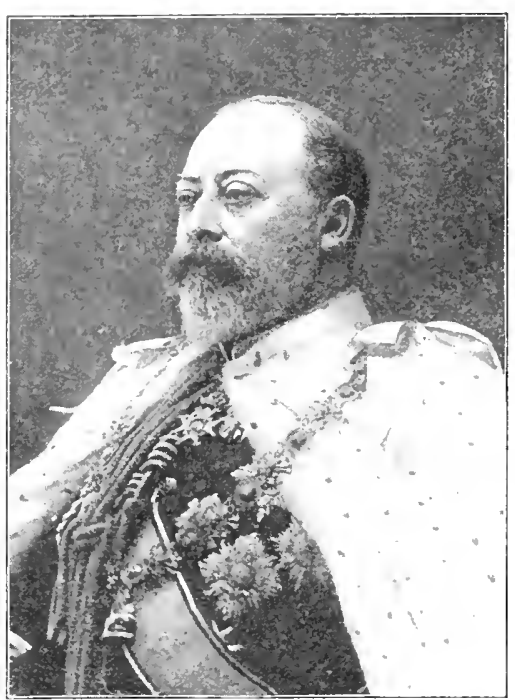

A KING IN HIS LRMINE number of substances, such as moth balls, have been prepared to protect furs and woolens. The most effective of all methods has been to store furs, when they are not in use, in refrigerated rooms; these rooms, maintained by the bis department stores in all large citics, are reduced to a temperature which is so low that the moths cannot breed.

In general it may be said that the finest furs come from the coldest regions, and that thereare few of the highest value outside the frigid zone or the colcler parts of the temperate

zone. This is because in the warmer zones the animals do not need such protection, while in the colder regions they could not live without the fur, which leeps them warm.

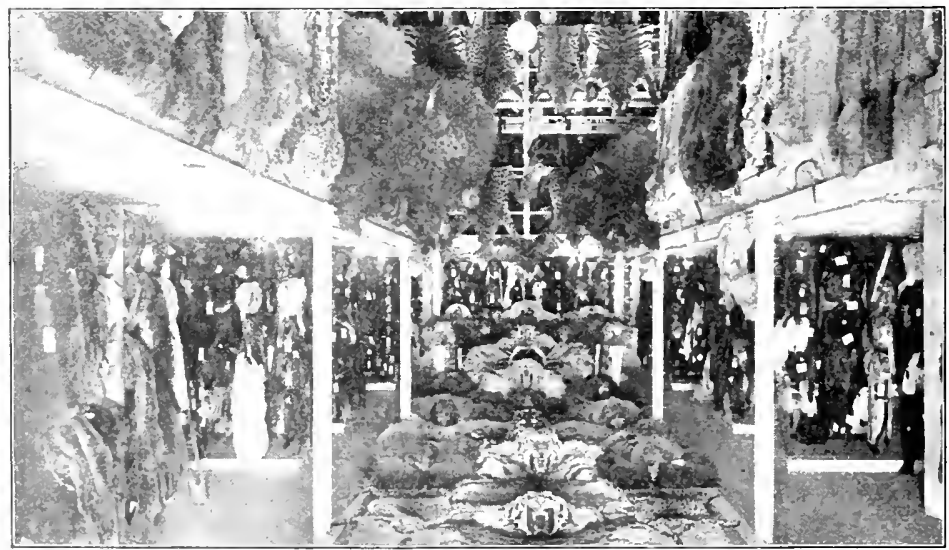

C'vurtesy of John Wanamaker

FUK-STURAGE VAULTS KEP' AT ABUUT 2 FAHRENHEIT 


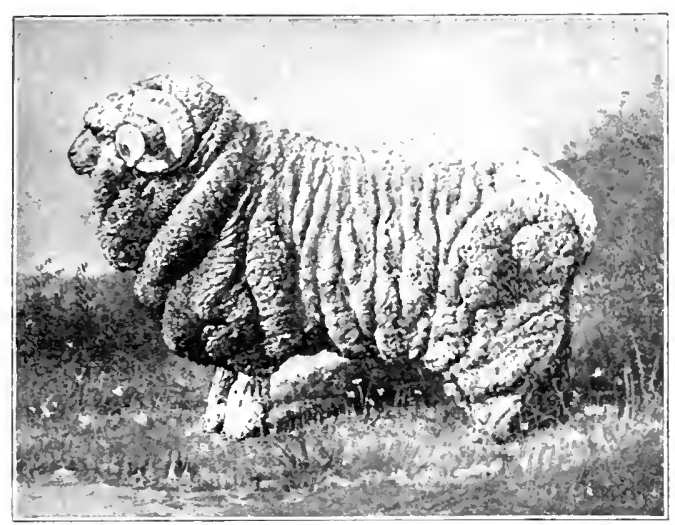

Merixo Sheep
Wool and hair. Wool is the name we give to a kind of tightly curling hair growing chiefly upon the bodies of sheep. The hairs of a sheep are flattened, and so they curl like a sharing; whereas if the hair is round or nearly so, it is straight like a cat's whiskers.

From shcep. The wool of sheep is the most important of all animal fibers, for from it is made much of the clothing of mankind. It is spun and woren into cloth in the same way as are vegetable fibers such as cotton and flax.

The most valuable variety of sheep for wool is the merino, which was imported into this country from Spain in large numbers in ISIO. The skin of the merino sheep does not fit its body very closely, but hangs in folds, like the overcoat of a large man on a small one. The

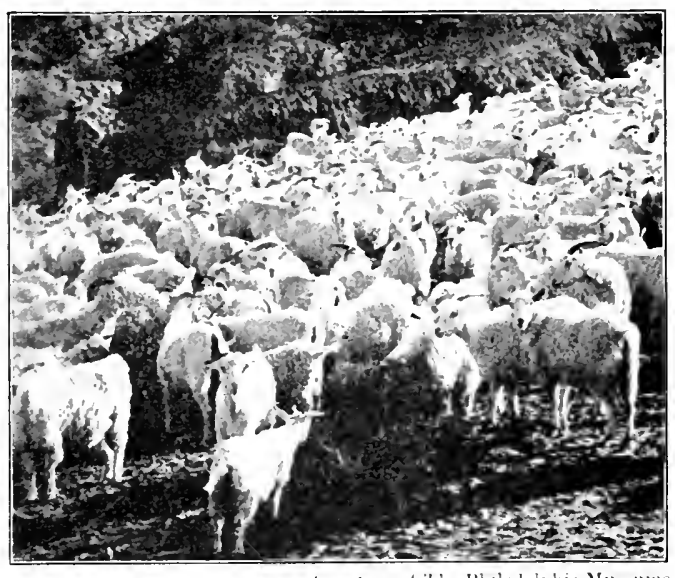

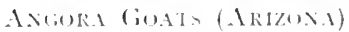

number of square inches of skin upon which wool can grow is therefore very large. The number of hairs too that wrow upon each square inch is very great; the old German sheep is said to 
have had 5500 hairs to the square inch, whereas the best merino breeds have $4 \$, 000$. This means not only that the wool is dense, but that the strands or fibers are very fine.

From goats. The hair of goats is woven into cloth of various kinds, which is coarser than that made from the wool of sheep. The most important breed of goat is the Angora, and from its hair the fabric known as mohair is manufactured. In South America there is a camel-like animal called the alpaca, whose hair is used

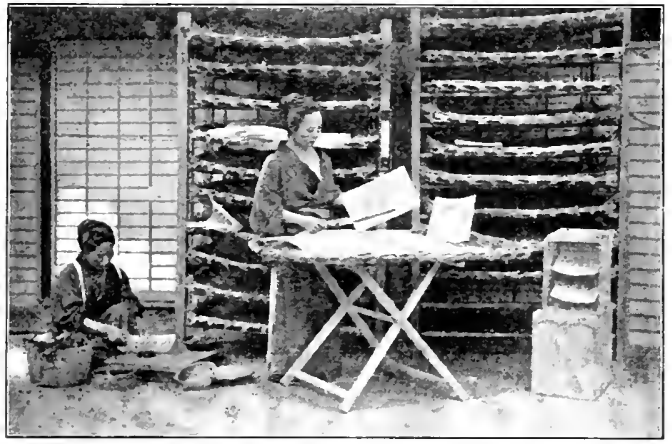

Gathering Eggs of Silkworms to make goods of a fine quality.

From camels. The hair of the camel also is used in the countries where that animal lives, and is manufactured into fabries of various sorts, especially shawls, which are exported to other countries. Camel's hair is used for the best paintbrushes, while the stiffer hair of badgers or swine is employed for shaving brushes and such other articles as require a less delicate material.

From other animals. Besides the animals which we have mentioned, there are others which furnish hair for various purposes. Sofas used to be covered with woven horsehair, which has a very smooth and shiny surface and is still regarded with favor as a durable material. Cow's hair is used for a number of purposes, especially for stuffing cushions and mattresses, or to make felt. The bristles of swine serve to make hairbrushes, blacking brushes, and the like.

Silk. Another animal fiber commonly used is silk. We have already learned that this fiber is produced by silkworms to form their cocoons. It is thin and delicate, and a number of the fibers have to be spun or twisted together to make a thread. A great 
deal of hand labor is necessary in connection with the manufacture of silk, especially silk of fine quality, and so in this country we have, in the past, given more attention to the coarser and stiffer varieties, and have imported the best handmade silks from countries like China, where hand labor is less expensive.

Any fiber which is not too delicate can be spun into a thread and then woven into a fabric. There have even been experiments made in producing spider silk. The strands were drawn from the spiders, and the fine fibers having been made into a sort of thread, were woven into a gossamer fabric. It has also been possible to use very thin strands of glass to make curiosities in the line of weaving.

\section{Prepakation OF Materials}

Processes of preparation. The preparation of clothing from any of these raw materials consists (I) in collecting or growing them, (2) in manufacturing them, and (3) in selling or marketing them. And, of course, they have to be transported from the place where they are made to the market. These processes will come out very clearly when we come to study, in the next section, one particular material, cotton. We shall then see what happens to the cotton from the time it is planted until it reaches the person who is going to wear it in the form of clothing.

If we go over the list of clothing materials which we have just made, we shall see that several of them demand certain peculiar forms of treatment. Let us take flax and hemp, among regetable fibers, as examples.

Flax. The greatest care has to be taken in raising flax in order that nothing shall happen to break or bruise the fiber, or to make it coarse and rough. The plant has to be hoed and cultivated in the most careful manner, the weeding generally being done by people who crawl between the plants on their hands and knees, and who do their best not to bend the stalks or otherwise injure the flax. When the harrest comes the stalks have to be pulled up with great care, or cut near the ground in order to save as much of the fiber as possible. After the harrest the stalks must be retted, 
or soaked in tepid water. This is often done in small ponds. Men have to wade in with forks and lift out the stalks very carefully, so that no harm shall come to them. After this, the fibers must be separated and cleaned before they are ready to be made into cloth.

Hemp. The same is true of hemp except, that being coarser and less valuable, it demands less care. In this country flax and hemp have been harvested by machines, which have so damaged the plant that fiber good enough for nuking fine cloth could not be obtained. In fact, much of the material which, with greater care, might have been made into cloth has been used as bedding for animals.

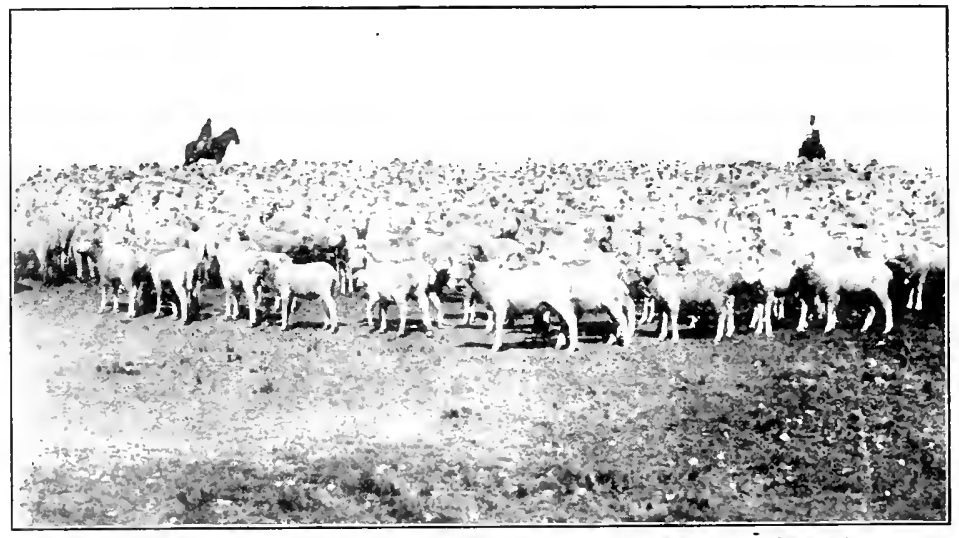

Flock of SIIEEP IN ARgextINA

Wool. When we consider wool we find that there are many processes connected with its manufacture. First of all, in raising the animals it is important that there shall be no dense undergrowth to tear the wool while it is on the sheep. This is one of the reasons why sheep growing prospers better in a dry country where grass flourishes, than in a place where there is much other vegetation.

When the wool is of sufficient length, it must be sheared from the sheep's body. This was formerly done by hand with a large pair of shears, but it is now accomplished largely by the use of machinery; clippers driven by electric power or steam are passed over the bodies of the sheep and clear off the wool rapidly and neatly. 
The wool, as it comes from the body of the sheep, is full of impurities and contains more or less grease. These substances have to be removed by " scouring," which greatly lessens the weight of the wool. There are many other processes connected with wool production before the product reaches the mill, but once in the mill, the method of manufacture is similar to that of cotton, which we shall study later.

Mixtures. In many cases different kinds of raw material enter into the manufacture of a single fabric. For instance, wool and cotton are frequently mingled, and ramie mixes well with either substance, giving the product a silky finish. Various cheaper fibers are frequently interworen with silk; rubber is mixed with other goods in order to make them waterproof; and adulterations of all sorts, whereby a cheaper material is put in with one which is more expensive, are practiced.

Marketing. The marketing of all these clothing materials

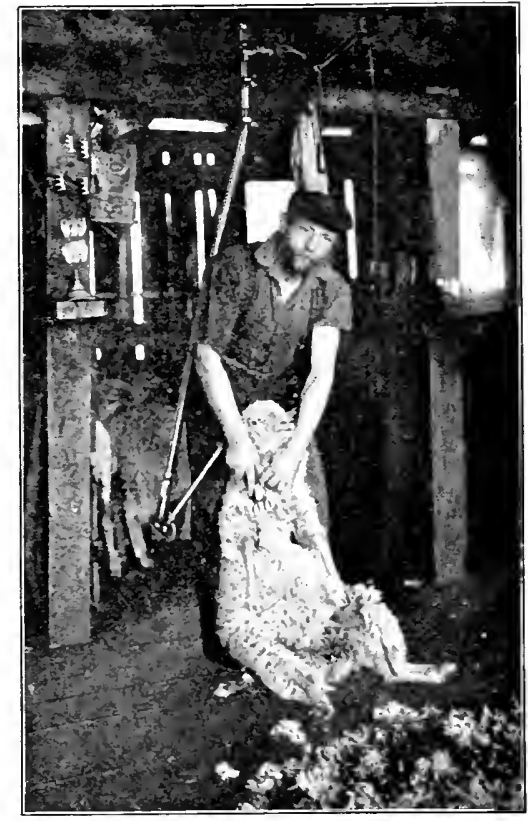

SHEARING SHEEY LY MACHINEKY makes an important branch of business. Furs, for instance, after being treated near the place where they are taken, are shipped to the more civilized parts of the world, when they are worked over still further. Then they go to the wholesale houses, from which they are distributed to the retail dealers, and so finally reach the persons who are going to wear them. Silk maly come into one of the European countries or into the United States as raw material; then it is taken to silk mills, where it is made into cloth or ribbons, which soon find their way, like other fabries, to the market. 


\section{CHAPTER XI}

\section{COTTON - ITS DISTRIBUTION AND CULTURE}

The use of cotton. Cotton is by far the most important material used by man for purposes of clothing. This has not always been the case, for such an expensive material as linen was once demanded for many purposes for which cotton is now used. The chief clothing material displaced by cotton has been wool. In order to compete with wool, processes have been developed by which cotton can be so treated as to resemble wool; flannelette, for example, is said to be made wholly from cotton.

Civilized man has made far more use of cotton than did his uncivilized brothers. Yet even uncivilized races, who have lived where cotton was grown, have long made many kinds of clothing from its fiber, which they have learned to weave in a crude fashion.

\section{The CotTon Regions of the IVorld}

Wide distribution. By looking at the map which shows the cotton-producing regions of the world, we see that cotton is found at the present day widely scattered over the earth, between about $40^{\circ}$ north and $30^{\circ}$ south latitude. The plant was not native to all regions of this wide belt, and in many places was not known until it was brought in from elsewhere.

One variety of cotton was native to the New World, but we cannot tell exactly where in the Americas it originated. When Columbus first saw the Indians, they knew about the cotton fiber and probably had known about it for a long time, because the plant was cultivated throughout most of the country - from New Mexico to Brazil, north and south, and from the West Indies to Peru, east and west. 


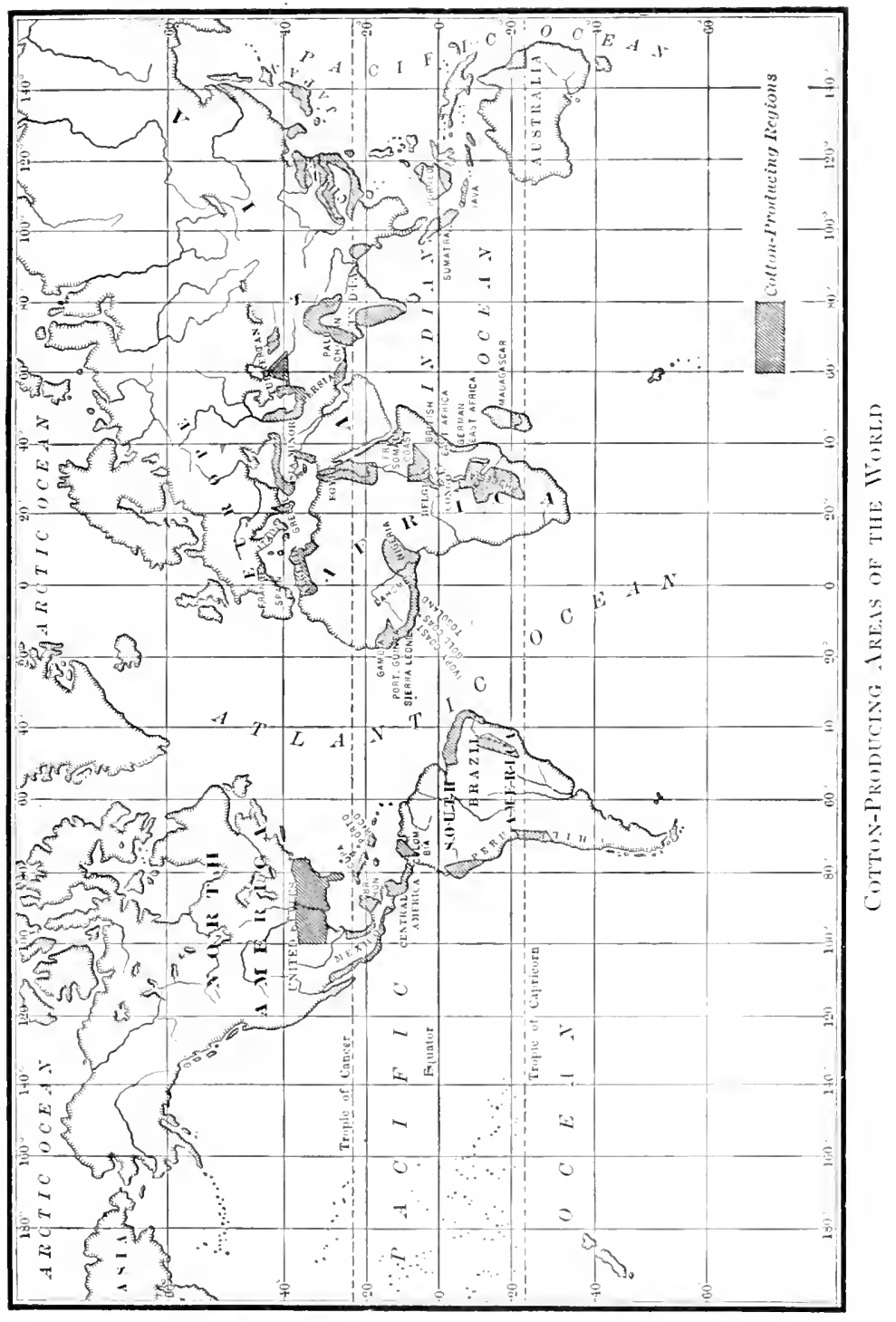


The kind of cotton that is grown chiefly in this country is what is known as "American upland" cotton. This variety was probably native to India, and it is said that Alexander the Great brought it to the countries of Europe bordering on the Mediterranean. Alexander the Great made his conquests more than three hundred years before the birth of Christ.

But eren though cotton is now grown in many countries, most of that used by the chief commercial peoples is grown in a few countries. These are, above all, the United States, India, and Egypt. China raises a great deal of cotton, but this does not

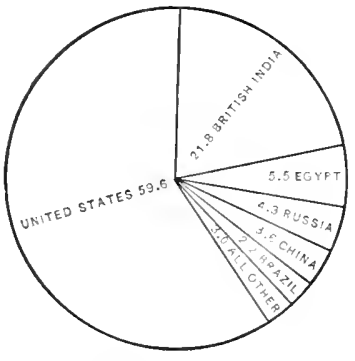

PERCENIAGE GF WURLD'S MHL. SIPILY GF COTTUN CONTRIFCTEI I:Y EACH (i) INTRY, IgO9) enter much into the commerce of the world, because it is used at home by the people themselves. Again, Russia raises cotton in Turkestan and Transcaucasia, and both Russia and China have recently come to surpass Brazil in the amount of raw cotton furnished to the cotton mills.

In I 909 the United States supplied almost three fifths and British India more than one fifth of the world's mill cotton; then came Egypt with about 5: $\frac{1}{2}$ per cent, Russia with about $4 \frac{1}{3}$ per cent, China with about $3 \frac{1}{2}$ per cent, and Brazil with a little over 2 per cent. All other countries together furnished only about 3 per cent. These figures show that in 1909 the United States, British India, and Egypt furnished nearly nine tenths of the whole supply; for a long time the United States alone has produced nearly two thirds of the world's cotton. When, therefore, we study the subject of cotton, we are learning about one of the products in which our country leads the world.

The United States. The map on page 66 shows the cottongrowing areas of the United States, and the diagram at the right of that map gives the percentage of cotton raised in each cottongrowing state in the year soos.

During the last century the cotton belt has gradually increased. In the eighteenth century the only places where much cotton was 
grown were North Carolina, South Carolina, and Virginia. But when the cotton gin and other machines were invented, they gave a great stimulus to cotton growing. Production moved farther west and south, so that, about I 850 , the center of cotton growing lay in Alabama. Later, cotton came to be grown still farther west, until, in rgo8, Texas alone was raising over a quarter of our cotton.

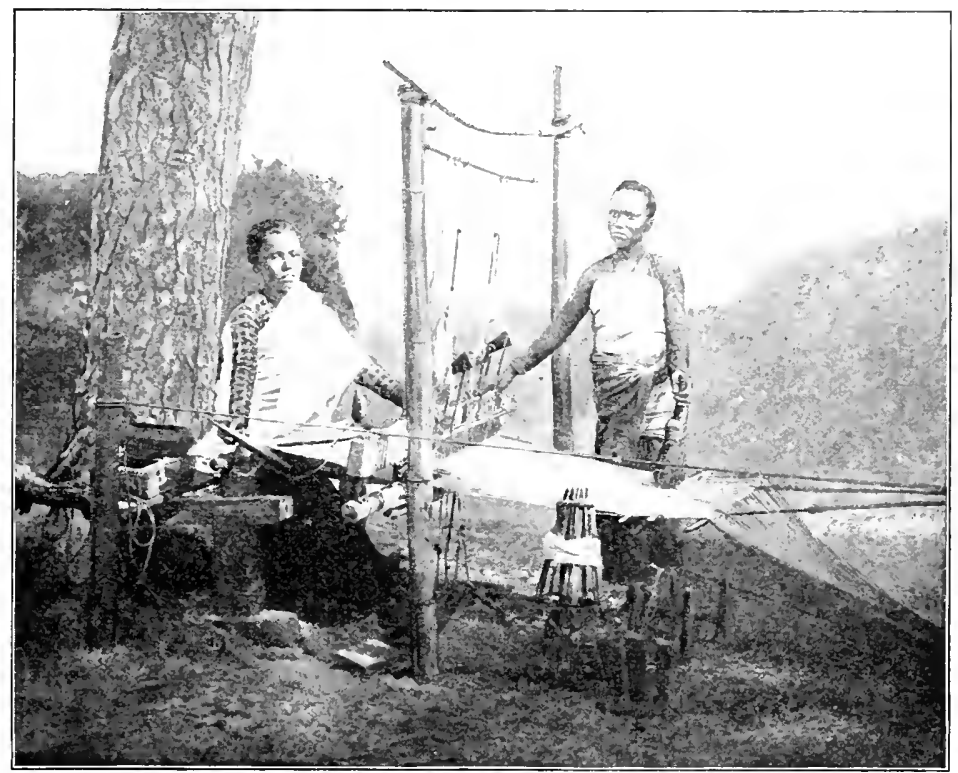

Courtesy of The Philadelpha Ilusetums

Nerdl, Wuarex WeAtixg Cloth

The real "cotton belt" is about I 450 miles long from east to west and about 500 miles in width, and includes all the Southern states from North Carolina to Texas. These are North Carolina, South Carolina, Georgia, Florida, Alabama, Mississippi, I ouisiana, Arkansas, Texas, and Oklahoma; also parts of Tennessee and of a few other states.

We must not imagine that all the cultivated ground in this region yields cotton. There are nearly $450,000,000$ acres in the cotton belt, but only about one acre in seventeen yields cotton. It is true, 
however, that although corn and other plants which can be grown in warm regions are raised in great quantities, the chicf source of agricultural wealth in the South is the cotton crop.

India. For a long time India produced large quantities of cotton - far more, indeed, than any other country. India produces

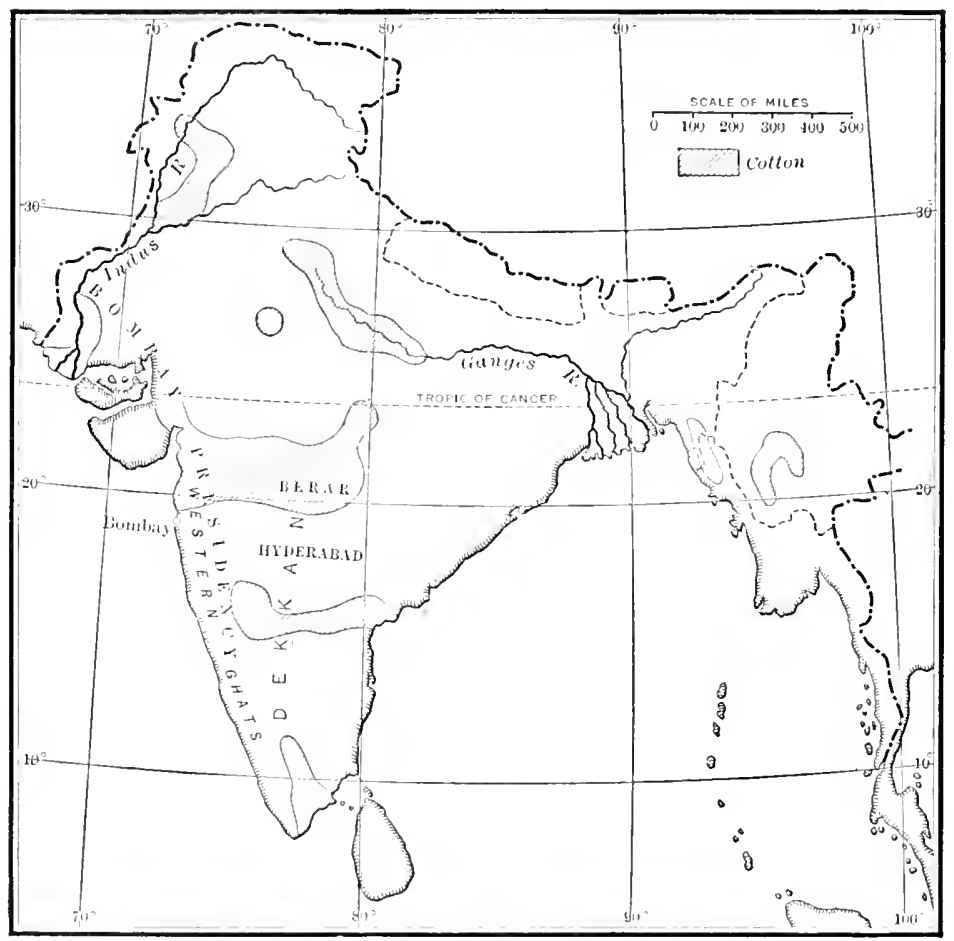

COTON-GROMNG; REGHONS OF INDHA

other fibers, such as jute, but cotton is widely cultivated, and probably it has been grown longer here than anywhere else in the world. It is the most valuable export, although the needs of the vast Indian population demand that a large part of the crop shall be used at home. Not only is the climate in India so warm, but the standard of living is so low that, for the masses of the people, cotton clothing answers every purpose. 
Since the introduction of modern methods of manufacturing cotton, a great cotton industry has grown up in India. The first mill was established near bombay about i $\$ 50$. 'There were many difficulties in the way of dereloping this industry, the chief one being that the only labor which was available, while cheap, was not very intelligent or effective. I'et there are at the present time over 200 mills in India, with more than 5,500,000 spindles and 60,000 looms.

The fiber is grown in many parts of India, notably in Bombay, Berar, and in other parts of the Jekkan. The Dekkan is a triangular plateau from two thousand to three thousand feet high, lying between the parallels of $8^{\circ}$ and $25^{\circ}$ north latitude. Indian cotton is of poor quality because the fibers are very short; and the yied per acre, owing to the crude methods applied, is very small.

Egypt. Legypt produces more cotton than any other country in Africa, and ranks third in the amount supplied to the world. It has been said that cotton is the "backbone" of Egyptian agriculture. It certiunly is the crop that brings the most money to the owners of the soil. Cotton is rased mainly in the delta of the Nile, and in the irrigated districts of middle Egypt, where, as we shall see, an enormous amount of labor and money has been cxpended to increase production. Iigyptian cotton is of good quality and finds a ready market in England and elscwhere.

Brazil. The cotton fields of Brazil are found in the tropical districts of the Atlantic scaboard and in parts of the interior of the country. Nore or less cotton is also raised in l'cru. The name "l'eruvian cotton" is often applied to that which grows in both of these countries. That cotton has been raised and manufactured in leru for a long time is shown by the fact that cotton cloth has been found in very ancient Peruvian tombs.

When South American cotton is imported into this country, it is used chicely for mixing with wool. It has formed an export of Brazil for a century or more, but has fallen off in recent years, because, with the growth of industries of all kinds in that country, cotton manufacture has increased, and the Brazilians use more of their raw material at home. 


\section{The Nature ani) Varieties of Cotton}

The cotton plant. The cotton plant belongs to a family of plants known as the mallow; the common wild mallow and the garden hollyhock are near relatives of the cotton.

The scid. Before the cotton plant was domesticated, that is, before mankind began to cultivate it, it was probably a perennial. By this we mean that when the seed had once been sown, the plant would continue to grow season after season without the planting of more seed every year. But now the best results seem to be obtained by cultivating the plant as an annual; that is, the seed is

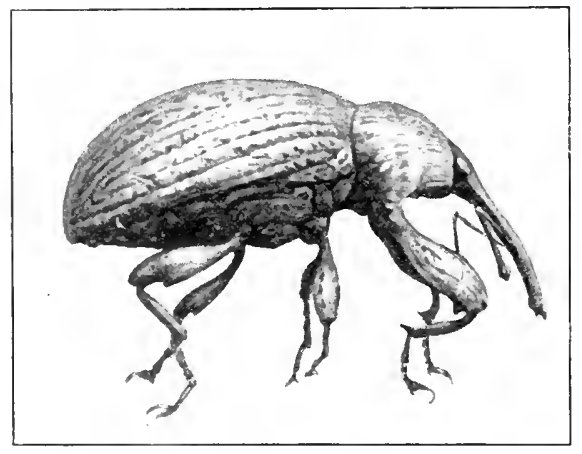

THE lioll Weeth (GREATLY ENLARged) sown at the beginning of the season, and when the plant has blossomed and its seeds are ripe, it is pulled up. The cotton crop is often seriously damaged by the operations of the boll weevil, and an energetic campaign against this pest is now in progress.

The plant. The plants which bear the cotton fiber differ greatly in height; some are mere herbs, others are like shrubs, and still others are small trees.

The difference in size of the plants is not of much importance, because the principal product is the fiber taken from the pods. For this reason the cotton plant is cultivated not for size but for fiber. In almost all cases where cotton is cultivated it is found as a low shrub. From a distance a cotton field before harvest time looks like a nursery of tiny maple trees; later the little bushes are sprinkled with flecks of white, as if a sudden snowstorm had surprised them. Closer examination shows the cotton "lint," which clings tightly to the seeds of the plant, and which is now bursting out of the green pod or "boll." 
The fiber. The cotton of commerce is a short fiber from half an inch to two and one half inches in length. The fibers, as shown in the picture, are found attached to and surrounding the seeds of the plant. A boll, before it bursts open, looks a little like a waterlily bud; the seeds are about the size of small peas, and are commonly brown or black. Some of the bolls are small, some are large ; if we take those of medium size, the fiber from about seventyfive of them would be required to make a pound of raw cotton.

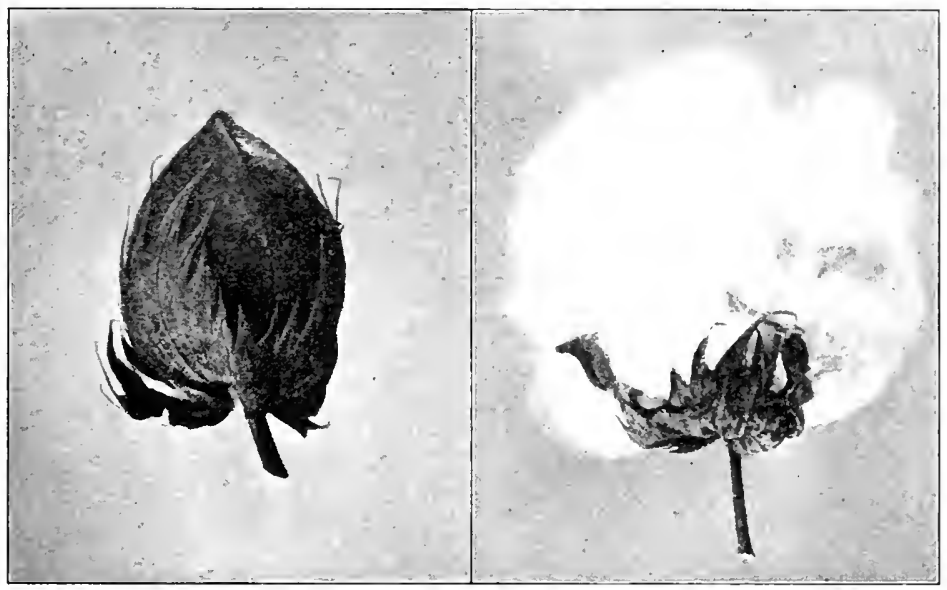

COTTON BuLLS (SLIHITLY REDL'CEI)

If we should look at one of these tiny fibers under the microscope, we should find that it has the appearance of a fire hose which has no water in it, and which is flattened and somewhat twisted. It is because the fibers are flat and roughened that they cling together closely and do not slip on each other, as horsehairs or wires would. Thus, even though they are very short, they can be so joined as to make a strong thread. (If course, if they were easily pulled apart when twisted into thread, it would be impossible to use them to make cloth. But the little twists and spirals hook into each other and hold tight.

Varieties of cotton. From a practical standpoint - that is, as the producer and the manufacturer look at it - there are five types 
of raw cotton. These are Amcrican upland, sca-island, Egyptian, Indium, and Pcmizun. There are other kinds, but they are of less importance. It should be remembered that man has been able to improve the types of cotton, as he has improved other plants, by breeding and crossing the varieties.

Amcrican upland cotton. This is the kind that is commonly grown at the present day in the United States. Consequently, it is the variety that appears to the greatest extent in the world's cotton trade. This variety was not native to America, but is supposed to have come here from Europe, and to Europe from Asia.

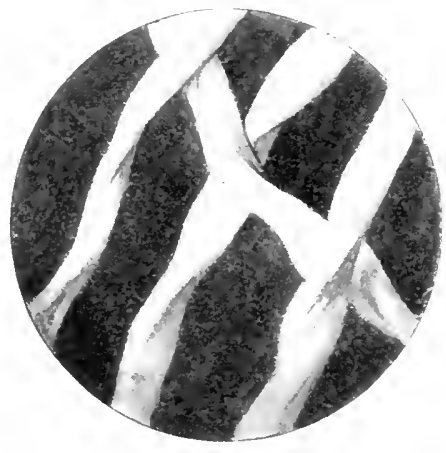

CuTTON

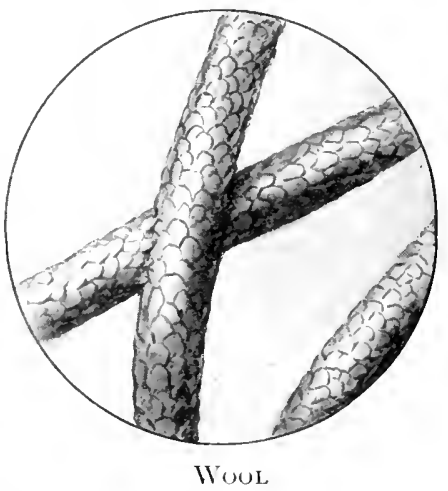

WUUL

Fibers of cotton and wool, greatly magnified

Upland cotton is now grown in other countries than the United States, as India and Persia. It is also grown in our island possession, l'urto Rico. It has a fiber of medium length, that is, longer than that of Indian or Brazilian cotton, but shorter and coarser than that of the sea-island variety.

Sea-island cotton. This is the best type of cotton, from the standpoint of trade, to be found anywhere in the world. Its fiber surpasses that of all other varieties in length and fineness, which accounts for its value.

This plant was a native of the New Wrord and is sometimes called "Barbados cotton," but we do not know just where it grew wild before it was cultivated. Some writers say in Mexico, others 


\section{COTTON - ITS ISSTRIBUTION ANI CLLTLRE 233}

in the Nest Indies. The rery best of this cotton is grown on the sea islands along the coast of South Carolina, but much of it is raised on the mainland, in feorsia and Florida.

Compared with other varicties, only a little sea-island cotton is grown. For many years the average annual production was under

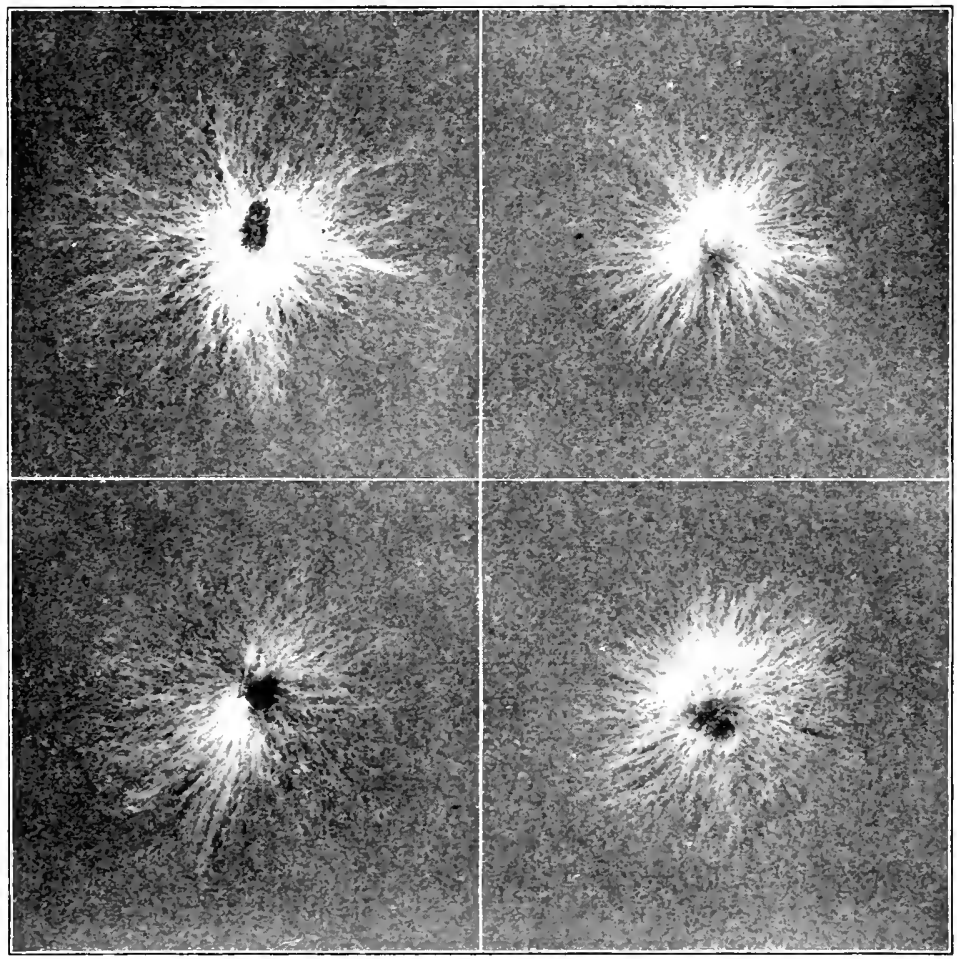

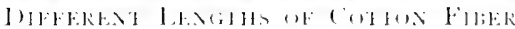

Sea Island

Egrptian
Lplind

ligyptian

a thousand bales; that is, less than a hundredth of the totil cotton crop of the L'nited States. In an ordinary year fierregia produces about 50,000 bales of sea-island cotton ; Florida, 3,.000; and South Carolina, I I, ooo. Sea-island cotton is so highly prized by cotton manufacturers abroad that a large part of our crop is exported. 
Iigrptian cotton. The cotton plant has been grown in Egypt a long time, but what is now called Egyptian cotton is not native there. It was introduced into that country about I 820 , and is generally believed to have been derived from the sea-island type of our country. In commercial value Egyptian cotton stands midway between sea-island and the best American upland. It is of great use in the manufacture of hosiery and mercerized goods. We import Egyptian cotton to the value of \$IO,ooo,ooo every year.

Indian cotton. This type is a native of southern Asia. The bolls are small and nearly round, and the fibers are coarse and short, ranging from a half inch to an inch in length. It is not so good as American upland cotton, and is used for coarse yarns and for mixing with other varieties of fiber.

Pcruian cotton. This type is often called "kidney" cotton because the seeds in each of the three divisions of the boll stick together in a mass which looks like a kidney. The fiber is not very good, and varies greatly in color, ranging from white to brown. In some cases it looks like wool. We import some of it into this country and use it chiefly for mixing with wool.

\section{The Cultivation uf Cotton}

Climatic conditions. Temperature. We have already shown that cotton is a warm-climate crop, grown widely between $40^{\circ}$ north and $30^{\circ}$ south latitude. But, within this area, the question as to whether cotton can be produced in paying quantities depends upon various factors of climate, such as temperature, rainfall, and sunshine. The cotton plant is not a hardy one. It is very sensitive to frost. Its growing season is long, and there must be a warm, even temperature during this period. A few days of cold will make the plant "fruit" too early. As it approaches maturity it is better to have cooler weather, because this will bring about fruiting and ripening at the proper season. About one hundred twenty-five days elapse between the time of planting and the opening of the first boll.

Where the climate suits the cotton plant best, there is an increase of temperature day by day from planting time on through July and 
even into August. Then the heat begins to decline, so that there are really two periods of temperature in the life of the cotton plant. If it is not in full growth during the hotter period, as it should be, and encounters sudden changes of weather, its development may be checked. Anything which tends to ripen and open the pods prematurely is bad for the crop.

Frosts are the great danger. For the best production, killing frosts should not come later than the first of April, nor earlier than the first of November, and if the interval between killing frosts can be longer, so much the better. In the northern regions of the cotton belt killing frosts are liable to come as late as the fifteenth of April and as early as the middle of October, and so successful cotton culture must come between these dates.

Sunshine. It takes from six to seven months to raise a good crop of cotton, and plenty of bright sunshine seems to be almost necessary to produce fiber of first-class quality. Thus the plant cannot be grown successfully in a region where there are many cloudy days every month.

Rainfall. In order to produce cotton successfully, the rainfall must be plentiful during the growing season. And it is unfortunate if the rains come all at one time; they should be pretty evenly distributed. But cotton requires dry weather during the ripening period; and when it is being picked, the fiber is likely to be injured if there are heavy rains or long-continued periods of dampness.

The cotton planter finds that certain conditions bring about results that are easily foretold. If the season is dry, there will be a small crop; but if it is very wet, while there will be a large crop. its quality will not be good.

Soils. If the climate is favorable, it is possible to grow good cotton upon a great variety of soils. I Iowever, the character of the soil seems to have an influence upon the nature of the fiber. Sandy soils are likely to give the smallest yield, but they will usually give some return, even though it is a small one, in seasons when the climate has been somewhat unfavorable. A soil containing silty clay is apparently the best for cotton production. 
In the Lnited States the best regions are found along the "bottoms" of the Mississippi. These are strips of land on the left or eastern bank of this river, which are at times inundated. Again, there is the "black belt" of Alabama, which runs across the state from east to west and is an excellent place for producing cotton.

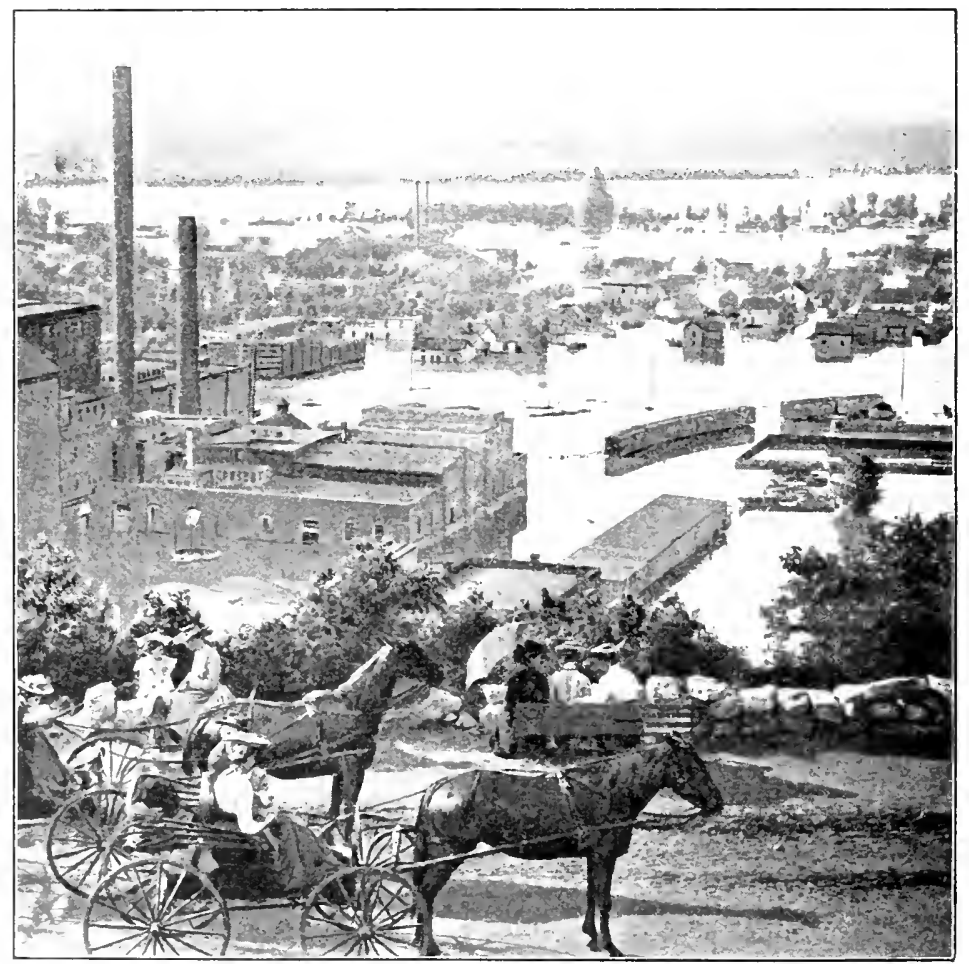

FL(m)L BOTTUM LANDS

Most of the sea-island cotton is grown on soil known as " Norfolk fine sand," which differs in some degree from that upon which the best types of upland cotton are grown.

Lpland cotton seems to grow very well where the soil is rich in lime. The cottom which is grown on some soils is more likely to be diseased or to be attacked by insects than that which is grown 
elsewhere. It is hard to explain why this is so; it is simply known as a matter of experience.

Planting. It is common in this country to practice bedding or ridging the land before planting the cotton seed. The distance between rows is from three to five feet, and if the soil is very fertile, the distance should be greater. As a general rule, fertilizers are put in the furrow before ridging takes place. The seed is put into the beds by a machine drawn by a horse or a mule. In southern Texas planting begins the latter part of February, while in the Carolinas it is not completed before the middle of May. The plants come up in from four to ten days, and cultivation, either by means of a hoe or a cultivator, begins soon after this.

Fortilizers. The use of fertilizers in cotton growing has come to be regarded as necessary, and it is fair to say that the cotton growers are well paid for using them freely. The reason why it is so necessary to use fertilizers in the growing of this crop is that the cotton robs the soil of important chemicals, which are really plant foods. The plant needs more food to produce its seeds than it does for its fiber. It is said that the chemical elements needed for the cottonseed in one crop would suffice for the fiber of ten crops. However, much of the cottonseed returns to the ground in the form of fertilizer.

Cottonseed oil is pressed from the cottonseed; what is left is called cottonseed cake. This cake is a very excellent and cheap fertilizer ; it can be used as manure by applying it directly to the ground or it can be fed to animals that are kept in cotton fields. It is an especially rich and nutritious food for stock, causing cattle to fatten rapidly.

Cultivation in India. The region in India where cotton is grown chiefly for export is in that part of the Dekkan which lies behind or to the east of the western Ghats. Here the rainfall is rather scanty because the moisture-bearing clouds are cut off by the mountains. In other parts of the country where cotton is grown, the rainfall is even scantier, so that there are large areas in the cotton belt of India where the fields have to be irrigated (see map on p. 228).

It is said that the principal places where cotton is raised in India have a temperature during the growing season which differs 
considerably from that of the cotton belt of the United States. For example, there is less bright sunshiny weather, and it is warmer during the early part of the growing season than in the latter part. Such facts may help to explain why the fiber grown in India is poorer than that of our Southern states.

The soil on the high table-land region of India is of excellent quality, especially for growing cotton, and is often spoken of as the "black cotton soil." Ne are told that it is so rich as to have yielded good crops for many centuries without fertilization. It contains a good deal of lime, which, as we have seen, is favorable for cotton growing. But the really important point regarding the soil is this : it has a wonderful capacity for holding moisture, becoming very muddy when it rains, but retaining the water so that it does not sink decp into the ground.

Cultivation in Egypt. Egyptian cotton is grown in middle Egypt, where the land can be irrigated during the growing season, and it is also raised in the delta of the Nile. Irrigation has been practiced in middle Egypt since very ancient times, but all that centuries of effort have accomplished does not compare with what the English have done within the last twenty years.

The whole life of Egypt depends upon the Nile River, which periodically overflows its banks and deposits silt upon the land. The Nile practically flows through the desert, but the soil of the desert, though very dry, is of good quality, and all that it needs is water. Therefore, when the river has been dammed up during the period of overflow and the waters have spread widely, a large amount of land has been made fit for cultivation. For almost a hundred years great efforts have been made to increase this area.

A dam was finished in I 86I, and atthough it was a poor affair, the outcome of its erection was that the cotton crop in I 884 was over five times as large as it had been in I86I. Still more attention was then given to irrigation, and the crop between I 884 and I 889 was almost doubled. Since then, waterworks to cost about \$I 25,000,000 have been in the process of building, and a great dam at Assuan, a mile and a quarter long and about one hundred feet thick at the base, was completed in I902. This 
dam raised the water level above it almost serenty feet, and formed a reservoir which holds water enough to furnish a year's full supply. for every town and village in the United Kingdom. Since that time it has been possible to carry on irrigation at all times of the

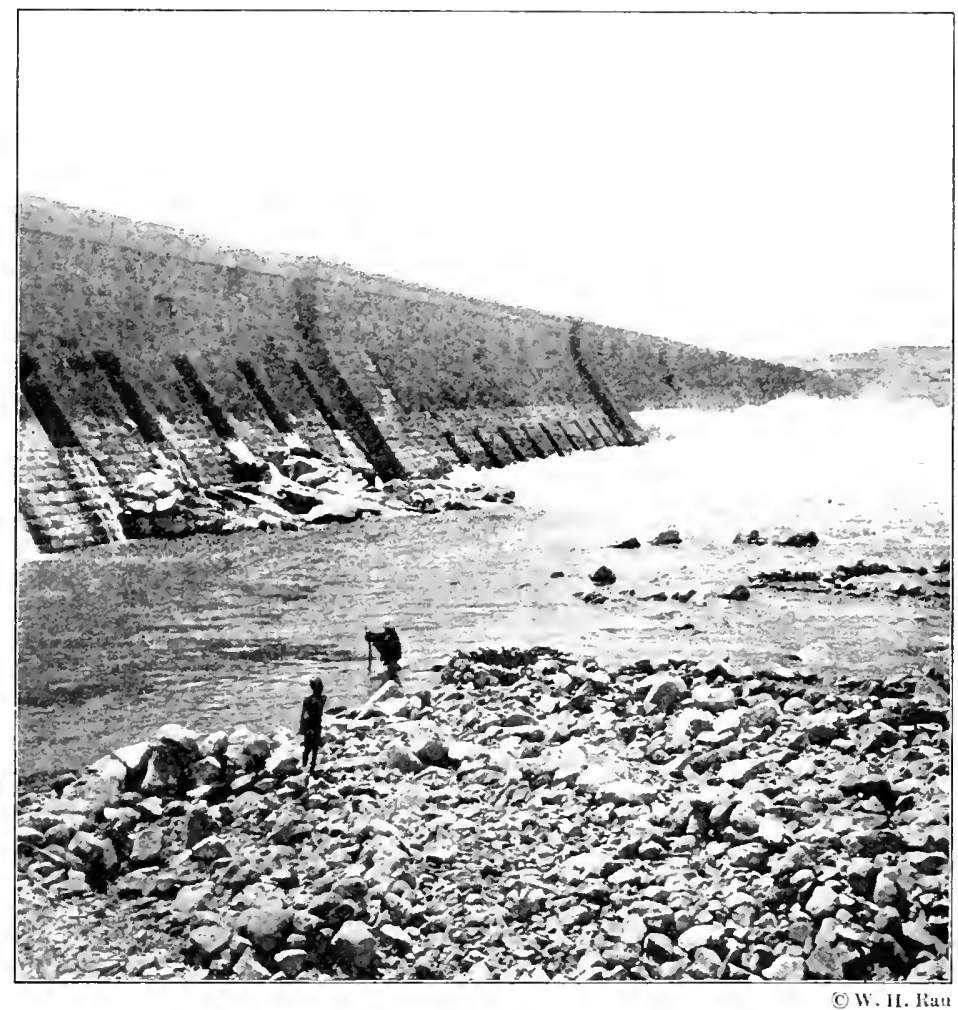

The Nile axis Assuax llam

year independently of the Nile overflow; and it is now proposed to go still farther along the same line. These great improvements have all been planned and carried out by the British.

A peculiar thing about the growing of cotton in Egypt is that the field may be entirely flooked from time to time without hurting the crop, whereas in the United States an excessive supply of 
moisture at any time is injurious. The reason why the crop may be flooded in Egypt without injury is that the atmosphere is so dry that evaporation takes place more quickly, and so an excess of moisture does not collect in the tissues of the plant.

We have seen that Egyptian cotton is of high grade. This is due, in part, to the fertility of the soil, and also to the peculiar climatic conditions. There is abundant sunshine in Egypt during the growing season, and the weather records throughout this period show remarkable uniformity.

Harvesting. Up to the present time cotton has been picked almost wholly by hand. Several machines have been invented to

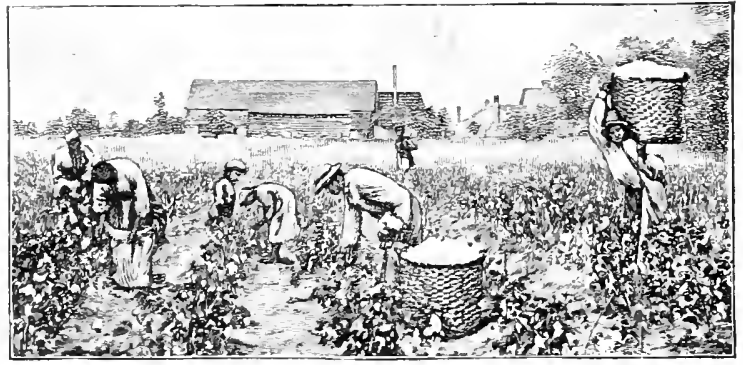

Picking Cutron on the Warm Southern l'lain do away with hand labor, but they have attained only a small measure of success. Cotton bolls do not all ripen at the same time. The use of a machine to pick off the ripe bolls so injures the plant that the bolls which are left will not ripen naturally. In an ordinary season cotton picking commenees about the first of September and does not stop until the first of January. In the warm section it may begin much earlier. If labor is scarce, the cotton will be picked only once rather than four times, which is the usual practice. In general, buth the best cotton and the largest yicld come from the second picking. The smallest yield is that from the fourth picking.

Cotton pickers get about forty cents for a hundred pounds of seed cotton, but sometimes the amount rises to one dollar. The pickers are, of course, unskilled laborers; and, in the past, they have generally been slaves. But though they cannot, even as free men, command high wages, yet the cost of picking is the largest item in cotton production. 
An average day's work would mean the picking of about one hundred pounds of seed cotton, and so it would take one and one half million persons four months to gather a crop as large as that grown in 1907.

\section{Preparation FOR U'se}

Ginning. When cotton is gathered it is carried to the ginhouse, where the fiber is separated from the seed. In the early history of cotton production this was done by hand. It was a difficult and

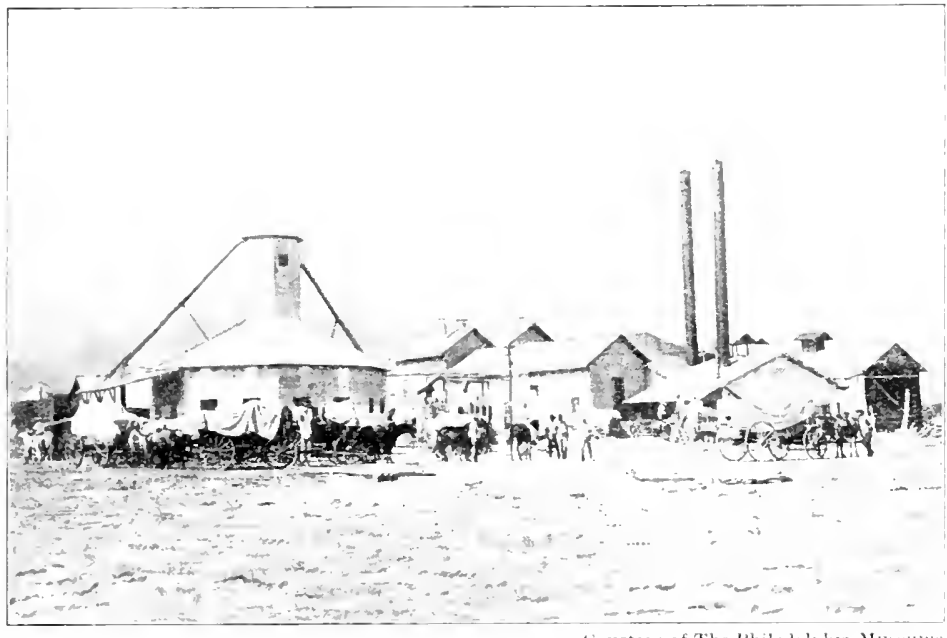

A CoTtux Gin IN Texis

expensive process. Evening after evening the whole family would engage in this tedious emplorment as its members sat around the fire. A pound per day was the amount that one person could clean in this way. About 1790 , the people who worked in the cotton fields were required to clean a certain amount of cotton per week, usually about four pounds, besides their regular work as laborers. There were simple machines in use in some places previous to the American Revolution, but these were not very satisfactory.

A successful machine for separating the seeds from the fiber, known as the cotton gin, was invented by Eli Whitney in 1794 . 
This gave so powerful a stimulus to the development of the cotton industry that the United States soon became the principal source of supply for the world's raw cotton. 'The machine has been greatly improved since Whitney's time. In using the modern cotton gin, the cotton is put into a hopper from which the revolving saws of the machine catch the fiber and tear it from the seeds. The seeds drop down through an opening, and the fibers are taken off the saws by a revolving eylinder with many rows of bristles on it. The

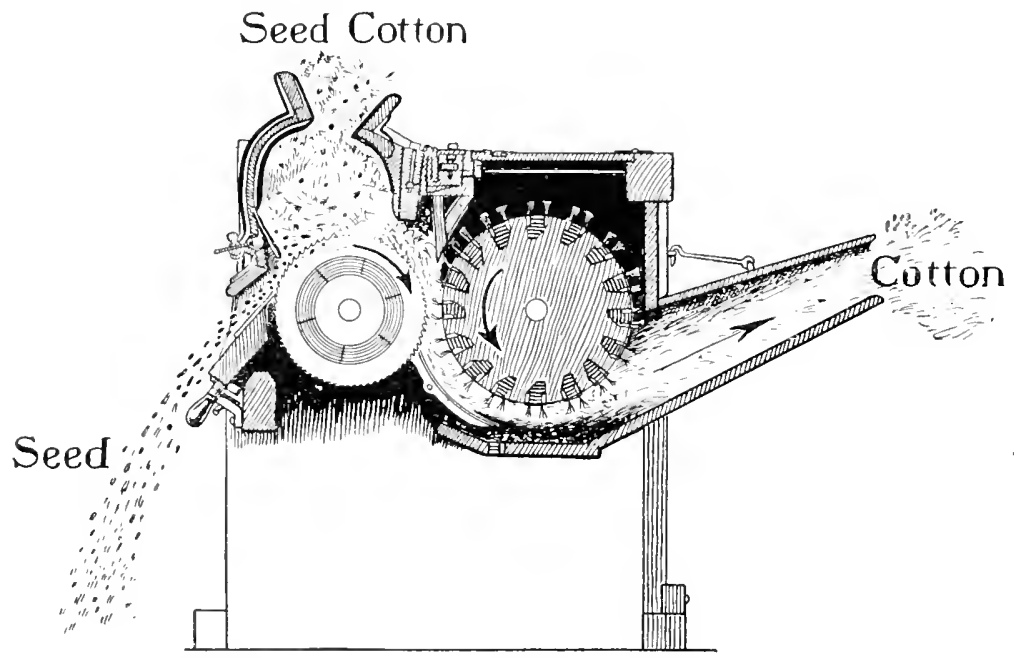

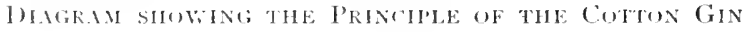

cotton fibers, thus set free from the saws, are moved on and worked up into a continuous sheet, which is earried to the cotton press.

Before the Civil W' ar a man who had fifty acres of cotton had his own gimning establishment. Mules were then used for the motive power. The cotton was hauled to the gimhouse, and human labor carried it to the platform over the gin stand and then into the gin. The seed dropped on the floor and was shoveled into a wagon and thrown away, because no one thought that it was of value.

Baling. The cotton lint is made up into bales before being shipped to market. In former times the lint, after the seeds were 
removed, was taken from the gin and dumped into a press box; then negroes trampled on it in the box until there was enough pressed together to make a bale. A screw press was next used to compress the lint until the desired size was obtained. Then this bale was inclosed in jute bagging and fastened with iron bands.

At the present time a ginnery is run by an eighty-horse-power engine and may have a daily capacity of two hundred fifty bales. The cotton does not have to be touched by hand at all after it leaves the wagon or bin until the bale appears upon a platform ready to be sent to market.

The bales are of about five hundred pounds each and are made according to a standard form by means of presses, which may be rum by water, steam, or animal power. The Egyptian cotton has commonly been put

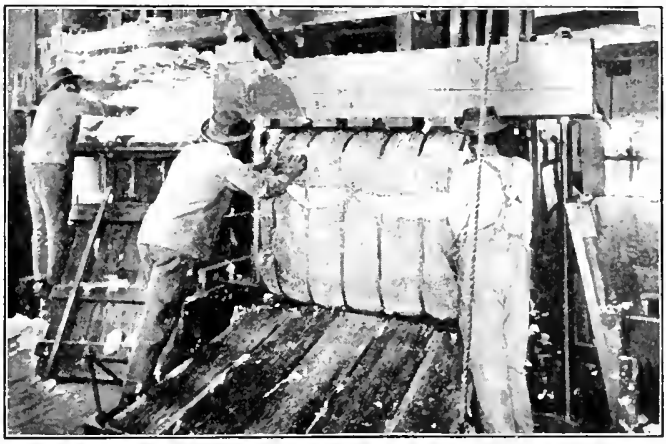

Courtesy of The Philadeiphia Muscuns

BALING COTTON BY MACHINERY

up into bales of about seven hundred fifty pounds each. These are bound by a coarse cover and are compressed so tightly that they are even smaller than the American bale, though they contain two hundred fifty pounds more.

Cottonseed. The cotton plant was first grown for the fiber, and is still grown chiefly for that product. It is only recently that the seed has been used for commercial purposes. It was formerly used to some extent as a fertilizer, but not largely even for that purpose. Often it was a great nuisance to the ginner, and was hauled away to some place to rot, becoming thus a danger to public health. But the introduction of the cottonseed mill has changed these conditions, so that now from the seed we get several food products for man and beast. A great business has grown up in connection with the use of cottonseed. 
Cottonseed oil. It is interesting to know that the Chinese were the first people to discover that there is oil in cottonseed. They were far ahead of the rest of the world in this discovery, just as they were in the invention of gunpowder, the compass, and the art of printing from movable blocks or type. Centuries ago they used to crush out the cottonseed oil and burn it in their hand lamps.

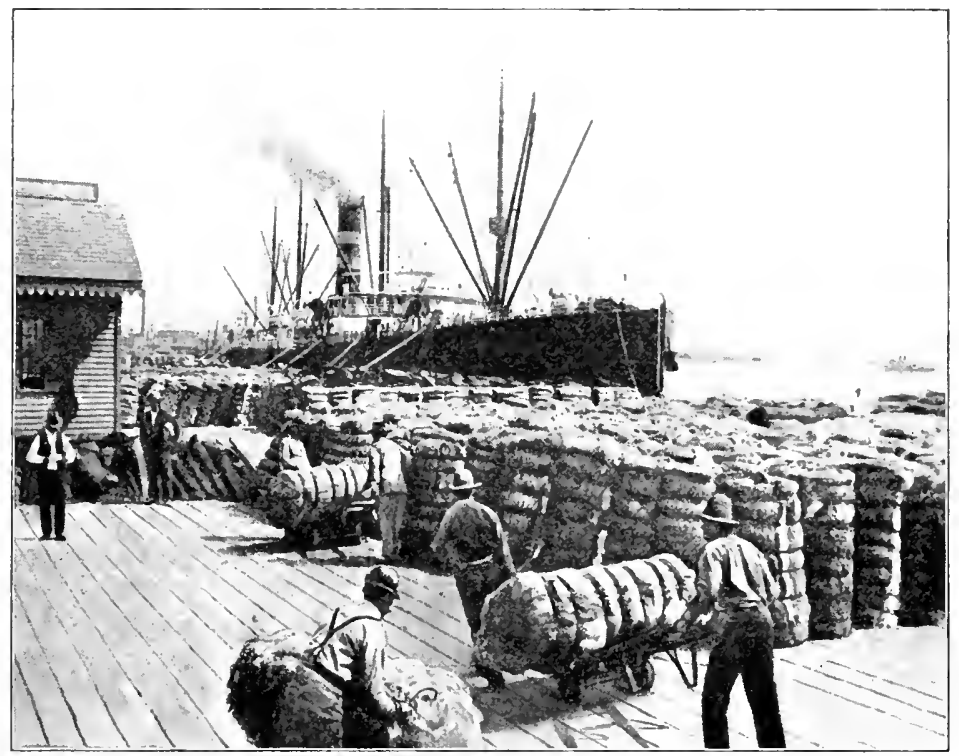

COTTON BALES REAUY FOR SIHIMENT

The English people seem to have been the first of western nations to make oil from cottonseed; in this country the industry dates from about I870. There were in I909 over eight hundred cottonseed-oil mills in this country, twenty-five in the United Kingdom, and a number in India, Egypt, Russia, and other countrles.

Oil mills. After the cotton has been ginned, the seed is sent to the oil mill, where it is re-ginned, to take off the "linters," or fuzz, which still remains on the seed. The next thing to do is to remove the hulls, for if this were not done, they would absorb the oil. Then the seeds are crushed with a pressure of about two tons to 
the square inch. The oil which is extracted is put into tank cars and sent to the refinery. Cottonseed oil is used in soap making and in cookery, and is frequently mixed with other oils (see diagram, P. 246$)$.

We now press in the United States about four million tons of cottonseed every year. The mills used to be very large, and were located at the railroad centers, because they collected the seed orer wide areas. But in recent years there has been such a demand for cottonseed products that there have been many small mills erected near the cotton fields, and these get their seed from the neighboring producers.

Cottonseed cake. The cake is what is left of the seed after the husked kernels have had the oil squeezed from them. When this is dried and pulverized it is known as cottonseed meal. The cake and meal are used chiefly for feeding stock, although they are also used in making fertilizers. They have almost as great a value in this country as the oil. It is said that flour made from cottonseed meal can be used to make bread, crackers, and other such foods.

The hulls used to be burned in the oil mills and their ashes used as a fertilizer. But some one found out that by mixing the hulls with cottonseed meal a good stock feed could be produced, and there is now so great a demand for this misture by stock raisers and dairymen that the husks are no longer used for fuel.

Use of by-products. It is clearly to be seen that there are many useful things about the cotton plant besides the fibers, for which it has been chiefly raised. One of the great developments in modern industry is the use of such products, which are known as by-products. Much that originally went to waste and was a great nuisance to the producer has now become of value and a source of profit. We have seen on a former page how important the by-products of the slaughtering industry have become; and if we took up the petroleum industry, we should find still more astonishing results. The more keen the competition between industries, the more necessary does it become to save in every possible way, in order to make profit. And as the processes of the industries are studied ever more carefully, in the effort to do better in both earning and 


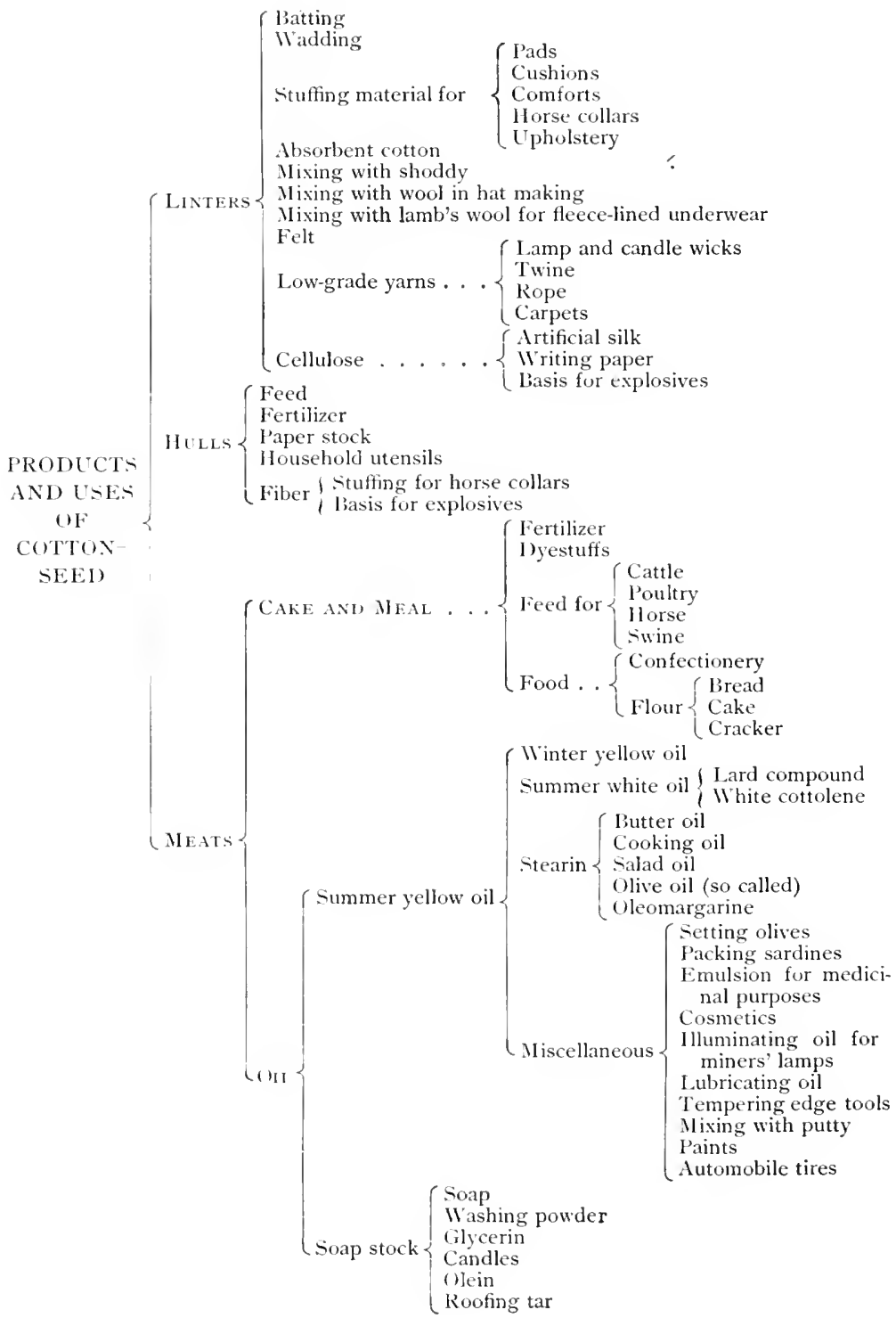


saving, more chances appear to make use of what seemed nearly valueless before. Some idea of the value of the cottonseed may be gained from a diagram made by the Census Bureau of the United States, as shown in Consus Bulletin No.III, reproduced on the opposite page. When we look over this long list of the uses and products of cottonseed, we can see how important to an industry may be the development of its by-products. Nor have we yet studied all the uses of the cotton plant, for pulp is now made from the stalks and is converted into a fine quality of writing paper. Cotton, in fact, is an excellent illustration of the tendency in modern industry to let nothing go to waste, but to find uses for what has hitherto been looked upon as of small value.

When we have studied the distribution and culture of cotton, we have hardly more than begun the subject. We must now follow the fiber as it is transported from the field and the gin, worked up into fabrics of various kinds, and finally delivered to the wearer. 


\title{
CHAPTER XII
}

\section{COTTON - ITS TRANSPORTATION AND MANUFACTURE}

\author{
TRANSPORTATION
}

It used to be the rule that every plantation of considerable size should have its own ginnery. These were often small and poorly equipped. Now large, well-equipped ginneries for general use have taken their places. After the cotton is picked it is taken to a great public ginnery in wagons holding fifteen hundred pounds or more. This is ginned and baled at the cost of about a dollar a bale. The owner of such bales may then, perhaps, sell them to a cotton buyer, in which case they are stored in a large warehouse. Such warehouses are likely to be located in railway towns, so that the cotton buyer can quickly make his shipments.

The cotton grown in our Southern states is sold for one of three purposes: (I) it may be used in the cotton mills which are now becoming common in the South; (2) it may be sent to the cotton mills of the Northern and Eastern states ; (3) it may be sent abroad.

Transportation routes. The cotton which is to go to some point in the United States - for instance, to the New England mills is sent either by rail directly to the places of manufacture, or by boat to the most convenient port. That which is to go abroad is likely to seek the nearest large city on the Atlantic or Gulf coast. The cotton of Texas goes to Galveston as a point of concentration and distribution. That of Louisiana, Mississippi, Oklahoma, Tennessee, Arkansas, and adjoining regions is concentrated at New Orleans, mainly by way of the Mississippi and its tributaries. The cotton grown in Alabama and other states of the south Atlantic coast is likely to be sent by rail to some such port as Charleston or Savannah. Thus a large proportion of the cotton is concentrated at the chief seaports of the South. 
Cost of inland transportation. A large item in the cotton business is the cost of transporting the raw material from the farm to the local market, and from this market to the place of manufacture. The United States Department of Agriculture has reckoned the average cost of transportation from the farm to the final point of destination to be so cents a bale.

Of the cotton arriving at Galveston, nearly three fourths is brought by rail at a uniform rate, which, in I906, was 55 cents per

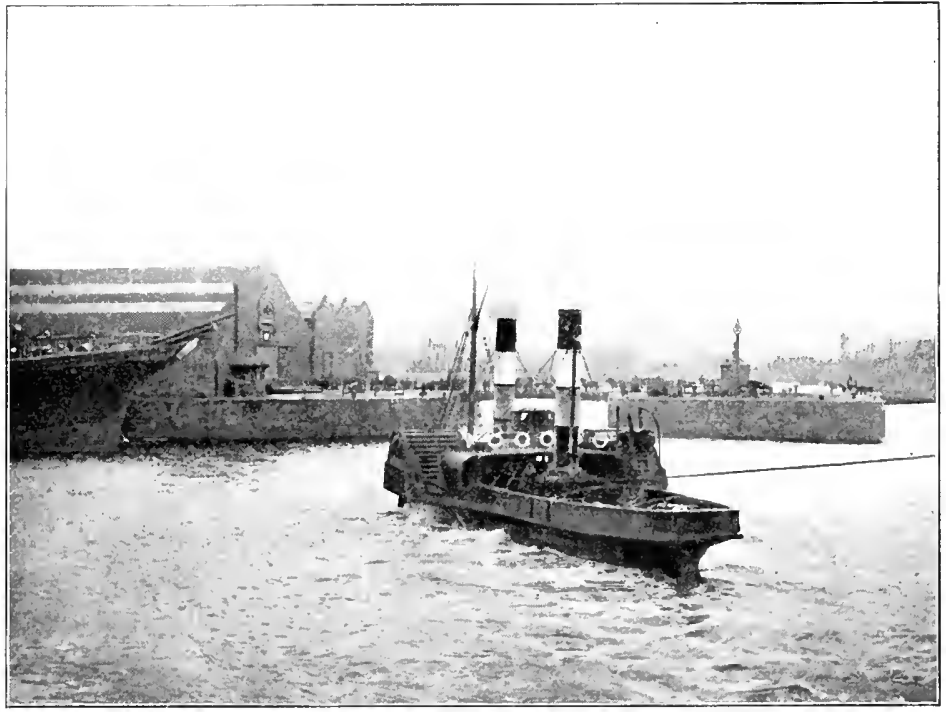

DoCKS IN LIVERPOOL

hundred pounds. The same rate applied to i I 8 out of I 88 counties in Texas which produce cotton. The rate from Olilahoma to Galveston in 1905 was about 72 cents a hundred pounds. The railroad rate from more than seven hundred points in Mississippi, North Carolina, South Carolina, Georgia, and Alabama, to New York was 54 cents a hundred pounds. This rate on cotton sent to New York was from 20 to 25 cents higher per hundred pounds than on similar shipments to New Orleans and Savannah. 
Coastwise transportation. While some of the cotton is shipped to New York and New England by rail, a large part of it goes by boat. On this the usual rate from Savannah to New York is 20 cents a hundred pounds.

Cost of ocean transportation. The average ocean freight rate from the United States to Liverpool has been about 32 cents a hundred pounds. If we add to this the average railway rate from the local shipping points to all seaports (40 cents a hundred), and also the average rate from farms to local shipping points (about I6 cents a hundred), we see that a fair estimate of the cost for moving the cotton from the farm to Liverpool is about 88 cents a hundred pounds, or $\$ 4.40$ for a five-hundred pound bale. This does not include warehouse or terminal charges.

Location of cotton factories. In this country the chief seat of the cotton-manufacturing industry has always been New England. Again and again in this book we have seen why New England is especially fitted for the manufacture not only of cotton but of other materials as well. However, within recent years important cotton-manufacturing-establishments have developed in the South, and much of the raw cotton is now manufactured very near where it is grown.

In 1880 there were only I6 I cotton manufactories in the South, but by 1904 the number had increased to 550 . Massachusetts is still the leading cotton-manufacturing state, but in recent years South Carolina has come to take second place. Rhode Island ranks third, and North Carolina and Georgia are fourth and fifth.

\section{Processes of Manufacture}

Two different sets of processes have, as a rule, to be gone through in order to make any kind of cloth. In the first place, the thread or yarn has to be spun by combining the fibers, and of course the fiber has to be prepared in some way before spinning is done. In the second place, the thread or yarn must be woven into cloth.

Perhaps cottonseed was used for food long before people learned to make the fiber into cloth; nevertheless spinning and weaving 
were familiar processes in very ancient times, and must have been among the earliest arts of the human race. At first they were done by hand, or at best with the assistance of some very clumsy tool. In some parts of the world where people are only partially civilized these rude devices may still be seen.

Spinning. The simplest way of making thread was to roll the fibers of cotton, flax, or other material between the thumb and finger. In the stories of the Scandinavians, one of the Norns, or Fates, is supposed to spin the thread of men's lives, and the thumb of this Norn is represented as being very broad and flat as the result of constantly rolling the thread. I ater, among some races, spinning consisted in rolling the fibers into thread on the bare leg with the palm of the hand. Of course, these were the first processes, and the thread thus made was very crudc.

The spindle. The

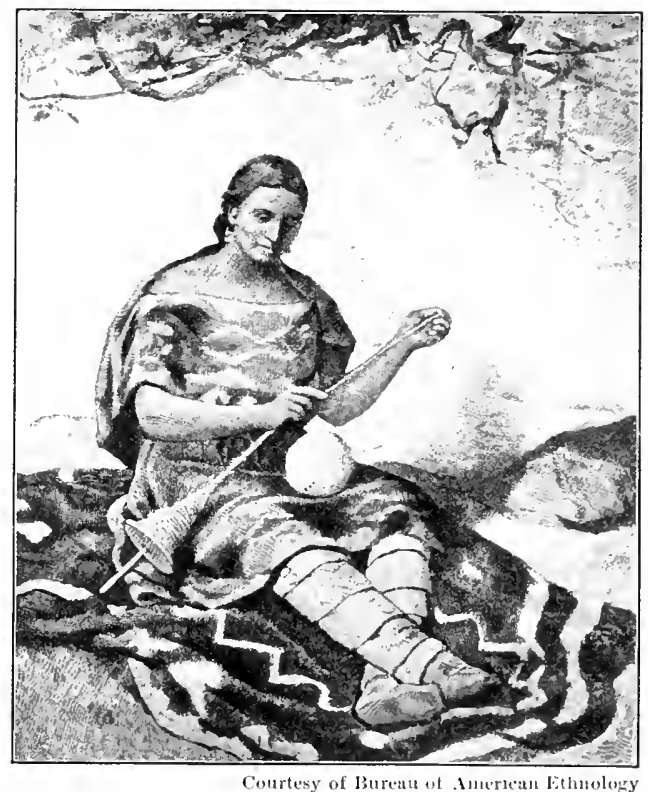

INDIAN WUMAN USTNG; SPINILE spindle was the first tool used in spinning, and was made of a disk of stone with a hote in the middle into which a stick was fitted, the whole looking somewhat like a top. The threads were attached to this instrument, and when it was whirled they were twisted together. The illustration represents an Indian woman using a spindle.

Distaff and spindle. A distaff and spindle form a combined machine, which also is very simple and crude. The distaff is a 
sort of forked stick upon which a bunch of prepared cotton is placed, and the fiber is made into a thread by twisting it with the thumb and finger. The thread is then wound on the spindle.

The spinning wheel. This was an advance upon the earliest methods, and was commonly used in this country by the early settlers and their descendants for spinning wool. There are people living to-day who remember when the spinning wheel was to be seen in nearly every household in the country districts. It is

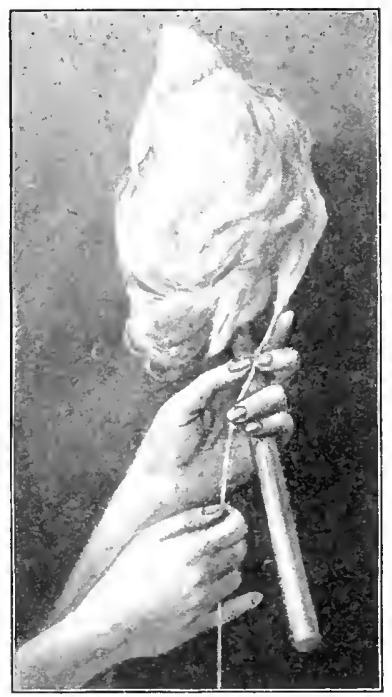

DIST.AFF seldom used now except in very backward sections, and is to be found chiefly in museums.

Although the spinning wheel was used chiefly in the manufacture of wool and flax threads, it represents an important step in the development of spinning, and so the method of its use will be briefly described here.

After the wool had been taken from the sheep's back and thoroughly washed to cleanse it from grease and other impurities, it was combed, or " carded," to disentangle it and to make it smooth for spinning. At first this was done by hand, but carding machines were afterwards invented. The wool was then in the form of soft and fluffy rolls, which were several feet long and less than an inch in cliameter. They were taken in bundles from the carding mill and were worked into yarn on the spinning wheel, as shown in the illustration.

To reduce these rolls to thread it was necessary that they should be twisted a good deal. They were so soft and fluffy that a roll considerably thicker than a pencil could be twisted down to the size of yarn. The purpose of the spinning wheel was to provide a rapidly revolving bar, to one end of which an end of the roll could be attached. Then if the spinner held the other end of the roll and the bar 


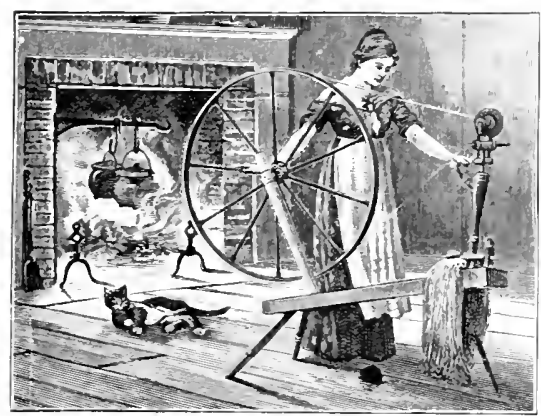

SPINNING WHEEL

was revolved, the roll would be rapidly twisted. The spinner could make a thinner thread by pulling out the roll as it was being twisted.

The spinning wheel consists of two wheels, one very large and the other considerably smaller: the axle of the latter is extended so that the roll can be attached to it. This smaller wheel and its attachments form the spindle. The two wheels are connected by an endless cord, and, of course, when the large one is set in motion, the small one will revolve a great number of times while the large one is going round once. The person who was spinning would revolve the large wheel with her right hand, and with the left would hold the roll which was attached to the spindle. The rapidly revolving small wheel would quickly twist the roll into a yarn, which would be wound on the spindle. When the roll was nearly used up, another would be attached to the end of it and the process would go on. By stretching the rolls each one would make several times its length of yarn. When the spindle was full the varn was unwound and made into a skein.

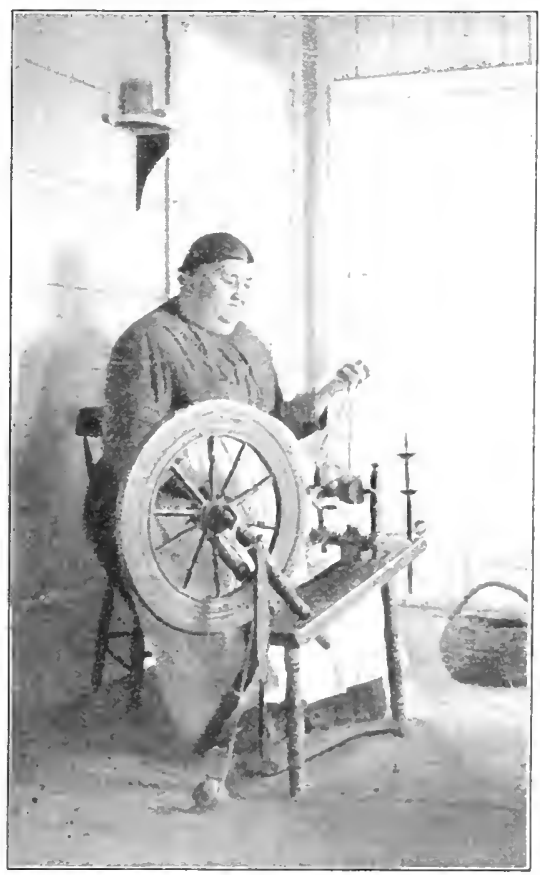

Plutorraph by bibth s. Watron FLAX WHEEL 
Where the spinning wheet originated is not known, but it was reinsented in Europe in the sixteenth century. Before the great mechanical inventions connected with spinning and weaving were made, it was in common use in most European countries.

The spinning jenny. As late as I 764 the best device for spinning could spin only a single thread at a time. But in that year an Englishman named Hargreaves invented a machine known as a spinning jenny. By its use one man or woman could spin

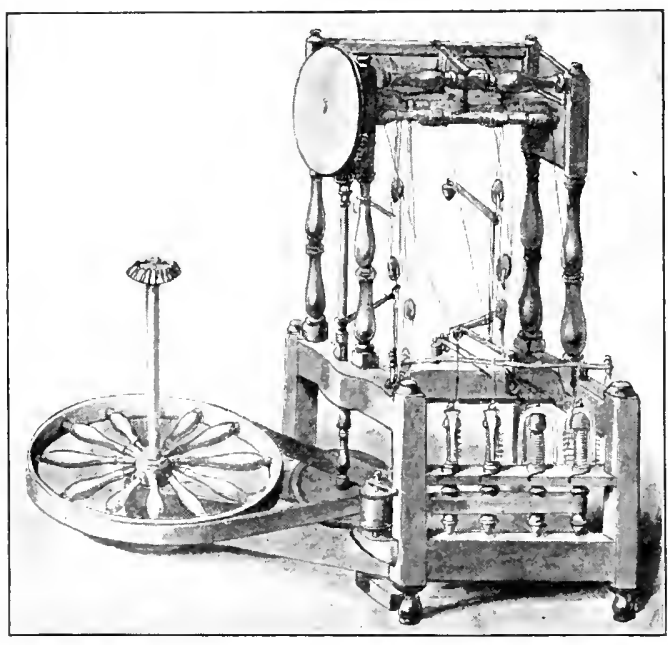

WATER FRAME

a number of threads at one time. The machine was patented about I770; and when once its principle had been worked out, it was only a question of time before a still greater number of threads could be made. It is almost impossible to describe the workings of the various spinning and weaving machines without elaborate diagrams, such as can be seen in the Encyclopedia Britannica and other standard books of reference.

The water frame. The next improvement came in I 769, when Arkwright patented a machine called a water frame. Up to that time it was impossible to spin cotton thread or yarn which was strong enough to make the warp of cloth. The warp of the cloth is formed by threads which run all the way through it in straight lines, and across which the woof or weft is made by carrying other threads over and under (see page 258 ). Of course the chief strain would come upon the threads of the warp, for they would have to stand all the pulling and friction during the weaving process. 
The throstle. Arkwright's invention made cotton threads strong enough for the warp, and it soon replaced the linen threads which had been used before. His machine was called a water frame because water was used as the motive power. The water frame was later much improved, and in this bettered form it came to be known as the throstle.

The mule. In 1776 Crompton invented a machine called a mule; this was patented in 1779, and combined the best features of the spinning jenny and the throstle. Then a man named Kelly invented a self-acting mule in 1792 , and others improved upon it, until by 1825 it had come to be used very extensively. The cotton-manufacturing business in Great Britain, where these inventions originated, was greatly changed by them. The spinning wheel, which had been in every cottage, fell into disuse; and since these new machines were better adapted to the factory than to the home, spinning began to be done in factories and ceased to be a home industry.

Ring spinning. Among the devices for spinning cotton, a later invention was what is known as the ring-spinning frame. In I 832 this machine was put into use in the United States, but it was not until the latter part of the nineteenth century that it became common in Great Britain. In some lines of manufacture mule spinning seems to be the best method, while in others ring spinning is more economical and profitable. The mule is in common use at the present day as the standard spinning machine. When it was first invented only a few threads were spum at one time, but to-day the spinning mule has more than a thousand spindles, all of which are operated by one person.

Weaving. The earliest weaving of which we know was done not with thread but with cane or rushes, in the making of mats and baskets. In weaving a basket the general form was made with larger sticks or ribs; then the reeds or strips of cane were woven over and under, as they are in similar baskets nowadays. In the caning of chair seats, first of all, canes are stretched from side to sicle and from back to front; other canes are then woven over and under the warp made by the original canes. 
After people had learned how to make yarn or thread, the same thing was done with threads which had been done with cane or rushes. A number of threads were attached to a beam, which sometimes, in warm countries, was a low branch of a tree, and these threads were all tied to a heavy stick at the bottom, so that they hung straight and a very short distance apart. Then the weaver passed a thread horizontally in and out among the perpendicular threads, going back and forth across the whole line of them, and pushing the cross threads tightly against each other with

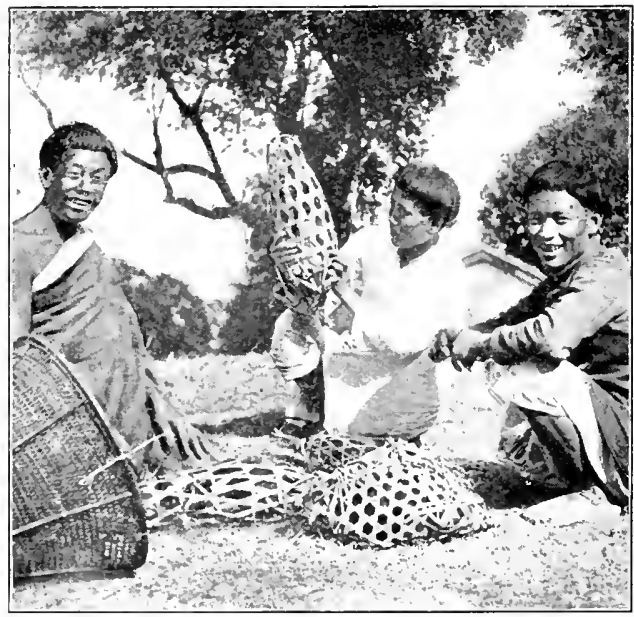

BASKET WEAVING

a stick. This was a very slow process, and when it was done, unless the greatest care had been taken, the weave was loose; that is, the threads were not firm and close, as they are in our modern textiles.

\section{The loom and shut-} tle. This was the foundation of all weaving, and the operation to-day is merely the same thing better done. If you look at a piece of cloth, or pull it to pieces, you will see that there are two sets of thread which run across each other, and that the cloth is formed by the lacing back and forth of these threads. The formation of a cloth or fabric by this process is known as weaving, and it is in principle the same process now that it was thousands of years ago. The machine used for weaving, whether it is simply a couple of beams with the threads extending between them, or whether these beams are made into a frame, is known as a loom. In orcler to cause the cross thread to pass more easily over and under the original threads, it was attached to a sort of needle called 
a shuttle, and the same name is still used for the much more complicated instrument which now performs the same function.

The hand loom. Improvements were added from time to time, and after a while there was developed what was known as the hand loom, where all the processes were more easily carried out, and where treadles enabled the operator to use foot power for some of them.

\section{The flying shuttle.} About the middle of the eighteenth century a man by the name of Kay invented the flying shuttle. This instrument enabled the weaver to produce about twice as much cloth in a day as he had been able to make before.

The power $100 \mathrm{~m}$. The inventions in spinning which we have just described stimulated an improvement in the looms, for the spinners could turn out yarn very much faster than the weavers could

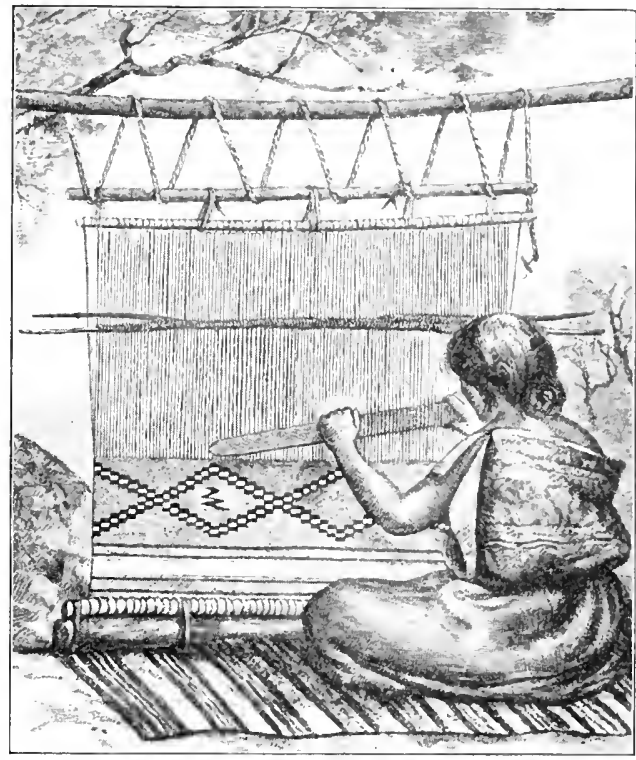

Courtesy of burean of Amerean Ethology

NAVAHo WoMAN WEAYNG

use it up. The improvement cane through the invention, by Cartwright, of a power loom, which was patented in 1785 . It was some time before this machine was sufficiently improved upon to make its use practical, but after a while power looms took the place of hand looms, for they proved themselves greatly superior. This hit another hard blow at the domestic or cottage industry, for the power looms were most easily run in factories. Much miscry resulted in England when the hand-loom weavers tried to compete with those who used the power looms. The change from 
25S (OMMERCIAL ANI) INDUSTRIAL GEOGRAPHY

handicraft to machinery was accompanied by terrible machinebreakine riots, which could only be put down by military force.

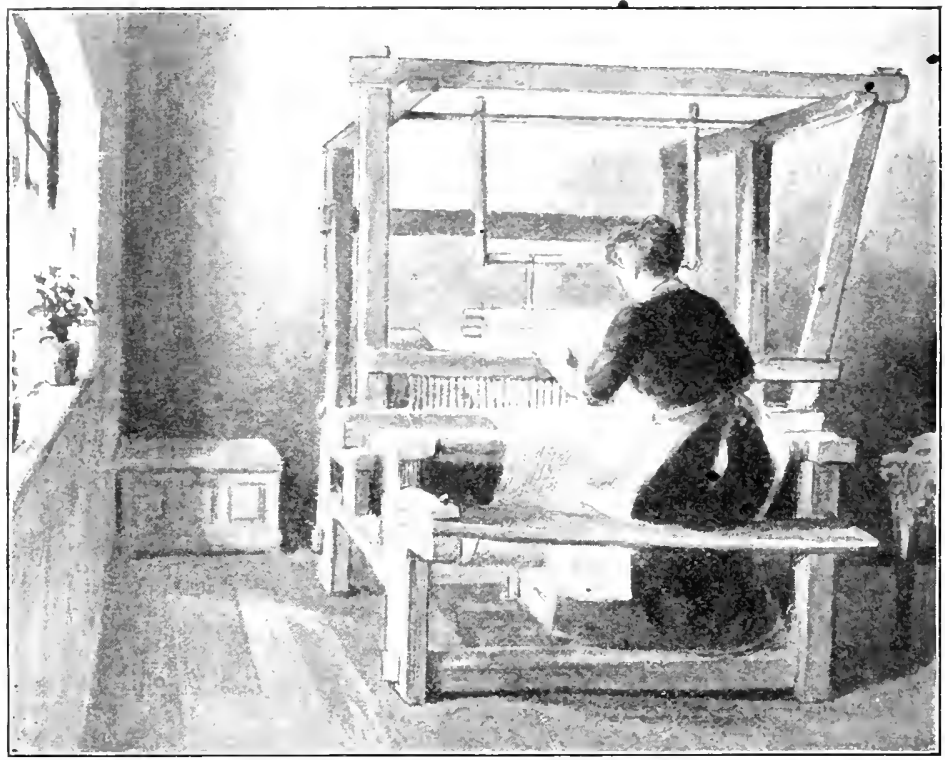

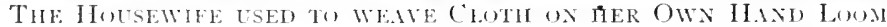

Mercerizing. This process has become common only within the last twenty years or so. It derives its name from an Englishman,

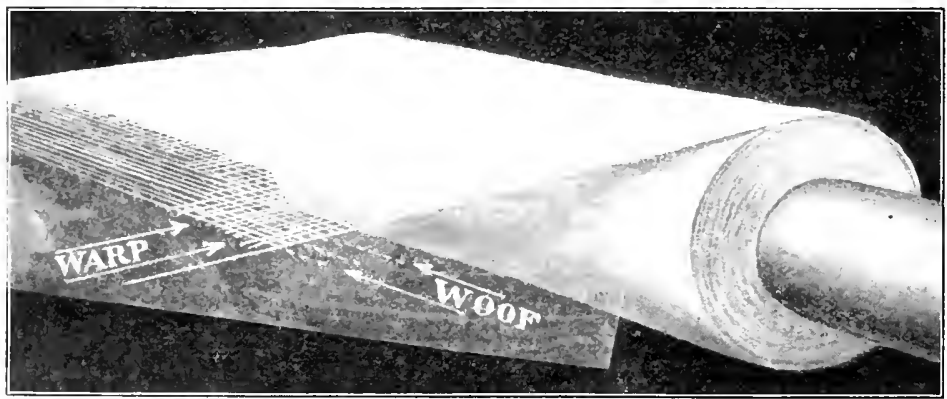

The Warp runs the Length of the Cluth and the Woof goes across 
John Mercer. Mercer was a hand-loom weaver, who later worked in a print establishment, and who became interested in chemical processes there. He brought out several new styles in calico printing, and was the inventor of the blue-print photographic process. His mercerizing process was patented in 1850 , but, like many other important inventions, it was not worked out successfully during the lifetime of the inventor.

The process may be applied to number of fabrics, but we shall describe it as applied to cotton. Cotton yarns or woven goods are treated to the action of caustic soda dissolved in water, and a weak solution of sulphuric acid is then applied to wash out the soda remaining in them. This process is said to bring about a number of changes in the make-up of the fabric. Mercer asserted, in applying for his patent, that the yarn or cloth after being sulb-

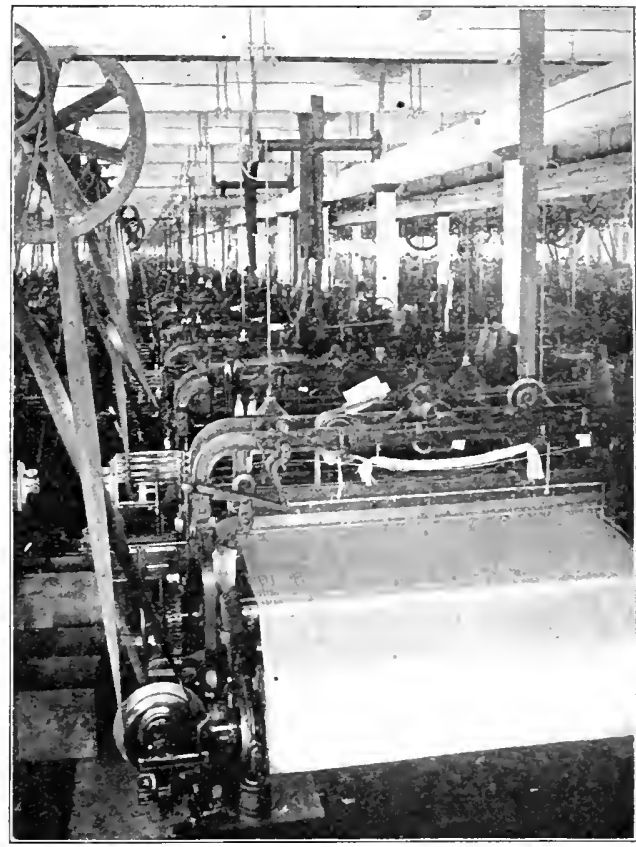

(c) Cnderwod \& I nderwoot

WEAYHg KUOM IN A LARGE MILL jected to his process

would be stronger than before, and would more easily take dyes; but the final success of the invention was not due to these advantageous results.

Mercerizing is now used chiefly to make the surface of the material smoother, and to give the yarn or woyen fabric a luster like that of silk. In the earlier day's of mercerization it was noticed that the goods so treated had a glossy appearance, but it is only recently 
that the commercial value of this fact has been recognized and the process revived. The method of procedure is a simple one, but it has to be carried out with great care. The goods are kept under tension, and the application of the chemicals must be very skillfully made.

Many articles are now made of mercerized cotton. Up to this time the process has been applied most successfully to the types of cotton which are naturally somewhat silky, such as the sea-island

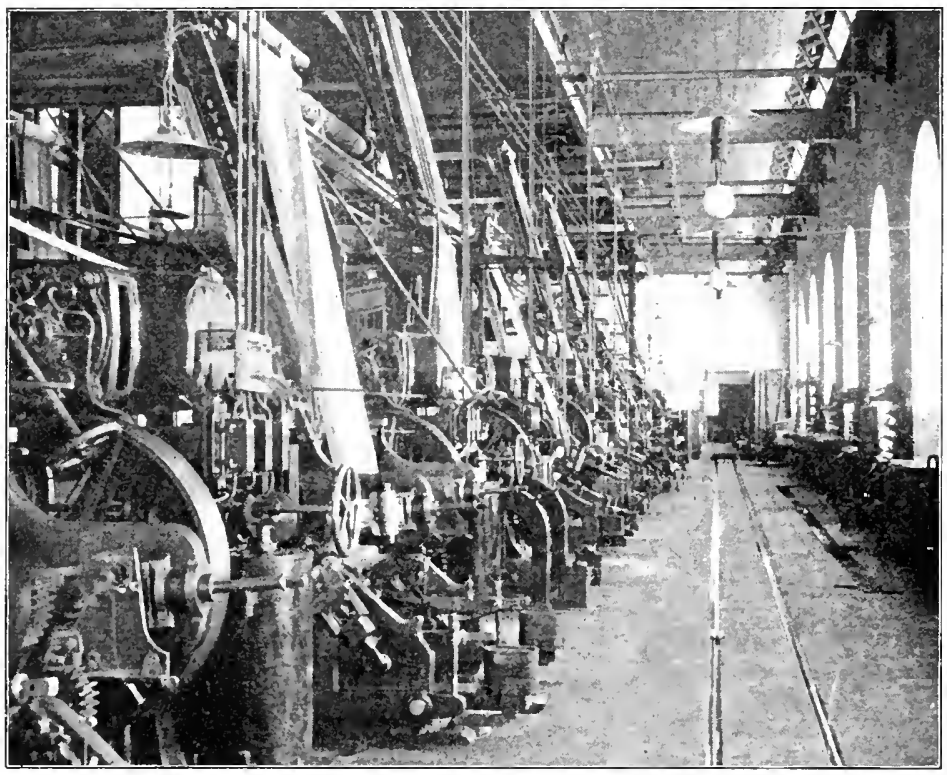

(C) Keystone View Co.

P'RINTING Room in a Mexican CotTun Mill

and the Egyptian fibers. Of course, if cotton can be made to look like silk, it not only acquires greater value as a separate fabric, but cotton fibers can be easily used to adulterate silk goods.

Dyeing and finishing. The dyeing and finishing of cotton goods is not, strictly speaking, one of the processes of textile manufacture, but it is a common practice in this country to do not only the spinning and wearing, but the dyeing and finishing also, in one establishment. The census figures show that more than half of the 
cotton goods woven in our mills are colored, either by printing or by dyeing, before they are used. The dyeing and finishing industry in this country is mainly a man's trade. As late as 1905 four fifths of the workers in this industry were men, although the proportion of women and children was increasing slightly.

The dyestuffs used in coloring fabrics and yarns come from all parts of the world, and the number of them has greatly increased since early times. There are vegetable, animal, and mineral dyes. One of the chief regetable dyes is indigo. Perhaps the most important animal dye in all history has been the famous "Tyrian purple," derived from a Mediterranean shellfish. In the Bible a man clothed in "purple and fine linen" is thus shown to be rich or of high rank. Under the rule of Rome this costly dye was reserved for imperial use. Hence the

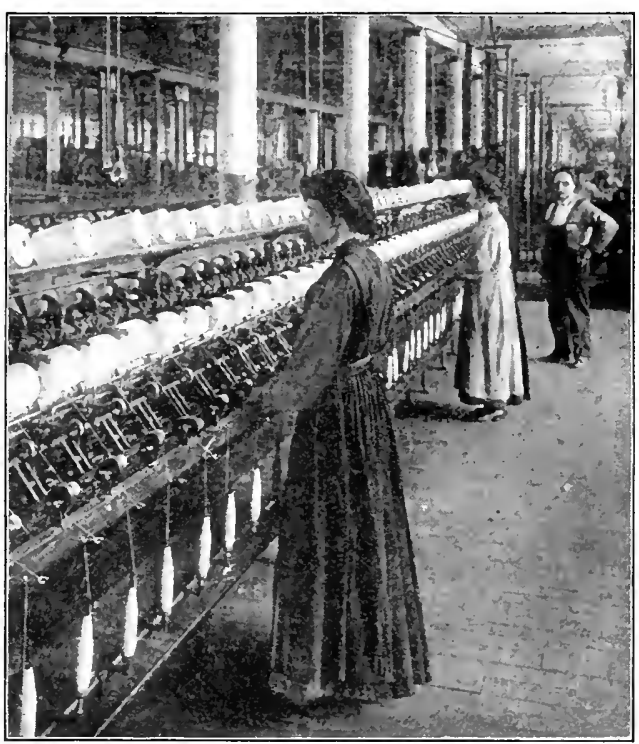

(c) ['nderwoud \& L'nderwom] WINUING IN A LARGE WOOLEN MII.L phrase "to put on the purple" means to become king or emperor. Some of the most common dyes of the present day are made from a by-product of coke manufacture known as coal tar. These dyes are very cheap because they are the by-product of a business which is profitable enough without them. Coal tar is nothing but a thick dark liquid which gathers in gas pipes when the gas is being taken from the coal, and yet this dirty-looking liquid can be combined with certain chemicals and used in making the most beautiful of colors. 
Sometimes the dyeing is done before the spinning takes place; sometimes not until after the wearing. Nercer's claim for his process, it will be remembered, was that goods treated by it would take the die better.

In order to make a dye permanent it has long been customary to use a mordant, which means a "biter," to fix or "bite in " the color. Alum or some similar substance, which unites with the diestuff to form an insoluble compound, has been largely used.

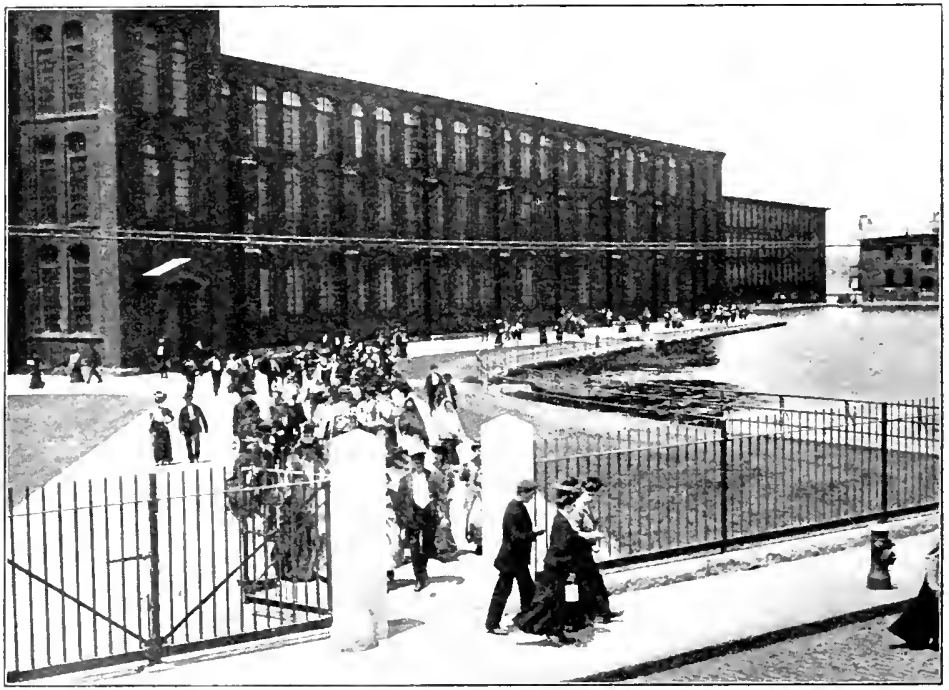

The END of The DaY at a Massachusetts Factoky

In general, the vegetable dyes are much less likely to fade than the mineral dyes. The Naraho Indians of the Vest used to color their famous blankets with regetable dyes, but when traders came to furnish the Indians with cheap mineral dyes, the value of their blankets and rugs speedily went down.

Location of cotton manufacture. Nea England. We have already studied the causes for the location of industries in certain places. The cotton-manufacturing industry is located largely in New England, and this has always been the case; for, as we 
have seen elsewhere, New England is particularly well adapted to manufacture of this kind.

In earlier times New England had the necessary water power, a moist climate, and enough labor, all of which were important in the cotton-manufacturing industry. Then, again, the people of New England were a very intelligent and industrious class, and when they came from the farms to work in the mills, they made excellent laborers.

At the present time New England, having found that water power is not inexhaustible, has come to depend largely upon steam. The moisture of the climate is also of less importance, because in the cotton mills to-day the air can always be kept moist, whaterer it is outside, and so the manufacturers, to some degree, create the sort of climate they need. Furthermore, there are comparatively few of the native population who now seek employment in the mills. But, as has been pointed out by a recent writer, there is to be found in New England, surrounding the cotton-manufacturing industry, an intrenchment of reputation, skilled labor, and capita! which strongly tends to hold the industry where it is. Another advantage is the nearness to the largest markets.

Massachusetts leads in the manufacture of cotton, but her superiority at the present time is due largely to the fact that she had an early start in the business. This state still has more spindles than the four cotton-manufacturing states next in importance put together. The other sections of New England in which this industry is concentrated are the southwestern part of Maine, the southern section of New Hampshire, eastern Connecticut, and Rhode Island. These regions, together with the state of l'ennsylvania, have so many of the advantages possessed by Massachusetts that they are still of great importance in cotton minufacture.

The South. Within recent years the South has become more energetic along this line. This is due in part to the general industrial awakening of that part of the country. An increasing proportion of the cotton grown in the cotton belt is now manufactured very near the points of production. There are over four times as many cotton manufactories in the South to-dily as there were 
thirty years ago, the mills being located chiefly in the Carolinas and Georgia.

New England still surpasses the South in the business of cotton manufacturing. The mills of Massachusetts have a capacity for spinning greater than that of all the cotton mills in the Southern states combined. The North, especially Massachusetts, has the momentum of an early start, and this means also a reputation for cotton manufacturing. A reputation like this is of great advantage,

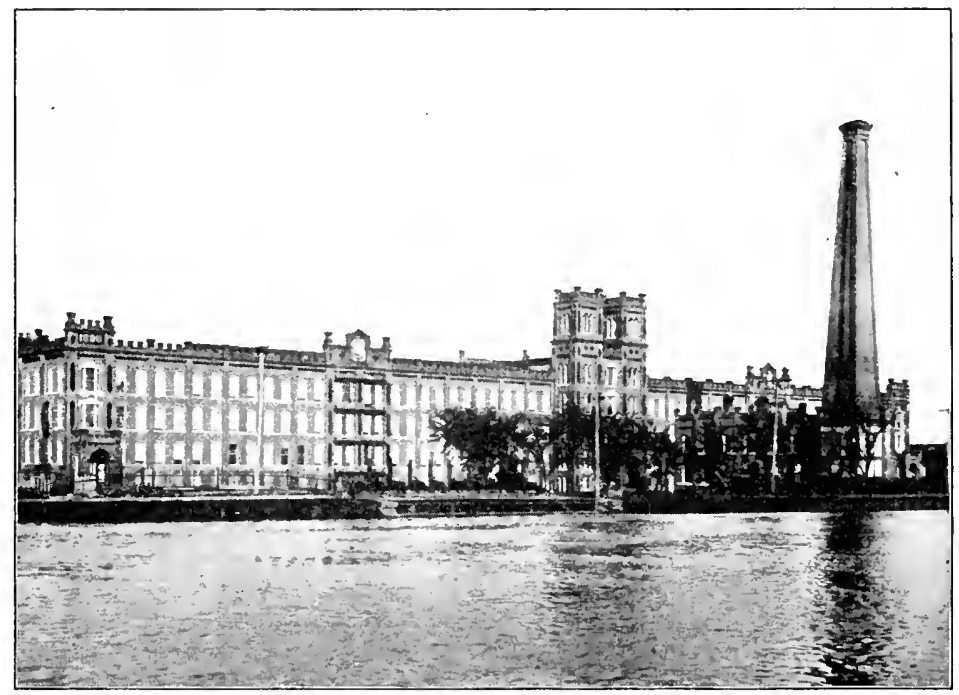

Cutton Mills at Augusta, Georgia

as it is in any business, for people trust the old and well-established concerns when they are a little distrustful of the new ones. It will take the South a good while to overcome all these points of superiority.

Distribution of woven fabrics. Manufactured products from the cotton mills may be distributed either to the stores or to great factories. In the first case the fabrics are sold to the stores by the piece; there they are sold by the yard and find their way in time into the homes of the people, where they are made up into various 
kinds of garments. The goods which go to the factories are there used in great quantities in the manufacture of ready-made garments, and then find their way to our homes by way of the wholesale and retail clothing stores. Some of the cotton goods are exported, either in the pieces, or "bolts," as they come from the factory, or as ready-made garments of various kinds.

Duties on cotton and cotton goods. We have seen in connection with the manufacture of rubber goods that the government collects import duties whenever it is desirable to protect some industry. There is no duty on raw cotton, because the prochuction in this country seems to need no help. But there is a heavy and very complex set of duties on cotton manufactures, which it is almost impossible even for an expert to understand. By the Tariff Act of 1909 the duty on certain classes of cotton goods, especially mercerized cottons, was increased; so also were the duties on certain grades of cotton hosiery, the cheaper grades in particular. It is evident that the cotton manufactures of our country are well protected. 


\title{
CHAPTER XII
}

\section{THE FACTORY SYSTEM IN THE MANUFACTURE OF CLOTHING}

\author{
The Growth of the Factory System
}

Every one is familiar with the modern method of manufacturing goods in large factories. This is known as the factory system of manufacture; although we are so used to it, we must remember that it has not been in existence very long.

Domestic manufacture. When the manufacturing was done by hand instead of by machinery, the articles were made in the homes
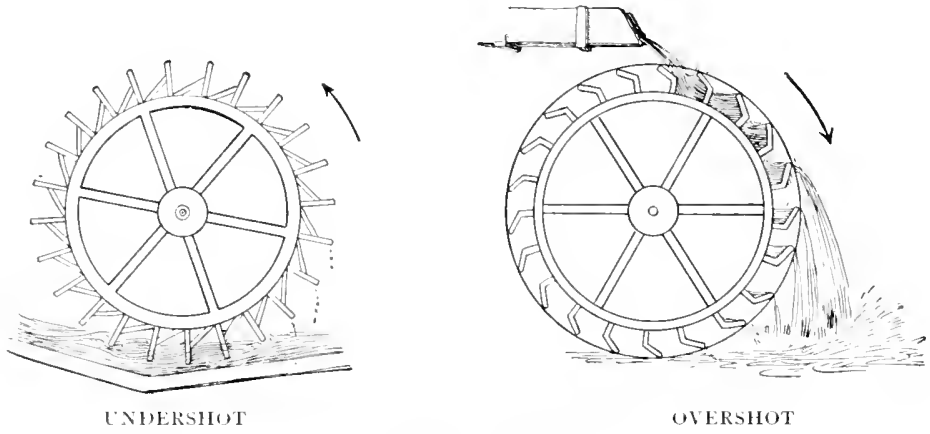

TyPes of WATER WhefLs

UVRSHOT

of workmen who owned the tools that they used. This is called the domestic system. It was a slow process, and manufacturing could not take place on a large scale. The factory system would not have been possible without the great mechanical inventions described in a previous section, and others of various sorts. These inventions were made in England, and it was in England that the factory system first arose.

Use of water power. Water power long ago took the place of human strength as a motive power for running various mechanical 
contrivances. In these contrivances a revolving wheel had furnished the motion for all the other parts. Water power was made useful by means of a water wheel which was turned by running or falling water. The motion of this whee turned the shaft to which it was attached. The motion of this shaft was carried by cords or belts to the principal wheel of the machine to be run, whether this machine consisted of stones for grinding corn, or saws for cutting wood, or mules for spinning cotton. At first, a wheel with paddles around its circumference was placed so that the water struck the paddles on the lower part of the wheel; this was called an " undershot wheel." Later, water was allowed to fall from a chute against the paddles on the top of the wheel, and was

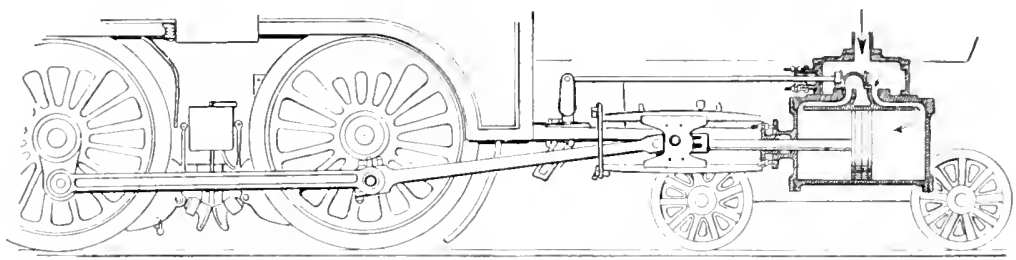

SIMPLE PLAN, SHUWING PRIXCIPLE UF S'TEAN ENGINE

more effective because the weight of the water as well as its current was used. This was called an "overshot wheel," and is the kind which we see most often in pictures of old mills. Then came the "turbine" wheel, which is much more complicated, and which utilized a much greater part of the power of streams.

Use of steam. Later, steam largely superseded other forms of power. When water is heated very hot, steam is generated, and this, if kept under pressure, possesses great power of expansion. Any one can see its power by watching water boil in a teakettle. In the steam chest of a modern engine this steam is admitted first on one side and then on the other of what is known as the piston. a tight-fitting plate which slides back and forth inside a steam cylinder, carying with it a piston rod. When the steam is let inter the cylinder on one side of the pistom, it expands and drive's the piston away from it to the other end of the cylinder: then the steam is let in at that end and drives the piston bak where it 
came from. As the piston moves, the rod attached to it also mores back and forth and causes a wheel to revolve with great speed and power.

Jame's Watt patented the steam engine in I769, just as the great mechanical inventions which revolutionized the spinning and wearing business were coming to be known. It is easy to see how the operation of great machines, which call for power far greater

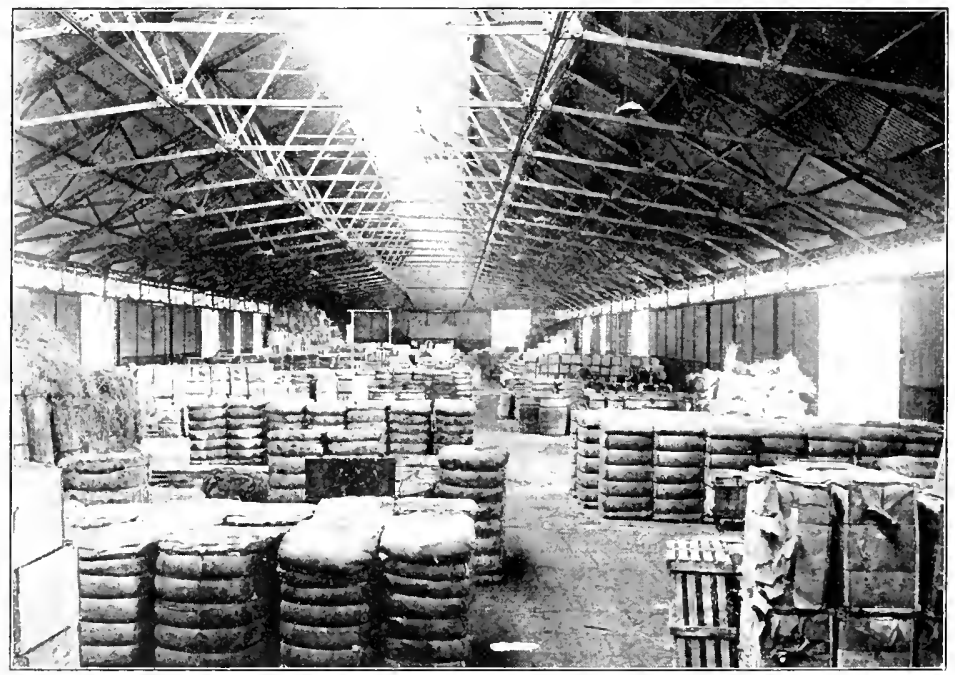

Courtesy of The Philalelphia Museams

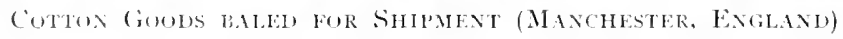

than human strength, would make it necessary for the manufacturing to be done in factories rather than in the homes of the workmen. The factory sites for the different industries were naturally selected according to the advantages offered. It is interesting to see how the various manufactories of England located themselves, one here and another there.

Location of factories in Lancashire. The great machines driven by water power were set up where that power was most available. It was plentiful in the northem counties of lingland, but in Lancashire conditions were the most favorable of all, for the water 
power was great in force and constant in supply. Besides, the rainfall caused a dampness in the air, which was of advantage in the spinning of the yarn. It is always desirable that fibers of any kind shall be limber when they are woven; even in caning chairs, the workman dips his cane in water before he uses it. For such reasons the cotton industry was located chicfly in I ancashire rather than in the districts of the south and east. In a similar way, when the falctory system came in, the other manufacturing industries of England were set up, each in the environment best suited to its needs.

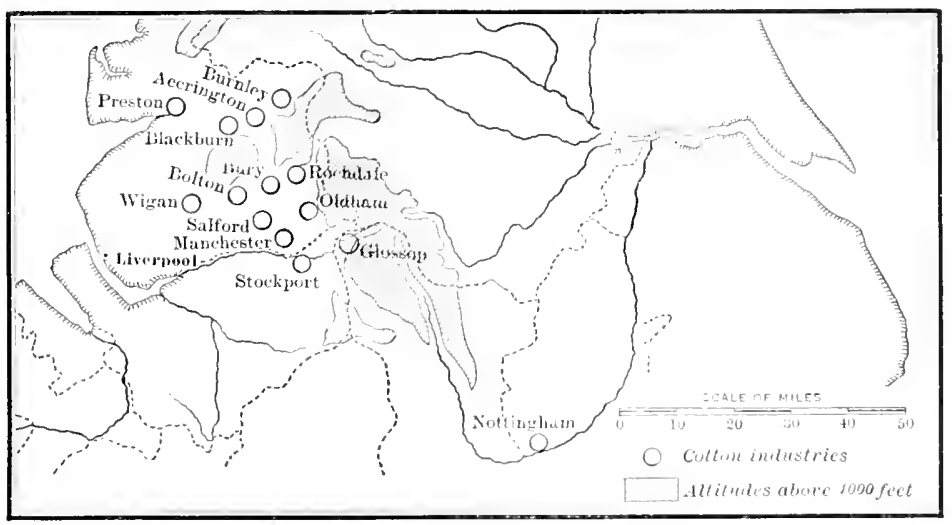

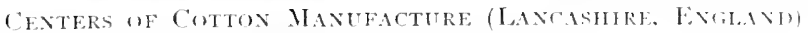

When steam took the place of water power, it was neamess to coal, the source of power, and to irom, the material for the malchines, which became most important. And lancashire wals well falvered in these particulars also. Furthermore, the cities and towns of this region furnished plenty of labor, and so it continued to be the great manufacturing center for cotton.

In the single county of Iancashire there can be found a third or more of the cotton spindles of the world. And, in addition to all the advantages mentioned, it should be watel that this regron is very near the port of liverpool, the chict cotton market of England and the home of the raw-entem exchange. It is to this port that the cotton exported from the Atlantic and ciuld consts of America is sent. 
Since the cotton industry has become so highly developed, it has naturally become greatly specialized in Lancashire. One region monopolizes the spinning trade, while another excels in weaving; some regions manufacture fine yarns, others coarser yarns, and so on.

\section{Evils of the Factory Sistem}

Nany evils and much misery came in with the factory system. Some of these evils went on for a long time; some still exist, but are being lessened by proper laws; while others were so great that they roused public indignation and so came to an end.

Loss of employment. The new machinery threw many people out of employment. One man, working with the new machines, could do as much as many men in the old household industry, and the introduction of the factory made it hard for a large number of people to earn a living. Thus workers in the household industry who were old, and who could not change their habits, suffered very great misery; to them the introduction of the new inventions which we have described meant poverty and even starvation. Many of those who were younger and who could not find a place in the factory system ran away, migrating in many cases to this country and becoming farmers or adopting some other form of occupation.

However, while the introduction of the factory system meant great discomfort to numbers of people, the result was that mankind as a whole received many benefits. Whenerer a great advance such as this is made, it means that there must be a readjustment of the way in which men live, and such changes are always hard. It is not easy to leare an employment we are used to, and take up a new and strange one. But it is only by such shake-ups that advance is made.

Employment of women and children. Another great eril of the factory system lay in the employment of women and children. With the new machines not only could one man do the work of many, but a weaker person could do the work of many stronger ones. There were tasks that even little children could do. The owners of the new machines wished to make as large profits as 
possible by getting all they could from their emplorees. Consequently, they hired women instead of men, and children instead of grown people; they paid them low wages and made them work very many hours a day. Moreover, the conditions in these factories were bad, and affected the health, comfort, and morals of the working people.

Since the factory system was so new, the law was not ready to understand its problems and to regulate them; and so weak women and little children were allowed to work all day and far into the

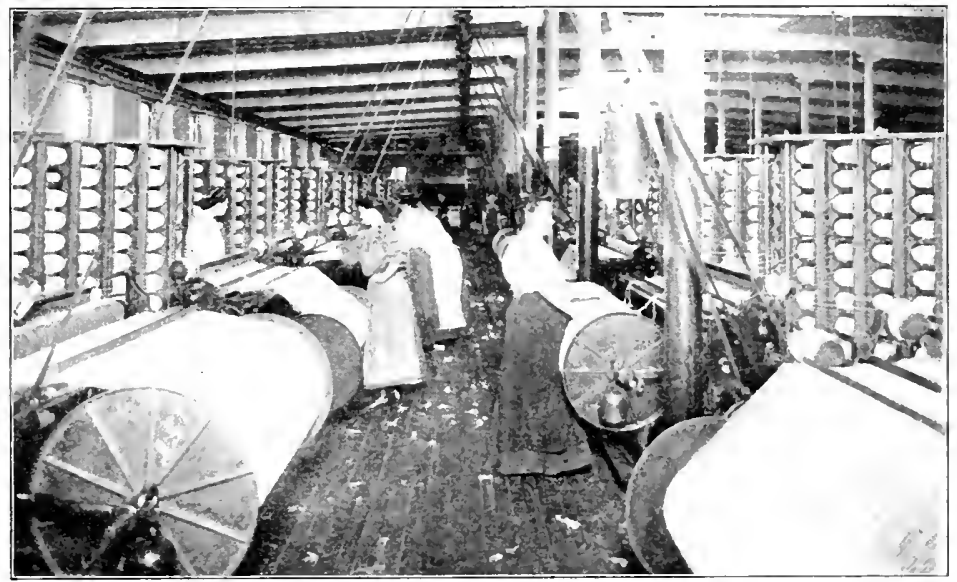

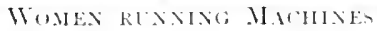

night under the most unwholesome conditions. In some cases children from six to twelve years of age had to work from fourteen to sixteen hours a day.

Danger from machinery. Another bad condition was that the workmen were not protected from the machines. At any time it is dangerous to go about a shop full of moving belts and wheels, and the workmen of that time had not become accustomed to machinery as they are at the present dily. Therefore ilecidents of all kinds were constantly occurring, because the machines were left exposed. Workmen frequently were caught in them and torn to pieces or horribly mangled. It was only necessiry to have a 
portion of one's garment eatch in a whirling band or wheel to be drawn into the machine and treated very much as the cotton would have been treated. And even if a man were not killed, but only crippled, there was no way in which damages could be collected from the owners. All these accidents seemed worse when the victims were women or children.

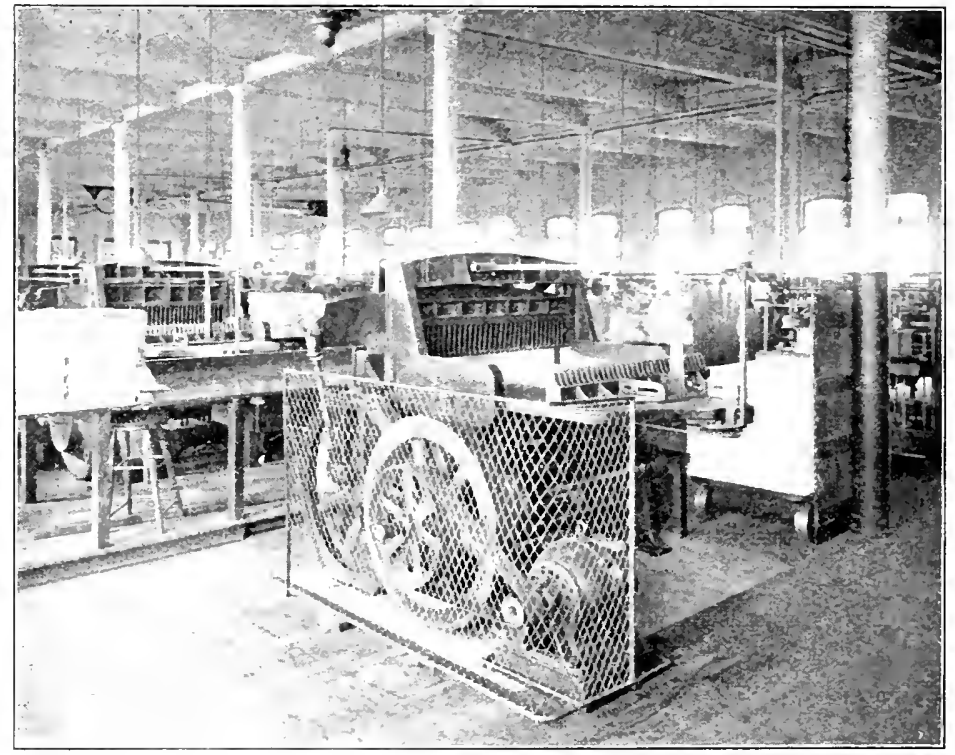

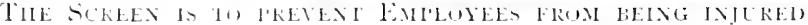

These conditions added greatly to the discontent which already existed. The hand laborers became angry when machines were installed, and there were riots. Bands of workmen went through the factory districts, burning the buildings and clestroying the machines. Gradually popular sentiment began to be aroused because it was seen that the evils were unendurable. Laws were passed, limiting the hours of labor for every one; preventing the (rerworking of women; prohibiting labor of very small children in factories: providing for rentilation and sanitation, and for safeguarding the workers against the worst accidents. 
Nuch of this improrenent came about many years ago. but complaints are still made, and with reason. Nor is the cottom industry the only one in which abuses of this sort are known. There are a number of other industries, such as matchmaking and whass grinding, in which one cannot work without clanger of shortening his life. It is easy to say that if a man does not wish to work in an industry of this kind, he can take up some other; but it is selelom easy to move from one form of labor to another, and people have to live. Consequently, many men are obliged to labor at occupaltions which they know, and everybody else linows, are dangerous: for this reason there is a growing demand for lecrislation for the protection of workmen from the dangers of their trades.

\section{Renenes FOR THE ENH.S}

Legislation. In this country labor laws of all sorts have been passed for protecting workmen against the evils of the factory system. In general, the hours of labor have been diminished, or, if cxtra time is put in, it is paid for at a higher rate. The hours of labor for women and children are limited by law, and they cammot be employed early in the morning or late at night. Young children are required to go to school, and

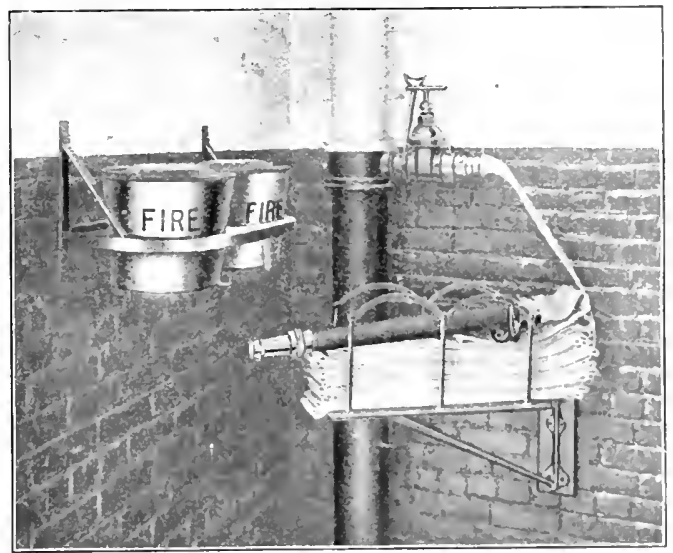

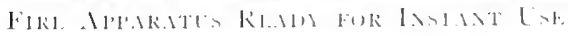
their parents must not put them into factories at a tender age.

Inspection. There are officers whese business it is to gro abust and inspect the factories, so that the lives and health of the workmen shall not be in constant dinger. Owners are obliged to keep their 
factories clean, to have plenty of fire extinguishers at hand, to provide fire escapes, and to carry out a fire drill, by which the operatives are trained to leave the building very rapidly and in an orderly manner.

Manufacturers are also obliged to have space enough between their machines so that a person passing through the room may not be in constant danger; for, in order to make the most money out of a manufacturing plant, one of the methods has been to crowd

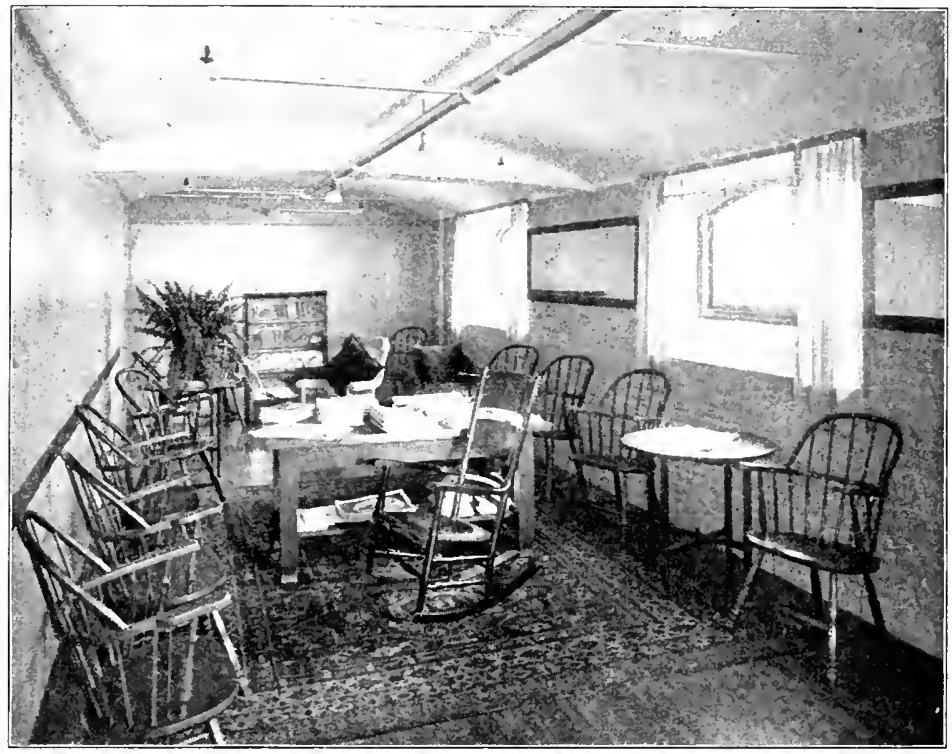

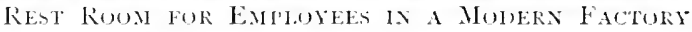

as many machines as possible into a small space. Also, it is required that the machines shall be inclosed in some way, so that even if the workman is careless, he may be protected from his own heedlessness.

A great many modern manufacturers go further and provide rest rooms, restaurants, reading rooms, and other comforts for their employees. Notwithstanding all that has been done, there are still inclustries which have not been humanized, and there are states where humane labor legislation is still backward. 
Labor unions. Some of the evils of the factory system have been remedied through the efforts of the workers themselves. They have formed themselves into unions and have been able to accomplish much which would have been impossible for any one of them to do alone. They have forced their grievances upon the attention of the public and have frequently won sympathy and support.

In the past, laborers have tried to obtain better wages or shorter hours or better conditions by refusing to work and by forcibly preventing others from working in their places. While this method has not wholly gone by, arbitration is now rapidly taking the place of force in disputes between employers and their employees, as it is in disputes between nations, and for the same reason - because it has been found to be better for both sides.

All that has been said about the fac-

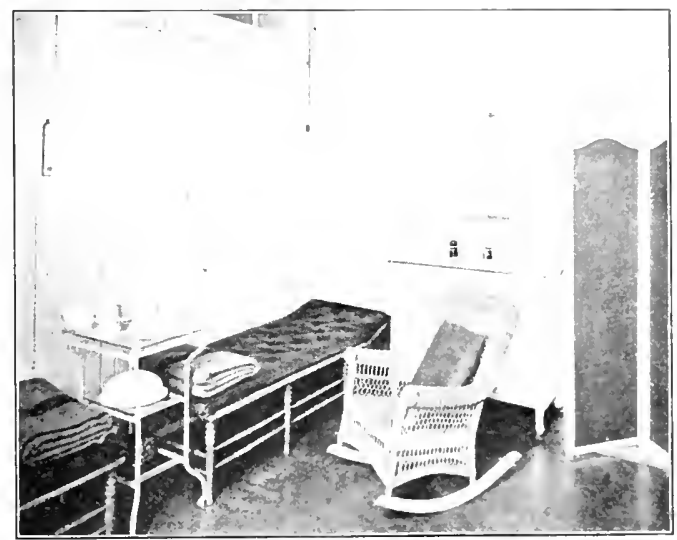

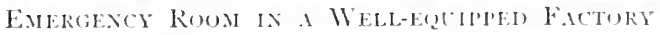
tory system applies to other forms of manufacture than that of cotton; but no one can understand the modern form of cotton manufacture without knowing something about these things. When we come to the manufacture of clothing from cotton we shall find many evils there also, but they will be mostly of the sort which we have already come to know. The study of the modern filctury system is an important and difficult one, and as our young people grow up, they should try to leam more and more about this and similar problems, so as to be able after a whike to help by their work and by their rotes to make the lives of all our people prosperous and happy. 


\section{The Mangfacture of Ciothing}

The manufacture of clothing from cotton is one of the special forms of the general cotton inclustry. But within this manufacture, whatever the materials, there is also much specialization, and a few examples of the clifferent sorts of products, made of various materials, may be given.

Hosiery and knit goods. A machine for knitting was invented in England in the sixteenth century, but it is only in rery recent

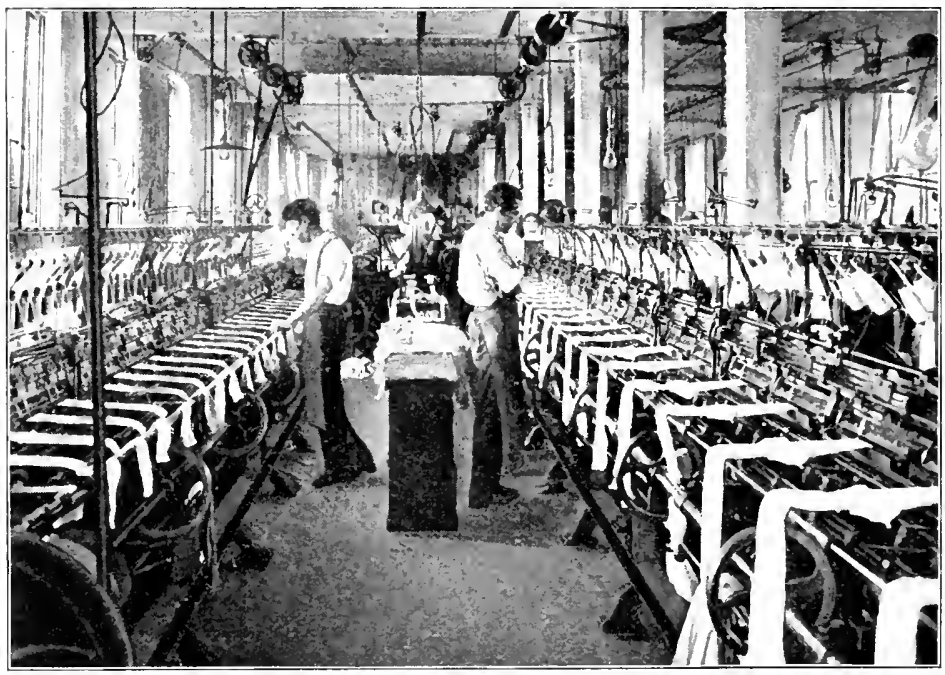

HuSLRY-KNITTING Macinises

times that it has been so improved that articles of clothing of good quality can be made by knitting machinery at a cost which will allow everybody to wear them. It is, in fact, within the last few decades that the making of hosiery and knit goods has come into prominence in this country ; but it is said that our people buy, per capita, three or four times as much clothing made by the knitting machine as they did twenty-five years ago. This increase has been almost wholly in American-made goods, for the amount of these commodities imported from abroad shows a decrease. 
In this comtry the concerns which manufacture hosiery and knit goods are rather widely scattered; in 1905 such factories were to be found in thirty-five different states. IIowever, more than three fifths of all the hosiery and knit-goods establishments were located in the states of New York, New Jersey, Pennsylvania, Delaware, and Maryland. ()f these, Pennsylvania and New York are the principal producers.

Some concerns specialize in hosiery and others in underwear. Massachusetts is an important producer of both hosiery and uncherwear, but does not specialize in either. The Southern and V'estern states are engaged almost wholly in manufacturing hosiery, and,

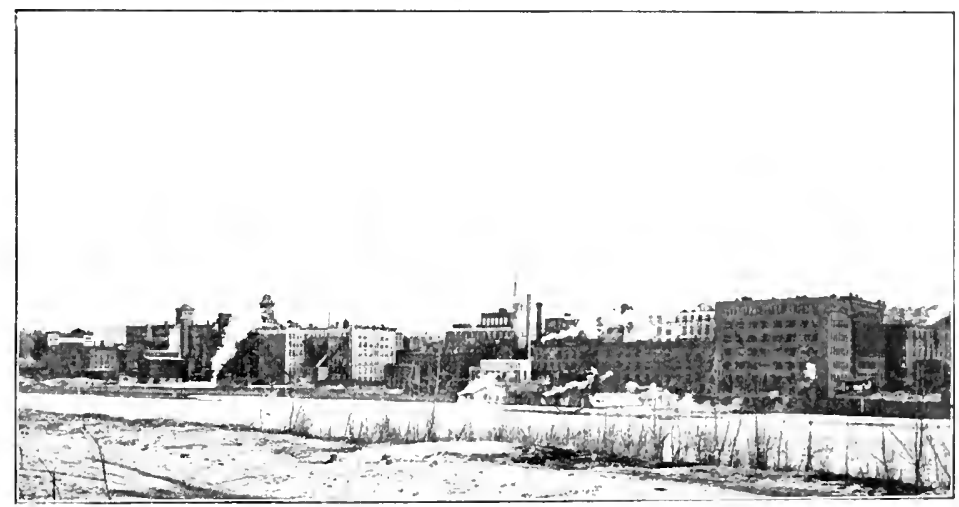

SHIRT AND CULLAR FACMRHA, TRU, NeW VURK

among the Middle Atlantic States, Pennsylvania and New Jersey grive special attention to it. New York, on the other hand, specializes in making underwear; in 1905 the manufacture of hosiery and knit goods was the most important branch of the textile industry in New York City. The value of the output was almost $\$ 50,000,000$.

Collars, cuffs, and shirts. There is no industry in the L'nited States which shows greater concentration than the manufacture of linen collars and cuffs. In the year 1900 the value of the output of collars and cuffs amounted to almost $\$ 16,000,000$, but less than I per cent of this value was produced outside New York state; 
and in this state the industry concentrated, as we have seen, largely in Troy, which produces about $\delta_{j}$ per cent of our collars and cuffs.

Troy got the impetus of an early start and has never lost it. It was about eighty-five years ago that the making of collars started in Troy. At that time most men had their shirts made at home, with the collars and cuffs attached, and when the collars were made separate it was a great innovation. It is said that a retired minister of Troy, who owned a small dry-goods store, first thought of making separate collars. His wife and daughters made them by hand, and starched and ironed them on the kitchen table. These "store collars" sold rery rapidly, and soon he had many of the women in the neighborhood working for him. The enterprising old man used to pay all workers in merchandise out of his store. Soon other people took up the manufacture of collars, and later the making of cuffs and shirts became an important business.

It 'vas not until I $\$ 45$ that the making of shirts commenced in Troy, but it was a natural accompaniment to the collar industry. In 1905 New lork had 225 shirt-making establishments, capitalized at nearly $\$ 9,000,000$; there were over I0,000 workmen engaged in the industry, and the value of the output was over \$20,000,000. In New York state alone this industry amounted to nearly two fifths of the total value of the product of the entire country.

Ready-made clothing. The manufacture of ready-made clothing on a large scale is almost a new industry. In the United States it had its rude beginnings in New York City about Is 30 . The first garments were of poor or medim grade, and were made to supply the demand coming from the West and South. After a while better gaments were made, but everything was done by hand and the output was small.

About is 50 the sewing machine was invented, and this gave a great impetus to the morement; then the Civil War came on, which helped the industry much, because clothing had to be provided on a large scale for the armies. Since that time the industry has grown steadily. 
Improvements in the industry. The quality of the materials from which ready-made clothing has been manufactured is generally rather poor as compared with that of tailor-made clothes. The cheaper grades of ready-made clothing, especially, do not contain much wool ; they are what is called "shoddy," and will neither wear nor preserve their color very well. But this inclustry has advanced until, at the present time, ready-made suits can be bought which are inferior only in fit to those mate by tailors.

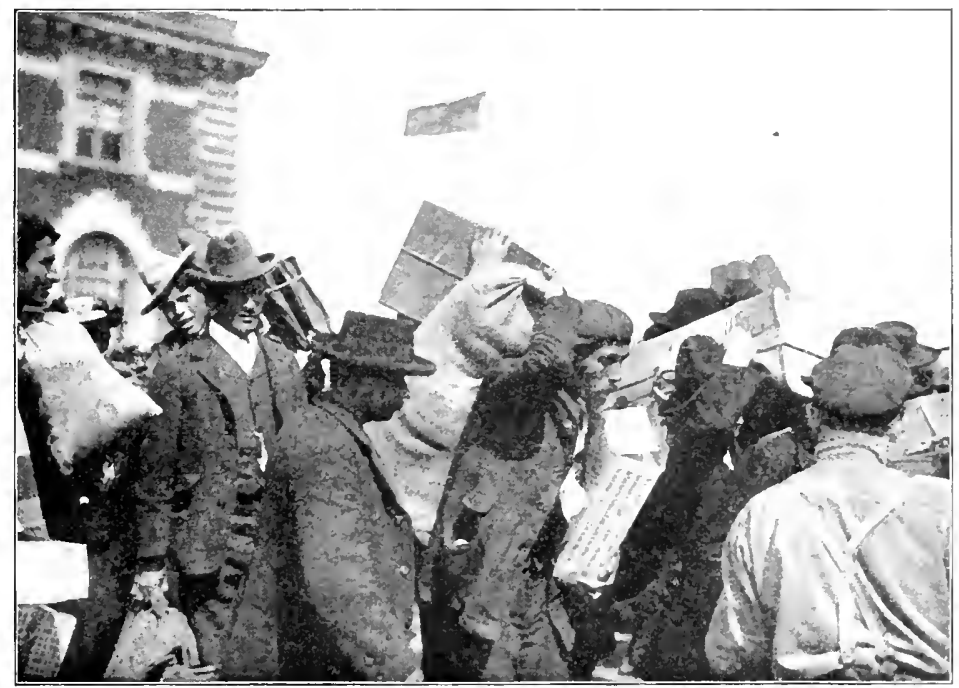

HMIGRANTS AT ELLIS ISLANI)

Photograph ly Brow a Bros.

A further development is in having clothing cut according to general patterns at some large manufactory, and then refitted at the local clothing store. A still closer approach to tailor-made clothing has been developed within a few years; a person's measurements are taken at the local store and sent to some large manufactory. where alterations in the stock patterns cam be mate before the garments are put together. Thus several stages of manufacture have developed between the cheapest form and that made by a high-priced tailor. 
The sweating system. The ready-made-clothing industry, like the factory system, has been attended by many evils. ()f these, the so-called "sweating" system is probably the worst. This was duc to the greed of employers, combined with the fact that great numbers of immigrants came to this country who knew very little about the comforts of life, proper wages, or sanitation. The "task system " was introduced, by which a contractor would make his

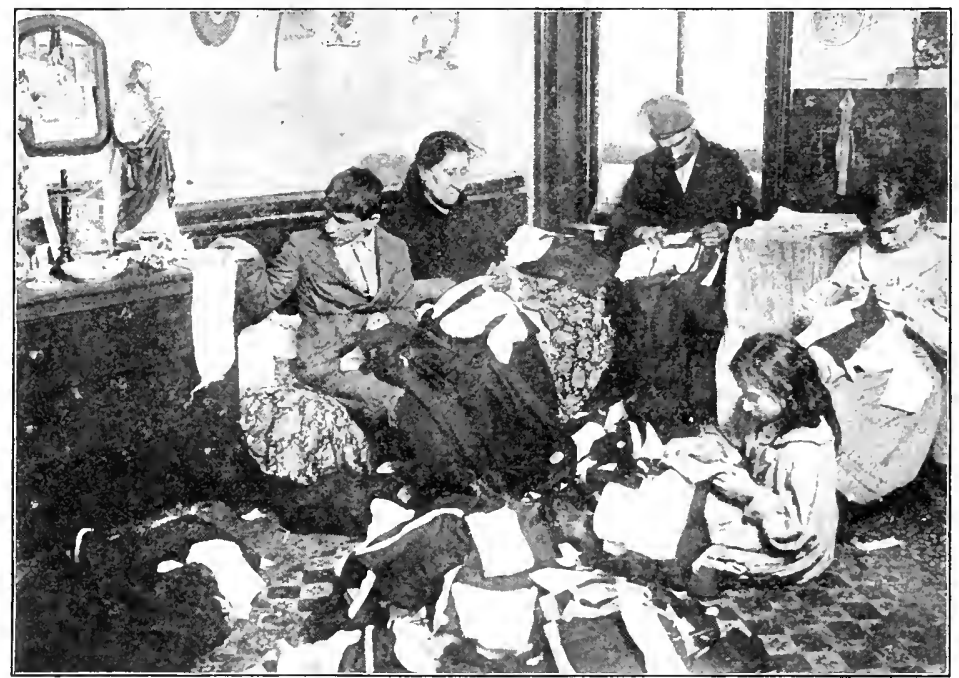

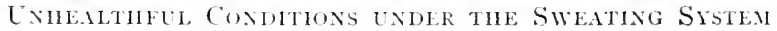

From Allen's "Civics and Ilealth"

laborers do from eight to twenty pieces of work per day; the wages remained the same in any case, but the hours of labor had to be increased in order to finish the day's task.

One of the worst features of the sweating system was the subcontractor. He did not do any work himself, but was a sort of middleman or overseer, whose profits depended upon the amount of work which he could get done.

The sweating system was like the old home industry in that it was not clone at first in factories. The only part of the work which was clone on the premises of the manufacturer was the cutting of 


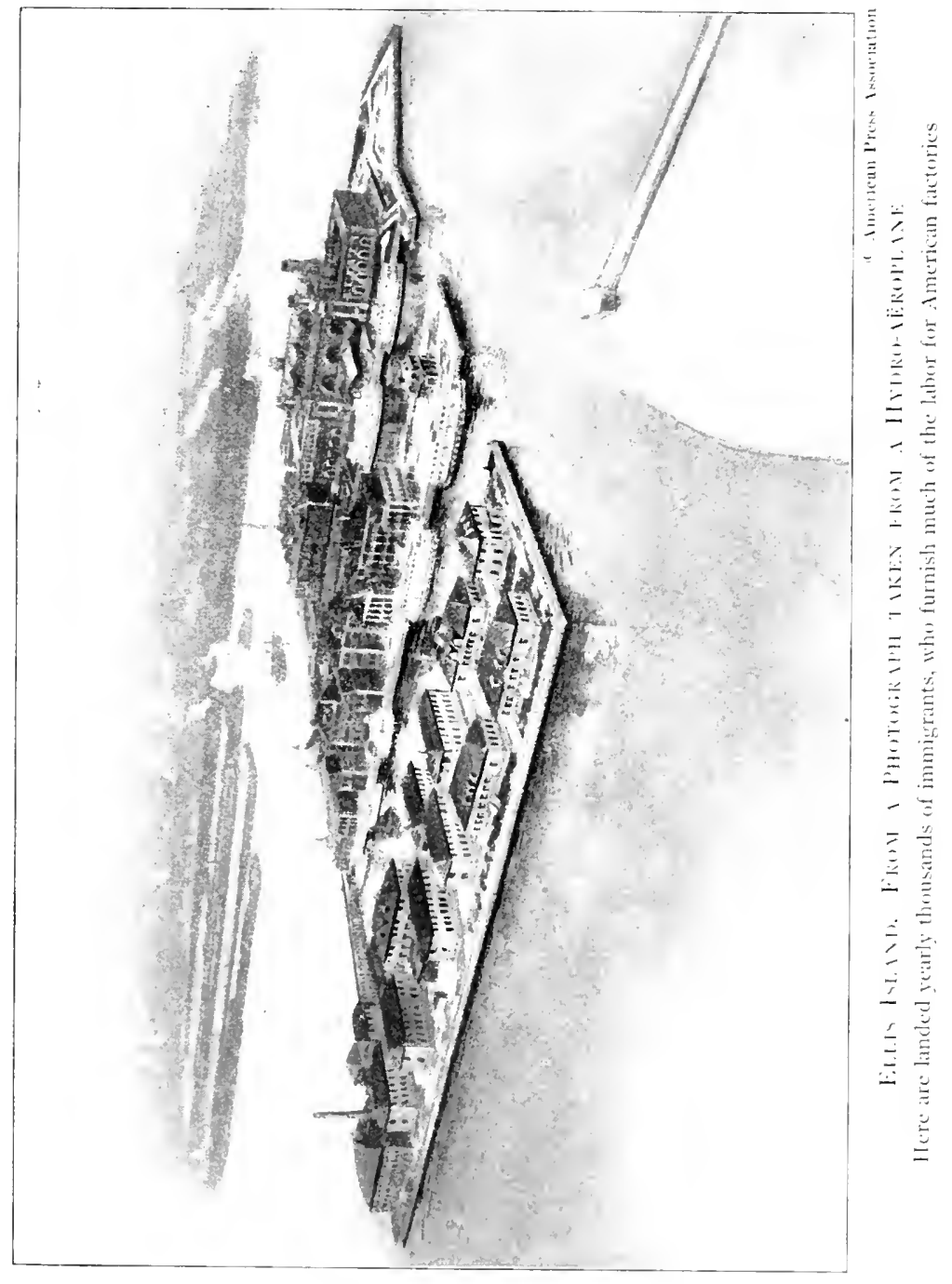


the cloth and of the lining. All the rest of the work was done by the por and ignorant laborers in their wretched homes. As has been said on a previous page, several families would herd together in tenement rooms which were not large enough for one small family, and which were provided with none of the sanitary and other conreniences to which we are all used. In these nurow quarters the whole family - father, mother, and children — worked as hard as

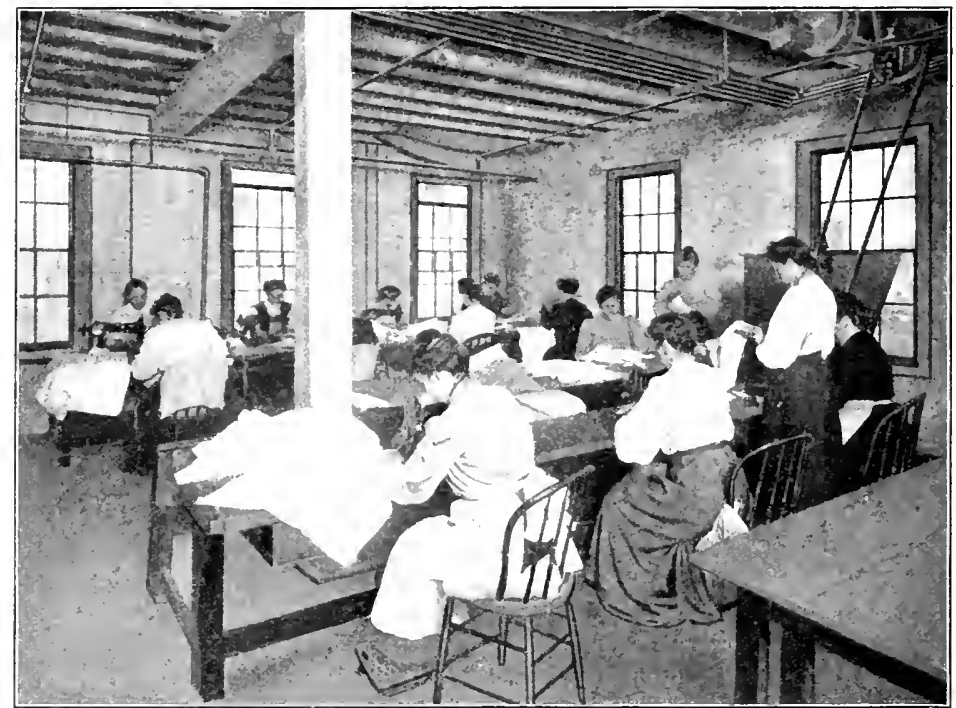

A MoDera SildTAK SilleAThHOP

they could for many hours in the day, with impure air all about them, and with poor food to eat. All sorts of misery and sickness resulted, and this caused the spread of disease along with the distribution of the garments. I ater the worliers were huddled together in an ill-smelling and poorly lighted " sweatshop " in a remote part of the citr, where the conditions were almost as unwholesome.

When the workmen in the factories had the troubles about which we halve read. they finally formed "mions" and defended themselves: their miseries could be seen by other people, and so public sympathy was aroused. But under the sweating system the oppressed 
people were too ignorant and helpless to resist, and since they carried on this industry in places which few people but themselve's ever saw, they met with little sympathy or help. The factory inspector often knew nothing about them, and if he had known, it was not his duty to look after them. Gradually, however, their condition came to be realized, and a number of laws have been passed to render their lives less miserable.

Change to the factory system. Within recent years there has been an improvement in the method of making ready-made clothes. Subcontracting is not so common as it used to be, and the contractors have been required to provide better quarters for their laborers. In fact, several of the largest manufacturers of readymade clothing have gone back to the factory system, and the clothing is no longer made in the homes of the workmen but in the factory buildings. This is a great advantage. The "sweater" or contractor acts as foreman, and the workmen can look for their wages to a responsible firm, where formerly they might be cheated by the subcontractor out of what little they had earned. Factory inspectors can see to it, also, that the hours of labor are not too long, that women and children are not overworked, and that the conditions are sanitary, since now the work is done in a regular factory. By better management the work can be evenly distributed throughout the year, so that there need not be rush seasons, which used to lead the manufacturer to demand of his workmen more than they could do.

For any reform we must look to an awakened public opinion, and public opinion is roused by knowledge of conditions. Then there follow laws which try to do away with abuses. The first state to pass laws regarding the sweating system was Massachusetts; in fact, the laws of that state have served in many cases as models for other legislatmes.

Factory laws in New York. Let us consider the factory law of New York state in its application to the clothing industry. And we must not forget that, with differences corresponding to differences in industries, the laws in regard to the clothing business are a good example of laws about labor in general. 
The law of 1903 limited the hours of labor for women and children to ten a day, or sixty a week. It also made it illegal to clean machinery while in motion, and it made provision for placing safety appliances around dangerous machinery. No child uncler fifteen may operate an elevator; further, the workrooms, halls, and other parts of the factory must be lighted at all hours, if necessary for the safety of employees.

A factory inspector passes upon the safety of factory buildings, and can condemn any that he thinks are unsafe. The law aimed

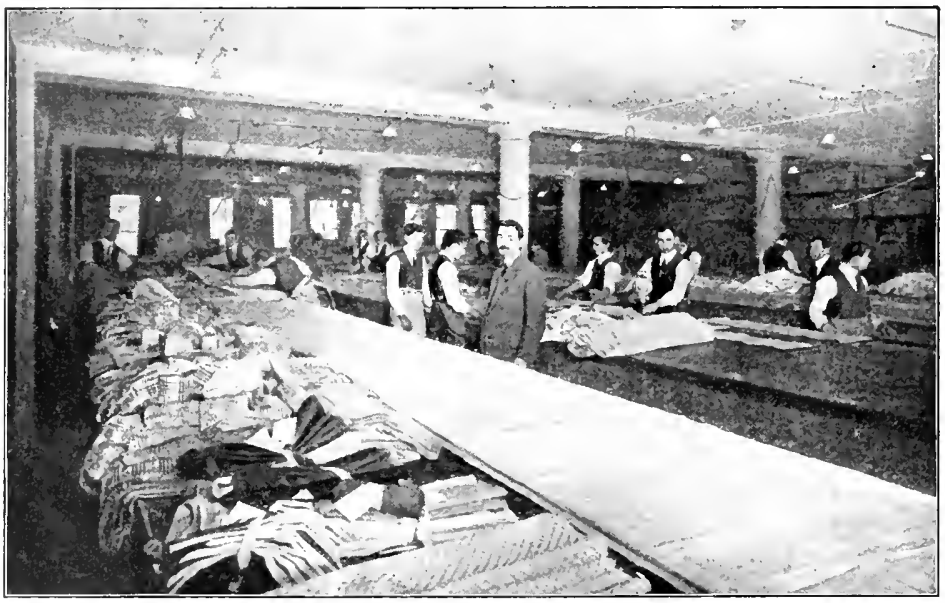

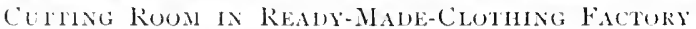

to prevent osercrowding, for it required in every room a certain number of cubic feet of space for each employee. On account of these factory laws there have been marked improvements in the conditions of work in the factories of New York state. Much, however, remains to be done, especially in protecting employees in large cities from the danger of fire.

Child labor. The employment of children in New York factories was scarcely regulated at all up to I $\$ 86$; before that date children under fourteen years of age were employed very commonly. Their auges ran from eight to fifteen years, and in some cases they began to work even carlier. A writer salys that before i $\$ 86$ little children 
from nine to thirteen years of age used to work all night in the cruller bakeries of New York City, the only sleep they could get being in the shops during the daytime.

Before the child-labor law was passed these and similar evils were common in New York. When people began to realize them, and to see the children who had been the victims of them, - children with diseases of all sorts, deformed and crippled, - a great wave of indignation arose. The factory law has been successful in doing away with most of the evils connected with child labor. The law forbids the employer to hire children under fourteen years of age, and if he hires those under sixteen, he does so. only under careful restriction.

The use of machines. About I 870 , machines were introduced for cutting the various parts of ready-made clothing; they were able to cut through several thicknesses at a time. Long knives were first used, but these were replaced by circular disks which revolve like buzz saws. The sewing

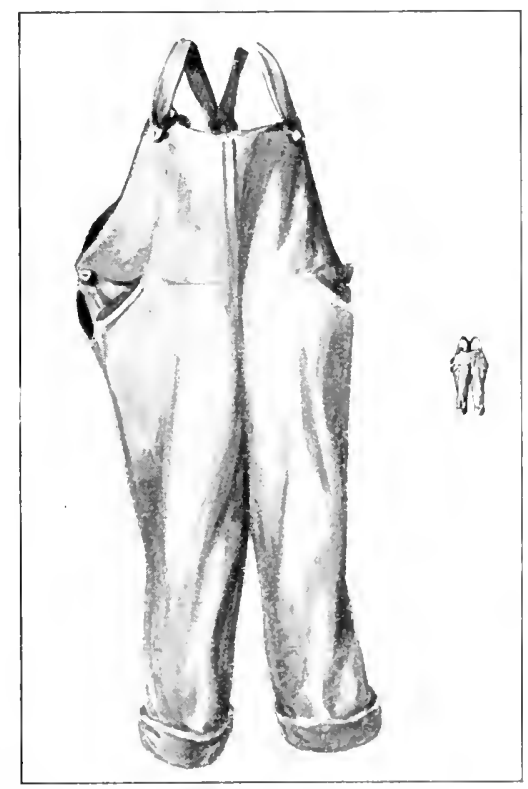

MACHNE OUTHT ANI IIANH, OUTH"T The small pair of overalls represents the output of one day under old methods, and the large pair shows the comparative size of the output with modern improved methods machines have also been greatly improved, so that they can do their work better and in a much shorter time than formerly. Instead of being driven by foot power, they are often operated by steam or electricity, but the introduction of artificial power has been very slow in this country. The way in which the making of ready-made clothes has been affected by the use of machinery and by improved methods in general can be shown by figures taken from the census 
of 1900. These figures show the results obtained in a factory as equipped in I $\$ 9 \$$, with those obtained in an old-fashioned shop.

In round numbers, counting all operations in manufacture, the time needed for making I 2 dozen overalls was reclueed from 720 hours to 7 I hours; for the cheaper grades of trousers, from I 440 hours to $148 \frac{1}{2}$ hours ; for making 12 dozen jackets, from 840 hours to $97 \frac{1}{4}$ hours; for vests of the medium grades, from $921 \frac{2}{3}$ hours to $26 \mathrm{O}_{2}^{1}$ hours ; for trousers, from I $125 \frac{2}{3}$ hours to $4 \mathrm{I} S$ hours ; and for coats, from 3302 hours to $1375 \frac{1}{3}$ hours.

Garments for women. The ready-made clothing thus far considered has been chiefly men's garments. The manufacture of women's ready-made garments did not become important before 1860 , and up to 1880 the manufacture of cloaks was about the only important branch of the ready-made-clothing industry for women. In the eighties women's suits began to be manufactured in factories, and since that time the making of all sorts of women's garments has become common. At first only the poorer grades of clothing were made, but now even the most expensive garments come from the factory. In our study of the clothing industry much that has been said about men's clothing may be considered as equally true of women's.

Importance of the industry in New York. In the ready-madeclothing industry the state of New York holds first place. Of the men's clothing manufactured in the United States in 1905, nearly half, in value, was produced in New York. The women's-clothing branch of the industry was even more important, representing about seven tenths of the value of the output of the whole country.

The manufacture of clothing is the leading industry in the state, attaining that position as early as isso. The prominent position of New York in this respect is due to sereral causes, among which one of the chicf has been the supply of cheap labor brought into New York City by ships carying immigrants. Further, New York is an important port of entry for materials; it is near the center of cotton and woolen manufacture; and, in addition to all this, it has that great advantage which we have noted over and over again - the impetus of an early start. 
The making of hats. The headgear of men, women, and children is made of a great variety of materials. These come chiefly from the vegetable and animal worlds. Some of the principal materials that go into the making of hats are fur, wool, cotton, silk, and straws of various kinds. The most valuable straws for this purpose come from a kind of wheat grown in Tuscany, Italy, and from the young leaves of a plant of Central and South America.

The styles of hats. The styles of hats vary greatly from time to time in the same country, although for men and children the style is more fixed than it is for women. Then, again, the form of headgear varies greatly in different countries. For example, the Arab wears a turban, and the cowboy a broad. brimmed slouch hat. The country people

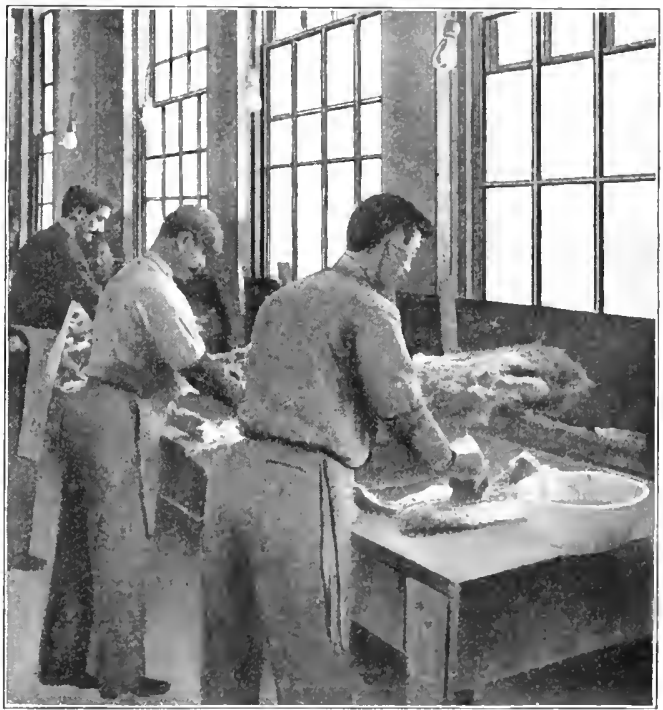

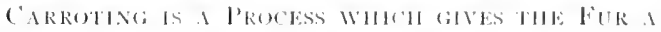
(2)MATS SUTABLE FUR FELTNG

in the southern part of China wear big bamboo hats, which they tie on with strings. Italian women wear bright-colored handkerchiefs over their heads. In northern countries, like Russiat, the healdgear is made of fur, which fits pretty tightly to the head.

The making of "felt" hats, from fur and wool, is an important industry in the United Siates. The ralue of the products of the fur-hat industry is several times greater than that of the wool product.

Processes of hat making. The process of making wool hats is a rather simple one. The wool is wound from a card upon a form 
which is shaped like a single cone, or like two cones with their bases placed together. While this cone is rotating, the wool is wound upron it in a lind of zigzag manner. The machine is stopped when enough wool has been wound on, and, where there is a double cone of wool, it is cut apart in the middle. Each cone forms a rough framework for making a hat, which is then shrunk in hot water until it reaches the desired size. These rude forms have to

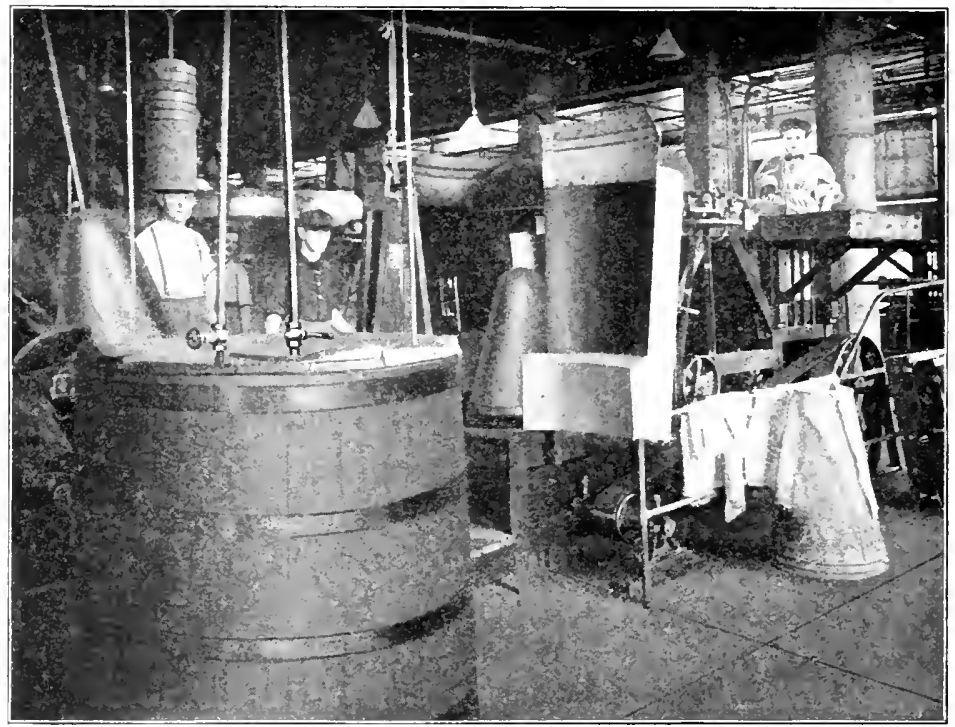

FORMANG DERARTMENT

Where felt is shaped for hats over large cones

be put through a number of processes, such as felting, dyeing, stiffening, blocking, finishing, and trimming. In going through these various processes even the simplest hat is passed on from one wriker to another for some special operation. Here is a good example of division of labor.

Fur hats are made from the fur of various animals, such as the rabbit, nutria, and others. The long hairs are first pulled out of the skin; the fur, while still on the skin, is then put through a process known as "carroting." This is done by applying certain chemicals 
which make the different fibers in the fur stick tightly to each other. After further treatment the fur is ready to be sheared from the skins.

In making felt hats from fur, the first thing to do is to mix torgether different kinds and qualities of fur, so as to give the desired quality to the material of which the hat is made. The fur is next subjected to a number of other processes before it becomes of the

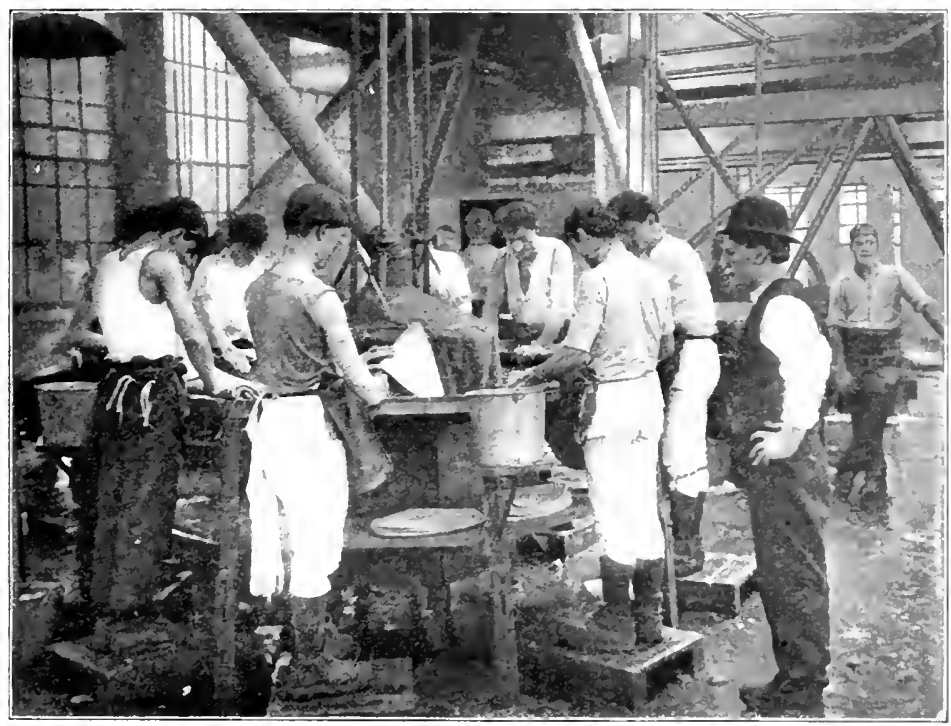

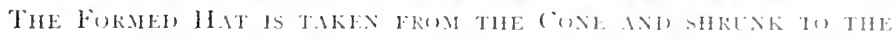
RIGHT SIZE

right texture and ready for felting. A workman then takes some of this prepared fur and feeds it into a felting machine. The fibers of the fur come into contact with a cone, and on it they are mate into a mass of thin felt. When the felt has been stripped from the cone, and has gone through a number of uther processes, it is ready to appear as a hat.

In the year I 900 there were iz I factories in the Lnited States engaged in the making of fur hats: 59 of these were in Xell Jersey, $5^{8}$ in Connecticut, 20 in Pennsylania, i 5 in New York, I I in Massachusetts, and $S$ in other states of the Linion. 
Miscellaneous. We have now studied the industries which have to do with the most important articles of clothing. There are, of course, numerous minor articles connected with garments, such as buttons and pins, which must be provided by manufacturers. As time has passed, there have been made and placed upon the market numerous inventions which assist in the manufacture of clothing, in the home or elsewhere. Hooks and eyes, for example, have been improved; the making of buttonholes is done by machinery - in fact, strange as it may seem, buttonholes may actually be purchased, for they are made on strips of tape which can be sewed on where buttonholes are needed. The country is flooded with advertisements of devices on this order, which make for convenience and comfort in clothing. Further, there are industries connected with the cleaning, pressing, and mending of garments, the renovation and sale of second-hand articles, and so on. In a book like this it is impossible to take up all these branches, so we must content ourselves with simply mentioning that they exist. We have laid down the main lines upon which clothing should be studied, and the student can fill out the smaller details for himself. 


\section{PART IV. SHELTER}

\section{CHAPTER XIV}

\section{HOUSES AND HOUSE MATERIALS}

The real use of clothing is to protect the body from harmful influences in the emrironment, such as heat, cold, or dampness. Shelter does much the same for man as clothing does, except that it is not fitted to the body and is not carried about with it, as the turtle carries his "house." It may, besides, afford protection from harmful animals or insects. It can be entered and left, as clothing can be put on or taken off, but it is generally made of different and heavier materials.

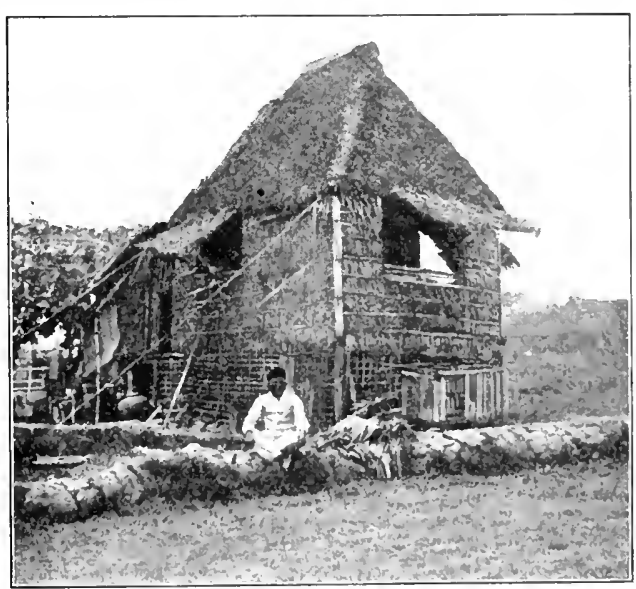

IIOUSE OF A WELLTO-DO FIIIPNO

Houses and civilization. The houses built by civilized men are much larger and better than those of sivages. Most of us would be uncomfortable if we had to live in the sort of house which to a savage seems luxurious. He is satisfied if he hats at mere cave or rude shelter into which he can crawl at night or during bad weather, whereas we fill our houses with things which we declare to be neeessary to our comfort, but of which the savage has never dreamed. 
As human beings increase in civilization, their wants increase, so that they are always becoming dissatisfied with what they have, and reaching out after something better. This is true in regard to food; men were once satisfied with food which to-day we would not eat, and were willing to eat such food raw or only partially cooked. Now we must have our food cleaned and purified and prepared for the table in many tempting ways. Clothing at first was very rude and clumsy, but people found no fault with it if only it kept them warm. Now we are not satisfied unless we can wear good materials, which have been made up to fit us and to look well.

So in the case of shelter, man's wants have constantly increased, until we have come to demand roofs that will not leak, walls that have no cracks through which the wind can enter, plenty of light from glass windows during the day and from lamps or electricity at night. With the increase of our wants we have constantly added to the comforts and luxuries of our homes, so that as civilization grows, our homes become more and more unlike those that once satisfied mankind.

\section{The Influence of Exvtroximest}

What we have seen to be true of food and clothing, as regards the influence of environment, is true of shelter also, and the kind of house built in any locality must fit the conditions which surround it. Let us consider first the influcnce of climate upon the style of house.

The influence of climate. In the tropics. In the hot lands the house is chicfly a shelter from heat and rain, or occasionally from wild beasts. A person does not expect to spend much of his time in the house, and occupies it chiefly during the hottest hours of the day, during storms, and at night. What is most necessary for a house in these regions is that it shall have a good roof. Even when there are no storms, as in the rainless districts, the roof is of great importance as a protection against the rays of the sun.

In folar regions. In the polar regions, however, it is necessary that there shall be protection chiefly against the cold, and so the house must be of a different sort from that of the tropics. 
We have already seen how the Iskimos make a weather-tight house out of snow. Other northern tribes have an undergromel house,

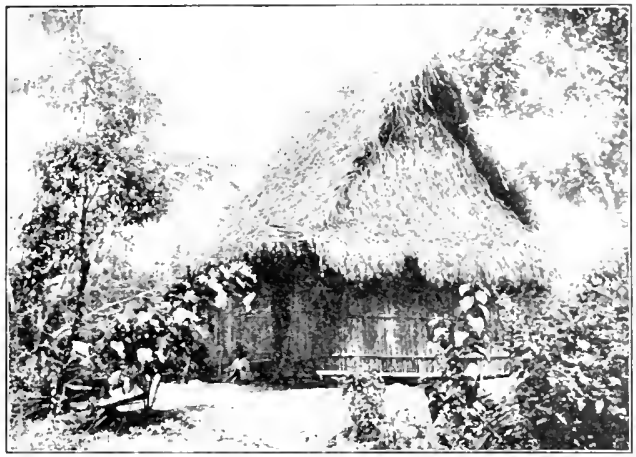

A TKSHAR, IIOH:

where, of course, the walls are miles thick. These underground durellings atre roofed orer with beams upon which earth is prickicel, and the entrance to them is closed up in sime wall.

One of the things which goeswith shelter is firc, which is, of course, more important in the cooler regions. In the tropics the fire is likely to $b+$ utside the house, for it is not needed for its heat at all. The cooliing is done outside, and the only fire insicke is for lighting purposes. but in northern regions the fireplace is inside the house, and serves at the same time for heating, cooking, and illumination.

In aniont Greces. This difference between the houses in warm and in cool regions is not confined to savage tribes, but can be clearly seen

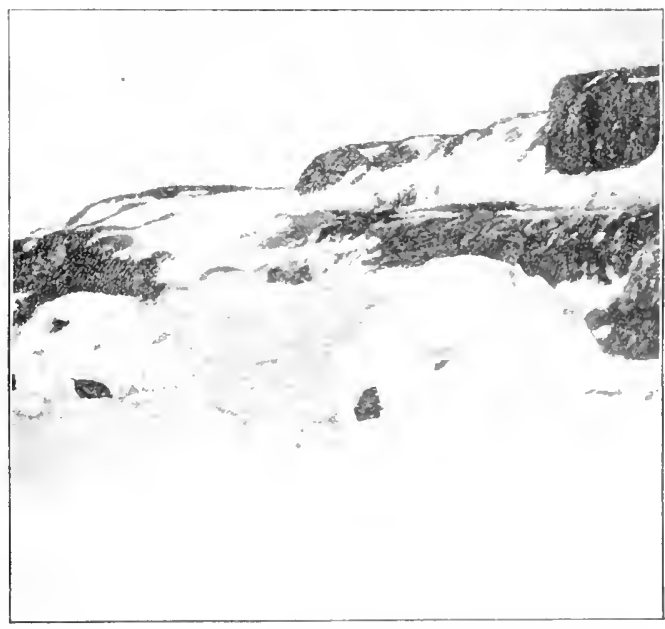

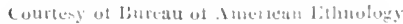

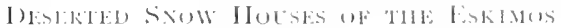
among peoples who are civilized. We find the sime sont of differences, depending chiefly upon climate, which we hatre already 
noted in the case of food and clothing. As an example of this let us compare the old Greck house with the kind built in north-

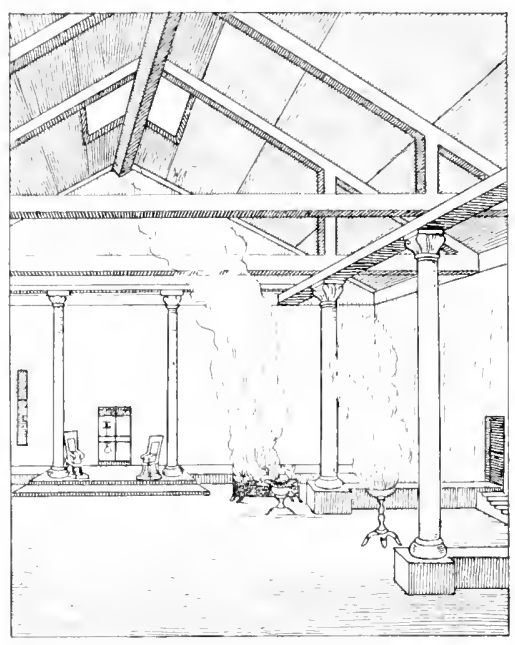

A GRIEK IIUUSE ern Europe.

In the warm country the chief purpose was to secure protection from the sun, and so it made very little difference whether the side walls of a house were solid or not, provided that the roof was upheld. As this could be done through the use of pillars, the old Greek house was in shape something like the Greek temples with which we are familiar in pictures. There was likely to be one large room surrounded with pillars which held the roof in place.

The room was lighted through a square hole in the middle of the roof, and this hole served at the same time as a chimney. There were no windows. The fire was kindled beneath the opening, and the smoke, after circling about and blackening the rafters, escaped through it. Around this main room, which was the

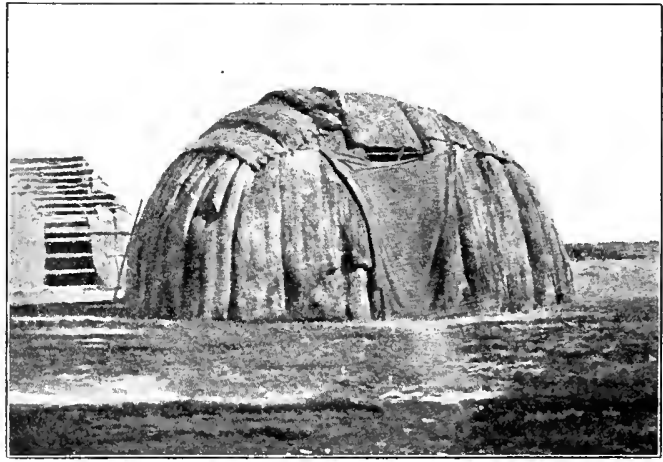

Courtesy of Bureau of American Ethuology WIGWAM MAIEE OF ASH BARK chief living room, there might be a number of small bedrooms, which were no more thin large berths used only for sleeping purposes. 
In northem Europe. Houses in nothern Europe were not built in this way, for they would have been too cold. The walls were made strong and water-tight, and no opening could be left in the roof. The interior would have been quite dark had it not been for holes in the side walls, which served as windows. These were covered with thin skins, tightly stretched, and admitted some light.

There was a certain portion of the house in which the cooking was done, and here the people spent most of therr time. The rest of the house was divided into small rooms, all inside the thick protecting walls. This division into smaller rooms was likely to darken the house still more, and so to call for more windows. But the main purpose, all through, was to keep warm.

Climate, then, has had a great deal to do with the shape and form of the house ; and climate, along with other

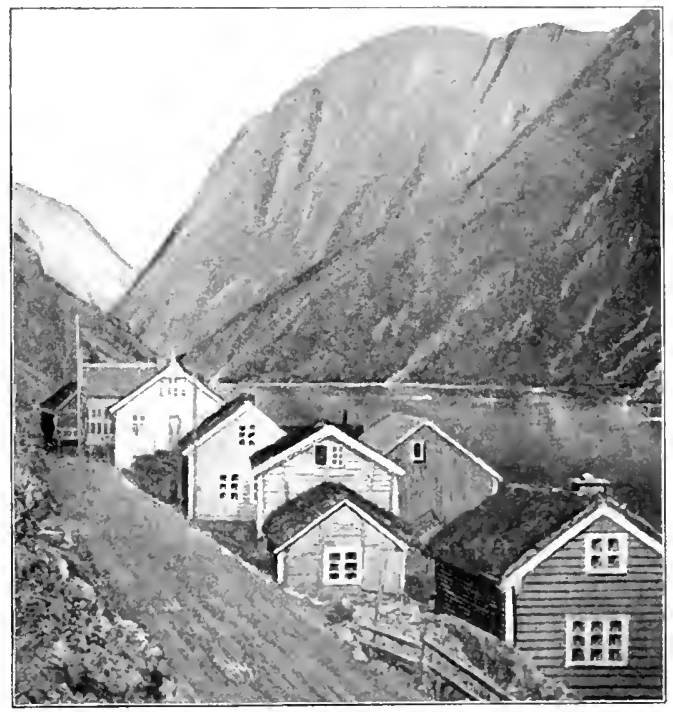

MODERN IIUUSES IN SEANUNMIII conditions of the environment, has also determined what materials should be used in building, in every region of the world.

other conditions. There are other conditions which hare influenced the type of house. In some countries the rivers overflow their banks every year and flood the whole region. This leads to the building of houses in trees or upon piles. Again, in a place where there are frequent earthquakes it is unwise to build houses out of stone or other permanent materials. It is best in these regions to use light materials, so that if the houses are shaken down, 
no serious damage shall be done. When such houses are destroyed they can easily be rebuilt. In the l'hilippines and in Japan, where earthquakes are common, this type of dwelling prevails.

The location of houses. Environment frequently decides the location of a house as well as its type. If a man is afraid of wild beasts or of his fellow man, he may build his dwelling in a tree or on the top of a cliff, and he will make it as strong and safe as he can. If there are natural caves, as there are likely to be in limestone regions, it is a simple matter to use them as houses, for then only a front wall needs to be built. The cliff dwellers in the southwestem part of our country had their houses far up on the cliffs,

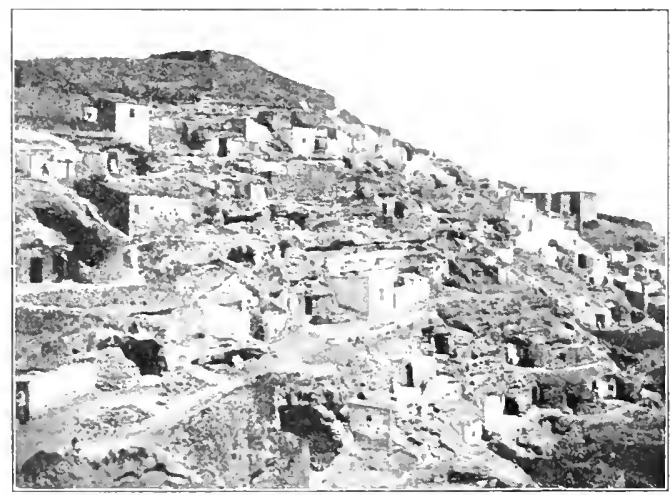

Chiff J Jellixgs and climbed up into them by a series of ladders, which they pulled up after them. Safe as these houses were, they were often a long way from the fields which had to be cultivated; but convenience was a secondary matter in those days.

Convenience, however, has always been considered to some degree in housebuilding. Since water is a constant need of man and of his domestic animals, houses are likely to be built near springs or streams. And nearness to a supply of food, such as game or fish, has often furnished a reason for choosing a certain location. A good example of this is the so-called pile" dwelling. Far out from the shore, on beaches where the water is shallow, sarage peoples have built groups of dwellings, rr rillages, upon stakes driven into the sea bottom. They can fish from their own doorsteps in their own back rards, and at the same time they are protected from wild animals and from human enemies. Tenice was originally built upon islands for the sake of 
protection, and its streets are canals. When the Spaniards saw the pile dwellings along the northern coast of South America. they named the country Venezuela, which means "I ittle Venice."

The environment, therefore, has had a strong influence upon the style and location of houses built by sarage tribes; and it has also influenced the housebuilding of civilized man. The miller used to live close to the waterfall which ran his mill wheel, and the house of the Naine fisherman is not very far from his fishing grounds and his boats. A man usually prefers to live near his place of business, and if that business is to be done under the same roof, it may even decide the type of house which he will build. This can be seen in the case of a shopkecper who lives in the upper stories of his shop building. His house is quite unlike what he would have built if it had been merely a house to live in.

The materials of houses. As in the case of the food raised and eaten and the clothing worn, so in housebuilding the sort of materials provided by

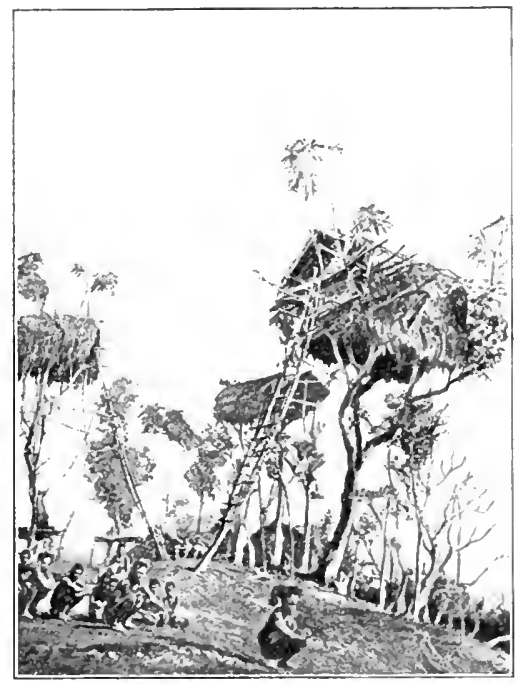

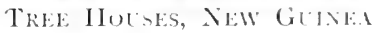
the environment has had and still has a very wide influence. The house must be made from the supplies at hand, unless transportation and commerce will bring to a certain region building stuffs not existing there. And so, since these resururees are not the same in all regions, the houses of one region will differ in their materials and construction from those of another. This is a condition with which we have become familiar in the case of food products and clothing.

Inorganic materials. The substances used for food and chothing are obtained chiefly from the plant and animal worlel. But this 
is not so definitely the case in houscbuilding. For this purpose much of the material is taken from the ground in the form of stone, clay, and the various metals. It is easy enough to show how food, clothing, and shelter, when they depend upon products from the plant and animal world, must differ in different environments, for the plants and animals are adapted to the region in which they live, and man has to use those that are at hand.

But when it comes to a lifeless substance like stone, climatic and other influences have little to do with its location. Ages ago such

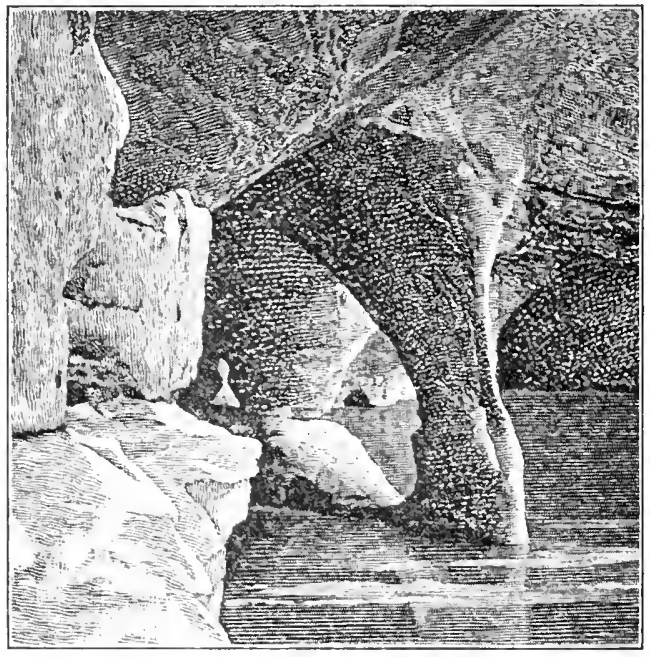

WEARING AWAY UF SUFT-RUCK STRATUM materials were located where they are by the great forces which shaped the crust of the earth. These forces we do not know much about, and, in regard to the stone, clay, and other articles used in building, we can only say that they occur in various places, and that when they do occur they have a marked effect upon the character of the houses in those regions.

For instance, stone caves, such as the cliff dwellers used, were formed chicfly by the action of water against the rock. If the rock is in layers, and if a soft layer lies between two hard ones, it will wear away faster than those above and below, and presently there will be a cave. These frequently formed the dwellings of ancient races of men. In France, where the soil is full of limestone, there are great underground caves, which we know were inhabited ages ago by man, because in them are the bones of animals that were slain and caten, while on the walls are rude drawings. 
There are certain kinds of stone which are specially useful for building purposes. We find the old temples of (ireece very latregely built of marble, which was quarried near by. To-dia granite and marble can be sent from one place to another, but in early times men found stone so difficult and costly to handle that for building purposes they regularly used whaterer kinds were clese at hand.

Another mineral substance which hats been of great importance in housebuilding is clay. Some of the carliest huts of sivage peoples were made of mud or clay, and even when a hut was

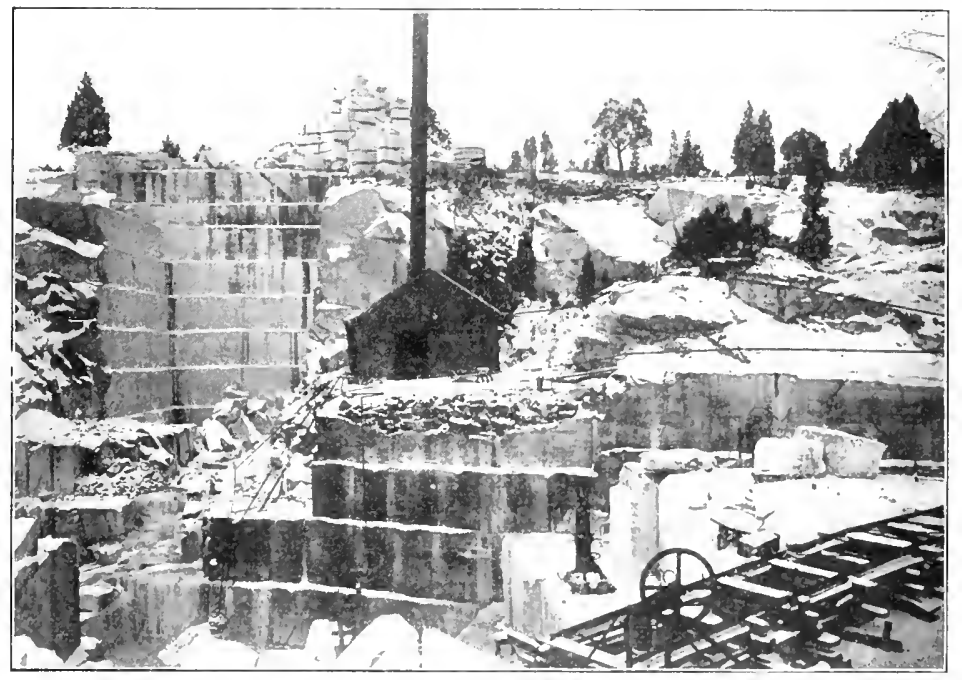

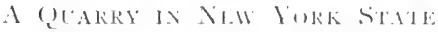

make of logs, clay was often used to fill up the craktis between them. Later it was made into blocks or bricks, and the walls were composed of a number of such blexks piled one upom anothere.

At first the blecks were hardened simply by the heat of the sum. As we have seen, the name griven to these smomped bricks was adobe, which was originally an liggptian word, transfered by way of the Arabic into Spanish.

Clay, when merely sum-dried, is mot very hard, and camnot stand much moisture without being washerl awaty : so this kind of material 
can be used only in rainless or nearly rainless regions. Adobe drellings are frequently seen in the American desert. A house of the Zuni Indians and a Kuni village composed of many of these houses built beside and above each other have been described in the early part of this book. There were several ways in which the clay was made into house walls. Sometimes two rows of sticks were put up and the space between them filled with clay; again, large blocks were formed in boxes whose sides could be remored, or in molds made of basketry. In no other place in the world can adube construction be seen to such an extent as among these Indians.

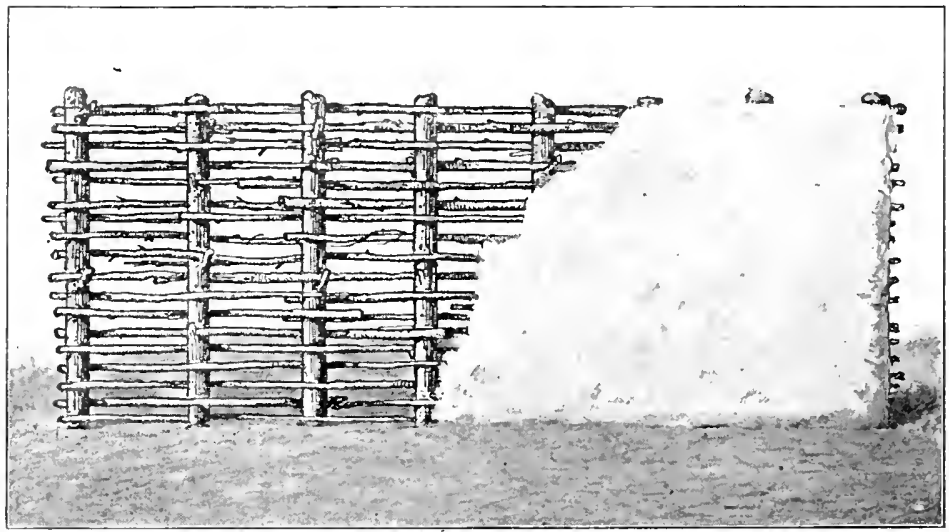

Courtery of the Bureau of Americau Ethnolory

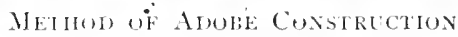

There are a number of other mineral substances which are necessary in our housebuilding, such as the sand and lime used to make mortar, the cement with which cellar floors are covered, the glass used for windows, and so on. To these must be added the metals from which nails, screws, and hardware in general are made. Metal was rarely used by uncivilized peoples in housebuilding, and its.presence in the modern dwelling is of no special value in discussing the effect of environment. Easy methods of transportation make many materials available in all civilized communities. One of the most curious instances of a liouse that is fitted to its environment is that in which the walls are made of water - in the form of snow and ice. 
Organic materials. In considering plant and animal products used in construction, we can see that they correspond to the environment, because they come from living things which, in order to exist, must correspond to it. For instance, in the tropics a house may be made of bamboo and thatched with palm leaves. The wooden beams may be cut from tropical trees, such as teak and palm wood. All sorts of tropical grasses, leaves, gums, and the like are employed. In the cooler regions, howerer, these wouls will be replaced by pine, spruce, and other woods of the locality, and the thatch, which must be more durable, will be made of shingles or even of slate.

In some countries curious substances are used; in Japan partitions of paper are common, and elsewhere they are made of matting. We have already learned the reason for building houses of light material in regions where earthqualies are common.

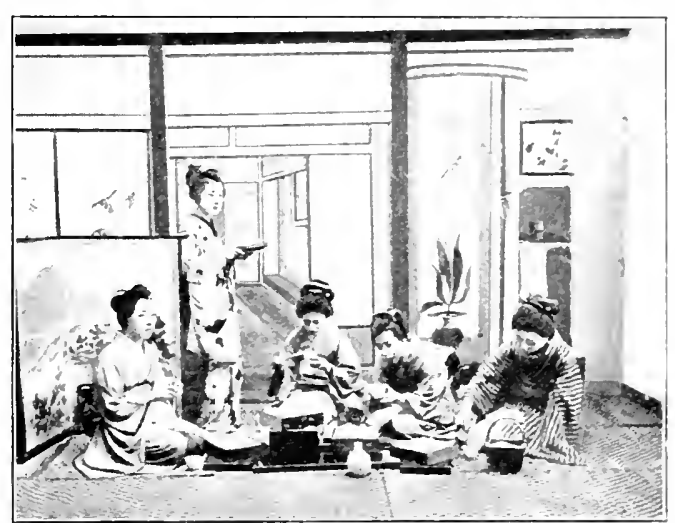

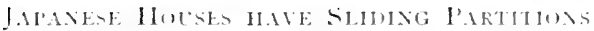

When we come to animal products we find them represented very fully in the houses of uncivilized peoples. The Eskimos use bone for the framework of slin tents, and practically all hunting and cattle-raising people use hides. The tent of the Indian tribes where the buffalo roam is made of buffalo skins sewed together and stretched over a number of poles, as inclicated in the picture on page 309. A flap is left open at the top to let out the smole, and the lower edges of the hides are pegred to the earth. In southern Siberia the tents are of felt, which is made of layers of animal hair matted and pressed together. Even when the houses are made of wood, the openings to admit light, since glatss is unknown or too costly, are frequently a sort of parchment made from animal skins. 
In modern houses animal substances are used to some extentin the form of hair, which is used in mortar, and in the leather, felt, and other materials used for one purpose or another.

If, along with houses, we consider the fuel used in heating them, we should include the mineral coal, mineral oil (coal oil or petroleum), wood from the plant world, oil such as the Eskimo gets from blubber, and tallow and wax from which candles are made. And if we were to consider also house furnishings, we

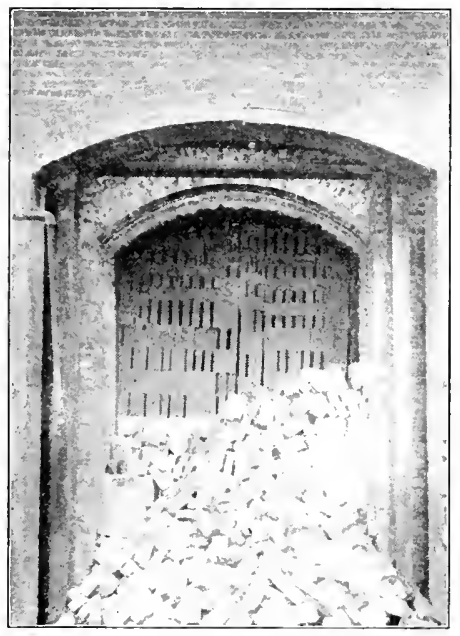

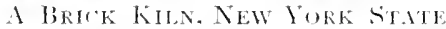
should open up a wide subject; for mineral substances are used for many household utensils, plant substances for furniture, and animal materials for rugs and other furnishings.

Early and modern houses. If we look at the history of the matter, we can see, then, that the earliest houses were generally made of materials from the plant or animal world, but that the forward movement, especially when it comes to building fireproof structures, is toward mineral or noncombustible materials. Bricks baked in a furnace or kiln, tiles, and especially structural iron and steel are coming to be the chicf building materials in those places where civilization is most advanced.

\section{MOMERA IMPROVEMENTS IN HoLSEBUILDAG}

Primitive needs. The art of building has improved steadily with the advance of civilization and with the increase of human needs. The first dwelling which man had, besides the cares which nature had made for him, was probably a mere shelter against the winda few branches twined together, forming a sort of fence behind which he could crawl. This was gradually improved upon until 


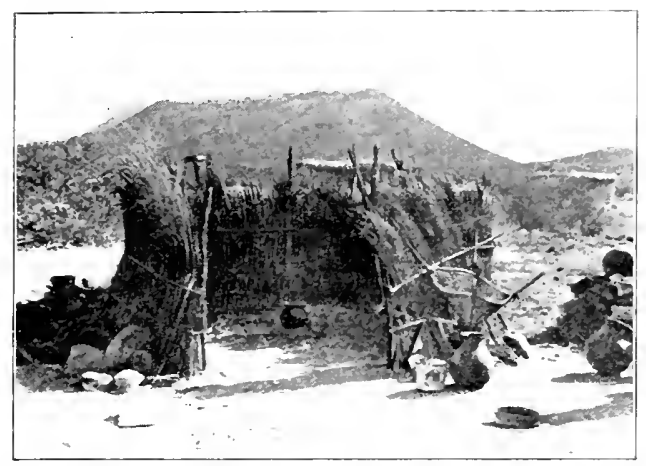

Conrteng of the lionean of Anerican Ethology

ONE OF THE MOST PRIMTISE HoLSES

there were walls and a roof. Nimy of the houses of savage peoples are circulir, because such a house included the most space with the least material. And so adrance in building went on from age to age by slow degrees until we get down to modern times.

From what has been studied abrut primitive houses it is clear that they were not built to live in, so much as to provide occasional shelter for human beings who lived for the most part out of doors. ()ur houses have a different purpose ; for many of us spend a large part of our lives indoors. We therefore seek to make the house not only se cure against the weather, but also attractive. With the advance in division of labor and in commeree, a house can be fitted out with more and more conveniences and luxuries.

The most rapid advance in the art of building and fitting up houses for the comfort and pleasure of those who are to divell in them has been made within the last century. This progress has been so rapid that an inexpensive and modest house of to-day has far more convenicnces and comforts than had the palaces of kings in the olden times.

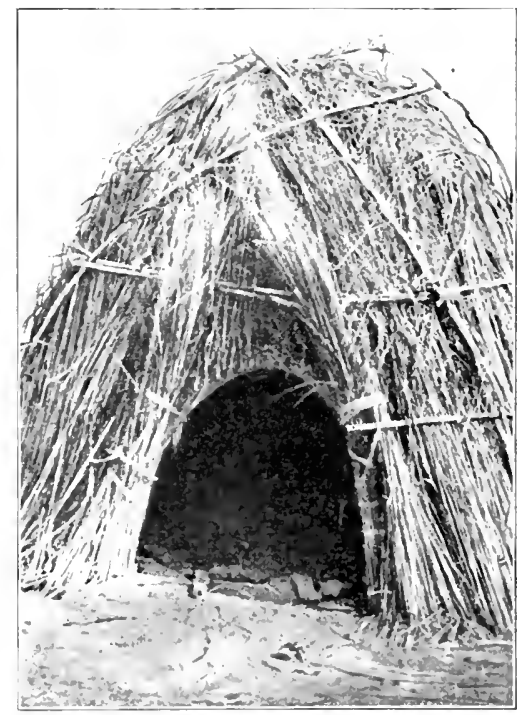

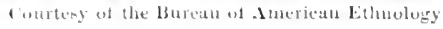

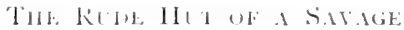


Medieval castles. While the castles of the Middle Ages were often spacious and picturesque, life in them was rery wretched. They were cold, dimp, dark, and not too clean. They were heated in winter by in enomous fire in an open fireplace, but the protection against the weather was so slight that although a person might be almost roasting on the side of his body which was turned toward the fire, the other side might be half-frozen. The winters were cheerless and full of discomfort. It is sometimes surprising

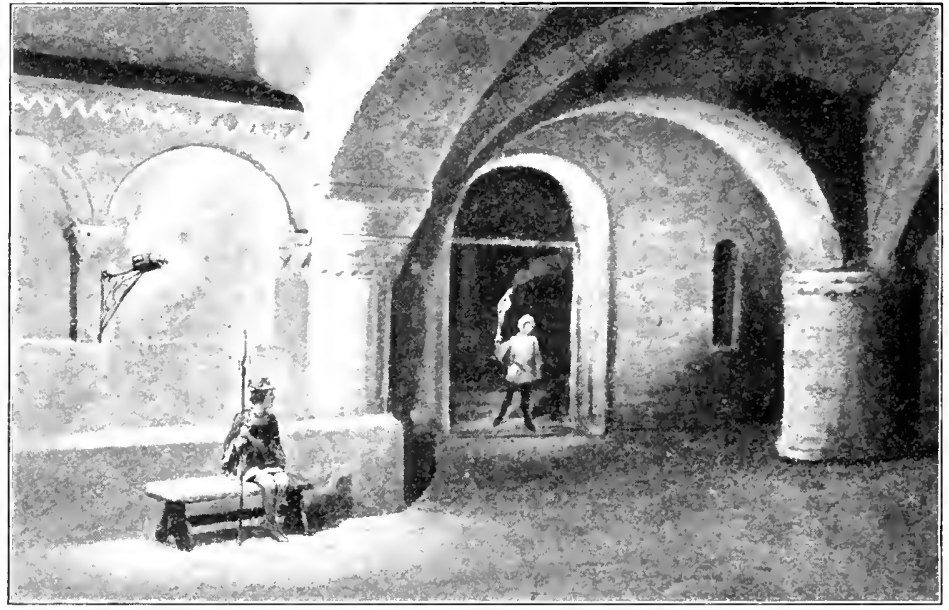

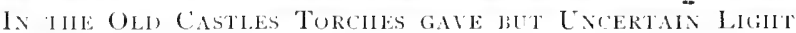

to us to find how often the poets of the Middle Ages sang about the coming of spring; but if we know how they lived, we cannot be much surprised. The coming of spring meant that they were going to be warm for a while, and that they could get out of the damp, chilly castles into the bright sunshine.

At night these castles were poorly lighted by flaming torches or by pieces of burning tow, set in brackets or in ressels attached to the wall. There were no sewers and no rumning water. In short, there were hardly any of the conveniences which we demand in a house ; and one can readily imagine the many discomforts which must have been endured by the oecupants. 
"Modern improvements." Heating and lightingr. Compare such a castle with the house of to-day. There are very few houses now that are dependent upon fireplaces for their heat; they are more likely to have wood or coal stoves or furnaces. Modern houses are lighted by something far better than torches, better even than the tallow candles of our ancestors. In the country there are large oil lamps, and in the city, gas and electricity. Thus the houses of to-day are dry and warm, and may be well lighted at all times.

Mater and a'aste. In the country the farmer's windmill pumps water into a tank, from which pipes lead to his house so that he may have running water there. Pipes may also pass through a boiler or through heating tubes and supply him with hot water as well as cold. The whole house can be kept clean, and the dwellers in it can have frequent baths and keep themselves in healthy condition much more readily because of these improvements.

Again, the drainage of the house, even in the country, is now carried off

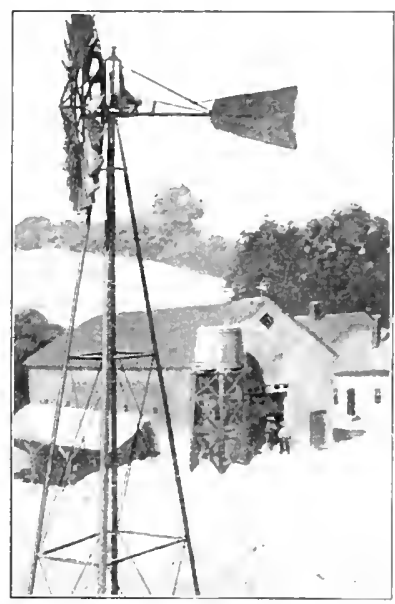

A WIXINHILL into cesspools and no lonerer breeds discomfort and disease; while in the city the houses are connected with great sewers, which run under the streets, carying the waste far away from the dwellings. This is of the utmost importance for the comfort and health of the people.

Necessity for division of labor. A modern house is a complicated one to build because all these conveniences have to be provided for. When the Germans of the Middle Ages built their houses, all they had to do was to lay a foundation, put up the beams, nail on the boards and shingles, and build a chimney. But now it is necessary that a number of different kinds of workmen, who pursue an extended division of labor among themselves, shall unite in building the house. 
First come the masons, who dig the cellar and lay the foundation: then the carpenter or bricklayer, who builds the walls, chimney, and roof. before the work can go any farther the plumber must dig the sewer trench and put in the pipes for the sewage, the water, and the gas. Perhaps at this point the electrician appears and wires the whole house. Then the carpenter takes hold again

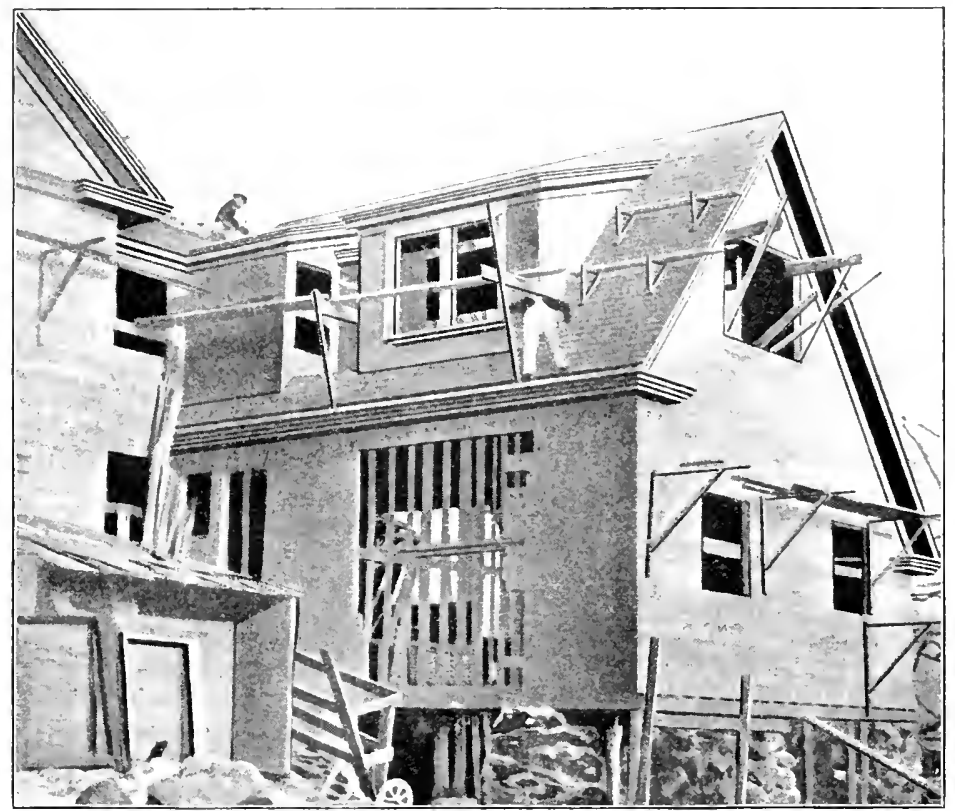

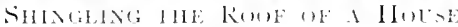

and lars the floors, while another workman puts on the laths. These men are followed by the mason, who plasters the side walls and ceilings of the rooms. After the plastering dries, the carpenter puts on the interior finish, hangs the doors, puts in the windows, and attends to many other matters of this sort, while the stair builder puts in the stairs. Meanwhile the furnace man has set up the furnace and the mason has cemented the cellar. Iater the painters paint the wookwork and finish the floors, and then come the paperhanegers. Outside the house other workmen have been 
smoothing the ground and planting or sodding it; perhaps another set of men are putting up an iron fence. It is evident that all this will take considerable time, because the various details must fit in, one with another, and certain workmen can do nothing until those who precede them have finished. It is, howerer, an excellent illustration of the division of labor.

Among sarage perples the man who is to own the house is generally the one who builds it, unless he is a pumerful or rich

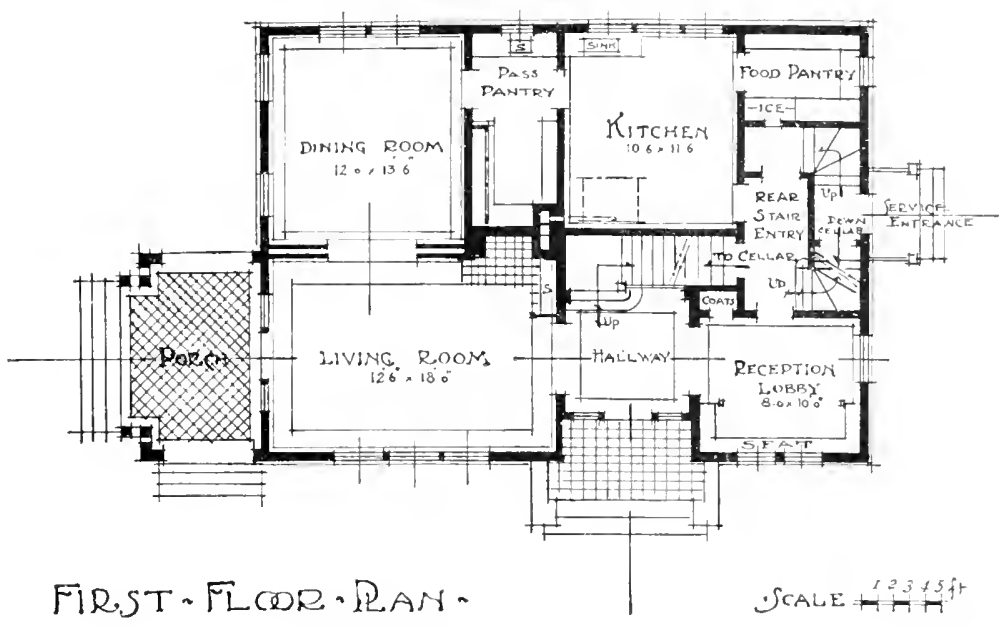

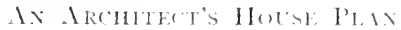

man who can make others do it for him. But in the erection of the modem house there are so miny different workmen that it is almost necessary to have an architect, who draws the plans and who is supposed to supervise all the various contractors. Probably no single contractor could do all the various kinds of work, howerer capable he might be. Ite might have a thorough knowledge of carpentering and painting, but he could not $b$ a plumber at the same time that he was busy with salw and hammer, ner could he do the work of an electrician. So that to-day in the buildines of even a small and simple house there is a specialization in labor which would have anazed the people of a few hundred vears ago. 
Comparison with simple structures. In order to bring out more clearly the difference between primitive methods of construction and the complicated operations of modern housebuilding, let us look for a moment at some of the uncivilized races of to-day and notice how their desire for shelter takes practical shape.

They do not need an architect to draw the plans of a house long before it is begun ; nor are there contractors who take these plans and figure out carefully the costs, finally submitting their "bids." All the houses in a certain region are built on precisely the same plan, some a little larger and some a little smaller. There is no choice of material, because everybody uses the same kind. There are few workmen who are really specialists, except perhaps the blacksmith.

The igloo. In the early part of this book we learned something about the housebuilding of the Eskimos. When a man is ready to build his house or "igloo," first of all he ciraws a circle in the snow with his knife, and after he has cut out the blocks which he intends to use, he fits them around this circle, each row leaning a little further toward the center and being firmly stuck to the next lower row, so that the whole will not cave in. He goes round and round with these blocks until finally only a small hole is left uncovered at the top, and into this he fits a piece of snow or ice, which completely closes it. Then the roof camnot cave in, because the last block is like the keystone in the arch of a bridge, which holds the rest of the arch in place.

After making the outer passage and cutting a block of snow for the door, the Eskimo carres out benches of snow for the inside of the hut, and finally covers the inner walls with skins. These skins hang rather loosely from the snow walls and ceiling, and give an added protection in case the snow of the roof begins to melt.

All that remains to do is to light the oil in the lamp, and to bring in the furs which serve as covers to the berths or benches, and as rugs. The making of an igloo is a simple operation, though it takes a good deal of skill to finish the clome neatly. To make a small igloo only a few hours are needed. 
The tcpec. The same is true of the "tepee" of the lndian. When the tribe wishes to malie a camp, each person about to set up his tepee, or tent, goes out and unpacks or cuts a dozen or so of straight poles more or less like bean poles. These poles are tied together in a bunch at the top and spread out bekw so that their lower ends form a circle; all together they form a cone. Then the skins are hung about this framework, and the lower

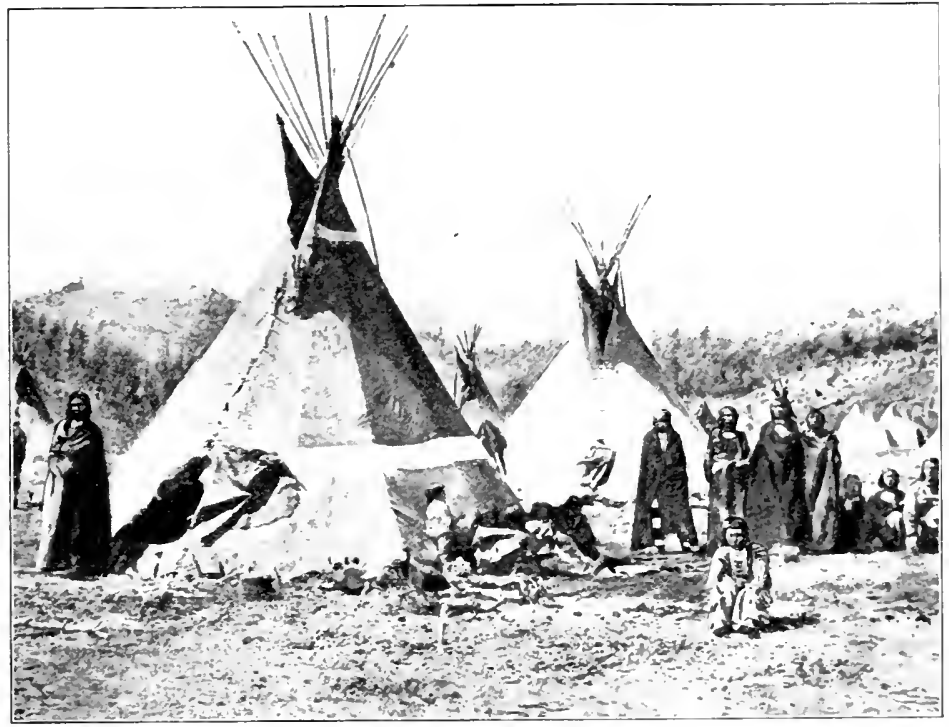

TEPles UF THE INIANS

edges of the skins are held down by pegs or heily stonces. The opening at the top for the smoke has a flap, which cam be so arranged as to prevent the wind from blowing the smoke back into the tepee. A flap lower down makes the door, and nothing then remains for the builder to do but to kindle a fire at the dexer or in the middle of the tepee, and bring in what furniture he possesses.

The ynut. Some of the Cossacks of Central Asia have a tent. a little more complicated than the tepee, which they call al "yurt." The walls of this tent are composed of a circular latticework which 
can be squeczed together or pulled apart, so as to make the tent larger or smaller. L Joun this latticework rest the roof beams, and the whole structure is cosered with lavers of felt.

When the Cossackis wish to build a house, they mast either make the latticework or have it ready to use. It is generally made once for all and carried about with them on their journeys, so that on reaching a camping place it is only necessary to set it

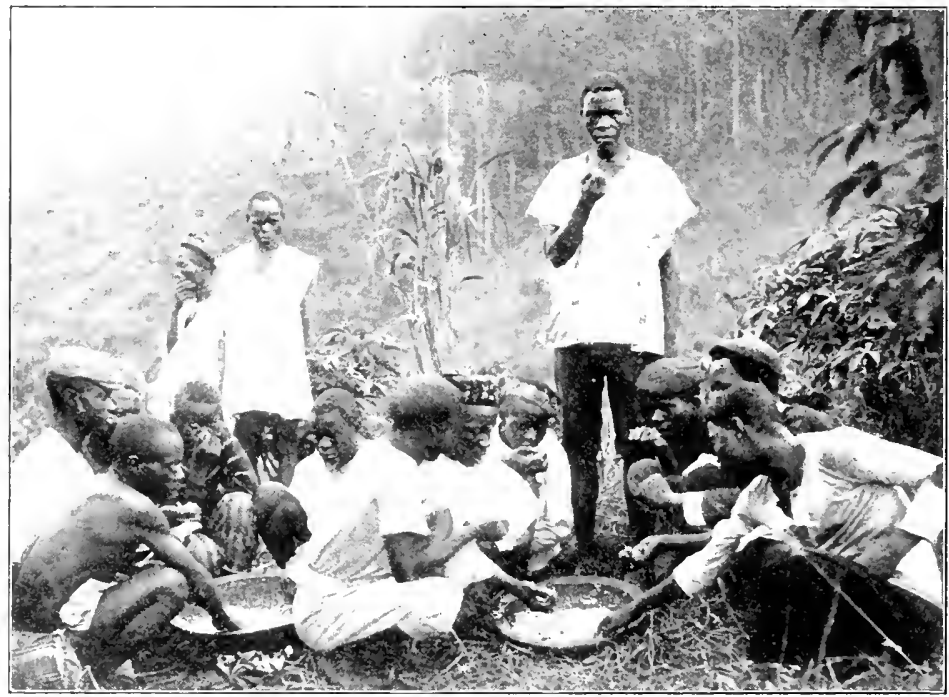

Contegy of The Philatelphia Muneuus

JREAKEIT I'AKTY IN SIIKKA LEONE

on the ground, put up the framework for the roof, and stretch corers orer the whole: the house is then ready for occupaney. sime of their houses are on wheels, like those of the gypsies, or like a "prairie schooner."

Improvements in furniture. It is perhaps right to consider the fumiture of a house as part of it. If we do this, we have another cxample of how, with the advance of civilization, the house has become more and more comfortable and lusurious. In the snow hut of the liskimo there is no furniture except that which we have mentioned and perhaps a few cooking utensils like pots and bowls. 
The same is true of the Indian houses. The Cossacks have more furniture of the same kind, and, in addition, a supply of cushions and rugs.

For many ages the furniture of a house was confined to articles of this kind. At first men did not have tables or chairs. When they were not standing they either lay or squatted upon the ground or on mattings or rugs, and when they ate they held the bowl of food between their knees. But after a while it became customary to sit upon something that was lifted from the ground, and then it was more convenient to have the bowl or plate placed upon some sort of table.

From these small beginnings, where the only furniture consisted of the cooking utensils, and of the skins and matting used to sit on, the house has been furnished until now we have conveniences of all sorts, as to whose uses the savage could

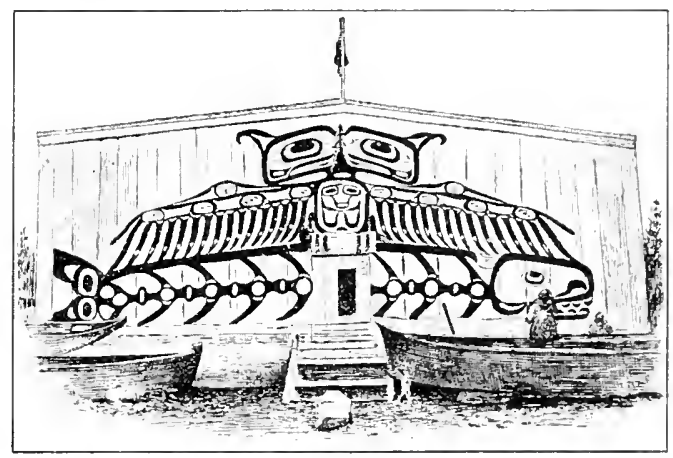

Courtery of the Bureau of Imerean Ethnoluy

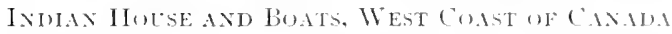
not eren guess. Of course, all such furnishings as bookicases and desks were of no use until reading and writing had been invented, and most of them were not linown until after the insention of printing, only a little over four centuries ago. When we read about the furniture of a house in the stories of Homer, what surprises us is that there was so little. Exen now, in Japan, people sleep and sit on the floor and have their meals served there.

Improvements in ornamentation. There was some omamentation of the houses of many primitive peoples. The Indians used to paint pictures of buffaloes on the outside of their tents, or draw fisures of imaginary birds and beasts on the walls of their wooken houses; and many of their rugs were rery beatutul and omanental. But it was reserved for more civilized people to decorate the interior of 


\section{2 ('NMER('AL, ANH) INHUSTRIAL, GEOGRAPHY}

their houses. This was because, as we have seen, civilized people spend more time in their houses, and naturally wish to make them pleasant and attractive. So, in these days, a house is not considered desirable unless it is painted or papered, and finished with varnished woodwork and paneled doors. Usually it has pictures and various other ornaments to make it seem, as we say, homelike.

Fireproof materials. One of the greatest advances in constructing buildings in mokern times is in the use of steel and of fireproof

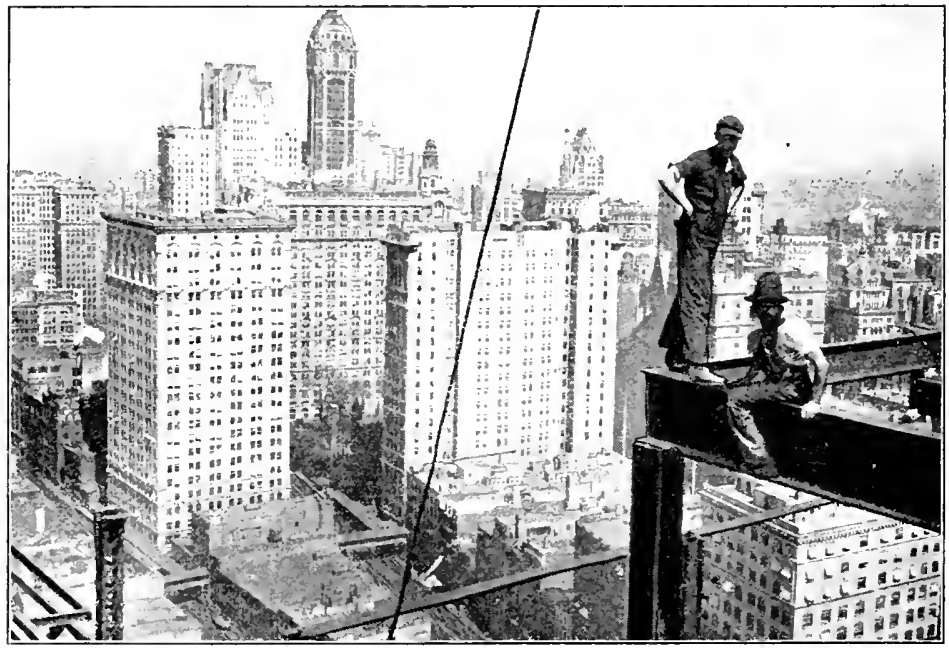

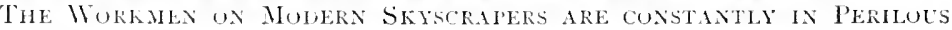

PosITIONS

materials. As there was need of larger and larger buildings, the weight of the structure became too great for wood, and the framework of buildings had to be made of stronger substances. The most developed form of such building is to be found in the modern skyscrapers, which are several times higher than the highest buildings of a few years ago. The framework of these skyscrapers is made of huge beams of steel, which are riveted to each other with reck-hot rivets, and which possess a strength enabling them to bear the enormous weight of stone and other materials now used, In the New York Municipal Building, now ( Í9 2) 
being completed, there are 25,240 tons of structural steel and 700,000 cubic feet of granite, the orders for steel and granite being the largest ever placed.

The highest building in the world is the Woolworth Building in New York City, which will reach 750 feet above the strect leve], and will have 55 stories above ground. Other big buildings run up 600 feet, 500 feet, etc., the number increasing as the height decreases. In the Woolworth there will be 28 elevators and 27 acres of floor space; a complete restaurant, Turkish bath, and swimming pool are included among the conveniences, although it is an office building.

An interesting feature of the Woolworth will be that the tenants on the top floors will enjoy three working days more of daylight a year than those on the street, for the sun will be seen two minutes earlier and later, morning and evening respectively, each day.

As cities have grown larger the danger of destruction by fire, with loss of life and property, has become greater and greater, and so buildings have come to be constructed more and more generally of fireproof materials. Cement and tiles of all sorts, as well as stone, are used ; and where wood is used, frequently it has been so treated as to burn very slowly or not at all. It has even been proposed by the famous inventor, Edison, that houses shall be built in huge molds into which the concrete which is to form their walls can be poured; in this way the four walls of a house could be "poured" in one day or less.

This is a long way from the mud hut of the savage, and it is a result of the development of civilization. It has been made possible by the division of labor between men, and by the fact that they trade ideas as well as materials with each other, so that each nation has not only its own inventions but those of all nations as well. The rate of this advance has been so rapid recently that there has been more progress within the last century than was formerly made in a thousand years. 


\section{CHAPTER XV}

\section{MODERN DWELLINGS IN COUNTRY AND CITY}

\section{The Colntri House}

In early times. As people became more numerous in various countries, along with the growth of civilization, there came to be a distinction between the city house and the country house, which has lasted down to the present time. In general, where many

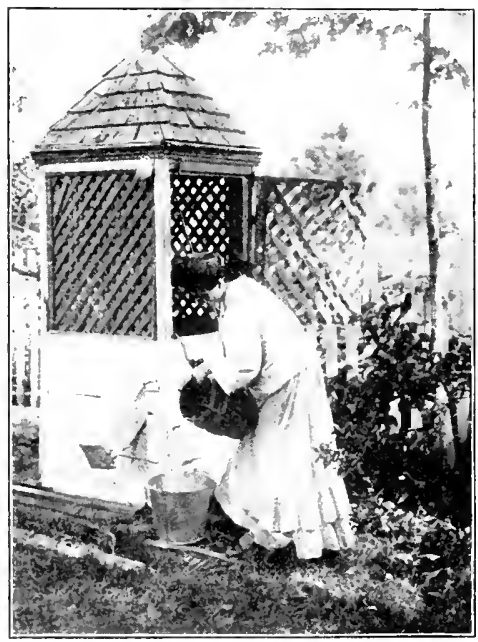

IRAWINE WALR FRUM IN OLIFASHIUNEI, WELL people live together, they combine to secure advantages which they could not have if they lived widely apart.

If we were to consider a country house of the present time, located at a distance from any town or city, we might find that many of the advantages which we think indispensable are lacking. If one goes away for the summer to a house of that sort, he discovers first of all, perhaps, that there is no running water in the house, and that a pump in a well or cistern furnishes the entire supply. If he is accustomed to a morning plunge, he will find that this is well-nigh impossible, because all the water has to be carried, and there is no such thing as a large bathtub. If hot water is needed, it will probably have to be heated in a kettle on the kitchen stove.

IThen exening comes, the reading lamp proves to be unsatisfactory, and a few rainy diys convince him that the house is cold and 


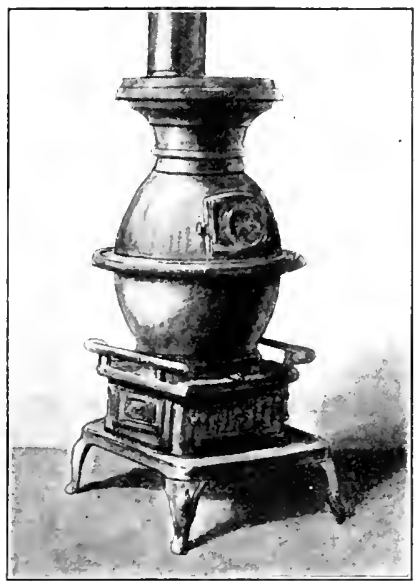

OLD-FASHIONEI STUVE

damp. If he were there in winter, he would have to sleep in an unheated bedroom unless he cared to build a fire for himself in a store or fireplace.

If he should examine the way in which the people about him lived, he would find an absence of many conreniences to which he had been accustomed, and of some things which he had considered necessities. He would also find that it was not ahways easy to get supplies, especially meat and ice, and that it might be neecessary to go several miles for his letters or to send a telegram or a teleplone message. Fifty years ago these would have been the usual conditions in the country, and they still exist in the more remote districts.

At the present time. To-day, however, the country house may differ widely from the one that has been described. There have been improventents of many kinds which are making country life more comfortable every year. In not a few of the rural districts hot-air furnaces are replacing fireplaces and stoves, and sometimes the houses are heated by steam or hot water. If they are lighted by oil lamps, the light may be entirely satisfactory, like that giren by the Rochester lamp; or the house may even be lighted by acetylene or some other gas.

Although there is no public sewer, there may yet be a large

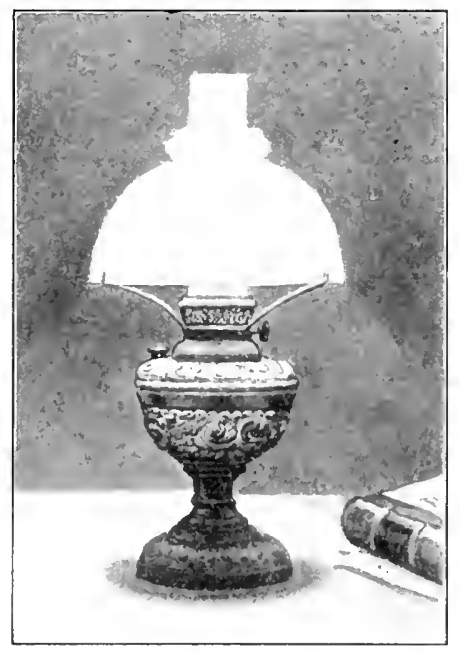

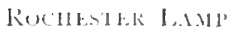


underground tank into which the waste of the house passes through pipes, and the plumbing system may be of the most sanitary kind. Again, there may be bathrooms and runing water, supplied from a tank into which the water can be pumped by hand or by a windmill.

Improved methods of communication. The trolley car. One of the great factors in country life in recent years has been the electric trolley car. No other influence has been so strong in the development of country districts near towns, or even of those at a distance from towns. In fact, after a trolley line has been established, the region through which it runs is no longer the country, but

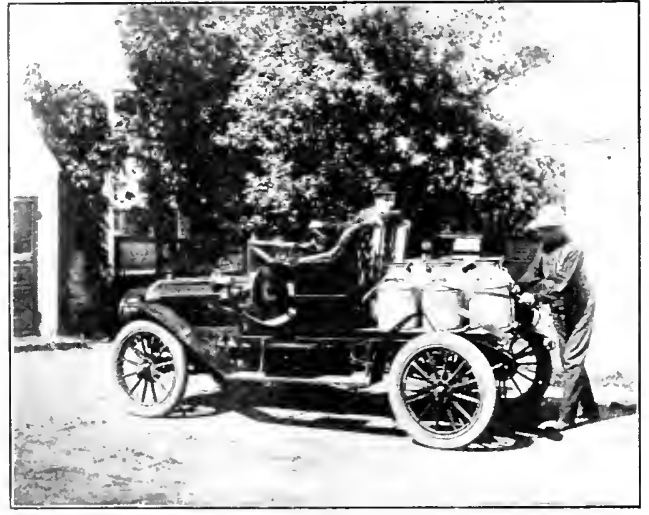

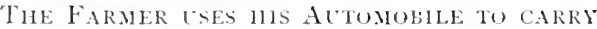
MHLK TO THE CREAMERY becomes a suburb of the city. Not only are passengers carried in and out, but frequently express cars deliver goods along the whole line. Between the railroads and the trolley roads, there are comparatively few isolated regions, especially in the eastern parts of the United States.

Postaldelivery. Another means of connection with the cities and the world in general is through the extended activity of the post office. Not long ago there was established in this country what is known as "rural free delivery." This means that there are letter carriers to visit the various country houses, just as they visit the houses in the city. The carriers do not come so often during the day, but it is possible to get one's letters or daily newspaper quite as early in the morning as if one lived within the city limits. Frequently the mail is delivered at short intervals from the city post office to the country post office by the electric cars. All this has drawn the country closer to the city. Moreover, to most people the country becomes more and 
more desirable as a place of residence, with every new link of communication with the outside world.

The telchlone. Finally, one of the chief influences in the development of country life has been the telephone. If people can talk with one another whenever they like, they are, for many practical purposes, as near as if they were in the same house, or eren room. In many districts the local exchange rates are so low that

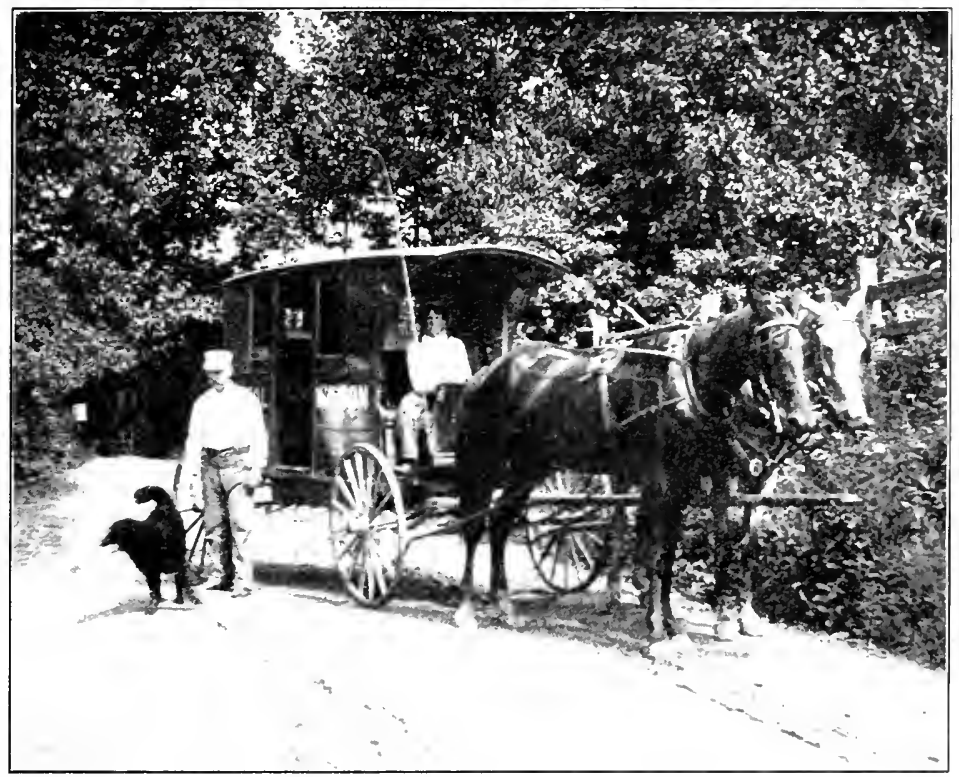

A Rural Free lelivery Wagox

every householder can afford to have a telephone under his own roof. To be able to summon the doctor, or give an orcler to the grocer, or merely to find out the exact time, without a journey of two or three miles, still seems a little like magic to some of the olcler residents.

All these improvements and inventions hare added greatly to the comfort of country people. Kural life has always had ecrtain advantages over life in the eity. Sunshinc and fresh air, beauty 
and quiet, belong to the country, but nevertheless country life, in the old days, was often hard and monotonous. At the present time, with new conveniences at home, and with inexpensive means of communication and transportation, those who live in the country have no reason to complain.

\section{Adrantages offered bi THE Cito}

People who live in a modern city, with the exception of those who dwell on the very outskirts of it, have not only all the conveniences we have mentioned, but many others. When a number of persons having the same needs live close together, they usually find it possible to unite upon some method of meeting those needs. This leads to the establishment of waterworks, gas works, and the like. Furthermore, they develop a system of protection against dangers of various sorts, such as fire.

Fire protection. Old mathods. Formerly, in the country, the only way to fight a fire was to get a number of people together who would form a "bucket line." Somebody would pump water from a well or a cistern into a pail, and this pail would be passed from hand to hand, until finally the last man in the row would throw it upon the blaze wherever he thought it would do the most good. of course no fire that was well started could be put out by this method.

The next step was to have large cisterns somewhere in the center of the town, and a fire engine, which was worked by hand. Such an engine had two long bars, one on each side, as handles; and a stream of water was pumped up by a number of men on each side of the engine, who worked these bars up and down. The water was carried to the engine through a hose let into one of the cisterns or into a well. This was better than the first system, but still it was not very effective. There was a fire department and a fire chicf, but they knew very little about fighting fires, and sometimes the only things which distinguished them were their uniforms and their great self-importance at the time of danger. Sometimes rival companies, in their efforts to prove the superiority 
of their respective engines, would wholly neglect the fure that had called them out. When once a fire was well started, all that prevented a wide derastation was the separation of the dwellings from each other.

Sea methods. But in a mokem American city the business of fighting fires has become a specialty: men are very fincly trained in this work, and are commanded by chiefs who have had long

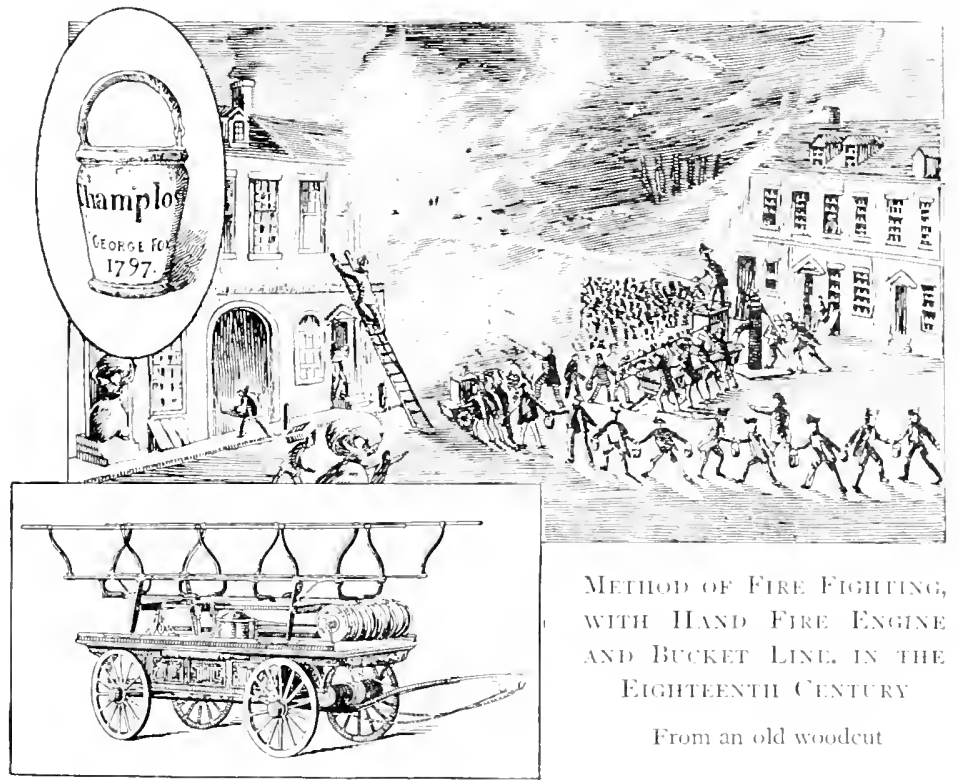

experience and know exactly what to do. The engincs, drawn by strong horses or driven by steam or electricity, pump the water in tremendous streams from the hydrants of the waterwerks. The stream is often so powerful that it takes several men to hold the nozzle of the hose. There are also at the disposal of the fire fighter's all sorts of hooks and ladekers. nets. and other derices to assist in the work. Certain chemicals are used, which put wut a fire very quickly if it has not gained much headway. ()ften the chemical engine has all the work done before the other engines arrive. 
Every instant of time is saved. The firemen sleep in the engine houses and do not take time even to come downstairs;

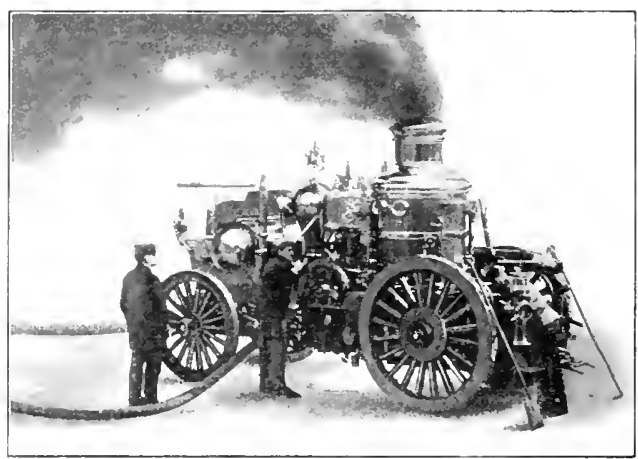

A Mulerx fike lingise

From Hill's "Lessons for Junior Citizens" having jumped into their clothes, they slicle down a brass pole to the lower floor. They are drilled so that they can do this in a very few seconds, because the best time to fight a fire is before it gets well started, and the sooner they get there the better. If horses are used, the harness is suspended from the ceiling and the intelligent creatures are trained to go and stand under it. At the first sound of the alarm bell or whistle they take their places. The harness is then dropped upon their bodies and very quickly bucklect on, the warning bell is somded, and the engine dashes off to the fire.

Formerly, if one had a fire in his house, the rooms were so deluged with water that sometimes the clamage by the fire was much less than that caused by the material used to

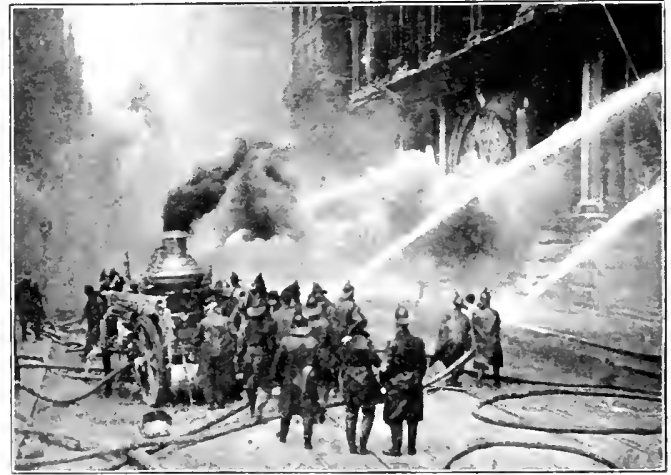

('ITY FIRE I)EPARTIENT AT A BIG BLAZE extinguish it. But with the use of chemicals, and with the greater care which is now taken, a large portion of a house roof may be burned off without the rooms below being disfigured in any way. 
Because of this efficient organization the man who owns a house in the city is not required to pay such high insurance premiums as he would if he were in a place without fire protection.

Police protection. Another benefit which the city dweller enjoys is police protection. Probably this is not needed so much in the country, because criminals and other dangerous members of society are usually to be found in the city. At all events, exery city has a large force of policemen, under a chief whose business it is to keep

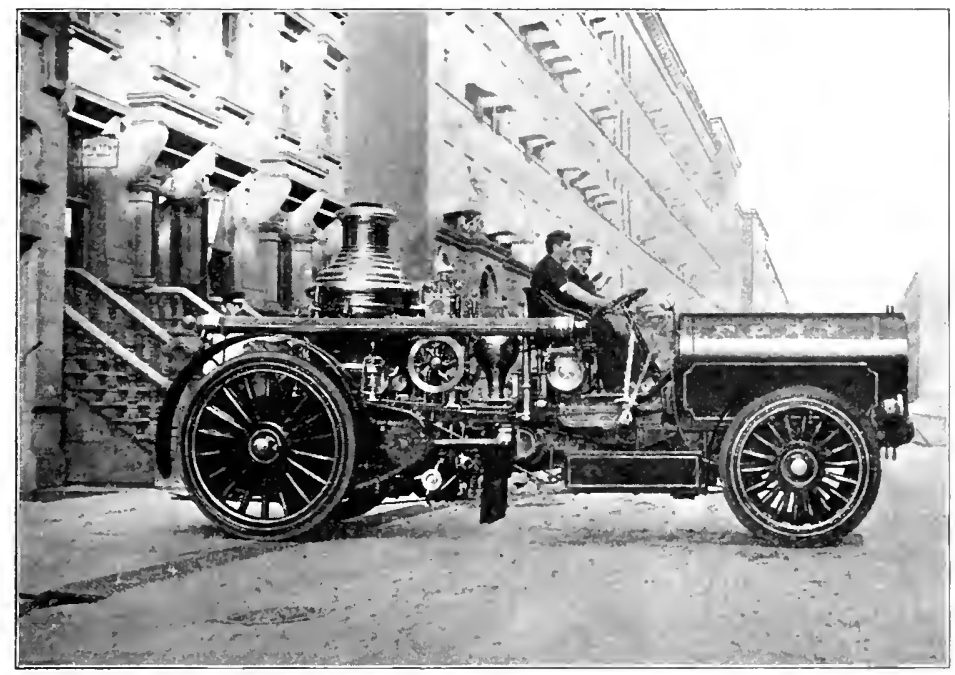

Muder Auto Fire Exainf, New lurk City

order and to arrest lawbreakers. Also the policemen are supposed to take care of people on the crowded streets, to guide the traffic, show strangers their way, and so on.

Usc of dogs. One of the most clever devices of recent times is that of using dogs as policemen, especially at night. This system was dereloped in Belgium and is beoming popular clsewhere. The night watchman has with him a dog who is specially traned to run around a house or other building and see if any suspiciouslooking persons are lurking about. The dogs are muzzled so that 
they cannot bite, but they will get in between the legs of a man who is running and trip him, thus delaying him until the policeman

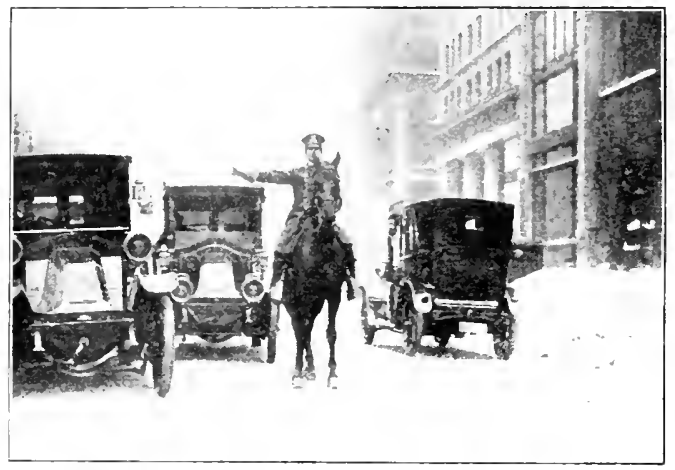

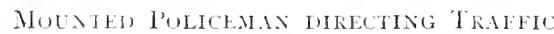

can come up. These dogs take great delight in their work and act as if they understood what is said to them. Their help considerably increases the efficiency of the police. Here is a case of division of labor and coöperation between a man and a dumb animal.

Streets and sidewalks. In the cities much attention is paid also to the condition of streets and sidewalks. A rough, dark country road is frequently an uncomfortable and even a dangerous place. But in the city the streets are macadamized or pared, the walks are level and dry; and the street crossings clean. I jirt and filth are not allowed to accumulate, and so disease is liept down.

Street lighting. Another city inprovement which has made life more comfortable is the lighting of the streets.

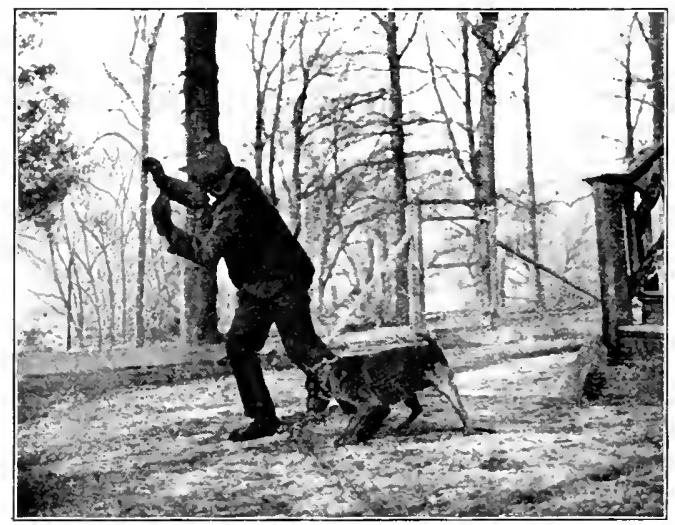

A NaW Takk cicy police log

I ears ago, before the city of I ondon was lighted by gas, it was almost all a man's life was worth to go about at night. Ruffians collected around the dark street corners and assaulted and robbed 


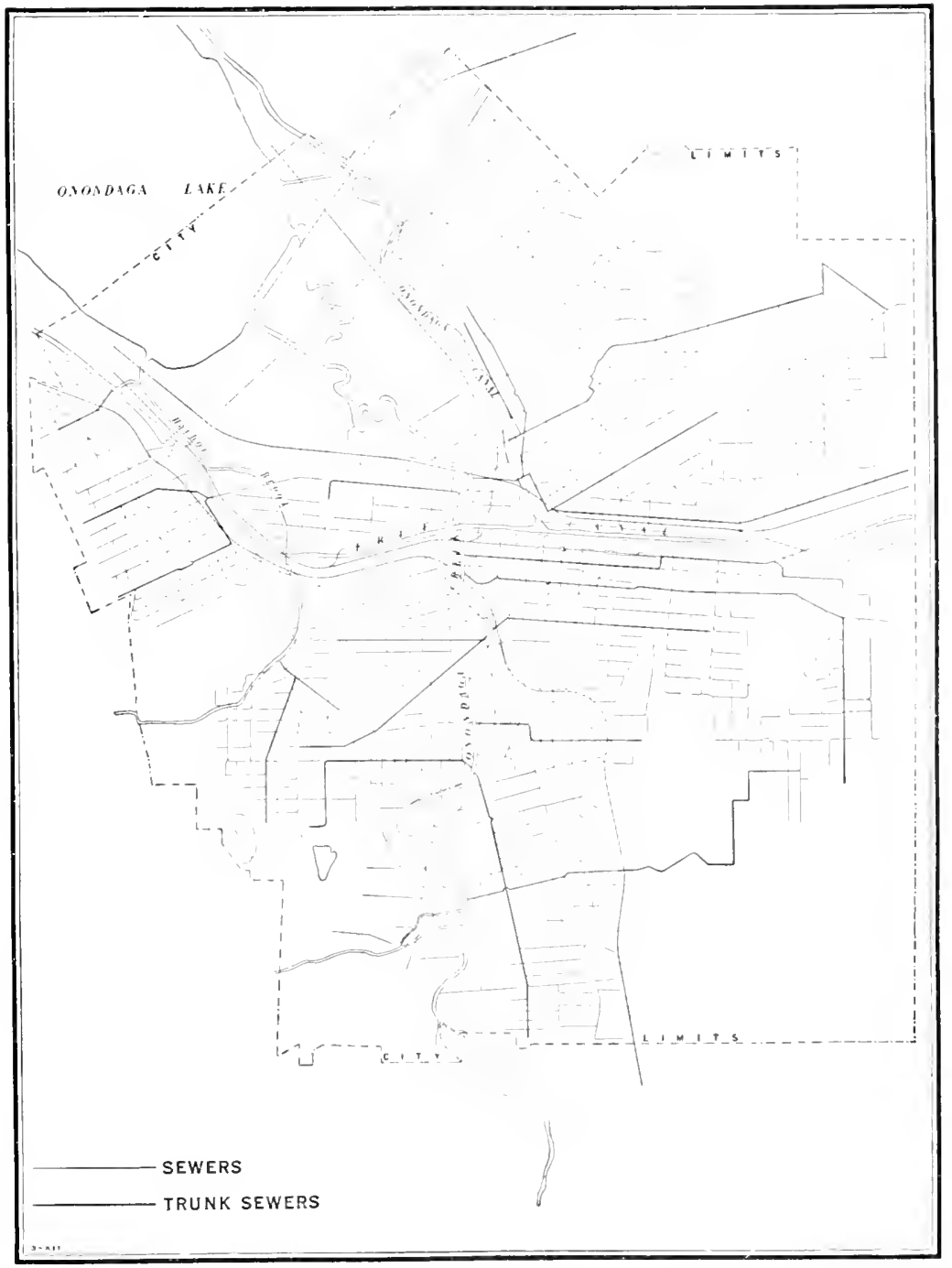

I)AGRAM SHUWIXG SEWLRART SYSTEM OF SIRACISE 
people who came by. But when gas was introduced all this lawlessness began to decline. With the use of electricity the lighting of streets has become more and more satisfactory, so that going about at all times of night has been made far easier and safer.

Removal of waste. The removal of waste from the house is carried on in the most efficient way. Garbage is collected daily and carried to some place where it will not be offensive. Sometimes it is burned, sometimes it is worked over into various useful products; the tin cans are picked out and the metal is used over again, while other portions of this refuse serve as fertilizer. Ashes also are carried off regularly, and used to fill in swampy grounds.

One of the most interesting parts of a city is its sewers. We do not realize sometimes that under the principal streets of our cities run huge tubes lined with brick or tile, through which flows the drainage from dwellings. The sewage system used to consist of separate tankis or cesspools, of which each house had one. Before this, what is known as surface sewage was common. In a number of cities of South America a sort of small canal flows through the town and carries off refuse of all kinds. In some towns of the Middle West, fifty years ago, the gutters were the hunting grounds for seores of pigs which roumed about through the streets. Now, in addition to the city garbage carts and ash carts, we have the subterranean passages which form a great system of underground drains. These are inspected and are kept in good condition by the use of various chemicals. In these ways all the waste of a house is taken care of without trouble to the owner.

Rapid transit. It was with the growth of cities, also, that the need of rapid transportation came about. As the cities grew, the business houses gradually came to be located in one place and the dwelling houses in another; and in the large cities, since the value of the land in the business centers has become so high, the dwellings have been removed farther and farther into the suburbs. New York City has thus gradually spread out to cover a number of smill towns from which sections of the city are now named, such 
as Manhattanville, I Iarlem, and so on. In order that business men may go to their work quickly, a variety of methods of transportation through the streets have been developed. The earliest of these was the stage or omnibus, and later the strect railway. Upon light rails ran small cars drawn by horses, but after a while horse cars were too slow, and a more rapid method of transportation was called for. IIorse cars have scarcely been used in large cities in recent years, except, strange as it may seem, in certain parts of New York City. Since there were so many vehicles and people on the streets, it was impossible that steam cars should run on them, and electric cars were then unknown. So it came about, a number of years ago, that elevated railroads were built in New York. The trains rum on a trestle through certain streets, and stop every five blocks or so, at elevated stations (see picture, page 327).

There was also an application of the cable system and cable cars to surface tracks; beneath the tracks ran constantlya large cable, which could be seized, through a slit between the tracks, by a device attached to the bottom of the car. Then came the use of electricity and the modern clectric car, sum by an overhead or underground

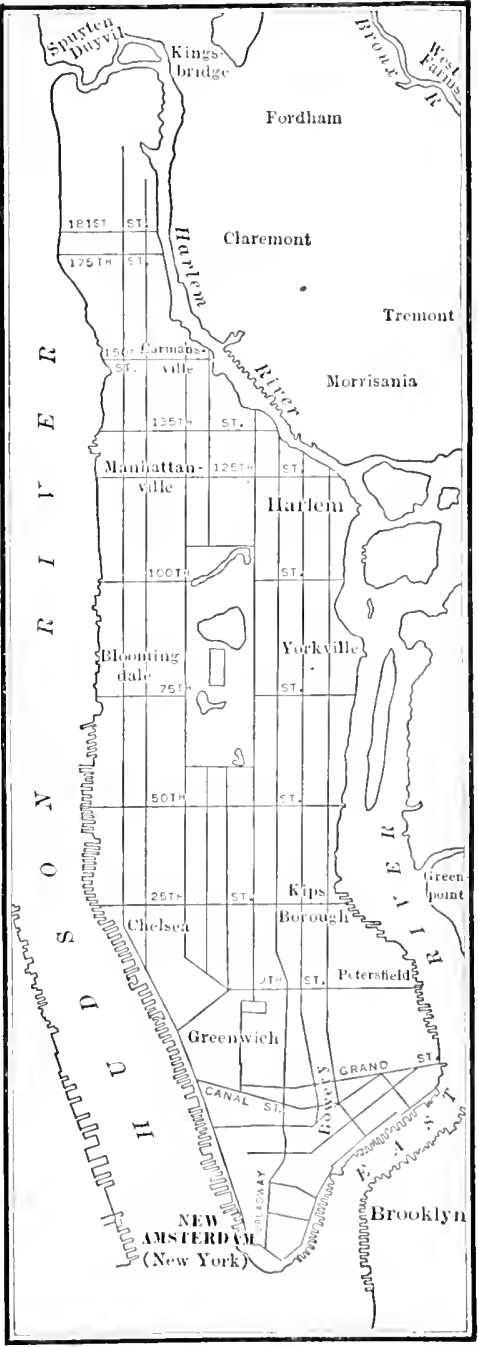

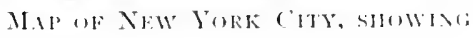

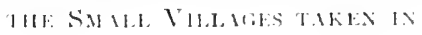




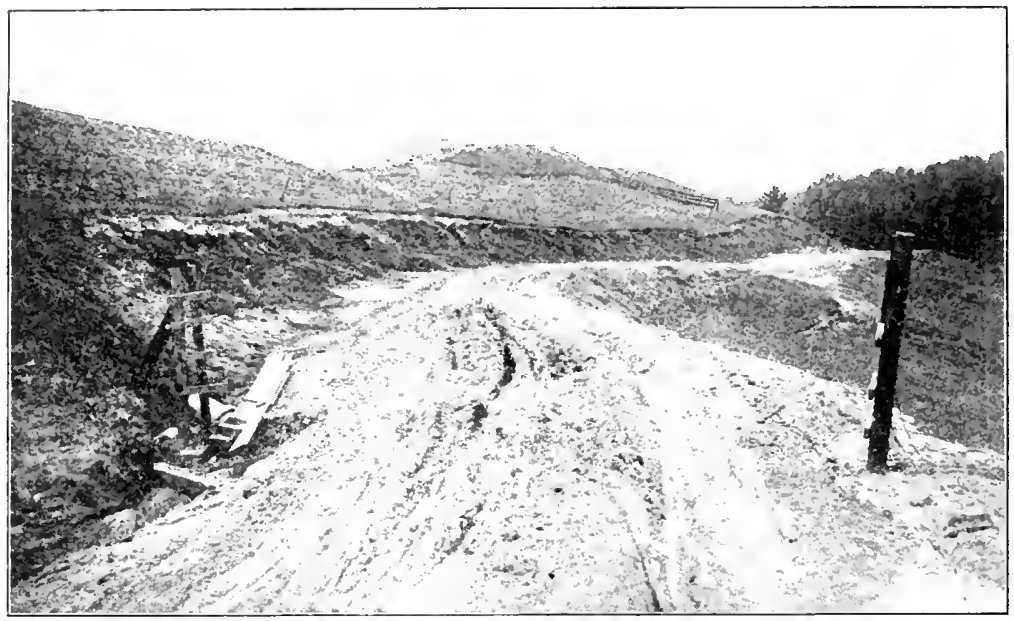

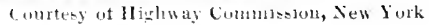

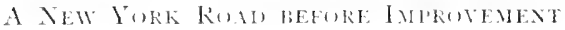

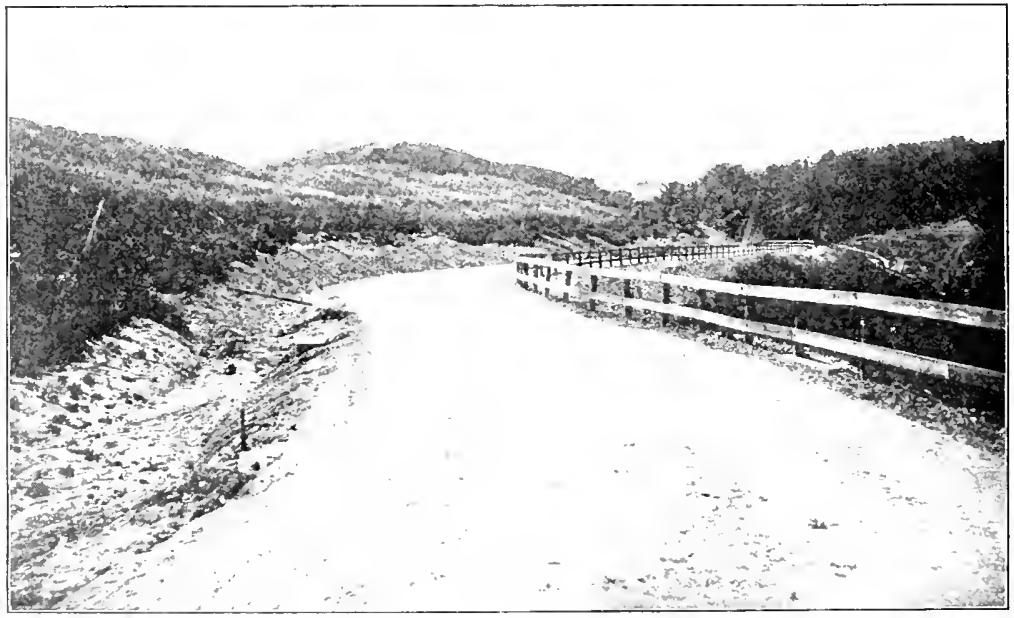

Cimrtery of lliglaway Commissiun, lew lork

THE SAME KUAW AFER IMHOYEMEXT 
system. Last of all, these electric cars have been made to rum through tunnels in the ground and under rivers, where they do not interfere with the traffic of the streets and bridges, and so

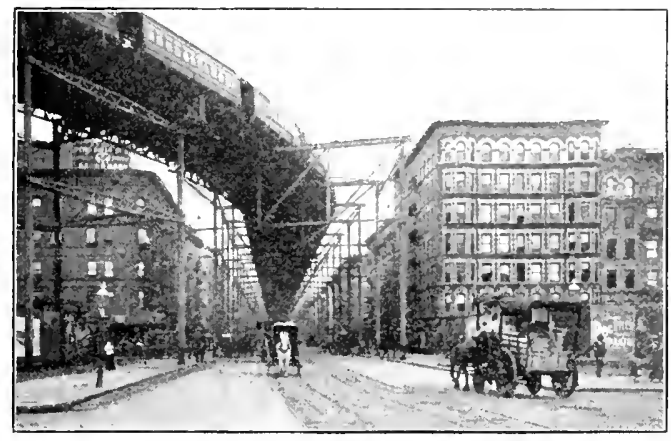

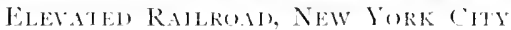
can go at a tremenclous rate.

In the distribution of groods in the tomns, the stores bewan with errand Loxs, who often dawdled atomes. played marbles, and wasted much time; horses and weroms next came into use; and now automobiles are common. In the handling of mail, carricrs have been superseded in large cities by the use of pnematic tubes through which the mail is blown by air pressure to smaller places of distribution, or from the railway stations to the central office. The telegraph and telephone, especially the latter, the newspapers, and other lines of communication are developed to a high degree in the large cities.

A complex system. If one were able to open a deep crack across the strect of a modern town, he would break apart a number of wires, pipes, and the like. 'This is what happened at the time of

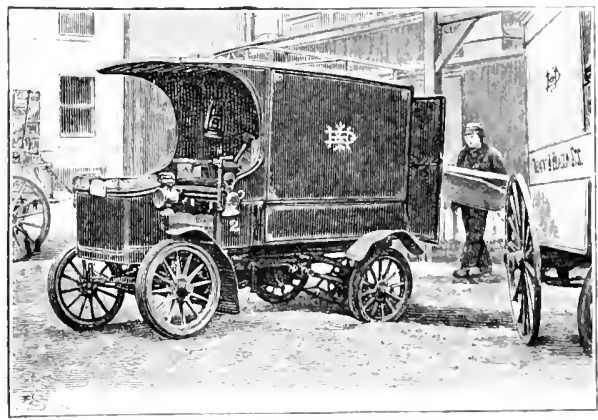

NCH J)LATHEY WHAS the San Francisco earthquake in loor; the ground crackel open and shifted so that these great bundles of wires and pipes were torn apart. The escaping gas became innited and callsed fires, which could not be put out because the water pipes were broken. 
City life is so complex that it is like some great piece of machinery in which a single bolt out of place may lead to a whole chain of disasters. It has now become clear that a modern city is an enormous combination of dwellings, stores, and other structures, all bound together by numerous ties. This, again, is a fine example of division of labor or specialization, and also of trade or communication. In different parts of the same city different occupations are pursued, and it is only by the multitudinous lines of transportation and communication that all these special parts are united in one whole. It is because a city dweller is able to be a part of such a system that he has so many advantages over a dweller in the country. In return, he has to sacrifice many of his own methods and ways.

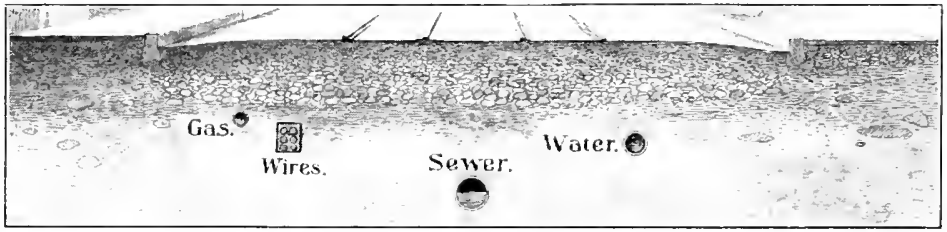

CRoss SEETHON aF STREET

Building restrictions. In the heart of a city a person is not always allowed to build the sort of building which he may wish to, or even to use such building materials as may seem to him desirable. Being part of this great system, he is obliged to do what is thought to be best for everybody in it, and his personal preferences have to be set aside. If he has a wooden house in the center of the city, and wishes to add to it, he is not allowed to build the addition of wook; it must be of brick, stone, or other noncombustible material. The old risk cannot be prevented, but no new risk must be undertaken. This is because of the great danger from fire in such localities; the buildings are so close together that if one of them burns, the loss is not likely to be confined to a single orner. And so, since others will lose if one person is careless. he is obliged to take precautions of all sorts. In some buildings it is required that fire extinguishers shall be kept, and in all the large buildings in which many people live or work, and which are 
not fireproof, there must be fire escapes and even fire drills, such as school children have.

In many cities a man may not build a building above a certain height, because if he does, he will shut off light from somebody. else. And he may not build over the sidewalk without special permission, or do anything else which will interfere with the rights of other people. Robinson Crusoe could do what he liked before his

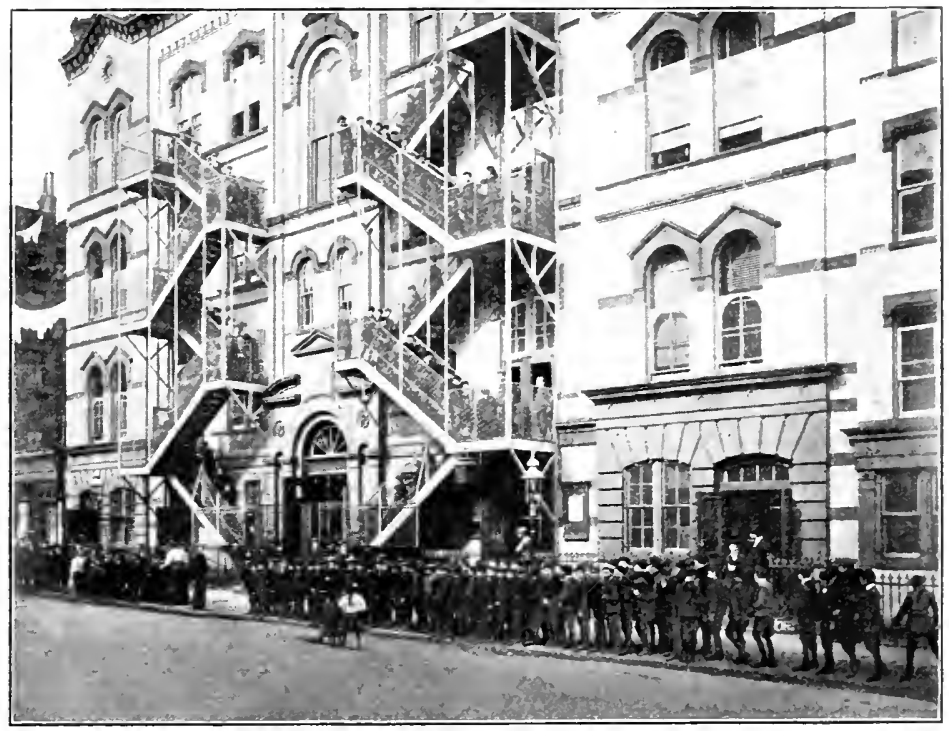

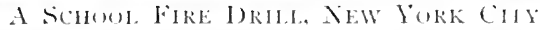

man Friday came, for there was no one but himself who had rights to be considered; but when many people live tugether, each is limited by the rights of the rest.

These rules about building are called al "building code," and every city of importance has one. In their general rules these codes are much alike, but it will always be valuable to the student to examine a copy of the building code of his own city and try to sec why the rules are what they are. 
The Inflence of Chmate cron Archotecture

Something has been said about the influence of climate and other conditions upon the shape and structure of a house, but so far we have considered chiefly the houses of uncivilized peoples. Now that we have been studying about more modern buildings, it will

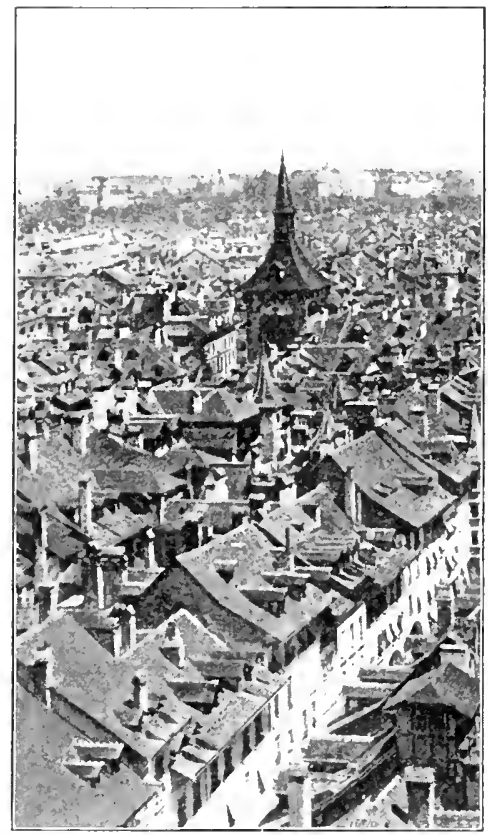

sills IIntols

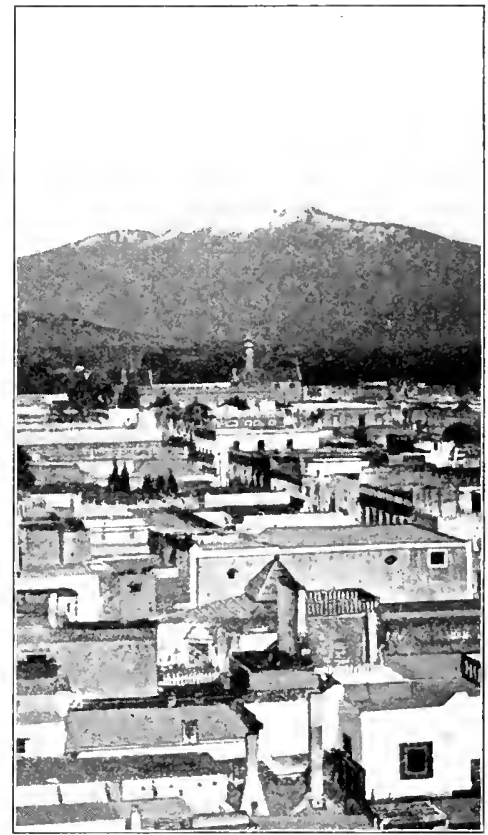

MHII IX MUUSES

be interesting to notice how the present styles of architecture vary according to climate.

Roofs. When there is a leak in the roof cluring the winter, the carpenter always loolis first at the joints where parts of the house covering come together. But if these are all right, he begins to examine the flat sections of the roof rather than the steeper ones. It is not often that a bad leak occurs, mless the shingles are broken or veryold, in a steep shingled roof; but in the case of the 
flatter type, the rain and snow are likely to beat in under the shingles and thus gradually to leak through.

Again, during snowstorms, if the roofs are flat, enormous weights of snow gather on them and are likely to strain the whole house; but the snow slides off steep roofs as soon as it begins to melt, and thus relieves the strain and lets them dry off. For these reasons the roofs of houses in rainy or snowy regions are more likely to be steep. They are almost always so, even among uncivilized peoples, in the regions of the heary tropical rains; in this climate most of the roofs have a considerable pitch.

In regions where the rain is light and there is abundant sunshine the houses generally have flat roofs and open courts. This is clearly. seen in Spanish types of architecture, and is observable in the case of the Greek temple, which was referred to some time ago. If the student will compare the two pictures of the Swiss and Mexican houses, he will see this distinction very clearly.

Doors and windows. ITe have already seen that shelter is similur to clothing in its purpose, and we find that in a cold climate houses as well as garments must be made of heary material with tight seams and few openings. It is common in this climate to have under the shingles or clapboards of a house a layer of paper, which is excellent to keep out the cold. The doors are often fitted with weather stripping, which prevents the wind from whistling through the cracks, and this is sometimes used on windows as well.

Most of the cold which gets into our houses, if the doors are kept shut, comes from the windows, for the plastering is sufficient to keep it out elsewhere. So if the winters are cold, the windous must be tight-fitting; often they are made double. In the same way an extra door is frequently put on a house, either as part of a vestibule, or as a "storm door."

On the other hand, when the climate is warm the houses maty be of light construction, and it does not make much difference if there are cracks of various kinds. In such climates it is more important to have the openings latticed and shuttered to keep out the sun's rays than it is to have them tightly closed to keep out the cold. 
In such houses there is every provision for the free circulation of air, and the furniture is likely to be made of reeds and bambor,

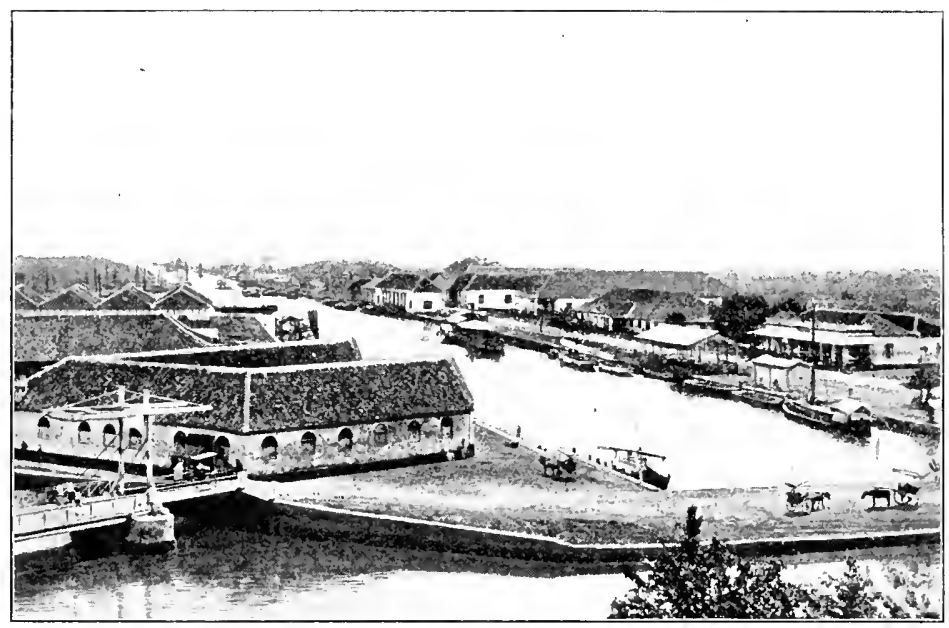

BATAVA, JAYA

Courte'sy of 'The I'holidelphia Musenums

without cushions. While in the cooler regions warmth is the chief thing desired, in the hot regions every effort is made to lieep

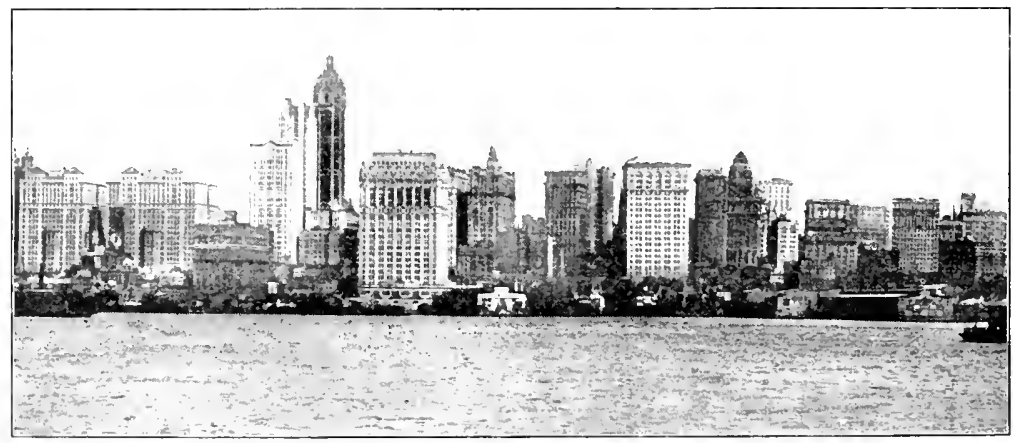

NeW YORK CITY

conl: maturally this primary requirement of the occupant has a very sreat influence upon the type of house that is built. 


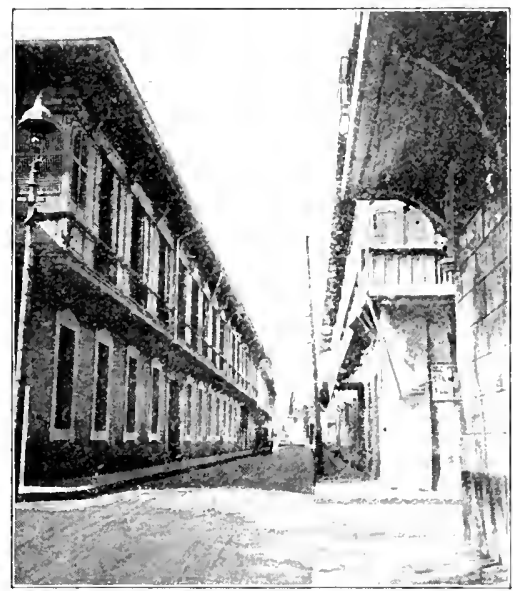

Minitay in a Tropical City

Porches. In the Eskimosnow houses there is no provision for porches upon which to sit and enjoy the air, for in that climate noborly wants to sit out in the open. But in warm countries the houses are provided with wide, decp porches, screened in by lattices and other openwork, and the families spend most of their time upon these verandas. In fact, all the words for "porch," such as "piazza," "reranda," "balcony," "terrace," and the like, come from the languages of the south.

Height and size of buildings. There is a great difference between the cities of a warm climate and those of the temperate zone, due to the difference between the peoples of these two regions. From a balloon the city of Batavia, in Java, would look very different from New York or Lendon. The lutch merchants who do business in Bitavia do not live in the city itself; every evening they go out to the suburbs, which are on higher land and so are cooler. Their houses are of the tropical type, although they have all the conveniences that can be obtained. If we looked at the city, we should see no great buildings pouring forth clouds of smoke, and no skyscrapers

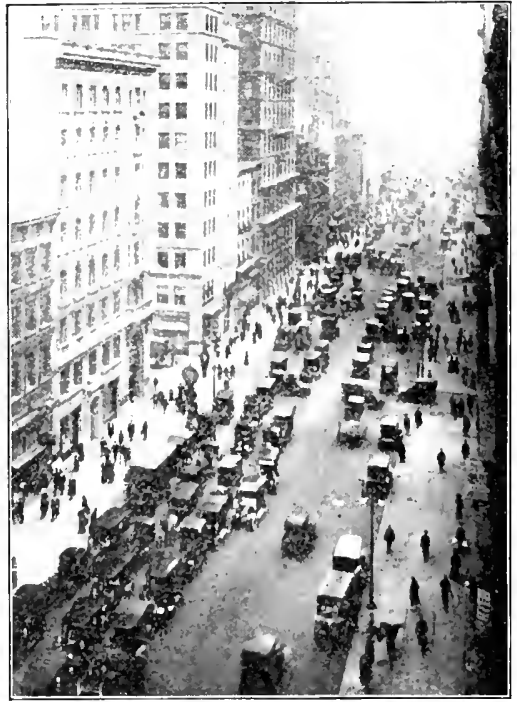

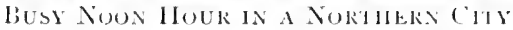


crowded in upon each other, such as we see as we come up to the Battery or sail down the East River in New York. If it is the noon hour, the streets in Batavia are nearly empty, for everybody is staying indoors to escape the heat. There is little indication of energy and industry in the quiet, almost rural appearance of the place.

If, now, our balloon were to float over New York at the noon hour, we should see thousands of human beings hurrying about like ants near an ant hill, and evidence of enormous labor of all kinds would appear. The pictures on the preceding pages show this contrast very clearly, as well as some of the differences in the construction of buildings and groups of buildings, which are brought about by differences in climate.

\section{The Heathe and Lighting of Houses}

Necessity of heating houses. In many regions of the world clothing and shelter alone would not be sufficient to maintain life. It is necessary that the temperature within the house shall be raised considerably above that outside. This is done by the use of fire in some form. It is clear that there are a number of regions on earth where man could not live without fire.

For this reason it is likely that before fire was discovered human beings lived in a warm climate, and were unable to live in colder regions until they had learned how to create, within the houses which they built, an artificial climate in which they could stay for a considerable part of the time. One of the uses of a house is to retain the heat generated within it. The walls of a house serve not only to keep out the cold but also to keep in the heat.

Fire for heating purposes is not of much importance in the warmer regions, so that here again is a case where climate exercises a great influence over the life of man and the kind of house which he builds.

Primitive fuels. For heating there must be fire, and for fire there must be fuel. Fuel was first derived from the plant world, and the savage peoples still burn grasses, reeds, and wood. Wood for many ages was the chief fuel known to man; he probably got 
fire originally from wood which had been kindled by a lightning stroke. The ancient myth that fire was the gift of the gods, or was stolen from heaven, may thus have had a natural origin. Mood is still widely used as fuel, especially in countries poor in coval, or in remote districts where wood is abundant and cheap, and where the carrying of coal is expensive. Men often burn wood in fireplaces, even in regions where there is an abundance of coal, for the pleasure of having a $\log$ fire.

The only fuel derived from the animal world is oil, and this has not been used for heating purposes in many parts of the earth. Among the Eskimos it is the only fuel, and so the one material which malies it possible for these cold countries to be inhabited.

Coal. The Chinese knew a long while ago that coal would burn, but they did not use

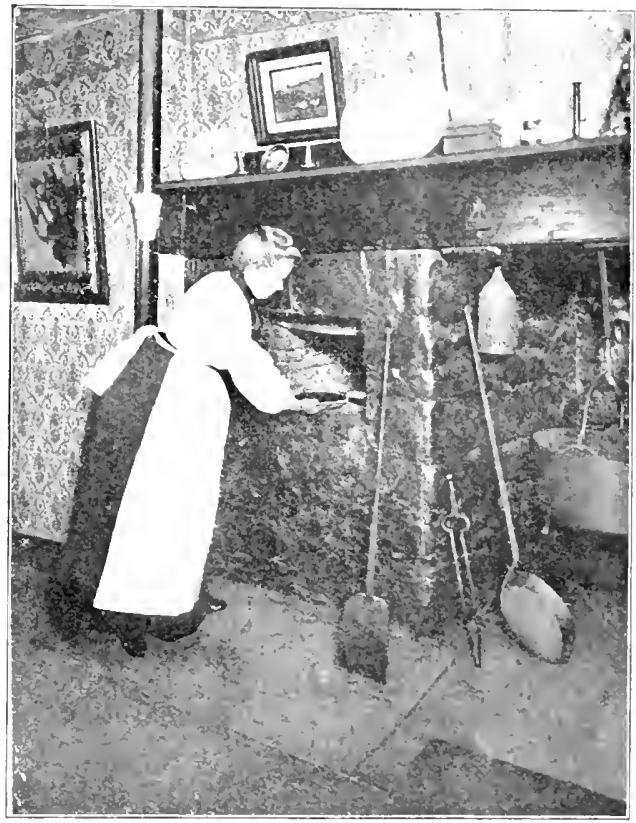

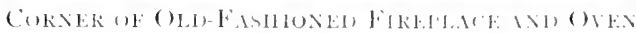
it. 'eetroleum (coal oil, kerosene) and natural gas have been known a good while, but it is only recently that they have been used for heating purposes.

The fuel of most civilized peoples is now coal, and the common variety used for heating and cooking in the eastern part of this country is hard coal or anthracite. We have seen that most of this comes from l'ennsylvania. When coal mas first used for heating, it wats burned in grates or stoves. Later these were very much improved, and after a while large stores, called furnates, were pliced in the 
basements of houses, so that all the heating could be clone in one place, and it woukd not be necessary to carry coal and wood upstairs.

There are several kinds of heating plants for houses - those which heat by hot air, by steam, and by hot water. Of late electricity has come to be usecl, but it has to be generated, and this usually calls for coal, though sometimes water power is used.

The hot-air furnace. The hot-air furnace, containing a pot

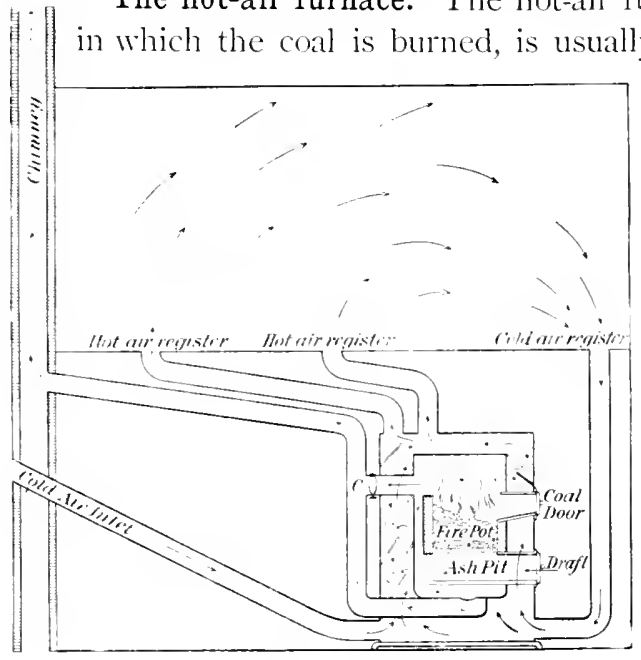

hot-dir hieatixg made, like a store, of cast jron. Surrounding this is a sort of jacket of thimner metal, usually rahanized iron. There is a space between the two, through which the cold air passes. When the air has been heated by contact with the hot surface around the fire pot, it rises through the pipes into different parts of the house. Generally this air is drawn from outdoors through an underground passige, which opens into the empty space around the fire pot. As the air in this space becomes hot it rises, and cooler air is comstantly drawn in and wamed; there is thus a regular current flowing from outdoors throush the furnace pipes into the rooms. The great advantage of this form of furnace is that it secures heat and rentilation at the same time, for the air that comes into the rooms through the registers is pure.

Steam heating. The steam heater has a boiler of water which is heated by a coal fire until steam is generated; the steam is then carried through pipes into radiators in the various rooms. It is plain that in this way only the air that is already in the rooms is heated, and no pure air is introduced. 
Hot-water heating. The steam heater is expensive to put in. and the third variety - the hot-water heater — is cren more costly. Here the water is heated to a high degree, but is not transformed into steam. As the hot water is lighter than the cold, it rises through the pipes into the house. The radjators have to be large in oreler to get into the rooms the amount of hot water which is sufficient to heat them.

The advantage of both the hot-water and the steam heater is that the heat can be brought to any part of the house, whereas in the case of hot-air furnaces it is often difficult to heat all parts, especially when a strong wind prevents the current of hot air from reaching certain rooins.

Fuel for cooking. Food was first cooked over an open fire of wood or of grass, or in water made hot by such a fire. Sometimes stones were heated and the food was laid upon them. If it was desirable to steam the food, a corering of wet grass or seaweed was spread over the stones, as in a "clambake." I ater vil, coal, gas, and electricity were used ats fucl. The "fireless cooker," a recent invention, dispenses with fire only

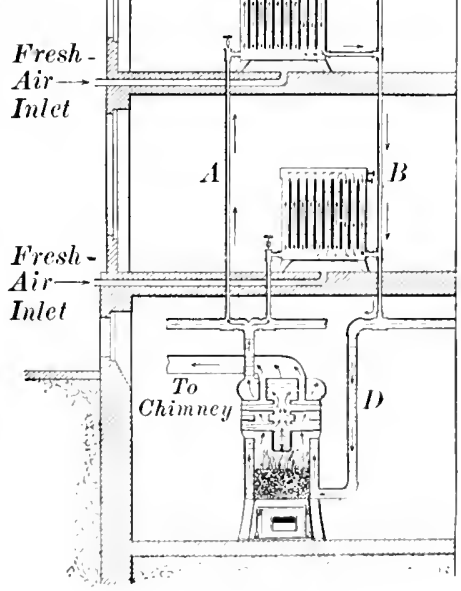

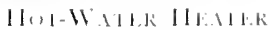
after the cooking process is well started, and depends for its suceess upon its capacity to retain a high degree of heat. It is interesting to know that in our own country there are boiling springs in which fish taken in a near-by stream have been cooked without being removed from the hook and line with which they were calught.

Primitive lighting. The lighting of the house was originally done by the same fire which did the heating and the cooking. later there were pots on lexs, called "braziers," which contained 
a mass of brightly burning tow. Sometimes pine torches, rich in resin, were stuck into holders on the walls and thus lighted the rooms. (Oil also came to be used, as among the Eskimos; and the Greeks had a little lamp somewhat like a gravy bowl, with a wick running out through the spout. In later times the common oil for illumination has been petroleum, out of which is made a refined product, familiar to all as kerosene.

Illuminating gas. At length it was discovered that if coal is treated in certain ways, it gives off a gas, now called "illuminating

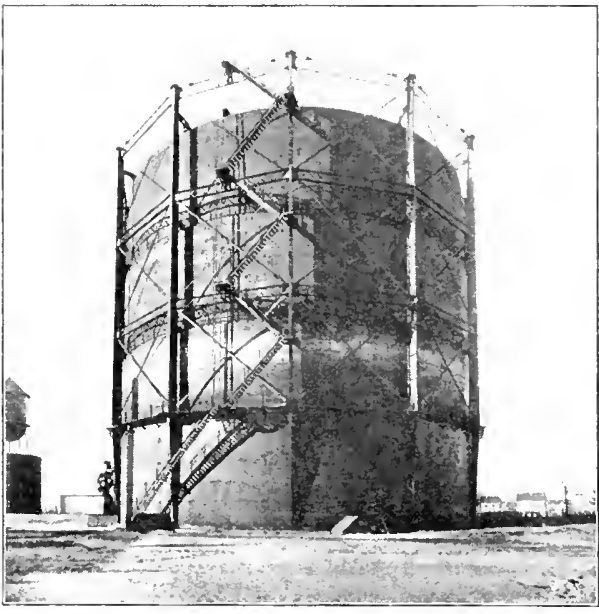

A GAS TANK gas," which became the commonest material for lighting purposes. Each city has its gas factory where the gas is made and stored in enormous tanks, from which it is forced through pipes laid under the streets. It passes from the streets into the houses and finally is allowed to escape through burners of several kinds.

Natural gas. There is another kind of gas which is formed in great quantities beneath the earth, and which is similar to illuminating gals; this is called "natural gas." It has been extensively used near the coal fields where it is found, being piped through the houses like artificial gas. Both of these forms have been used to some extent for heating purposes also, and natural gas was used for cooking some years before the modern gas stove was known.

Other gases have been made which were useful for manufacturing purposes, such as acetylene gas. One of the most useful of all is that which is generated from gasoline and used in gas engines, in those, for instance, of automobiles and motor-boats. 
Electricity. The most modern form of illuminant, and one which is coming more and more into use, is electricity. Electricity is generated and distributed over wires, as gas is distributed through pipes. When the current is sent through a thin wire it heats the wire until it is white-hot or incandescent. If this incandescent wire is surrounded by air, it quickly burns out; but Mr. Edison, after experimenting a good while, finally invented the modern bulb light which every one knows. He sends the current through a thin wire, and to prevent this wire from burning out, all the air is removed from the bulb, which is then sealed up. Since the wire is in a racuum, it will last a long time without burning out.

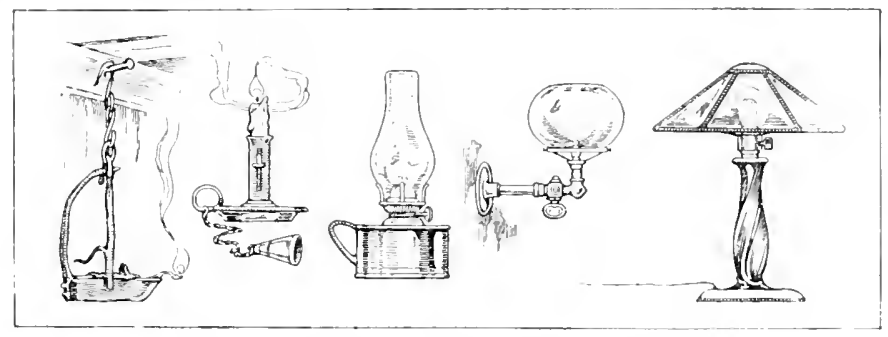

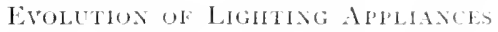

When the streets are lighted by electricity a common form of lamp is the "arc light." Here the electric current jumps from the end of one stick of carbon to the end of another, forming a bow or are of great brilliancy. The mechanism of the light causes the carbons, as their ends burn away, to approach each other, so that the ends are always just so far apart. Modifications of the old are light are constantly being made and new modes of street lighting introduced. In order to see the great usefulness of electricity for lighting purposes, all one needs to do is to pass around the city of New York on a steamer in the early evening.

Summary. We have now studied the history of the shelter which man has made for himself, from the earliest huts and cares to the modern city house with all its conveniences and comforts. We have seen, first, that environment has had as powerful an influence upon the housing of mankind as it has had upon food and 
clothing. The effect of climate, in particular, upon the location, materials, and style of human dwellings has been fully explained. We have seen also that it is easier to observe the influence of environment upon savage peoples than to trace it in countries where trade and commerce have helped to overcome natural limitations. Therefore we studied primitive dwellings of various kinds and noted that each is adapted to its surroundings. We found that even in civilized lands the environment is alwavs considered in housebuilding, and that while low structures made of light materials are common in countries subject to earthquakes, very high buildings are erected in a city like New York, where land is costly and must be fully utilized - where the pressure of population on the surface of the earth is so great that it has forced people, as it were, up into the air hundreds of feet, there to live and do their work.

Lastly we have seen how great has been the increase both in the necessaries and in the luxuries of life during the last fifty years. We have compared the castle of the medieval prince with the modern house as we find it in city and country, and we may fairly conclude that in no other section of our study has the progress of mankind in the art of living been more steady and sure.

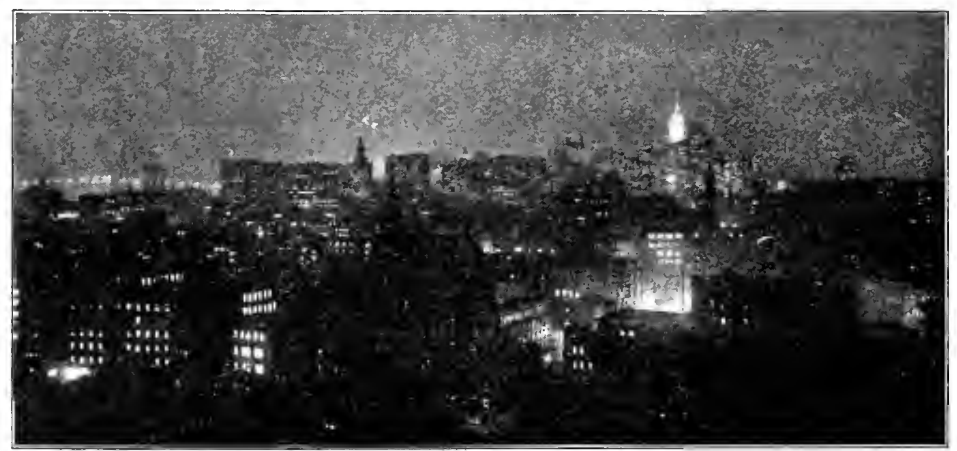

New Juke City a Night 


\section{QUESTIONS FOR REVIEW}

\section{CHAP'TER I}

THE (HIEF NEEHS OF MAN ANI) HOW THEY ARE SLPHLIED

What is the chief need of man? How is waste of the body produced? How is the body repaired? What changes does the food undergo in order to nourish the body? Why is drink necessary? What is the use of clothing? Why is more food required in winter than in summer? What is the use of shelter? How does fire protect the body? Why may clothing, shelter, and fire partly take the place of food?

What part of a man's wages is spent for food? for clothing? for shelter? Why do people spend more than is necessary ror food? for clothing? for shelter? What mineral substances do men use to supply their needs? How have these been located in the earth?

What organic substances do men use? What is meant by the word "environment"? Show how the polar bear is fitted to his environment. Show the same for the camel. Show that plants are fitted to their environment. What food do the arctic regions furnish to the Eskimo? What clothing? What sheiter?

What does "pueblo" mean? How do the l'ueblo Indians try to get rain? Compare the Pueblo Indian with the Eskimo as to food; as to clothing : as to shelter. To what is the difference due?

What is meant by "division of labor"? How is time saved by division of labor? What other advantages has it? How may groups of men, as nations. find advantage in the division of labor?

How does commerce aid in the supply of food? of clothing? What advantage does commerce offer in providing shelter? Why' is the study of trade important? Just what does "commercial geography" mean? "industrial geography"?

How are the environments of plants and animals changed? In changing the environments, what are the conditions of success? Why could not the camel be used in America? 


\section{CHAPTER II}

\section{TIF, INIUSTRIAL REGIONS OF TIE, ITORLI}

How does the climate affect the people of the tropics? of the frigid zones? How do the people of the temperate zones differ from the others? What reward does a farmer get for his labor? What race leads the world in trade? Which one comes next? Why are some peoples backward? By whom are the industries of the world controlled?

Where are the mining regions of the world? What have mountains to do with mining? Where is fishing carried on as an industry? lumbering? grazing: What are the favorable conditions for agriculture? Where are such conditions found?

In what parts of the world is manufacturing an important industry? Why is it not so everywhere? What nations are in the first rank in manufacturing? Why are iron and coal important in manufacturing? Uf what importance are transportation facilities?

\section{CH.IPTER III}

\section{TIIE INIUSTRIAL REGIONS OF TIIE LXITED STATES}

Where in the Lnited States is iron mined? Why is I'ennsylvania a leading iron state? Describe two kinds of coal which are in common use. Where is soft coal mined? hard coal? Describe the hard-coal mines.

Why was copper in early use? What is its chief later use? Where are the most important copper mines?

In what various forms does gold occur? Why is it an important metal? How is it obtained? Where is it found in the United States? What place has gold in the history of California? Where are the most recently discovered gold mines: Where are the chief silver mines? What are the chief uses of silver?

Of what importance is whale fishing? Where is codfishing chiefly carried on? Why is it a hazardous business? Describe the business of oyster raising. Where are the great saimon fisheries?

Where is seal hunting carried on? What international questions have arisen in connection with it?

Uf what use to the people are the forests of the United States? What operations precede the actual manufacture of wood? Where are they carried on? What is meant by conservation? Where are the chief pine forests? the chicf hardwood forests? What are the peculiarities of redwood? Where is it found? 
How did cattle first come to the United States? Where are the chicf cattle regions? the chief sheep regions? Why are cattle and sheep not raised ererywhere? Where is the hog chiefly raised? Why?

Why has farming moved westward? Where are the chief wheat states? Where is the corn belt in the United States? How important is orn as a product? Why is it so important?

Where is cotton the leading crop? Where are the most favorable conditions for rice growing? Name the chief fruit-raising regions. What varictics are raised in each? Where is market gardening most profitable?

Name six conditions of success in manufacturing. Where in the I nited States is most of the manufacturing done? How do transportation facilities affect manufacturing? What is meant by the "fall line"? Trace this line from north to south. What is the leading industry of 'Troy. New York, and why? IIow many different kinds of manufactures are there in the I'nited States? Which employs the most laborers?

In what states is meat packing a leading industry? Why is (hicago a great packing center? How has refrigeration helped to develop the meat industry? What are some of the by-products of the meat industry? Where are the chief milling centers?

Where is cotton manufacturing chiefly carried on? Why can this inclustry be made especially profitable in New England? Where is most of the wool raised? Where is it manufactured?

What are the chief sources of raw silk? Where is it manufactured in the United States? What eity is called the "Lyons of America"? Why? In what states is most of the textile manufacturing done?

What is the "sweating system"? Why is New York a great chothing center? What is included under iron and steel manufacture? Where is the inclustry chiefly carried on? Why? What was the old way of making bonts and shoes? How are they made now? Where are they chiefly made?

\section{CHAPTER IV}

THE MANLFACTURE OF RLBHER BOOTS ANI SHOLS

What are the chief sources of raw rubber? How is rubber obtained? What methods of "tapping" trees are used? I)escribe the process of preparing rubber for market. How do the Indians of Brazil get rubber? How do they get it to market? By what routes does the raw rubber reach the l'nited states? Why does most of the rubber come by way of Europe?

For what purposes are customs duties levied? What are rerenue duties? protective duties? Why is there no duty on raw rubber? What were some 
early uses of rubber? Why was it called "rubber"? Describe the early attempts to manufacture rubber goods. Why did they fail? Who finally succeeded in manufacturing rubber? Why and how did he succeed? Show that he was a public benefactor.

Where are rubber boots and shoes chiefly made? Describe the process of cleansing rubber. How is cloth used in making boots and shoes? How is waste rubber used? Why is the rubber industry chiefly confined to the Eastern states? Give five reasons. What duties are levied on rubber manufactures? Why?

\section{CHAPTER V}

DISTRIBLTION OF FOOD MATERIAL IN TIE L NITEI STATES

What are the chief wheat-producing states? What states are included in the corn belt? When and where did rice culture begin in the Enited States? Where is most of the rice now raised? Where did the potato originate? ()f what importance has the potat, been to Ireland? Where are most of the potatoes of the Lnited States raised? For what are they used besides food for men? Where are sweet potatoes raised? What are the special fruit-growing regions? Where and how can market gardening be made to pay?

What are the three great meat-producing regions of the world? What are the chief cattle-raising states? For what purposes are cattle raised in the East? What are the chief swine-producing states? Why? What are the sheep-raising states? Where are codfish chiefly caught? Whitefish? salmon? oysters? Where is poultry raising a special industry? Why? Where are turkeys raised? ducks?

Where is most of the maple sugar made? cane sugar? beet sugar? honey? In what parts of the L'nited States is coffee raised? From what sources does most of the tea come? (of what importance are mineral waters?

\section{CHAP'TER VI}

\section{DISTKILETION OF FOOH MATEKIALS IN OTHER COLNTRIES}

What are the principal food products of the British Isles. and where are they raised? Why does England import most of her meat? Where is sea fishing carried on around Great Britain?

What are the chief products of Canada, and where are they raised? What is the chief industry of Australia? What agricultural products are raised? 
What advantages has New Zealand for agriculture? What are the chief features and products of agriculture in India? What peculiarity has cotton raising in India? For what industry is South Africa fitted by its climate?

From what plant is tapioca made? Where does it grow? How is tapioca made?

What is the chief food product of Brazil: Why does Africa contribute little to the world's food supply? By whom is Java owned, and what does it raise? Describe the Spice Islands. their history and their productions. 11 ow did the Dutch treat the people of the Moluccas? Where is I'olynesia. and what food products are raised there?

Of what importance is Mexico as a food producer? Where is cacao grown? What use is made of it? What two animals are peculiar to northern South America? What is the chief industry of Argentina? of southern liazil?

Where is rye chiefly produced? In what countries is oats a leading crop? barley? Why can (iermany raise sugar beets successfully?

What can you say of the food products of southern Eumpe? of Central Asia? of Chima and Japan?

Describe in review, with illustrations, the relation of the food of men to their environment

\section{CH.MPTER TII}

THE PKOIOCTION, MANEFATLKE, ANI IMSTRIBLTION (1F WHE.IT

What states constitute the interior wheat belt of the Inited States? the Westem wheat belt? What are the characteristics of wheat growing in the Eastern states? In what Southern states is wheat now raised?

Deseribe the wheat lands of Russia. What are the peculiar features of wheat growing in India? How extensive is wheat growing in France? Why is the yield per acre so large there? How is wheat growing encouraged by the French government? Deseribe Austria-Hungary as a wheat-growing country.

In what parts of Canada is wheat chiefly raised? What is likely to be the future of wheat raising in Canada and Argentina? Why?

What is the best soil for wheat? What climatic conditions are most farorable? Where are such conditions chiefly found?

What are the two ehief varieties of wheat? Where does each thurish? What conditions of rainfall are most farorable to wheat?

What conditions fix the time and depth of plowing? What determines the amount of seed required in general? the amount required in Callifornia?

What conditions favorable to agriculture have existed in the I'nited States? 
What important difference between farming in the United States and Europe? Why can wheat be raised cheaply in India? Why is the yield of wheat small in Russia? What is meant by the rotation of crops? What are the advantages of it?

Iiy what method was harvesting done in carly days? When and where has the sickle been used? the scythe? the cradle? the reaper? What advantages has the reaper and binder? What is a header? What early forms were used? Where is the header chiefly used? I)escribe the work of the "combined harvester." Where can it be used most advantageously? What is the purpose of threshing? What were the early modes of threshing? Describe a flail and the mode of using it.

l)escribe the work of a modern threshing machine.

How is the wheat harvest of the country distributed? How does the wheat get from the farm to the railroad? What are grain elevators, and what is their use? What are local markets? primary markets? Compare the movement of wheat $t$ o the movement of water from springs. How has hand labor been superseded?

What are the great primary wheat markets of the United States? Show why each has become a center. In what two ways is the grain shipped to the seaports? Iescribe the different routes. How is the cost of transportation divided?

\section{CHAP'TER VIII}

\section{TIE MANLFACTLKE OF FLOUR}

How is wheat purified before grinding? What is meant by tempering? How did men first grind grain? Describe the mortar and pestle; the hominy block; the saddle stone; the quem.

What were the early mills in this country? How was the miller paid? When were roller mills first used? Why were they better than the old kind?

Into what three parts is the grain made? Describe the process of grinding. What is the difference between a merchant miller and a custom miller?

Why is New York a great milling state? Why is Minnesota the leading milling state? What is the chief milling center in Ohio? Why is milling an important industry in Indiana? in Illinois? in Kansas? in Missouri?

11 ww does exchange help in feeding the people of the United States? Trace the " stream of wheat" back to the consumer. Why is it harder for an American boy than for an Indian boy to know where his food comes from and how it comes? 
How could the amount of wheat raised in the United States be increased? From whom does Great Britain buy wheat, and why? By what two means are people made independent of their environment in the matter of food, clothing. and shelter?

\section{CHAPTER IX \\ LSES ANI VAKIETIES OF CLOTIING}

What is the chief use of clothing? Why is clothing needed in hot countries? What kind of people do without clothing? Why is the clothing of uncivilized people simple?

Where do people find the material for their clothing? Show that climate makes a difference in clothing. How have the people of northern countries learned to make clothing which will keep them warm? How did the (ireeks and Scythians differ in their food, and why? How did they differ in their clothing? Where can the articles of clothing be used for only one purpose? Why? Where and why can they be used for many purposes?

Show by your own experience that change in environment makes change of clothing necessary. What is the effect of altitude on clothing?

For what purpose besides protection is clothing worn? How do savage people show this? How does custom affect clothing? Show that civilized people wear clothing for ornament. How is comfort sometimes sacrificed for the sake of ornament? How does fashion influence clothing? Illustrate the origin of some fashions. How does the style of clothing indicate the occur ${ }^{-1}$ tion? How may it show character? How has superstition influenced clothing? How does clothing indicate religious belief? How does fashion affect trade?

\section{CHAPTER X}

\section{MATERILS USIEI) IN MAKING (ITTHING}

For what purpose is flax used? Where is it chiefly raised? Why is it not raised much for fiber in the Lnited States? How is it prepared for use?

What use is made of hemp? Where is it raised? Where does ramic grow? What use is made of it? What are qualities of jute? of sisal?

From what animals is leather obtained? I)escribe the uses of leather obtained from cattle; from calves: from sheep: from goats.

From what animals are furs obtained? Why are some furs increasingly costly? Why do fur garments need protection? Why do furs come chictly from the arctic regions? 
What use is made of the wool of sheep? Why are merino sheep valuable? What is made of goat's hair? From what are mohair and alpaca made? What use is made of camel's hair? What other animals furnish hair for similar purposes?

Why cannot the finest silk be made in this country? Why is great care necessary in the raising of flax? What special means are used to prevent damage? What is the chief use of flax and hemp in this country? Why? What processes are used in the preparation of wool for manufacture? Why are materials mixed in the manufacture of textiles?

\section{CHAPTER XI \\ COTTON-ITS HITKRHLTION ANI CLITLRE}

What is the relative importance of cotton in the making of clothing? What are the chief cotton-raising countries of the world? What proportion of the world's cotton supply is raised in the United States? How large is the cotton belt of the I'nited States, and what states does it include? Describe India as a cotton-producing country: Egypt : South America.

Describe the cotton plant. Describe the cotton fiber. What varieties of cotton are used? How important is upland cotton? Where is sea-island cotton raised, and what is its relative importance? For what is Egyptian cotton chiefly used? Describe Indian cotton. Describe l'erurian cotton.

What temperature is most favorable to cotton raising? Between what dates in the year is the culture most successful?

How does the presence or absence of sunshine affect the crop? What must be the character of the rainfall?

Upon what soils will cotton grow best? Where are such soils found? What mode of planting is most common? Why are fertilizers necessary?

l)escribe cotton cultivation in India. How is cotton culture made possible in Egypt? Of what importance is the Nile River? How has its usefulness been increased in recent years?

How is cotton picked? Why cannot machines be successfully used? When is most of the picking done? At what cost is it done?

What is the most important operation in preparing cotton for market? Why is it difficult? Describe the process of ginning. Who invented the cotton gin? Compare the early and the later processes of ginning and baling.

What is the chief use of cottonseed? How is the oil obtained? For what is it used? What is done with the cottonseed cake? How does cottonseed illustrate the use of by-products? What other illustrations have you known? 


\section{CHAPTER XII}

\section{COTTON - ITS TRANSPORTATION ANU MANLFACTEKE}

What is the first step in transpurting cotton from the plantation? Where is the cotton grown in the Lnited States used? By what routes does most of the cotton reach the seaboard? What is the cost of transportation to the sea? By what two ways is cotton conreyed to the mills in New England? What items make up the total cost of transporting cotton from the farm to Liverpool? How do the states of our country now rank in cotton manufacturing?

What are the two primary processes in making any kind of cloth? What were the earliest modes of spinning? Describe the spindle and its use: the spindle and distaff.

What process must precede the spinning? Describe the spinning wheel and its use. What successive improvements in spinning machines have been made in modern times? What names of distinguished inventors are associated with them?

Describe the process of weaving. What names are given to the two sets of threads? How do they differ? What is a loom? How is weaving done on it?

What great social change was brought about by the invention of the power loom? Describe the process of mercerizing. What use is made of it?

What animal dye has been famous in history? From what source are mineral dyes now chiefly obtained? How are dyes "fixed"? What adrantage have vegetable over mineral dyes?

Why did the manufacture of cotton become established in New England early? What changes in the manufacture have come with time? Why does Massachusetts still lead in the industry? In what other sections of New England is the business carried on? To what extent, and why, has the cotton manufacture increased in the South?

How are the products of the cotton mills distributed? What aid does the business of manufacturing cotton receive from the government?

\section{CHAPTER XIII}

THE FACTOKV AYSTEM IN TIL MANLFICTLRE OF CIOTIING

What is meant by comestic manufacture? Ifow is water made to furnish power for running machinery? How is steam used as a motive power? What change in manufacturing came with the use of water and steam as motive power? Why? Where is Lancashire? How did Lancashire come to be the great cotton-manufacturing center of England? 
How did the factory system become a cause of suffering among the people? How did it affect women and children? What dangers came from the machinery? What feetings did the new conditions cause among the working people? Why do men engage in occupations which they know to be dangerous?

What attempts to alleriate the erils of the factory system have been made by law? What provisions for the health and safety of operatives are required by law: How are these requirements enforced?

of what benefit have labor unions been to workmen in factories? What change is coming about in the mode of settling disputes between employers and employees?

What general advantage has come with the invention of the knitting machine? Where are hosiery and underwear chiefly made? Where are most of the collars and cuffs made? How did the industry start? Where are most of the shirts made?

Describe the beginnings of the manufacture of ready-made clothing. What improsements in the industry have been made? What were the evils of the sweating system? Cpon what classes of people did the system bear the hardest? What improvements came with the change to the factory system?

What factory laws in New York tried to improve the condition of the workers: What good have child-labor laws done?

How has the use of machinery changed the business of making clothing? What saving of time has resulted? How has the factory system been applied to women s clothing? How important is the clothing industry in New York state?

What rarieties of head covering are used by different people? What materials are used in making hats? Describe the process of making a felt hat. Where is the hat industry chiefly carried on?

\section{CHAP'TER XIV}

\section{HOLSES AND HOLSE MATERIALS}

Compare the houses of civilized with those of uncivilized man. Show how climate determines the kind of houses men build. by comparing the houses of tropical with those of polar regions.

How did the houses of the ancient Cireeks differ from those of more northern peoples? What other conditions than climate have determined the type of house?

Show that environment has determined the location of houses? How and for what purpose were pile dwellings built? What influence has environment hat on the materials used in house building? Where have cave dwellings been 
found? How has clay been used in house building? What is adobe, and where has it been used? What other minerals are useful in house builcling? I low has the plant world been made useful by man in providing shelter? Where and by whom have materials from the animal world been used: What great change has been made in the use of building materials since early times: What other difference between modern houses and those of primitive men? Why does this difference exist? What comforts and crmveniences dicl the castles of the Middle Ages lack? Compare a modern home with a castle as wh hating and lighting: as to water and waste.

Show how the building of a modern house illustrates the division of habor. Name the kinds of workmen employed.

What is the house of an Eskimo called? Describe the building of such it house. I)escribe the building of a tepee. What is a cossack housc called? How is it built?

What improvements have been made in the furniture of housen: What improvement in ormamentation: Why has it come to be necessary to use fire-proof materials? What are some of these materials. Describe the Worlworth Building. What is concrete. and how is it used:

\section{C'H.APTER XV}

\section{MOUERN DWELLINGS IN COLXTKY ANH GITY}

What conveniences were lacking in country houses in the okden time? How have these defects been remedied in modern times? of what advantige has the trolley car been to the dweller in the country? the rural free cletivery the telephone? Name all the modem improvements which have made cumtry living more desirable.

What advantage has the city over the country in protection againet fire: What was the old method of fire protection? the hand-engine system: Why were these methods unsatisfactory? Describe the modern city system of firte protection, and show its adrantages. Why does it cost more for insurance in the country than in the city?

What advantages have cities over the country in police protection? in strects and sidewalks? in street lighting? in the removal of waste? What use is made of dogs by the police in some countries?

By what successive steps has traveling within the cities been male mone rapid and convenient? Show how dependent and interkependent ate the dwellers in a city. What restrictions upon building do cities imperse. and why 
Show how climate determines the shape of roofs of houses in different countries. How are houses made air-tight in cool countries? How do the houses in warm countries differ from these? Where are porches most common? Why?

Compare Batavia with New York, as they would look when seen from a balloon or an aëroplane.

What fuels have been used for heating purposes in primitive times? Describe the mode of heating by a hot-air furnace: by steam : by hot water.

What varieties of fuel have been used for cooking? What early methods of lighting houses were used? What modes are now in use? What advantages have they over the old ways? Show in review how environment determines the kind of houses men build, and the comforts and conveniences which they contain. 


\section{INDEX}

Adobe, I S, 299, 300

Africa, food products of, 121

Agriculture, 39: in the United states, 62, 101, 146; in Canada, 116: in Australia, I 7 ; in New Zealand, Is in India, 18 , 147 ; in South Ifrica, 159 ; in Argentina. 127 : in liussia. 147

Alaska, fisheries of, 3 (map). 54; gold mining, $5 \mathrm{I}$

Alexander the Great, 226

Alpaca, 127

Animal products, as food. 74,105 ; as clothing materials, I So, 214 ; as build ing materials, $30 \mathrm{I}$

Animals, distribution of, 10; artificial environment of, 20; as sources of clothing materials, 189,214

Architecture influenced by climate. 3.30

Argentina, agriculture and grazing in, I 27 ; wheat, I 40

Arkwright, 254

Asia, food products of. I 31

Assuan dam, $23 S$

Australasia, is

Australia, agriculture and grazing in, I I 7

Austria-1 Iungary, wheat production of, 139

lamboo, uses of, 23

Barley, 129

Batavia, 333

Beverages, 113

Bolivia, chicf products of, I 26

Boots and shoes, manufacture of $\mathrm{is}_{4}$ : rubber, 94

lirazil, coffee raising in, I21; agriculture, 127 ; cotton production, 226 . 229

Iritish Isles. (Set Great Britain)

liuffalo, wheat market, 163 ; milling center, 176 , 177

Building restrictions, 328

liy-products, $76,245.261$
( able cars. 325

('acao, 126

Calfskin, 214

California, gold mining in, 50: giant trees, 60: fruit growing, 6 ;

Camels, II; in the 11 est. 30 : hair of. as a clothing material, 220

Canada, fisheries of. 38 (map), 52, 117 ; agricultural products, I I 6 ; wheat, 1 fo

Caoutchouc. 85

Cartwight, 25

Castles, 304

(attle raising. in the Cnited Sitates, bo, 105; in India. s10; in south Ifrica, II9) in Mexico. 125: in Argentina, I 27

("ave dwellings, $20 \mathrm{~s}$

("hicago, center of packing inclustrs. ?t; wheat market, ifo, I6; advantageous location, $1-8$

C'hicory, IIt

('hildren in factories. $270.25+$

china, food products of, 1 i2: cotem production. 226

("ity life, $31 \mathrm{~s}$

('lay as a building material. 2us

("liff dwellings. 20)

climate, and man. 31 ; and chothing ISS: and houses, 202: architecture influenced by. 3.30

Clothing. man's need bî. 4 : suluces of materials for, zo: mantitacture of Si, 276 ; uses and varieties of, $183 ;$ development of. Iosi; fashion and, 203: materials used in making. 211; cotton used for. $\approx 21$

(inal as fuel, 3,35

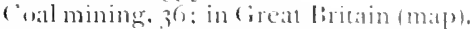

t.i; in the [nited states, ty

(oal tar. 2() $\mathrm{I}$

(iecost. 126

("ollishing, 52. 107

(offec, 113,121

folie. 47

collars and culfs. manufiteture of, 27 


\section{$35+$ COMMERCIAL ANI) INDUSTRIAL GEORAPHY}

Commerce man's dependence on, $24,4^{2}$

Conservation of forests, $5^{\mathrm{S}}$

Copper, 48 ; in the United States, 49

('orn in the Lnited States, 63, 102

('ossacks, 300

('otton, in the United States, 65, 226; manufactures of, $77,250.269$; distribution and culture, 224 ; varieties. 231 ; preparation for use, 241 ; transportation, 24 ; duties on manufactures, 265

('ottonseed, 243 ; table of products and uses, 246

('ountry life, $3 \mathrm{I} 4$

('rompton, 255

1) airying, 106

I)ogs as policemen, $32 \mathrm{I}$

I) ucks, 1 Io

I) uluth, wheat market, 163

butch in the East Indies, 1 22, I 23

l) uty. customs, 9I ; on rubber goods, IOO; on sugar, I I 2 ; on cotton goods. 265

Dyeing, 260

East Indies, spice industry of, 122

Ecuador, chief products of, $1 \geq 6$

Edison, 313, 339

Egspt, cotton production in, $2 \geq 6,229$, 234,238 ; improvements in irrigation, 238

Electric cars, 316.325

Electric lighting, 339

England, factory system in. $26 \mathrm{~S}$

Environment, influence of, S, $3 \mathrm{I}, \mathrm{IS} 7$. 292; artificial, 20

Erie (anal, 164 (map), 165

Eskimos, 12, $30 \mathrm{~S}$

Europe, food products of, $\mathrm{I} z \mathrm{~S}$

Factory system, 266, 283

Fashion and clothing. 203

Fire, man's need of, 6,334 ; protection against, $3 \mathrm{IS}$

Fireproof building materials, 3 I 2

Fisheries, of the United States, Alaska, and southern Canada, map of, $3 \mathrm{~S}$; of the United States. 5I, I07; of the British Isles. I I 6

Fishing, 37

Flax, 212, 221

Flour, manufacture of, 167

Food, man's need of, I ; sources of materials for, 24 ; distribution of materials in the United States, IoI ; distribution of materials in other countries, I I 5 ; cooking of, 337

Forests in the United States, map of, 57

France, wheat production of, 139

Fruit growing, in the United States, 66, I04; in Canada, 116 ; in southern Europe, 130

Fur, 215

Furniture, $j^{10}$

Galveston, cotton port, 248,249

Garbage, 324

Gas, $33^{8}$

Germany, sugar production in, 129

Goats' hair as a clothing material, 220

Goatskins, 2 I 5

Gold, 49 ; in the Lnited States, 50

Goodyear, 93

Grain elevators, 160

Grazing, 37 ; in the Lnited states, 60, 105; in Argentina. 127; in central Asia, I3 1

Great liritain, map of coal and iron deposits of, 43 ; food materials, I15; importation of food materials, I $S_{I}$

Great Lakes, map of iron-ore routes on, $4 t$

Greeks, contempt for foreigners, I9I ; clothing of, 192 : houses of, 294

Grinding machinery, development of, 167

I Iair as a clothing material, 220

Ilargreaves, 254

I Iarvesting machinery, derelopment of, 150

Hats, $2 S_{7}$

Hawailan lslands, sugar production in, I I I, I 25

Heating, methods of, 334

Hemp, 212,222

Hens, ios

Hides, $21+$

Ilog raising in the Lnited States, 6z, 106

IIoney, i 2

Hosiery industry. 276

11 ouses, forms and materials of, 29I ; country, 314; influence of climate on architecture of, $33^{\circ}$

Igloo, $30 \mathrm{~S}$

Illinois, milling industry in, $1-S$

India, agriculture and grazing in, $11 S$; 
wheat production, 138,147 ; cotton production, $226,228,234,237$

Indiana, milling industry in. $1,-5$

Indians, Pueblo (Zuñi). I 5, 300; tepees of, 309

Industrial regions, of the world, 31 ; of the United States, 46

Industries, the great, 34 ; in the Lnited Sitates, $4^{6}$

Iron, map of deposits in Great Britain, 43 ; map of transportation routes on the Great Lakes, $4+$; mining in the United States, 46 ; manufactures in the United Sitates, 82

Iapan, food products of, I32; houses. 296. 301

Iava, food products of, 122

Iute, 213

Kansas, milling industry in, 178

Kansas ( ity. wheat market, I63

Lay, 257

Kelly, 255

Kipling. 52

linit goods, 276

Labor, division of, 19,34

Labor laws, 273.283

labor unions, 275

I ancashire, cotton industry in, 260

Leather, 214

Lighting, methods of. 3.37

Linen manufactures, 277

Liverpool, cotton market, 260

L.lama, 127

Lumbering, 37 ; in the Lnited States. 50

Malay Archipelago, food products of, I 22

Man, needs of, and how they are supplied, I ; influenced by climate. $3 \mathbf{I}$

Manioc, I 20

Manufacturing, 40,70 ; in the United States, 7 I

Marco Polo. 47

Narket gardening, 69, 104

Massachusetts. cotton manufacturing in, $77,263,265$; center of boot and shoe industry, 84,94 ; labor legislation, $28_{3}$

Meat products, 74.105

Nercer, 259

Mexico, agriculture and grazing in, 125

Milk, IoG
Nilling. 76,167

Mineral waters, I I 4

Minerals, distribution of, 9: as building materials, 209

Mining, regions of, 34 : in the Lnited States, $t 6$

Minneapolis, milling center, 76,177 ; wheat market, $16_{3}$; roller mills, 172

Minnesota, milling industry in. 76.177 ; chief wheat-producing state, 101. 136

Nissouri, milling industry in, $1,-5$

Moluccas, Iutch in, I 24

New England. cotton manufacturing in. 262

New Orleans, wheat-shipping center, 164, 165; cotton market. 24s

New York, fruit growing in, 6-: importance of manufactures. 71 : milling industry, 176: collar-and-cuff industry, 277 : shirt-making industry, $27 \$$; factory laws. $28_{3}$; clothing industry, $2 \$ 6$

New Jork City. map showing sources of milk supply, +5 : clothing center. S1, 27\$: wheat-shipping center, 163 , 16.4. 165; milling center, 1,6, 177; cotton market. 249 ; hosiery and knit goods. 277; map of. 325

New Zealand, agriculture and grazing in. Is

Newfoundland lanks, fisheries of, 52

Nile River, $23 S^{3}$

Oats, I 28

Ohio, milling industry in. I 77

Oil, as fuel, 335 : for lighting. 338

Olives, 130

Organic sulostances, Io

Ornament, clothing as, 195

Oyster fishing. $53,10 \mathrm{~s}$

Packing industry, -7

lennsylynia, iron and coal mining in, 47 . 4 is center of iron and stcel in. dustries, is 2

Peru, chief products of, 126 ; cotton. 229.234

Ihilippines, houses in, 296

ligskin. 215

l'ile dwellings, 206

I'ine lumber. $5 \mathrm{~s}$

'lants, distribution of, 10,11 : artificial environment of. 20): dependence on rainfall, 1.4; as sources of materals 
for clothing. 21 I ; as sources of building materials, $30 \mathrm{r}$

l'olar bear. so

l'olice. 32 I

I'olynesia, food products of, I 25

I'ortland (Oregon). wheat-shipping center. ${ }^{6} 6_{j}$

Iotatoes, Irish. 103: sweet, I04

Poultry, ros

Primary wheat markets, I60, I62

I'ueblo (Zuñi) Indians, 15, 300

Kailroads, wheat transportation on, I 66: cotton transportation. 249 ; street. 325

Rainfall. I 43 : cotton affected by, 235

Kamie, 212

Kapid transit. 324

Ready-made clothing, $2,-5$

Redwood, 60

Refrigeration, 75

keindeer, I 31

Rice, in the Lnited Sitates. 66, 102 ; in Asia, 132

Kochester, milling and nursery center. $1 ; 6$

Rotation of crops. I 49

Rubber, the raw material, S5: manufac. ture of, 92

Rural free delivery, 316

Russia. wheat production of, 13 S. 147 : flax production, 212 ; cotton production, $\geq 26$

Rye, 128

sit. Louis, wheat market, 161,163

Salmon fishing, 54. IoS

San Francisco. wheat-shipping center, 163

Seal fishing. it

Seattle. wheat-shipping center. 164

Sewers. 323 (diagram). 324

Sheep raising, in the Lnited States, 6I, I 7 ; in Australia, 117 ; in New Zealand, i is

sheepskin, 214

Shelter, man's need of, 6 ; sources of materials for. 26 ; different forms of, 291

shirt-making industry. 277

silk, production and manufactures of. in the L'nited States, 79,220

silver. $5 \mathrm{r}$

Sisal, 213

Skins, as clothing material. IS9. 214 ; as windows, 295,301 : houses of, 301
Sikyscrapers, 312

south Africa, agriculture and grazing in, II 19

South America, food products of. 120

Spice Islands. (Sic Moluccas)

Sipices, I 22

Sipinning. $25 \mathrm{I}$

Steam power, $26 \%$

Siteel as a building material, 312

Steel industry, in the L'nited sitates, $\$ 2$

Sugar production, in the United States, I10; in Germany, 129

Superior. lake, iron-ore district of, $+t$ (map), 47

Supply and demand, 27

sweating system, Si, 280

Swine in the United States, 62, 106

Tacoma, wheat-shipping center, 163

Теa, 1 I 3

Telephone, $3 \mathbf{I}$

Temperat $€$ zone, industries centered in, 32

Tepee, 304)

Textiles, -6

Tobacco, 122

Toledo, wheat market, I6z: milling center, iz

Trade routes, map of, 35; for iron ore, on the Great Lakes. map of $4 t$

Transportation. dependence of trade on, 28,43 ; relation of manufacturing to, 71 ; of wheat, $15 S$; of cotton. $24 \mathrm{~S}$; by trolley cars, 3 I 6

Trolley cars, 316,325

Troy, center of collar-and-cuff industry, $72,27 \mathrm{~S}$

Turkeys, 109

United sitates. fisheries of. $3^{S}$ (map), 51 ; industrial regions, 46 ; mining, 46; lumbering. 56; grazing, 60 ; agriculture, 62 : manufacturing, 70 ; foodproducing regions, $7 f$; textile regions, 76 ; iron and steel regions, $S_{2}$; boot and shoe industry, $S_{+}$; distribution of food materials, ror ; wheat fields, 136 ; varieties of wheat, $1+2$; rainfall, $\mathrm{I}+\mathrm{j}$ (map), I $+\mathrm{t}$ : economic conditions of agriculture, $1+6$; wheat transportation, I 58 ; milling industry, 176 ; cotton production, 226,232

Vasco dat Gama. 123 
Water, man's need of. 3

Water power, 266

Watt, $26 \mathrm{~s}$

Weaving. 255

Whalebacks, 165

Wheat, principal regions producing. 63 . IOI, 135 (map), 136 : conditions of cultivation, If $\mathrm{I}$; methods of cultivation, Ift; economic conditions, $1_{46}$ : harvesting, I 50; transportation, I 5 '; making into flour, 167: marketing the products. 179

White race, trade controlled by, 33
Whitefish, 10;

Whitney, Eli, 24I

Women employed in factories, $2,0,21$

Wood as fuel. 334

Wool, production and manufactures of. in the Inited states, -8 : the raw material, 2119. 222: spinning, 252

Yurt, 309

Zones, $3 \mathrm{r}, \mathrm{I}=\mathrm{O}$

Zuñi (P'ueblo) Inclians, 15.300 



UC SOLUTHERN REGIONAL LIBRARY FACILITY

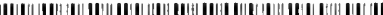
AA $001006805 \quad 4$ 
